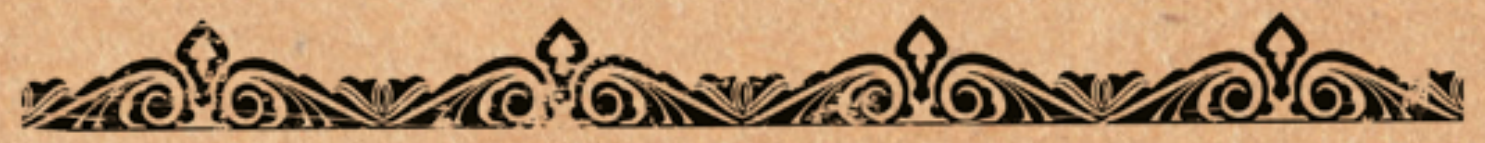

Universidade de São Paulo. Instituto de Estudos B̀r asileiros Programa de Pós-Graduaçao em Culturas e Identidades Brasileiras

\title{
EMEOLADAS
}

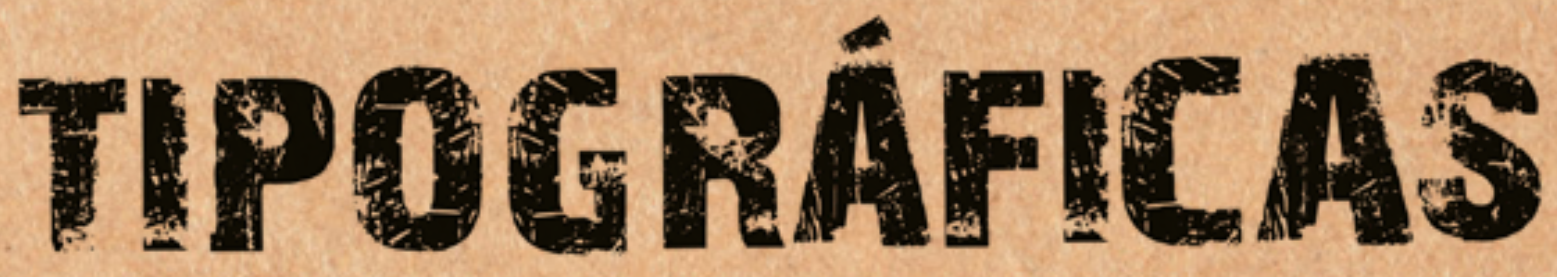

E M C A M P I N A

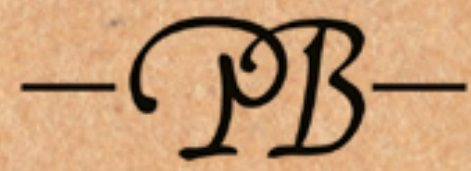

Permanências e rupturas

na ediçāo dos folhetos

do poeta Toinho da Mulatirha

$$
1925-2016
$$

Milla M. P. Pizzignacco

Sāo Paulo, 2020

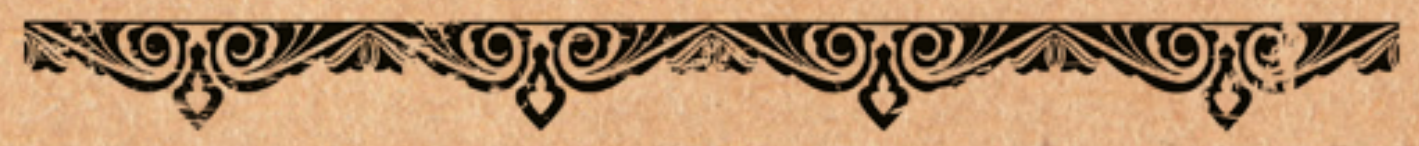




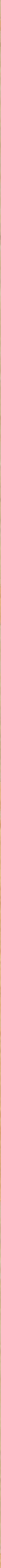




\title{
UNIVERSIDADE DE SÃO PAULO \\ INSTITUTO DE ESTUDOS BRASILEIROS \\ Programa de Pós-Graduação \\ em Culturas e Identidades Brasileiras
}

\section{EMBOLADAS TIPOGRÁFICAS EM CAMPINA GRANDE (PB): \\ Permanências e rupturas na edição dos folhetos do poeta Toinho da Mulatinha (1925 - 2016)}

\author{
VERSÃO CORRIGIDA \\ Versão original disponível no Instituto de Estudos Brasileiros \\ da Universidade de São Paulo (IEB - USP)
}

\begin{abstract}
Milla Maués Pelúcio Pizzignacco
Dissertação apresentada ao Programa de Pós-Graduação em Culturas e Identidades Brasileiras do Instituto de Estudos Brasileiros da Universidade de São Paulo para obtenção do título de Mestre.
\end{abstract}

Área de Concentração: Estudos Brasileiros

Orientador: Prof. Dr. Paulo Teixeira Iumatti 
DADOS DE CATALOGAÇÃO NA PUBLICAÇÃO (CIP)

Serviço de Biblioteca e Documentação do

Instituto de Estudos Brasileiros da Universidade de São Paulo

\section{P695}

Pizzignacco, Milla Maués Pelúcio

Emboladas tipográficas em Campina Grande (PB): Permanências e rupturas na edição dos folhetos do poeta Toinho da Mulatinha (1925-2016) / Milla Maués Pelúcio Pizzignacco; Paulo Teixeira Iumatti, orientador - São Paulo, 2020.

Dissertação (Mestrado) - Universidade de São Paulo. Instituto de Estudos Brasileiros. Programa de Pós-Graduação em Culturas e Identidades Brasileiras. Área de concentração: Estudos Brasileiros. Linha de pesquisa: Brasil: tensões, rupturas e continuidades entre passado, presente e futuro.

Título em inglês: Typographic entanglements in Campina Grande (Paraíba - Brazil): permanences and ruptures in Toinho da Mulatinha's brochures editions (1925- 2016) - São Paulo, SP.

Descritores: 1. Mulatinha, Toinho da, 1927-2016 2. Feira Central de Campina Grande (PB) 3. Literatura popular 4. Embolada de coco 5. Patrimônio cultural 6. Tipografia - Campina Grande (PB) I. Universidade de São Paulo. Instituto de Estudos Brasileiros. Programa de Pós-Graduação II. Iumatti, Paulo Teixeira, orient. III. Título. 


\section{EMBOLADAS TIPOGRÁFICAS EM CAMPINA GRANDE (PB): \\ Permanências e rupturas na edição dos folhetos do poeta Toinho da Mulatinha (1925 - 2016)}

Dissertação apresentada ao Programa de Pós-Graduação em Culturas e Identidades Brasileiras do Instituto de Estudos Brasileiros da Universidade de São Paulo para obtenção do título de Mestre.

\section{BANCA EXAMINADORA}

Prof. Dr. Paulo Teixeira Iumatti

Universidade de São Paulo/ Université Sorbonne Nouvelle - Paris 3

(Presidente/ Orientador)

Prof. Dr. Alberto Tsuyoshi Ikeda

Universidade de São Paulo

Profa. Dra. Rosilene Alves de Melo

Universidade Federal de Campina Grande

Profa. Dra. Sylvia Regina Bastos Nemer

Universidade do Estado do Rio de Janeiro

São Paulo, 19 de fevereiro de 2020. 


\section{AGRADECIMENTOS}

\section{Passa um rio}

Dentro de mim

Vez em quando

Ele transborda

Esse trabalho é o jorro de muitos afluentes que deságuam em mim. É fruto de encontros silenciosos e buliçosos de águas, que fazem de um mesmo rio sempre um novo rio. $\mathrm{Na}$ correnteza da vida, aportei às margens da poesia no Açude Velho de Campina Grande, cidade que deu morada pra experiências profundas. Agradecer é lembrar desse transcurso e, sobretudo, da gente que faz parte dele.

Agradeço, primeiramente, ao Professor Paulo Teixeira Iumatti, orientador desse trabalho e norteador da minha primeira viagem pelas narrativas em folhetos, realizada através da disciplina História, Cultura Popular e Folhetos de Cordel no Brasil (Instituto de Estudos Brasileiros da Universidade de São Paulo, 2014), que principiou minha ida à Paraíba. Ainda na esfera acadêmica, manifesto meu respeito e gratidão aos professores Alberto Ikeda, Rosilene Alves de Melo e Sylvia Nemer, que subsidiaram teoricamente a pesquisa e partilharam análises significativas na banca de defesa desta dissertação.

Em Campina Grande, saúdo o poeta ancião que me mostrou as beiras da cidade, me fez ouvir a Feira Central campinense, comer e beber desse entreposto comercial: Toinho da Mulatinha (in memoriam). Na antiga Folhetaria Estrela do Oriente, residência da família do poeta, cumprimento Dona Digna, sua companheira, merecedora deste nome. Noêmia, enteada do poeta, quem me abriu muitas portas.

Dedico cada linha dessa glosa aos poetas/poetizas, cantadores/cantadoras, que versaram meus dias na Paraíba: Condor, Lindalva, Silas Silva, Diva da Vaquejada, Arnaldo Cipriano, Maroca, Poroca, Indaiá, Josafá de Orós, dentre uma lista grande de pessoas que me habilitaram a "cantar ciência" nesta Dissertação. Agradeço às filhas do poeta Manoel Monteiro, Kátia e Valentina, pelas prosas em meio a centenas de histórias em brochuras. Aos feirantes da Feira Central de Campina Grande (PB), por me alimentarem de diversas formas no período em que me instalei na Rua Quebra Quilos (2016), por me ensinarem sobre pesos e medidas da balança social. A Agnaldo Batista, administrador da Feira Central de Campina Grande, por sustentar a pisada naquele chão. À Severina Tavares (in memoriam) e Antônio Silva, agricultores e feirantes da feira orgânica de Campina Grande, por dividirem comigo segredos da terra. 
Meus genuínos agradecimentos a Gabriel Mendes, meu companheiro de tantas caminhadas, que semeou comigo tudo isso, tecendo nosso ninho, nossos nós, cá e lá. Ogã cantador da ancestralidade, Gabriel é também sabido do presente e me ensina diariamente sobre estar inteira no aqui e no agora. Nesse instante, se lê um impresso formatado graficamente por ele.

Juntos, homenageamos as/os parceiras/os que fizeram Campina grande na nossa história de vida e me abrigaram em incursões a campo: Arlandson Matheus Oliveira, Bruno Ambrosino, Evellyn Lima, Izabelle Cristina, Laise França, Lucas Medeiros, Luiz Arthur Saraiva, Marcella Alencar, Maria Luiza Pereira, Martha Ysis Cabral, Rebeca Souza e Victor Rafael da Silva. Especialmente, Jussara Costa, professora arretada que nos ensinou sobre micropolíticas, nos levou pra ver o luar do sertão. A Paraíba na sua voz é um Galope à Beira Mar. Na linha das professoras porretas, agradeço à Joseilda Diniz, pesquisadora comprometida e enamorada da poesia, pela parceria na realização de projetos com os poetas locais, por me receber com café. Sem açúcar com afeto.

Celebro as amizades compositoras dessa travessia, todas aquelas "daninhas" que brotaram no asfalto de uma cidade de milhões de habitantes. Nomeadamente, Nádia Bosquê e Giovanni Fernandes, irmãos que São Paulo me deu.

Agradeço às mulheres acadêmicas da minha vida: Larissa Pelúcio, minha mãe, autora da poesia em minha biografia. Movedora de ventos que, mesmo na sua jornada tripla, criou condições para uma educação sensível e libertadora. Olgaíses Maués, minha avó, antes disso, admirável professora e militante, por viabilizar minha graduação na capital paulista, por dividir comigo vivências em São Paulo e em outros cantos da terra. Ainda na família materna, agradeço ao voinho, Flamarion Pelúcio, veterano de batalhas políticas, figura que não deixou a brutalidade tirar a magia da existência. Ao meu queridíssimo tio Flamarion Maués, historiador, o mais velho entre todos nós.

No campo das artes, agradeço ao meu pai Mário Pizzignacco, homem terno que desenha a vida em linhas sinuosas. Meu guia espiritual. Com todo carinho, agradeço aos meus avós paternos, Rodolfo e Luiza Pizzignacco, por me inserirem no universo livresco, por estarem no cerne das minhas experiências estéticas e afetivas.

Às minhas irmãs Giulia e Tainá, mulheres fortes com as quais dividi a meninice. À Helena, nossa luz, minha sobrinha, por me ensinar sobre esse fenômeno que chamamos de vida. À saudosa cabocla Julieta, firmeza das nossas raízes. 


\section{RESUMO}

Esta dissertação de mestrado, inserida na linha de pesquisa "Brasil: tensões, rupturas e continuidades entre passado, presente e futuro", tem como objetivo central dimensionar os processos sociais, culturais e históricos que impactaram a edição e a circulação dos folhetos de feira (cordel) em Campina Grande - Paraíba, por meio da análise da trajetória e produção do poeta Toinho da Mulatinha (Antônio Patrício de Souza, 1925 - 2016). A pesquisa, propõe uma perspectiva expandida sobre a obra do poeta-embolador (1950 - 2010), mas tem como baliza cronológica medular o período entre as décadas de 1950 e 1980, no qual o cordelista circulou ativamente pelo itinerário geo-poético paraibano - cantando embolada de coco e comercializando folhetos de feira - e desenvolveu extensa produção de cordel em tipografias especializadas no gênero, fundando a "Folhetaria Estrela do Oriente". Poeta de profissão mantenedor de banca de folhetos durante 60 anos na Feira Central de Campina Grande, Toinho propiciou encontros com agentes do circuito folheteiro campinense substanciais para a composição desse trabalho: Manoel Camilo dos Santos (poeta-editor), Antônio Lucena (poeta-xilogravador), José Alves Sobrinho (poeta-pesquisador) e Manoel Monteiro, propulsor do "novo cordel" na cidade. Ao atravessar o auge e a queda da indústria gráfica especializada em folhetos na Paraíba, Mulatinha reinscreveu sua produção no início do século XXI de acordo com as possibilidades técnicas/financeiras de materialização das próprias publicações, auferindo resultados estéticos que desafiam imaginários folcloristas enraizados nas políticas públicas da terra do "Maior São João do Mundo". Nessa direção, essa dissertação tem como principais eixos de discussão: A relação entre forma artística e forma social no âmbito dos processos de globalização econômica e mundialização da cultura; os sistemas de hibridação cultural (entre cultura popular tradicional, cultura letrada e indústria cultural) no quadro das transformações da produção, difusão e consumo da literatura de folhetos em Campina Grande; os movimentos de descolonização intelectual no Brasil e as vinculações dos/as cordelistas com universidades locais; a gestão municipal dos bens culturais campinenses no contexto de mercantilização dos patrimônios nacionais. Os processos de patrimonialização da Feira Central de Campina Grande (2017) e da Literatura de Cordel (2018) pelo Instituto do Patrimônio Histórico e Artístico Nacional (Iphan), motivam análises relativas às dimensões implicadas nas ações de fomento e salvaguarda das culturas populares na contemporaneidade, abrindo espaço para exposição das tensões e negociações entre diferentes campos de saber/ poder e das práticas de (r)existência urdidas por aqueles/as que aprenderam a viver nas "brechas". Trata-se de uma investigação multidisciplinar inserida na área de concentração de "Estudos Brasileiros", na qual a pesquisa documental, o trabalho de campo e a coleta de narrativas, subsidiada teoricamente pela História Oral, constituem recursos metodológicos centrais no levantamento dos dados que suscitam as discussões inscritas neste texto.

Palavras-chave: Toinho da Mulatinha; Folhetos de Feira (cordel); Embolada de coco; Feira Central de Campina Grande (PB); Tipografias e Folhetarias em Campina Grande; Patrimônio Cultural Imaterial. 


\section{ABSTRACT}

This Master's dissertation, inserted in the research line "Brazil: tensions, ruptures and continuities between past, present and future", has as its central objective to dimension the social, cultural and historical processes that impacted the edition and circulation of the fair leaflets in Campina Grande - Paraíba, through the analysis of the trajectory and production of the poet Toinho da Mulatinha (Antônio Patrício de Souza, 1925 - 2016). It is, therefore, a multidisciplinary research within the concentration area of "Brazilian Studies". I use oral history, ethnography and documentary research as central methodological resources in collecting data that raise the discussions included in this text. Although it proposes an expanded perspective on the poet-embolador's work (1950 - 2010), the research has as its central chronological goal the 1950 s to 1980 s, a period in which it actively circulated through the Paraiban geo-poetic itinerary, singing "embolada de coco" and fair leaflets ("cordel”), and has maintained extensive / extensive production in specialized / non-specialized brochure printers, founding the "Folhetaria Estrela do Oriente". A professional poet who held a booklet trading stand for 60 years at the Campina Grande Central Fair, Toinho provided meetings with agents from the Campinese leaflet circuit that were substantial for the composition of this work: Manoel Camilo dos Santos (poet-editor), Antônio Lucena (poet-illustrator), José Alves Sobrinho (poet-researcher) and Manoel Monteiro, propeller of the "Novo Cordel" in the city. Passing through the heyday and fall of the leaflet printing industry in Paraíba, Mulatinha rewrote its production at the beginning of the 21st century according to the technical / financial possibilities of materializing the publications themselves, yielding aesthetic results that challenge folkloric imaginary rooted in public policy from the land of the "Maior São João do Mundo". Thus, the main axes of discussion presented from the research developed in this dissertation are relationship between artistic form and social form in the context of the processes of economic globalization and globalization of culture; cultural hybridization systems (between traditional popular culture, literate culture and cultural industry) in the context of transformations in the production, diffusion and consumption of the literature of leaflets in Campina Grande; intellectual decolonization movements through popular verse literature and poets' links with local universities; municipal management of the cultural goods in the context of commodification of national heritage. The patrimonialization of the Central Fair of Campina Grande (2017) and Cordel Literature (2018) by the Instituto do Patrimônio Histórico e Artístico Nacional (Iphan), exposed through this research, encourages analyzes related to the dimensions involved in the actions of fostering and safeguarding popular cultures in contemporary times, making room for the exposure of tensions and negotiations between different fields of knowledge / power and (r)existence practices created by those who have learned to live in the "on the shores".

Keywords: Toinho da Mulatinha; Fair Flyers (“cordel”); Embolada de coco; Campina Grande Central Fair (PB); Printers and Booklets in Campina Grande; Cultural Heritage. 
Coordenação de Aperfeiçoamento de Pessoal de Nível Superior (CAPES) vigência: 01/12/2017 - 01/06/2018

Fundação de Amparo à Pesquisa do Estado de São Paulo (FAPESP) vigência: 01/06/2018 - 30/11/2019 número do processo: 2017/21761-0 


\section{SUMÁRIO}

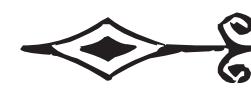

Histórias que vós me nordestes 12

Introdução: percursos narrativos 14

Materiais e métodos: modos de saber/fazer 21

Capítulo 1 - A FEIRA E A VOZ 27

0 Marco da Borborema 29

Um poeta de Esperança na Grande Campina 45

Embolando caracteres 62

0 vendedor de canções 71

Capítulo 2 - UMA VIAGEM GEO-POÉTICA (1950 - 1960) 78

Histórias pasmosas de brochuras populares 80

Nascimento, vida e milagres da Estrella da Poesia na Serra da Borborema 88

Aventuras de um narrador peregrino 102

Dois matutos nos trilhos da modernidade 117

Capítulo 3 - A MODERNIDADE COMO PROMESSA E COMO RUÍNA (1960 - 1980) 138

0 esvanecer da Estrella da Poesia 140

0 cintilar da Estrela do Oriente 149

Estrelando na "cultura" 173

Capítulo 4: PURA (CON)TRADIÇÃO [1980 - XXI] 185

A veia poética da política campinense 187

Xerocar o passado, imprimir o futuro 206

Novos suportes para uma prática anciã 224

À margem do novo Açude Velho 234

Desembolando narrativas 246

Considerações finais 247

Referências 257

Referências bibliográficas 258

Referências literárias - cordéis 270

Referências das entrevistas 278

Lista de figuras 280

Corpus central da pesquisa (Toinho da Mulatinha) 287

Folhetos do acervo da Biblioteca de Obras Raras Átila Almeida 288

Folhetos do acervo da pesquisadora 291

Manuscritos do acervo da Folhetaria Estrela do Oriente 293

Folhas-soltas do acervo da Folhetaria Estrela do Oriente 295

Matrizes de xilogravura do acervo da Folhetaria Estrela do Oriente 295

Matriz de zincogravura do acervo da Folhetaria Estrela do Oriente 297

Clichês fotográficos do acervo da Folhetaria Estrela do Oriente 297 
histórias que vós

me nordestes 


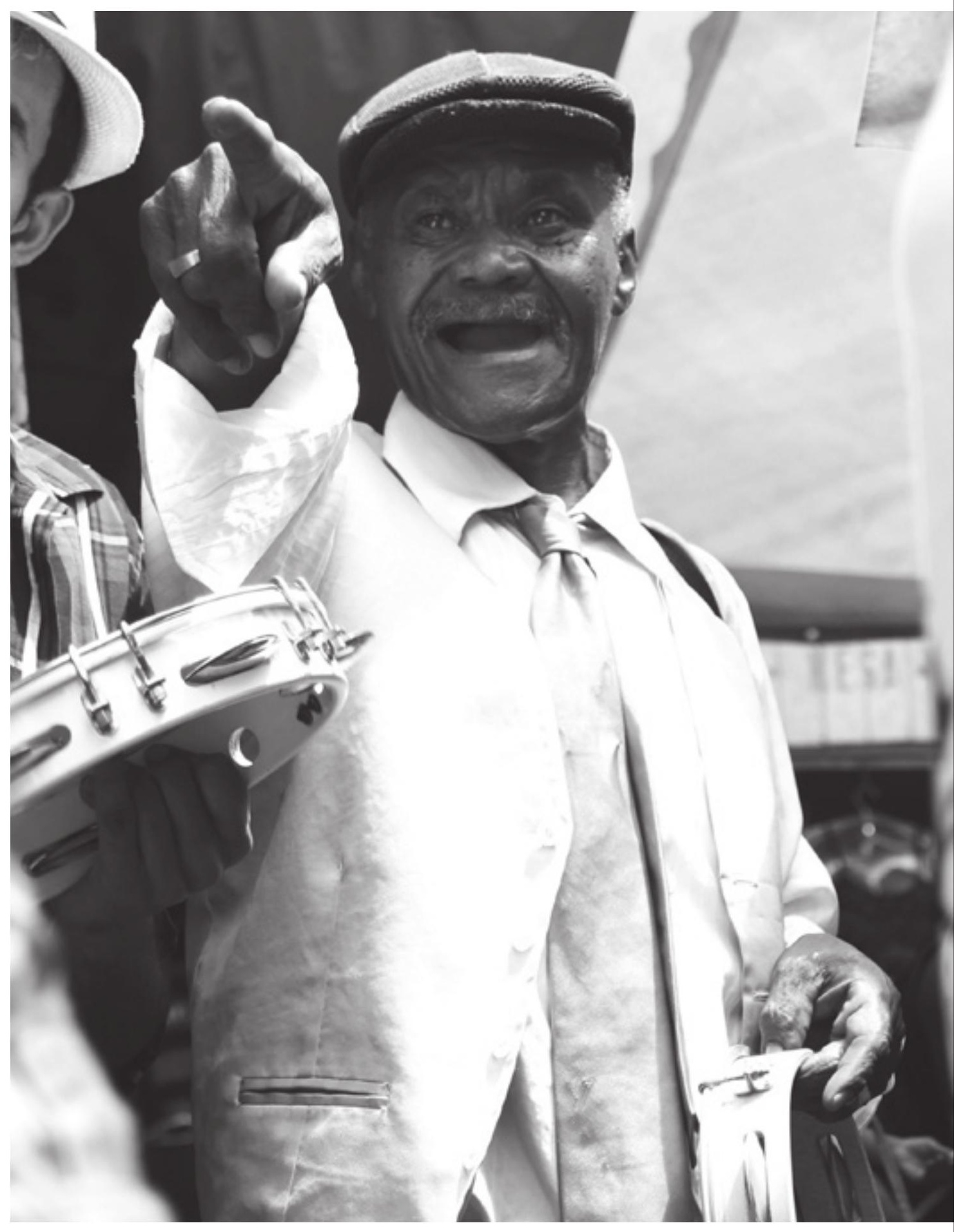

Figura 1 - Sábado de embolada na Feira Central de Campina Grande - Lua Nova no arranco do grito

Fonte: Milla Pizzignacco, 2016 


\section{INTRODUÇÃO: PERCURSOS NARRATIVOS}

Antes de se tornar uma pesquisa acadêmica, esse trabalho é fruto de uma viagem que fiz em busca de histórias, aquelas que mesmo quando capturadas pelo papel, materializadas em folhetos, continuam a se propagar pelos ventos, equilibrando-se no balanço de pandeiros e ganzás, nas cordas dos violeiros, nas vocais de poetas e de tanta gente que teve a oralidade como fonte primordial do saber.

A fim de ouvir as vozes dos poetas denominados populares e me aproximar da literatura de folhetos, viajei em janeiro de 2015 com objetivo de percorrer algumas cidades dos estados de Pernambuco, Paraíba e Ceará, tríade por onde os folhetos de feira circularam com mais destaque em seu apogeu, meados do século XX, sobretudo por configurarem um núcleo tipográfico expressivo no que se refere à impressão dessas publicações ${ }^{1}$. Acabei me fixando em Campina Grande - Paraíba, não por acaso, mas em função de um conjunto de fatores relevantes que me levaram a fazer desta experiência uma pesquisa acadêmica - Trabalho de Conclusão de Curso em Artes Visuais na Universidade Estadual Paulista “Júlio de Mesquita Filho” (UNESP), Histórias que vós me Nordestes - Discursos sobre 'o popular' em Campina Grande ${ }^{2}$.

O ingresso no "Programa de Pós-Graduação Multidisciplinar em Culturas e Identidades Brasileiras” no Instituto de Estudos Brasileiros da Universidade de São Paulo - IEB/USP (2017), representou na minha trajetória acadêmica, a possibilidade de explorar as ramificações profícuas oriundas de Histórias que vós me Nordestes sob orientação de pesquisadores/as experientes. Na dissertação de mestrado ora apresentada, adenso investigações sobre a vida e a obra de uma personagem que embolou a Feira Central de Campina Grande (PB) durante meio século, a quem pude conhecer ainda vivo, Toinho da Mulatinha (Antônio Patrício de Souza, 1925, Esperança, PB - 2016, Campina Grande, PB).

Raizeiro, poeta folheteiro e embolador de coco, Toinho da Mulatinha simboliza uma geração de poetas/poetisas de bancada responsáveis por práticas orais de socialização do escrito e pela circulação de narrativas em brochuras, que fizeram dos versos impressos em folhetos possibilidade concreta de sobrevivência, licença poética

1 Esta viagem foi instigada pela disciplina "História, Cultura Popular e Folhetos de Cordel no Brasil", lecionada pelo Prof. Dr. Paulo Teixeira lumatti, no Instituto de Estudos Brasileiros, cursada em 2014.

2 Em pesquisa anterior, realizada no Instituto de Artes da UNESP (IA/UNESP), propus historicizar a forma como instituições governamentais, acadêmicas e museológicas apoiam e anunciam as culturas denominadas populares, localizando as operações científicas e políticas que colocam "o popular" e "o Nordeste" em cena em Campina Grande, Paraíba. Para empreender esta discussão foram analisadas ações específicas de fomento e salvaguarda das culturas populares - relativas aos folhetos de feira, poetas/poetizas e o local de comercialização dessas publicações, a Feira Central da cidade - realizadas pelo Governo Municipal campinense, pela Universidade Estadual da Paraíba (UEPB) e pelo Museu de Arte Popular da Paraíba (MAPP). 
para "ter voz" em uma sociedade hierarquizada. Reavivar a trajetória deste poeta é tocar em questões concernentes a uma prática cultural inextricavelmente ligada às feiras e viabilizada por uma maquinaria editorial complexa.

Através da análise da produção de Toinho da Mulatinha, proponho ao longo do texto, dimensionar os processos sociais, culturais e históricos que impactaram a edição e circulação dos folhetos de feira em Campina Grande (PB). Para tanto, este estudo, inserido na linha de pesquisa "Brasil: tensões, rupturas e continuidades entre passado, presente e futuro”, abrange uma perspectiva expandida sobre a obra do poeta-embolador, atravessando as décadas nas quais manteve sua produção ativa (1950 - 2010).

Poeta de profissão pertencente a uma geração oriunda do universo rural e semianalfabeto, Toinho manteve banca de comercialização de folhetos durante mais de 60 anos na Feira Central de Campina Grande (PB) e uma folhetaria ativa em sua própria residência, a Folhetaria Estrela do Oriente. Imerso no período áureo da indústria gráfica especializada em folhetos na Paraíba, desenvolveu intensa/ extensa produção entre as décadas de 1950 a 1980 - baliza cronológica fulcral dos três primeiros capítulos desse trabalho.

Ao atravessar a queda do circuito tipográfico do gênero, o poeta realocou sua produção, no desfecho do século XX, recorrendo a recursos alternativos ao meio gráfico hegemônico para viabilizar a tiragem de suas edições. As estratégias urdidas por Toinho e colegas de profissão para sobreviver no lado B da modernidade, respaldam o espinhoso debate sobre "culturas populares" e as reavaliações históricas acerca da literatura de folhetos, que tensionam teorias folcloristas prenunciadoras do "fim do cordel".

Em prol de uma perspectiva sistêmica, busco no decorrer da dissertação reconstituir a trama de relações estabelecidas dentro do circuito campinense específico do gênero. Nesse sentido, Toinho aparece como fio condutor de histórias de folhetos e de histórias de vida que se cruzam - histórias individuais que são também sociais. Como poeta itinerante, Toinho promoveu muitos encontros, inserindo na tessitura narrativa personagens substanciais na constituição de um campo profícuo para o desenvolvimento desta prática cultural na cidade, tais como: Manoel Camilo dos Santos (poeta-editor), Antônio Lucena (poeta-xilogravador), José Alves Sobrinho (poeta-pesquisador), Manoel Monteiro, poeta-escritor do "Novo Cordel” em Campina Grande.

Os encontros com essas figuras viabilizaram o acesso a narrativas abafadas pelos discursos historiográficos que construíram Campina (como) Grande. Na tentativa de reconstituir memórias da poesia de cordel na Paraíba, amarrando-as ao presente, essa pesquisa se vale das narrativas de feirantes, de poetas campinenses, mas sobretudo de folhetos de feira. Afinal, os papéis, os tipos móveis e os diferentes tipos de gravura 
que compõe a primeira impressão do consumidor de folhetos são ilustrativos de uma história que está aquém e além do conteúdo dos folhetos, a história do circuito editorial da literatura popular em verso em Campina Grande.

Nessa caminhada extensa, seguindo os passos de um poeta que viveu quase um século e comercializou folhetos por mais de meio século pelo estado da Paraíba, a dissertação não inclina-se ao biografismo, mas às mudanças socioculturais significativas desenroladas no contexto nacional ao longo da segunda metade do século XX e suas reverberações na vida de poetas nordestinos que fizeram de Campina Grande um parnaso. Busca-se interpretar esse passado, conferindo-lhe sentidos que respondam inquietações contemporâneas, eminentes no último capítulo dessa pesquisa.

Para desenvolver as problemáticas apontadas, o texto foi estruturado da seguinte forma ${ }^{3}$ :

“A Feira e a voz”, abre a dissertação exibindo narrativas históricas, impressas em folhetos, que tendem a fincar Campina Grande (PB) como um Marco na Serra da Borborema. Nelas, a Feira Central da cidade aparece como fundamento dessa edificação, responsável por assentar um terreno fértil para a economia da cidade e fazer brotar a identidade campinense. A Feira, registrada como Patrimônio Cultural Imaterial da Humanidade pelo Instituto do Patrimônio Histórico e Artístico Nacional (2017), é exibida ao longo do capítulo como um lócus de sociabilidade, memória, trocas culturais e resistência (ARAÚJO, 2006).

Localizada na intersecção de muitas vias que se cruzam, a Grande Campina é abordada como ponto alto da trajetória de cantadores/as, poetas/poetisas e editores/ as de folhetos que projetaram suas vozes, armaram suas bancas e tipografias na feira campinense, ou em seu entorno, em meados do século XX. Relatos de poetas, assim como trechos de folhetos de Toinho da Mulatinha, que guardam vozes iminentes, articulam as relações entre o comércio de folhetos na feira, os pregões - "gênero verbal da praça pública” (BAKHTIN, 1993) -, e a performance na cantoria (ZUMTHOR, 2000).

A relação de Toinho da Mulatinha com o coco de embolada é explorada, ao longo da biografia do poeta composta neste capítulo,com intuito de enfatizar sua relação com poéticas orais de matriz afro-brasileira (IUMATTI, 2014). Questões acerca dos trânsitos entre texto escrito e vocalizado ganham contornos empíricos por meio do levantamento de "índices de oralidade” (GALVÃO, 2001) chancelados na produção impressa do poeta. Estes elementos, imagéticos e textuais, são analisados em prol de uma concepção "verbivocovisual” de suas publicações, e, de maneira mais alargada, deste gênero literário.

3 Assinalo, entre parênteses, as/os principais autoras/es que aportam as temáticas que o subsidiam. 
O segundo capítulo, “Uma viagem geo-poética”, aproxima a/o leitor/a das brochuras que arrancaram versos em meio ao ambiente polifônico das feiras, convidando-a/o a observar, na palavra impressa, os mecanismos que viabilizaram a existência da literatura de folhetos no Nordeste brasileiro. Para tanto, o primeiro deslocamento realizado nesse capítulo é longínquo, no tempo e no espaço: conduz ao cais de desembarque de "histórias baratas ao gosto do povo", vindas de além-mar, no Brasil oitocentista (ABREU; BRAGANÇA, 2010). A partir desse preâmbulo, tencionouse inscrever a literatura popular em verso desenvolvida no país na historiografia da editoração, suprimindo narrativas essencialistas e/ou excludentes acerca das manifestações culturais denominadas populares. Ao mesmo tempo que pretendeu-se evidenciar os aspectos que singularizam as "brochuras módicas" nacionais.

Com essa superfície preparada, insere-se na trama narrativa o mais influente editor especializado no gênero na Paraíba de meados do século XX: Manoel Camilo dos Santos. Personagem que fez de Campina Grande mote para sua epopeia com a poesia impressa, Camilo é figura fundamental para compreendermos as estruturas do circuito editorial não hegemônico na cidade (DIAS, 2009), assim como o movimento de popularização da literatura de folhetos em um país de leitura rarefeita. A instalação da tipografia do poeta-editor na Feira Central de Campina Grande (1957), A Estrella do Oriente, marca seu ápice produtivo e reforça a relação imbricada entre feira e folheto, circunscrita no início desse trabalho de pesquisa. Poeta-empresário aliado às tecnologias acessíveis no período, corrobora na dissolução de concepções arcaizantes sobre o cordel, aliando esse fenômeno cultural aos processos de modernização, industrialização e urbanização do país.

Nessa passagem do trabalho de pesquisa, Toinho da Mulatinha pega carona nos trilhos do progresso e dos trens remanescentes do período áureo da economia algodoeira em Campina Grande, integrando a narrativa acadêmica como agente ativo na rede de distribuição da literatura de folhetos no estado da Paraíba. O ciclo do algodão tece vínculos com a vida do poeta-itinerante por determinar os trajetos dos poetas-cantadores e poetas-mascates (vendedores de folhetos) pelo mapa da Paraíba. O circuito geo-poético estabelecido no estado é apresentado pelas linhas marcadas pelos pés e pela voz de Toinho, exemplar narrador benjamianiano (1985), que deixou fixado em manuscritos emboladas nas quais “canta ciência” enumerando os lugares que (en)cantou.

As biografias de Manoel Camilo dos Santos e Toinho da Mulatinha são colocadas lado a lado e lidas através da "dialética da ordem e da desordem" (CANDIDO, 1970), por meio da qual busca-se analisar a oscilação dos poetas entre a esfera da vida moderna urbana, cada vez mais racionalizada, e a aquela propensa à relativização dos protocolos, bem representada pelo espaço da feira, atravessado por relações mais orgânicas, pela 
ética da "malandragem" - capaz de transfigurar dores sociais em alegrias culturais. Os paraísos utópicos engendrados em versos pelo poeta-embolador e pelo poeta-editor, Uma viagem à Lua (MULATINHA, 1945) e Viagem a São Saruê (CAMILO DOS SANTOS,1948), apresentam, nesse capítulo, os modos como estas personagens se colocaram como poetas, complexificando as formas de existir nessa profissão, e expõe seus sonhos de viver sob "outra ordem” em uma sociedade socialmente estratificada.

"A modernidade como promessa e como ruína”, terceiro capítulo da dissertação, exibe o movimento de declínio da Estrella da Poesia e, por conseguinte, do circuito de folhetos em Campina Grande, impulsionado por transformações socioculturais vinculadas a processos políticos "modernizatórios" e globalitários (SANTOS, 2003) que abalaram concreta e simbolicamente a literatura de folhetos a partir da década de 1960 (MELO, 2010). A Feira Central campinense é circunscrita nesse contexto como um espaço que, de signo de prosperidade da cidade passa a ser reconhecido como uma chaga que macula as aspirações grandiosas da Rainha da Borborema.

A Folhetaria Estrela do Oriente, inaugurada por Toinho da Mulatinha na década de 1970, norteia o trabalho para o espectro das resistências impressas pelos poetas de bancada no período de crise do comércio folheteiro. No intermédio do capítulo 3, examina-se a produção editorial de Mulatinha, materializada em tipografias nãoespecializadas em folhetos - as quais busca-se mapear.

Com intuito de delinear as parcerias estabelecidas entre o embolador-folheteiro e agentes do seu campo profissional, são cotejados ao longo do texto, publicações de editadas por Toinho da Mulatinha pertencentes ao acervo da Biblioteca de Obras Raras Átila Almeida e materiais armazenados na Folhetaria Estrela do Oriente - manuscritos e matrizes de gravura (tutelados pela viúva do poeta). Nesse processo de reconstituição de encontros, o xilógrafo Antônio Lucena ganha relevo na narrativa, tanto por calcar ilustrações em inúmeras capas de Toinho da Mulatinha, quanto por desafiar estigmas estéticos sobre a gravura popular (RAMOS, 2010), introduzindo questões substanciais para o desenvolvimento dos próximos tópicos da dissertação.

O trabalho adquire dimensão metalinguística por meio da exposição do processo de formação do acervo de folhetos de Toinho da Mulatinha salvaguardados pela Biblioteca de Obras Raras Átila Almeida, assim como através de discussões sobre a relação entre poetas/poetizas e acadêmicos/as. O poeta José Alves Sobrinho, um dos responsáveis pela salvaguarda da coleção referida, mobiliza o debate sobre os trânsitos entre campos de saber/poder (BORDIEU, 2003), sobretudo, pelo fato de ter atuado como pesquisador vinculado à Universidade Federal da Paraíba, a partir de 1977. Nesse capítulo exibe-se os desdobramentos práticos desse contato fronteiriço, promovidos pelas mudanças epistemológicas relativas às práticas culturais 
tradicionais no campo acadêmico, que culminaram no rompimento com matrizes ideológicas folcloristas (MELO, 2019b).

“Pura (con)tradição” é um capítulo motivado pelos vazios encontrados na produção de Toinho da Mulatinha nas duas últimas décadas do século XX, justamente no momento em que a literatura de cordel se consolida como campo de pesquisa. $\mathrm{O}$ folheto O Maior São João do Mundo e a Micarande em Campina Grande (MULATINHA, 1992), financiado pela prefeitura municipal no período abordado, provocou o campo investigativo, conduzindo reflexões sobre os projetos políticos implementados pelos criadores das festas publicizadas em verso: Ronaldo e Cássio Cunha Lima, prefeitos que não mediram esforços para transformar a falida Capital do Trabalho em uma Capital Cultural, a partir da década de 1980 (GEMINIANO DOS SANTOS, 2016). Ao longo deste excerto mostra-se a institucionalização do uso espetacular do "patrimônio cultural" (IKEDA, 2013) em Campina Grande e as manifestações, na contemporaneidade, desse projeto político prenhe de "tradições inventadas" (HOBSBWAN; RANGER, 1997).

Às margens da terra do Maior São João do Mundo, Toinho da Mulatinha passa, no início do século XXI, a diagramar e realizar as tiragens das publicações editadas na Folhetaria Estrela do Oriente por meio da máquina fotocopiadora (xérox), ilustrandoas com colagens de imagens oriundas de jornais e revistas - recursos utilizados por alguns poetas que resistiram produzindo na década de 2000. Nesse tópico, apresentase os procedimentos de composição e impressão implementados na "tipografia de improviso" de Toinho da Mulatinha, perscrutando em que medida estes reatualizam as técnicas peculiares dos antigos prelos tipográficos. No trecho dedicado à segunda fase de produção do poeta-editor, mostra-se a tradição das brochuras em suas descontinuidades e recriações, a partir de uma perspectiva crítica que considera as manifestações culturais denominadas populares como fenômenos híbridos (CANCLINI, 2001). A ênfase nas impressões fotocopiadas da Estrela do Oriente, foi realizada com intuito de incluir nesse campo de pesquisa folhetos ainda pouco explorados pelas publicações da área, talvez pelo fato de desafiarem imaginários sedimentados sobre um Nordeste e suas artes (ALBUQUERQUE, 2001).

Como fenômeno híbrido, aliado às tecnologias, o cordel chega à internet nesse ponto do trabalho (AMORIM, 2009), através de uma geração que tramou circuitos desconectados de Toinho da Mulatinha - poeta que se manteve arraigado às raízes da sua poesia, cravadas na Feira Central Campinense. No raiar do século XXI vemos a renovação de práticas discursivas no cordel, versado a partir de um vocabulário mais inclusivo, e escutamos as vozes das mulheres compositoras dessa literatura. A terminologia "novo cordel”, implementada nesse interim é discutida em suas controvérsias e lida nos folhetos paradidáticos do poeta Manoel Monteiro (MONTENEGRO, 2014). A menção a 
Monteiro, poeta que viveu a profissão em dois tempos (1950 - 1960 / 1990 - 2014), torna-se imprescindível nesse estudo, posto que é um vetor de reinscrição da poesia de bancada em novos espaços e suportes (CHARTIER, 2001) e agente que corrobora o processo de realocação de Campina Grande como um espaço privilegiado dessa literatura.

A dissertação é encerrada com os registros da Feira Central de Campina Grande e do Cordel como patrimônios culturais pelo Instituto do Patrimônio Histórico e Artístico Nacional - Iphan (2017 e 2018, respectivamente), representados em Campina Grande pela figura de Toinho da Mulatinha. Porém, esses eventos não consumam na narrativa uma "festa de encerramento", mas principiam reflexões sobre a instrumentalidade da patrimonialização e as dimensões implicadas nessas titulações (MELO, 2019a). Para tanto, coloca-se em cena as tensões e negociações em torno da Feira Central da cidade, confrontadas a partir de dois projetos de requalificação (2009/2013) desenhados para o local, que compreendem o registro da feira a partir de perspectivas distintas: (1) Como etiqueta estratégica para integrá-la ao mercado cultural da Grande Campina; (2) como via de salvaguarda das formas de apropriação do espaço urbano pelos feirantes, ameaçadas pelo projeto anterior (PIZZIGNACCO, 2019). Nesse momento destaca-se o papel dos intelectuais acadêmicos que somam suas ações com os intelectuais orgânicos da feira na luta por um projeto mais democrático para reestruturação da feira, capaz de abarcar as demandas daqueles/as que trabalham diariamente na manutenção da cultura local.

Por fim, realizamos um passeio pelo perímetro turístico da cidade, assentado nas imediações da Feira Central campinense. Em meio às tradições arquitetadas em monumentos modernos, observarmos manifestações culturais que abrem espaços de (r)existência na Grande Campina, reinscrevendo tradições que motivaram o trabalho de mestrado ora apresentado, encarnadas por Toinho da Mulatinha. 


\section{MATERIAIS E MÉTODOS: MODOS DE SABER/FAZER}

Esta narrativa começa no meio. No "meio do tempo”, como dizem “para as bandas de lá”. No meio de um "mói” de gente, nos labirintos sinestésicos da Feira campinense. No meio de histórias de folhetos e daquelas compartilhadas ao pé de uma barraca de raízes. A fim de compartilhar com a leitora e o leitor aspectos relevantes sobre o processo de pesquisa desse trabalho, retomo aproximações com o campo etnográfico iniciadas em 2015, que assentaram terreno para a continuação da minha caminhada em solo paraibano.

Mobilizada pelo interesse nas práticas de poesia oral desenvolvidas na Feira Central de Campina Grande, iniciei um trabalho de observação-participante (2015), no qual tive como mote para a prosa perguntas curiosas sobre um poeta-feirante mencionado por amigas/os da cidade que o tinha vivo na lembrança: Toinho da Mulatinha. Nas prosas com suas/seus companheiras/os de feira o poeta foi dado como falecido. E foi a morte, essa danada “Caetana”, que provocou as/os feirantes a reabrirem caixas da memória cobertas pela poeira do tempo.

Instigada, percorri trajetos que, de boca a boca, me levaram até a rua Santo Antônio, no bairro Santo Antônio, próximo à igreja Santo Antônio, onde encontrei pela primeira vez Antônio Patrício de Souza, Toinho. O cantador sem voz, seus versos sufocados em folhetos embolorados. Milhares de histórias acumuladas em um canto da casa, folhetos de sua autoria e de outros/as colegas que encontrou na caminhada de poeta itinerante. Histórias consumidas pelos fungos, pela ausência de ações palpáveis voltadas para os/as produtores/as da cultura local, apagados/as na terra do "Maior São João do Mundo" - festejo que vem sempre em boa hora para a economia campinense.

Envolvida na trama das histórias armazenadas na Folhetaria Estrela do Oriente e daquelas compartilhadas por feirantes, me fixei em 2016 na vizinhança da Feira Central de Campina Grande, tornando-me neste enredo "turista aprendiz”, não “missionária”, mas freguesa do local. Após o ingresso na Pós-Graduação retornei à Campina duas vezes, em março de 2018 e em agosto de 2019, para investigação documental no acervo da Biblioteca de Obras Raras Átila Almeida (Universidade Estadual da Paraíba), realização de entrevistas semiestruturadas e trabalho de campo.

As vivências provenientes das minhas itinerâncias de viés etnográfico pela feira, conjugadas com a aproximação teórica com a História Oral provocaram meu campo investigativo, motivando-me a fazer da pesquisa científica possibilidade de afetar também. A leitura do texto "O ensaio e a escrita acadêmica”, autoria de Jorge Larrosa (2003), foi um ponto crucial nesse processo reflexivo sobre os modos de fazer/saber, posto que sinalizou a possibilidade de trabalhar com uma razão capaz de enamorar a vida. 
Do ensaio, extraí o potencial político da escrita acadêmica afeita aos afetos: ao recusar os dispositivos reguladores do discurso, institucionalizados e institucionalizantes, e, sobretudo, homogeneizantes, derivados de forças hegemônicas, configura modos decoloniais de fazer ciência. Para Larrosa (2003), o/a pensador/a emancipado/a exercita, além da liberdade temática, a liberdade formal. Nas palavras do autor: "A liberdade de espírito não só tem a ver com a liberdade de dizer o que se queira mas, também, de dizer como se queira.” (Op. cit., p. 109), premissa que apreendi também das Artes Visuais, minha área de formação. ${ }^{4}$

Em consonância com as considerações do ensaio redigido pelo filósofo latino americano referenciado, proponho como desafio para a minha prática a diluição das fronteiras "entre escrita (se podemos dizer assim) pensante ou cognoscitiva e entre imaginativa ou poética”. (LARROSA, 2003, p.105). Penso que a produção textual acadêmica inscrita neste interstício pode criar condições para a experiência, tal como as publicações que fundamentam este estudo: os folhetos de feira - narrativas que estão sempre na iminência de propiciar uma sensibilização coletiva.

Nesse sentido, interessa a delicadeza da escrita, a superação da pretensão científica da "neutralidade do texto", imprescindível para uma pesquisa alicerçada por memórias, embasada pela História Oral. José Sebe Bom Meihy e Fabíola Holanda (2007) forneceram fundamentação teórica para a utilização de narrativas como elemento norteador do trabalho científico, revelando a História Oral como um caminho técnico, teórico e político para a constituição de fontes e para a produção de conhecimento.

A entrevista gravada, procedimento metodológico central da História Oral, foi incorporada em prol da implementação de uma dinâmica dialógica e colaborativa com os sujeitos que protagonizam a pesquisa, detentores de um papel ativo na composição do texto. Procurei aproveitar ao máximo os relatos concedidos, valorizando o que há neles de memória afetiva, subjetiva e objetiva - presentes em todas as fontes históricas.

\footnotetext{
4 A realização da intervenção urbana "Histórias que vós me nordestes" (2016), elaborada em parceria com feirantes campinenes, foi um desdobramento das reflexões que vinham inquietando minha prática acadêmica. Efetivada através da exposição de 75 retratos de feirantes nos muros de Campina Grande, fixados por meio da técnica do lambe-lambe, teve por intuito criar novas cartografias na cidade, atravessar os caminhos das/ dos habitantes que deixaram de frequentar (ou não se permitiram conhecer) a Feira, geograficamente central, mas simbolicamente marginalizada. A proposição de uma intervenção urbana com a fotoetnografia do local foi motivada pelo desejo de materializar o Trabalho de Conclusão de Curso (UNESP), em andamento naquele momento, por meio de uma outra linguagem. Mais acessível. Expandida para fora da comunidade acadêmica. Potencialmente disparadora de experiências. A ação foi realizada junto aos membros da coletiva Gaia e do coletivo Bruta Flor (Campina Grande - PB) e viabilizada por financiamento coletivo na plataforma Catarse. A execução do projeto foi registrada em matéria da TV Itararé/ Cultura (PB) - Disponível em: <https://www. youtube.com/watch?time continue $=225 \& \mathrm{rv}=$ ohE-NcuQWuM/>. Acesso em: 20 nov. 2019. Reflexões sobre 0 processo e os sentidos implicados nesta intervenção urbana foram desenvolvidas no artigo: PIZZIGNACCO, Milla Maués Pelúcio. Estetização das Disputas Narrativas sobre a Feira Central de Campina Grande (PB). In: Anais do 27o Encontro Nacional da Anpap - Práticas e Confrontações, São Paulo, 2018. p. 1083-1098.
} 
Sob a perspectiva da História Oral, a entrevista não deve ser reduzida a dado informativo. A lida com o relato requer um movimento de transcriação (MEIHY, 2002), que extrapola a atividade mecânica de transposição da voz para o texto escrito, configurando um processo de análise do discurso. Este ato interpretativo, além de agregar elementos extra-texto, cumprindo função relacional e de síntese, devolve à narrativa o gestual, o olhar, a voz - assegurados pelo registro sonoro e/ou imagético.

Os registros são sempre recortes, representações de realidades vividas e imaginadas. A sobreposição dessas camadas imaginativas, advém tanto da/do pesquisador, ao forçar a nota interpretativa no ato de elaboração textual, quanto da/ do depoente, que ao perceber que está deixando um registro em seu ato de narrar, testemunhando fatos que serão transpostos para um meio legitimador (o escrito), projeta um retrato de seu interesse, de maneira deliberada ou inconsciente. $O$ certo é que trabalhos desenvolvidos sob o viés História Oral detêm certa "literacidade" (SANTHIAGO, 2008), noção que não se reduz à mera "pitada ficcional”, mas que se relaciona com a estrutura textual das narrativas, com a articulação entre forma e conteúdo, expressa na performance do/a contador/a, na poética do/a escritor/a.

Metodologicamente a História Oral requer responsabilidade, para que as perguntas lançadas em entrevistas não busquem ecos nas respostas e os sujeitos não se tornem objetos de pesquisa. $O$ processo de trabalho com relatos exige pré-disposição à escuta, suspensão de juízos, do automatismo da ação. Atenção nos detalhes. Abertura para a arte do encontro. Da tensão entre as variáveis culturais dos/as envolvidos/as emerge a possibilidade de troca e, principalmente, de agregação.

Componho a dissertação em parceria com uma quantidade reduzida de entrevistados/as em razão de tratar-se de uma pesquisa qualitativa, que alicerça as bases de sua análise no estabelecimento de vínculos mais sólidos com alguns sujeitos da comunidade, gerando uma profundidade investigativa (MARTINELLI, 1999). As entrevistas que integram o tex to foram realizadas entre $2015^{5}$ e 2018, com trabalhadores/ as da Feira Central de Campina Grande, poetas locais e familiares de poetas falecidos. As referências das entrevistas incorporadas ao trabalho encontram-se na página 278.

Para a realização dessa pesquisa de mestrado, trabalho com a História Oral Híbrida, ou seja, a partir da combinação de relatos e outras fontes documentais, tais como: mapas da Paraíba e de Campina Grande, jornais locais, matrizes de gravura, manuscritos e folhetos de feira. Acredito que por meio do cruzamento desses registros podem ser arquitetadas hipóteses e relações mais complexas.

5 Estas entrevistas foram realizadas em razão do Trabalho de Conclusão de Curso em Artes Visuais na Universidade Estadual Paulista "Júlio de Mesquita Filho" (UNESP], Histórias que vós me Nordestes: Discursos sobre "o popular" em Campina Grande (2016). 
Desde 2015 venho construindo meu próprio arcabouço documental, recolhendo relatos e imagens dos/as trabalhadores/as da Feira Central de Campina Grande - com as quais realizei um projeto de intervenção urbana na cidade (PIZZIGNACCO, 2018) - e registrando poetas, músicos e cantadores locais/regionais, como: Toinho da Mulatinha, Lua Nova, Condor, Biliu de Campina, as Três Ceguinhas de Campina Grande (Maroca, Poroca e Indaiá), Zabé da Loca, dentre outros/as.

Ao longo dessa trajetória de pesquisa fiz inúmeras peregrinações atrás de Toinho da Mulatinha, caminhando pelas ruas de Campina Grande bati na porta de poetas/poetizas e cantadores/as radicados na cidade 6 , circulei pelos seus espaços de sociabilidade, como o Bar da Tereza - encontro dos poetas, o Bar do Genival, a Casa do Poeta e do Cantador, o Calçadão da Rua Cardoso Vieira, a Cordelaria Poeta Manoel Monteiro e adentrei instituições de memória da Rainha da Borborema (Museu do Algodão; Museu Histórico e Geográfico de Campina Grande; Instituto Histórico de Campina Grande; Arquivo Público Municipal de Campina Grande; Secretaria de Planejamento, Gestão e Transparência de Campina Grande).

Há léguas de distância da Paraíba, continuei minhas itinerâncias em busca de vestígios do cantador. Navegando pelo ciberespaço estabeleci contatos com pesquisadores/ as que recolheram fragmentos de sua história: os/as professores/as Hélder Pinheiro (Universidade Federal de Campina Grande), Maurílio Antônio Dias (Universidade do Estado da Bahia), Candace Slater (University of California) e Alyere Farias (Universidade Federal da Paraíba); com o escritor Bráulio Tavares e com o coeditor do blog "Retalhos Históricos de Campina Grande”, Emmanuel do Nascimento Sousa. Através dos correios eletrônicos trocados com estes/as colaboradores/as percebi a possibilidade de construir redes de apoio nesse segmento da escrita de bancada, o acadêmico.

Na minha primeira incursão à Campina, após afiliação ao Instituto de Estudos Brasileiros (IEB/USP), selecionei e coletei, fotograficamente, mais de duas centenas de folhetos salvaguardados pela Biblioteca de Obras Raras Átila Almeida (Universidade Estadual da Paraíba - campus Campina Grande), de acordo com categorias estipuladas: 1) Folhetos de Toinho da Mulatinha publicados entre 1955 e 1982 - 45 cordéis; 2) Publicações de Manoel Camilo dos Santos editadas durante o período em que manteve a Tipografia e Folhetaria Santos/A Estrella da Poesia instalada em Campina Grande (1953 - 1963) - 85 cordéis; 3) Brochuras de autoria de outros/as poetas/poetizas publicadas em Campina Grande entre 1953 - 1983, com atenção para aquelas de autoria dos poetas que compõem este trabalho - Dedé da Mulatinha, Manoel Monteiro, Antônio Lucena e José Alves Sobrinho - 100 cordéis. Os documentos digitalizados foram tratados em software de edição de imagens e reunidos em catálogos organizados para minha própria consulta.

6 Silas Silva da Paraíba, Josafá de Orós, Diva da Vaquejada, Arnaldo Cipriano, Biliu de Campina, Tião Lima, Condor, Lua Nova, Três Ceguinhas de Campina Grande, dentre outras/os. 
Integram o corpus central dessa pesquisa, focalizado na obra de Toinho da Mulatinha (catalogação na página 287): os folhetos registrados na Biblioteca de Obras Raras Átila Almeida (45); manuscritos (24), folhas-soltas (3) e matrizes de gravura (37) constituintes do arcabouço da antiga folhetaria do poeta, a Estrela do Oriente; publicações de Toinho componentes do meu acerco pessoal - 35 folhetos editados entre 1999 e 2008, comprados nas mãos do poeta em 2015.

A fim de tornar estes documentos fontes de pesquisa busquei fundamentos teóricos capazes de elucidar possíveis usos e necessários cuidados para a investigação dos mesmos. O livro Fontes históricas, (PINSKY; LUCA, 2005) propiciou uma aproximação com o campo da historiografia documental, ao mostrar as diferentes acepções atribuídas às noções de documentos e fontes históricas desde o século XIX e a renovação do repertório documental da disciplina ao longo do século XX. O historiador e suas fontes, organizado pelas mesmas pesquisadoras em 2009, dispôs trabalhos elaborados, por autores/as conceituados/as ${ }^{7}$, a partir de fontes focalizadas (memória, fotografia, literatura, testamentos, processos criminais, registros paroquiais e civis, arquivos de regimes repressivos, correspondências, pronunciamentos, diários e patrimônio cultural), analisadas com amparo de reflexões acerca das questões teóricas, metodológicas e técnicas que as circundam.

Antonio Celso Ferreira, um dos autores que compõe o livro mencionado, traz contribuições para esta pesquisa ao abordar a literatura como "fonte fecunda". Para o autor, o potencial das fontes literárias para o trabalho historiográfico reside no fato de serem "materiais propícios a múltiplas leituras, especialmente por sua riqueza de significados para o entendimento do universo cultural, dos valores sociais e das experiências subjetivas de homens e mulheres no tempo.” (FERREIRA, 2009, p. 61). Sua análise é pertinente na medida em que coloca a literatura como documento capaz de iluminar um contexto mais amplo.

É justamente desta relação, entre o particular e o geral - a obra/trajetória de Toinho da Mulatinha e as histórias de/dos folhetos em Campina Grande - que corporifico a análise das "Emboladas Tipográficas" que tematizam essa pesquisa. Com intuito de investigar as permanências e rupturas no percurso deste gênero pelo tempo na Serra da Borborema, busco analisar as formas como se manifesta a literatura de cordel ao longo do tempo, os suportes sobre os quais repousa, as imagens que grava no imaginário de quem a consome. O dito e o não dito na materialidade dos folhetos.

7 Ana Luiza Martins, Antonio Celso Ferreira, Caroline Silveira Bauer, Durval de Albuquerque Júnior, Elias Thomé Saliba, Flavia Galli Tatsch, Júnia Ferreira Furtado, Keila Grinberg, Leandro Karnal, Maria Silvia Bassanezi, Maria Teresa Cunha, Réne E. Gertz, Solange Ferraz de Lima, Teresa Malatian e Vânia Carneiro de Carvalho. 
As poesias inseridas ao longo do texto não servem de "adorno", elas são incluídas como fontes históricas, de maneira não hierarquizada em relação aos outros documentos, de modo que nenhum vestígio textualizado do passado ganha estatuto de verdade maior que outro. Aliás, nenhuma fonte ganha condição de prova nesse trabalho, mas de material de expressão dotado de visões possíveis sobre determinados referentes espaciais e temporais, discursos produtores de realidades produzidos por realidades específicas.

Nesse sentido, a literatura popular em verso não é reduzida nesse trabalho a uma forma poética capaz de reportar aspectos da "realidade" (que já é relativa), mas compreendida como fonte potente na "desrealização" do "real” (GONÇALVES, 2011, p. 220), posto que recria universos sociais vividos e imaginados, a partir de múltiplas relações entre esferas culturais distintas. As narrativas de folhetos, urdidas na trama do tecido social pela subjetividade de quem as compõem e de quem a lê, são "armadilhas da memória” (FERREIRA, 2004), investidas discursivas sujeitas a processos interpretativos, imaginativos e inventivos. Afinal, as fontes não são espelhos planos, mas poliedros de muitas faces, que demandam um posicionamento de quem as observa.

Embora esse trabalho lide com uma variedade de folhetos, os vazios, derivados da dificuldade de encontrar determinados vestígios verbais e imagéticos relacionados a Toinho da Mulatinha, possibilitaram interpretações profícuas sobre a historiografia da poesia em Campina Grande, vinculada a questões políticas que amarram o passado e o presente dessa cidade grandiosa, nascida na encruzilhada de muitos caminhos. A ausência de registros, nesse campo de pesquisa, sobre o poeta que deu o timbre da literatura de folhetos na Feira Central campinense é força motriz dessa dissertação, por meio da qual aprendi que escrever é uma maneira de não morrer de todo. 


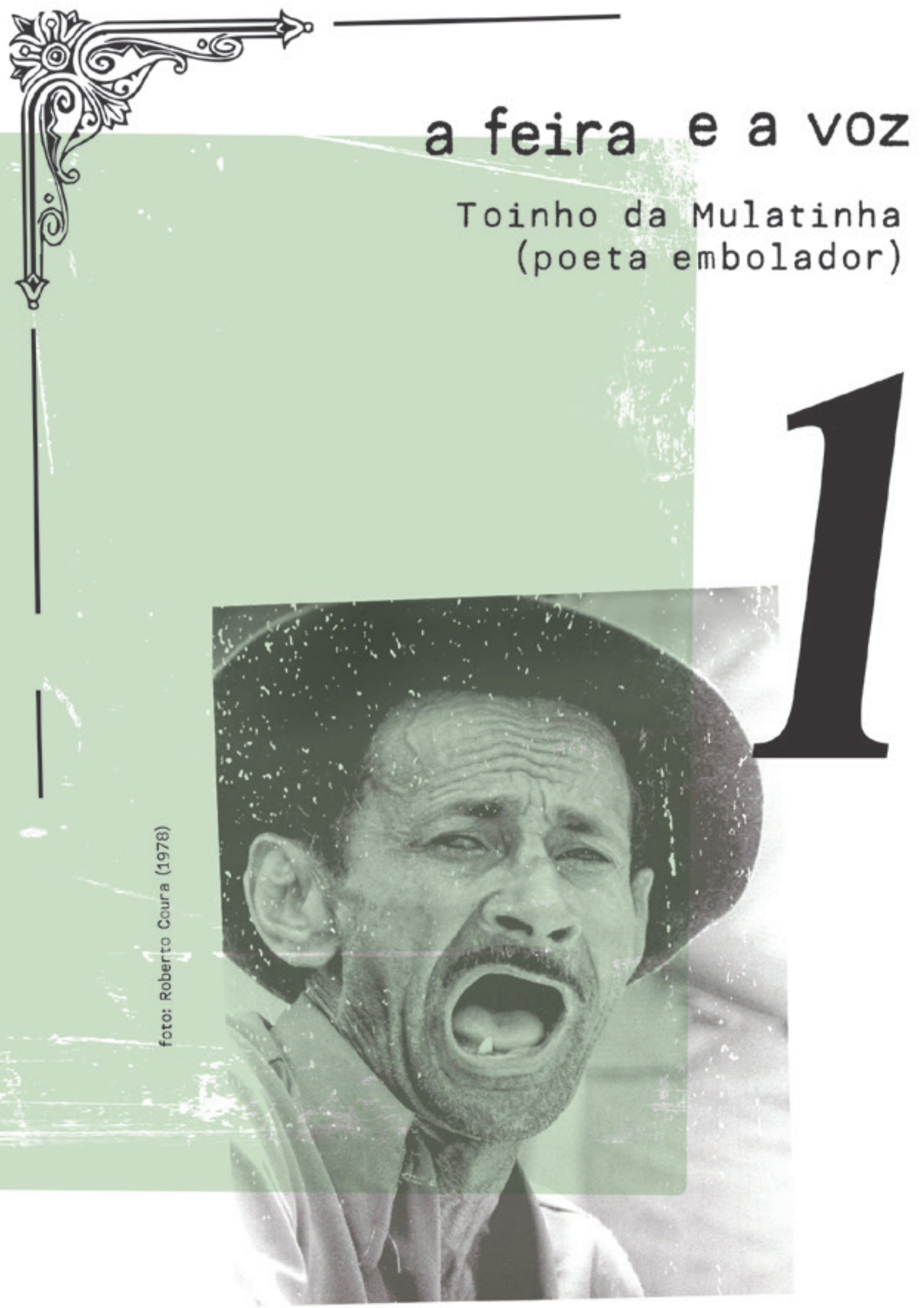




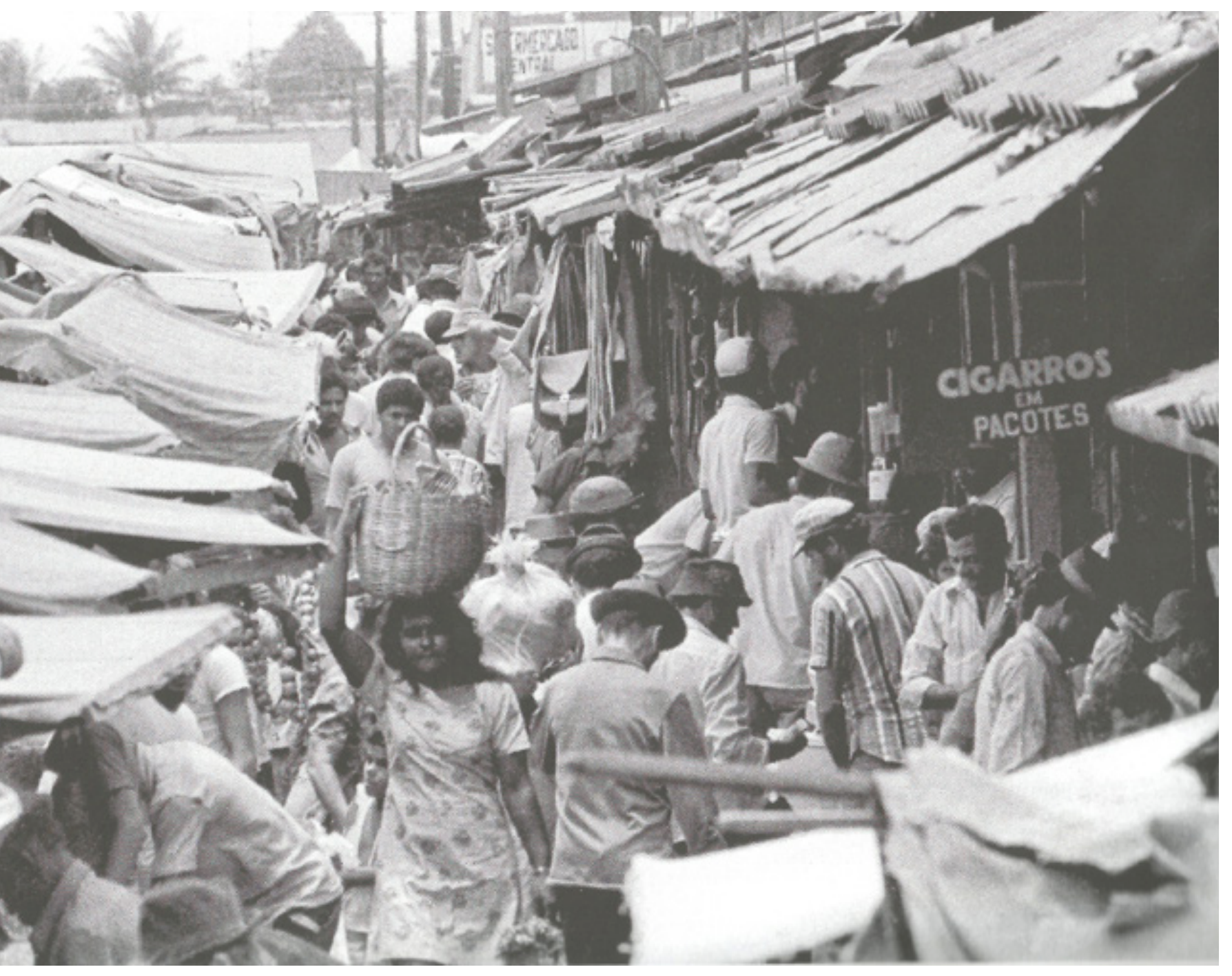

Figura 2 - Feira Central de Campina Grande (1978)

Fonte: Roberto Coura, 2014 


\title{
O MARCO DA BORBOREMA
}

\author{
Campina ponto central \\ dos sertões paraibanos \\ dos sertões pernambucanos \\ é o caminho da capital \\ de João Pessoa e Natal \\ é o centro algodoeiro \\ de beleza e de dinheiro \\ de estudo e liberdade \\ e é a maior cidade \\ do nordeste brasileiro \\ [...] \\ Aqui faço um paradeiro \\ nas belezas de Campina \\ maravilha nordestina \\ falada no mundo inteiro \\ lugar onde brasileiro \\ ganha mais fácil seu pão \\ com melodia e canção \\ com embolada e soneto \\ e no segundo folheto \\ findarei a descrição.
}

(MULATINHA, 1976, p. 03-08) ${ }^{8}$

8 MULATINHA, Toinho da. [Antônio Patrício de Souza]. Campina Grande, a Viola e as Belezas do Nordeste. Campina Grande - PB: Folhetaria Estrela do Oriente, 1976. 
A importância de Campina Grande, no estado da Paraíba, é atribuída historicamente pela fertilidade dos seus solos, e, sobretudo, pela sua centralidade geográfica. Fincada nas bordas orientais do planalto da Borborema, a povoação denominada em 1698 de Campina Grande, conformou-se como entreposto comercial cardial da região, um local de trocas e trânsitos, parada de pouso para os tropeiros e boiadeiros que viajavam entre o litoral e o sertão paraibanos, deslocando-se entre as mesorregiões do estado, como também para estados vizinhos. (ALMEIDA, 1962) ${ }^{9}$

A formação da "Rainha da Borborema” funde-se/confunde-se com o surgimento da Feira Central de Campina Grande e sua identidade é tecida por múltiplos discursos que disputam a paternidade de sua grandiosidade. Ponto central de abastecimento de farinha de mandioca da hinterlândia paraibana, dotada da principal feira de gado do interior nordestino no século XIX e polarizadora do mercado algodoeiro no início do século $\mathrm{XX}^{\mathbf{1 0}}$ - alavancado pela implantação de uma rede ferroviária espraiada pelas sub-regiões nordestinas -, a cidade-mercado manteve até a década de 1970 a função organizadora do espaço regional, sustentando acirrada disputa política com a capital do estado, João Pessoa.

De acordo com a historiadora Giovanna de Aquino Fonseca Araújo (2011), na década de 1950 a feira campinense passou a figurar como "a feira das feiras", um espaço luminoso na rede dendrítica paraibana, visto que escoava insumos pelas rodovias inauguradas para propiciar a comunicação entre mercados. Neste período, marcado pela intensificada urbanização da "Capital do Nordeste brasileiro", a Feira Central configurou-se também como um ponto de difusão de notícias, tornando-se lócus privilegiado de encontro, de lazer, de trocas imateriais e simbólicas.

A Feira, um nó que arrematava vias, tornou-se inevitavelmente um local de recepção e disseminação de novidades. Como o gramofone, "bicho falante” apresentado à sociedade campinense em 1905, recebido como um “espetáculo" que mobilizou multidões (PIMENTEL, 2001), abrigou também o primeiro cinema, em 1909, quando ainda estava localizada nos arredores da Rua Maciel Pinheiro, além do famoso Cassino

\footnotetext{
9 A tese consolidada acerca do processo de urbanização da cidade, instituída pelo historiador e político brasileiro Elpídio de Almeida (Areia, 1 de setembro de 1893 - Campina Grande, 26 de março de 1971), aponta como núcleo inicial de sua formação a ocupação dos índios Ariús (grupo pertencente a nação dos Kariri), liderada pelo CapitãoMor Teodósio de Oliveira Lêdo, em 169?. Este aldeamento apareceu como povoação, denominada Campina Grande, no mapa publicado no livro História da Guerra do Reino do Brasil, publicado em 1968. Em 1790 a povoação foi promovida à vila, sendo nomeada de Vila Nova da Rainha em homenagem D. Maria I de Portugal. 0 nome permaneceu associado à região durante 75 anos, até ser elevada à categoria de cidade, em 1864, quando torna a chamar-se Campina Grande.

10 No período de 1930 a 1950 Campina Grande ocupou a posição de maior produtora de algodão do Brasil e segundo pólo mundial em comércio de algodão, sendo o primeiro lugar Liverpool, na Grã-Bretanha. Polarizadora deste comércio reconhecido como "ouro branco" passou a abastecer o mercado internacional e ser denominada, por associação, de "Liverpool Brasileira". (ARAUJO, 2006)
} 
Eldorado ${ }^{11}$, instalado nas imediações da Feira Central em 1939 - período em que o mercado é transferido para o Bairro das Piabas, onde permanece até os dias de hoje. O geógrafo Eduardo Pazera Júnior (2003) ressalta atividades comuns às feiras da região Nordeste, designadas para variadas práticas da vida social:

\begin{abstract}
Ali são feitos os anúncios de utilidade pública. Comícios, geralmente ocorrem em dia de feira, podendo contar assim com o maior público possível da zona rural. Espetáculos artísticos, dentre eles alguns hoje ditos folclóricos, desenvolvem-se na feira. Apresentam-se espetáculos com o fito de promover algum produto, como é o caso dos remédios, ou ainda como forma de entretenimento (cuja remuneração é voluntária), a exemplo dos cantadores que evocam os trovadores medievais, apresentando riqueza em experiência e memória. (PAZERA JR., 2003, p.13)
\end{abstract}

Os "atrativos" da Feira Central campinense, aparecem nos relatos coletados para a realização desta pesquisa como experiências significativas vivenciadas naquele espaço entre os anos de 1950 e 1980. Os retalhos de lembranças individuais acerca do que ali acontecia compõe uma tessitura narrativa sobre o ambiente sociocultural da feira em suas expressões artísticas e pitorescas.

Agnaldo Batista, atual administrador da Feira Central, rememora: "Na época que eu comercializava tinha tanto palhaços, tanto aquele pessoal que trazia a cobra, o peixe elétrico, o cara que comia gilete, caco de vidro, prego... Todo sábado aqui na feira tinha um atrativo diferenciado!". Segundo este entrevistado, que começou suas atividades na feira aos oito anos de idade, "era isso que fazia a gente, quando criança, levar 'puxavante' de orelha. Porque a gente parava de trabalhar para poder ver estes artistas aqui dentro da feira."

O carregador de mercadorias Luiz Beleza se recorda de "um tal de mamulengo", e descreve: "O cabra pegava um canto de parede, botava a cortina e ficava fazendo teatro com boneco em cima da cortina. Agora, aquilo era tudo! Era contando história, era discutindo, brigando de faca e coisa e tal. Eles manobrava os boneco na mão, era uma agilidade que eles tinha!" ${ }^{13}$

De acordo Dona Teresa Gorda, comerciante de carnes no Mercado Central, "Tinha cantador de coco, cantador de viola... poeta de toda qualidade! Hoje não existe mais isso aqui. Eles diz que é folcloro. Se tem esse tal de flolcoro é pra banda de lá, porque aqui dentro num vem mais não.” A feirante se lembra com alegria de dois cantadores que versavam sua rotina: “Tinha Dedé da Mulatinha e tinha Toinho. Era dois irmãos. Um era

11 O Cassino Eldorado foi uma casa de espetáculos, jogos, dança e prostituição construída em 1937 na Rua Manoel Pereira de Araújo, localizada nas adjacências da Feira Central. A edificação, em estilo art déco, foi um espaço significativo de sociabilidade para os "barões do ouro branco", a elite agrária local. (SOUZA, 2005) 12 BATISTA, Agnaldo. Depoimento [jul. 2015]. Entrevista concedida à pesquisadora. Campina Grande (PB), 2015. As demais declarações de Agnaldo Batista têm como fonte esta entrevista.

13 BELEZA, Luiz. Depoimento [jul. 2015]. Entrevista concedida à pesquisadora. Campina Grande (PB), 2015. 
branco e o outro era negro, bem moreno. [...] O Dedé até oito anos atrás andava aqui pela feira. E Toinho, nunca mas eu vi ele não, com certeza foi-se embora também, viajou."14

Os cantos e os pregões entoados, o brado dos balaieiros pedindo passagem, a prosas lançadas entre barracas orquestram o ambiente polifônico das Feira. Esta "territorialidade subjetiva" (GUATTARI, 1985), modo como a coletividade vivencia e concebe o espaço, faz da feira campinense um lugar de representação.

A feira é conformada como um tecido espacial costurado por relações de proximidade, de apadrinhamento, vizinhança e amizade, entre feirantes e fregueses, que mantêm relações delonga data. Nela as forçascentrípetasprópriasdas "horizontalidades" (SANTOS, 1999) reforçam o lugar, conformando o espaço “do acontecer homólogo", onde os agentes reconhecem sua interdependência. A sociabilidade e as trocas mercantis se organizam mutuamente, de modo que a competição apregoada é permeada por uma solidariedade orgânica que beneficia a potência local.

Em contraponto à lógica moderna de produção e regulação dos espaços urbanos, as feiras constituem-se como ilhas de vivência comunitária na cidade, localizadas em espaços abertos, espontâneos e públicos, em seu sentido mais completo, sendo estes, de acordo com Leite (2008), estruturados por um conjunto de ações que lhe atribuem sentido. Nesta perspectiva "a feira livre representa uma experiência peculiar de sociabilidade e de uso da rua, uma territorialidade alheia ao projeto dominante" (MASCARENHAS, 2008, p.74), por ocupar as vias públicas e preservá-las como lugares de encontro, como espaço de cidadania, e não apenas de consumo - como é o caso de outros espaços de comércio, os supermercados, por exemplo.

Giovanna de Aquino Fonseca Araújo, responsável pelo encaminhamento do registro da Feira como Patrimônio Imaterial Nacional no Livro dos Lugares pelo Instituto do Patrimônio Histórico e Artístico Nacional (IPHAN) ${ }^{15}$, destaca que os aspectos que lhe conferem esta condição estão vinculados às relações interpessoais substanciadas neste espaço físico, acomodando “[...] uma vasta subjetividade de valores simultâneos com temáticas ecléticas que, em conjunto, formam uma memória coletiva, sendo essencialmente um documento da História viva presente” (ARAÚJO, 2006, p.100).

14 MACIEL, Teresa. Depoimento [jul. 2015]. Entrevista concedida à pesquisadora. Campina Grande (PB), 2015. As demais declarações de Teresa Gorda têm como fonte esta entrevista.

15 A Feira Central de Campina Grande foi registrada como Patrimônio Cultural Imaterial em setembro de 201 . 

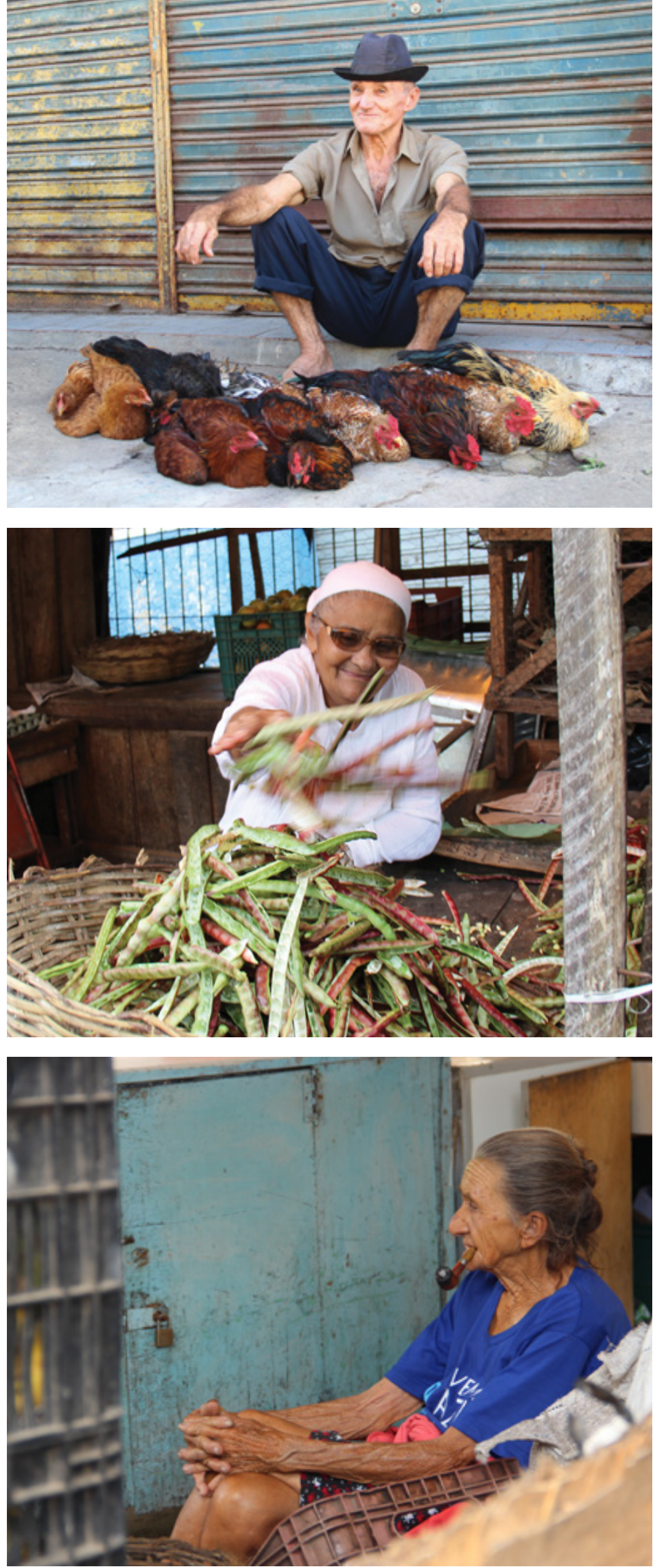

Figura 3 - Cenas da Feira Central de Campina Grande

Fonte: Milla Pizzignacco, 2016 

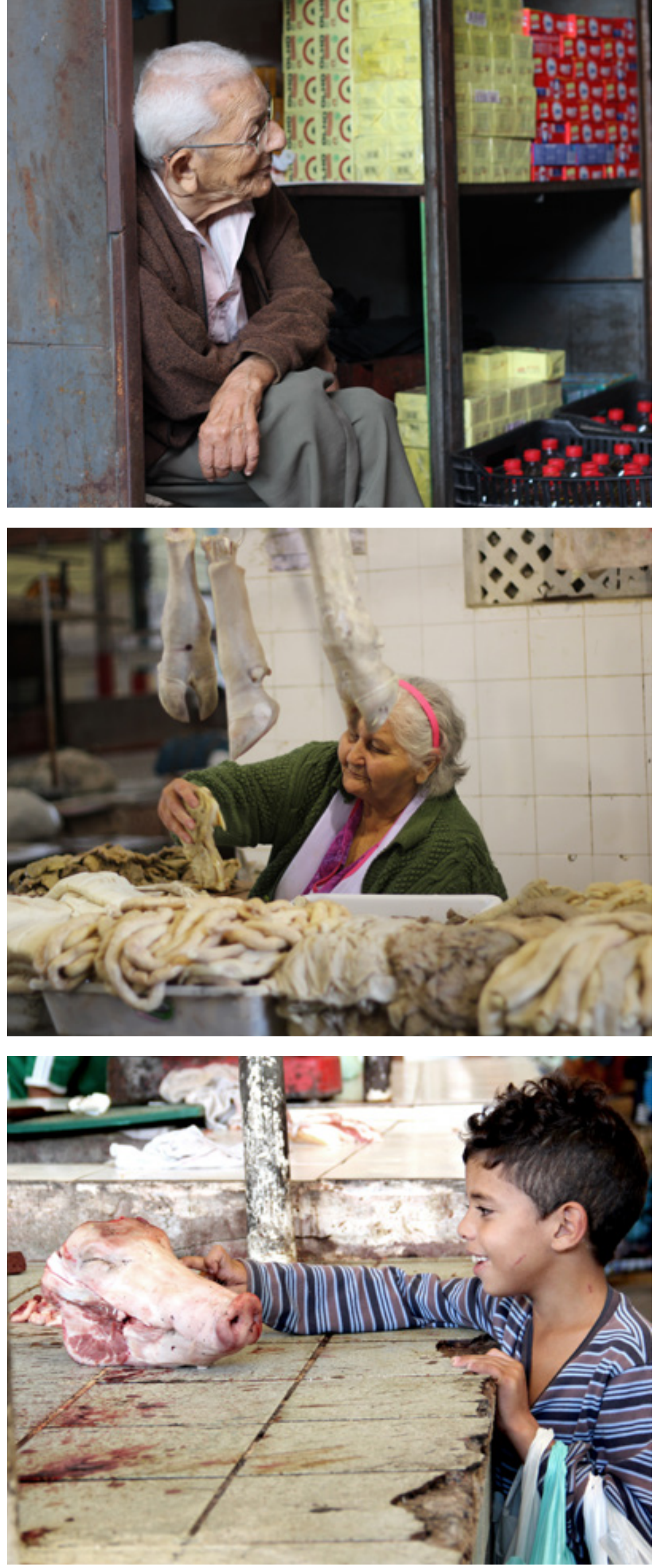
A cidade de Campina Grande e a sua Feira Central, foram edificadas em folhetos escritos por poetas que a tiveram como local que promoveu suas vidas não só no sentido econômico, mas no plano das relações sociais. Autores de publicações inspiradas pela "Rainha da Borborema": A descrição da cidade de Campina Grande estado da Parahyba (Moysés M. O. Mota Junior, 1936), A história de Campina Centenária (Toinho da Mulatinha, 1964), Campina Grande, a Viola e as belezas do Nordeste (Toinho da Mulatinha, 1976), Campina dos meus amores - Ode a Rainha da Borborema (Manoel Monteiro, 2000), A História de Campina Grande em Versos (José Aves Sobrinho, 2004) Grande marco de Campina Grande (Manoel Monteiro, 2009), Descripção parahybana / Elevação de Campina Grande (Alceu Cabral de Vasconcellos, s.d.), A deusa da Borborema e Meu amor por Campina (Gerson Lucena, s.d.) ${ }^{16}$.

Campina Grande e a Feira Central aparecem em versos como indissociáveis e indefectíveis, com virtudes atribuídas aos elementos já destacados na abertura deste capítulo, tais como a localização geográfica, a atividade pecuária, o cultivo de algodão e de cereais ${ }^{17}$, reiteradas no folheto Descripção do Estado da Parahyba do Norte (19--) ${ }^{18}$ de autoria de João Melchiades (“Cantor da Borborema”), publicado possivelmente por volta de 1910:

\author{
Campina é uma cidade \\ Que sua concentração \\ E' na Cruz de 4 estradas \\ Que faz communicação \\ Para o sul e para o norte \\ Para o brejo e o sertão \\ Campina está conhecida \\ Na maior feira do estado \\ Pelo seu commercio em grosso \\ Também a feira do gado \\ Cereaes e algodão \\ E' o que mais tem botado \\ (MELCHIADES, 19--, p. 20 - 21)
}

A tematização da cidade é permeada por discursos que privilegiam a memória de uma elite local, bem representada na obra historiográfica de Elpídio de Almeida (1964), responsável pela construção de Campina como Grande. A recorrente exaltação ao

16 Folhetos integrantes do acervo da Biblioteca de Obras Raras Átila Almeida (Universidade Estadual da Paraíba). Acesso: março de 2018.

17 0 cultivo de cereais, que promoveu Campina Grande desde sua formação, resistiu às transformações mobilizadas pela inserção da cidade no meio técnico-científico-informacional, mantendo-se como símbolo de prosperidade (COSTA, 2003).

18 Coleção Mário de Andrade - Fundo Villa Lobos (Instituto de Estudos Brasileiros da Universidade de São Paulo). Acesso: junho de 2018. 
português miliciano Teodósio de Oliveira Ledo, o qual é atribuída a fundação de algumas vilas paraibanas, compõe a narrativa que atravessa o imaginário de poetas e poetisas ${ }^{\mathbf{1 9}}$.

\author{
Teodosio Oliveira Ledo \\ Um honradíssimo varão \\ Capitão mór dos sertões \\ Homem de força e ação \\ Iniciou de Campina \\ A sua povoação \\ (MULATINHA, 1964, p. 01) ${ }^{20}$
}

Erguida como um Marco $^{\mathbf{2 1}}$ na Serra da Borborema, Campina também é exibida em versos como terra fértil para poetas/poetisas, exaltação que tem como objetivo demarcar geograficamente esse próspero espaço de atuação, como é possível observar nas estrofes extraídas de Campina Grande, a Viola e as Belezas do Nordeste (1976), compostas por Toinho da Mulatinha, comerciante de folhetos durante 60 anos na Feira Central de Campina Grande:
Da grande Associação
jesus do céu é o dono
Campina Grande é o trono
dos poetas da nação
de vates de expiração
nossa cidade é completa
e a poesia secreta
fazendo ela crescer
em cada esquina a gente ve
um poema e um poeta.
Vem poetas populares
de outras ricas cidades
fazerem festividades
em casas familiares
cantam sim os violeiros
os seus versos verdadeiros

\footnotetext{
19 Este discurso histórico é relativizado no folheto Campina dos meus amores: Ode a Rainha da Borborema (2000), de autoria de Manoel Monteiro. Nele o autor enfatiza a participação, forçada, dos indígenas aculturados, Airús, na saga dos "pioneiros" da Borborema.

20 MULATINHA, Toinho da. [Antônio Patrício de Souza]. A Historia de Campina Centenária. Esperança - PB: Gráfica São Paulo, 19--. (data estimada: 1964)

210 Marco é uma narrativa fantástica e hiperbólica, na qual a/o poetisa/poeta edifica uma fortificação imaginária, desafiando seus pares a atentar contra sua argumentação. 0 Marco, como fortaleza simbólica é uma metáfora da própria construção literária, da operação criativa, "[...] evocado, assim, para significar o território pelo qual se estenderia a fama de um cantador ou poeta, representando os limites de seu domínio invencível. Seus contornos particulares constituiriam, ao mesmo tempo, a forma específica que assumiria todo um estilo e uma imaginação poéticos". (IUMATTI, 2017, p. 08)
} 
tudo tirado de dentro

Campina Grande é o centro

dos poetas brasileiros.

(MULATINHA, 1976, p. 04) ${ }^{22}$

Circunscrita por vias de tráfego implementadas com fins comerciais, Campina Grande tornou-se um ponto de encontro de versejadores/as que viajavam realizando cantorias nas fazendas, como também cidade propícia para atuação e instalação de poetas/poetisas dada a existência da Feira Central, que se arma diariamente para o fluxo. Tal qualidade é evidente na fala de Kátia Monteiro ao referir-se à trajetória de seu pai, o poeta Manoel Monteiro, que deslocou-se de Bezerros para Campina Grande em 1952:

Então duas coisas chamaram muito a atenção dele para vir aqui pra Campina Grande, foi a Feira, porque aqui tem feira todo dia e a tipografia de Manoel Camilo. Eles fizeram uma parceria muito grande nessa época! Então meu pai publicava os cordéis e vendia na Feira de Campina e em outras feiras também... Na década de 1950, 1960 ele se manteve com a venda de cordel na feira. (MONTEIRO, 2018) ${ }^{23}$

Os motivos elencados por Monteiro fizeram de Campina um ponto estratégico para que poetas/poetisas pudessem fazer do comércio de folhetos uma possibilidade concreta de renda. Embora a morte da literatura de folhetos tenha sido anunciada por intelectuais, como Câmara Cascudo, em meados do século XX, assombrada pelo advento do rádio e mais tarde, pelo da televisão, "conheceu, nos anos cinquenta, as condições mais favoráveis ao seu fortalecimento no Brasil.” (MELO, 2010, p. 129). Nesse período houve uma eclosão de tipografias, que armaram acirradas batalhas de caracteres, por meio das quais poetas da região encontraram suporte para suas publicações.

A instauração de um circuito específico para a produção e circulação da literatura de folhetos, descolado do universo editorial que a princípio foi dependente, como as tipografias de jornais, gráficas publicitárias e livrarias, foi fator determinante para que os mercados municipais e feiras se estabelecessem como principais pontos de venda de folhetos a partir da década de 1930 (GALVÃO, 2001).

A multiplicação de poetas-editores, atividade inaugurada por João Martins de Athayde em 1909, fomentou a apropriação de todas as etapas de produção do folheto por poetas/ poetisas: criação, materialização e circulação do impresso. Ao comercializar diretamente suas produções para o público leitor, por meio da entoação dos folhetos nas

22 MULATINHA, Toinho. [Antônio Patrício de Souza]. Campina Grande, a Viola e as Belezas do Nordeste. Campina Grande - PB: Folhetaria Estrela do Oriente, 1976. Grifos da pesquisadora.

23 Grifos da pesquisadora. 
feiras, o poeta/ a poetisa passou a gozar de uma autonomia financeira não conhecida pelo/a cantador/a, que "vivia geralmente sob tutela de fazendeiros, promotores de cantorias” (TERRA, 1983, p. 17).

O relato de Kátia sobre a atuação de Manoel Monteiro, comerciante de folhetos em meados do século XX na Feira Central de Campina Grande, nos permite averiguar o quão profícua foi essa ocupação no período:

Durante muitos anos ele manteve a família com a venda de cordel. Inclusive na morte de Getúlio Vargas ele vendeu mais de 5 mil cordéis... Quando Getúlio morreu ele passou a noite escrevendo e daí no outro dia imprimiu e foi pra feira... Ele disse que comprou toda a mobília da casa, ficou rico [risos]...num foi mãe? Porque não era como agora, né? Que acontece uma coisa e em fração de segundos todo mundo já sabe através internet. Antes era o rádio, mas nem todo mundo tinha rádio, a televisão ainda tava muito no início, pouquíssimas pessoas tinham televisão. Getúlio morreu em 54 ...a televisão chegou em 53, né? Então era uma coisa muito inicial. E ele escreveu o cordel contando os detalhes, como se lá ele estivesse. Então na feira as pessoas choravam com ele lendo o cordel, formava aquela roda de gente e ele lia o cordel de como tinha acontecido o fato todo. (MONTEIRO, 2018).

O suicídio do Presidente Getúlio Vargas não rendeu lucro exclusivamente para Monteiro, este episódio "desencadeou as edições únicas mais vendidas na história do cordel, com pelo menos meia dúzia de versões ultrapassando a marca dos cem milheiros" (SLATER, 1984, p. 21). Os algarismos revelam que os folhetos se tornaram impressos de grande circulação entre as camadas populares urbanas e rurais, mediados pela experiência catalisadora das feiras - primeira instância de leitura e audição dos folhetos nesse período.

Pregão e mercadoria se fundem na atuação do poeta-feirante. O folheteiro declama, canta o folheto como quem oferece um pedaço de fruta madura para a freguesa e o freguês. Notícias frescas, histórias encantadas e moralizantes se alastram pelo ambiente sinestésico da feira, fazendo com que transeuntes se aglomerem, tornandose público instigado em devorar o folheto "até o caroço".

Para o poeta-folheteiro, o pregão opera como "chave da performance" (BAUMAN, 1977), abertura para interações com potenciais consumidores/as, que vão sendo agenciadas de acordo com as reações dos/as mesmos/as. Como mercadores/as, poetas, poetisas e feirantes, conjugam forma estética e função utilitária na linguagem comercial. É recorrente que folhetos sejam iniciados com estrofes que guardam a virtualidade da voz do pregoeiro, a intencionalidade de aproximação com o freguês: 


\section{Amigo demore um pouco}

Se não for muito apressado

Pra escutar um folheto

Dum título penalizado

Duma brigada assombrosa

Do Cedro para o Salgado.

(MULATINHA, 1977, p. 01) $)^{24}$

Os versos de Toinho da Mulatinha contém vestígios orais que remetem à comercialização do folheto no ambiente da feira. O uso da palavra "amigo", por exemplo, é uma evocação que se inscreve como "chave da performance" no ambiente das feiras, tal como "madame”, "doutor", “dona de casa” etc. Padrões tipológicos ativados com intenção de conferir uma relação de afinidade com o transeunte, assim como atribuir autoridade ao freguês/ à freguesa. A ideia de fluxo acelerado, próprio do ambiente comercial dos mercados populares, faz-se evidente quando o poeta requisita que o sujeito desacelere o passo para ouvir a declamação do folheto. A presença do verbo "escutar" é uma patente marca de oralidade.

O pregão, forma de publicidade medieval vernacular que atravessa gerações, é um importante recurso de aproximação entre vendedores/as e passantes. Tião Lima, atual vice-presidente da Casa do Poeta e do Cantador de Campina Grande, lembra das artimanhas utilizadas por um poeta na feira de Patos (PB): "Ele pegava aquela mala cheia de folheto e botava uns cinco na mão. Começava lendo... e daí interrompia: 'só tem essel', daí dizia 'vou ver se tem mais aqui, daí pegava mais cinco" ". ${ }^{25}$

O intuitivo, o espontâneo e o jocoso, subsídios comunicativos incorporados pelas/ os negociantes informais, provém do universo de referências da tradição cultural dos mercados de origem ibérica à céu aberto. De acordo com Mikhail Bakhtin (1993), em análise sobre o "vocabulário da praça pública"26, as formas cômicas suspendem temporariamente as hierarquias e convenções sociais, são expressões elementares da "sensação popular no mundo": "É preciso observar que a 'propaganda popular' foi sempre "brincalhona' [...] ela 'sempre gracejou de si mesma'[...]; na praça pública, a sedução da ganância e da esperteza tomavam um caráter irônico e semifranco" (BAKHTIN, 1993, p. 138).

A menção à "brincadeira" foi recorrente em entrevista realizada com Condor, embolador campinense atuante no mercado local, que ao contar sua trajetória na

24 MULATINHA, Toinho da. [Antônio Patrício de Souza]. O Folheto da Brigada em Salgado de Solânea. Campina Grande - PB: Folhetaria Estrela do Oriente, 1977. Grifo da pesquisadora.

25 LIMA, Tião. Depoimento [mar. 2018]. Entrevista concedida à pesquisadora. Campina Grande (PB), 2018. As demais citações de Tião Lima têm como fonte esta entrevista.

26 Resgatado nas obras de François Rabelais, escritor Francês do século XVI. 
profissão afirma: "É uma brincadeira mas também é o nosso ganha pão"27. O "humor" também é destacado na declaração de Batista, administrador da Feira Central, ao relatar a atuação do embolador de coco Dedé da Mulatinha: "Ele era engraçado, era o cara que chegava na frente".

A "mangação" - "linguagem carnavalesca" do "gênero verbal da praça pública" (BAKHTIN, 1993) - obedece a entendimentos prévios compartilhados pela comunidade frequentadora do local. Este tipo de "pacto cênico" estabelecido entre freguês e feirante, poeta e público, faz-se patente em diversos gêneros da "cantoria popular", como no "desafio malcriado" da embolada de coco, em que o vocabulário chistoso irrestrito é levado ao extremo.

A performance é elemento essencial no ambiente da feira. Do latim per mais formáre, dar forma, ela modela e individualiza a ação da/do feirante, do/da cantador/a em meio ao "moi de gente”, à “zuada”, própria desse ambiente comercial. A musicista Christiane Assano (2007) aponta para a experimentação teatral dos/das vendedores/as, ao definir a maneira como se corporifica o "pregão”:

[...] do encontro entre o ritmo das palavras e sua musicalidade, das inúmeras repetições lançadas pelo pregoeiro, que parece experimentar sua voz, seu timbre, sua capacidade de sedução por meio do som. É do encontro entre os sons conhecidos e desconhecidos que nascem essas músicas que se dão em performance. (ASSANO, 2007, p. 107)

Na perspectiva de Paul Zumthor (1993), o gesto e a voz colaboram para compor o sentido do texto, transmutando o simbólico produzido pela palavra. Para o autor, a performance é um momento singular da receptividade do texto pelo público, tanto na acepção “especial”, por mobilizar emoções, quanto no sentido de "único", irreprodutível.

A singularidade performática se manifesta mesmo no caso da entoação de um conteúdo escrito, pois, do texto, a voz em performance extrai a obra (ZUMTHOR, 2000). Aspecto perceptível no relato de Kátia Monteiro acerca da declamação do folheto dedicado a Getúlio Vargas, realizada pelo pai: "Então na feira as pessoas choravam com ele lendo o cordel". Nesta situação de leitura concentra-se "o poder do agora", consubstanciado pela trama em jogo naquele momento: a atualidade de uma notícia de impacto nacional, a dramaticidade propiciada pelo gênero (se comparado às notícias veiculadas em outro meio), a energia do grupo que circunda o poeta e, sobretudo, sua habilidade de lançar no ar as palavras impressas.

27 SILVA, José Robério da. [Condor]. Depoimento [mar. 2018]. Entrevista concedida à pesquisadora. Campina Grande (PB), 2018. As demais citações do embolador têm como fonte esta entrevista. 
A atualização do arquétipo (texto escrito impregnado no papel, vinculado à tradição) pela voz (“palavra viva” no tempo presente), é denominada por Paul Zumthor (2000) de "movência". A impossibilidade de reprodução das formas no ato da reiteração do texto escrito é expressa pelo poeta-feirante Toinho da Mulatinha, ao referir-se à excelência da performance de seu irmão: “Dedé o meu velho irmão/ morreu sendo renomado/ até no exterior/ o seu nome foi gravado/ e foi quem cantou melhor/ o coco pinto pelado ${ }^{\mathbf{2 8}}$."29 Nesse sentido, o texto pode ser compreendido em sua dimensão inacabada, posto que não poderá ser reproduzido de maneira homóloga, inclusive por um mesmo autor.

De natureza teatral, a performance na cantoria se configura no encontro entre o narrador e o público de auditores, abarcando a totalidade de elementos visuais e situacionais em um determinado tempo e espaço, assim como a corporeidade dos participantes e sua existência social enquanto grupo.

O caráter oral da literatura de folhetos tornou-a mais próxima daqueles que apresentavam pouca ou nenhuma familiaridade com o universo da leitura. Essa relação do sujeito pouco letrado com uma peça gráfica escrita se estabeleceu tanto pela natureza da publicação, quanto pela natureza das práticas em que era lida e ouvida - no ambiente das feiras, em festas, entre familiares, vizinhos, sendo realizada por sujeitos com domínio da leitura, que eram muitas vezes crianças.

Ana Maria Galvão (2001) compreende que as situações de leitura constituíram um fator decisivo para que, mesmo os analfabetos, vivenciassem práticas efetivas de usos da leitura/escrita e em alguns casos aprendessem a ler. O potencial educativo dos folhetos de feira no processo de alfabetização nas primeiras décadas do século XX é evidenciado pelo cantador Tião Lima: "Daí meu pai comprava folheto na feira pra pessoa aprender a ler com aquilo. Como é que pode? Pra você desarnar [aprender]. E eu lutei pra aprender a ler aquilo ali sem saber. Meu pai era leitor, cantava folheto, e o povo enchia pra ouvir. Sem acompanhamento de nada, só cantando”.

No empenho de conferir significado ao sistema de códigos impressos no folheto, o/a leitor/a em potencial elaborava hipóteses, sobrepondo a sonoridade da narrativa, apreendida pela memória, sobre o conjunto de imagem-palavra. As características formais da poesia, o ritmo das frases e a semelhança das partes finais ou iniciais, assim como as marcas de oralidade (o regionalismo, o uso do discurso direto, a adjetivação, por exemplo), colaboram no processo de memorização. A repetição também é fator

28 0 "ciclo temático do Pinto Pelado" (AZEVÊDO, 2000, p. 98) abarca narrativas populares presentes em diversas regiões do Brasil, nas quais o protagonista é um pinto, frango, capão ou galo misterioso, de aspecto hediondo e poderes assombrosos (CASCUDO, 1988, p. 618 - 619).

29 Grifo da pesquisadora. 
fundamental para a retenção do conteúdo, pois é desta forma que acontece a introjeção das fórmulas básicas da poesia de folheto.

O sabor da leitura/audição intensiva de uma mesma narrativa não reside na surpresa do enredo, visto que seu desenlace já teria se efetivado, tampouco na atualidade da notícia, no caso dos folhetos de época. O frescor das histórias de folhetos encontra-se na possibilidade de rememoração e apropriação do texto (GALVÃO, 2001), como conta o poeta Condor: "O meu avô, com mais de 70 anos, deitado na rede pedia que eu ficasse lendo as histórias. [...] Ele sabia as histórias de cor porque ele já tinha lido muitas vezes. Mesmo assim ele dizia: 'compre esse lá na feira, é Juvenal e o Dragão', por exemplo, que é um grande conto das histórias de Luzeiro ${ }^{30}$, 'Canção de fogo', 'Pedro Malazarte'...”.

Nesse sentido, o folheto atua como "suporte da memória" (TERRA, 1983), representação física dos conteúdos já assimilados através da audição das narrativas. Formulação fundamentada pela fala de Kátia Monteiro: "Inclusive pessoas que não sabiam ler compravam cordel... Até hoje mesmo as pessoas analfabetas tem cordel e sabem de cor o cordel né? Outras pessoas leem. O meu pai [Manoel Monteiro] lia os cordéis que as pessoas compravam, o pessoal pagava ele pra ele ler os cordéis".

Pode-se comprar os livretos sem saber ler, para fazê-los serem lidos ocasionalmente, e para adquirir qualquer coisa que seria como um objeto mágico, o papel que fala. É certo que o livro adquire um poder, um valor, e é considerado assim, precisamente pelo seu caráter 'reservado'; porque só pode ser lido por quem o possui e detém o saber, saber encoberto, guardado em segredo. Ter um livro (...) é prender nas mãos um pouco deste saber" (BOLLÈME apud TERRA, 1983, p. 35-36)

$\mathrm{Na}$ feira, os/as poetas/poetisas que arrancavam narrativas do papel agiam como disparadores de memórias. A compra da publicação representava a captura concreta, por meio da posse do objeto, da história, previamente armazenada pela mente. $\mathrm{O}$ aparecimento de uma literatura impressa em meio a uma população majoritariamente analfabeta "foi possível por ser difundida junto a um 'público de auditores", afirma Ruth Terra (1983, p. 75), apropriando-se de expressão utilizada por Antonio Candido (1980) para definir o público leitor brasileiro da época, incluindo a elite.

30 Refere-se às publicações da Editora Luzeiro de São Paulo. A editora, denominada em 1952 de Prelúdio (derivada da Tipografia Souza, que iniciou suas atividades na década de 1920 na capital Paulista, editando modinhas musicais, folhas soltas, dentre outros gêneros populares), especializou-se na publicação folhetos nordestinos na década de 1970, com objetivo de reerguer-se de uma crise. Nesta década, nasceu a Luzeiro, editora que simbolizou a introdução de formas tecnológicas para a impressão de folhetos e de uma nova estética para as publicações, sendo criticada por editores e tipógrafos que cultivavam modos artesanais de produção e perdiam consumidores frente à concorrência com as imagens coloridas que ilustravam histórias tradicionais deste gênero literário. (MOTTA, 1997). 
Mediadores entre o escrito e o oral, os poetas gozavam de um lugar de autoridade perante a comunidade em termos de "cultura letrada", tanto por desvendarem os códigos registrados no papel, quanto pela capacidade de escrevê-los e o poder de difundí-los. Diante disso, Manoel Monteiro, ainda menino, foi apelidado de "professor" na comunidade em que vivia em Bezerros (PE), segundo relato da viúva Lindalva ${ }^{31}$.

Esta atividade profissional era considerada diferenciada, pois o poeta/ a poetisa eram reconhecidos/as como figuras agraciadas por um dom, atribuído ao divino - ideia que sempre circundou o campo das artes, conforme é possível perceber na fala de Condor:

Eu costumo dizer que poesia, embolada, não é algo assim que se aprende. Melhor dizendo, tudo se aprende... Mas eu falo pela questão...Vou te dar um exemplo aqui: o cara que tem o dom de matemática, ele resolve uma questão e sabe tudo o que está se passando, tranquilamente. Se você pedir pra ele dar a teoria daquela questão, ele vai dar a teoria. Não é mais ou menos isso? E o cara que não tem o dom de matemática, ele vai se esforçar pra aprender. Ele vai aprender. Ele vai chegar a responder aquela questão, mas com mais dificuldade...né? Então assim eu costumo dizer que embolada é um dom. Você acha que um Toinho da Mulatinha ia ficar se esforçando pra cantar embolada? Era algo dele...Tá entendendo? (SILVA, 2018).

Os poetas/ as poetisas, embora compartilhassem com seu público a condição social, o vínculo com a cultura oral ${ }^{32}$, como também sistemas de crenças e valores similares (TERRA, 1983, p. 38), se destacam perante a comunidade pela capacidade de transitar por esferas culturais diversas. Essa competência confere ao poeta "o papel de mediador entre a literatura popular e erudita, entre os fatos acontecidos e o povo, entre o governo e a população e, especialmente, o de representante de seu público” (HATA, 1999, p. 13).

Tal como os tropeiros do Brasil Colonial o/a poeta/poetisa itinerante deslocavase entre paisagens geográficas, sociais, sonoras, culturais. Trocava mercadorias (i) materiais, matéria prima para sua atividade criativa/criadora, fruto das experiências apreendidas nos trânsitos entre os múltiplos nordestes que coexistem em uma ampla região condensada por um codinome.

31 FELIPE, Lindalva. Depoimento [mar. 2018]. Entrevista concedida à pesquisadora. Campina Grande (PB), 2018.

32 Essa questão vem sendo relativizada por alguns pesquisadores da área. 0 historiador Durval Muniz de Albuquerque aventa em A feira dos mitos: a fabricação do folclore e da cultura popular - Nordeste 1920-1950 (2013), a possibilidade de os poetas da $1^{\text {a }}$ geração serem de famílias oligárquicas decadentes. Ana Maria Galvão, autora do livro Cordel: leitores e ouvintes (2001), constata que no início do século XX o público consumidor de "poesias populares" não era tão "popular" quanto a nomenclatura nos faz supor, posto que abarcava um estrato alfabetizado da população - em um período em que a inserção na cultura letrada era um privilégio para poucos. Apesar dos folhetos terem contado com a audiência de um público majoritariamente rural e analfabeto, a partir dos anos 1930, Ruth Terra (1983) observa que os folhetos eram consumidos por pessoas de diversos estratos sociais, como grandes fazendeiros, por exemplo. 
Nas entrelinhas de seus versos habitavam narrativas "colhidas da boca do povo"33, extraídas dos impressos peculiares do meio letrado e dos aparelhos midiáticos que aos poucos se conectavam ao seu torrão. "Naquele tempo o cordel ele era o jornal. Quando acontecia uma hecatombe, um desastre, a virada de um caminhão... O pessoal escrevia aquilo ali e ia pras feiras vender. Cordel botaram o nome depois, porque era folheto, naquele tempo era folheto de feira”, recorda Tião Lima (em entrevista concedida à pesquisadora, em março de 2018).

As feiras foram espaços pertinentes para fazer ecoar essa literatura da voz, nelas o canto emanado dos folhetos catalisou encontros e instituiu o "direito à literatura", anunciado por Antonio Candido (1989) como uma necessidade universal. Uma literatura consubstanciada entre histórias eruditas, populares, fatos de época, entre o escrito e o oral.

A feira popularizou o folheto. Por figurar como principal local de comercialização desta literatura, a partir da década de 1930, esse tipo de publicação ficou conhecido como "folheto de feira", como podemos observar na fala de Tião Lima e nas narrativas daqueles/as nascidos antes dos anos 1960/70 - quando a nomenclatura "cordel” ainda não havia sido implementada pelos/as missionários folcloristas ${ }^{34}$.

Assim como a feira constituiu-se como um lugar identitário para os/as poetas, eles/as passaram a compor a identidade da feira. Figurando como indissociáveis deste ambiente de comércio. Tal como a cidade de Campina Grande está para o mesmo.

Toinho da Mulatinha foi um dos mais importantes "homens-memória” (NORA, 1984) da Feira Central campinense, atravessou o auge do comércio da feira e envelheceu junto a decadência do local - que impactou seu ofício. Representante de uma geração de poetas de bancada, responsáveis por práticas orais de socialização do escrito e pela circulação do manuscrito, Toinho é protagonista da história da literatura de folhetos em Campina Grande - prática cultural inextricavelmente ligada à feira. Nos deixou seu canto guardado em folhetos empoeirados, sua história gravada nas vozes de feirantes que têm sua imagem nítida na lembrança.

33 Registro de Pedro Batista na contracapa do folheto A lira do sertanejo/folclore nordestino (1917).

340 emprego da palavra cordel advém da comparação desta literatura com sua congênere europeia, sobretudo com folhetos portugueses, denominados "literatura de cordel" diante dos modos que eram expostos à venda, pendurados em barbantes. Por comparação direta, o termo foi adotado e difundido no Brasil através de estudos acadêmicos sobre o tema, que ignoraram as diferenças poéticas entre os gêneros. Até os anos 1960 esta produção era conhecida entre os próprios produtores por "folhete", "folheto de feira", "verso", "romance", dentre outras denominações populares. 


\section{UM POETA DE ESPERANÇA NA GRANDE CAMPINA}

O dezoito de outubro foi o dia que num sítio visinho a Esperança uma mãe descansou uma criança para outra servir de companhia na jaqueira de frente a moradia poi-se um galo cantando sem parar como quem pretendia anunciar que naquela bendita manhãsinha Deus deixou lá na cama a criancinha O futuro poeta popular

Figura 4 - Toinho da Mulatinha no Sítio São João (Campina Grande, 2006)

Fonte: Acervo do poeta
(MULATINHA, 19--, p.01) $)^{35}$

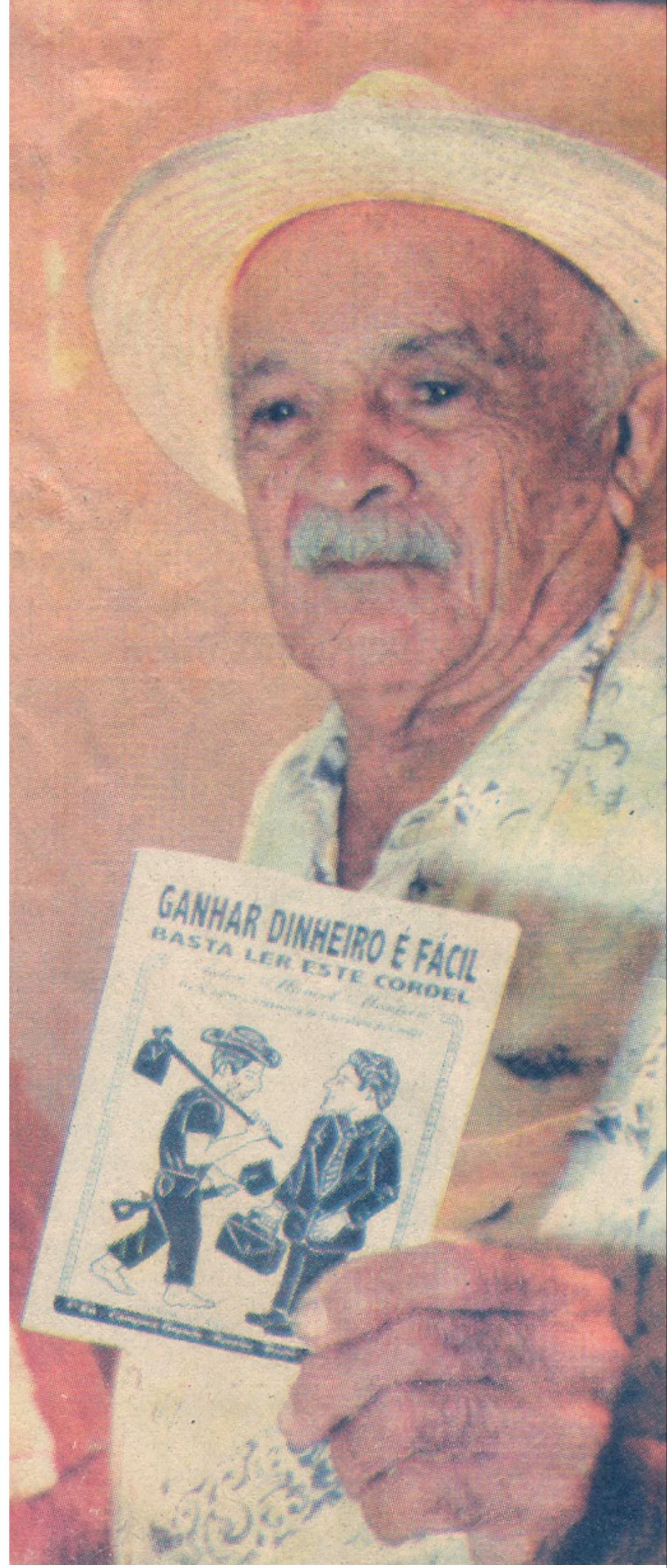

35 MULATINHA, Toinho da. [Antônio Patrício de Souza]. Toinho da Mulatinha e sua biografia. 20--. 
Antônio Patrício de Souza nasceu em 1925, no sítio da Mulatinha, chão de sua avó mulata, Maria, no município de Esperança - Paraíba. Da terra que o alimentou herdou o codinome, Toinho da Mulatinha, como conta em sua autobiografia em folheto: "Dai vem a sua história/ que nos versos se encaminha/ sua avó era mulata/ chamavam de mulatinha/ seu nome cresceu demais e eu vou na mesma linha” (MULATINHA, 20--, p. 01). Sua mãe, Severina Maria da Conceição, fazia utensílios de barro e foi raizeira na Feira Central de Campina Grande, seu pai, Manoel Patrício de Souza, trabalhava no roçado.

Um dos mais novos entre 11 filhos e filhas, Toinho teve Dedé, José Patrício de Souza (1914 - 1994), o irmão primogênito, como mestre no ofício da cantoria: "Dedé seguia na frente/ e eu caminhando atrás/ Dedé porque lia muito/ arranjou nome e cartaz/ ainda vou pelejando/ e ele não canta mais.”(MULATINHA, 19--, p. 04). De acordo com os relatos de Dona Inácia Firmino Bezerra, a mais antiga raizeira da Feira Central ${ }^{36}$ e, cunhada dos emboladores da Mulatinha37, "Antônio aprendeu com Dedé. Dedé era o mais sabido, nasceu para cantar coco de embolada. E Dedé já aprendeu mais com ele, né?"38.

Dedé da Mulatinha começou ainda menino, com doze anos de idade, a cantar coco de embolada. No documentário O Patrimônio Cultural de Campina Grande, de Azevêdo (1997), podemos acompanhar um breve relato do mentor de Toinho:

Quando demorava chegava em casa e papai perguntava: 'onde estava?' Eu digo 'papai eu estava na brincadeira, com meus amigos'. 'Pois meu filho, você vai apanhar uma surra viu, vai levar surra pra deixar de cantar que isso aí é preguiça de trabalhar'. Eu digo 'não papai, é porque quando eu termino o serviço e tal e o pessoal admira minha inteligência, um pede uma coisa, outro pede outra... como teve lá Manuel Farias, e outras gente delicada de Esperança, delegado, prefeito e tudo mais: 'ô menino vem cantar uma coisa pra nois ouvir!'. Aí papai, eu envolvia o tempo... (AZEVÊDO, 1997)

Influenciado pelo irmão, registrado com admiração em sua autobiografia, Toinho da Mulatinha começou a embolar coco com 10 anos de idade. A poesia escrita apareceu depois, na sua juventude. Seu primeiro folheto, Uma viagem a Lua, data de 1945. O poeta frequentou a escola por três meses, mas aprendeu no universo rural o segredo das palavras e a sua capacidade de empoderamento. Antônio enveredou pelo caminho da escrita e José manteve-se praticante da cantoria de embolada, publicando quantidade reduzida de folhetos se comparado ao irmão, de acordo com os relatos de Mundinho, neto de Dedé: “O pessoal naquela época comprava muito livro [folheto] lá no

36 Atuante no local até 2016.

37 Viúva do irmão caçula de Dedé e Toinho.

38 BEZERRA, Inácia Firmino. Depoimento [jul. 2015]. Entrevista concedida à pesquisadora. Campina Grande (PB), 2015. As demais citações de Dona Inácia têm como fonte esta entrevista. 
centro da cidade... Lá na Feira Central. O irmão dele [Toinho] era mais assíduo com folheto, ele [Dedé] não, às vezes colocava uns na banca de raiz, mas ele cantava mais. O negócio dele era cantar, viajar por aî”.

Mediadores entre os universos urbano e rural, o litoral e o sertão, os irmãos "da Mulatinha”, poetas nômades, viajavam pelas redondezas de Campina Grande cantando coco de embolada e vendendo folhetos. "Fazia cantoria nesses interior aí. E nesse tempo eles iam de pau-de-arara, naqueles caminhão”, conta Dona Inácia. De acordo com Toinho39 faziam cantoria principalmente nos estados da Paraíba, Pernambuco e Rio Grande do Norte, nas feiras de Areia, Arara, Esperança, Mamanguape, Remígio, Pocinhos, Barra de Santa Rosa, Aroeiras (PB), Natal (RN), Recife (PE), para citar algumas.

No folheto Peleja de Antonio da Mulatinha com Manoel Batista ${ }^{40}$, Toinho nos conduz para o universo das cantorias encomendadas por fazendeiros e figuras do campo da política, ao relatar o recebimento de uma carta do Dr. João Clemente ${ }^{41}$, entregue a ele na Feira Central de Campina Grande:
A carta dizia assim
Antonio da Mulatinha
tratei uma cantoria
pra você e batistinha
na cidade Nova Cruz
em casa de gente minha
tem muitos interessados
no sítio e na cidade
a ouvirem coisas bôas
de sua mentalidade
junto a Manuel Batista
que também diz a verdade
(MULATINHA, 19--, p. 01)

Os irmãos da Mulatinha fizeram, cada qual, dupla com outros cantadores, como Colombita, lembrado pelas Três Ceguinhas de Campina Grande ${ }^{42}$ em entrevista ${ }^{43}$, personagens que assim como os irmãos sonorizaram a Feira Central campinense.

39 Em depoimento no já citado documentário 0 patrimônio cultural de Campina Grande, gravado em 1997.

40 Folheto sem data, com preço em Cruzeiro (CR\$15,00) e capa impressa em xilogravura. Em uma perspectiva comparativa com a visualidade dos folhetos pertencentes ao acervo do poeta (Biblioteca de Obras Raras Átila Almeida, UEPB), avento a hipótese de ter sido produzido entre as décadas de 1950 e 1960.

410 uso do pronome de tratamento "doutor" é um indício de que o poeta refere-se a uma figura de autoridade.

42 Maroca (Maria das Neves Barbosa, 1945 - 2017), Poroca (Regina Barbosa, 1944) e Indaiá (Francisca Conceição Barbosa,1950) são irmãs cegas de nascença que cresceram cantando coco e tocando ganzá nas ruas e na Feira Central de Campina Grande. Protagonistas do documentário A pessoa é para o que nasce, de Roberto Berliner, ganharam notoriedade nacional no começo dos anos 2000.

43 Entrevista concedida à pesquisadora no dia 19/07/2015. 
Outros parceiros de ofício são citados por Toinho em sua autobiografia em cordel: "Dedé segurou seu nome/ por toda zona brejeira/ viajou com Colombita/ Maximino e Lavandeira/ findou sua temporada lá no alto da palmeira” (MULATINHA, 19--, p. 07). Mundinho, neto de Dedé, também faz referência aos parceiros do avô:

Era Lauro, eu não sei o nome completo de Lauro, tinha um jeitinho na perna... Tinha Vem-vem também, Cachimbinho...Geraldo Mousinho, era outro cantor daqui que improvisava. Eles viajavam aqui em volta, ia, voltava... ficava fora dois, três dias...Se apresentavam pra esse pessoal da agricultura que gostam...Daí depois já ia pra outro canto. (MUNDINHO, 2018) ${ }^{44}$

Campina Grande foi um ponto de convergência de interesses para irmãos “da Mulatinha”, tanto pelas possibilidades de deslocamento oferecidas pela localização deste entreposto comercial, quanto pela existência da Feira Central. Além disso, na década de 1950 a cidade era um núcleo tipográfico expressivo no que se refere à impressão de folhetos, como já enunciado neste capítulo. Diante desta conjuntura, Campina tornou-se mote para os versos de Antônio da Mulatinha, aparecendo como Grande em sua produção poética, que abarca seus festejos e aspectos da cultura local, como no folheto O Maior São João do Mundo e a Micarande em Campina (2001) e A Grande Feira da Prata na Cultura Nordestina (1999).

A relação com a cidade, foi previamente estabelecida pelos seus antepassados, raizeiros atuantes na Feira Central. A raizeira Dona Inácia relembra os ensinamentos da mãe de Toinho e Dedé (Severina Maria da Conceição): “A mãe deles foi a primeira que trabalhou vendendo isso aqui, o pai dele colocou uma banquinha para mim que era daqui pra ali, vizinha a da mãe dele. Então ela me ajudava. As muié chegava: 'tem quixaba?' E eu dizia: 'eu não sei'. Ela vinha de lá e dizia: 'tem'. Ai ensinava o que era e tudo”.

44 MUNDINHO, Eduardo Lima. Depoimento [mar. 2018]. Entrevista concedida à pesquisadora. Campina Grande (PB), 2018. As demais citações de Eduardo Mundinho têm como fonte esta entrevista. Grifos da pesquisadora. 


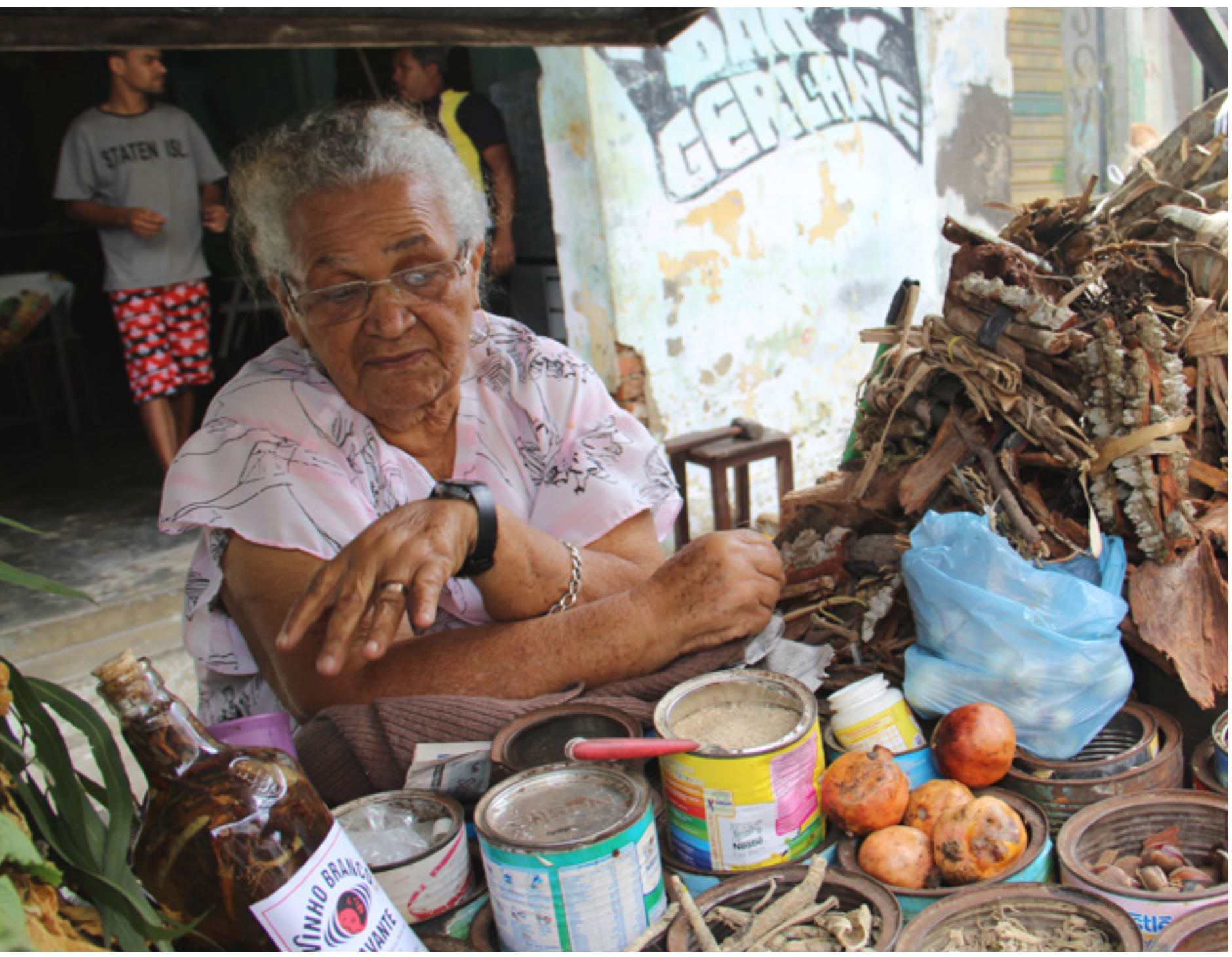

Figura 5 - Dona Inácia comercializando raízes na Rua Manoel Pereira de Araújo (2015)

Fonte: Milla Pizzignacco, 2016 
O folheto Descrição da Flora Medicinal - Quais Plantas que Curam (1977)

[Figura 6], escrito por Dedé da Mulatinha é dedicado ao ofício herdado da família:

Na verdejante Campina

Tem tudo que é importante

Plantas que curam o universo

Do pracista ao viajante

Do adulto ao inocente

Vem por Deus Onipotente

Nossa cura radiante.

$[\ldots]$

Chá de endro cura dor

Pra catarro amalinado

Usem a cebola branca

Com juá asserenado

Ensino por minha prática

Pra quem tem bronquite asmática

O alho do mato é sagrado.

(MULATINHA,1977, p. 1; 5)

Figura 6 - Capa do folheto Descrição da Flora Medicinal - Quais Plantas que Curam (Dedé da Mulatinha, 1977)

Fonte: Biblioteca de Obras Raras Átila Almeida (BORAA/UEPB)

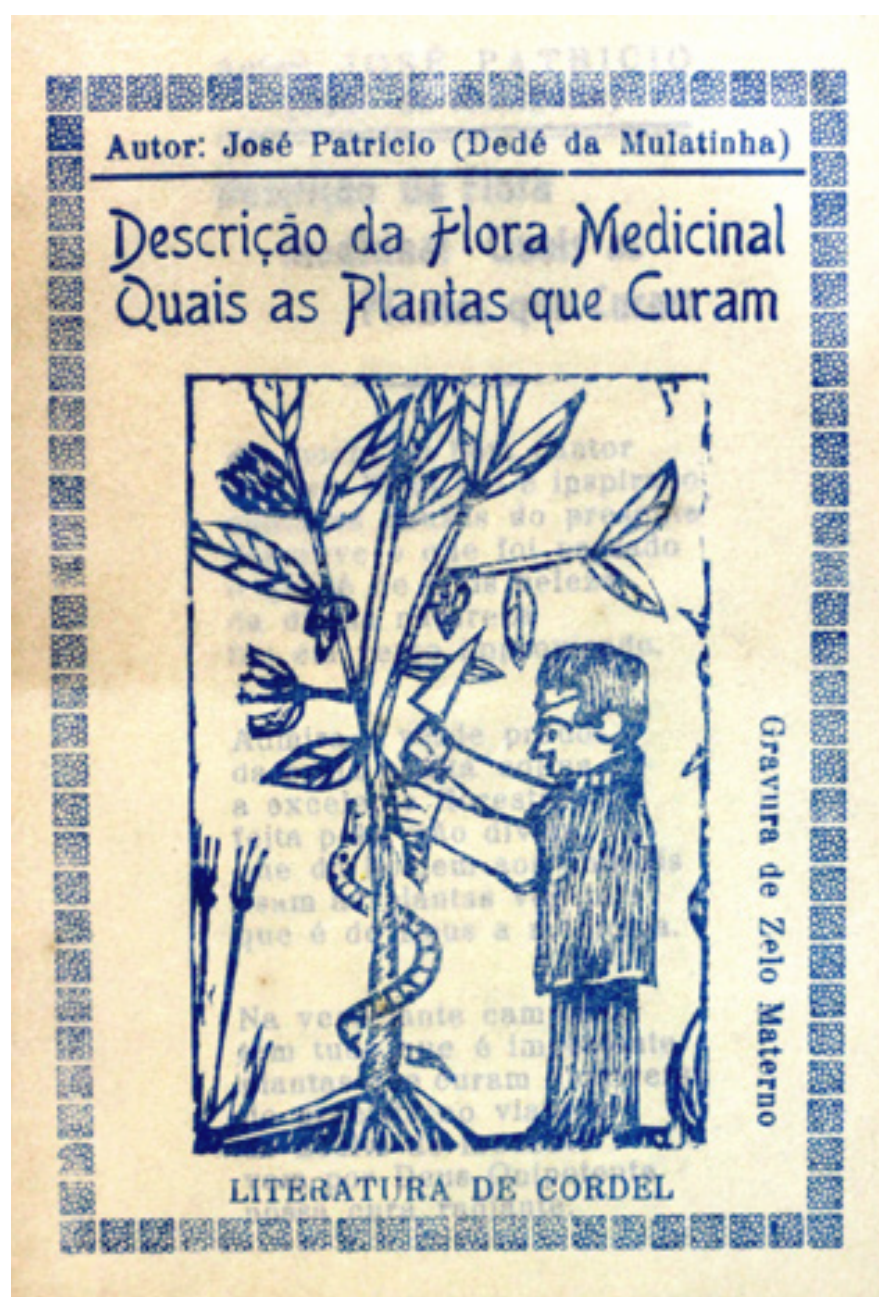

Neste poema, Dedé “canta ciência” enumerando ervas e raízes, seguidas da descrição do potencial de cura de cada uma, seja física ou espiritual. Saber apreendido empiricamente e pela oralidade, que "dá lição em doutor", como afirma ao longo do folheto. Poeta em trânsito entre lugares e, sobretudo, entre esferas culturais, Dedé também extraiu dos livros substância para seu ofício como raizeiro e para sua composição poética: "Ele tinha um livro de 1940 que era 'As plantas curam'. Ele tirava muita coisa desse livro fazia as garrafada de umas raízes e curava as pessoas. Muita gente que tava desenganada, passava dois meses e ia lá agradecer, que voltou a vida, que tinha curado tudo", relembra o neto Mundinho.

$\mathrm{Na}$ Feira Central campinense os irmãos comercializaram a cura pelas raízes, pela cana, pelo canto. Dedé da Mulatinha manteve por meio século banca de raízes na Rua Manoel Pereira de Araújo (Feira Central de Campina Grande), que ainda hoje 
tem três bancas dedicadas a esse fazer/saber ${ }^{45}$. Poeta de bancada, Toinho da Mulatinha arraigou sua banca de folhetos no cruzamento da Rua Doutor Carlos Agra com a Rua Cristovão Colombo, "pra baixo da feira de peixe" [Figura 7], lembra Lindalva Felipe, na época feirante e cônjuge de Manoel Monteiro, contemporâneo do poeta. Toinho teve sempre ao lado uma figura feminina colaborando no trabalho da feira: a primeira esposa, Maria Gorda, tinha um “hotel de comida” 46 dentro na Feira Central e a segunda, Digna Maria dos Santos, o acompanhou durante parte de sua vida de embolada.

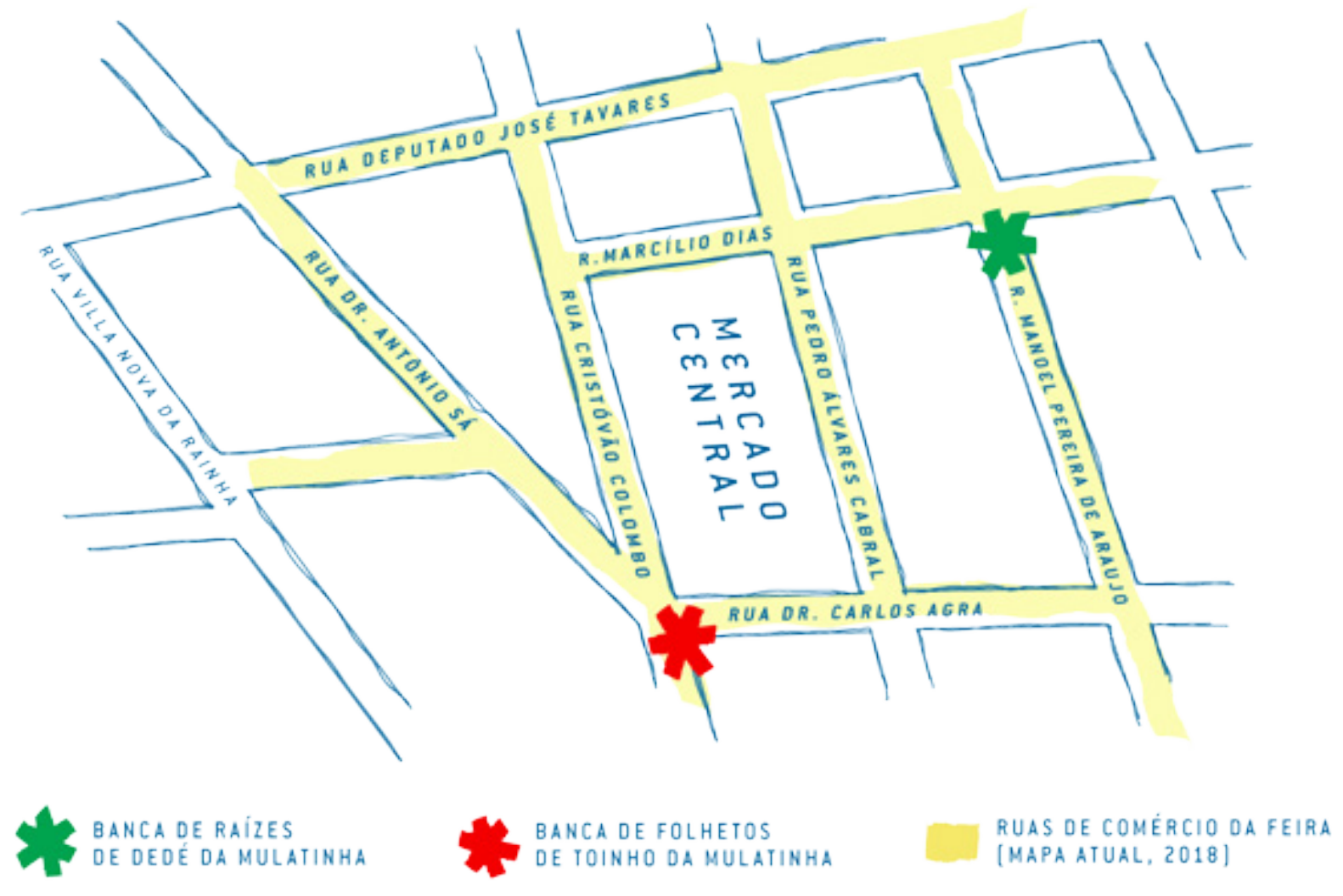

Figura 7 - Mapa indicativo dos pontos onde foram fixadas as bancas de folhetos e raízes dos irmãos Dedé e Toinho da Mulatinha na Feira Central de Campina Grande, em meados do século XX Fonte: Milla Pizzignacco, 2018. Mapa desenhado pela pesquisadora com base cartográfica do Google Maps

45 A Rua Manoel Pereira de Araújo é atualmente conhecida como "rua da feira de galinha". Nela também ocorre, aos sábados, a "feira do rolo".

46 Casa de alimentação, onde se vende lanche, almoço e café, como um boteco - definida pelas/os feirantes como "hotel". 
O cultivo da relação entre raízes, poesia e cantoria não foi exclusividade dos irmãos da Mulatinha. De acordo com Ana Maria Galvão (2001), a partir da década de 1930/40, quando os poetas passam a privilegiar as feiras como locais de venda, se instalam em áreas pontuais, geralmente, naquelas dedicadas à venda de plantas medicinais. "Nesta época e nas décadas seguintes, os folhetos eram vendidos junto com almanaques, orações impressas, canções, remédios caseiros e imagens de santos, assim como revistas usadas” (GALVÃO, 2001, p. 35).

Mikhail Bakhtin (1993), percorrendo a história não oficial dos mercados e feiras através de livros que trazem elementos deste microcosmo ${ }^{47}$, ressalta a confluência dos ofícios de mercadores de "ervas miraculosas" e "vendedores de livros de quatro centavos". "Charlatões de feira" que se dedicavam a contar causos, histórias fantásticas, "receitas paródicas". O autor associa o pregão emitido por estes mercadores populares, na França do século XVI, à cantoria, definindo como: "O reclame que os mercadores da capital gritam em alta voz, dando-lhe uma forma rimada e rítmica; [...] uma quadra destinada a propor uma mercadoria e a louvar-lhe as qualidades" (BAKTHIN, 1993, p. 156). Estas passagens textuais nos inserem no pulsante mercado-mundo medieval e renascentista, trazendo vozes cotidianas de um passado reverberado na boca de cantadores como Toinho e Dedé da Mulatinha.

Não há feirante que não encontre os irmãos “da Mulatinha” pelos túneis da memória. Samuel da Silveira, comerciante de feijão, conta: "Vendia negócio de folhete, essas coisa... Vendia também raiz de pau, casca de pau pra fazer remédio, gostava de vender essas coisa. Eu achava bom quando eles tavam aqui trabalhando, era uma animação legal, muita gente vinha aqui!"48. João Agra, proprietário de "hotel de comida”, lembrou-se dos irmãos na Feira Central e da sua relação com os folhetos de feira: "Eles cantavam aqueles versos bonitos, não era? Eu comprei muitos! Gostava de ler, depois cantava em casa." ${ }^{9}$

A raizeira Dona Inácia, também era consumidora assídua deste gênero literário. Vizinha de Toinho da Mulatinha, lembra-se que Toinho e Dedé iam até a sua casa em busca de expandir o repertório de histórias para contar e cantar. "Quando dava fé eles chegava lá em casa e dizia 'canta aí o folhete, lê aí o folhete'. Aí eu lia o folhete pra eles escutá e eles ia gravando aquelas história de folhete, pra contar. Sabe o que é verso né? Folhetezim?... Quem tem esses dons é assim...Pega coisinha daqui, dacolá, vai juntando".

Ao referirem-se a estes momentos de compartilhamento de narrativas, as/os colaboradoras/es desta pesquisa alternam os verbos cantar eler de maneira espontânea,

47 Ver mais em: Pantagruel (1532) e Gargântua, (1534), autoria de François Rabelais (1494 - 1553).

48 SILVEIRA, Samuel Lopes da. Depoimento [jul. 2015]. Entrevista concedida à pesquisadora. Campina Grande (PB), 2015.

49 AGRA, João. Depoimento [jan. 2016]. Entrevista concedida à pesquisadora. Campina Grande (PB), 2016. 
como na frase proferida por Dona Inácia: "Canta aí o folhete. Lê aí o folhete". A dissolução das diferenças entre as palavras remete às origens difusas desta tradição literária, fruto de processos híbridos próprios de um território colonizado e escravocrata, marcado pela oralidade. Porém, ainda que possa ser associada com as pelejas e outras formas de cantoria desenvolvidas no nordeste brasileiro, a literatura de folhetos distinguese destas manifestações da poesia oral diante das especificidades derivadas de sua destinação gráfica (CASCUDO, 1988).

Multicultural por excelência, este gênero literário assentado em solo nordestino emerge dos cruzamentos entre elementos precedentes de diversas classes e nações, ressignificando aspectos relativos às poéticas fundamentalmente orais como: as cantorias lusitanas e de matriz africana, os pregões comerciais de origem medieval e ao hábito milenar de compartilhar narrativas, presente em todas as sociedades, apropriando-se, assim, de referências concernentes a textos impressos como os romances tradicionais ibéricos, principalmente os portugueses, publicados em folhas volantes e pendurados em cordel (barbante), como também da poesia erudita inserida pelos colonizadores, tal como a de Gil Vicente (PROENÇA, 1977).

A descendência portuguesa na constituição da literatura de folhetos, constantemente reiterada por pesquisadoras/es da área, vem sendo relativizada em prol de uma visão mais abrangente, capaz de abarcar outras influências - como de literaturas congêneres encontradas no continente americano: corrido, contrapuento, pliegos sueltos (DIEGUES JÚNIOR, 1989) -, e, principalmente, superar a busca de uma prevalência genética para uma manifestação que se particulariza no solo em que foi semeada.

Certa corrente folclorista que prima pelo "retorno às origens" de nossa cultura e literatura popular parece não perceber que na medida em que é reelaborada constantemente, essa tradição assume matizes e especificidades inegavelmente "nossas", locais, próprias, ligadas a seu contexto de produção e a todos os fatores sócio-culturais que o influenciam. Nunca é demais reiterar que o "folclore não flutua no ar". (AZEVÊDO, 2000b, p.83)

A leitura oralizada não foi exclusividade da literatura "popular" em verso, no campo da poesia erudita esta foi uma prática comum. Derivada tanto dos significativos índices de analfabetismo no Brasil ${ }^{50}$, quanto das particularidades do gênero literário, conformado mediante associações entre palavras, ritmos e imagens, o caráter melódico da poesia engendrou práticas orais de socialização do escrito.

50 Índices de analfabetismo no Brasil (ano - população): 1890 - 84\%; 1920 - 75\%; 1940 -57\%. (CANDIDO, 1976, p. 137) 
A aproximação com o universo da leitura/escrita foi profícua mesmo para aqueles poetas-cantadores que se mantiveram vinculados estritamente às práticas orais, como repentistas e emboladores de coco. Dedé da Mulatinha, por exemplo, teve o papel como superfície para retenção de situações vivenciadas, suporte para a ordenação das ideias, tela para a visualização da obra em sua totalidade. O neto, Mundinho, rememora a rotina do avô: "Quando chegava em casa era aquela coisa, sentava ali e ficava o dia todinho escrevendo. Ele gostava sempre de ficar escrevendo alguma coisa...O que ele ia apresentar, ou que já tinha apresentado antes, ou o que tava na memória dele pra futuramente".

Dos livros os poetas extraíram informações para "cantar ciência”: exibir o repertório adquirido sobre algum tema determinado (FERREIRA, 2004). Este recurso utilizado com recorrência na construção deDesafios como Marcos, Pelejas eEmboladas de Coco,éativadoemalgumaspublicações de ToinhodaMulatinha.EmEmboladassobreocorpo humano, versos registrados a caneta em um caderno, o poeta demonstra o saber livresco, enciclopédico, ao enumerar e nomear alguns ossos, órgãos, tecidos, músculos e nervos que compõe o corpo humano, dizendo suas funções. A exemplo do trecho focado no olho:

\footnotetext{
É a esclerótica ou córnea

Opaca certamente

Tem ela um furo na frente

Ao qual a córnea está

Lúcida ou transparente

Como discreve a lição

Debaixo da mesma então

A membrana coroide está

Coróide é a membrana

Conjuntiva do olho

No olho cego ou caolho

Essa se pode encontrar

Está entre a esclerótica

Sim também a retina

A história me incina

O outro poço incinar .

(MULATINHA, 19--, n.p.)
}

Alforriados/as pelo domínio do desenho-palavra, poetas e poetizas motivavam a comunidade de ouvintes a apropriar-se destes códigos, como podemos observar na quarta capa de um dos folhetos encontrados no acervo de Toinho da Mulatinha, de autoria de José Carlos da Silva"51, ainda no rascunho: "Vamos acabar com

51 SILVA, José Carlos. As bravuras de Luís e a corage de Jacira. Campina Grande, 2002. 
o analfabetismo ler é o mais importante. Viva nosso Brasil" (SILVA, 2002). Na contracapa do folheto Chiquinho e Juliana - O amor que vence ${ }^{52}$ [Figura 8], de autoria de Joaquim Batista de Sena e propriedade do editor Manoel Caboclo e Silva, a literatura de cordel é mencionada, em tom hiperbólico, como material didático profícuo: "A literatura de cordel é o carro alegórico que ajuda o Mobral. É a escada de luz. Não seja um analfabeto”.

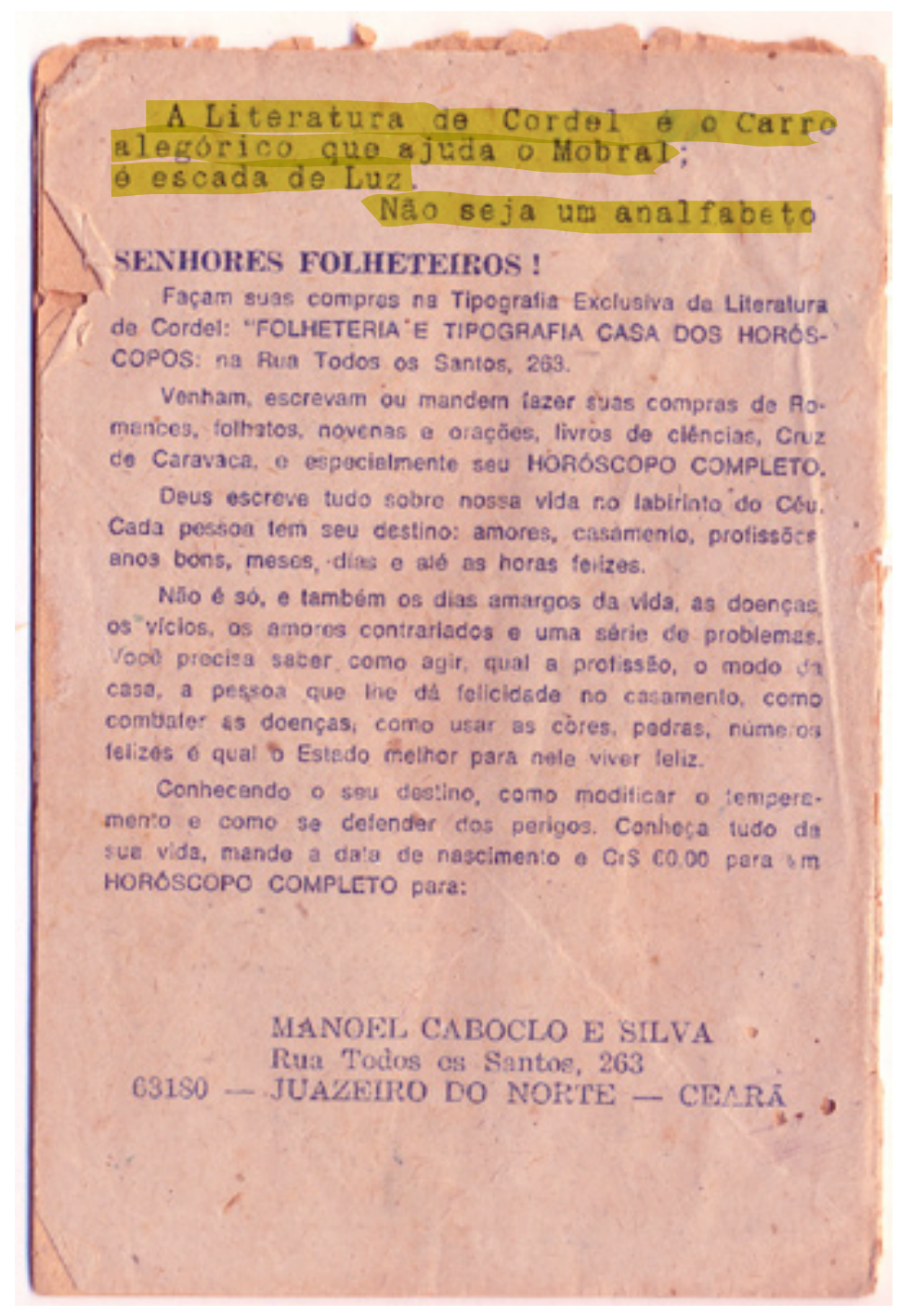

Figura 8 - Quarta capa do folheto Chiquinho e Juliana - 0 amor que vence (19--). Grifo realizado digitalmente pela pesquisadora.

Fonte: Acervo da pesquisadora

52 Agradeço Victor Rafael Limeira da Silva por me presentear com este folheto da coleção de seu falecido bisavô, o cordelista Manoel Tomaz de Assis ou Manoel Limão (1899 - 1978, Alagoa Grande - PB). 
O recorrente incentivo à alfabetização do público consumidor de folhetos pelos/ as poetas/poetisas de bancada, testemunha que estes/as reconheceram a fecundidade da relação estabelecida com a cultura escrita, que se empunha na vida urbana. É também reverberação dos projetos governamentais de erradicação do analfabetismo, como o Movimento Brasileiro de Alfabetização - Mobral, mencionado no folheto supracitado, implementado no ano de 1967 sob a presidência do ditador General Alberto Costa e Silva.

O Mobral, prolongamento da Campanha de Educação de Adolescentes e Adultos (CEAA) lançada em 1947 por Lourenço Filho, interrompeu o Plano Nacional de Alfabetização orientado pela proposta pedagógica de Paulo Freire (1964). O método freiriano de alfabetização de adultos ${ }^{53}$ aproxima-se, em certa medida, das práticas de aprendizagem da leitura/escrita por meio dos folhetos, posto que privilegia a significação de palavras atreladas às experiências vistais dos sujeitos, às temáticas concernentes ao local.

Por meio da leitura performática de folhetos na Feira Central de Campina Grande Toinho da Mulatinha cativou potenciais leitores. Não é possível mensurar a quantidade de folhetos que produziu. A Biblioteca de Obras Raras Átila Almeida ${ }^{54}$ tem cerca de 45 títulos catalogados ${ }^{55}$, que datam do início 1950 ao final de 1980 - baliza dos três primeiros capítulos dessa pesquisa. Eu pude adquirir em sua residência em torno de 30 títulos produzidos na primeira década do século XXI.

A superfície dos folhetos abriu-se para Toinho como vasto espaço para experimentação poética, propício para aventurar-se na produção ficcional, informacional e comunicacional - agrupamentos com limites pouco precisos. A partir das publicações do autor é possível traçar aspectos do imaginário deste poeta e daqueles que vivenciaram o mesmo contexto sociocultural.

Católico devoto, Toinho derramou suas crenças e conhecimentos bíblicos em forma de sextilhas, quadras e décimas. Clamou por inspiração divina na primeira estrofe de algumas de suas publicações, como no folheto A morte do Radialista e Compositor Nordestino Rosil de Assis Cavalcanti (1968):

\footnotetext{
53 BRANDÃO, Carlos Rodrigues (Org). 0 que é método Paulo Freire. São Paulo: Brasiliense, 1981.; FEITOSA, Sonia Couto Souza. Método Paulo Freire, a reinvenção de um legado. 1ª ed. Brasília: Liber Livro Editora Ltda, 2008.

54 A Biblioteca de Obras Raras Átila Almeida, localizada na Universidade Estadual da Paraíba (UEPB) - Campina Grande, contém o maior acervo de folhetos de feira da América Latina, atualmente com 18.191 exemplares.

55 A catalogação dos folhetos pertencentes ao acervo da Biblioteca Átila Almeida está disponível em: https://drive.google.com/file/d/OB10DC_Vdi-vNTUNTRVU5dXc5RTg/view. Os folhetos de Antônio da Mulatinha pertencentes a este acervo foram produzidos entre meados da década de 1950 e início dos anos 1980, sendo que mais da metade das publicações catalogadas não contêm data.
} 
Peço conforto a Jesus

e a Virgem Casta e boa

para escrever um folheto

sem botar rima atoa

da inesperada morte

do Capitão Zé Lagoa ${ }^{56}$

(MULATINHA, 1968, p.01)

Beato de Frei Damião, publicou quantidade significativa de folhetos religiosos dedicados ao clérigo: As missões de Frei Damião em Bom Jardim e a tempestade em Limoeiro (1955); As missões de Frei Damião em Solênea, Bananeiras e Serraria ele se despedindo do povo e explicando a missa aos católicos (1955); O povo chora com pena do frade Frei Damião (1977); Os milagres de Frei Damião (1978); As missões de Frei Damião em nossa Campina Grande (2001); As missões de Frei Damião em Solidade e o castigo de um amancebado (sem data).

Toinho também publicou folhetos: moralizantes ( $O$ exemplo da moça que virou cachorra no carnaval de oitenta porque zombou de Frei Damião, sem data / Satanás no inferno está contente porque lá chega errado todo dia, 2001); proféticos (O Dilúvio de Roldão não veio - As borboletas azuis erraram a profecia, 1980/ Almanaque e Profecia de Frei Vidal da Penha ,1974).; satíricos (O homem que deixou a mulher para viver com uma jumenta, 1982); históricos (A história de Campina centenária, 1964/ História do Treze Futebol Clube o famoso Galo da Borborema, 1975); biográficos (A morte do radialista e compositor nordestino Rosil Assis Cavalcante, 1968/ Nascimento, vida e morte de Dedé da Mulatinha, 1999); com temáticas sociais (O Cruzeiro Novo, 1967/ Os sofrimentos dos nortistas no Sul ganhando o pão, 1959).

Abarcando variados gêneros da poesia de folhetos ${ }^{57}$, Toinho compôs desafios, edificando marcos, como O Navio Brasileiro (1969) e armando pelejas, tais como: Peleja de Antonio da Mulatinha com Francisco de Sena (sem data) e Peleja de Antonio da Mulatinha com Manuel Batista (sem data). Produziu ao longo da sua carreira, sobretudo, poemas de época, a exemplo: A história do monstro que roubou e incendiou a igreja do Rosário, 1956; A reportagem do fogo no Paraná e a mortandade do povo, 1960; O desastre do caminhão que ia de Esperança a usina Santa Maria, 1977; O folheto do turco que atirou no santo Papa João Paulo II, 1981; O cordel de Isabela [Nardoni], o folheto mais recente dentre os acessados, publicado em 2008 - ano no qual sucedeu-se este crime de repercussão nacional.

Em folhetos desse gênero os/as poetas/poetisas transformam matérias veiculadas em mídias hegemônicas em narrativas, fixando-as em um suporte com

56 Grifos da pesquisadora.

57 Os gêneros da literatura de folhetos são definidos por Ruth Terra (1983) em três grandes grupos: desafios - envolve as pelejas (sucedidas ou fictícias) e cantorias registradas em folhetos, como emboladas de coco; poemas de época, de viés jornalístico referentes a fatos cotidianos e políticos; romances e histórias, englobam narrativas com temáticas diversas, românticas, cômicas, trágicas e de aventura. 
o qual seu público tem familiaridade. Segundo Ana Maria Galvão (2001), nas composições do gênero as/os autoras/es extraem das situações noticiadas elementos capazes de reforçar valores presentes no imaginário de quem os consome. De acordo com a autora "o que parece importar mais para o suposto leitor, é menos a 'atualidade da notícia' ou a informação objetiva do fato/notícia, e mais valores universais rememorados pela história, nos quais ele crê e se alimenta cotidianamente” (2001, p. 90).

A literatura "popular" em folhetos, não foi, necessariamente, um meio de comunicação no qual prevaleceram narrativas contrastantes com os discursos hegemônicos. As/os poetisas/poetas, sobretudo aquelas/es que produziram folhetos até a segunda metade do século XX, parecem muito mais veiculadores de discursos dominantes acerca de marcadores sociais, principalmente de raça e de gênero, do que autoras/es potentes em instaurar uma "educação libertadora”, tal como a proposta por Paulo Freire (1996).

A história dos folhetos e as narrativas neles calcadas refletem a ambiguidade inerente às culturas denominadas populares: fragmentárias, heterogêneas, fruto de interações e integrações (produtivas e conflitivas) entre as categorias culturais simuladas pela modernidade: erudito, popular e massivo. Propagadoras de concepções questionadoras - mobilizada pelo fato de existirem à margem dos sistemas dominantes - e reprodutoras de noções veiculadas pelos mesmos sistemas que as fazem subalternas.

Paradoxos desta ordem estão atrelados à figura de Toinho da Mulatinha, enquanto homem pobre e "mulato”, que rejeita os próprios marcadores de sua existência. O racismo explícito, volumoso em sua produção, aparece em folhetos como $O$ folheto da negra da trouxa grande (1957) e Satanás no inferno está contente porque lá chega errado todo dia (2001). A questão racial é levantada pelo poeta como ponto fulcral das ofensas lançadas ao cantador Manoel Batista em peleja simulada em folheto:
A.M. Ladrão é você seu negro errado cantador que não tem mentalidade conquista de tua qualidade para mim o valor é de um cruzado cretino imbecil atravessado diz que sabe das cousas sem saber és um negro pobre sem proceder o valor de um negro é quaze nada quando não faz um papel feio na entrada na saída é na certeza fazer.
(MULATINHA, 19--, p. 15) ${ }^{58}$

58 MULATINHA, Toinho da [Antônio Patrício de Souza]. Peleja de Antonio da Mulatinha com Manoel Batista, 19--. 
O codinome, da Mulatinha, refere-se a sua herança negra, declarada em versos dedicados à sua avó, presentes em sua autobiografia em cordel: "Aqui termino o cordel / Dos irmãos da Mulatinha / Criados com água doce ${ }^{59 / D a}$ querida cacimbinha / Do chão de Maria Preta / Moreninha e vovozinha ${ }^{60 "}$ (MULATINHA, 19--, p. 08). O vínculo com a embolada de coco assinala a relação do poeta com uma forma poética associada às comunidades de matriz afro-brasileira.

Maria Ignez Ayala (1999) e Elizabeth Travassos (2010) apontam para a origem afrobrasileira dos cocos, sejam dançados (cocos de roda) ou apenas cantados (emboladas de coco), derivados provavelmente do primeiro. Manifestados sob formas variadas em cada contexto no qual se desenvolvem, os cocos são atribuídos às comunidades afrodescendentes por guardarem vínculos genéticos sonoros/coreográficos com manifestações da mesma matriz: contraste entre refrão e estrofe, jogo vocal de chamada e resposta, dança/simulação de umbigada, comunicação por metáforas, o ritmo sincopado e uso de instrumentos percussivos. ${ }^{61}$

Praticados ainda hoje por comunidades afrodescendentes, os cocos são tanto afirmados como forma de resistência cultural, quanto identificados de maneira pejorativa como "dança de negros". A questão étnica, associada a outros fatores socioculturais que dizem respeito aos coletivos praticantes, como localização geográfica, condição econômica e nível de escolaridade, motivam a rejeição ao coco pelos jovens das localidades onde são exercitados (AYALA, 1999).

Segundo o historiador Paulo Iumatti (2014), a embolada de coco trilhou o caminho de segregação destinado aos descendentes das populações negras escravizadas no Brasil, sendo marginalizada no "espaço ritual" da cantoria nordestina, no qual a viola, "arma de branco" foi instituída como legítima. Consolidada no contato conflitivo entre brancos e negros no contexto de crise da sociedade escravista/ pós-abolicionista, a cantoria desenvolvida na extensão territorial então denominada como Norte do país, engendrou-se de maneira a tolher a presença de negros e negras. Hostilizados/as em versos estes/as pelejaram nas disputas por voz, por memória, por territórios físicos e simbólicos e, até, por liberdade.

Referência implícita à escravidão é encontrada em passagem da autobiografia de Toinho, quando menciona a origem da palavra “mulato”, da qual deriva o nome da extensão territorial da família, Sítio da Mulatinha, e o codinome dos/das que ali habitavam:

59 Referência ao "poço da mulatinha". Antes denominado "olho d'água", foi renomeado por estar localizado na região de posse da família, Sítio da Mulatinha.

60 Grifos da pesquisadora.

61 São estes aspectos comuns às expressões musicais carregadas em navios negreiros, que podem ser encontradas nos lundus, nos cateretês, no batuque de umbigada, no jongo, no samba de roda, no samba de partido alto e na capoeira, para citar alguns. 
Aquele nome vulgar

Vem de abelha melípona

Que tem a cor preta e branca

Mulato tem dono e dona

Deles vem o derivado

Que mistura toda zona

(MULATINHA, 20--, p. 03) ${ }^{62}$

Os irmãos mulatos habitam o quadro inquieto da memória da Feira Central campinense como emboladores de coco. Aspecto observável no folheto Louvação a Toinho da Mulatinha (2016), homenagem póstuma ao poeta:

Eu, menino, andava pela feira

Vi Antônio e Dedé da Mulatinha

Embolando. Dois galos numa rinha

Cada um numa rima mais ligeira.

Como cocos rolando numa esteira

Grandes vates numa longa jornada

Poesia em dupla retesada

Hoje o fim, nem o arco, nem a seta...

Deus levou para o céu mais um poeta

Que viveu nessa vida de embolada. ${ }^{63}$

(RANGEL JR., 2016, p. 24)

Condor, embolador de coco atuante na Feira campinense, conta que ainda menino conheceu Toinho da Mulatinha, quando ia fazer feira com seu pai: "Eu me inspirei em Toinho. É uma das minhas primeiras inspirações! [...] Inclusive, ele me entregou um dos trabalhos dele pra que eu pudesse cantar... Que é: 'eu tenho pena de morrer deixar o mundo, mas eu morrendo o mundo pode se acabar". Com brilho nos olhos, relata que o poeta pegou no colo as emboladoras de coco Lindalva e Terezinha ${ }^{64}$, quando estas senhoras eram meninas, e acrescenta, "pensou, que cena?”.

O relato do "discípulo" indica que diferentes gerações tiveram como mestre Toinho da Mulatinha e demonstra vínculo do poeta-folheteiro com a cantoria de embolada, visto que as figuras mencionadas, que nele se inspiraram, dedicaram as próprias vidas a este fazer.

62 MULATINHA, Toinho. Toinho da Mulatinha e sua biografia. 20--. Grifo da pesquisadora.

63 Estrofe de autoria de Rangel Junior, atual reitor da Universidade Estadual da Paraíba e um dos "poetaspolíticos" da cidade.

64 As irmãs Lindalva Dantas Lucena (Várzea Nova - PE) e Otília Dantas Lima (Currais Novos - RN) - que se autodenominou Terezinha -, são cantadoras nordestinas que ingressaram na embolada de coco na infância. Fizeram carreira no sudeste entre as décadas de 1980 e 1990, cantando coco de improviso e comercializando fitas cassete na cidade do Rio de Janeiro. Tornaram-se conhecidas pelo "coco de malcriação", representado no disco "Olha o palavrão!" (2002). Após desmancharem a dupla, no início dos anos 2000, Terezinha passou a cantar com Roque José, no Distrito Federal, e Lindalva com Lavandeira do Ingá, na Paraíba. Lindalva permanece na profissão, em parceria com emboladores locais (como o poeta Condor) e Terezinha descansa a voz mediante questões de saúde. 


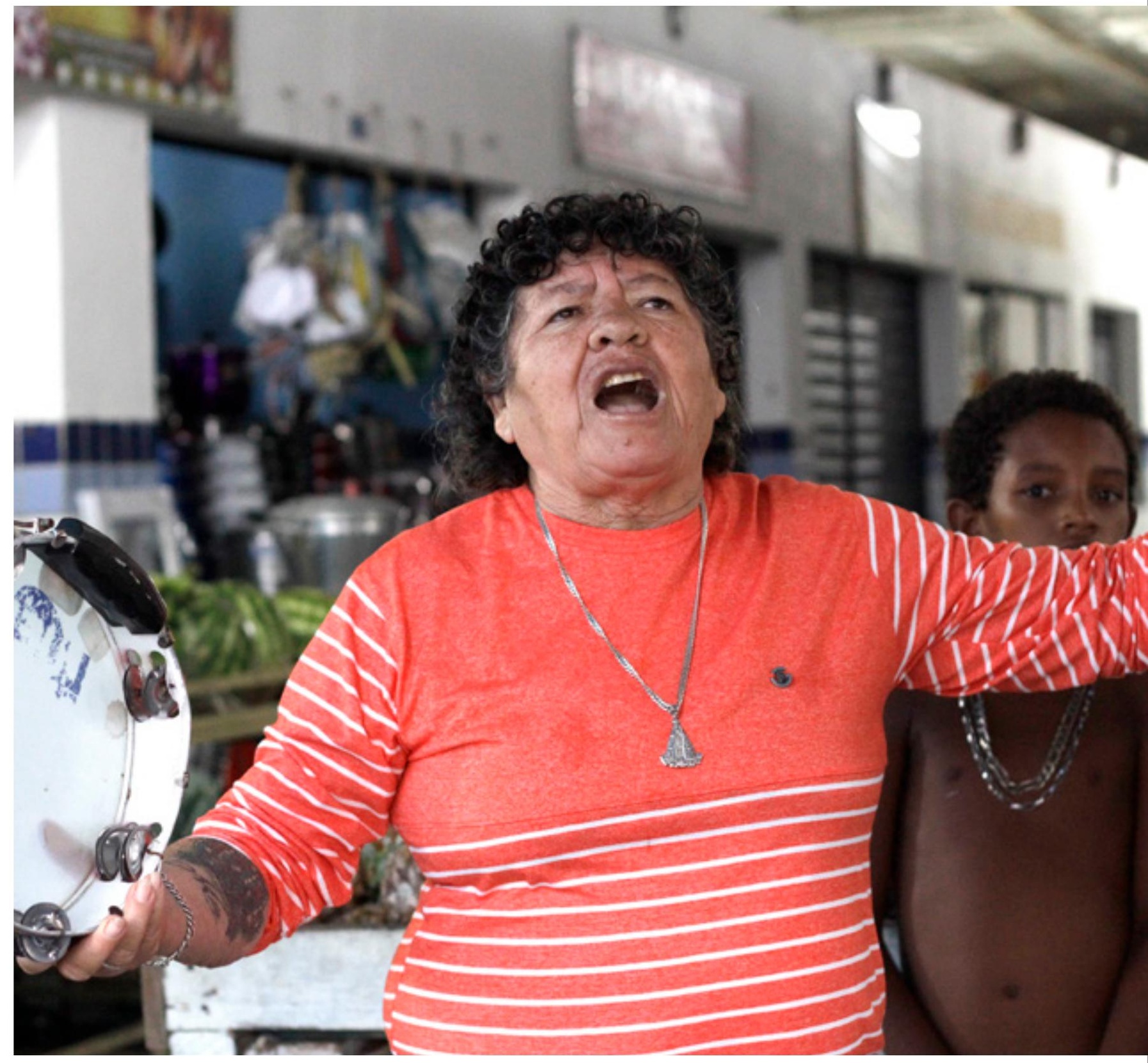

Figura 9 - Lindalva desafiando Condor na

Feira de Cabedelo, João Pessoa (2018)

Fonte: Milla Pizzignacco, 2018 


\section{EMBOLANDO CARACTERES}

No profundo e dinâmico mar de cocos nordestinos ${ }^{65}$, Toinho firmou seu barco como embolador. Embolada de coco, é uma denominação popular da tradição oral a um gênero poético-musical ritmado por pandeiro e/ou ganzá ${ }^{66}$, cantado em dupla, seja em forma de "improviso", comum nas práticas de desafio, ou de "trabalho", no qual os versos são previamente elaborados. Os emboladores praticam-na de diferentes formas: (1) Alternam as vozes nas estrofes, justapondo-as no refrão - quando existente; (2) Um dos componentes atua como solista, cantando todas as estrofes, enquanto o outro se encarrega do estribilho.

A embolada cultivou o caráter dialogal do coco de roda, do qual provavelmente se desprendeu. De acordo com Elizabeth Travassos (2010), "bola", "bolada”, "rebolar", variantes do termo embolada, frequentam a poética dos cocos e referem-se tanto aos versos lançados pelo solista na dança do coco, quanto à sagacidade intelectual no ato do desafio: "Rebola bola/ você diz que dá que dá/ você diz que dá na bola/ na bola você não dá!”, embola a quadra popular.

Ao analisar a raiz da palavra, a autora afirma: “Bola é, em suma tino, cabeça; por extensão, o jeito de catar. Bolada são versos que o solista lança, e que serão respondidos pelos parceiros-rivais. Rebolar é revirar a mente, realizar operações mentais em busca das palavras" (TRAVASSOS, 2010, p. 23). Embolar é, então, uma técnica de cantar que privilegia a articulação de fonemas, a compressão de palavras no tempo e a vocalização quase instantânea de pensamentos, resultando em uma forma intensa, dinâmica e, em certa medida, enigmática. Potente em embaraçar o desafiado, embalar o público de ouvintes.

Os folhetos de Toinho da Mulatinha guardam vozes iminentes e chancelam a relação do autor com a cantoria, especificamente com o coco de embolada, prática que sempre esteve amalgamada ao seu fazer enquanto poeta de bancada. O poeta escapa aos modelos fixos da literatura de folhetos, nos quais prevalecem as sextilhas em sete sílabas, em virtude do vínculo com cantoria. De modo que utiliza as quadras (com o primeiro

65 Abarcadas pela mesma designação, coco, estas brincadeiras de canto/dança/poesia de matriz afro-brasileira, guardam variações significativas vinculadas aos contextos geoculturais nos quais se desenvolvem, podendo ser consideradas manifestações distintas. Os cocos, colocados em cena por agentes da Missão de Pesquisas Folclóricas (1938), sobretudo, por Mário de Andrade (Na pancada do ganzá, 1929, inacabado; A literatura dos cocos, organizado por Oneyda Alvarenga, 1984), constam com poucos estudos sistematizados e rigorosos quanto suas especificidades, sendo os mais relevantes publicados recentemente e, referenciados neste trabalho de pesquisa: Cocos, alegria e devoção (2000), organizado por Maria Ignez Ayala e Marcos Ayala; Palavras que consomem: contribuição à análise dos cocos-de-embolada (2001), artigo de autoria de Elizabeth Travassos.

66 Atualmente é mais raro encontrar o ganzá na mão de emboladores. 
verso com “pé quebrado” ${ }^{67}$, particulares do coco, e por vezes as décimas ${ }^{68}$, características do desafio de viola e dos "trabalhos" de embolada.

A transposição do coco do universo oral para o escrito pode ser observada no folheto Uma viagem Sagrada (1953):

\section{COCO:}

Vou viajar

Andar em campos sagrados

Visitar os santos prados

Ver coisa boa e cantar.

Repete: Vou viajar...

Sou velho na cantoria

Nasci na antiguidade

Só Deus sabe minha idade

E minha sabedoria.

Vi quando nasceu Maria

Mãe das mães penalizadas,

Sei dizer quantas moradas

Existem no outro mundo

Quando Deus fez esse mundo

Eu já cantava emboladas

Vou viajar...

(MULATINHA, 1953, p. 01)

Ao indicar, antes da primeira estrofe, que os versos pertencem ao gênero do “coco" - aspecto anunciado também (para o público familiarizado) pela presença do mote $^{69}$ associado ao esquema rimático/métrico empregado - Toinho da Mulatinha sugere ao/à leitor/a que o texto deve ser vocalizado de uma maneira específica, ligeira, ritmada. De forma a borrar determinadas áreas em branco que separam as palavras calcadas no papel. Deste modo, o autor convoca o/a leitor/a, cantador/a em potencial, a virar do avesso o "bordado" nítido impresso pela palavra escrita, "embolando" as palavras visualmente ordenadas.

Em Viagem Sagrada, Toinho da Mulatinha apresenta um “coco de amarração”, no qual liga "versos em sequências, de acordo com modelos métrico-musicais conhecidos,

67 É uma forma literária composta por estrofes de quatro versos que utilizam, geralmente, esquema rítmico semelhante ao da trova, rimas cruzadas (ABAB) ou interpoladas (ABBA). As estrofes das quadras podem ser encontradas também no esquema XAXAXA, que utiliza a rima final apenas nos versos pares.

68 É uma forma literária composta por estrofes de dez versos que apresenta esquema rítmico diverso, sendo o mais utilizado o ABBAACCDDC. Os versos em décimas são considerados uma "forma erudita" na cantoria pelo grau de dificuldade colocado pelo modelo. É neste formato que aparece o "Martelo agalopado" e o "galope à beira-mar".

69 Mote ou Tema é uma frase metrificada em versos que se dá ou se escolhe para uma composição poética (de improviso ou não] e que pode se repetir na composição como uma espécie de estribilho. 
sem ser interrompido pelo refrão coral ou pela resposta do embolador-parceiro" (TRAVASSOS, 2001, p. 27). O autor também explora outras modalidades do coco em sua produção escrita, como o "coco de desafio", tônica do folheto Peleja de Antônio da Mulatinha com Vem-vem do Piancó (1964):

\author{
A- É bonito cantar \\ Mulatinha com Vem-vem \\ Vai voando volta e vem \\ Vendo as belezas do ar \\ V- Antônio da Mulatinha \\ O côco vai ser pesado \\ Não quero côco embolado \\ E em dez em misturar \\ É tudo improvisado \\ Cada um, um carreirão \\ Certo em malcriação \\ Ganha quem poder ganhar
}

A- Você quer eu também quero

Cantar tudo improvisado

Verso feito ou decorado

É bom a gente deixar

Os versos malcriados

Que os cantadores cantam

Esses não nos adiantam

Iremos outros cantar.

(MULATINHA, 1964, p.02)

Nos versos transcritos verifica-se a noção de disputa através da marcação das iniciais dos cantadores antes de cada estrofe. No próprio título o autor anuncia a qual gênero da literatura de cordel o folheto pertence, a peleja: centrada no diálogo improvisado estruturado pelo insulto poético e pela criação de "nós", dificuldades que um/a cantador/a lança para o/a adversário/a “desamarrar”. A xilogravura que estampa a capa deste folheto [Figura 10] indica que a peleja evocada ao longo do texto é aquela proveniente do coco de embolada e não do repente de viola - quantitativamente mais representado nos folhetos pertencentes ao gênero.

A peleja, simulação do improviso poético oral real ou imaginado, é um gênero da literatura de folhetos que exibe disputas entre poetas/poetisas conhecidos(as)/ inventados(as) ou desafios que se passaram e foram recriados pela memória 
e interpretação de quem os relata (FERREIRA, 2004). Folhetos pertencentes ao gênero da peleja podem ser identificados pelo título, que geralmente traz os termos “desafio", “peleja”, “discussão” ou “encontro" e visualmente pela imagem das capas, na maioria das vezes ilustradas com dois/duas cantadores/as, lado a lado, segurando seus instrumento.

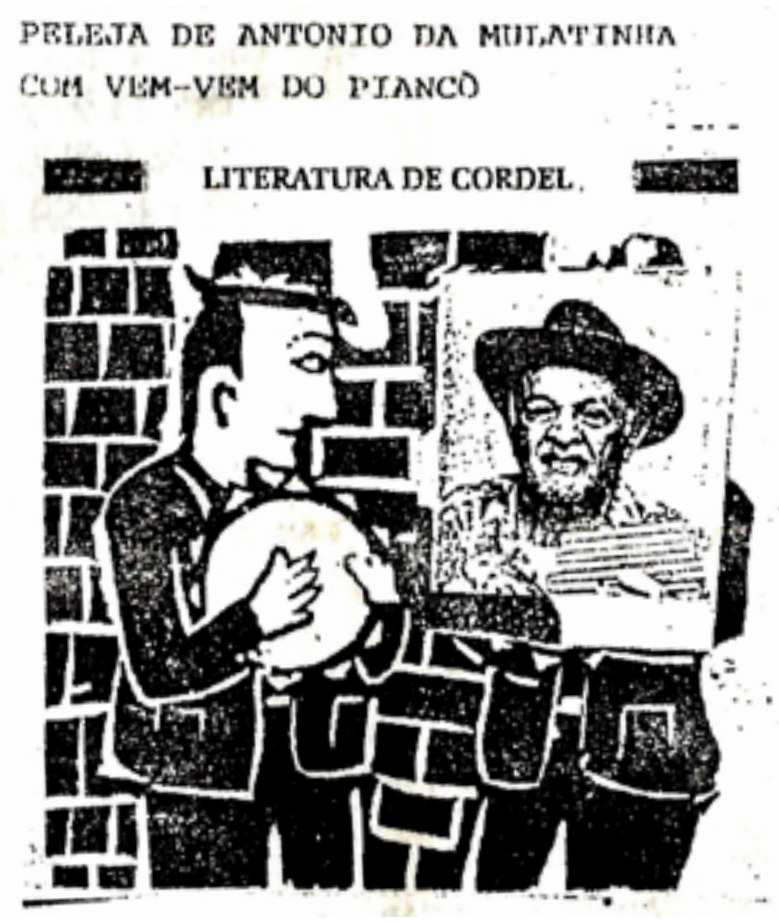

Figura 10 - Capa do folheto Peleja de Antônio da Mulatinha com Vem-vem do Piancó (Toinho da Mulatinha, 2000)

Fonte: Acervo da pesquisadora
Os primeiros textos poéticos registrados como pertencentes ao gênero começam a aparecer em 1903, tematizando o "Desafio de Patos", ocorrido em 1874 no sertão da Paraíba, estabelecido entre Romano da Mãe d’Água e Inácio da Catingueira (LEWIN, 2007). Neste desafio, Inácio teria utilizado para disputa uma "arma de negro", o pandeiro, que revela sua identidade enquanto embolador de origem afro-brasileira. Marcas identitárias alicerçadas também à existência de Toinho da Mulatinha.

A ilustração presente na capa de Peleja de Antônio da Mulatinha com Vem-vem do Piancó (publicado em 1964 e reeditado no início dos anos 2000) exibe a figura

de dois emboladores [Figura 10]. Aspecto que pode ser concluído pela presença de um pandeiro, na mão de um dos personagens xilogravados, e de um ganzá, registrado na fotografia 3x4 de Toinho da Mulatinha, sobreposta à impressão original (sobre a face da outra figura integrante da peleja).

Na imagem, os emboladores aparecem em pé, diferentemente dos/das repentistas, que são representados/as sentados/as em folhetos do gênero. As situações de cantoria/audição do coco são armadas tais quais a abertura de um folheto, se dão no lançamento de um verso "no meio do tempo", não tem hora para acontecer (distinto do repente de viola, com dia e ponteiros acertados no Bar da Tereza, localizado na Feira Central). Em pé, e, muitas vezes em movimento, (en)cantadoras/es de feira debulham narrativas mirabolantes para cativar seu público.

Na peleja supracitada, Toinho da Mulatinha sugere, logo na primeira página, dedicada à construção de um espaço de disputa entre os cantadores, que o coco cantado não será um “coco de malcriação” ("Os versos malcriados/ Que os cantadores cantam/ 
Esses não nos adiantam / Iremos outros cantar”). Porém, logo em seguida, o autor designa a Vem-Vem do Piancó uma provocação, lançada em décimas, responsável por desenrolar um desafio malcriado pelas oito páginas do folheto:

V- Tú és um catimbozeiro

Beco velho sem saída

Cara de mulher perdida

Protetor de maconheiro

Mochila de favozeiro

Portador de fuxiqueira

Maleta de xangozeira

Coração de caranguejo

Juízo de percevejo

Gato velho de tripeira

A- És azar de fim de feira

Tristeza de fim de era

Cabelo de besta fera

Espírito de cachaceira

Plano de mulher chifreira

Consciência de Caim

Cabeleira de saguim

Coceira de bode seco

Moléstia de fim de beco

Xeleléu de cabra ruim .

(MULATINHA, 1964, p. 02-03)

Nestas estrofes destaca-se o caráter combativo característico do coco de embolada, no qual a "peia” em versos é ativada como ferramenta de disputa pela honra do/da cantador/a. De acordo com as análises do pesquisador Jimmy Vasconcelos de Azevêdo (2000) sobre “a embolada enquanto manifestação oral e escrita”, o exercício de grafar a embolada provoca uma "redução" de aspectos estruturantes deste gênero poético-musical, marcado pela espontaneidade e o desprendimento que são próprios da prática improvisada oral realizada na praça pública.

Para o autor, o procedimento de transposição do gênero para o meio escrito acaba por solidificar modelos canônicos recusados pelo processo criativo intrínseco à embolada, no qual a métrica perfeita e a lógica narrativa são relevadas em prol da ressonância sonora das palavras e da "brincadeira”. O poeta Condor, apesar de dominar a métrica/rima do coco de embolada, conta que no contexto da feira há uma "licença" para fugir a estas regras: 
É uma brincadeira, então a gente rima do jeito que quer. Na regra da embolada de coco eu não posso ficar parado tocando o pandeiro pensando no que eu vou dizer... isso sim é fugir da regra. Então como eu vou parar uma embolada pra cantar e dar um intervalo no meio pra voltar pro meu verso? Eu não posso fazer isso. A embolada não me permite, eu tenho que seguir ela. E ela é pegada na deixa. [...] O violeiro ele tem tempo de pensar. Enquanto ele tá na viola ele faz o verso, permite-se que ele faça um verso mais bonito. [...] Então eu costumo dizer que a embolada é o verdadeiro repente pela forma, pela velocidade. (SILVA, 2018).

Na perspectiva de Azevêdo (2000), o coco de embolada registrado em folheto sucumbe mecanismos ativadores do riso, como a blasfêmia, o escatológico, o obsceno, que ignoram qualquer sombra de moralidade. Para o autor, o papel captura os insultos que na prática oral diluem-se no ar e confundem-se ao riso, de modo que o/a poeta/ poetisa ao depositá-los no suporte, pesa a carga das palavras impressas, passíveis de julgamento na "prova” escrita. Nesse sentido, conforme Jimmy Azevêdo, o folheto opera como um filtro que transforma o palavrão em eufemismo.

Porém, nesta pesquisa, supõe-se o oposto: a embolada "criada em bancada" tem o potencial de ativar metáforas mais complexas, derivadas do tempo de elaboração do verso, que percorre a distância entre mente e punho. Diante disso, a incitação do riso pode ser intensificada pelo jogo de palavras pinçadas, estudadas, (re)combinadas no processo laboratorial de formulação da "mandinga”. Aspecto saliente na bazófia "azar de fim de feira”, proclamada por Toinho na peleja referenciada, capaz de substantivar um sentimento não condensável em uma palavra, em um palavrão.

Poeta feirante e embolador, Toinho devolveu para a feira a "mangação" guardada no folheto, colocando a escrita a favor da oralidade. Dedé da Mulatinha, seu irmão, também fez da escrita instrumento para aprimorar seu coco, utilizando-a para registrar as lembranças de improvisos certeiros, dignos de repetição.

O uso de frases elaboradas previamente pela/o autor/a ou por terceiros/as, assim como a apropriação de versos "prontos" pertencentes a outras vertentes da tradição oral, são procedimentos convencionados pela embolada de coco, ressaltados na Peleja de Antônio da Mulatinha com Vem-vem do Piancó: "verso feito ou decorado / É bom a gente deixar". Na "brincadeira" da embolada a repetição daquilo que teve êxito não é motivo de desprestígio, tal como na cantoria de viola, imbuída de maior rigor técnico.

Ao referir-se ao improviso oral da embolada de coco, Mário de Andrade afirma que praticantes do gênero desprendem-se da lógica intelectual em seu processo criativo, sujeitando-se a processos associativos mais inconscientes do que analíticos, colaborando, em certa medida, a sedimentar a imagem da embolada como um fazer displicente. De acordo com as análises do folclorista o embolador "se atira à embolada, a palavra 
é explícita, em que a 'bola' inventa com grande libertação de sentido, rebola a bola, sem saber muitas vezes o que está dizendo” (ANDRADE, 1993 apud TRAVASSOS, 2010, p.19).

A liberdade da embolada na lida com a metrificação, o componente non sense da narrativa do coco (decorrente da agilidade mental exigida e da exploração do som em detrimento do sentido das palavras), assim como a “malcriação" em versos e, sua origem na dança afro-brasileira dos cocos, são particularidades que tornam o gênero subalternizado no ambiente da cantoria. Problemática esta evidenciada na disputa simulada entre Toinho da Mulatinha e Manoel Batista, de autoria do primeiro, que demonstra reconhecer as depreciações alheias sobre seu ofício:

\author{
M.B. Antônio da Mulatinha \\ dê volta na sua bola \\ que a cantiga vai ser \\ no estilo da viola \\ que embolada de côco \\ isto muito descontrola.
}

\begin{abstract}
A.M. Esse estilo me consola pois nele estou preparado seja em seis ou em dez quadrão martelo e trocado só não canto beira-mar por ser muito viciado.

M.B. Mesmo é trabalho pesado

o galope a beira-mar todo coquista não canta este assunto popular por não ter bom pensamento escuta o outro cantar ${ }^{70}$. (MULATINHA, 19--, p. 03)
\end{abstract}

Embora reconheça "o lugar" dado ao coco na cantoria popular, "Toinho levantou a bandeira da embolada. Segurou até o dia da morte dele.”, relata Condor. Poeta de bancada, Toinho da Mulatinha reitera a matriz de seu ofício nas capas de alguns folhetos, imprimindo entre parênteses após demarcação de sua a autoria, as seguintes denominações: "poeta conquista”, “poeta embolador", “cantador de coco”, dentre outras [Figura 11].

70 Grifos da pesquisadora. 
Figura 11 - Capas e quarta capa de folhetos nos quais Toinho da Mulatinha reitera seu vínculo com a oralidade. Grifos realizados digitalmente pela pesquisadora

Fonte: Acervo da pesquisadora
CAMPINA GRANDE E AS VIOLAS

LITERATURA DE CORDEL
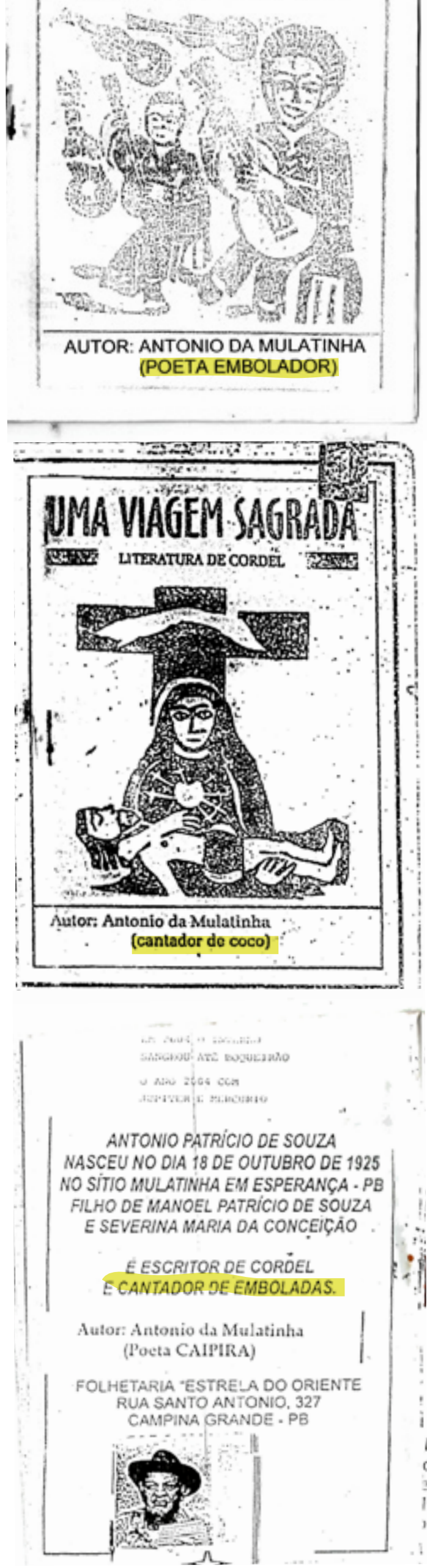
O vínculo com a oralidade manifesta-se sob variadas formas nas capas das publicações do poeta, como no folheto A paixão de Cristo (2001), em que o título aparece seguido da frase "Canta: Toinho da Mulatinha” [Figura 12].

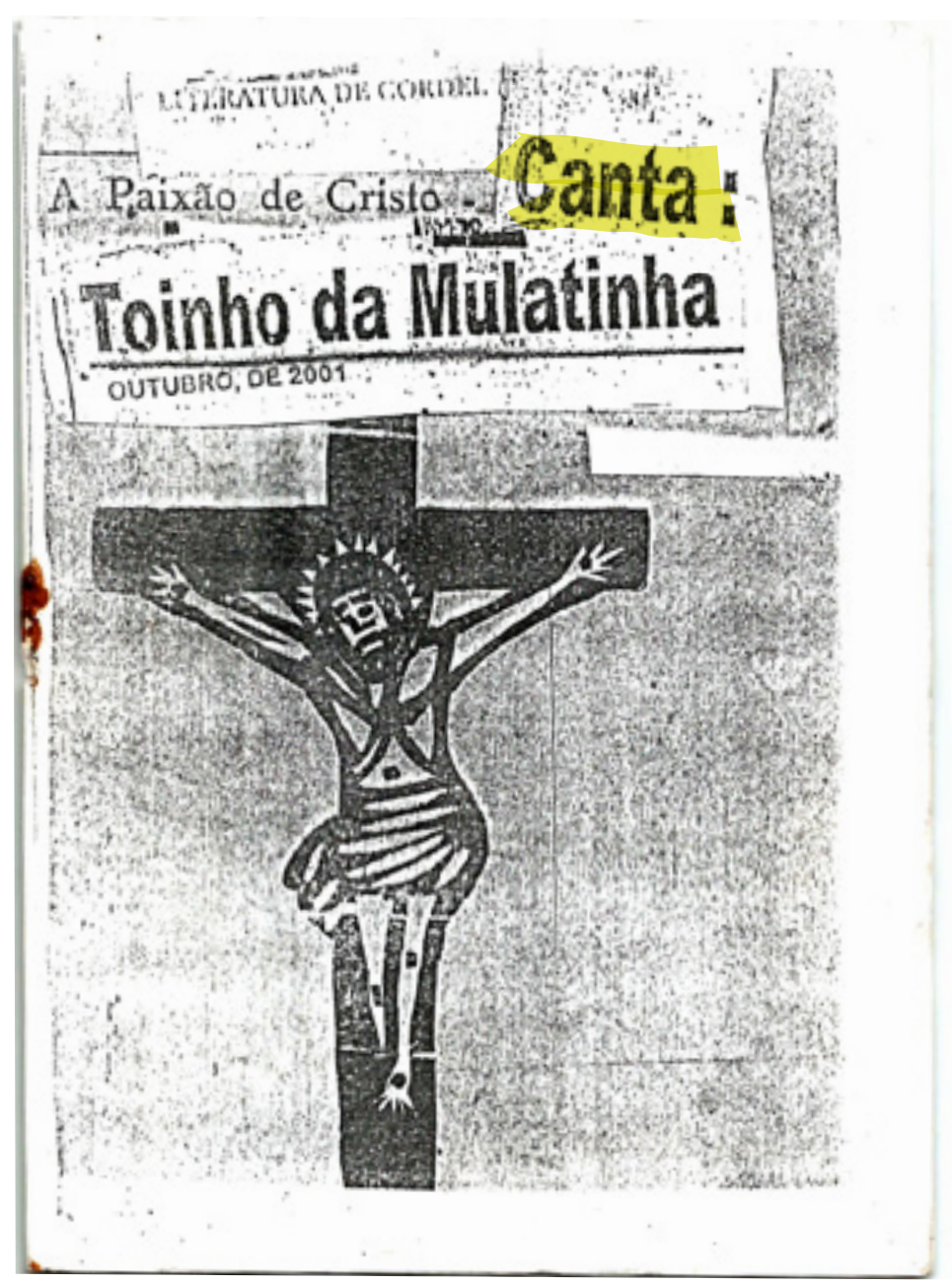

Figura 12 - Capa do folheto A paixão de Cristo (Toinho da Mulatinha, 2001), em destaque menção à oralidade. Grifo realizado digitalmente pela pesquisadora

Fonte: Acervo da pesquisadora

A complexidade de sua produção não nos permite incorrer no equívoco de reduzir a literatura de cordel a um produto da oralidade. Agente de um gênero e sistema cultural específico, Toinho da Mulatinha fez do papel membrana permeável às trocas entre gêneros que encontraram eco nas feiras. 


\title{
O VENDEDOR DE CANÇÕES
}

“Folhetaria 'Estrela do Oriente' - Grande sortimento de Romances, Folhetos e Canções Populares"71. Esta é uma subscrição presente na quarta capa de alguns folhetos de Toinho da Mulatinha, que remete ao seu medular ponto de venda, também sua residência:

\author{
Endereço do poéta \\ Antônio da Mulatinha \\ É na rua Santo Antônio \\ Cazado com uma velhinha ${ }^{72}$ \\ E trezentos e vinte e sete \\ É o número da casinha.
}

(MULATINHA, 1964, p. 08)

A oferta de "canções populares", mencionada como uma das categorias de produtos comercializados na folhetaria, denota que Toinho da Mulatinha distinguia os folhetos que mantinham uma relação mais direta com as poéticas da voz daqueles agrupados como "romances" e "folhetos", tal como o já citado Uma Viagem Sagrada (1953), no qual a escrita parece servir à vocalização.

Nas publicações de Toinho da Mulatinha podemos encontrar alguns "índices de oralidade" (GALVÃO, 2001) que permeiam a produção de poetas de sua geração. A convocação da comunidade de leitores/ouvintes na primeira estrofe dos folhetos, recurso imperativo que remete ao pregão entoado na feira (exposto no início do capítulo), assim como a tentativa de empreender um diálogo com o/a freguês/a hipotético/a, são recorrências que indicam a destinação oral das poesias do feirante. Visíveis no folheto A queda do Skylab e o medo do pessoal (1975):

\author{
Quem gostar de ler gracejo \\ sem ser gracejo imoral \\ leia este folhetinho \\ e diga está legal \\ a queda do Skylab \\ e o medo do pessoal ${ }^{73}$ \\ (MULATINHA, 1975, p. 01)
}

\footnotetext{
71 Grifo da pesquisadora.

72 Refere-se à Maria Gorda, sua primeira esposa, que tinha diferença de idade significativa em relação ao poeta, conforme relato das/os feirantes entrevistadas/os.

73 Grifo da pesquisadora.
} 
A ausência de pontuação no verso a seguir, transcrito do folheto $O$ homem que deixou a mulher para viver com uma jumenta (1982), insinua que o texto deve ser demarcado pelo ritmo da fala. A mudança de interlocução na estrofe (uso do discurso direto), carente de sinais gráficos indicativos da transcrição, responsabiliza o/a leitor/a ou cantador/a de conferir o discurso à personagem por meio da entonação.

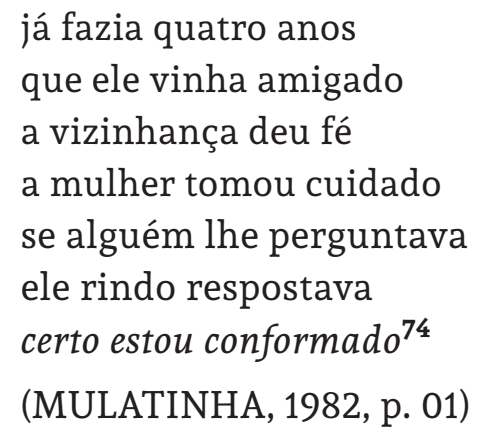

Além de elementos que assinalam a disposição verbal do texto impresso, os poemas de Toinho guardam resquícios orais provenientes do léxico coloquial, tal como na frase grifada na estrofe abaixo, extraída do mesmo poema, estruturada por meio de uma inversão recorrente no vocabulário paraibano ("é não", “fui não", "gosto não"):

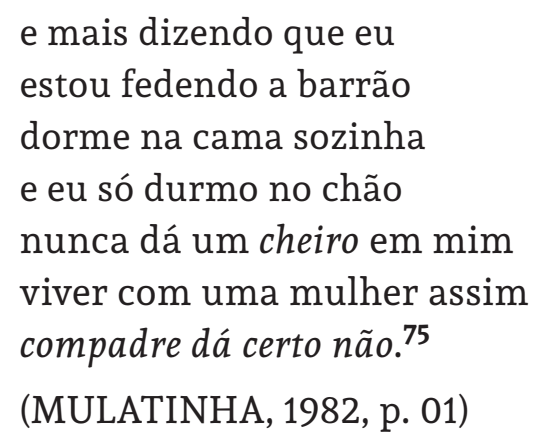

Em ambos os trechos apresentados o autor recorre a expressões próprias do dialeto oral, como os regionalismos: "deu fé" (percebeu) e "cheiro" (palavra utilizada em alguns estados do Nordeste para exprimir uma ação de carinho, aplicada com frequência como sinônimo de 'beijo'). O emprego de particularidades linguísticas compartilhadas pela comunidade local cumpre a função de armar uma relação de proximidade com a leitora/ o leitor.

Toinho da Mulatinha também se aproxima da comunidade de leitores por meio da construção de narrativas capazes de emitir convicções compartilhadas pelo senso comum, como aquelas que expressam princípios "universais" maniqueístas,

74 Grifos da pesquisadora.

75 Grifo da pesquisadora. 
opondo “o bem e o mal”, por exemplo. Estes juízos, geralmente permeados de crenças católicas, são emitidos através da exposição de personagens arquetípicas, peculiares das narrativas orais. A qualificação destas figuras e de suas ações é construída pela adjetivação, artifício comum na linguagem falada informal. De valor "mais agregativo do que analítico" (ONG, 1982 apud GALVÃO, 2001, p. 79) os adjetivos são inseridos com o objetivo de dar um tom emocional ao enredo.

No folheto O Bebê Diabo - A história do menino que nasceu com dois chifres e peludo em São Bernardo do Campo - SP (1975), podemos apreender alguns dos mecanismos ativados para o empreendimento de uma moralidade. O autor logo no primeiro verso elenca máculas humanas dignas de punição divina, preparando um terreno fértil para a expor uma história exemplar ${ }^{76}$.

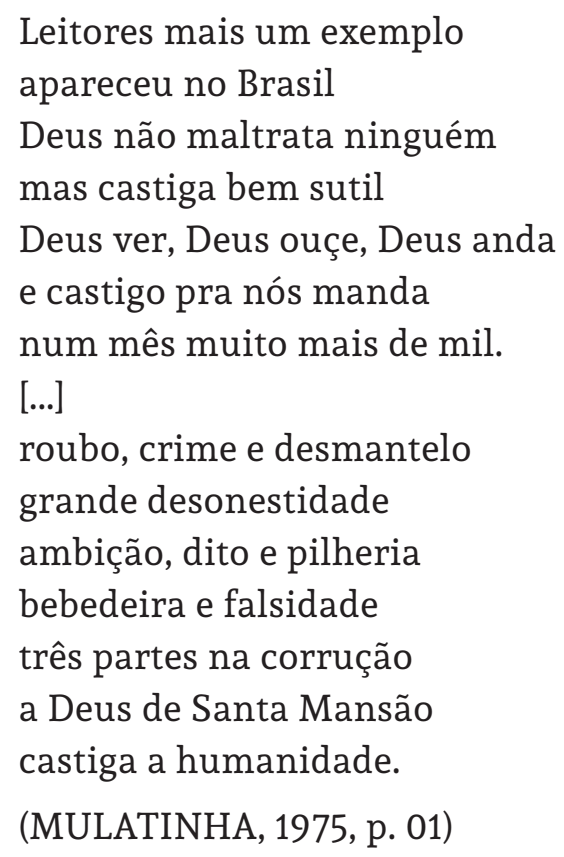

Toinho é autor de algumas histórias “exemplares”, como O Exemplo da Moça que virou Cachorra no Carnaval de 80 porque zombou Frei Damião (1980) e A discussão de um protestante com um moço biriteiro (2001). Narrativas desta ordem, tais como as fábulas e as lendas - gêneros que assumem matizes e especificidades ligadas ao contexto sociocultural no qual se desenvolvem -, contêm padrões estruturais que contribuem para a fixação do texto, e, portanto, favorecem a transmissão oral por gerações (TAVARES JUNIOR, 1980).

76 Neste folheto, Mulatinha narra a história de uma mulher que foi castigada com um "bebê diabo" diante do "pecado" cometido: a tentativa de "extrair o filho", "querendo desmanchar/ o que fez a natureza", como anunciado na $22^{\mathrm{a}}$ estrofe. 
Para a pesquisadora Luli Hata (1999), "enquanto a poesia pode ser memorizada a partir da audição (ou mesmo da visão, através da leitura), as capas dos folhetos e os personagens são memorizados a partir da visão, auxiliando a identificação do folheto inclusive quanto à sua autenticidade.” (1999, p. 113). Autora de um trabalho concentrado na dimensão estética dos folhetos, Hata amplia a concepção do folheto enquanto "suporte da memória”, elaborada por Ruth Terra (1983), definindo-o como “suporte da memória audiovisual”.

A incorporação de imagens nas capas dos folhetos, implementada de maneira regular pelo artificioso empresário João Martins de Athayde (1880-1959), que enxergou nos clichês fotográficos e nas zincogravuras potencial comercial de sedução da clientela, tornase, a partir da década de 1920, elemento indissociável desta literatura e representativo dos gêneros dos folhetos - desafios, poemas de época, romances e histórias. ${ }^{77}$

A inserção dos poetas-editores na cultura urbana e a decorrente facilidade de conseguir materiais obsoletos das tipografias, assim como o contato com as imagens publicitárias, foram fatores que influenciaram o desenvolvimento de um design vernacular pelos próprios autores de folhetos.

A maioria dos folhetos presentes no espólio de Toinho da Mulatinha acessado na Biblioteca de Obras Raras Átila Almeida contém capas ilustradas ${ }^{78}$. Apenas cinco das capas deste acervo (composto por mais de 50 títulos) são constituídas por tipos móveis, associados a vinhetas e molduras [Figura 13]. Estes recursos gráficos, responsáveis por adornar e organizar as informações presentes na capa dos folhetos, foram predominantes durante as duas primeiras décadas do século XX. Período em que os folhetos eram impressos em tipografias

77 Categorização determinada pela pesquisadora Ruth Terra (1979).

78 As capas das publicações de Toinho da Mulatinha exibem imagens impressas por meio das variadas matrizes (zincogravura, clichê fotográfico e xilogravura), cabedal das gerações anteriores que será exposto com detalhes no segundo capítulo.

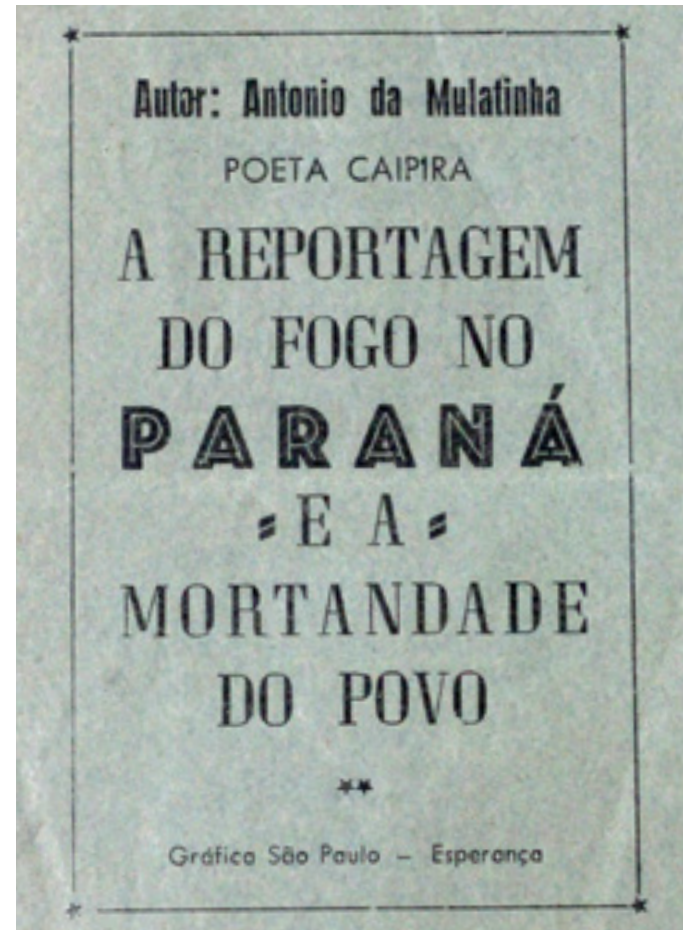

Figura 13 - Capa de folheto diagramada a partir da composição de tipos móveis Fonte: Biblioteca de Obras Raras Átila Almeida (BORAA/ UEPB) 
de livrarias e jornais e exibiam, portanto, aproximações com a visualidade destas publicações, de notório requinte técnico.

De acordo com Ana Maria Galvão (2001), o público a quem eram destinadas as publicações de "literatura popular" não era, a princípio, tão abrangente como a nomenclatura que a categoriza nos faz supor. A autora atribui a popularização dos folhetos à instauração de um circuito específico para a produção e circulação da literatura de folhetos, descolado do universo editorial hegemônico de que a princípio foi dependente. As feiras aparecem em suas análises como difusoras desse gênero literário entre as camadas populares urbanas e, principalmente, semeadoras dos impressos no meio rural.

A exponencial predisposição oral das publicações e o estabelecimento da ilustração nas capas dos folhetos, são, para Galvão (2001), marcadores da crescente disseminação dos folhetos entre pessoas com restrito grau de escolaridade, analfabetas e semianalfabetas. Outras tendências editoriais instituídas a partir de 1930, elencadas pela autora como indício que os folhetos passam a angariar um público mais amplo, são encontradas nos folhetos de Toinho da Mulatinha: a publicação de um só poema por folheto e a consequente redução do número de páginas do impresso (aproximadamente $87 \%$ dos 80 folhetos acessados contêm 8 páginas); a não utilização da quebra de estrofe, favorecendo o ritmo da leitura e memorização pela apreensão visual (predicado de todas as publicações do poeta); a retirada de excessos gráficos das páginas do miolo dos folheto, como as eliminação das vinhetas e a retirada de “páginas extras”.

Parece haver uma tendência, ao longo do tempo, de produzir poemas e publicá-los em um formato que facilite a leitura para um público pouco habituado a ter contato, por escrito, com objetos de leitura densos, com muitas informações.[...] Essas transformações ocorridas na produção dos cordéis revelam um progressivo barateamento dos custos na impressão e, consequentemente, na produção de um objeto menos sofisticado e mais "popular". (GALVÃO, 2001, p. 48)

As transformações textuais e gráficas referenciadas até aqui revelam que os folhetos passam a ser produzidos com objetivo de proporcionar uma experiência fluida de leitura oralizada, ou de cantoria, transformando-se em um material "verbivocovisual”. Esta expressão, emprestada do movimento concreto na poesia/ artes plásticas ${ }^{79}$, foi adotada com intuito de ampliar a noção de "verbo-visualidade", implementada por Alberto Roiphe (2012) diante da relação indissociável entre os códigos verbais registrados no cordel e as imagens da capa, que não são meramente ilustrativas, mas estruturantes do gênero.

790 conceito "verbivocovisual", criado pelo poeta irlandês James Joyce (1882 - 1941), foi apropriado pelos irmãos Campos (Augusto e Haroldo) para integrar o plano-piloto da poesia concreta brasileira (1950). 
A integração do morfema "voco" no conceito ora referenciado deve-se ao fato do folheto ser imbuído de função gráfico-fonética. Tal como poetas do movimento concreto exploraram a dimensão tridimensional da palavra (semântica, sonora, visual: verbivocovisual), poetas/ poetisas comerciantes de folhetos trabalharam com a totalidade do livreto, materializado na confluência de imagem (ilustração presente na capa), forma (livro de pequena dimensão/ texto em verso), ritmo (métrica/rima), conteúdo (gênero/tema).

Neste sentido, a atividade criativa do poeta de bancada é considerada como um exercício de conexão entre os elementos que compõem o sentido do texto e os usos do impresso. Deste processo nasce o folheto inteiro, que extrapola os limites do papel almaço no qual foi previamente registrado o texto. $O$ folheto torna-se um objeto-ativo, um papel em vias de falar, potente propositor de experiências.

A matéria do folheto ganha forma no espaço por meio da voz que dota de melodia e ritmo os signos verbais impressos. O objeto é apreendido simultaneamente pelos olhos, pelo ouvido, pelo tato, pelos elementos situacionais do momento performático compartilhado coletivamente, motivado pela abertura de um pequeno livreto.

O texto dos folhetos é permeado de componentes visuais que determinam a performance, proporcionando a "dialética simultânea entre olho e fôlego" anunciada por Augusto de Campos (1956 apud JACKSON, 2004). Ou seja, a visualidade do poema não encontra-se apenas na capa, mas está impressa no esquema de estrofes e de rimas, que funcionam como uma partitura que conduz a vocalização. A exemplo:

$\begin{array}{ll}\text { Fiz ourives enjeitar ouro } & \text { A } \\ \text { Fiz galinha enjeitar milho } & \text { B } \\ \text { Fiz mãe enjeitar } o \text { filho } & \text { B } \\ \text { E a arara enjeitar } o \text { louro } & \text { A } \\ \text { Fiz a vaca enjeitar } o \text { touro } & \text { A } \\ \text { Fiz ele chorar atrás } & \text { C } \\ \text { Fiz moça enjeitar rapaz } & \text { C } \\ \text { Fiz ele roer por ela } & \text { D } \\ \text { Fiz cavalo enjeitar sela } & \text { D } \\ \text { O que falta fazer mais } & \text { C } \\ \text { (MULATINHA, 1982, p. 01) }^{80} & \end{array}$

A literatura de folhetos brasileira ativa aquilo que Kenneth David Jackson (2004) denominou de "olho sonoro", ao analisar aspectos da poesia de Augusto de Campos: "é o olho que respira e fala, consequência de uma estrutura linguística tonal e vocalizada. Existe uma performance, isto é, uma leitura preparada, de viva voz, representando o 'voco' do verbivocovisual” (JACKSON, 2004, p. 19).

80 MULATINHA, Toinho da. [Antônio Patrício de Souza]. O homem que deixou a mulher para viver com uma jumenta. Campina Grande - PB: Gráfica Vitória, 1982. Marcações realizadas pela pesquisadora. 
Seria forçar a nota interpretativa a justapor aspectos da poesia concreta à literatura de folhetos. O que se busca nessa análise é extrair a operacionalidade do conceito de verbivocovisualidade para a compreensão do folheto como um objeto que se efetiva por meio de uma prática relacional entre conteúdo e continente.

A atividade de extração do potencial verbivocovisual do folheto pelos poetas e poetizas "populares” não foi/é necessariamente deliberada e consciente (contrária a hiperconsciência da função criativa exercitada pelos concretistas na lida com a palavra), mas fruto de um processo histórico no qual se origina e desenvolve este gênero literário: derivado das cantorias que ocorriam no Nordeste desde o século XIX, geneticamente associadas às literaturas erudita e popular, escrita ou oral, introduzidas por colonizadores e colonizados.

A apropriação de prelos de "segunda mão" pelos poetas de bancada na primeira metade do século XX e a consequente conformação de uma rede cooperativa entre poetas-escritores, poetas-editores e editores-proprietários, constituiu uma dinâmica fundamental para que estas figuras se tornassem compositoras de uma peça complexa, “verbivocovisual”. O domínio do processo completo, da criação à circulação, impactou na multiplicação de narrativas e de narradores.

O movimento de dissolução da autoria dos folhetos de feira em meados dos anos 1930, com a consolidação da figura do editor-proprietário, é um dos indícios de que o gênero agrega ao longo da primeira metade do século XX particulares das narrativas orais (GALVÃO, 2001, p. 57). As transformações do livreto-impresso, atreladas ao ponto de comercialização preponderante no período em que Toinho da Mulatinha fincou suas raízes como poeta, a feira, foram determinantes para a constituição dos folhetos como "fenômeno sócio-discursivo irredutível ao que chamamos de literatura". (ZUMTHOR, 1993, p. 146).

Não por acaso, o bairro Santo Antônio em Campina Grande, vizinho à Feira Central, foi escolhido como local profícuo para poetas armarem suas residências e pontos de venda/ criação, em meados do século XX. Dentre as casas destinadas à produção e circulação de folhetos no bairro estão: a consagrada Tipografia Estrella da Poesia, de Manoel Camilo dos Santos, um cometa que passou pela cidade; a Folhetaria Estrela do Oriente, projetada na primeira "viagem a lua" de seu fundador; a cordelaria de Manoel Monteiro que, feito uma estrela manteve sua luz após a morte. 


\section{uma viagem geo-poética 1950-1960 \\ Toinho da Mulatinha (poeta mascate)}

(2)

धी

()

Ge



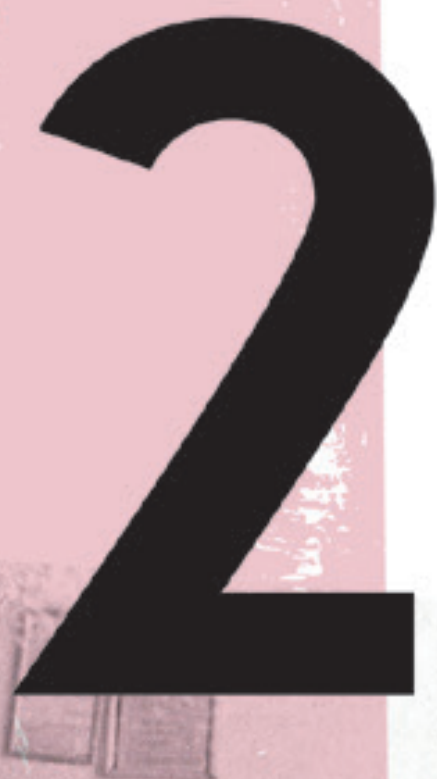

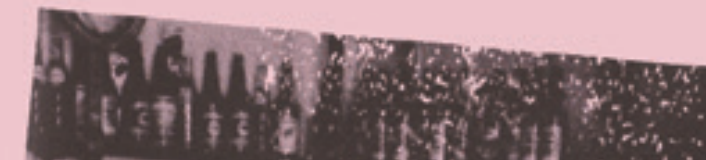
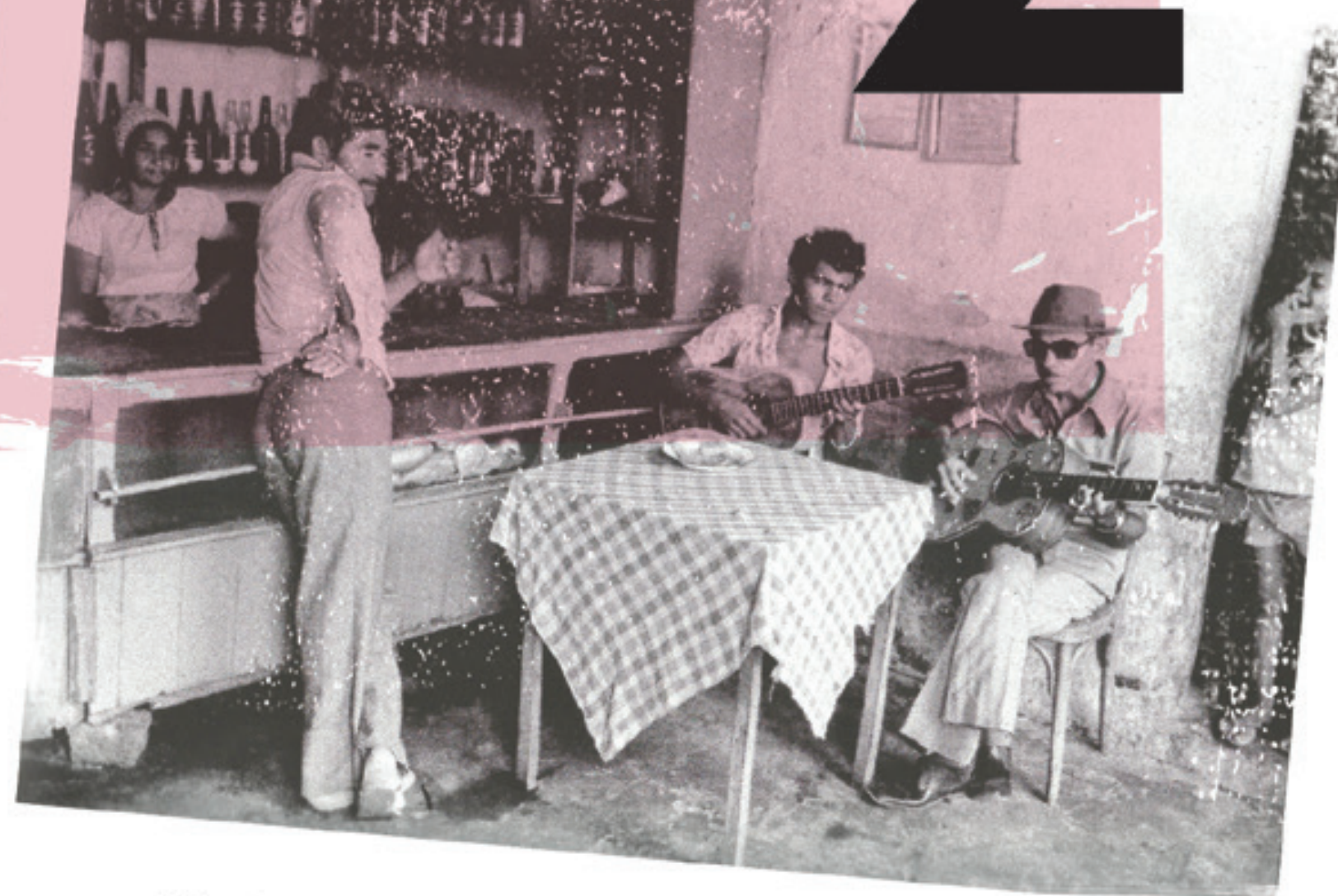

foto: Roberto Coura (1978) 


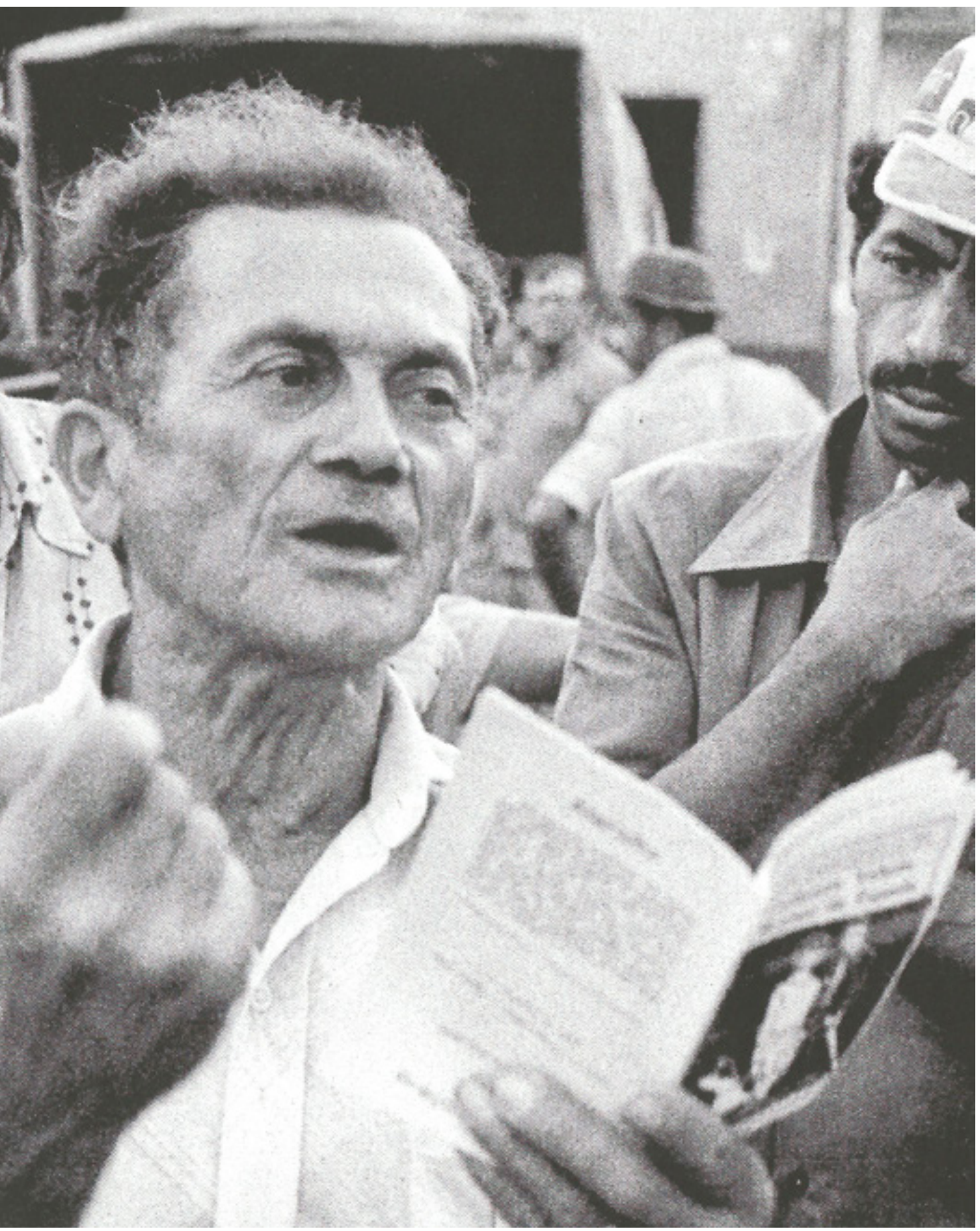

Figura 14 - Declamação de folheto na Feira Central de Campina Grande (1978)

Fonte: Roberto Coura, 2014 


\section{HISTÓRIAS PASMOSAS DE BROCHURAS POPULARES}

Deve se lembrar que não há texto fora do suporte que o dá a ler (ouvir), e sublinhar o fato de que não existe a compreensão de um texto, qualquer que seja, que não dependa das formas através das quais ele atinge o seu leitor. (CHARTIER, 1994, p.17)

Folheando "histórias de acontecido" de Toinho da Mulatinha vimos que a literatura popular angariou leitores no arranco do grito, mas teve o papel como suporte de sua existência. Já que a narrativa nos permite, nos deslocaremos no tempo para apreendermos o contexto que viabilizou grandes expoentes da poesia em Campina Grande fazerem de suas vidas autobiografias impressas.

Aolongo deste capítulo, a literatura de folhetos será abordada como um fenômeno moderno, desenvolvido a partir de dois pilares estruturantes: a expansão da indústria gráfica no Brasil e a formação de uma extensa rede ferroviária na Paraíba durante o ciclo do algodão. A atividade tipográfica em meados do século XX será retratada através da figura de Manoel Camilo dos Santos, poeta-editor que monopolizou o comércio de folhetos no estado, armando acirrada disputa com aqueles que, como ele, enxergaram na reprodutibilidade técnica possibilidade de multiplicação monetária.

Desenrolando linhas da história, podemos observar que o cordel brasileiro está entrelaçado ao processo de publicação de edições de baixo custo na Europa, despertado pela revolução gutenberguiana: a invenção da técnica de impressão através da prensa de tipos móveis, entorno de 1450. De acordo com Carlos Nogueira (2012), desde o advento da imprensa, tipógrafos já se empenhavam em disseminar narrativas que, por muito tempo, permaneceram restritas a uma parcela econômica e culturalmente privilegiada da população. O autor sustenta esta premissa sublinhando a data de publicação do romance francês História da Princesa Magalona em folheto (1482), três décadas depois da data de registro do mais antigo texto impresso com caracteres móveis (1454).

Enfileirando letra por letra, agentes do ramo gráfico produziram uma nova história da leitura, cuja trama integra personagens pertencentes a diferentes estratos sociais, que atuaram na expansão das fronteiras do acesso ao impresso. Por meio da criação de "fórmulas editoriais" para a divulgação de textos de origens e gêneros variados de maneira econômica, esboçaram uma expressão preambular da indústria cultural, que tem seu ápice na Europa do século XIX. Aliados às tecnologias de impressão, esses artífices criaram um novo território cultural para a literatura, entre aquela convencionada como oficial e a de transmissão oral. Podem ser agrupados nesta tendência: os chapbooks na Inglaterra, o libri popolari na Itália, o volksbücher na Alemanha, os pliegos sueltos na Espanha, o cordel em Portugal, os livrets bleus ou livrets 
de colportage na França - país que muito ensinou sobre a confecção em larga escala de livretos em pequenos volumes de capa brochada e papel barato.

A publicação dos primeiros romances em solo brasileiro deveu-se à iniciativa de Paulo Martin Filho. Considerado por Rubens Borba de Moraes (1993) nosso primeiro editor, publicou através dos prelos da Impressão Régia do Rio de Janeiro (1808 -1822) pelo menos uma dezena de obras ficcionais ${ }^{\mathbf{8 1}}$ - dentre elas História da donzela Theodora (1815), narrativa que irá se consolidar como um clássico da literatura de cordel nordestina um século depois. Na loja da rua da Quitanda n. 34, vendeu "romances, novelas, folhetos políticos, poemas, orações fúnebres” (MORAES, 1975, p. 173), impressos exclusivamente em forma de brochura (NIZZA DA SILVA, 1986).

Em sua pequena livraria comercializou, além de folhetos paridos na colônia, livros e livretos importados da metrópole, sobretudo os editados pelo seu pai, o francês radicado em Portugal, Paul Martin, do qual herdou o ofício de editor-tipógrafo-livreiro. No raiar do século XX, os Martin desembarcaram impressos em alto mar, desbravando um comércio narrativo que demandava o enfrentamento da censura e a burocracia impostas pelos poderes real e eclesiástico.

A partir de 1821, com o encerramento do monopólio da Impressão Régia, impressores e impressos proliferam-se no território. A antropóloga Alessandra El Far (2010), destaca o trabalho do editor David Augusto Corazzi, em Portugal, como um agente da propagação literária nas três últimas décadas do século XIX, que alcançou notabilidade no comércio livreiro internacional por meio da confecção de romances clássicos primorosamente ilustrados ${ }^{82}$, dentre outras traduções de autores de prestígio ${ }^{83}$, vendidas a preços módicos. Em sua empresa, Horas Românticas, também encabeçou um projeto de publicações instrutivas, por meio do lançamento da coleção “Biblioteca

81 A pesquisadora Simone Cristina de Souza (2007) enumera dozes títulos publicados pelo editor Paulo Martin Filho na Impressão Régia: 0 diabo coxo, verdades sonhadas e novellas de outra vida (1810); $A$ filosofa por amor, ou cartas de dous amantes apaixonados e virtuosos (1811); Historia de dois amantes ou o templo de Jatab(1811); Paulo e Virgínia (1811); Aventuras pasmozas do celebre Barão Munkausen (1814); 0 castigo da prostituição (1815); As duas desafortunadas(1815); Historia da donzella Theodora (1815); Triste effeito de huma infidelidade (1815); Aventuras galantes de dois fidalgos estudantes, (1818); Leituras para os meninos (1818); Carta escrita pela Senhora de ${ }^{* * *}$ rezidente em Constantinopla a huma sua Amiga (1819). No artigo "Duzentos anos: Os primeiros livros brasileiros" (2010), Márcia Abreu exibe o conjunto de publicações atribuídas ao editor, colocando a tese Primeiras impressões: romances publicados pela Impressão Régia do Rio de Janeiro, 1808 - 1822 (SOUZA, 2007) em confronto com pesquisas anteriores que reconstituem o catálogo de publicações da Imprensa Nacional: Anais da Imprensa Nacional do Rio de Janeiro, 1808 - 1822 (CABRAL, 1881); Cultura e Sociedade no Rio de Janeiro, 1808 - 1821 (NIZZA DA SILVA, 1978); Bibliografia da Impressão Régia no Rio de Janeiro (CAMARGO; MORAES, 1993).

820 inferno (Dante Alighieri, 1304 - 1321), 0 Paraíso Perdido (John Milton, 1667) e Orlando Furioso (Ludovico Ariosto, 1516), por exemplo. (EL FAR, 2010).

83 Julio Verne, Emilio Zola, Adolfo Bellot, Xavier de Montepin, dentre outros. (EL FAR, 2010) 
do Povo e das Escolas”, composta 237 volumes de 64 páginas, no formato 15,5 x 10,5, que tematizavam assuntos de diversas áreas do saber ${ }^{84}$.

A megalomania do empreendimento editorial de Corazzi manifestouse, sobretudo, através da rede de distribuição de publicações estabelecida com representantes espalhados pelo globo: África, China, Europa e América. No Rio de Janeiro, o representante de Corazzi, José de Mello, colaborou na disseminação de “publicações de bolso” nos trajes nacionais.

Neste período, 50 anos após a regulamentação da imprensa e o fim do monopólio sobre a impressão, pela Impressão Régia da Coroa portuguesa (1821), editoras nacionais passaram a seguir essa tendência editorial. É o caso da Livraria do Povo, inaugurada em 1870 por Pedro da Silva Quaresma na então capital federal do país, responsável por imprimir brochuras de romances, trovas, cantigas e livretos de teor pornográfico. Até mesmo editoras brasileiras reconhecidas pelas encadernações de luxo, começaram a comercializar "livros de algibeira", como, por exemplo, a Livraria Garnier, que vislumbrou aumentar seus lucros em progressão geométrica através da produção seriada de mercadorias que, literalmente, cabiam no bolso dos consumidores (EL FAR, 2010).

No final do século XIX, poetas que passaram a imprimir regularmente poesia em folhetos no Nordeste do Brasil, instituíram padrões gráficos muito semelhantes àqueles utilizados por Corazzi e por Quaresma - amalgamados a uma longa tradição de impressão de edições baratas no continente europeu. Correspondências gráficas como esta, levaram pesquisadores/as comprometidos com o projeto identitário nacional a enxertarem um cordão umbilical artificial entre a literatura de folhetos nordestina e o cordel português, cujo nome foi importado nos anos 1960 para rebatizar os folhetos da antiga colônia, pelo critério de associação entre suportes que sustentavam diferentes formas literárias ${ }^{85}$.

84 Tecnologia (A luz elétrica; A Fotografia; Máquinas de Vapor), biologia (História natural das aves; Anatomia humana), artes (Noções de Música; Leitura e recitação) literatura (Romanceiro Português), ofícios (Manual do Carpineiro), legislações (Direito internacional marítimo), saúde pública (0 cólera e seus inimigos) dentre outras edições "tão úteis quanto baratas". (EL FAR, 2010, p. 92)

85 "Segundo Idelette Muzart-Fonseca Santos (2006), o primeiro intelectual brasileiro a utilizar a expressão 'Literatura de Cordel' foi Silvio Romero, em 1888, no seu livro Estudos sobre a poesia popular do Brasil, inspirado 'na evidência do exemplo português, ao qual seu mestre Teófilo Braga havia consagrado diversos estudos'. Para Horácio de Almeida (1976) se a expressão 'Literatura de Cordel' é antiga e corrente em Portugal, a sua introdução no Brasil é recente, uma vez que 'no tempo de Leandro desconhecia-se a expressão'. Por sua vez, Umberto Peregrino (1984) defende que Francisco das Chagas Batista (1929), contemporâneo de Leandro Gomes de Barros (1929), já tinha empregado em 'Cantadores e Poetas Populares' a expressão 'popular literatura poética de cordel'. Por outro lado, o poeta e pesquisador José Alves Sobrinho (2003) argumenta que a definitiva introdução do termo 'Literatura de Cordel' no âmbito da poesia popular do Nordeste deveuse em muito, a partir da década de 1960, ao trabalho de articulação mais intensamente desenvolvido pelos pesquisadores, sobretudo pelo jornalista Mark Curran, que em muito se empenhou entre os poetas para que essa designação se estabelecesse." (DIAS, 2009, p. 45) 
O certo é que esta nomenclatura foi assimilada e hoje é indissociável desta prática cultural, registrada pelo Instituto do Patrimônio Histórico e Artístico Nacional (Iphan) como "Literatura de Cordel". Ainda assim a terminologia mobiliza pesquisadores da área, abrindo espaço para um questionamento pontual no contexto deste estudo: por que os "livros de bolso"/ "livros de algibeira" desenvolvidos no Nordeste não foram denominados com estas nomenclaturas por estudiosos/as do tema?

Respondo a esta pergunta por meio da elaboração de duas hipóteses que conduzem a caminhos opostos: (1) A transposição de uma terminologia advinda do "primeiro mundo", pelos intelectuais brasileiros, colaboraria na legitimação de uma cultura subalternizada, "genuinamente" nacional, em um momento de edificação de uma modernidade nativa - concepção fundadora do Movimento Armorial (1970). (2) Como o termo "cordel" designava em Portugal livros reconhecidos como "intelectualmente inferiores", posto que eram adaptados para o acesso de um segmento social abrangente, foi transferido justamente para uma literatura mestiça, fecundada em uma área marginalizada do país: o Nordeste da seca e da fome - projetado, naquele momento, discursiva e imageticamente pela Sudene (Superintendência do Desenvolvimento do Nordeste).

As associações gráficas entre os folhetos brasileiros e europeus, são realizadas neste trabalho com intuito de integrar os impressos nacionais à história do impresso, evidenciando essa literatura como uma manifestação da indústria gráfica que se particulariza no contexto sociocultural no qual foi gestada. Localizo as práticas editoriais que antecederam a literatura de folhetos brasileira com objetivo de pontuar o que há de factual no discurso que imprimiu o nome cordel para os folhetos locais, assim como pela intenção de borrar narrativas essencialistas que inscrevem as manifestações das “culturas populares” como flores na seca, espontâneas e autênticas, desatadas do cordão historiográfico.

Márcia Abreu (1993), traz inestimáveis contribuições para o campo dos estudos de folhetos ao confrontar os impressos brasileiros e os lusitanos conhecidos por “cordel”. De acordo com a autora, a categoria já apresenta fragilidades em seu local de origem, Portugal, dada as significativas diferenças entre as formas literárias, os temas e as características visuais das produções que foram condensadas sob esta definição: adaptações e traduções de histórias eruditas de projeção transnacional, peças teatrais, autos, novelas, contos, sátiras, notícias, livretos de divulgação de conhecimentos específicos, como cadernos de receitas, dentre outros temas que dificultam a delimitação de um corpus. As semelhanças entre as publicações lusitanas que permitem esse agrupamento residem nas características físicas do suporte, aliadas às formas de exposição comercial dos folhetos. 
A associação do cordel português com os folhetos brasileiros, certamente devese ao fato de poetas nordestinos precursores da literatura de folhetos terem versado e publicado adaptações de romances clássicos europeus que circulavam entre a elite local, como a História da Donzela Teodora, interpretada por Leandro Gomes de Barros e a História da Imperatriz Porcina, editada por Francisco das Chagas Batista.

Além das recorrências intertextuais no interior do repertório de cordel lusitano e brasileiro, eles podem ser relacionados pelo uso de estruturas narrativas similares - “a caracterização linear das personagens [alegóricas], a ênfase na ação, a inexistência de digressões psicologizantes, permitindo uma assimilação dos textos por públicos não completamente familiarizados com a escrita” (ABREU, 1993, p. 251) e pela implementação de fórmulas narrativas de sucesso, muito bem exprimidas nos títulos de caráter sensacional, como: Maria José, ou a filha que assassinou, degolou e esquartejou sua própria mãe, Mathilde do Rosário da Luz na cidade de Lisboa em 1848 (Camilo Castelo Branco, 1890) e A história da mãe que degolou o filho com uma hora de nascido em Lagoa Seca no dia 16 de Janeiro de 1980 (Toinho da Mulatinha, 1980).

Há mais diferenças do que semelhanças entre estas publicações reconhecidas pela mesma designação, sobretudo no que diz respeito a características internas aos folhetos, relativas ao texto. Diversas/os autoras/es apontaram a falta deunidadena forma literária abrigada pelos cordéis portugueses ${ }^{86}$, porém, esta asserção é intransponível para os folhetos nordestinos, concebidos através de regras bem delineadas: versos em sextilhas, septilhas ou décimas em redondilha maior ou menor, que ocupam entre 8 e 64 páginas do impresso de acordo com o gênero do folheto, também delimitado romance, acontecido e peleja.

Márcia Abreu ressalta a presença dos desafios cantados na produção nacional de folhetos, inexistentes nos cordéis lusitanos publicados entre os séculos XVI e XX. Para a autora, o vínculo dos folhetos brasileiros com a oralidade tensiona ainda mais a relação com o cordel lusitano, posto que tem desdobramentos concretos na estrutura textual, pautada em estratégias de memorização - ostensivamente abordadas no capítulo anterior, através da produção de Toinho da Mulatinha. Arrematado com a tradição oral, o cordel brasileiro, se circunscreveu em uma esfera de produção e circulação restrita às classes economicamente menos privilegiadas.

86 ABREU, Márcia. Cordel português/folhetos nordestinos: confrontos um estudo histórico-comparativo. 1993. 360p. Tese (Doutorado em Teoria Literária) - Instituto de Estudos da Linguagem, Universidade Estadual de Campinas, Campinas, SP; GUERREIRO, Manuel Viegas. Guia de Recolha de Literatura Popular. Lisboa: Ministério da Educação e Investigação Cientifica, 1976; LIMA, Fernando de Castro Pires de. Literatura de cordel, Separata das Actas do $1^{\circ}$. Congresso de Etnografia e folclore, vol. I (Braga, 1956), Lisboa, 1963; NOGUEIRA, Carlos. A literatura de cordel portuguesa. Ehumanista, n. 21, p.195-222, 2012.; SAMPAIO, Albino Forjaz de. Teatro de cordel (catálogo da colecção do autor): subsídios para a História do teatro português. Lisboa: Academia das Ciências, 1922; SARAIVA, Arnaldo. Literatura Marginal/izada: novos ensaios. Porto: Edições Árvore, 1980. 
Ainda que os poetas nordestinos tenham versado narrativas portuguesas protagonizadas pela nobreza, de caráter "supra-social" 87 , imprimiram nas páginas dos folhetos temas relativos às desigualdades sociais da região, denunciando os impostos abusivos e a exploração do trabalho.

No contexto das tematizações de viés econômico, há uma questão interessante apontada por Abreu (1993, p. 262), acerca da caraterização dos personagens vilões das tramas: "Nos textos portugueses analisados, não se faz qualquer relação entre riqueza e mau-caratismo; já no Nordeste esta associação é frequente, pois além de os 'malvados' serem, muitas vezes, caracterizados a partir de suas posses, não há ninguém muito pobre no papel de malfeitor”. Esta percepção dos autores sobre os malfeitores abastados, faz muito sentido em um país fustigado por quase quatro séculos de chibata.

Ao contrário dos escritores lusitanos, os poetas folheteiros brasileiros estavam localizados na base da pirâmide social ${ }^{88}$, principalmente aqueles da $2^{\text {a }}$ geração ${ }^{89}$ que muito colaboram para a popularização dos folhetos. Antes de tornarem-se poetas de profissão trabalhavam como operários, carpinteiros, marceneiros, feirantes e, sobretudo, como pequenos agricultores. Estes escritores de primeira viagem, muitos deles alfabetizados através dos folhetos, compartilhavam, com parte significativa de seu público, experiências de vida. A comunhão mnemônica entre produtores e receptores motivou a consagração de temas da realidade local, como o cangaço, o boi e a seca, nessa vertente literária.

Estas características da literatura de folhetos nordestina permitem que ela seja entendida corno um fenômeno da cultura popular, enquanto o cordel português poderia ser compreendido como uma manifestação incipiente da cultura de massa, já que ele representa uma linha editorial produzida com a finalidade de atingir grandes públicos de diferentes condições sociais. (ABREU, 1993, p. 252)

Nesta perspectiva, o critério que viabiliza a compreensão dos cordéis "de lá" como populares é a dimensão material do impresso, seu suporte singelo que proporciona

87 Os cordéis portugueses exportados para o Brasil retratam histórias de cunho moral interpretadas pela nobreza, nas quais as distinções de classe são irrelevantes. Quando figuras pertencentes a classes economicamente desfavorecidas integram o enredo, compactuam com os valores hegemônicos veiculados na narrativa (ABREU, 1993).

88 Márcia Abreu (1993) ressalta que os autores de folhetos portugueses do século XVIII exerciam profissões consideradas "socialmente elevadas", como por exemplo advocacia, medicina, docência, assim como cargos militares e eclesiásticos.

89 De acordo com a Fundação Casa Rui Barbosa, os poetas que protagonizam a segunda geração de cordelistas brasileiros são: João Ferreira de Lima, João Martins de Athayde, José Costa Leite, José João dos Santos (Azulão), José Pacheco, José Soares, Manoel Camilo dos Santos, Manuel d'Almeida Filho. Manuel Pereira Sobrinho, Minelvino Francisco Silva, Raimundo Santa Helena e Rodolfo Coelho Cavalcanti. 
o baixo custo da mercadoria. Enquanto isso, os cordéis "de cá” podem ser agrupados na chave do "popular" (com todo cuidado que o uso da palavra prescreve) a partir de outro fundamento: seu desenvolvimento como um sistema gráfico-poético independente, produzido e consumido em um campo de saber marginalizado. Em síntese a palavra cordel em Portugal define uma linha editorial, e no Brasil uma literatura - indissociável de sua estrutura.

Há outra diferença que merece relevo em relação aos cordéis "de lá e de cá": os editores de além-mar não eram autores, enquanto os autores brasileiros fizeramse editores. Ao final da segunda década do século XX, as tipografias especializadas em folhetos, coordenadas por poetas-editores, se instituem como o principal meio de impressão desta literatura, prevalecendo sobre as gráficas de jornais, as quais os poetas recorreram inicialmente (TERRA, 1983). Franklin Maxado (1982), sublinha algumas tipografias pernambucanas nas quais os folheteiros encontraram suporte: a Imprensa Industrial, a Livraria Francesa, o Jornal do Recife e a Typographia da F.C. Lemos e Silva, também em Recife - a esta, o autor atribui a impressão do mais antigo folheto regido pelas normas literárias do que se convencionou chamar de cordel no Brasil, Testamento que faz um macaco, especificando suas gentilezas, gaiatices, sagacidades, etc (autor desconhecido, 1865).

A centralidade de Pernambuco no mercado gráfico da região, especificamente de Recife - capital que comportou uma das primeiras gráficas em território nacional90, justifica o fato dos poetas paraibanos João Martins de Athayde (1880 - 1959), fundador da primeira oficina especializada no gênero, e Leandro Gomes de Barros (1865-1918), precursor unânime da sistematização da produção dos folhetos de feira, terem inaugurado suas editoras na cidade. Com a instalação destes prelos no final da primeira década do século XX, instituíram uma nova ordem de enunciação poética.

No ano em que Leandro instalava a "Perseverança” em Pernambuco (1909), seu conterrâneo Francisco das Chagas Batista (1882 - 1930) entrava no mercado folheteiro publicando regularmente poesias autorais na “Tipografia Livraria do Povo” (Guarabira, Paraíba), propriedade de seu irmão Pedro Batista (1890-1938) - que inclusive era genro de Leandro Gomes de Barros e já havia impresso folhetos de autoria deste mestre folheteiro. Em 1913, Francisco funda seu próprio negócio, a "Livraria Popular Editora", na capital do estado (Parahyba, atual João Pessoa). No seu maquinário materializa paródias, modinhas, novelas, contos e poesia de folhetos - que logo irão se transformar na especialidade da casa.

90 Recife (PE) abrigou a segunda tipografia licenciada pelos poderes da Coroa portuguesa no Brasil, instalada em 1817 por Ricardo Fernandes Castanho. Para aprofundamento no tema ver: BERNARDES, Denis Antônio de Mendonça. Impressos e liberdade: notas para uma história da tipografia em Pernambuco - 1817 1850. In: BRAGANÇA, Aníbal; ABREU, Márcia (orgs.). Impresso no Brasil: Dois séculos de livros brasileiros. 1. ed. São Paulo: Editora Unesp, 2010. p. 191-204. 
As tipografias dos irmãos Batista sinalizam o diálogo entre a produção da primeira geração dos editores-cordelistas brasileiros com as brochuras baratas do final do século XIX, comercializadas em livrarias. Além da confluência de produtos, como as novelas, os próprios nomes das empresas, "Tipografia Livraria do Povo" e "Livraria Popular Editora”, nos remetem a empreendimentos símiles, como a "Livraria do Povo", propriedade do já mencionado editor Pedro Quaresma - Integrante de um movimento de democratização do impresso, de escala global, implementado por editores que desvinculavam o livro do campo erudito e da educação formal, transformando-o em objeto de lazer.

\begin{abstract}
Além de publicarem livros a baixos custos, estes negociantes procuravam também oferecer enredos inéditos e de fácil leitura, capazes de entreter o público heterogêneo e diversificado da grande cidade, que não tardou a receber a denominação "povo". Nos catálogos das livrarias ou nos anúncios de jornais, multiplicavam-se os títulos com tal indicação. Livros como o Orador do povo, Médico do povo, Trovador do povo, Lira popular, História natural popular, Mistérios do povo, Cozinheiro popular e Livro do povo ou o silabário brasileiro, este último um compêndio didático "ao alcance dos deserdados da fortuna”, encontravam-se em constante divulgação. (EL FAR, 2010, p. 95)
\end{abstract}

Ao longo das duas primeiras décadas do século XX, poetas da primeira geração de folheteiros (1900 - 1920/30) ${ }^{91}$, consolidam um público consumidor bastante específico do "povo": pessoas ligadas à terra e a cultura local, cativadas pelos cantadores de feira que mediavam os ambientes rurais e urbanos, o texto escrito e o oral. Cabe ressaltar que os poetas-editores desbravadores deste mercado, Leandro Gomes de Barros e Francisco das Chagas Batista, além de se alimentarem dos livretos para o "povo" e das quadras portuguesas de cordel, beberam, ainda na infância, direto da fonte da poesia oral local, na Serra do Teixeira, sertão da Paraíba.

Apesar de inextricavelmente ligada à poesia oral sertaneja, "a literatura de cordel supõe o folheto, e ao mesmo tempo é sua razão de ser" (DIAS, 2009, p. 32). Por meio do impresso poetas-editores promoveram a autonomia da obra poética do corpo, criaram a possibilidade de cantadores expandirem seu público imediato de auditores, ganharem outras vozes. Conformaram redes de distribuição que permitiram que os folhetos se espalhassem pelo espaço. Pelo tempo. Atravessando gerações e motivando o movimento das teclas que nesse instante reinscrevem as histórias de folhetos

91 Antônio Ferreira da Cruz, Francisco das Chagas Batista, João Melquíades Ferreira da Silva, José Camelo de Melo Resende, Leandro Gomes de Barros, Severino Milanês da Silva e Silvino Pirauá de Lima. (De acordo com a delimitação realizada pela Fundação Casa de Rui Barbosa). 
e a história dos tipos móveis. Conceberam um mercado, no qual a poesia inspirada pelos violeiros e cantadores de coco, podia ser adquirida, consumida ao sabor do freguês. Inventaram uma nova forma de sustento, permitindo que homens e mulheres da roça fizessem da literatura suas lavouras, como proferiu Manoel Camilo dos Santos (LESSA,1984).

Figura ilustre que compõe a segunda geração de poetas-editores, Camilo será fundamental para compreendermos o movimento de popularização da poesia de folhetos, assim como acessarmos as estranhas do mercado editorial especializado no gênero na Paraíba. Autor-proprietário, edifica a “Tipografia e Folhetaria Santos" por meio do arcabouço imaterial deixado pelos poetas-editores de folhetos da primeira geração, e, consequentemente, pelos editores de "livretos ao gosto do povo" que escreveram a história das brochuras no Brasil. As quartas-capas de seus folhetos imprimem: a sagacidade da composição catalográfica de Paulo Martin Filho; o tino publicitário de Pedro Quaresma; a sede de distribuição de impressos de David Corazzi, manifestada por meio de pontos comerciais que grafaram na cartografia regional sua epopeia.

\title{
NASCIMENTO, VIDA E MILAGRES DA ESTRELLA DA POESIA NA SERRA DA BORBOREMA
}

\author{
Poeta de mente sã \\ Manoel Camilo fazia \\ Um parnaso Campinense \\ A sua tipografia \\ Aproximando os obreiros \\ Escritores, folheteiros, \\ Quem comprava, quem vendia. \\ (MONTEIRO, 2002) ${ }^{\mathbf{2}}$
}

Manoel Camilo dos Santos (1905 - 1987), natural de Guarabira, iniciou sua carreira como cantador em 1936 em João Pessoa, orientado pelo mestre Antônio Correia Bastos. Em 1937 vende a viola para adquirir livros, afinal, "poeta sem geografia não sai do lugar”, afirmou em entrevista a Orígenes Lessa (1984, p. 55). Dedica-se, durante meio ano, à leitura dos volumes enciclopédicos comprados: geografia, língua materna, ciências físicas e naturais, assim como da Bíblia para graduar-se como poeta de bancada e, então, iniciar suas atividades em Campina Grande. Com o capital do trabalho de folheteiro acumulado pelas rotas do brejo paraibano, Camilo abre as portas da Tipografia e Folhetaria Santos, no ano de 1942, em sua terra natal, Guarabira - cidade

92 MONTEIRO, Manoel. Uma Longa Viagem - De Campina à Santa Teresa. Campina Grande: Cordelaria Poeta Manoel Monteiro, 2002. 
consolidada como centro tipográfico da área de cordel na década de 1930, mesmo após o fechamento da tipografia pioneira no ramo na cidade, de Francisco Chagas Batista.

A trajetória profissional de Manoel Camilo dos Santos revela, sobretudo, sua vocaçãopara os negócios, seu poder defazerprosperar. Inicia sua carreira transformando a madeira em viola, depois a viola em livro, o saber livresco em folheto, a poesia escrita em dinheiro, o dinheiro em maquinaria tipográfica, para enfim firmar-se como poeta de bancada, impressor e editor. No folheto Autobiografia do Poeta (CAMILO DOS SANTOS, 1953, p. 18), justifica a transição de cantador para poeta de bancada: "Graças a Deus Pai bondoso/ Eu vivo da poesia/ Já exerci a cantoria/ Porém fiquei desgostoso,/ Por vê cantador forçoso/ Morrer na flor da idade,/ Por esta justa verdade/ Tenho a fronte pensativa/ E por mais que o cantor viva/ Nunca faz prosperidade.”

Segundo relatos do poeta-editor, o melhor negócio que fez na vida, depois de deixar a cantoria para tornar-se poeta de bancada, foi resgatar os direitos autorais das próprias obras, vendidos ao editor João José da Silva no início da carreira com a poesia escrita (LESSA, 1984). Munido do direito de seus folhetos e de uma prensa tipográfica de ferro e madeira, inicia o ofício como editor de si e tipógrafo, empiricamente.

Autodidata na tipografia e com um maquinário rústico, Camilo encontra um mercado favorável para a lançar A Voz da Poesia em Guarabira (nome fantasia da Tipografia e Folhetaria Santos), aquecido pela concentração comercial da feira livre da cidade, que atraia poetas dos municípios circunvizinhos e, sobretudo pelas tipografias, a maioria não-especializadas, que desde 1920 centralizavam a produção de folhetos da cidade, tais como: Tipografia e Livraria Lima, Tipografia Nossa Senhora da Luz, A Voz do Brejo, Moderna, Nordeste, São Joaquim e São Paulo (SOBRINHO, 2003, p. 23).

Este é também um momento de ascensão das tipografias especializadas na produção de folhetos no mercado gráfico nordestino, como a Livraria Popular Editora (João Pessoa - PB), propriedade de Francisco Chagas Batista; a Casa Athayde (Recife $\mathrm{PE}$ ), de João Martins de Athayde e a Tipografia São Francisco (Juazeiro do Norte - CE), fundada por José Bernardo da Silva.

De acordo com as análises de Maurílio Dias (2009) ${ }^{93}$, derivadas de diálogos com José Alves Sobrinho, a predileção por estas tipografias pelos/as poetas/poetisas de bancada deveu-se ao fato dos poetas-editores proprietários destas oficinas coordenarem o processo completo de publicação, responsabilizando-se desde a revisão ortográfica e métrica do texto manuscrito (geralmente taxada) até a formação da brochura, incluindo a ilustração da capa ${ }^{94}$. O conhecimento das peculiaridades da poesia-popular-impressa pelos poetas-editores também motivou a fidelização dos seus pares, assim como o

93 Autor do mais completo trabalho de pesquisa sobre vida, obra e atividade editorial de Manoel Camilo dos Santos. 94 A imagem capaz de sintetizar graficamente a narrativa, era selecionada pelo editor no próprio arsenal de clichês (adquiridos, geralmente, em gráficas de jornais) ou encomendada a um ilustrador do ramo. 
zelo sobre particularidades do gênero, como a inserção do acróstico e a predileção por manter as estrofes inteiras em uma mesma página para facilitar a vocalização do folheto, por exemplo.

O fator financeiro foi determinante para o firmamento dessas parcerias entre poetas de bancada e poetas do ramo gráfico, pois a integração de todas as atividades em um só local, da produção à distribuição do produto aos representantes de venda e agências, contribuía para a redução de custos dos serviços.

A implementação de novas formas de negociação pelos editores especializados viabilizou autores com poucos recursos materializarem suas poesias. Uma prática bastante comum nesse sentido era a côngrua, modalidade de transação na qual o autor deixava de 70 a $80 \%$ dos exemplares da tiragem dos folhetos com o editor como forma de pagamento (DIAS, 2009). Para os poetas, a côngrua era vantajosa não apenas da perspectiva econômica, mas também simbólica, posto que a chancela de uma casa editorial de renome agregava valor à publicação.

Outra categoria de negociação era a aquisição de títulos pelo editor, que trocava impressões da obra pelos direitos autorais da mesma ou pagava uma porcentagem (em espécie) das vendas do título ao autor, para seguir reproduzindo-o e comercializando-o. Essa prática foi adotada na relação autor/editor entre Manoel Monteiro e Manoel Camilo, conforme relatos de Kátia, uma das filhas do primeiro:

Inclusive meu pai vendeu alguns títulos a Manoel Camilo. Vendia a autoria.
Muitos cordelistas faziam isso porque não tinham dinheiro pra pagar a
publicação. Era prática comum naquela época. Quando o cordelista não tinha
dinheiro pra pagar ele vendia. Ele ganhava só um valor bem menor... Mas o
cordel era vendido a ele, a Manoel Camilo. Meu pai fez vários cordéis, sempre
fazia na tipografia dele porque tinha poucas tipografias naquela época, o
pessoal vinha do interior, de outras cidades para publicar os cordéis aqui em
Campina Grande. Aí tinha lá no Ceará, mas não era todo local que tinha como
publicar como hoje em dia. Era muito difícil. (MONTEIRO, 2018)

Com uma clientela sedenta por materializar os próprios versos, a editora de Camilo se fortaleceu em Guarabira. O crescimento da demanda foi impulsionado pelo fechamento de gráficas não-especializadas produtoras de folhetos na cidade, no início de 1940 (DIAS, 2009) e, principalmente, pela sagacidade empresarial do poeta-editor, explicitada nas entrelinhas das quarta capas de suas publicações.

Camilo fez da última capa das brochuras cartaz publicitário atado ao produto, por meio do qual comunicava-se com o seu público. Além de defender seus 
direitos autorais 95 , enaltecia as qualidades de sua produção editorial, vinculadas às virtudes morais do editor ${ }^{96}$. Dentre os maiores atributos divulgados nos folhetos estava o "potencial produtivo, gráfico, comercial e de distribuição” (DIAS, 2009) da Folhetaria Santos, empresa aliada a "agentes grossistas” que alargavam os horizontes mercadológicos do seu proprietário.

A capacidade administrativa do editor-impressor, aliada à oferta de "tecnologias descartadas" (FERREIRA, 1985) no período, possibilitou a renovação do maquinário da tipografia (CAMILO DOS SANTOS, 1953, p. 22) e, consequentemente a ampliação da produção e redução de custos do folheto. A propaganda estampada na quarta capa do folheto Nascimento, Vida, Milagres e Morte de Jesus (1952) é um exemplo profícuo do "potencial produtivo, gráfico, comercial e de distribuição" que o empreendimento editorial de Manoel Camilo dos Santos alcançara paulatinamente:

\begin{abstract}
ATENÇÃO!...
AS Tipografias e Folhetarias Santos, já despondo de um completo sortimento de romances e folhetos (p'ra mais de duas centenas de milheiros) e de máquinas suficiente para abastecer, a sua numerosa freguezias, ultimamente arranjàra novas máquinas impressoras. Por isto aviza aos Srs. Poetas e publicadores de folhetos, que aceita todo e qualquer trabalho consernente ao ramo. E que além dos grandes descontos que vem dando aos revendedores resolveu à beneficiar aos mesmos ainda mais, com os seguintes abatimentos; nas compras de Cr\$ 100,00 á 500,005 por cento de 600,00 à 1000,0010 por cento de $1000,00 \mathrm{a}$ 2000,0015 por cento e de 2000,00 acima 20 por cento cujos abatimentos lhes serão entregue em livros. Dirijam-se ou peçam a estes endereços: Manoel Camilo dos Santos, rua Santo Antonio n. 179 Campina Grande. Ou a Antônio Cantalice de Barros <〈GERENTE〉> rua Prefeito Manuel Simões n. 119 Guarabira, PB. ${ }^{97}$
\end{abstract}

\footnotetext{
95 Prática inaugurada por Leandro Gomes de Barros.

96 Maurílio Antônio Dias (2009, p. 209), identifica dezenove formas de publicidade na produção do poetaeditor: a ) apresentação e apelo; b] anúncio, apelo e advertência; c) anúncio e listagem; d] anúncio de registro e advertência sobre o direito de reprodução; e) projeção do potencial produtivo, gráfico, comercial e de distribuição; f) publicação promocional; g) declaração de autoria e venda como fortalecimento institucional; h) atualização do catálogo; i] considerações poéticas; j) informar sobre a política de distribuição do produto e fortalecer as medidas de proteção aos direitos de autoria e de reprodução; k) informação como forma de participação cultural; I) informar aos revendedores sobre a integridade e legalidade institucional; $m$ ) informar para esclarecer e aperfeiçoar o relacionamento empresarial; n] assegurar a aceitação da editora por parte do público em geral; o] estimular o interesse do público pela casa editorial e por suas publicações, p) servir mediante informações úteis; q) informar os autores sobre a política editorial para criar uma atitude favorável por parte dos poetas e intermediadores; r] prestar um serviço público; s] apresentação orientada. 97 CAMILO DOS SANTOS, Manoel. Nascimento, Vida, Milagres e Morte de Jesus. Guarabira - PB: Tipografia e Folhetaria Santos, 1952.
} 
Após uma década de sucesso em Guarabira, Manoel Camilo dos Santos, visionário por excelência, começa a analisar as possibilidades mercadológicas oferecidas por Campina Grande, diante da centralidade da Feira da cidade, que nos anos 1950 passa a figurar como "a Feira das feiras". Seguro de sua aposta, transfere a Tipografia e Folhetaria Santos para a "capital do nordeste brasileiro"98 em 1953.

Taticamente plantada às margens da Feira Central de Campina Grande (Rua Santo Antônio, $n^{\circ}$. 114), a primeira tipografia especializada em folhetos na cidade, vivencia um crescimento exponencial. Alavancada por três máquinas tipográficas (duas delas, Minervas), uma cortadeira e cinco operários trabalhando no setor gráfico, a Folhetaria Santos dispunha, em meados da década de 1950, 100 mil folhetos em suas prateleiras, o equivalente a 138.000 cruzeiros (LESSA, 1984, p.62).

Tamanho é o brilho do empreendimento, que seu proprietário rebatiza a Tipografia de A Estrella da Poesia, em 1957, ano em que realiza mais um lance certeiro: a instalação de seu comércio dentro da feira campinense, aos pés do Mercado Central - área que abriga atualmente o comércio de carnes99. Na quarta capa do folheto As palhaçadas de Biu (1958), Manoel Camilo exalta seu ápice produtivo:

Esta ESTRÊLA é um reflexo lacteo, que se desprende das Ribaltas siderais; candensificando as poesias desta firma: - a mais credenciada e legalisada do paiz; cujo brilho de radiosidade benemerênte, se estende por sôbre tôdos os apreciadores das mais aplaudidas tróvas poéticas, da atualidade; que são as desta casa.

Mas enquanto (A ESTRELLA DA POESIA) por sua candidêsa, vem aurificando o mundo poético; os revêses e labeunados, vêem ofuscandose, (já em diluidez) seus combros eigidos por ribaldatárias consciências... Por tanto, leiam as mais brilhantes poesias atuais, que são os romances e folhetos da (A ESTRELLA DA POESIA): Bons, Bonitos, bem feitos e Baratos. (CAMILO DOS SANTOS, 1958)

A transferência de Camilo para o coração de Campina Grande, revela a importância que as feiras continuaram a cumprir na comercialização da literatura de folhetos, quase cinco décadas depois de um dos desbravadores dessa atividade comercial, João Martins de Athayde, ter instalado sua tipografia nas bordas do Mercado São José, no Recife (PE).

98 No final de 1950, Campina Grande recebeu essa denominação por ser a cidade mais populosa da Paraíba, ultrapassando numericamente a Capital, João Pessoa. No período, Campina também era vista como grande economicamente, pois arrecadava entorno de $40 \%$ dos tributos do estado. (AGRA DO 0́, 2007).

99 Hoje o espaço ocupado pela "Granja Fortaleza - A mais higiênica", instalada na Rua Cristóvão Colombo $\mathrm{N}^{0} 304$, não deixa rastros do seu passado poético. 
A feira configurou-se como um ponto estratégico para a indústria tipográfica do gênero por fornecer "a fruta direto do pé" para poetas-folheteiros que tinham nesse espaço sua maior freguesia. A tipografia de Camilo, assim como a feira campinense, passou a figurar como um entreposto comercial no qual poetas-folheteiros e agentefolheteiros preenchiam seus estoques. A Estrella da Poesia também lucrava com a venda a varejo direto no balcão, realizada pelo próprio editor, que recomendava títulos aos seus clientes, tal como em uma livraria.

Sem concorrentes expressivos em Campina Grande, Manoel Camilo dos Santos monopolizou o comércio local e regional. O domínio comercial da Estrella da Poesia faz-se evidente no grupo de folhetos selecionados na Biblioteca de Obras Raras Átila Almeida (UEPB) para compor o corpus dessa pesquisa. Dentre os 100 folhetos agrupados sob o critério da publicação ter sido editada em Campina Grande entre 1950 - 1960, apenas 20 foram impressos em outras gráficas, que não na Tipografia e Folhetaria Santos/ Estrella da Poesia. A maioria deles não guardam as insígnias das gráficas nas quais foram impressos - aspecto que dificulta o mapeamento dos prelos impressores de folhetos no período de expansão desta literatura.

Figuram entre as gráficas "não especializadas" atuantes no mercado folheteiro de Campina Grande nesse ínterim: a Tipografia Borborema, a Gráfica São Jorge, a "Gráfica Júlio Costa", a tipografia do jornal "O Rebate" (de Pedro Aragão) e o "prelo do Sr. Agenor". As três últimas casas impressoras mencionadas, aparecem nos relatos de José Alves Sobrinho como as prediletas dos poetas folheteiros antes da instalação da Tipografia e Folhetaria Santos na cidade (SOBRINHO, 2007 apud DIAS, 2009). Na Biblioteca de Obras Raras Átila Almeida foram encontrados folhetos que guardam as marcas das duas primeiras, a Tipografia Boborema e a Gráfica São Jorge [Figuras 15 e 16]: 


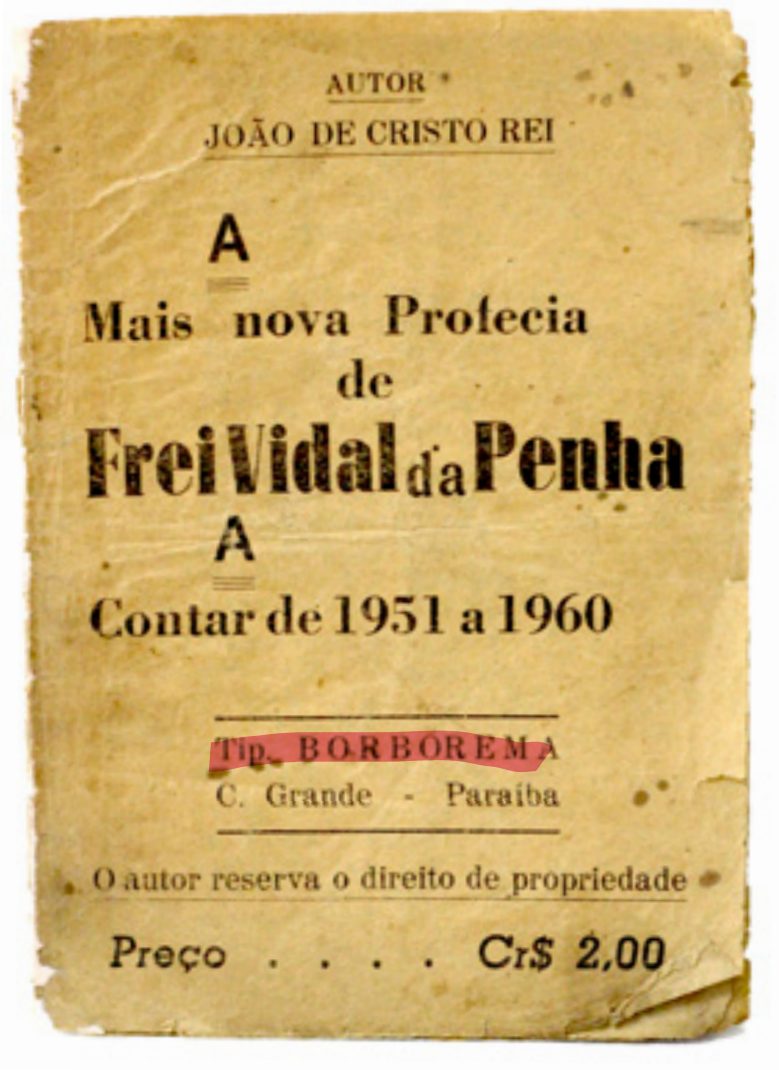

ATENÇĀO: aos leitores.

O ano de 1951, o inverno é mediano, inverno temperado, mortandade em abelhas, infermidades no pôvo, e grandes dezastres, agitacão de política e muita doença na criação que causa admiracũo! Punco mel, linho caro, grande carestia nos gênervis alirveatiofos.

O ano de 1951 domina a laa e rege mereurio traz ano mediano.

Aviso mais quem colher no ano de 51, guarde para 52. Que é mediano e de chôro.
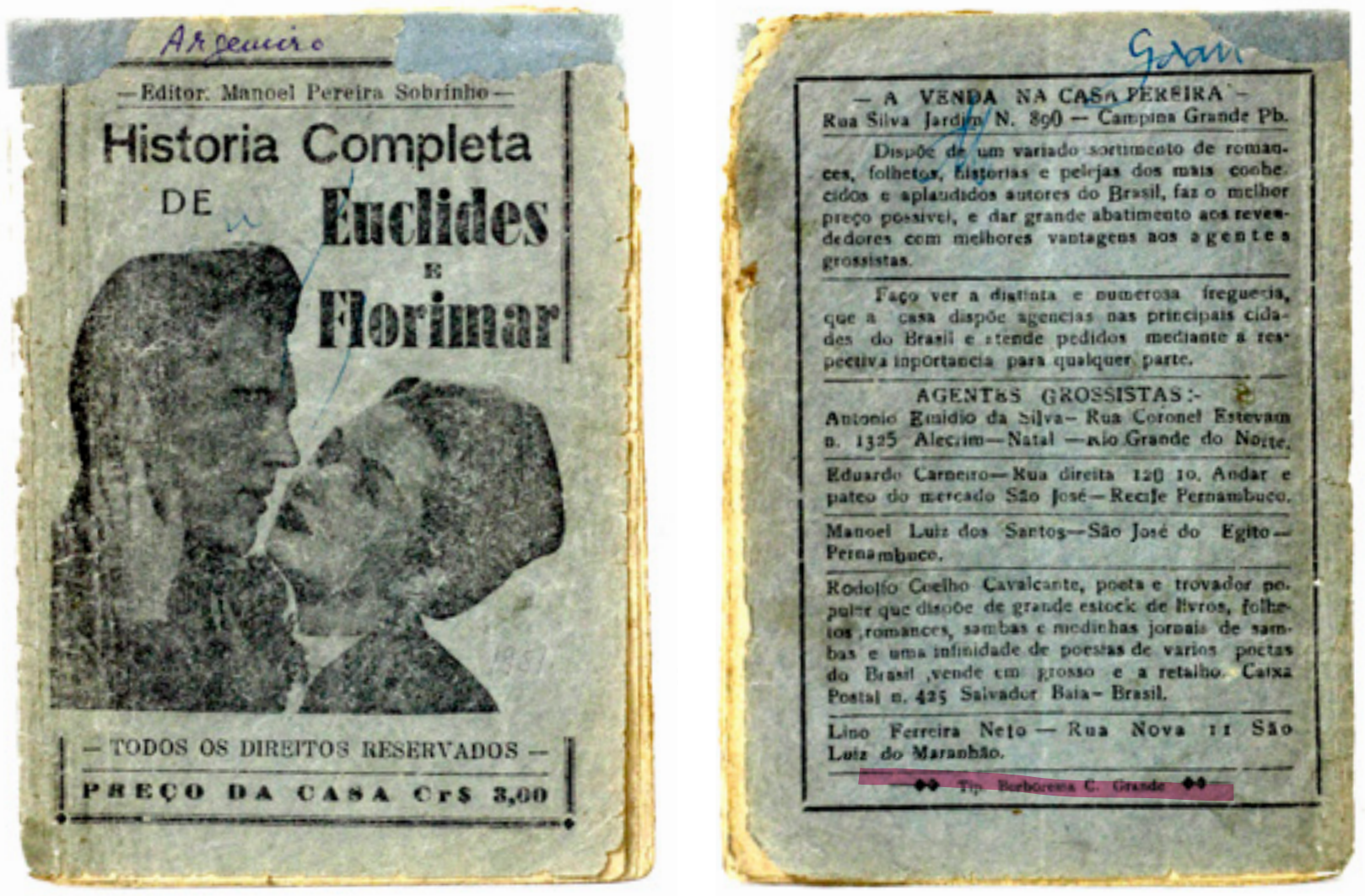

Figura 15 - Folhetos com a chancela da Tipografia Borborema. Grifos realizados digitalmente pela pesquisadora

Fonte: Biblioteca de Obras Raras Átila Almeida (BORAA/ UEPB) 

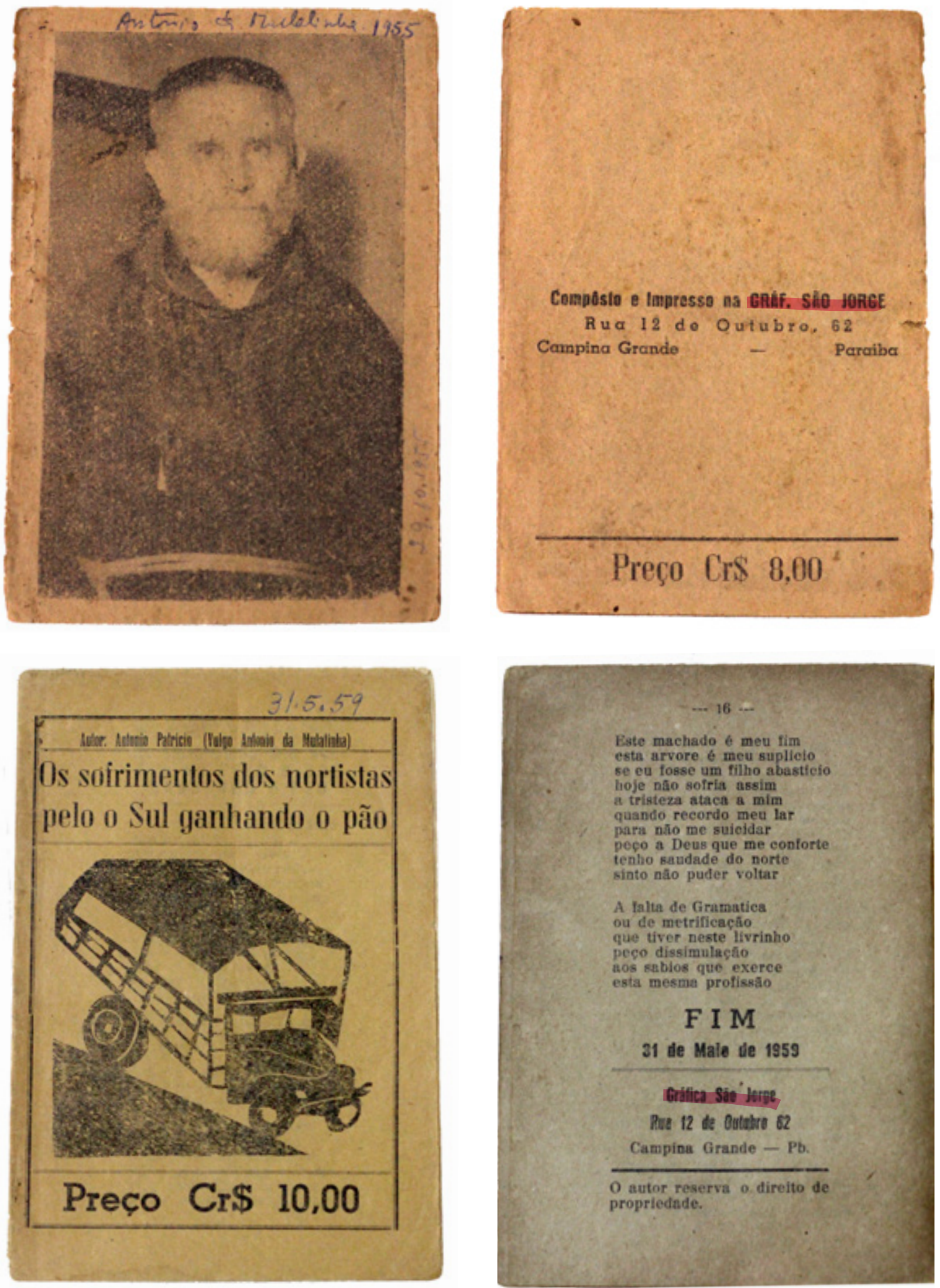

Figura 16 - Folhetos com o timbre da Gráfica São Jorge. Grifos realizados digitalmente pela pesquisadora

Fonte: Biblioteca de Obras Raras Átila Almeida (BORAA/ UEPB) 
Dentre as casas especializadas na edição (mas não necessariamente na confecção) de folhetos que orbitavam a Estrella da Poesia em Campina Grande estão: a Tipografia Graça de Fátima, propriedade do editor Joaquim Batista de Sena, que se acomodou na cidade no ano de 1955, antes de fixar-se permanentemente em Fortaleza, Ceará; A Casa Pereira [Figura 17], coordenada por Manoel Pereira Sobrinho, ativa entre os anos de 1948 e 1956; A editora de Sebastião José do Nascimento (atuante até a década de 1960, ano de falecimento do poeta), um dos primeiros agentes grossistas vinculados a Manoel Camilo dos Santos ${ }^{\mathbf{1 0 0}}$ [Figura 18].

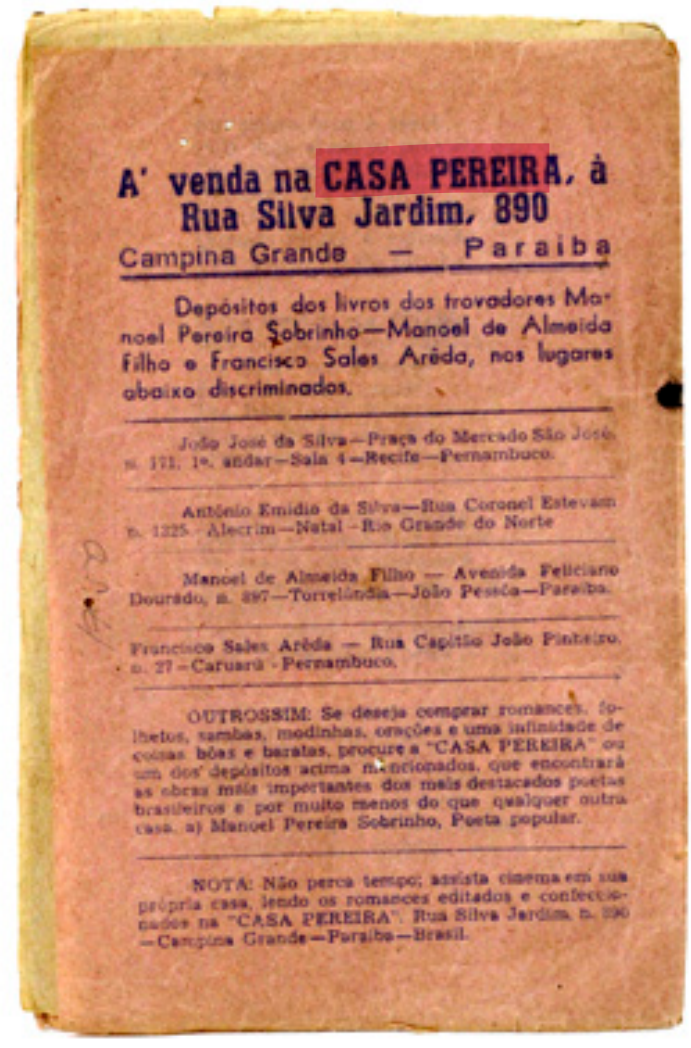

Figura 17 - Folheto de autoria de Manoel Pereira Sobrinho editado e comercializado pela Casa Pereira, propriedade do autor. Grifo realizados digitalmente pela pesquisadora

Fonte: Biblioteca de Obras Raras Átila Almeida (BORAA/ UEPB)

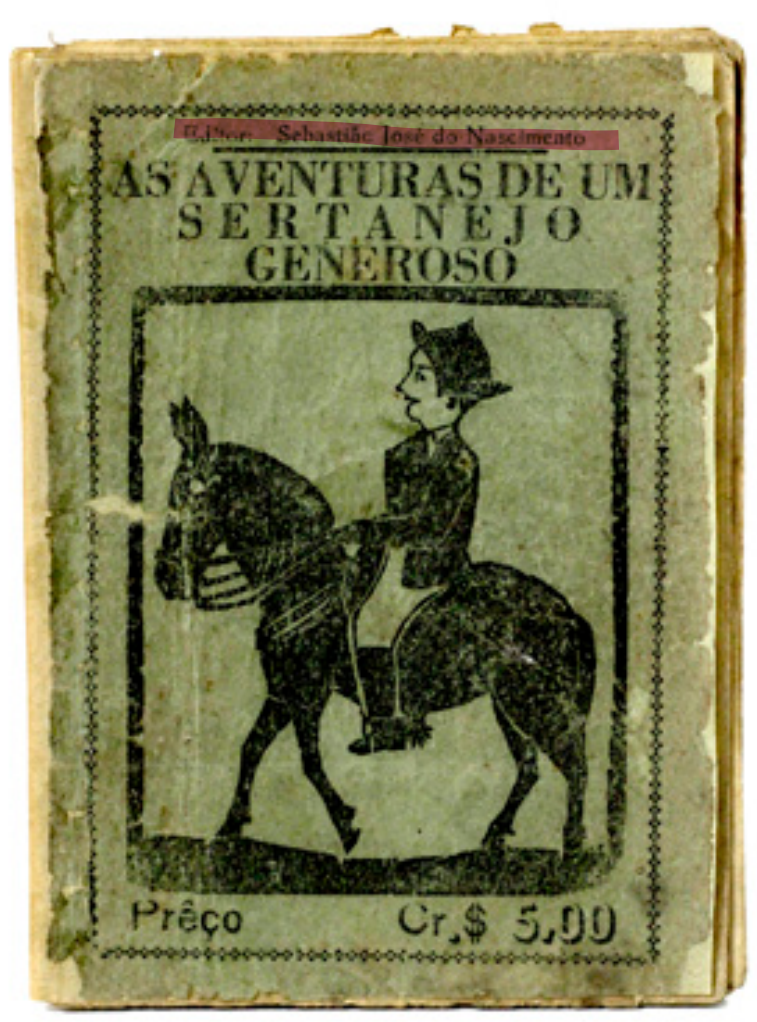

Figura 18 - Folheto de autoria de José Camelo editado por Sebastião José do Nascimento. Grifo realizados digitalmente pela pesquisadora

Fonte: Biblioteca de Obras Raras Átila Almeida (BORAA/ UEPB)

Com A Estrella da Poesia Camilo imprimiu uma marca editorial cognoscível à primeira vista, por meio dos esquemas gráficos das capas de impressão bicolor (uma inovação no ramo!), organizadas por molduras volumosas; pelas quartas-capas verborrágicas, nas quais projetava uma identidade empresarial, pautada nos conceitos de moralidade e transparência; por meio da sua logomarca, uma estrela de 5 pontas.

100 Vale sublinhar que a pesquisa documental apresenta limitações investigativas, derivadas da demarcação de um corpus específico e, até mesmo, da ausência de registros documentais. Portanto, alguns editores campinenses especializados em folhetos podem ter sido olvidados na narrativa historiográfica. 

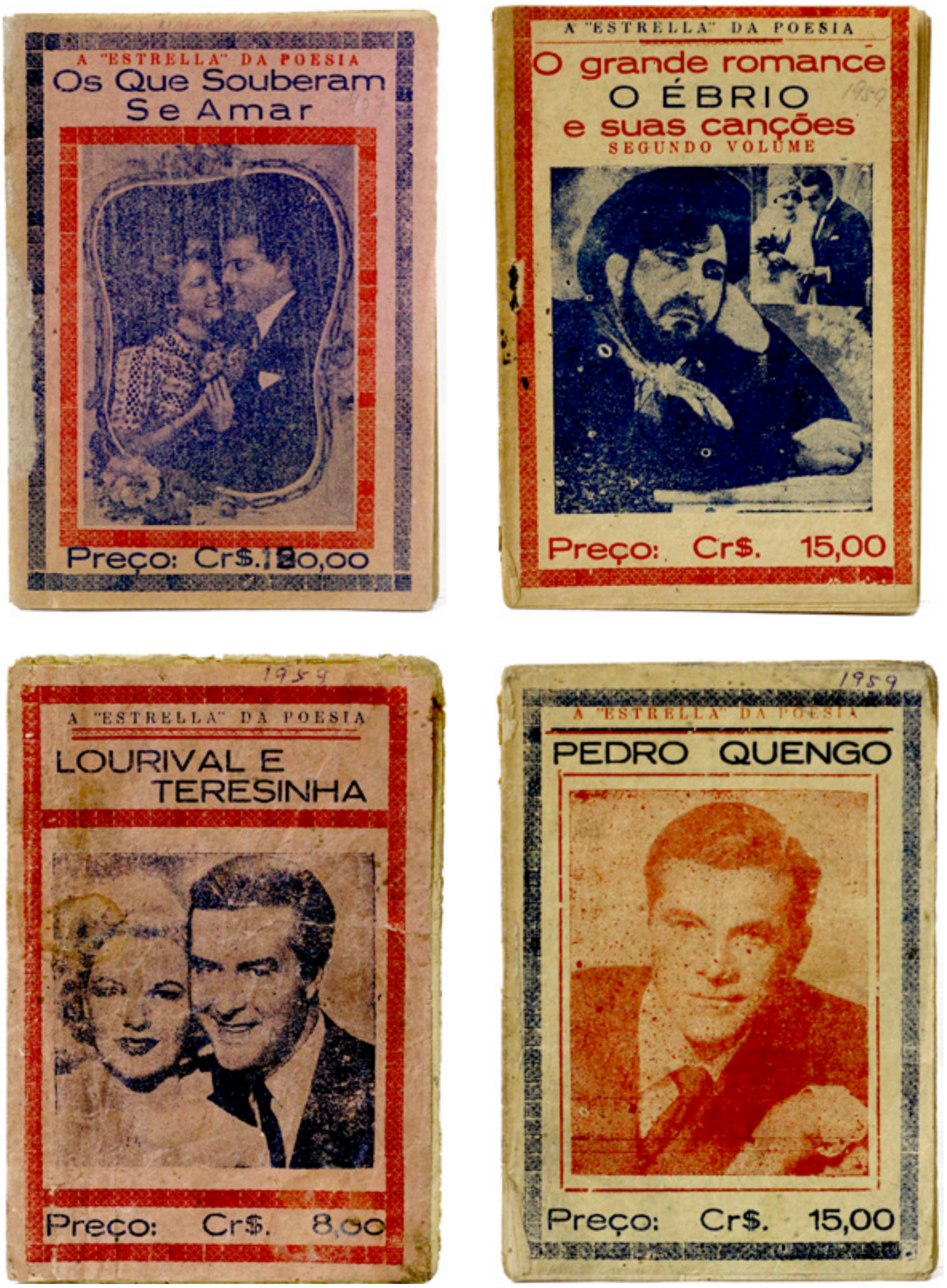

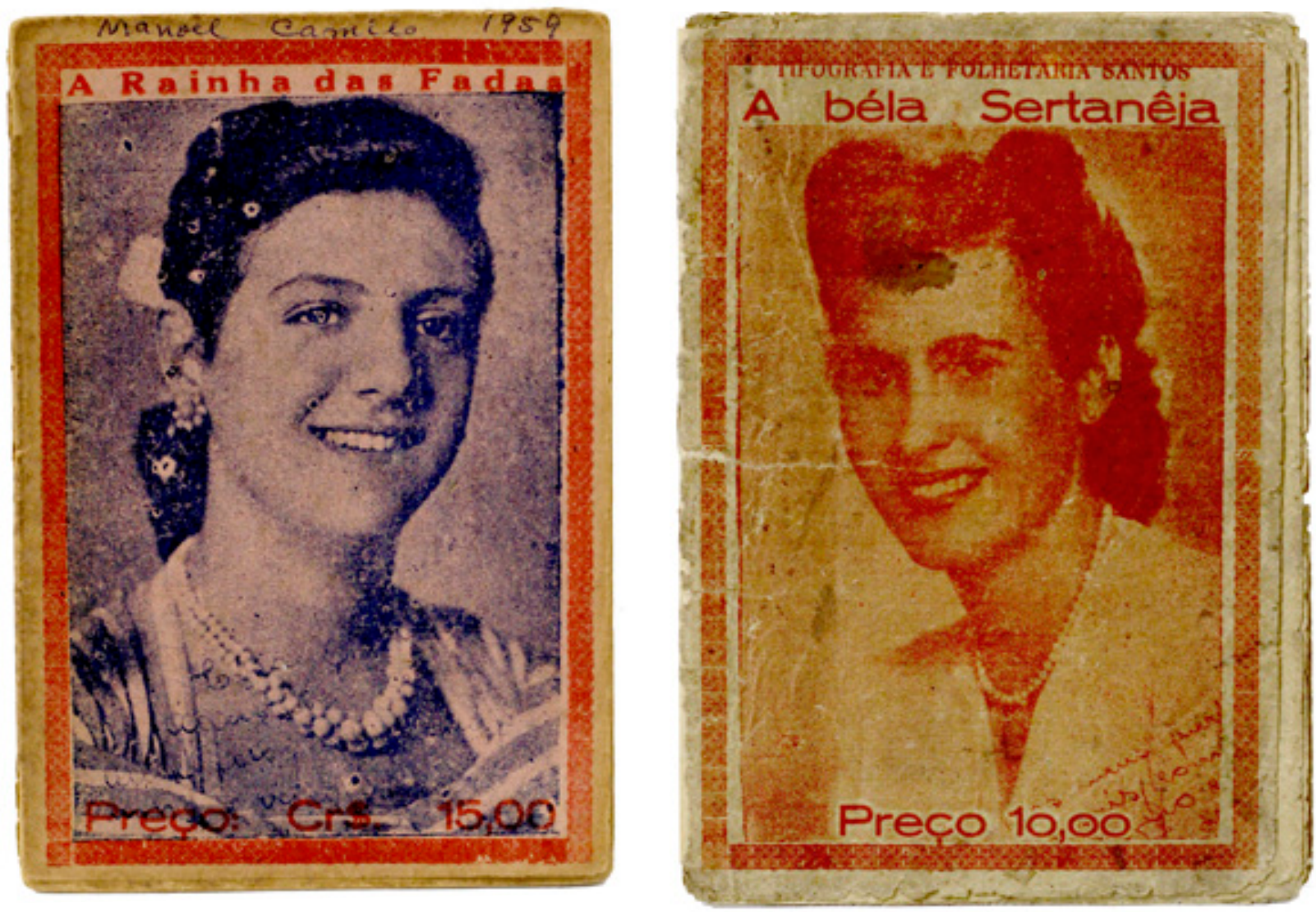

Figura 19 - Folhetos de autoria de Manoel Camilo dos Santos editados pela Estrella da Poesia no período em que se manteve instalada na Feira Central de Campina Grande. Observa-se a homologia visual das impressões do período

Fonte: Biblioteca de Obras Raras Átila Almeida [BORAA/ UEPB] 

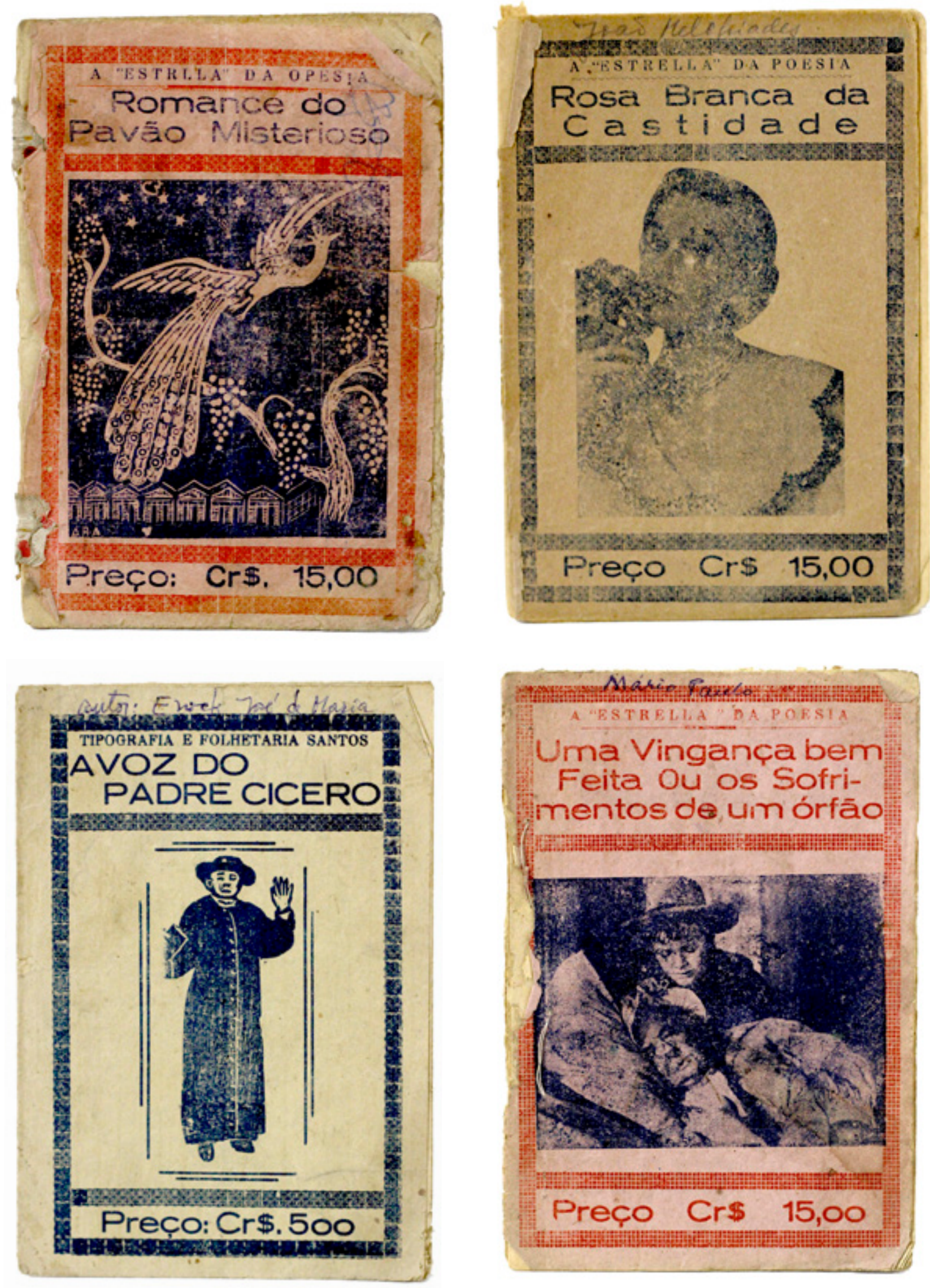

Figura 20 - Folhetos de autores diversos editados por Manoel Camilo dos Santos. É possível perceber nas publicações a manutenção de uma identidade gráfica, estabelecida a partir do renovado maquinário da Tipografia Estrella da Poesia, durante seu auge comercial

Fonte: Biblioteca de Obras Raras Átila Almeida (BORAA/ UEPB] 
A partir de um "capital econômico" miúdo, Camilo se apropriou dos meios de produção de impressos e mobilizou todo seu "capital cultural e social” até adquirir um "capital simbólico" (BORDIEU, 2003) expressivo no ramo, tornando-se "embaixador da classe" (DIAS, 2009, p. 148). Status que impulsionou o capital que deu início a esse círculo virtuoso: o econômico, do qual poucos poetas gozaram.

O resplendor da "Estrella" concedeu a Manoel Camilo dos Santos o poder de legitimar poetas e poesias. Nas estantes de sua tipografia armazenou milhares de títulos de autores/as diversos/as e quase duas centenas de narrativas de sua autoria. Algumas delas repousavam rapidamente no aparato expositor, sendo reeditadas mensalmente até o esmaecer da casa tipográfica. Tamanho a demanda de seu público de escritoras/ es, agentes folheteiros e leitores/as (categorias que não são auto excludentes), que entre 1954 e 1960 o editor chegou a ofertar 1.840 .000 folhetos (DIAS, 2009, p. 199).

Além de instrumento multiplicador de narrativas, Camilo fez do seu prelo ferramenta de projeção de sua persona, imprimindo em suas publicações textos que o delineiam como "poeta bacharelesco" ou empresário de princípios éticos e, até mesmo, sua imagem fotográfica - chancela de seus direitos autorais sobre obras literárias [Figura 21]. Herdeiro da indústria gráfica não-hegemônica, arquitetou uma carreira distinta daquela vivenciada pelos/as livreiros/as e tipógrafos/as editores/as de pequenos jornais e folhetins na Paraíba oitocentista, denominados por Socorro de Fátima Pacífico Barbosa (2010) como "intermediários esquecidos": figuras que, apesar de desempenharem papel central na divulgação da cultura escrita no estado, permaneceram anônimas.

No topo da Serra da Borbore-ma a Estrella de Manoel irradiou-se através das rádios campinenses, Cariri e Caturité, percorrendo léguas com suas narrativas em folhetos, já descoladas do corpo-suporte após a consolidação da indústria gráfica do gênero. Sua atuação na rádio coincide com o ano de instalação da Estrella da Poesia na Feira Central, o ponto mais alto de sua carreira profissional. Nestas rádios eram entoadas, por radialistas, poesias de autoria de Camilo e anunciados folhetos a serem lançados. Reciprocamente rádio e folhetos se promoviam.

Ao seu estilo "marqueteiro", o poeta-editor prescreve na quarta capa do folheto o a Pobre Orfã Engeitada nas Malhas da Traição (1957) que leitores/ouvintes sintonizem pontualmente suas radiolas para desfrutar de sua arte: "Escute a RÁDIO CARIRI todos os dias as 12 h, e 5 minutos; e lembrem-se que estamos na época da poesia, a qual instrui, diverte e alegra: portanto façam da poesia o seu melhor passa-tempo".

Manoel Camilo dos Santos tornou-se expoente da popularização da literatura de folhetos diante da capacidade produtiva de sua tipografia (intensificada com a modernização do seu maquinário e a contratação de operários), da aptidão publicitária 
para projetar seu negócio, mas, sobretudo, pela sua habilidade de agenciamento da distribuição de narrativas. No final da década de 1950, o poeta-editor contava com dez agências revendedoras vinculadas à casa matriz, espalhadas por sete estados nordestinos: Bahia, Ceará, Maranhão, Pará, Paraíba, Pernambuco e Rio Grande do Norte. A localização de sua sede, situada na Feira Central Campinense, por certo colaborou no escoamento de suas publicações em uma rede interestadual.

Em distintos contextos históricos e culturais editores enfrentaram o desafio de disseminar impressos em um território de dimensões continentais e de leitura rarefeita. Aníbal Bragança (2010), nos mostra que desde o período colonial o proprietário da Casa Literária do Arco do Cego (1799 - 1801, Lisboa), Frei Veloso ${ }^{101}$, empreendeu, aliado ao governo português, um projeto de distribuição de livros úteis e baratos pelo Brasil, utilizando funcionários da administração da colônia como agentes executores da primeira ação pública voltada para o oferecimento de conhecimentos através dos livros no contexto nacional.

Na indústria editorial do circuito intelectual paulista da década de1920, Monteiro Lobato recebeu o título de "editor revolucionário” por criar uma rede de distribuição nacional de livros, através da indicação de agências de correios que comercializavam as publicações da Cia Graphico-Editora

101 José Mariano da Conceição Veloso (1742, Minas Gerais - 1811, Rio de Janeiro], foi um naturalista que produziu vasto material sobre a flora brasileira. Começou sua carreira como editor em Lisboa em 1793, onde publicou intensamente brochuras, de cunho pedagógico e técnico, sobretudo para divulgação de conhecimentos da nova economia agrícola, direcionados para pequenos proprietários de terra e artesãos. Em 1799 inaugura a Officina da Casa Literária do Arco do Cego a convite do Ministro D. Rodrigo de Sousa Coutinho, e inicia seu projeto megalômano e generoso: "mandar traduzir (sobretudo do francês) o que de melhor se publicava lá fora no campo da divulgação científica e abastecer o Brasil, seu país natal" (ANSELMO, 1997, p. 110). Nas palavras do Frei: "para que nada falte a estes homens úteis, que habitão os campos, e sustentão as cidades" (ARAGÃO, 1800 apud BRAGANÇA, 2010, p. 34). Movido pela aspiração progressista de "instruir deleitando", publicou mais de 140 títulos bibliográficos até o encerramento das atividades da tipografia, em 1801.

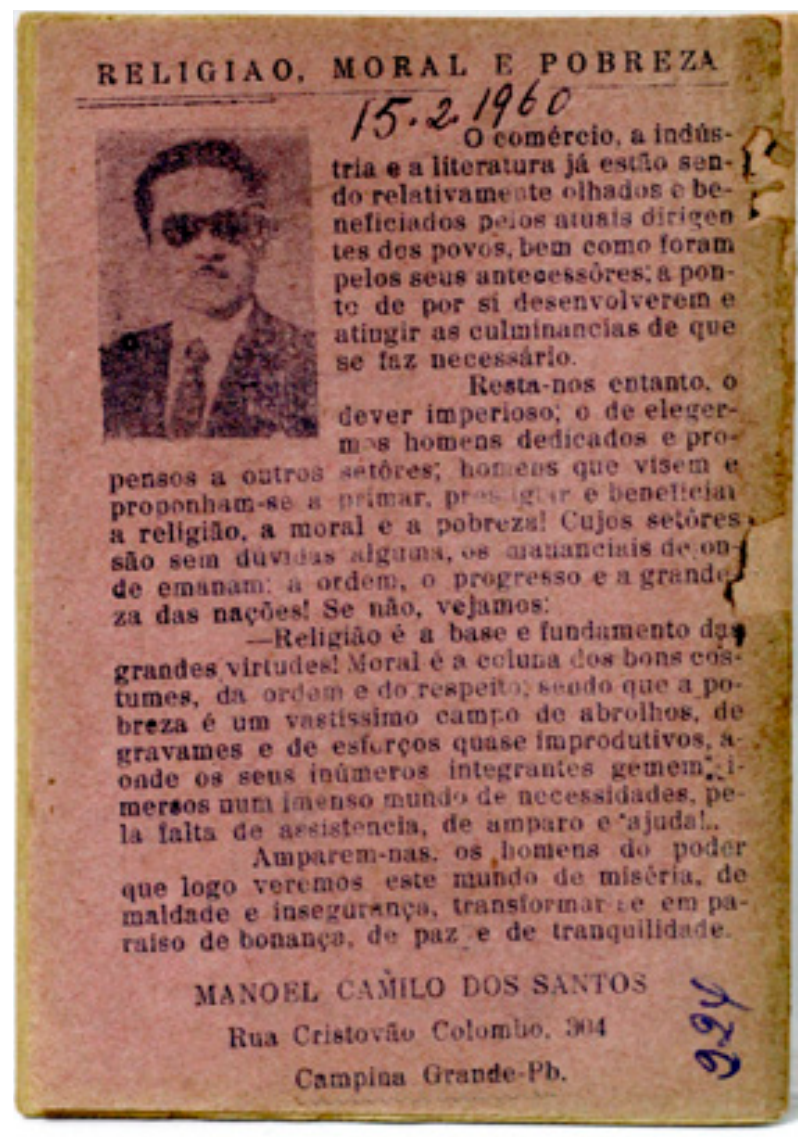

Figura 21 - Fotografia de Manoel Camilo dos Santos fixada na quarta capa do folheto A Béla Sertanêja (1960), de sua autoria

Fonte: Biblioteca de Obras Raras Átila Almeida (BORAA/ UEPB] 
Monteiro Lobato, com intuito de fazer do livro um objeto acessível (BIGNOTO, 2010) 102. Relacionado com a "nata da classe dirigente paulista intelectual" (AZEVEDO, 1998 apud BIGNOTO, 2010, p. 122), Lobato não teve tanto êxito no seu plano disseminador como os editores de folhetos da primeira metade do século XX, que tiveram a voz dos cantadores de feira como propagadoras do impresso.

Os agentes-folheteiros e poetas-folheteiros vinculados a Manoel Camilo foram figuras fundamentais na conformação de uma rede de distribuição que fez com que os folhetos impressos tivessem larga circulação. Esses cantadores e essas cantadoras mediavam a relação entre editora e o público consumidor agindo como semeadores/as da poesia de folhetos, guiados pelo clima de cada bioma. Harmoniosamente conectados, editor e poetas/poetizas paraibanos/as revolucionaram o acesso à literatura escrita em pequenos municípios de estados nordestinos que pegavam carona na rabeira do projeto modernizador do país.

\section{AVENTURAS DE UM NARRADOR PEREGRINO}

A literatura de folhetos brasileira é um fenômeno desenvolvido em consonância com o processo de industrialização do país, bem representada pelo ruído das máquinas tipográficas e das locomotivas dos trens, transporte que viabilizou o escoamento dos impressos das tipografias para os agentes-revendedores e poetas-folheteiros na década de 1950, substituindo o envio postal ${ }^{\mathbf{1 0 3}}$. De acordo com Maurílio Antonio Dias:

O "malote do trem" foi utilizado durante muitos anos por Manoel Camilo, tanto na cidade de Guarabira como em Campina Grande, já que nessas cidades havia duas estações ferroviárias importantes para o desenvolvimento da malha ferroviária estadual. A primeira porque distribuía o acesso para todo o Agreste e a segunda porque era um eixo de expansão para todo o estado da Paraíba. (DIAS, 2009, p. 254)

\footnotetext{
1020 título, atribuído pelo próprio Lobato e reproduzido por pesquisadores da área, deveu-se a um conjunto de iniciativas do editor somadas à implantação de uma rede de distribuição de livros no território brasileiro: a renovação gráfica dos impressos; a inserção de novos autores no mercado editorial; o compromisso com o pagamento de direitos autorais (BRAGANÇA, 2010).

103 Na primeira metade do século XX os correios foram aliados no serviço de distribuição dos folhetos. As tipografias estabeleciam critérios para receber pedidos por este meio, estampados pelos editoresimpressores nos folhetos. No folheto 0 Valente Sebastião (1946), Manoel Camilo dos Santos elenca as condições para a venda à distância para os agentes revendedores: "remete pelo correio qualquer pedido para qualquer parte, mediante a importância do pedido e o reembolso da mesma”. Ou seja, a editora realizaria o envio mediante o pagamento da mercadoria e do "reembolso postal". Para mais informações sobre a rede de distribuição dos folhetos ver DIAS (2009, p. 238 - 268).
} 
Guarabira já estava nos trilhos da primeira estrada de ferro do Estado da Paraíba (1883), o que justifica, em partes, o desenvolvimento das tipografias nessa cidade nas primeiras décadas do século XX. A linha férrea - construída pela Companhia Inglesa Conde D’Eu Railway - saía do porto no capim, localizado na Capital João Pessoa (denominada Parahyba, à época), e bifurcava-se em forma de "Y" em direção ao interior, sendo o trecho norte no sentido Guarabira (inaugurada em 1884) e o Sul no sentido Pilar, que se estenderia à Campina Grande em 1907 (CAMILO DE MELO, 2000) [Figura 23].

A construção de ramais ferroviários que ligavam a Paraíba ao Estado de Pernambuco e do Rio Grande do Norte, encampada em 1901 pela Great Western do Brasil Railway Company, tornou aquele localizado no meio dos outros dois uma centralidade (SANTOS, 1979). Campina Grande, naquele momento já reconhecida pela sua posição privilegiada no Estado, enreda-se nas teias de ferro da sociedade industrial e desponta, no final da primeira década do século XX, "como o maior centro comercial e urbano do interior da Paraíba, apoiada no tripé: algodão, comércio e via férrea” (TARGINO, 2001, p. 60).

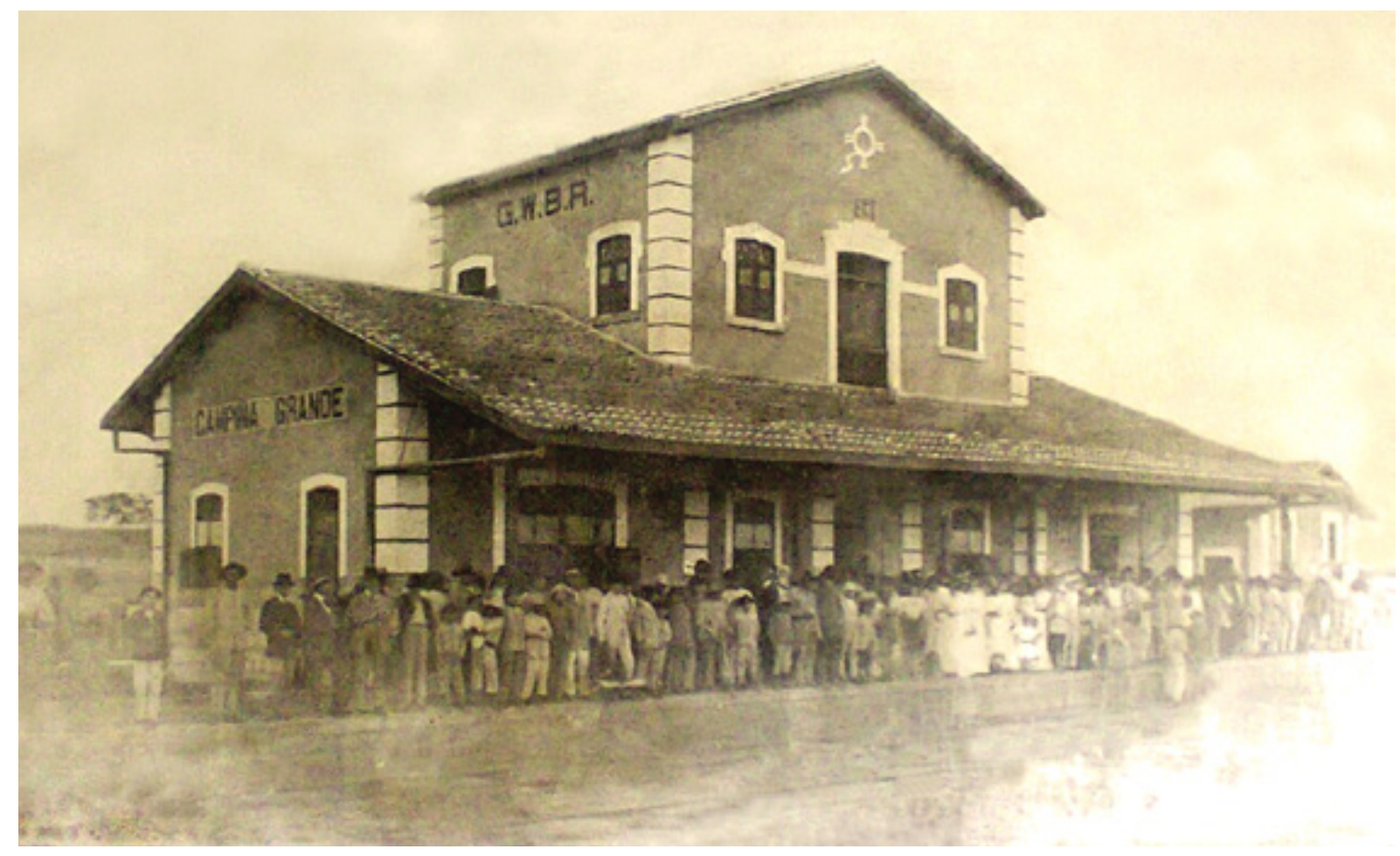

Figura 22 - Multidão esperando o trem na estação ferroviária de Campina Grande (1907) Fonte: Blog "Retalhos Históricos de Campina Grande" 


\section{$\begin{array}{llllllllllllllll}M & A & P & A & F & E & R & R & 0 & V & I & A & R & I & 0\end{array}$}

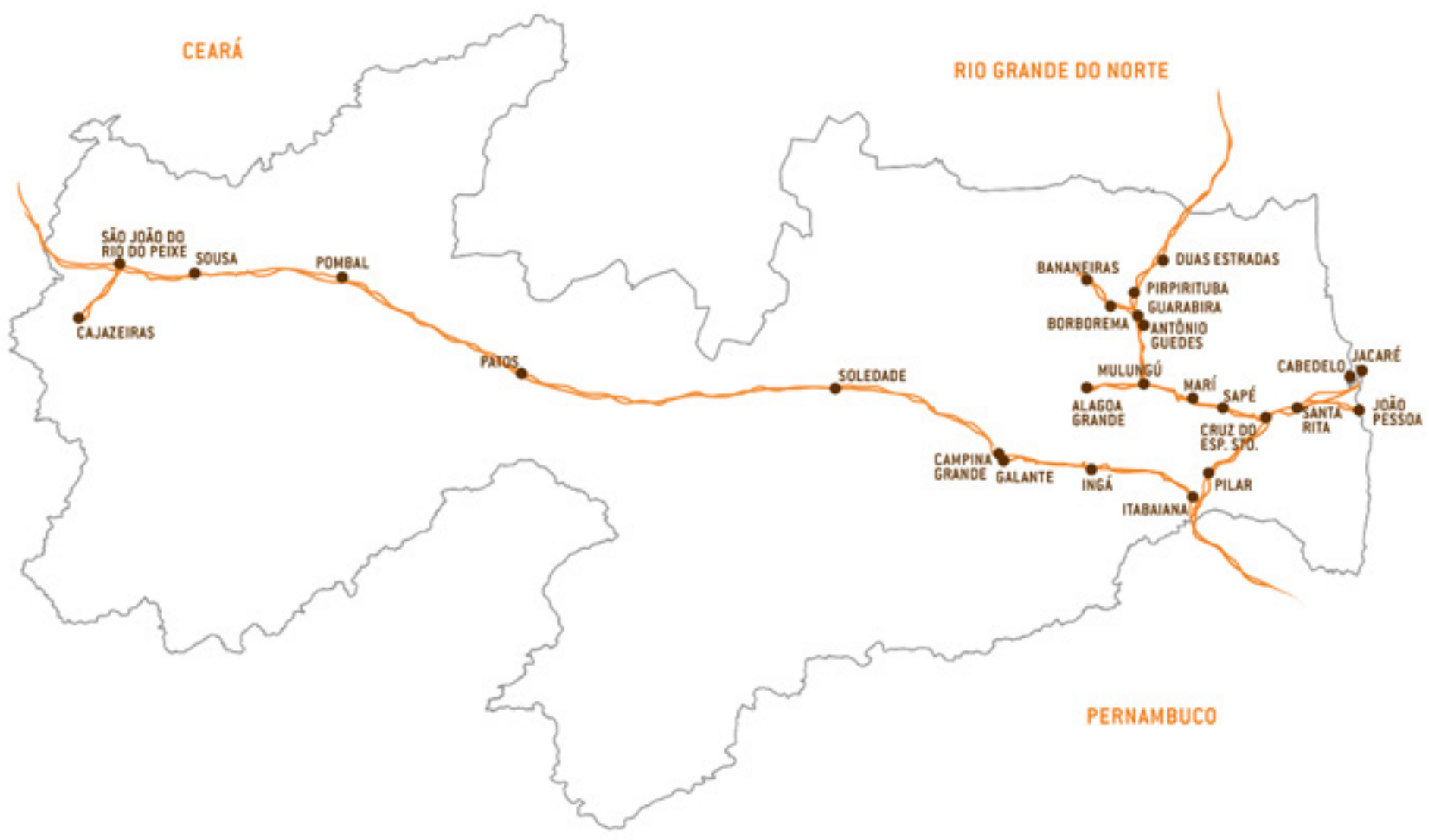

1 João Pessoa
2 Santa Rita
3 Cruz do Espírito Santo
4 Sapé
5 Marí

6 Pilar

7 Guarabira

8 Antônio Guedes

9 Jacaré

10 Cabedelo

11 Itabaiana
12 Mulungú

13 Alagoa Grande

14 Duas Estradas

15 Ingá

16 Galante

17 Campina Grande

18 Pirpirituba

19 Borborema

20 Bananeiras

21 São João do Rio do Peixe

22 Cajazeiras
23 Sousa

24 Pombal

25 Patos

26 Soledade

Figura 23 - Mapa das linhas férreas inauguradas no estado da Paraíba entre 1883 e 1960. Os municípios indicados são aqueles que receberam estações de trem no período. A imagem foi redesenhada pela pesquisadora com base no mapa de TARGINO, 2001 
Manoel Monteiro associa, em versos, a história do transporte com a do comércio, relacionando a produção algodoeira, a formação de vias e o desenvolvimento de cidades e indústrias na Paraíba:

\author{
Movidas a algodão \\ Vilas se desenvolviam \\ Portos se movimentavam, \\ Estradas se construíam \\ Para carros e caminhões, \\ Trens penetravam sertões \\ Indústrias têxteis nasciam. \\ (MONTEIRO, 2003) ${ }^{104}$
}

A rede de vazão produzida pelo ciclo do algodão em Campina Grande, serviu aos atores responsáveis pela circulação de folhetos de feira produzidos em tipografias especializadas: agentes-revendedores e poetas-folheteiros, figuras que ocupavam diferentes posições na cadeia de disseminação do impresso.

As agências geralmente precediam os folheteiros no fluxo de propagação dos impressos. Elas eram instaladas em cidades onde não haviam tipografias produtoras de folhetos e comercializavam, principalmente, em atacado para "poetas do mundo" (LEMAIRE, 2008), andarilhos que reabasteciam a mercadoria em pontos estratégicos onde eram fixados esses pequenos armazéns. Os agentes não eram, necessariamente, poetas, mas comerciantes do ramo que recebiam por consignação significativa quantidade de títulos do editor-impressor, a ser paga conforme a venda do material (seja em atacado ou no varejo, direto no balcão).

Os poetas mascates espalhavam pelo estado da Paraíba e pelos estados vizinhos os folhetos adquiridos em agências e/ou tipografias, arrematando o ciclo de comercialização do impresso, ao entregar à população narrativas ilustradas pelas curvas da voz, ornamentadas por tons de suspense, de pilhéria, de sedução. Deslocando-se pelas estradas de ferro, remanescentes do ciclo do algodão, ou de concreto - estabelecidas como principais vias de deslocamento na década de 1960, com o processo do "desenvolvimentismo" à brasileira -, estes comerciantes costuraram a forma oblonga do Estado da paraíba, produzindo um bordado de histórias regionais.

Repentista e mascate radicado em Campina Grande, José Alves Sobrinho relembra a dinâmica dos transportes:

104 MONTEIRO, Manoel. O milagre do algodão colorido. Campina Grande: Cordelaria Poeta Manoel Monteiro, 2003. 
De trem era... pra João Pessoa era sempre de trem, de Guarabira pra João Pessoa, daqui [Campina Grande] pra João Pessoa era sempre de trem, mas no sertão o nosso [transporte] era caminhão, às vezes havia regiões que havia o "misto" [...]. A gente vinha em cima daqueles caminhão carregado com algodão, os bichos fazia assim, né? Nesse tempo não tinha asfalto, a estrada era barro, [...] as estrada era um perigo, isso enfrentava assim. (ALVES SOBRINHO, 2008 apud DIAS, 2009, p.86).

Manoel Camilo dos Santos, reconhece a importância da rede conformada entre ele, produtor, e os poetas disseminadores, em entrevista a Orígenes Lessa (1984): "Lessa: - 'quantos vendedores você tem?'; Camilo: '- Dez. Todos cantam. Cantando sai melhor do que lendo. O povo aprecia mais' " (LESSA, 1984, p. 57). O editor da Borborema aliouse a um dos grandes poetas peregrinos do século passado, Toinho da Mulatinha, ao qual confiava a venda de suas publicações. O poeta-mascate relata: "Manoel Camilo dos Santos era meu amigo, eu vendi muito folheto dele, também entregava a mim uma mala cheinha e eu ia pra cada feira, Puxinanã, Esperança, Queimadas, Massaranduba, Serra Redonda...” (MULATINHA, 2007 apud DIAS, 2009, p. 259).

No corpus de folhetos publicados por Toinho da Mulatinha (1950 - 2010) não há registro de impressões realizadas na Estrella da Poesia, porém, o poeta-embolador afirma ter realizado uma variedade de tiragens na gráfica de Manoel Camilo dos Santos:

\begin{abstract}
A folhetaria de cordel de Manoel Camilo dos Santos era aqui na Rua Santo Antonio, do lado esquerdo, depois tinha o nome de A Estrella da Poesia... Fiz também nele os folhetos desde A filha que matou a mãe em Lagoa do Mato e interrou debaixo do pé de pimenta, A explosão no bairro de Zé Pinheiro, A mulher que castrou o marido em Esperança, também fui eu que fiz. Os quatro meninos que morreram afogados em Santo André, perto de Juazeirinho, fiz também, o folheto do Mata Sete, aquele do Roldão Mangueira, também fiz aquele folheto A tromba d'água em Solânea, também fiz, tudinho e assim por diante, tem um bucado... Muito freguês, ele mandava folheto pra toda parte do Brasil. (MULATINHA, 2007 apud DIAS, 2009, p. 259) ${ }^{105}$
\end{abstract}

105 Mata Sete foi o único título, dentre os mencionados, encontrado em um dos acervos consultados: o da Biblioteca de Obras Raras Átila Almeida. Porém, a edição acessada foi impressa na Zane Gráfica, segundo anotação a lápis realizada na quarta capa do folheto. É possível reconhecer as datas de alguns dos impressos listados por Toinho da Mulatinha, posto que pertencem ao gênero "acontecido": A explosão no bairro de Zé Pinheiro, Mata Sete e Roldão Mangueira, por exemplo, são da década de 1970, período no qual a Estrella da Poesia, de Manoel Camilo dos Santos, já não era mais um empreendimento de sucesso. 
Católico, inserido em uma comunidade praticante da romaria ${ }^{\mathbf{1 0 6}}$, Toinho da Mulatinha fazia travessias nas quais propagava sua religião, por meio de folhetos substanciados por essa temática. Deste modo, fez-se um poeta missionário, tal como seu guia de devoção, Frei Damião. Alguns rastros das rotas do clérigo são mencionados nos folhetos do autor: As missões de Frei Damião em Bom Jardim e a tempestade em

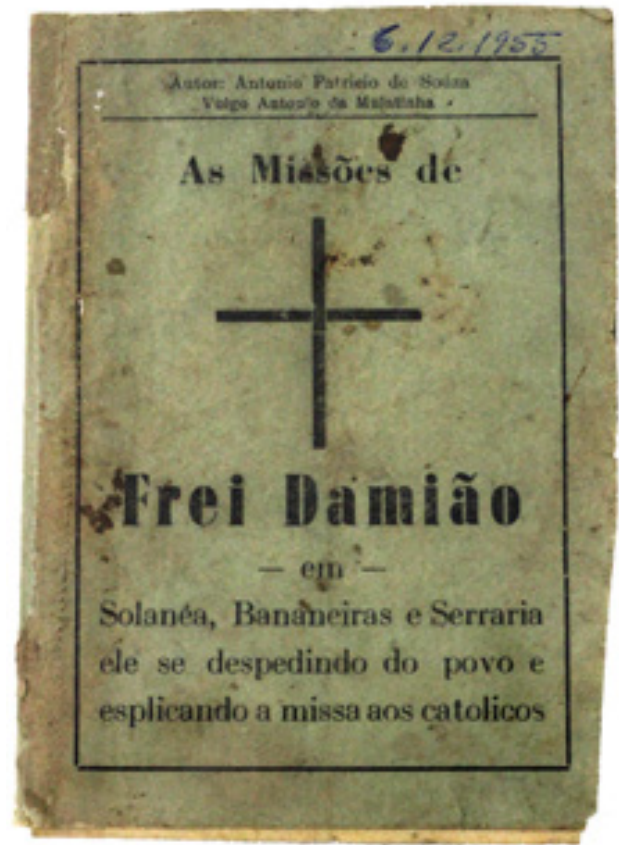

Figura 24 - Capa: As missões de Frei Damião em Solênea, Bananeiras e Serraria ele se despedindo do povo e explicando a missa aos católicos (1955)

Fonte: Biblioteca de Obras Raras Átila Almeida (BORAA/ UEPB)
Limoeiro (1955); As missões de Frei Damião em Solênea, Bananeiras e Serraria ele se despedindo do povo e explicando a missa aos católicos (1955).

A quantidade reduzida de folhetos de Toinho da Mulatinha datados entre 1950 - 1960 ( 5 de um corpus de 80$)^{107}$, a maioria de conotação religiosa, pode ser atribuída ao intenso trânsito do poeta peregrino no período e, portanto, a impermanência das publicações em Campina Grande, cidade onde está arquivado o acervo mais completo de sua obra. Há também de se considerar que as coleções públicas do gênero começam a ser formadas por intelectuais a partir das décadas subsequentes, principalmente na década de 1970, sendo esse um motivo plausível para o desencontro como esses impressos.

Um outro prognóstico para a "escassez" de publicações na primeira fase de produção do poeta-embolador, de acordo com os parâmetros estabelecidos nessa pesquisa, é que no início da carreira tenha exercido com mais afinco as atividades profissionais de poeta mascate e cantador de emboladas. Alguns manuscritos inscritos nessa baliza temporal parecem ter sido redigidos para serem decorados e cantados, como: Toinho da Mulatinha Cantando coco nas feiras (1955) e Coco de embolada sobre Leandro rei do cordel (1955) ${ }^{108}$.

106 No manuscrito Uma Viagem a Juazeiro, Toinho da Mulatinha relata com detalhes as romarias rumo à terra sagrada de Padre Cícero Romão.

107 (1) A história do monstro que roubou e incendiou a igreja do Rosário (1956); (2) As missões de Frei Damião em Bom Jardim e a tempestade em Limoeiro (1955); (3/4) As missões de Frei Damião em Solênea, Bananeiras e Serraria ele se despedindo do povo e explicando a missa aos católicos ( $1955-1^{\text {a }}$ e $2^{\mathrm{a}}$ edições); (5) Os sofrimentos dos nortistas pelo o Sul ganhando o pão (1959). Apesar de sem data, os folhetos a seguir podem ser atribuídos ao período pelas suas características gráficas: (6) A morte do trovador Patricio de Oliveira Antonio Patricio de Souza; (?) Os sofrimentos do povo cearense, com medo do Jaguaribe ou os dessastres do inverno e as cobras da Bahia; (8) Peleja de Antonio da Mulatinha com Francisco de Sena.

108 Os manuscritos acessados, que carregam textos produzidos na década de 1950, foram redigidos na década de 1970, quando Toinho da Mulatinha abre a folhetaria Estrela do Oriente e, com auxílio de terceiro, "passa a limpo" emboladas e títulos de sua autoria, em vistas de sistematizar a própria produção. 
Neste último documento, Toinho da Mulatinha "canta ciência" enumerando títulos consagrados de Leandro Gomes de Barros e os municípios/ distritos do estado da Paraíba pelos quais estas narrativas circularam. O conhecimento sobre a geografia paraibana, adquirido empiricamente, é ostentado em sua produção poética:

Mais de 5000 folhetos

$\mathrm{O}$ bom poeta escreveu

Porque com o dom nasceu

De poeta popular

$[\ldots]$

Na Paraíba deixou

Cordel ali em Teixeira

Em Pombal e na Palmeira

Em Patos e Taperoá

Deixou livro em Cajazeiras

Em Boqueirão e Queimadas

Em Esperança e Montadas

No Mogeiro e no Ingá

Em Remígio em Areia

No Riachão em Cabaceiras

Em Gado Bravo e Aroeiras

No Sapé no Araçá

Cordel em Lagoa Grande

Guarabira Coitegi

No Mulungu no Mari

No areal no Cambucá

Tem cordel em Rio Tinto

Em Santa Rosa em Cuité

Em Serra Branca em Sumé

E na Serra do Jatobá

Cordel em Juazeirinho

Em Soledade em Cubati

Em Solânea em Picuí

Em Pilões e no Cajá.

(MULATINHA, 1955a, n.p.) ${ }^{109}$

109 MULATINHA, Toinho da. [Antônio Patrício de Souza]. Coco de embolada sobre Leandro rei do cordel. Manuscrito - Formato "Linguado". 1955. 
A "munganga" da embolada não escapa ao coco sobre o "rei do cordel". Ao enumerar as pelejas escritas por Leandro Gomes de Barros, Toinho versa:

Só não escreveu comigo

Que não era conhecido

Também não era nascido

Nem sabia improvisar

(MULATINHA 1955a, n.p.) $)^{\mathbf{1 1 0}}$

O poeta-embolador, que pisou em terras de todo estado da Paraíba vendendo histórias em brochuras, deixou registrado em manuscritos, folhetos e entrevistas, testemunhos de seu itinerário geo-poético. No manuscrito Toinho da Mulatinha cantando coco nas feiras (1955), o cantador pontua os lugares que embolou e cria versos para demandar a remuneração pelo trabalho, justificando o destino do dinheiro ao público de ouvintes: a manutenção de sua caminhada.

Assim eu cantava côco

De embolada nas feiras

De Campina a Cajazeiras

De Esperança a pilar

Cantei muito em Rio Tinto

Em Guarabira em Sapé

Em Solânea em Sumé

No Juncó e no Aguiar

[...]

Agora é a embolada

Pedindo dinheiro ao povo

Ao velho e ao novo

Paga quem quiser pagar

[...]

Não quero prá beber cana

Preciso para a viagem

Para pagar a passagem

E um cigarrinho fumar

[...]

Aquele que me ouvir

Cantando a embolada

Achar bom e não der nada

Se eu morrer venho buscar.

(MULATINHA, 1955b, n.p.) ${ }^{111}$

110 Ibidem.

111 MULATINHA, Toinho da. [Antônio Patrício de Souza]. Toinho da Mulatinha Cantando coco nas feiras. Manuscrito - Formato "Linguado". 1955. Grifos da pesquisadora. 
A partir de relatos de Toinho da Mulatinha e José Alves Sobrinho, Maurílio Antonio Dias (2009) compôs um mapa que revela os percursos desenhado pelos profissionais da poesia em suas peregrinações, trazendo inestimável contribuição para compreendermos o circuito específico do comércio de folhetos na Paraíba. A escolha de Toinho como porta-voz da rota da cantoria no estado, pelo filólogo, confirma o protagonismo do folheteiro no processo histórico de socialização do texto impresso.

A macrorrota da cantoria na Paraíba, desenhada pelas mãos do pesquisador e pelo canto de poetas andarilhos, é composta por microrrotas concentradas nas quatro mesorregiões do estado: Mata Paraibana, Agrestre Paraibano, Borborema e Sertão Paraibano [Figura 25]. Importante salientar, que as mesorregiões e microrregiões geográficas definidas pelo Instituto Brasileiro de Geografia e Estatística guardam diferenças em relação às determinadas pelos poetas, por exemplo: a mesorregião denominada Borborema, pelo IBGE, "para os poetas populares chama-se Curimatáu" e "as cidades limítrofes dessa microrregião confundem-se a oeste com a microrregião do Sertão e a leste com a microrregião do Agreste” (DIAS, 2009, p. 70). 


\section{$\begin{array}{llllllllllllll}M & A & P & A & D & A & C & A & N & T & O & R & I & A\end{array}$}

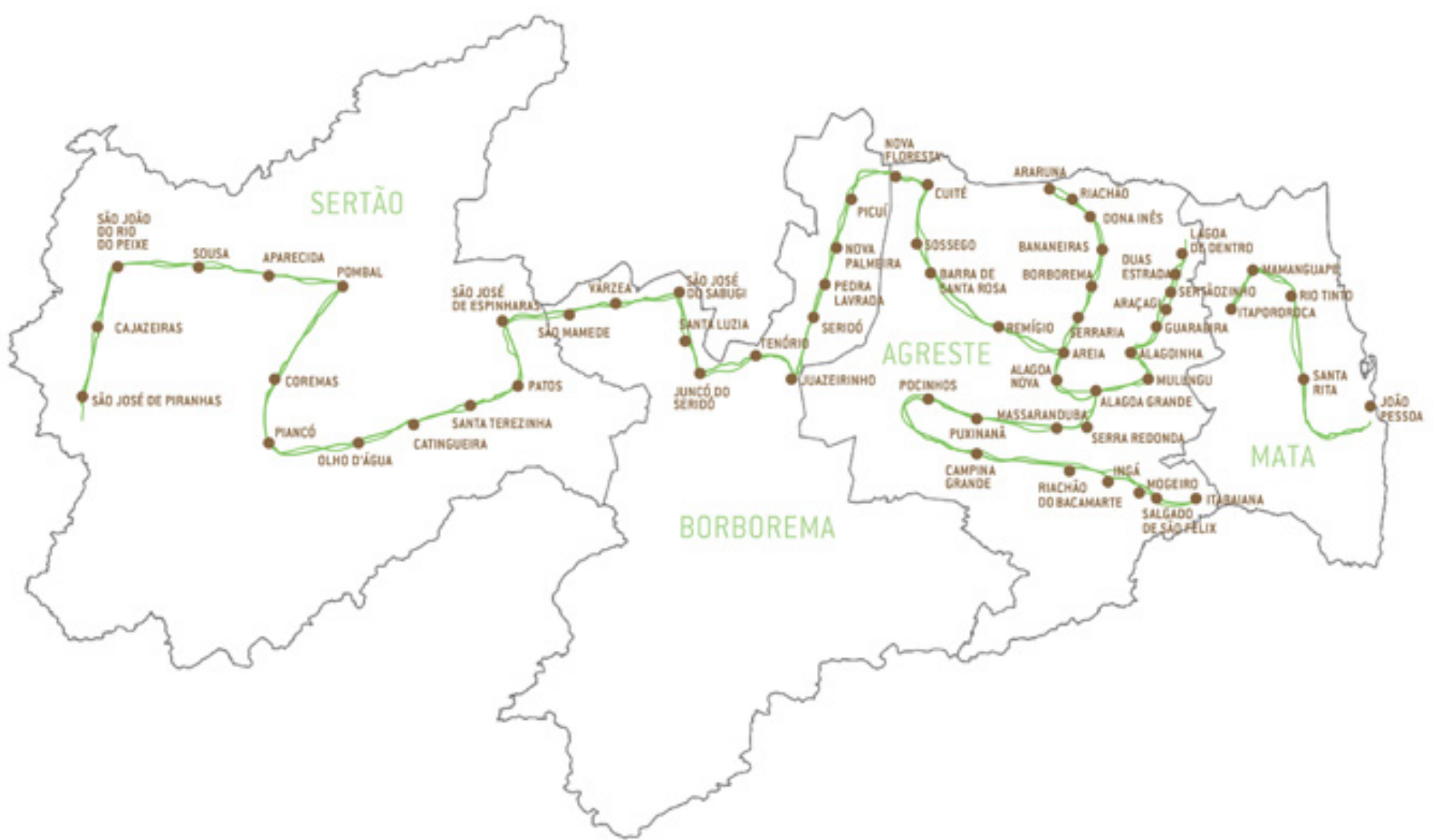

1 João Pessoa

2 Santa Rita

3 Rio Tinto

4 Mamanguape

5 Itapororoca

6 Lagoa de Dentro

7 Duas Estradas

8 Sertãozinho

9 Araçagi

10 Guarabira

11 Alagoinha

12 Mulungú

13 Alagoa Grande

14 Serra Redonda

15 Massaranduba

16 Puxinanã

17 Pocinhos

18 Campina Grande

19 Riachão do

Bacamarte

20 Ingá
21 Mogeiro

22 Salgado de São Felix

23 Itabaiana

24 Alagoa Nova

25 Areia

26 Serraria

27 Borborema

28 Bananeiras

29 Dona Inês

30 Riachão

31Araruna

32 Remígio

33 Barra de Sta. Rosa

34 Sossego

35 Cuité

36 Nova Floresta

37 Picuí

38 Nova Palmeira

39 Pedra Lavrada

40 Seridó
41Juazeirinho

42 Tenório

43Juncó do Seridó

44 Santa Luzia

45 São José do Sabugi

46 Várzea

47 São Mamede

48 São José do

Espinharas

49 Patos

50 Santa Terezinha
51 Catingueira

52 Olho D'água

53 Piancó

54 Coremas

55 Pombal

56 Aparecida

57 Sousa

58 S. João do Rio do Peixe

59 Cajazeiras

60 São José de Piranhas

Figura 25 - Mapa da Paraíba grafado com o conjunto de rotas do itinerário da cantoria no estado, realizado por Maurílio Antônio Dias (2009) a partir dos relatos de José Alves Sobrinho e Toinho da Mulatinha. A imagem foi redesenhada pela pesquisadora

Fonte: DIAS (2009, p. 84] 
No último manuscrito citado, Toinho da Mulatinha Cantando coco nasfeiras (1955b), o poeta menciona cidades-eixo e cidades-satélite que percorreu, abrangendo as quatro mesorregiões da Paraíba, provando, portanto, que atravessara o Estado, dominava o território. A exibição do domínio, tanto em relação à ocupação territorial quanto ao conhecimento da geografia como ciência, é ainda mais evidente no manuscrito Toinho da Mulatinha na Paraíba - cidades principais vilas e povoações e os lugares onde passou e cantou (19--d), no qual cita mais de duzentas localidades do estado ${ }^{112}$, em 23 estrofes. Segue um trecho:

Cantei em Cajaseirinha

Sai de Algibeira Cheia

Fui a Cacimba de Areia

Emas Santa Teresinha

Estaca zero a feirinha

No domingo é o dia

Em São Bento fiz cantoria

Esforcei-me o quanto pude

Em Quixaba Santa Gertrude

Gerimum Santa Maria

[...]

Deixei a terra da cana

Segui para outro lado

Poço comprido Salgado

De São Felix e Itabaiana

Fui a Barra de Santana

Bem distante de Pilar

Frei Matinho Alagamar

Onde fiz cantigas caras

Em São José das Espinharas

Vereda Grande Aguiar

[...]

Serra do Ponta é falada

Várzea comprida Aldeia

Escrivão Ponta de Areia

São José de Lagoa Tapada

Cordeiros terra Sagrada

Lucena e Tamatai

Do Brejo ao Cariri

Tenho tudo na lembrança

Areial de Esperança

O Sipilho e o Umari. (MULATINHA, 1955b, n.p)

112 No manuscrito Toinho da Mulatinha na Paraíba - cidades principais vilas e povoações e os lugares onde passou e cantou (19--), o poeta lista os 223 municípios do estado da Paraíba e localidades com denominações não-oficializadas, como relativas às áreas de sítios por exemplo. 
A partir do manuscrito referenciado e do "mapa da cantoria” podemos ter um panorama geral das rotas fundadas e mantidas por poetas paraibanos, da $1^{\text {a }}$ geração de cantadores até a geração de Toinho da Mulatinha, que por viver mais de 90 anos, cruzou com algumas. No mapa as linhas que seguem os passos dos poetas, são vivas, móveis, redesenhadas por artistas contemporâneos em sua peleja profissional. Provavelmente muitas delas já estão desvanecidas, posto que a poesia ocupa novos lugares, sustentando-se em fibras óticas e redes sociais digitais.

O traçado do mapa, reúne uma amostra parcial dos diversos itinerários seguidos pelos poetas, compostos por microrrotas dentro de cada mesorregião do Estado, pelas quais podia-se seguir sentidos diferentes (DIAS, 2009, p. 63 - 87). Cada uma dessas microrrotas dispõe de cidades-eixo, eleitas de acordo com a relevância da feira regional, contornada por cidades-satélite, detentoras de feiras menores.

No mapa que exibe a macrorrota da cantoria na Paraíba, podemos perceber que a mesorregião do "Agreste", foi a de maior circulação de poetas e cantadores ${ }^{113}$. O desenho reforça a centralidade de Campina Grande, cidade-eixo do trajeto no sentido do “Grande Brejo Paraibano” (DIAS, 2009) - diante da sua Feira Central, aberta todos os dias da semana, com exceção do domingo - e comprova a escolha certeira de Manoel Camilo dos Santos de instalar sua tipografia na cidade-entreposto engrandecida pela industrialização.

As microrrotas constituintes do percurso dos folheteiros eram combinadas entre si diante de vários fatores, desde a região de origem do poeta, geralmente privilegiada diante da facilidade de locomoção e maior segurança financeiras, os dias de feira em cada cidade, a presença de tipografias ou agências para abastecimento.

As rotas da cantoria no estado da Paraíba eram vinculadas, predominantemente, às safras da agricultura local e, portanto, às condições climáticas, imbricadas às estações do ano. De acordo com DIAS (2009, p 85), "no inverno [época de chuva] o poeta cumpria as rotas do litoral e na seca (verão) as do sertão”. Isto porque o ciclo produtivo do algodão herbáceo era determinante para o cumprimento do circuito sertanejo, que deveria ser trilhado após a colheita e distribuição do algodão, posto que este período implicava na ocupação dos salões em que ocorriam cantorias nas fazendas com as sacas do produto, relata José Alves Sobrinho (apud DIAS, 2009, p. 85).

Avento a hipótese de que a mobilização regional para a colheita do algodão prejudicava, em certa medida, o movimento das feiras sertanejas, tanto por mobilizar trabalhadoras/es para esta atividade específica, quanto pela diminuição da produção

113 A pesquisa de Dias (2009), revela que folheteiros e repentistas de viola compartilharam rotas comuns, embora exibissem seus trabalhos em diferentes espaços de sociabilidade - os primeiros em feiras e os segundos em salões. Vale pontuar que os lugares de atuação privilegiados por estes agentes não eram exclusividade de um grupo ou de outro, muitas vezes poetas-folheteiros eram convidados para cantar histórias de folhetos em salões do município em que estavam temporariamente instalados. 
de outros gêneros agrícolas em detrimento da concentração entorno do "ouro branco". Estes fatores determinavam que os poetas se espalhassem pelo sertão nos meses de seca, antes e após o fechamento do ciclo do algodão, já escoado para o porto e distribuído para os estados/municípios que concentravam a atividade têxtil.

No início do inverno (junho), os poetas voltam paulatinamente a ocupar mesorregião da Borborema e do Agreste, dada a abundância da colheita do milho, que gera a produção de derivados, como canjica e pamonha que abastecem feiras e festas, sendo a de São João a mais acolhedora para manifestações poéticas e musicais da cultura local.

Manoel Camilo determina o melhor período para venda de folhetos na mesorregião da Borborema, reforçando a narrativa de que as rotas mais próximas do litoral eram frutíferas no inverno paraibano: "Veio a seca, a poesia desmerece. A seca não ajuda o povo, menos ainda os poetas. Nem a irmã dela, que é a inundação. Tudo atrapalha o poeta. Tempo bom de vender é só setembro em diante, com a safra do algodão" (LESSA, 1984, p. 56). A seca prejudicava os ganhos dos pequenos agricultores.

Seguindo o tempo das coisas na terra, poetas e poetizas de bancada semearam histórias de forma sistemática e perene pelo estado, se alimentando das narrativas colhidas nessas itinerâcias para produzir mais folhetos em suas oficinas criativas, a própria residência. Depois das viagens os poetas permaneciam dias mantendo seu trabalho na região de origem, onde eram figuras conhecidas associadas a pontos fixos da cidade, geralmente as feiras.

Toinho da Mulatinha era tido como um sujeito referencial em Campina Grande, aquele que poderia compartilhar na Feira Central da cidade as últimas notícias recolhidas em suas peregrinações pelo estado da Paraíba. Sua popularidade, fazia com que os profissionais da poesia (poetas-folheteiros, agentes e tipógrafos) o reconhecessem como relevante mediador do comércio folhetos, aspecto notório na quarta capa do folheto O Monstro do Pageú (1974), de Manoel Camilo dos Santos:

Atenção
Quem possuir os romances de: “O Sertanejo Orgulhoso e os seus Filhos na
Praça”, “O Conde de Monte Cristo” ( $1^{\circ}$ e $2^{\circ}$ volumes), “O Anão Encantado e
os Três Vinténs da Macaca (ou vice-versa, e a "Segunda Peleja de Manoel
Camilo com Romano Elias”, em prefeito estado de leitura traga neste
enderêço: Rua Mato Grosso, 202 - Bairro Monte Castelo-Campina Grande
ou entregue a Antônio da Mulatinha, que receberá a importância de Cr\$ 3,00
(Três Cruzeiros) por cada um dos referidos. (CAMILO DOS SANTOS, 1974) ${ }^{114}$

Na década de 1970, período no qual o folheto mencionado acima foi publicado, Toinho já havia construído uma carreira de duas décadas na Feira Central e em outras

114 Grifo da pesquisadora. 
feiras do circuito geo-poético paraibano. O interessante do excerto é que o próprio Mulatinha é mencionado como ponto referencial de entrega dos romances listados, sem que seja atribuído a ele um endereço, o que lhe confere o papel de poeta em trânsito, capaz de expandir a possibilidade de resgate dos títulos mencionados, pelo potencial de espraiar-se. Mas, sobretudo, de figura representante do comércio popular literário, situado em um ponto de referencia ligado aos folhetos e a sua figura: a Feira Central Campinense.

Toinho pode ser interpretado como um modelar narrador benjaminiano no universo desse gênero poético, capaz de interpolar os "dois tipos fundamentais" determinados por Walter Benjamin (1985) como determinantes na constituição da arte da narrativa: o "marinheiro comerciante", que transita entre esferas socioculturais e recolhe histórias para contar, e o "camponês sedentário", que vive em seu local e sabe suas histórias e tradições. Figuras arcaicas que sobrepostas evocam um movimento de intercâmbio de experiências entre o próximo e o distante, o conhecido e o desconhecido.

As trocas imateriais propiciadas pelos seus deslocamentos interestaduais e pela vivência na Feira Central campinense - local de trânsito de terceiros - criaram condições para firmar-se enquanto artífice da palavra, tecelão de experiências prenhes de ensinamentos. Toinho da Mulatinha mostra-se um narrador nato, na perspectiva benjaminiana, ao explorar a dimensão utilitária dos folhetos, que "pode consistir num ensinamento moral, seja numa sugestão prática, seja num provérbio ou numa norma de vida" (BENJAMIN, 1985, p. 200).

No folheto As Missões de Frei Damião em Solidade e o Castigo de um amancebado (2001), Toinho, narrador apto a "dar conselhos", apropria-se dos preceitos da religiosidade cristã para empreender um caráter moralizante à história recolhida em suas andanças em Soledade. Na primeira estrofe, o poeta recomenda que a/o leitora/ ouvinte apreenda aquilo que irá pronunciar ao longo da narrativa:

Quem for filho de Maria

a mãe da humanidade

guarde este folheto

na sua mentalidade

as missões de frei Damião

na cidade de solidade

(MULATINHA, 2001, p.01)

Para Benjamin "os narradores gostam de começar sua história com uma descrição das circunstâncias em que foram informados dos fatos que vão contar” (1985, p. 205), aspecto evidente nas estrofes a seguir, que conferem a Toinho autoridade como narrador-conselheiro: 


\author{
Eu estava em Juazeiro \\ quando 1 senhor decente \\ contou me esse passado \\ o mesmo me fez ciente \\ que não contasse a ninguém \\ porque o homem é valente \\ disse ele faça o folheto \\ sem medo que foi verdade \\ não bote o nome do homem \\ da mulher nem a idade \\ pode ele achar ruim \\ e usar de falsidade. \\ (MULATINHA, 2001, p.01)
}

Ao ocultar o nome das personagens da trama, o poeta produz uma "carapuça" que pode servir a qualquer leitor(a)/ouvinte da história. Ou seja, não importa quem vivenciou o fato, mas o que se deu e, principalmente porque se deu o castigo e, em seguida, a redenção do "amancebado”. A história compartilhada com a comunidade via impresso/cantoria assume um caráter de ditado popular: "aqui se faz, aqui se paga" (castigo); "antes tarde do que nunca” (redenção).

As histórias redigidas por Toinho aproximam-se das narrativas orais diante do caráter metafórico (constituinte das parábolas, fábulas, alegorias, contos de fadas e outras histórias exemplares que deslocam-se entre o real e o imaginado); da presença de elementos míticos-religiosos e sobrenaturais que circundam o imaginário popular (no caso do folheto supracitado a aparição do satanás em forma de cão); do feitio universal, por tocarem em temas que atravessas as mais diversas culturas, como a necessidade de devoção e fé do ser humano. Pelos motivos elencados, guardam um potencial de repetição.

De acordo com Walter Benjamim o romance e a informação são sintomas da morte da narrativa, isto porque, na perspectiva do autor, o romance está essencialmente vinculado à experiência individual livresca, "nem procede da tradição oral nem a alimenta” (1985, p. 201) e a informação é descartável, acaba no presente, não guarda a faculdade da reincidência, por interpelar a liberdade interpretativa do leitor. O filósofo prevê a extinção da narrativa na literatura, embora reconheça a obra de Nikolai Leskov, mote do seu ensaio, uma exceção à regra que se impõe na modernidade. Se tivesse conhecido os folhetos de feira brasileiros na década em que publicou "O narrador", provavelmente o crítico literário encontraria desafios para a sua tese.

Decorrentes do processo modernizador, essas histórias (que têm a imprensa como genitora) reinscrevem romances da tradição literária europeia em paisagens sertanejas; revestem histórias épicas com a roupagem de personagens locais; misturam 
dialetos regionais com um forjado linguajar bacharelesco; colam textos enciclopédicos em disputas orais simuladas; fundem experiências de vida em romances e folhetos de época; guardam páginas nas quais seus autores e suas autoras emitem opiniões, visões de mundo, aconselhamentos, apregoações.

Toinho da Mulatinha configura-se como um narrador benjaminiano por aproximar narrativas escritas das orais, cultivando a faculdade de intercambiar experiências com a comunidade de ouvintes, reunida através de seu canto nas feiras - aptidão que nem todo poeta de bancada possuiu. Nesse sentido, Toinho pode ser considerado um agente de re-humanização das práticas sociais, assim como a própria Feira Central campinense, espaço onde os indivíduos rearticulam coletivamente relações espaço-temporais capturadas pela modernidade.

\section{DOIS MATUTOS NOS TRILHOS DA MODERNIDADE}

Toinho da Mulatinha e Manoel Camilo dos Santos foram homens pobres, oriundos de pequenas propriedades rurais, que transitaram de maneiras distintas nas frestas da modernidade, entre os mundos da "ordem" e da "desordem" (CANDIDO, 1970). Com objetivo de delinear o espaço simbólico que cada poeta ocupou no processo de modernização da Paraíba e na constelação do circuito poético local, alavancado pelas tecnologias do período, será empreendida uma análise comparativa da produção textual e das trajetórias desses poetas (narradas pelos próprios em entrevistas e relatadas em folhetos autobiográficos).

Busca-se sublinhar nesses textos como se manifesta a oscilação destes poetas entre as novas formas de vida a qual estavam submetidos, urbanas e cada vez mais racionalizadas pela lógica capitalista, e aquelas que compunham o repertório sociocultural por eles compartilhados enquanto homens nascidos em ambiente rural atravessado por relações de outra ordem, ou da "desordem".

Estes termos, oriundos do esquema interpretativo de Antonio Candido em "Dialética da malandragem" (1970), tornam-se operativos para a leitura dos modos de sociabilidade internas ao campo dos poetas de bancada por sintetizarem aspectos do "ritmo geral da sociedade brasileira" que coordenavam o cotidiano nacional e, portanto, a dinâmica de vida desses atores, definidos por Maria Sylvia de Carvalho Franco (1979) como homens livres oriundos da ordem escravocrata. Neste contexto, lavradores independentes que fizeram da poesia seu roçado. 
Candido interpreta o romance Memórias de um Sargento de Milícias (1853), de Manuel Antonio de Almeida, como uma estetização da estrutura social brasileira do início do século XIX [que deixa resíduos em pleno século XXI!] e extrai elementos fundamentais para a compreensão desse país [sempre] em vias de construção, no qual a população, formada como um estrato entre senhores e escravos, estabelece um "modo de ser nacional” (SCHWARZ, 1987) que consiste na oscilação entre as esferas da "ordem” e da "desordem".

Na obra do ensaísta, a “ordem” reside nos mecanismos disciplinares e símbolos repressivos inerentes à lógica sociocultural dos colonizadores, expressos em diversas dimensões da vida nacional e, de maneira mais evidente nas normas jurídicas rígidas que insistiam em domesticar os impulsos de uma "jovem sociedade”, enquanto a "desordem", palavra utilizada a mérito de contraste, constitui um jeito de ser em desacordo com aquele compulsório, propenso a relativização dos protocolos, das convenções, dos costumes. O constante balanceio entre a "ordem” e a "desordem" por homens e mulheres livres pobres, sintetiza o processo social de concomitante ajustamento e evasão das normas prescritas.

$\mathrm{Na}$ visão de Candido, essas estratégias de sobrevivência processadas com a colonização, poderiam ser favoráveis na transformação do movimento histórico e organização de renovadas (r)existências por aqueles que assumiriam seu papel histórico, o povo. Nos pressupostos de Roberto Schwarz, essa nova ordem proposta, pode ser concebida "como um trunfo para a hipótese de nos integrarmos num mundo mais aberto (socialismo?)" (SCHWARZ, 1987, p. 152)

Nesse trabalho, pressupõe-se que os poetas de bancada criaram novas possibilidades de inserção profissional em uma sociedade severamente hierarquizada. Os termos “ordem/desordem”, fornecem subsídios para a reflexão sobre os modos como os dois poetas paraibanos abordados, Manoel Camilo dos Santos e Antônio Patrício de Souza, se inscreveram na estrutura que passa a organizar, na primeira metade do século XX, a vida moderna brasileira. No exercício de síntese interpretativa proposta serão destacadas, primeiramente, as estratégias do poeta-editor para projetar-se nesse contexto, para, em seguida e, por antítese, vislumbrarmos a figura do poeta-embolador nos trilhos do "progresso".

Parte-se do princípio que Manoel Camilo dos Santos é uma figura representativa da transfiguração do homem rural em urbano, que não mediu esforços para fazerse moderno, produzindo folhetos ("equivalente aos bons cinemas!"115) de acordo com

115 Frase veiculada na quarta capa de algumas das publicações de Manoel Camilo dos Santos, como no folheto A vida de Maria Madalena (1954): "Habitantes às cidades, vilas e sítios, divirtam-se lendo ou ouvindo ler os romances e folhetos de poesias populares de autoria ou propriedade do poéta Manoel Camilo dos Santos, equivalentes aos bons cinemas e dramas...". 
a lógica vigente no mercado editorial hegemônico, como podemos observar na quarta capa de O Monstro do Pageú, 1950:

\begin{abstract}
Aviso Nacional
"ATENÇÃO Manoel Camilo dos Santos, autor e proprietário de várias obras poéticas de gênero folclórico, avisa ao pùblico em geral que essas mesmas publicações acham-se registradas algumas e outras em via disso, no Departamento dos Direitos Autorais da Biblioteca Nacional no Rio de Janeiro, nos termos dos arts. 300 e 301 do Decreto n.4.857, de 9 de novembro de 1939. A ele pertence, portanto, exclusivamente, o direito de reproduzi-las, perdendo em seu benefício os infratores, inclusive revendedores, os exemplares que for possível apreender, da reprodução fraudulenta, pagando-lhe ainda ditos infratores o valor de toda a edição, além de ficarem sujeitos às penas criminais por violação de direito de autor, tudo isso na forma da legislação civil e penal da República. P.P. Dustan Soares de Miranda - Advogado.” (CAMILO DOS SANTOS, 1950) $)^{116}$
\end{abstract}

No trecho o poeta-editor filia-se ao mundo da "ordem" por meio da adesão às normas jurídicas rígidas das "velhas sociedades", proferidas no Decreto de Lei que salvaguarda o direito autoral de suas obras e personificadas na figura do advogado. O profissional representante da "ordem" liberal burguesa, aparece em outras quartascapas de folhetos de sua autoria e em entrevista concedida pelo poeta a Orígenes Lessa (Campina Grande, 05/04/1954): “A gente precisa sempre de um Doutor na vida. Eu tenho um que é a salvação, o doutor Duston Miranda...” (LESSA, 1984, p. 50).

Camilo registrou, além de obras literárias, a própria casa editorial na instituição que simboliza o bacharelismo imperial lusitano - A Biblioteca Nacional do Rio de Janeiro117. Em 1953, a Tipografia e Folhetaria Santos, passa a integrar o "quadro das editoras, livrarias e tipografias estabelecidas no Brasil (Boletim Bibliográfico. $2^{\circ}$ semestre -1953 - página 395)", tornando-se a "única casa do gênero poético no Brasil, que goza das legalidades, dos direitos e garantias das leis Nacionais”, conforme veiculado no folheto A vida de Padre Cícero (1956) ${ }^{118}$.

116 CAMILO DOS SANTOS, Manoel. 0 monstro do Pageú. Campina Grande - PB: Estrella da Poesia, 1974.

117 A Biblioteca Nacional foi fundada oficialmente em 1810, para abrigar cerca de 60 mil peças (entre livros, manuscritos, mapas, estampas, moedas e medalhas] desembarcadas com D. João VI e sua corte no Rio de Janeiro (1808). Este acervo foi acoplado ao da antiga Livraria de D. José, organizada para substituir a coleção da Livraria Real, consumida por incêndio em Lisboa (1755). Hoje, a Biblioteca Nacional do Brasil, registrada como a maior da América Latina, tem um acervo composto por mais de dez milhões de itens. Informações disponíveis no site oficial da Biblioteca Nacional: <https://www.bn.gov.br/sobre-bn/historico $>$. Acesso em: 20 nov. 2019.

118 Ao afirmar que sua casa editorial era a única com situação legalizada, Manoel Camilo arma batalha, através das quartas-capas dos folhetos, com o seu maior concorrente no mercado editorial, José Bernardo da Silva, na disputa pela condição de homem integrado à "ordem". (MELO, 2010). 
Os substantivos sublinhados ao final desta quarta capa merecem ser destacados, posto que corroboram a construção da tese de que Camilo foi um homem que procurou estabelecer sua imagem alinhada ao universo da "ordem": podemos ler a palavra "perfeição", como indicativa do seu trabalho rigoroso como editor e sistematizado como distribuidor, mobilizada também para salientar a precisão do seu maquinário tipográfico moderno; O termo "legalidade" empregado em referência à institucionalização de seus bens culturais, demonstrada atéentão;Ovocábulo “honestidade”, vinculado à transparência que a lei, impessoal e racionalizada, oportuniza [Figura 26].

\section{AVISO NACIONAL}

O Ministério da Educação e Cultura, da $\mathrm{Bl}$ blioteca Nacional do Rio de Janeiro.-pelo boletim bibliográfico. do $2^{*}$. seraestre de 1953; faz público. que a Tipografia e Folhetaria Sontos. de propriedade de Manoel Camilo dos Santos. fôra considerada, registrade e integrada no quadro das editoras. livrarias e tipografias, estabelecidas no Brasil. pagina 395.)

(Boletim Bibliográfico, $2^{\circ}$. semestre - 1953 -

E como todas as obras poeticas, da autoria do seu proprietário e as que prende-se a sua proprieda. de literapoftica, acham-se registradas na seçä́o de contribuiçăo legal d'aquele Ministécio, nas folhas $6-7$, v. do livro 7, sobre os nûmeros: - 7989 a 7993: este órgâo de publicaşáo folclore. isto $\varepsilon_{\text {; }}$ a Tipografia e Fo. lhetaria Santos. è a única casa do gênero poético, no Brasil. que goza das legalidades, dos direitos e garaa. tias das leis Nacionais.

Assim $\dot{e}$, que todos os comerciantes do ramo de poesla, d'esta casa; isto $\epsilon$, os revendedores dos pro. dutos desta firma. ficas participando dos mesmos direitos que assistem \& Tipografia e Folhetaria Santos, situada a Rua Santo Antonio 114. Campioa Gratice (PB.) com agencias em: Guarabira. Natal. Patos. Joa zeiro, Fortaleza, Caruarù e en Salvador.

cios, ê o triplice carater desta firma.)

(Acabamento, novidades consecutivas e preços os mais baixos possiveis, săo as vantagens para os revendedores.)

MANOEL CAMILO DOS SANTTOS

Figura 26 - Quarta capa do folheto $A$ vida de Padre Cícero (CAMILO DOS SANTOS, 1956). Grifo realizado digitalmente pela pesquisadora

Fonte: Biblioteca de Obras Raras Átila Almeida (BORAA/UEPB) 
A insistente tentativa de firmar sua tipografia no campo polido e protocolar que a civilização ocidental prometeu, aparece inscrita em alguns folhetos sob roupagens semelhantes: "A mais bem organisada, credenciada e legalisada, casa do ramo folclore do Nordeste” [Figura 27].

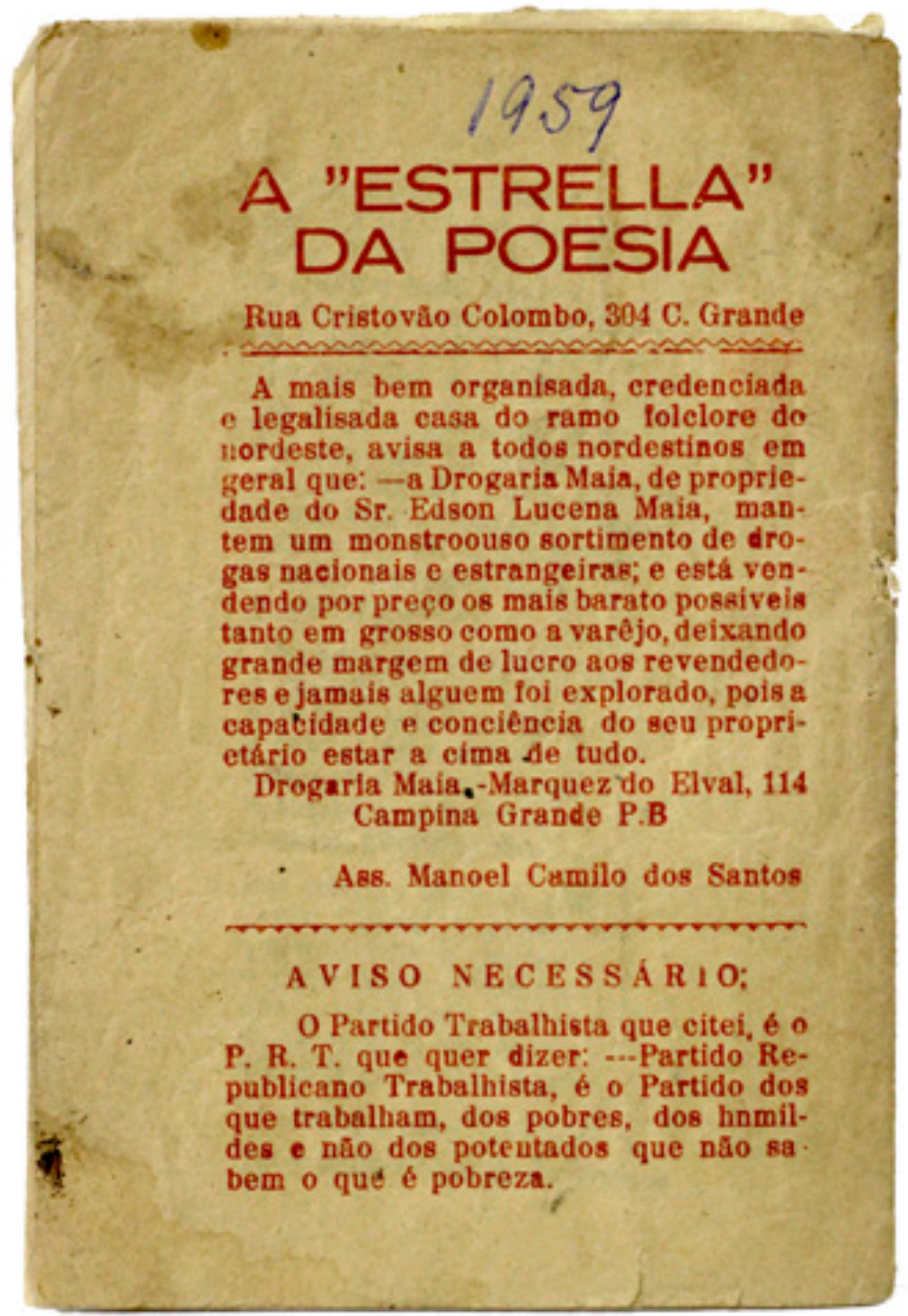

Figura 27 - Quarta capa do folheto A Candidatura do deputado Severino Cabral [CAMILO DOS SANTOS, 1959]

Fonte: Biblioteca de Obras Raras Átila Almeida (BORAA/UEPB)

Manoel Camilo dos Santos fez das quarta capas de seus folhetos seu "portal de transparência”, imprimindo declarações sobre os títulos por ele comprados de outros poetas e editores, assinadas por ele próprio ou pelos/as concedentes das obras, como 
pode-se observar nos textos presentes nas imagens das quartas-capas a seguir, A vida de Maria Madalena (1954) e O sabido sem estudo (1957), respectivamente:

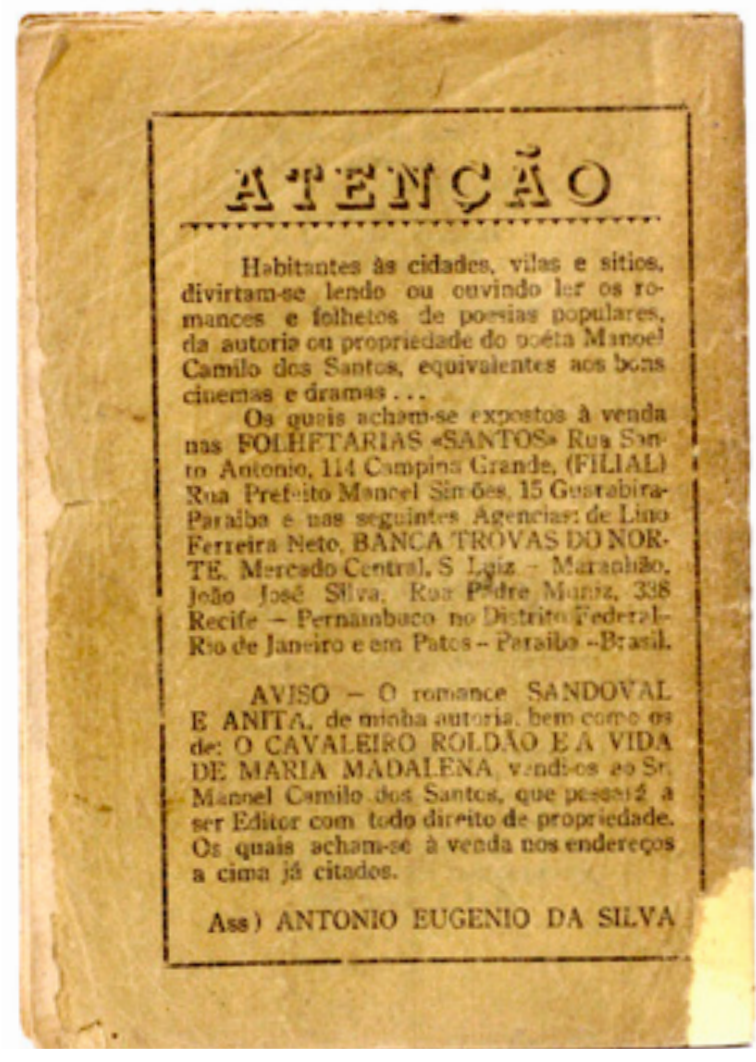

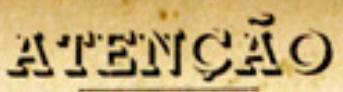

Obras pokticas que comprei ao poeta Cicero Vieira da Silva: Os Sofrimentos de Eliza. Jorge e Iraci, Um Cidadho Generoso Traido pela Consorte. Os Martifios Cidadho Generoso Traido pela Consorte. Os Martirios
de Coriaa. Tragedia de una Amigo ou o Solrer de Leaira. A Sofredora do Bosque. e $O$ Filho Amaldiçado. Em quasto que: Ellas e Açucena. A Escrava do Destino, O Castelo do Homem sem Alma, A Virgem das Aguas Verdes.Un Encostro com a Morte. A Queda do Orgulhoso oa o. Poter de lesas A Prisionieita do Castelo do Mar. A Casa Branca da Serra ou a Prin. cesa da Fonte. A Escrava Sonhadora. O Conde de cesa da Fonte. A Escrava Sonhadora. Calais, All-Ba.
Monie Cristo, $\left(1^{0}\right.$ e $2^{2}$ vol. ) Jolo de Cande de ba $e$ os 40 Ladrốes. A Vids de Antoaio Silvina. (1 ${ }^{\circ}$ e $2^{2}$ vol.) Os Sofrimentos de Analia. O Filho da Na. vem Branca ou o Escravo da Sorte, A Eserava do A. mor O Morro dos Ventos Uivantes. Os Sacrificios do Homem ou a Traichio da Mulher, O Cachorro Toni. A Visa das llias Verdes ou a Escrava da Sorte, O Direito da Viqancas ou o Poder do Destino. Comprei-as ao poeta Manoel Pereira Sobrinho.

Sendo que: O Paváo Misterioso. O Valeate Ze Gareia. A Cigana Esmeralda e Seu Testa mento. luvenal e Leopoldiaa, Roldăo no Leăo de Ouro, Cazuza Satiro O Matador de Onças, O Sertanejo Orgulhoso e os seus Fithos na Praça. lose Colatino e o Carranca do Piaul. As Quatro Orfis de Portugal e todas as mais da autoria do poeta loáo Melquiades Ferreira da Sada autoria do poets lobio Melquiades erefreira da propriedade. acham-se escrituradas e registradas, aa $\mathrm{Bi}$. blioteca Nacional do Rio de Janeiro. MANOEL CAMILO DOS SANTOS

Rua Santo Antoaio, 114 - Campina Grande - (Pb.)

Figura 28 - Quarta capas de folhetos editados por Manoel Camilo dos Santos contendo declarações acerca da aquisição de títulos

Fonte: Biblioteca de Obras Raras Átila Almeida (BORAA/UEPB)

A respeito da aquisição de folhetos pelo editor proprietário, vale destacar que Manoel Camilo comprava os direitos sobre títulos em dinheiro, fato evidenciado em entrevista a Orígenes Lessa (1984), na qual registra que não é um homem de fazer escambos, ao modo pré-capitalista. O poeta exalta seu capital financeiro em "Advertência" presente na quarta capa do folheto Os horrores do Nordeste e a solidariedade campinense (1953). No excerto, Manoel Camilo distingue-se na “classe dos poetas”, opondo-se àqueles "folheteiros, camelôres, poetaços [...], invejosos [que] estribam-se na pequenez de suas incapacidade [...]" [Figura 29]. A partir da frase destacada, podemos perceber que o poeta-editor constrói sua identidade de escritor-empresário alinhado ao mundo da "ordem", que é o da meritocracia e da lisura, timbrando a "diferença”, com aqueles vinculados ao universo da "desordem": sujeitos maliciosos que recorrem à fraude, à depreciação alheia para destacarem-se no campo profissional. 


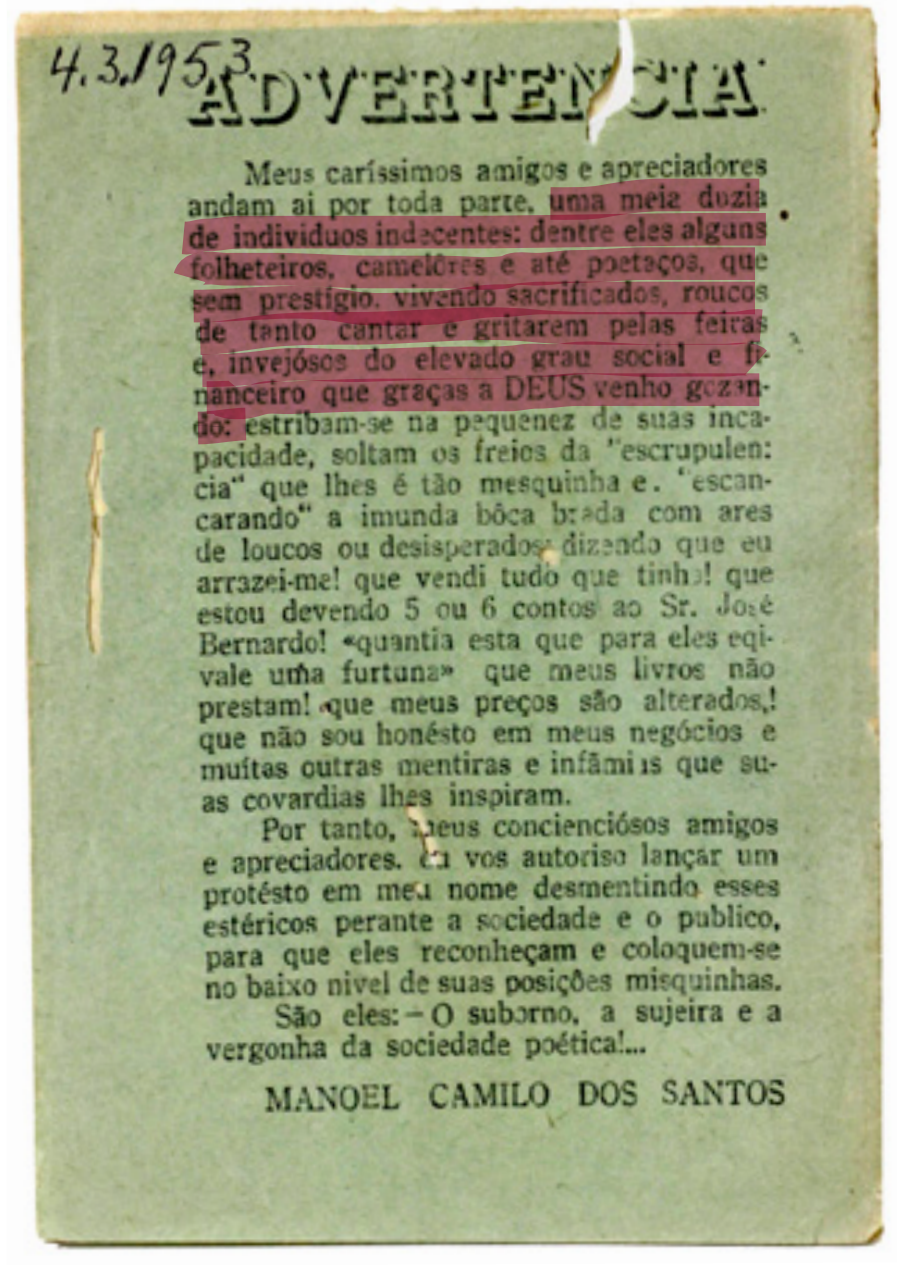

Figura 29 - Quarta capa do folheto Os horrores do Nordeste e a solidariedade campinense (CAMILO DOS SANTOS, 1953]. Grifo realizado digitalmente pela pesquisadora

Fonte: Biblioteca de Obras Raras Átila Almeida (BORAA/UEPB)

A postura de Camilo nos mostra que a "identidade" não é sinônimo de identificação, mas abarca processos mais amplos de representação: o jogo da semelhança e da diferença (HALL, 2003). Em algumas ocasiões Camilo se reconhece como integrante do grupo homogeneizado sob as denominações "poetas populares", "matutos" (como ele mesmo pronuncia), assumindo a identidade em uma perspectiva unificadora estratégica, que cria, a partir da coletividade, um referencial para sua existência. Em outras circunstâncias, se aparta do grupo, construindo para si mesmo um outro lugar de pertencimento cultural, por meio de discursos que o projetam como sujeito erudito, moderno - categorias demarcadas em oposição às anteriores por atores do universo hegemônico, da "ordem", que detêm o poder classificatório.

A cantoria e, por extensão, a oralidade, exaltada por Camilo em outros momentos como forma estética estruturante da sua atuação poética, capaz de motivar a apreciação do público pelos seus romances, aparece recusada na quarta capa do folheto Os horrores 
do Nordeste e a solidariedade campinense (1953). A desvalorização do ofício dos poetasfeirantes (“folheteiros e camelôres roucos de tanto gritarem pelas feiras”), impulsionada pelo ressentimento do poeta-editor, deixa escapar as influencias de valores burgueses que vexam aquele grupo cultural regional do qual, em outras declarações, reconhece fazer parte.

Enraivecido com as calúnias propagadas ao seu respeito, Camilo abdica das relações abstratas do mundo liberal burguês, pelo qual demonstra apreço e não mede esforços para participar. Essa atitude atravessada pelos afetos, que o transporta para a esfera da “desordem”, é evidente no folheto O grande romance de ébrio (1956):

Outrossim, fui informado, por pessôas insofismaveis, que um editor de folhetos, têm arquivado um exemplar de cada romance e folheto dos meus e de outros, com o fim de publicà-los e vender em regiões diversas como é de seu costume. Creio não ser mais necessário avisar a esse inescrupuloso, que toda minha propriedade literapoética, acha-se registrada no Departamento dos Direitos Autorais, na Biblioteca Nacional do Rio de Janeiro; e que a minha firma dispõe de dois grandes advogados, que são sem favor, os Drs. Dustan Soares de Miranda e Manoel Casado de Oliveira Nobre; dois Grandes Glória que honra a Magistratura paraibana... E que, deante o desenrolar dos acontecimentos, não serei jamais aquele tolerante de outr'ora, qualquer dano causado em minha propriedade como seja: publicação indébitas, plage ou outros de quaisquer natureza dolificante, agirei com rigor da lei.

"Quem avisa, amigo é"119 (CAMILO DOS SANTOS, 1956)

Os advogados aparecem no texto como figuras com as quais Manoel Camilo dos Santos estabelece uma relação "sem favor", mobilizadas para a projeção do próprio poeta como sujeito avesso às "relações cordiais" (HOLANDA, 1936) Porém, o elogio exagerado aos homens "que honram a Magistratura paraibana”, é carregado de um tom passional que abre espaço para imaginarmos que Camilo busca estabelecer com os "doutores" uma relação de cordialidade, assim como exibir para seus concorrentes “com quem anda” e, portanto, "quem é”.

Apesar de demonstrar impessoalidade ao longo da referida quarta capa, direcionada a "um editor de folhetos" ${ }^{\mathbf{1 2 0}}$, Camilo não retém a afetividade da escrita, referindo-se ao mesmo como "inescrupuloso" e deixando um apelo intimidatório na conclusão do texto: "quem avisa amigo é”. A coexistência do ditado popular e da linguagem jurídica na quarta capa colocam em cena a oscilação do poeta-editor entre os mundos da "ordem" e da "desordem".

119 Grifos da pesquisadora.

120 Refere-se ao poeta-editor José Bernardo da Silva (MELO, 2010). 
Ainda que faça investidas para firmar-se como um homem que cumpre e postula direitos e deveres, é possível perceber que, em determinadas situações, Manoel Camilo flexibiliza os limites do lícito e do ilícito, do justo e do injusto. O afrouxamento das regras, pelo editor, é perceptível no episódio narrado por Orígenes Lessa (1984), transcorrido na Folhetaria (Campina Grande, 1954) sob os olhos da tabuleta "não vendo fiado":

\author{
[...] \\ Entra nesse momento, um vendedor que vem se prevenir para a feira \\ da manhã seguinte. Enumera os folhetos e as quantidades. Camilo vai \\ separando. Empilha. Conta. Embrulha. \\ - Posso pagar amanhã depois da feira? \\ Camilo sorri, ajeita os óculos escuros, aponta para a tabuleta. \\ - O que é que tá escrito lá? \\ - Eu não sei ler - diz com humildade e malícia o vendedor. \\ - Leva, mas não envergonha a classe e nem mata de fome a família \\ do poeta. \\ Volta-se pra mim: \\ - Este é um cidadão de honra, tá entendendo? Em homem assim a gente \\ pode confiar. Analfabeto - sem desfazer . . . - mas honrado. Um dos \\ melhores vendedores de Campina. (LESSA, 1984, p. 55 56)
}

$\mathrm{Na}$ passagem, pode-se perceber um "apego pelas formas espontâneas de sociabilidade” (CÂNDIDO, 1970, p. 51), próprias da rede de solidariedade do circuito poético do gênero - engendrada pela coletividade como tática de sobrevivência no mundo da "ordem", que exclui aqueles/as que não se encaixam no modelo produtivo moderno. Da cena, pode-se aventar também uma atitude patriarcal de Camilo (em relação ao "poeta analfabeto"), propiciada pela ascensão dos seus capitais social, financeiro e simbólico.

Apesar de se pretender "doutor", Camilo guarda trejeitos de sociabilidade do "matuto" e se identifica como tal em diálogo com o ensaísta Orígenes Lessa: "Quem não é matuto como a gente e gosta de poesia popular, pra mim é doutor. Dos bons...”121 (CAMILO DOS SANTOS, 1954 apud LESSA, 1984, p. 50). No mesmo livro, A Voz dos Poetas, o poeta-editor estreita o abismo social imposto entre ele e o pesquisador: "Eu gosto do doutor porque pensa depressa. É dos meus...” (LESSA, 1984, p. 65).

Manoel Camilo dos Santos é um sujeito que se equilibra nas brechas pois "se encontra em um espaço social que julga insuficiente para si” (NUNES, 2014, p. 104), mas não consegue transpô-lo. Isto porque integra um sistema de produção apartado do campo literário hegemônico, que demarca, antes de tudo, as clivagens sociais do Brasil.

121 Grifo da pesquisadora. 
De acordo com a tese de doutoramento de Geice Peres Nunes (2014), pesquisadora da dimensão literária dos folhetos de Manoel Camilo dos Santos, a Autobiografia do Poeta, livro escrito em prosa e em verso, publicado pela editora da Universidade Federal da Paraíba (1979), é o símbolo máximo do alcance público do poeta e da sua aproximação com o campo literário erudito. Para Nunes (2014, p. 15), o estilo culto do livro "corresponde a uma retórica ornamentada, repleta de adjetivações, superlativos, elogios e distancia-se do modelo contemporâneo de produção literária para aproximarse da 'fala de pena em punho', da retórica bacharelesca”.

Na década de 1950 o "poeta popular”, Manoel Camilo, vale-se do cabedal estilístico do romantismo brasileiro para materializar seus textos, enquanto João Cabral de Melo Neto, representante da elite intelectual do país e da terceira fase do modernismo brasileiro na literatura, publicava Morte e Vida Severina (1955) utilizando recursos da poesia popular para compor sua obra, colocando na "boca" do personagem nordestino a poesia popular em forma de sextilhas, oitavas e décimas em redondilha maior:

O meu nome é Severino, não tenho outro de pia. Como há muitos Severinos, que é santo de romaria, deram então de me chamar Severino de Maria; como há muitos Severinos com mães chamadas Maria, fiquei sendo o da Maria do finado Zacarias.

[...]

Como então dizer quem falo ora a Vossas Senhorias?

Vejamos: é o Severino da Maria do Zacarias, lá da serra da Costela, limites da Paraíba.

[...]

Somos muitos Severinos iguais em tudo na vida: na mesma cabeça grande que a custo é que se equilibra, no mesmo ventre crescido sobre as mesmas pernas finas e iguais também porque o sangue, que usamos tem pouca tinta. (MELO NETO, 1955) ${ }^{\mathbf{1 2 2}}$

122 MELO NETO, João Cabral de. Morte e vida severina, 1955. 
Manoel Camilo dos Santos apresenta-se em sua autobiografia de maneira bastante distinta do personagem de João Cabral de Melo Neto. As imagens do próprio nascimento, suscitadas pela prosa, o distanciam da figura do "Severino genérico", do "paraíba” de sina demarcada, mas o projetam como um “escolhido”, agraciado por fenômenos naturais:

[...] depois de uma manhã clara e radiante em que a brisa suave e aromática acabava de exalar pelos campos e bosques, o astro rei elevase sem estância, tendo já espargido suas palhetas douradas por todas as fraldas dos montes e serranias e, antes mesmo que a sua benéfica luz o tornasse causticante e penetrasse pelos píncaros e cumíadas: no sopé da Borborema, este já banhado pela matutina luz febéia, num sitio denominado "Bom-Fim” distrito de Alagoinha, município de Guarabira, Estado da Paraíba do Norte - uma senhora de nome: Maria Tomaz Ferreira dos Santos, casada com o Sr. Antonio Camilo Pereira, acabava de ser mãe pela quarta vez. (CAMILOS DOS SANTOS, 1979, p. 01).

O texto de Camilo, está muito mais próximo da prosa lírica de contornos épicos de José de Alencar, do que da literatura modernista desenvolvida no país nos anos 1920, que alcança nos anos 1950 sua forma mais sintética com o movimento concreto na poesia: empenhado em "abolir a tirania do verso", em suas formas tradicionais, e valorizar o espaço gráfico como agente estruturador do poema ${ }^{123}$. Vejamos o trecho de Iracema (1865) que, assim como a "Autobiografia do Poeta”, ocupa a página em branco com ornamentação hiperbólica que exige do/a leitor/a atenção para apreender o que se passa entre os rococós que edificam a imagem da natureza tropical:

Verdes mares bravios de minha terra natal, onde canta a jandaia nas frondes da carnaúba; Verdes mares que brilhais como líquida esmeralda aos raios do Sol nascente, perlongando as alvas praias ensombradas de coqueiros. Serenai verdes mares, e alisai docemente a vaga impetuosa, para que o barco aventureiro manso resvale à flor das águas. Onde vai a afouta jangada, que deixa rápida a costa cearense, aberta ao fresco terral a grande vela? Onde vai como branca alcíone buscando o rochedo pátrio nas solidões do oceano? Três entes respiram sobre o frágil lenho que vai singrando veloce, mar em fora; Um jovem guerreiro cuja tez branca não cora o sangue americano; uma criança e um rafeiro que viram a luz no berço das florestas, e brincam irmãos, filhos ambos da mesma terra selvagem. (ALENCAR, 1865, p. 45)

123 Vale relativizar essa análise, posto que o modernismo dos anos 1950 é marcado pela retomada formas clássicas na literatura. Caso não exacerbasse um linguajar bacharelesco arcaico, Manoel Camilo dos Santos não estaria tão distante de seus contemporâneos atuantes no campo hegemônico. 
Nos trechos em verso da Autobiografia do Poeta, Camilo também mata sua sede nas fontes murmurantes dos românticos que tiveram como principal projeto a fundação de uma literatura nacional:

\author{
Aquele dia surgiu \\ Alegrando os horizontes \\ E o sol dourando as fontes \\ Pelas florestas espargiu, \\ A fauna toda afluiu \\ Despertando as cordilheiras \\ As aves alviçareiras \\ Gorgeando nas colinas \\ E os galos nas campinas \\ Sobre os leques das palmeiras.
}

(CAMILOS DOS SANTOS, 1979, p. 02)

A simultaneidade de poesia e prosa no livro de Manoel Camilo dos Santos, mostra o espaço fronteiriço que o poeta, que aprendeu a "contar nos dêdos e escrever na areia”. (CAMILO DOS SANTOS, 1979, p. 06), ocupou no campo literário brasileiro. Em sua autobiografia (1979) Camilo flexibiliza muros (invisíveis, mas rígidos) que segregam diferentes formas literárias e reinscreve simbolicamente aquela que fora minimizada, ao publicá-la em livro (sob o selo de uma editora universitária!).

A fim de transpor sua condição de "poeta popular" Camilo busca persuadir o/a leitor/a por meio de um linguajar rebuscado e eloquente, próprio de uma matriz acadêmica retórica - identificada pelo poeta como modelo capaz de legitimá-lo como escritor. É possível perceber no conjunto da obra do poeta o "delineamento de uma 'persona' que busca adaptar-se e ser incluída na literatura culta por meio do compartilhamento de códigos alheios à categoria a qual pertence, códigos relativos a um grupo que faz dele um elemento externo” (NUNES, 2014, p. 103).

A tentativa de integrar-se ao universo erudito, pode ser percebida no prefácio do livro Autobiografia do Poeta (1979), posto que Manoel Camilo dos Santos homenageia aqueles que representam a classe intelectual do período. São eles: Orígenes Lessa, Ariano Suassuna, Liêdo Maranhão, dentre uma ampla lista de sujeitos que se debruçaram sobre as poéticas populares e que "poderiam" abrir portas para que ingressasse no campo da literatura erudita.

No prelúdio do declínio econômico do circuito editorial de folhetos, Manoel Camilo lança sua mais ousada investida carreirista: a candidatura a Deputado Estadual pelo Partido Republicano (1962). A aspiração de integrar o campo da política, revela o anseio do poeta-editor de ter voz em uma sociedade estratificada, não apenas 
através dos folhetos - suporte de construção do seu público (e)leitor -, mas por meio da integração concreta no universo da “ordem”.

Se a produção de Manoel Camilo dos Santos flerta com o universo da “ordem”, manifestada por meio de formalidades literárias e através da declaração de documentos e leis que asseguram sua obra, a de Toinho esbarra no universo da "desordem". A “desordem”, na perspectiva de Antonio Candido (1970), não é valorativamente avaliada como um polo negativo da "ordem”, é denominada como tal para timbrar oposição às formas de convivência e sociabilidade vindas da "metrópole", que remodelavam a sociedade brasileira no contexto da obra criticada ${ }^{124}$. Nesse sentido, a “desordem" é interpretada pelo autor de maneira positiva, pois inclui posturas que apontam para a flexibilização do modelo econômico, político e cultural burguês.

Comecemos a aproximar o poeta-embolador do universo da "desordem" a partir do epíteto pelo qual foi reconhecido nas feiras, Toinho da Mulatinha. Esse codinome o afasta da condição de homem moderno, integrante da "ordem”, posto que assume um sentido coletivo e não individualizante: do sítio “da” Mulatinha - referência de um espaço compartilhado; "neto da Mulatinha” - associação de parentesco. Vale ressaltar a afetividade presentes nos diminutivos (Toinho/ Mulatinha), alheios a esfera da "ordem", na qual as relações são [leia-se: deveriam ser] abstratas e, portanto, o indivíduo é tratado de maneira formal, tal como registrado em cartório (como é o caso do editor Manoel Camilo dos Santos).

O codinome "popular" de Antônio Patrício de Souza identifica o autor [Figura 30]. Mesmo nos folhetos em que registra seu nome de batismo, assinala entre parênteses: "vulgo Antônio da Mulatinha"125. Ao utilizar a palavra "vulgo" (do latim vulgus: "multidão" ou "povo" - alguém conhecido como pertencente a plebe; sinônimo de homem comum, no sentido de não pertencer a nenhum grupo social exclusivo ou aristocrático), o poeta reforça a posição de horizontalidade em relação ao seu público.

124 "Era no tempo do rei [D. João VI]...". 0 romance Memórias de um Sargento de Milícias (ALMEIDA, 1853] passa-se no Brasil oitocentista, monárquico, no cenário urbano da cidade Rio de Janeiro.

125 Grifo da pesquisadora. 
slor: Antonio Patricio die Souza (Withng Inlonis da Mulalinha)

\section{Ass Missões de Frei}

\section{Damião em Bom}

ardim e a tempes-

Icde em Limoeiro

$$
\text { Preco } 8.00
$$

Figura 30 - Folheto de autoria de Toinho contendo a autodenominação "vulgo Antônio da Mulatinha". Grifo realizado digitalmente pela pesquisadora Fonte: Biblioteca de Obras Raras Átila Almeida (BORAA/UEPB)
A partir das autobiografias de ToinhodaMulatinhaedeManoelCamilo dos Santos, podemos perceber que os poetas constroem diferentes lugares sociais para si, reais e imaginários. Se Camilo prenuncia seu nascimento de acordo com um preceito básico da "fórmula do herói" (NEWMANN, 1995) - anunciado por acontecimentos naturais incomuns ou exuberantes -, Toinho descreve sua chegada à terra de maneira despretensiosa, numa "bendita manhasinha”:

[...]

$\mathrm{Na}$ jaqueira de frente a moradia poi-se um galo cantando sem parar como quem pretendia anunciar que naquela bendita manhãsinha Deus deixou lá na cama a criancinha o futuro poeta popular.

(MULATINHA, 19--, p.01) ${ }^{126}$

Dos versos acima também podemos extrair um sentido comunitário, posto que Toinho informa o nascimento do "poeta popular", identificando-se através da função que exerce na sociedade e, portanto, em correspondência com a coletividade.

A autodeclaração do autor como "poeta caipira", registrada na capa de folhetos publicados ao longo da década de 1960 [Figura 31], denota sua identificação com o ambiente rural e, portanto, sua associação com a "desordem" (CANDIDO, 1970).

126 MULATINHA, Toinho. Toinho da Mulatinha e sua biografia. 20--. Grifos da pesquisadora. 

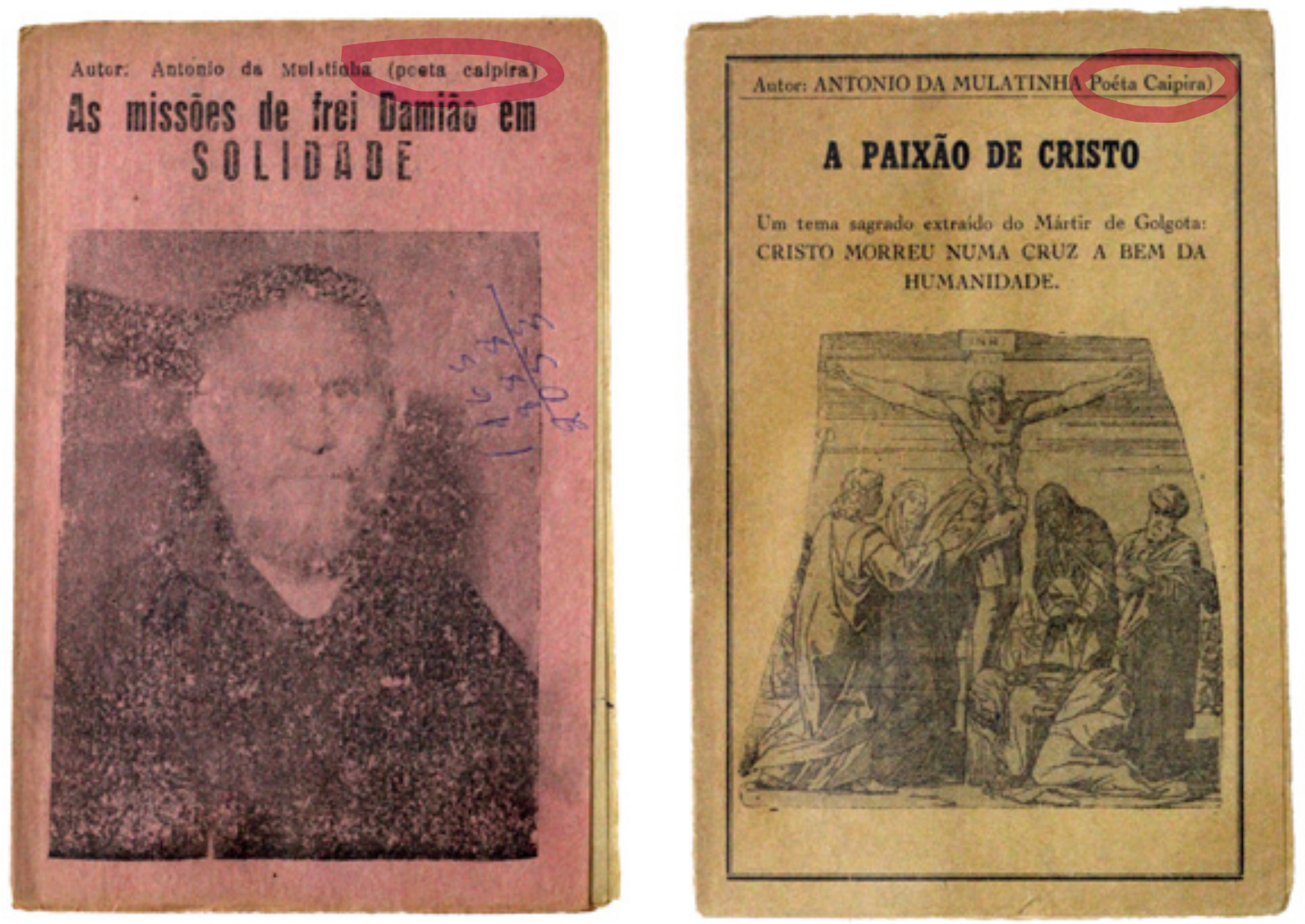

Figura 31-Folhetos de autoria de Toinho da Mulatinha contendo a autodenominação "poeta caipira". Grifos realizados digitalmente pela pesquisadora Fonte: Biblioteca de Obras Raras Átila Almeida (BORAA/UEPB)

Embora utilize o termo "caipira” para identificar-se, Toinho não se enquadra na definição do "homem rústico" de Antônio Cândido (1964), aquele germinado nos interstícios do latifúndio, que tem como ponto estruturante sua "unidade mínima" de sociabilidade, o "bairro rural": configurado como um "círculo fechado" ou, nas palavras de Maria Isaura Pereira de Queiroz, "unidade funcional autônoma” (QUEIROZ, 1973), dentro da qual o caipira renova seu modo de vida sem traçar pontos de fuga para além daquele horizonte de "equilíbrio instável”.

Toinho da Mulatinha, poeta em trânsito, costura horizontes entre paisagens rurais e urbanas, tal como a Feira de Campina Grande, seu lócus de trabalho, o faz. Habitante das fissuras da modernidade, a Feira é sistematizada por aspectos do mundo da “ordem” - tendo, por exemplo, seu regimento interno regulamentado pelo poder público municipal-, mas permeada por características do mundo da “desordem”, constituintes do ambiente rural, afeito a determinações mais orgânicas, distintas daquelas que norteiam o trabalho dos operários urbanos, guiados pelos ponteiros do relógio em "panópticos” (FOUCAULT, 1987). Nela persistem relações informais inconcebíveis em estabelecimentos do mundo urbano-moderno, nos quais não há espaço para pechincha e para escambos, 
posto que os preços tabelados se impõem. Isto porque estes comércios são pautados por relações abstratas, e não por relações de compadrio e de amizade, como na feira.

O ofício de feirante, raizeiro e folheteiro, afasta Toinho do campo da burocracia, das estruturas organizativas caracterizadas por regras e procedimentos explícitos da racionalidade moderna tratada por Max Weber (2004), evidentes na produção de Manoel Camilo dos Santos. O poeta-editor, ao se referir às transações comerciais operadas em sua empresa diz: "Muitos pensam que não sou poeta porque não vou em conversa de matuto. É isso não... Será que eles pensam que o poeta não tem família para sustentar? Que eu não pago operário?” (LESSA, 1984, p. 53).

Manoel Camilo dos Santos ascendeu no ramo editorial por meio da rotina regular e mecânica, da otimização das técnicas de produção, das propagandas publicitárias veiculadas em suas quartas-capas e tantas outras ações projetadas para o crescimento da empresa. Camilo é um homem moderno, de senso prático, não se estabelece poetaeditor pelo “dom” - palavra frequentemente associada à poesia popular.

Enquanto Camilo atendia os fregueses "condignamente" das 6 horas da manhã às 9h da noite, em sua firma ${ }^{127}$, Toinho trafegava pelo mapa da Paraíba guiado pelo clima e pelas feiras regionais, para comercializar folhetos, conforme mostrado no subcapítulo anterior. Esta pré-disposição ao trânsito, pode ser associada à dinâmica de ambientes rurais, nos quais as pessoas se deslocam em busca de um solo favorável para a produção da própria subsistência, onde a noção de patrimônio não faz tanto sentido como na vida urbana moderna - para aqueles que não são grandes proprietários de terra.

No folheto Toinho da Mulatinha e sua biografia, a profissão de poeta aparece como rejeição ao trabalho bruto da roça, atrelada à brincadeira, ao "mundo sem culpa" (CANDIDO, 1970). No trecho a seguir, a negação do trabalho "grosseiro" (no caso a lida diária na agricultura), manifesta o desejo do poeta de viver sob outra ordem, aquela que possibilita a liberdade do corpo e da voz.

Papai criou onze filhos

Trabalhando no pesado

Fazia uma empreitada

Saia o dia um cruzado

Tinha filho preguiçoso

Que não ia no roçado.

Dedé era preguiçoso

Gostava de brincadeira

De matar pássaro no mato

127 Informação extraída do folheto: A pobre orfã engeitada nas malhas da traição (1957). 


$$
\begin{aligned}
& \text { De bodoque e baladeira } \\
& \text { Jogar bola de futebol } \\
& \text { E cantar coco na feira. } \\
& \text { (MULATINHA, 20--, p. 07) }
\end{aligned}
$$

A associação da preguiça à cantoria nos versos de Mulatinha pode ser percebida como uma incorporação do pensamento dominante enraizado em uma sociedade de origem escravagista, para a qual o corpo negro se reduzia a uma máquina produtiva. Entretanto, as tradições culturais desenvolvidas nesse contexto são justamente manifestações de resistência a este imperativo social (CABRAL, 1998). A cantoria aparece na vida dessas figuras que "trabalham no pesado" como forma de reapropriação do corpo ("mulato"), historicamente expropriado pelo regime em questão - pano de fundo da crítica social/literária de Candido (1970). Nesta perspectiva, cantar é uma forma de "transfiguração da dor em alegria" (GARCIA, 2013, p. 130), subterfúgio de muitos homens e mulheres pobres que se fizeram poetas e poetizas.

O contato com práticas artísticas levou Toinho a "desaprender a pegar na enxada”. De acordo com os relatos do poeta-folheteiro, depois que passou a cantar e escrever folhetos "ia pra roça e não sabia mais limpar o mato", passou a "achar pesado $o$ serviço" ${ }^{128}$. A troca da caneta pela enxada pode ser lida como produto da negação do movimento histórico, posto que representa a apropriação de uma ferramenta do campo hegemônico por aquele que fora subalternizado.

O primeiro folheto escrito por Toinho da Mulatinha, Uma Viagem à Lua (1945), é um exemplo nítido do anseio de suplantação do universo social do qual fazia parte. Em versos constrói um espaço digno para residir, de abundância e fartura, concedidas por uma natureza surrealmente generosa - inversa aquela que tanto "castigou" os sertões nordestinos com a seca. Na Lua de Toinho podemos encontrar: terra sempre molhada, feijão que nasce temperado, melancia de quatro metros de altura, assim como produtos gratuitos: “[...] Querosene, açúcar, sal/ café, colorau, cachaça/ Lá não se vende é de graça/ para todo pessoal" (MULATINHA, 1945, p. 02).

Tal como no Mito medieval do País da Cocanha ${ }^{129}$, associado por pesquisadores/ as $^{130}$ à Viagem a São Saruê (Manoel Camilo dos Santos, 1956), a interpretação presente em Uma Viagem à Lua (1945) reitera "o traço carnavalizante que se mantém desde a

128 Relata em entrevista à revistinha Cordeletras $-n^{0} 6$ (2007, p.6).

1290 mito medieval do País da Cocanha, cuja representação estética advém do século XIII, ilustra a viagem de um personagem anônimo a uma terra de fartura e deleite constante, uma espécie de paraíso terrestre sem uma localização precisa. A narrativa, registrada a partir da tradição oral, é composta por duzentos versos octossílabos. (ver: FRANCO JUNIOR, Hilário. Cocanha: Várias faces de uma utopia. Cotia: Ateliê Editorial, 1998a; FRANCO JUNIOR, Hilário. Cocanha: A história de um país imaginário. São Paulo: Companhia das Letras, 1998b). 130 FRANCO JR., 1998a; MARQUES, 2011; NUNES, 2014. 
versão francesa, quando situa em um país fictício a realização de desejos pulantes, como a satisfação alimentar e inexistência de classes sociais” (NUNES, 2014, p. 110). Afinal, tudo "é de graça para todo pessoal".

O "efeito carnavalizante" manifesta-se tanto pela exposição de uma existência cerceada de prazeres terrenos exagerados, visto que "se come sem ter vontade" (MULATINHA, 1945, p. 02), quanto pela negação do trabalho, que nos remete ao universo da "desordem". A apologia ao ócio, é expressa indiretamente em Uma viagem à Lua e, de maneira mais direta, no País de Camilo:

O povo em São Saruê

tudo tem felicidade

não há contrariedade

não precisa trabalhar

e tem dinheiro a vontade.

(CAMILO DOS SANTOS, 1948, p. 3-4)

As versões nordestinas da utopia da Cocanha são, igualmente, permeadas pelo desfrute de uma riqueza fácil, seja em forma de alimentos ou, até mesmo, de metais preciosos e dinheiro:

Lá eu vi pé de dinheiro

Vi níquel prata e vintém

Nota de mil e de cem

De dois e de um cruzeiro [...]

(MULATINHA, 1945, p. 05)

Sítios de pés de dinheiro que faz chamar atenção os cachos de notas grandes

chega arrastam pelo chão

as moitas de prata e ouro

são mesmo que algodão.

(CAMILO DOS SANTOS, 1948, p. 6)

Os mundos sociais que os poetas constroem não são os das alianças, das carreiras, das heranças, próprios das sociedades aristocrática e burguesa. As árvores de dinheiro relativizam a força do sistema econômico e social vigente, do lucro e da acumulação de riquezas, posto que elas estão acessíveis a toda comunidade que habita esses paraísos e não sob domínio daquele que detêm os meios de produção - inexistentes, uma vez que a natureza tudo produz e fornece. $\mathrm{O}$ acesso ao excesso de alimentos faz com que esse 
dinheiro, que brota incessantemente, perca seu real valor, mantendo-se apenas como símbolo de riqueza, um adorno ostensivo na paisagem.

Nos folhetos, os paraísos utópicos de Toinho da Mulatinha e de Manoel Camilo dos Santos são também a poesia, posto que recriam a própria realidade por meio dessa linguagem, no plano imaginário e na dimensão material - afinal, essa literatura encheu a barriga de homens e mulheres pobres que viviam em condições adversas.

O trajeto a té a Lua, no folheto de Toinho, pode ser compreendido como o caminho de acesso à composição poética:

\author{
Ouvindo alguém dizer \\ Que a lua é um país \\ D'um povo bom e feliz \\ Deu-me coragem e prazer \\ De ir lá pra conhecer \\ Se era verdade ou não \\ Um bonito avião \\ Do estudo preparei \\ E para lua viajei \\ Cheio de satisfação \\ Segui no meu avião \\ Em busca do firmamento \\ Vendo chuva, nuvem e vento \\ Neve, neblina, trovão \\ Corisco, raio, zelação \\ Vi nevoeiro e geada \\ E sem perder a estrada \\ A viagem continua \\ Cheguei no país da lua \\ A uma da madrugada. \\ (MULATINHA, 1945, p. 01)
}

A primeira aventura do poeta pelo universo da poesia escrita é marcada por um percurso tumultuado por "chuva, vento, neblina” e outros fenômenos metafóricos do trajeto criativo, que eleva o artista para um campo distante do plano terreno. Toinho conta em entrevista sobre o processo de produção do seu primeiro folheto: "eu fui dormir e me veio aquele pensamento, uma vontade de escrever. Então no outro dia comprei um caderninho e um lápis para começar a escrever verso" ${ }^{131}$.

131 Toinho da Mulatinha em entrevista à revistinha Cordeletras - $n^{0} 6$ (2007, p. 6). 
O “avião do estudo" transporta Toinho da Mulatinha para esse universo de fartura e o "Doutor mestre pensamento” é aquele que conduz Manoel Camilo para esse espaço simbólico, o paraíso imaginativo, onde encontra uma fartura de palavras que o saciam enquanto poeta nato:

\author{
Doutor mestre pensamento \\ me disse um dia: -Você \\ Camilo vá visitar \\ O país São Saruê \\ Pois é o lugar melhor \\ Que neste mundo se vê. \\ (CAMILO DOS SANTOS, 1948, p. 01) ${ }^{132}$
}

A atividade mental aparece nas "viagens” em oposição ao trabalho realizado através corpo, o trabalho braçal. Lidar com o sublime da palavra, com as estruturas delgadas das letras em tipos móveis em um contexto embrutecedor, é adentrar no paraíso estético do campo artístico. A pesquisadora Leda Ribeiro (1986), interpreta a partida de Manoel Camilo a São Saruê como um "voo mágico", libertador, que manifesta "o desejo de livrar-se das peias que o limitam e subjugam, que o mantém ancorado à terra”.

O voo significa uma ruptura, mas significa também um ato de transcendência, um desejo de superação "pelo alto" da própria condição humana traduzindo uma ruptura ontológica. [...] Se não pode livrar-se do seu cotidiano massacrante, tenta fugir dessa realidade através do voo fantástico - tão veloz quanto o pensamento - é uma opção que ninguém lhe pode frustrar. (RIBEIRO, 1986, p. 134).

Apesar das "viagens" de Toinho e Camilo terem temática comum, assim como estrutura narrativa e versos indiscutivelmente similares (entre si e com o mito da Cocanha) $)^{133}$, elas têm finais distintos. No espaço criado por Toinho: "Quando a lua é crescente tudo é sobrando e barato”, mas “Quando a Lua é minguante/ até o sol

132 CAMILO DOS SANTOS, Manoel. Viagem a São Saruê. Campina Grande - PB: Estrella da Poesia, 1965. (1 $1^{\mathrm{a}}$ edição 1948)

133 Abundância, ociosidade, prazeres carnais, liberdade e juventude subsidiam as utopias carnavalizantes do Mito da Cocanha, do País São Saruê e de Uma Viagem à Lua. A seguir três versos, de cada poema, tematizando a promessa de eterna mocidade, respectivamente: "A Fonte da Juventude/ que rejuvenesce as pessoas/ e traz outros benefícios./ Lá não haverá, bem o sei,/ homem tão velho ou tão encanecido,/ nem mulher tão velha que,/ tendo cãs ou cabelos grisalhos,/ não volte a ter trinta anos de idade, se à fonte puder ir" (FRANCO JUNIOR, 1998a, p.30); "Lá tem um rio chamado/ o banho da mocidade/ onde um velho de cem anos/tomando banho à vontade/ quando sai fora parece/ ter 20 anos de idade" (SANTOS, 1947, p. 3); "Lá tem um tanque sagrado/ Que um idoso ou doente/ Entra nele certamente/ Quando sai do outro lado/ Vem novo, gordo e corado/ Haja gozar mocidade/Vem com outra novidade/ Muita força outros planos/ Entra com noventa anos e sai com vinte de idade" (MULATINHA, 1945, p.3). 
é minguado/ Planta, gente, açude e gado/ Mingua tudo num instante”. Ou seja, o paraíso prometido revela suas agruras. O poeta encerra a narrativa com o retorno desse universo onírico, através de um verso inesperado, cômico, que revela o choque com a realidade: "Mas de volta a minha terra/ houve um grande fracasso/ o aparelho quebrou-se/ e eu fraturei um braço”. O caráter satírico remete ao vínculo do autor com o gênero do coco, que exprime sua resiliência diante das emboladas da vida.

A despedida de Camilo de São Saruê é bastante distinta da relatada por Toinho no retorno à terra. Na ocasião o poeta-editor é condecorado e recebe um valioso regalo: “[...] na véspera de eu sair naquele dia/ um discurso poético, lá eu fiz,/ me deram a mandado de um juiz /um anel de brilhante e de "rubim"/ no qual um letreiro diz assim: / - é feliz quem visita este país." (CAMILOS DOS SANTOS, 1965, p. 08). A obtenção do anel de rubi é uma alegoria da busca de Camilo, sujeito que tanto almejou ser equiparado aos bacharéis, pelo reconhecimento como poeta - sem o "popular". A joia de Rubi, geralmente associada à graduação em advocacia, é emblemática no poema de Camilo, homem que demonstrou muito apreço por esse ofício nas quartas-capas de seus folhetos.

Nos próximos capítulos veremos que Camilo, tal como Toinho, se despede da vivência terrestre sem anel de bacharel. Como poetas populares essas figuras não prescindiram da "ordem", nem conseguiram viver inteiramente nela. Mulatinha, cantador das brechas, vai armar estratégias editoriais, nas décadas subsequentes, para que seu marco poético não se torne ruína. Pena, a última estrofe de sua Viagem à Lua se consolidar como profecia. 


\section{a modernidade como promessa e como ruína 1960-1980}

Toinho da Mulatinha (poeta editor)

foto: Roberto Coura (1978)
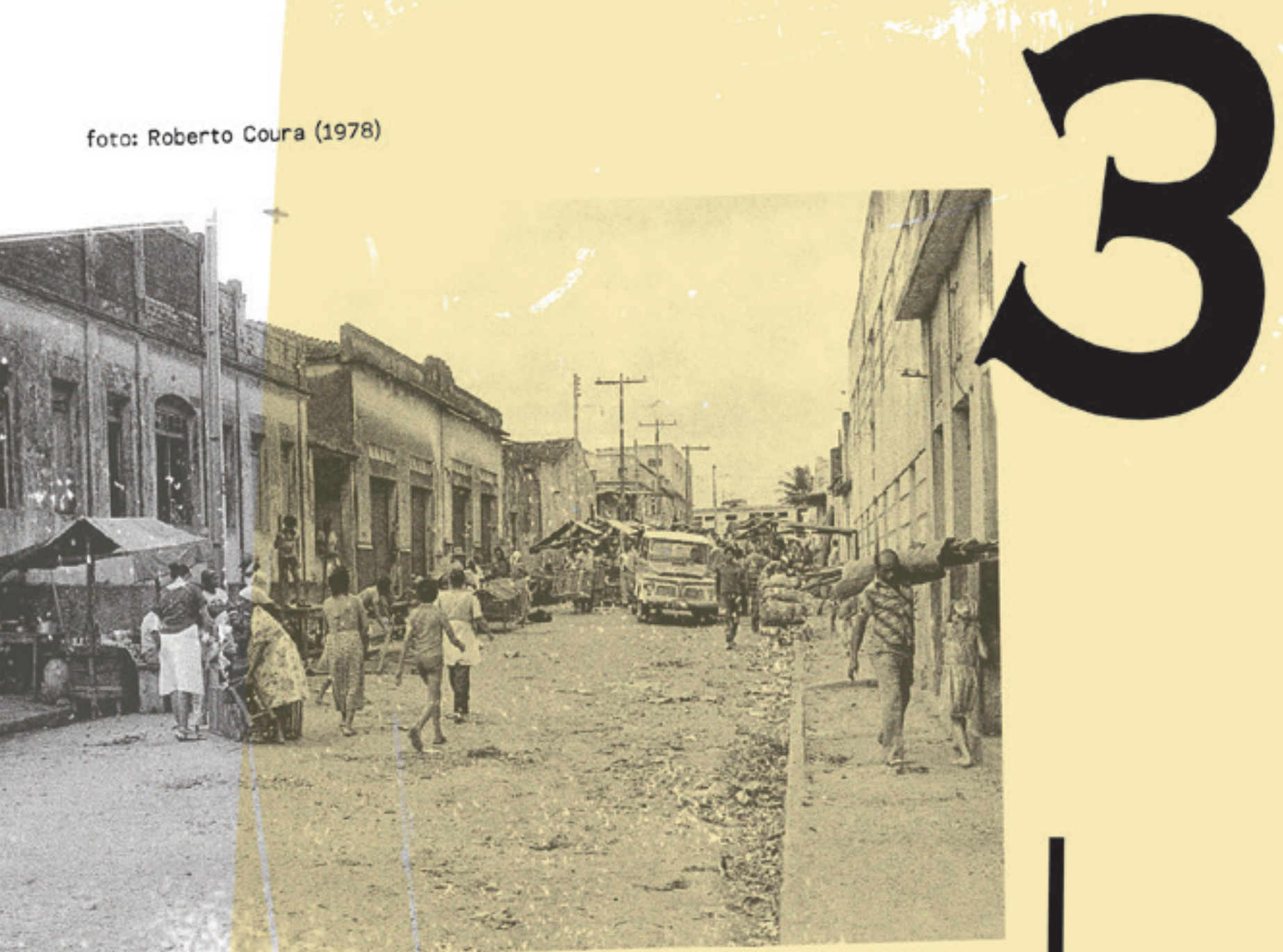


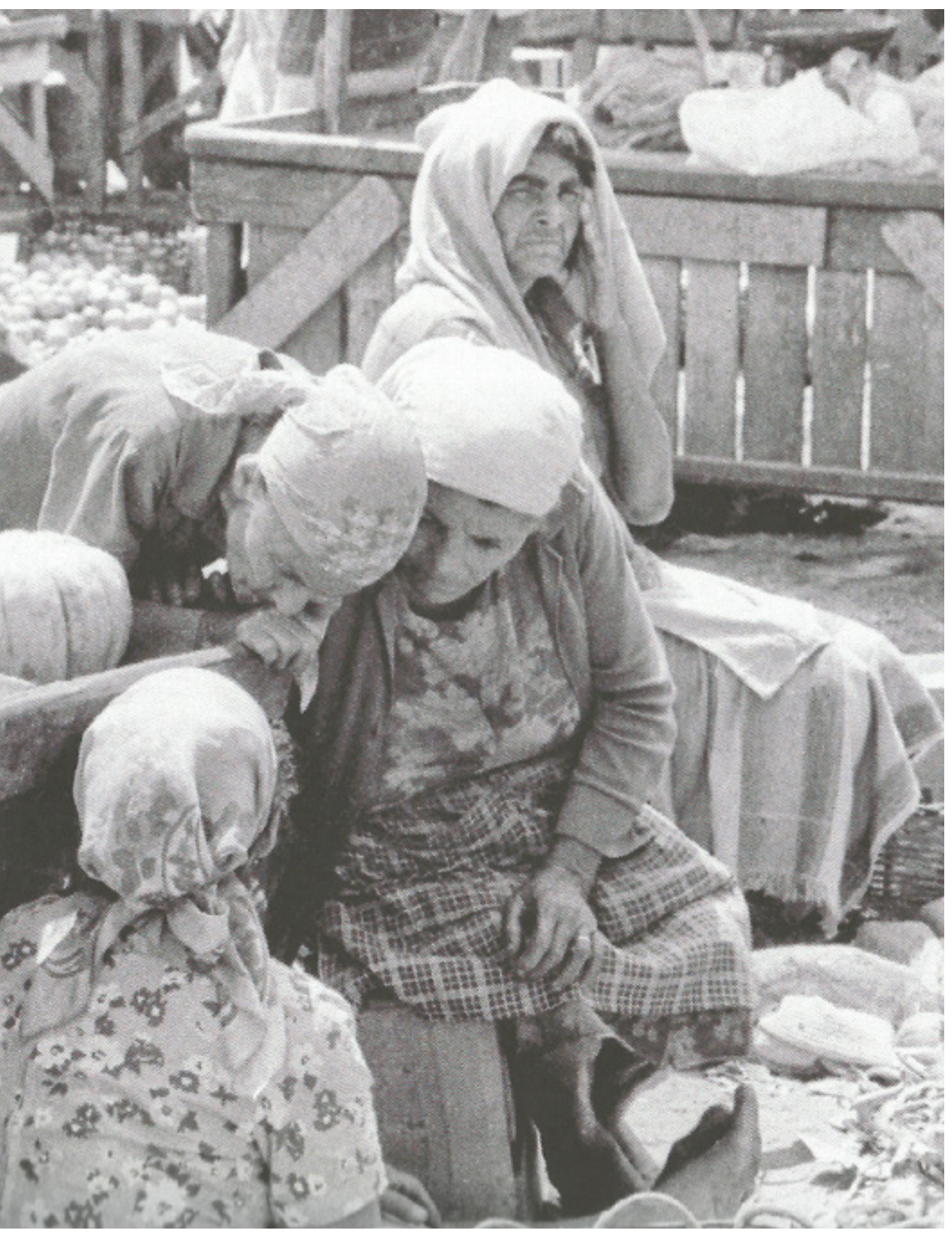

Figura 32 - Bochicho na Feira Central de Campina Grande (1978)

Fonte: Roberto Coura, 2014 


\section{O ESVANECER DA ESTRELLA DA POESIA}

Prensas rodando mundos imaginados, de segunda a sábado, do nascer ao pôr do sol. Brochuras dobradas e refiladas por muitas mãos, uma a uma. Mais de 100.000 folhetos de Lourival e Terezinha na boca do povo no ano de $1954^{134}$.

Se ao longo da década de 1950 a Estrella da Poesia subiu aos céus, dominando o mercado de folhetos na Paraíba e emanando seu brilho para além das fronteiras do estado, na década seguinte passa por um declínio vertiginoso. O desmoronamento daquilo que fora edificado meticulosamente pelo poeta-editor Manoel Camilo dos Santos, foi provocado por apostas arriscadas, do próprio, em uma conjuntura socioeconômica muito frágil para aqueles que estavam a nordeste do centro industrial do país.

Em 1962, encorajado pelo sucesso de sua casa tipográfica, Manoel Camilo dos Santos injetou o capital econômico acumulado através da Estrella da Poesia na sua candidatura para deputado estadual - mencionada no capítulo anterior como a mais ousada investida do poeta em fazer-se um homem moderno. Porém, os passos largos de Camilo não alcançaram o degrau mais alto da trajetória meritocrática por ele projetada. Em sua autobiografia, registra o desfecho daquela eleição: “Um ano de trabalho, muitas despesas, a quantia de 1811 votos e por fim a palavra não, não fui eleito. E essa palavra não, é terrível! É dura! É àspera! É afrontuosa![...] Além de tudo isto, a palavra não, mata a esperança, o último remédio que a natureza deixou a todos os males" (CAMILO DOS SANTOS, 1979, p. 43).

Consciente da dificuldade de lutar em um campo de forças atravessado por práticas nepotistas, Camilo declara em seu livro (1979) ter sido derrotado pela "fraude, o suborno, a roubalheira dos oligarcas mandões", pela a "afilhadagem" das elites locais, que tornam inconstitucionais "as eleições populares, [...] via respiratória da vida nacional". (ibidem, p. 41).

No ano seguinte ao da derrota no campo da política, 1963, Manoel Camilo dos Santos se muda para o Rio Grande do Norte com a família e vende parte significativa do seu maquinário tipográfico a José Alves de Pontes, um jovem operário da “Tipografia e Folhetaria Santos" nos anos 1950 (DIAS, 2009). Sem sucesso profissional e conjugal na capital do estado, Natal, o poeta volta sozinho à Campina Grande em 1964. Com os resíduos materiais da Estrella da Poesia instala uma modesta tipografia na Rua Sindolfo Montenegro, n. 173, no bairro Santo Antônio, aquele que lhe recebeu na certeira mudança para a Rainha da Borborema na década anterior.

134 Informação acerca da tiragem do folheto Lourival e Terezinha extraída do livro A Voz dos Poetas (LESSA, 1984, p. 50) 
Todavia, o despencar da Estrella da Poesia não pode ser atribuído apenas a questões personalistas. Por conseguinte, torna-se imprescindível nesse trabalho uma leitura das transformações socioculturais que culminaram no silenciamento do maquinário tipográfico desta e de outras casas relevantes do gênero, depois da euforia promovida pela década de 1950, como a tipografia Graça de Fátima do poeta Joaquim Batista de Sena (Fortaleza - CE), fechada em 1968, e a editora Luzeiro do Norte de João José da Silva (Recife - PE), que teve suas atividades encerradas em 1973, década registrada na lápide de muitas impressoras artesanais de folhetos.

Até mesmo a promissora Tipografia São Francisco (Juazeiro - CE) e a Editora Prelúdio (São Paulo - SP) - registrada em alguns trabalhos desta área de pesquisa como a vilã da retração desse mercado literário, que assombrava os "tradicionais-populares" folhetinhos nordestinos com suas capas coloridas impressas em offset ${ }^{135}$-, também foram impactadas pela política econômica nacional sobre o setor gráfico. O proprietário da tipografia cearense teve que vender parte de seu maquinário para pagar dívidas com fornecedores de matéria prima, na virada de 1950 para 1960, e a Prelúdio fica com as pernas bambas nos anos 1970, recuperando-se apenas na década seguinte (MELO, 2010).

Rosilene Alves de Melo, autora da mais expressiva publicação acerca das editoras do gênero, Arcanos do verso: trajetórias da literatura de cordel (2010), delineia a conjuntura que conduziu trabalhadores/as do ramo gráfico artesanal à falência ${ }^{136}$. A pesquisadora atribui a crise econômica na indústria de folhetos aos impactos do projeto desenvolvimentista de Juscelino Kubitschek, que governou o país entre 1956 e 1961. O então presidente da república anunciava, com seu "Plano de Metas", o progresso econômico do Brasil, gerando entusiasmo em uma classe média ascendente, sedenta para consumir os objetos que simbolizavam o estilo de vida moderno do norte global. A geometria urbana da nova capital do país do futuro, próximo e próspero, Brasília, arquitetava a concretização desse sonho.

A instalação de grandes indústrias no território, fomentada pela injeção de capital estrangeiro e amparada por redes técnicas, informacionais e organizacionais

135 A impressão offset, realizada a partir de máquinas rotativas fotogravadas, surgiu no preâmbulo do século XX substituindo sistemas anteriores mais artesanais, como a tipografia e a litografia. 0 advento desta tecnologia marca uma revolução na indústria gráfica por aprimorar a resolução das imagens, propiciar a impressão colorida em escala tonal, além de consumar grandes tiragens de forma veloz e automatizada. Este método de impressão, ainda em vigor, chegou ao Brasil em 1920 e se popularizou a partir da segunda metade do século XX. A editora Luzeiro (São Paulo) adotou esta técnica de impressão em 1952.

136 Em Arcanos do verso, Rosilene Melo analisa a ascensão e a queda da Tipografia São Francisco, de Juazeiro do Norte (CE), referência na edição de folhetos de cordel no Brasil. A obra explora o universo poético da cidade e daquela tipografia, que, entre 1926 e 1982, foi símbolo da fase áurea da produção de literatura de cordel no Brasil. Acompanhando as transformações ocorridas na Tipografia São Francisco durante quatro décadas, a obra sublinha a importância simbólica e cultural dos folhetos de cordel - fonte histórica privilegiada da memória popular. 
(infraestruturas de transportes, telecomunicações e energia), desenhou novos espaços de fluxos no país, consolidando a região Sudeste como "um espaço do mandar" (SANTOS, 2008) no contexto nacional. Com políticas públicas concentradas neste "espaço luminoso"137, o presidente deixou árida a região Nordeste, já debilitada pela crise do setor agroexportador açucareiro e algodoeiro ${ }^{138}$.

O colapso dos "ouros brancos" afetou outras áreas da economia local, dando início ao intenso fluxo migratório em direção à região regada pelos "anos dourados", avultado pela grande seca de 1958 . No folheto $O$ sofrimento dos nortistas pelo sul ganhando o pão (1959), Toinho da Mulatinha expõe o processo de sedução de mão-de-obra nortista para o labor nos lugares que recebiam maior atenção do capital estrangeiro:

Só se ver no velho norte milhares de motoristas outros donos de carros uns até capitalistas andando de rua em rua comprando araras nortistas

Diz assim para o nortista no sul um dia é oitenta cruzeiros e eu conheço quem paga até por noventa se o cabra for bom mesmo o seu ganho ainda aumenta

Diz ele o que não tiver dinheiro eu posso levar e todas suas despesas eu tenho com que pagar vamos, vamos que no sul é bom do homem enricar. (MULATINHA, 1959, p.1-2)

O poeta Manoel Camilo dos Santos, em O Choro dos nortistas no Rio e a palestra de Luiz Gonzaga (19--), satiriza aqueles que se deslocavam para a terra da Bossa Nova, rumo aos braços abertos do Cristo Redentor.

137 Segundo Milton Santos (2008) os "espaços luminosos" são aqueles que acumulam as densidades técnicas e recebem atenção do capital principal.

138 Em meados do século XX Campina Grande enfrenta a decadência do seu mercado algodoeiro, derivada sobretudo da concorrência com o estado de São Paulo, que se insere neste ramo agrícola após à crise cafeeira. Com a economia solapada, a Rainha da Borborema começa a perder, entre os anos de 1960 e 1970, a função organizadora do espaço regional. 


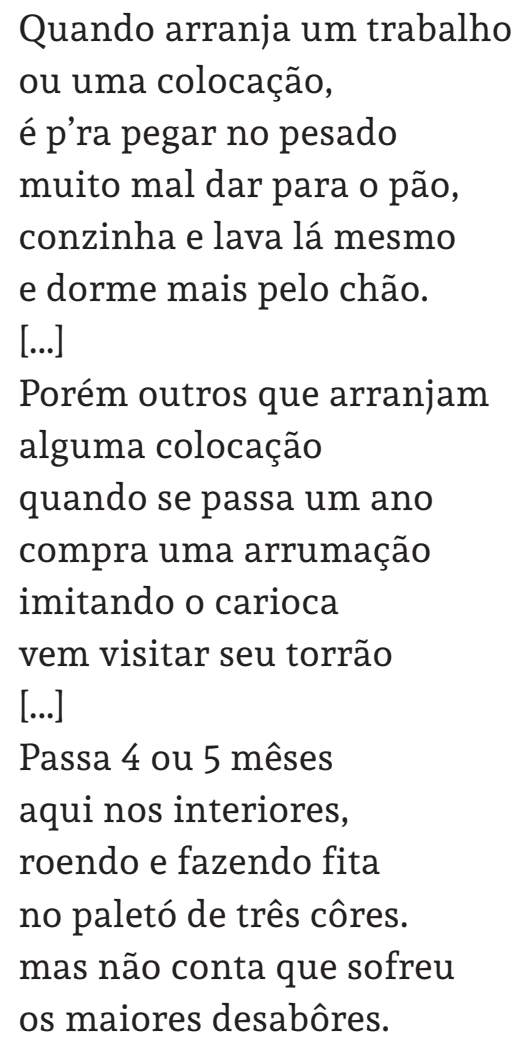

As transformações do meio técnico-científico-informacional, “50 anos em 5!”, se estenderam para a indústria gráfica hegemônica brasileira, que, após um longo período de restrições à importação, atualizou-se e, consequentemente, dilatou-se. A introdução de novos dispositivos de diagramação e de impressão, na virada da década de 1950 para a de 1960, acarretou na proliferação de periódicos e jornais. Com tiragens cada vez mais volumosas distribuídas em pontos de vendas espalhados pelo país, as editoras difundiam publicidades incumbidas de multiplicar os desejos dos/as novos/ as consumidores/as, assim como seu próprio capital. “A modernização do parque industrial significou, em contrapartida, o sucateamento das pequenas indústrias artesanais, cujo volume de produção se tornou inferior às fábricas mais modernas”. (MELO, 2010, p.144)

Os editores de folhetos também foram impactados com o encolhimento do seu público consumidor, o operariado urbano e rural que pagava pelo endividamento externo oriundo do desenvolvimentismo de JK - através de uma política inflacionária que galopava $25 \%$ ao ano. O aumento progressivo dos preços é notável nas capas dos folhetos produzidos no período: As aventuras de Pedro Quengo, por exemplo, folheto de 24 páginas de Manoel Camilo dos Santos, custava Cr\$ 8,00 em 1957 e passa a custar 25 cruzeiros em 1961. A omissão do valor dos impressos se torna uma constante nas publicações da época, diante das mudanças recorrentes e abruptas no custo de vida. 
Outros episódios de ordem econômica, diretamente relacionados ao mercado de folhetos, irão corroborar para o aprofundamento da crise das tipografias artesanais nas décadas subsequentes. Entre os acontecimentos relevantes figuram um relacionado à produção e outro à distribuição das brochuras, respectivamente: o encarecimento da principal matéria-prima que corporifica os folhetos, mediante a retirada dos subsídios sobre o papel em 1964 (MELO, 2010); o aumento dos transportes com a crise do "ouro negro", o petróleo, no início da década de 1970.

A crise do setor petroleiro impactou o abastecimento do papel de imprensa ${ }^{139}$ (insumo importado escoado pelo país por meio de serviços de transportadoras), assim como a dinâmica de distribuição das publicações. Os elevados custos das passagens de ônibus ${ }^{140}$ acometeram o mercado folheteiro, atravancando as vendas dos editores-tipógrafos para os agentes-revendedores/folheteiros via "malote de ônibus" e a comercialização das narrativas impressas pelas mãos dos próprios poetas, que passaram a depender deste meio para cumprirem seus itinerários geo-poéticos depois do projeto rodoviarista do "presidente bossa-nova"141.

Não podendo viajar mais, o poeta fica fazendo as feirinhas perto de casa. "as grandes viagens dos bons tempos" (anos 40 e 50) de até 8 meses, do Ceará ao amazonas, com uma bagagem de 20 mil folhetos, por terra e de canoa, de cidade em cidade, de capital em capital, de praia em praia, como fizera Joaquim Batista de Sena, hoje nem pensar. (MARANHÃO, 1981, p.21)

As modernas maquinarias, que prometeram aos poetas-editores e aos poetascantadores a materialização de mundos fantásticos e viagens épicas entre paisagens regionais, eram novidades de eminência pretérita.

Orígenes Lessa (1984) leu no vazio das prateleiras da nova casa tipográfica de Manoel Camilo dos Santos - transferida nos anos 1970 para a rua Mato Grosso, n. 202 (Monte Castelo - Campina Grande) -, a história da crise do mercado editorial popular. A fim de explorar este enredo, levanta uma prosa:

139 "Com a crise do petróleo em 1973 o papel de imprensa passou de US\$ 171,00 a tonelada, em 1971, para US\$ 320,00 em 1974 - um aumento de $187 \%$. Nesse período o país importava $60 \%$ do seu consumo de papel jornal." (ALVES DE ABREU, 2002, p. 18)

1400 jornal Diário da Noite divulgou em 1975 o aumento de 30\% do valor das passagens das linhas de ônibus que saiam do Recife, uma das grandes capitais produtoras de folhetos, rumo às cidades do interior de Pernambuco (MARANHÃO, 1981).

1410 governo Kubitschek implementou de maneira contundente o rodoviarismo no país, inaugurando políticas de sucateamento das ferrovias - exponenciadas pelos governos militares que deram carona para a privatização das estradas. Ao ampliar a malha rodoviária nacional o presidente pretendia integrar e ocupar o território brasileiro, tramando pontos de contato com o novo coração político do país, Brasília, assim como criar espaços de fluxos adequados para a implantação de polos industriais internacionais, sobretudo do ramo automobilístico, capaz de atrair empresas correlatas (autopeças, componentes elétricos, lubrificantes etc). Na segunda metade do século XX as linhas férreas passam a ter uma participação irrisória na logística de transportes nacional e insignificante no que diz respeito ao transporte de passageiros. 
O.L. - Como é Manuel Camilo? Produzindo sempre?

M.C. - Pra quê? Pra quem? Folheto acabou. O leitor antigo se encolheu. $\mathrm{O}$ poeta tem apenas uma esperança no coração: aparecer alguém de mercados distantes que veja o estoque, faça um preço, leve tudo. Eu facilito...

O.L. - Mas a feira de Campina?

M.C. - Vá ver. Tá no fim ...

O.L. - A de São Cristóvão, no Rio, vende folheto como nunca... ${ }^{142}$

M.C. - Isso é lá! Nordestino com saudade. Mas aqui não. O povo deu pra achar que é feio ser matuto. (LESSA, 1984, p. 74-76)

A fala de Camilo revela que a feira não escapou dos processos “modernizatórios”, que vão ganhar ainda mais força nas últimas décadas do século XX no estado da Paraíba. Isto porque o desembarque do capitalismo financeiro na periferia da globalização vai gerar, além de novas formas de consumo, novas subjetividades, formas de pensar e sentir, evidentes na frase: "O povo deu pra achar que é feio ser matuto"143. Tal fato gera também processos de desterritorialização, não apenas no sentido físico - como no caso dos deslocamentos para o Rio de Janeiro mencionados por Camilo -, mas no simbólico, onde estão os territórios assentados por memórias e práticas culturais. Nesse sentido é possível viver processos de desterritorialização na sua própria localidade.

O desenvolvimentismo globalitário (SANTOS, 2003) 144 $^{14}$ no Brasil estruturou, além de uma nova "tecnoesfera", uma nova "psicosfera", capaz de achatar "imagens do mundo" em imagens de um mundo, massificando valores que fabulam uma nova identidade social: da/o “cidadã/o do mundo”. Para o geógrafo Milton Santos, o globalitarismo tende a instalar forças centrífugas, que se afastam do centro, do próprio território, pois caracteriza um modelo de "integração" econômica, social, cultural e política planejado para ser indiferente ao local.

Os vetores de racionalidade globalitária se difundem por meio das macroempresas que incidem e/ou instalam-se no território, formando um espaço de fluxos adequados às suas necessidades produtivas. A expressão destas forças hegemônicas do capital, as verticalidades (SANTOS, 1999) vindas de fora, de cima e de longe se sustentam através de redes técnicas, informacionais e organizacionais construídas com aliança do Estado Nacional. Comandadas pelos atores hegemônicos do capital, estas empresas implantam-

142 Para ler mais sobre o cordel na Feira de São Cristóvão ver: NEMER, Sylvia. Feira de São Cristóvão: Contando histórias, tecendo memórias. 2012. 255f. Tese (Doutorado em História) - Departamento de História, Pontífica Universidade Católica do Rio de Janeiro, Rio de Janeiro, 2012.

143 CAMILO DOS SANTOS, 1979 apud LESSA, 1984, p. 74 - 76.

1440 termo globalitarismo foi engendrado por Milton Santos para expressar, grosso modo, um processo de colonização universal, que consiste no totalitarismo imposto em escala global pelas nações hegemônicas, no âmbito econômico e sociocultural. Para aprofundamento conceitual ver: SANTOS, Milton. Por uma outra globalização: do pensamento único à consciência universal. 10. ed. Rio de Janeiro: Record, 2003. 
se também simbolicamente, gerando uma homogeneização ideológica, dependente e alienadora das pessoas que habitam os lugares, segundo uma ordem estratégica imposta para seu próprio proveito. Para as verticalidades o território é recurso.

Hoje, feirantes avaliam a chegada dos supermercados na cidade como o principal fator de decadência da Feira Central de Campina Grande. S. Severino, mais conhecido como Biu da Batata, que iniciou seus trabalhos por lá há 60 anos, testemunha:

Os mercadinho tirou o pessoal da feira né, mas era uma feira arrochada de tudo. Isso era cheio de banco, todo mundo vendendo, todo mundo comprando isso aqui tudim. Hoje tá muito esquisito, tá vendo aí os banco fechado? Isso era box de mercadoria. Estiva [gêneros alimentícios], cereais, roupa, calçado, de tudo tinha aqui. Era conhecido como "Mercado Central de Campina Grande” [fala em tom eloquente]. Era uma tradição aqui, hoje em dia tá tudo acabado. (apud PIZZIGNACCO, 2019, p. 94)

Nos anos 1960 os supermercados aparecem pela primeira vez nas metrópoles brasileiras e multiplicam-se de forma acelerada pelo território. A difusão de grandes redes empresariais internacionais e o surgimento de grupos nacionais se dá no país por meio de parcerias público-privadas que visavam inseri-lo, cada vez mais, no capitalismo mundializado. Pautados no autosserviço, próprio do sistema moderno urbano, estes estabelecimentos de consumo passam a atender e estimular a dinâmica das grandes cidades, assim como a viabilizar o acesso ao excesso de produtos industrializados de diferentes marcas que passam a desfilar na linha de baixo do Equador.

Lindete Martins Pereira, Dete da Buchada, trabalha há mais de 70 anos na feira e conta sobre as mudanças ocorridas durante sua trajetória de feirante em relação às vendas, determinadas pela concorrência com os novos estabelecimentos comerciais:

Se for pra mim vender com o pessoal passando aqui eu num vendia não... Porque eu forneço [para restaurantes] mais do que vendo aqui. [...] É, antes vendia muito. Agora também tem uma coisa né, antes não tinha supermercado. Num era? Hoje tem feira em todo o bairro e tem supermercado. Eles bota tudo...até buchada eles bota pra vender. (apud PIZZIGNACO, 2019, p. 94)

A geógrafa Silvana Maria Pintaudi (1984) analisa que os supermercados são zonas de comércio que centralizam o capital, visto que concentram o lucro na mão de proprietários/multinacionais e condensam o território, ao oferecer uma variedade de mercadorias que antes tinham de ser adquiridas em variados pontos comerciais como nos mostrou dona Dete, ao afirmar que "até buchada eles [os supermercados] bota pra vender”. Dona Teresa, feirante há pelo menos 65 anos, complementa, “[...] e 
o pequeno para disputar com o grande só vai pra trás. Tem nem como você disputar com o grande". ${ }^{145}$

Os mercados de origem ibérica a céu aberto começaram a ser redefinidos por essa lógica progressista, pela racionalidade higienista pautada na ideia de limpeza e conforto oferecidas pelos supermercados, espaços de temperatura agradável onde se pode deslizar os carrinhos pelo chão branco e regular com trilha sonora que imerge o cliente em uma atmosfera que remete às imagens publicitárias.

Importante lembrar que o conflito entre feirantes e supermercados não se restringiu às esferas econômica e jurídico-política. No plano do imaginário, recriam-se as feiras livres como territórios do desconforto, do informal, do transtorno, do atraso, do barulho e sujeira das ruas, enquanto os supermercados são massivamente apresentados como portadores do novo, do belo, do conforto, do american way of life. (MASCARENHAS, 2008, p.79)

As falas das/dos feirantes nos levam a refletir sobre os impactos da modernidade urbana nos espaços públicos, capaz de formatá-los, normatiza-los ou excluí-los do projeto hegemônico. É o caso de muitas feiras livres, que segundo Gilmar Mascarenhas (2008) têm se tornado obsoletas devido às novas formas de varejo e a difusão do automóvel, que monopolizou o espaço de convivência comunitária onde as feiras se armam, a rua.

A sociabilidade detida aos espaços fechados privados e o aumento da violência urbana, e, portanto, do temor à rua, inauguram um modelo de vida onde o significado da rua enquanto território privilegiado da convivência e do lazer comunitário é esvaziado. Toinho da Mulatinha associa o aumento da violência citadina a diminuição da sua clientela da feira campinense: "Rapaz, antigamente era diferente eu cantava dez, doze folhetinho e o embolador de coco até às seis da tarde, o dia todinho. Hoje a gente canta não chega ninguém não, com medo de ladrão, ave Maria!” (MULATINHA, 20-- apud ARAÚJO, 2006, p.75)

Se durante a década de 1950 a Feira era um local onde as classes populares e a elite local se encontravam, ainda que dentro de relações assimétricas de contato, hoje a elite campinense já não aparece por lá. Dona Teresa Gorda cita com orgulho os "ilustres clientes” que atendia em sua juventude, quando ajudava na barraca de sua mãe: “O pai de Cássio [Cunha Lima], Vital do Rêgo, Raimundo Asfora ${ }^{146}$, tudo era homis que vinha

145 MACIEL, Teresa. Depoimento [jul. 2015]. Entrevista concedida à pesquisadora. Campina Grande (PB], 2015. 146 Ronaldo Cunha Lima ( 1936 - 2002), Vital do Rêgo ( 1935 - 2010) e Raimundo Asfora ( 1930 - 1987) foram políticos paraibanos que ocuparam cargos estaduais e municipais em Campina Grande. Falecidos, deixaram uma geração de filhos e netos que dão continuidade ao nepotismo das famílias na política local. 
cumê na barraca de minha mãe picado com galinha de capoeira. Isso em 1954/ 55... e pra descer doze horas pro Eldorado, pra festa do Eldorado"147, relembra. Agnaldo Batista, atual administrador da Feira Central de Campina, reitera que a elite local era parte integrante da freguesia da feira: "O pessoal fazia feira, as madame faziam feira. O arroz, a verdura iam colocando no balaio. O camarada corria, andava a feira todinha com esse balaio na cabeça, até chegar em suas casas ou nos seus automóveis” (apud PIZZIGNACCO, 2019, p.95)

No processo crescente de segmentação física e simbólica dos espaços urbanos de Campina Grande, potencializado pelo projeto globalizatório, a Feira Central foi sendo identificada como espaço social das classes subalternizadas.

A partir dos anos 1960 a Feira Central começa a despencar no imaginário como a genitora da Grande Campina, um Marco na Serra da Borborema, (en)cantada por poetas. De signo da prosperidade da "Capital do Nordeste brasileiro", passou a ser reconhecida como um testemunho material de um Nordeste rural e pré-capitalista, recusada como uma chaga que macula as pretensões de modernidade que Campina Grande aspira, na sua busca por realocar-se na economia regional.

Assim como a Feira, um marco tornado ruína na modernidade campinense, a literatura de folhetos passa a simbolizar resíduo de um Nordeste rudimentar. Uma poesia matuta, sob olhares de tons sudestes. Ou mesmo uma poesia "vagabunda”, de camelô, apreendida por ações policiais - conhecidas popularmente como "rapa"148.

Apesar do caminho a São Saruê ser mais tortuoso do que a modernidade prometeu, ele não leva ao abismo, afinal, poetas-editores e poetas-feirantes não ficaram inertes frente às transformações socioculturais vivenciadas. Isto porque as forças verticais, geradoras de movimentos de desagregação, são também produtoras de tensões, disparadoras de horizontalidades, "da contrafinalidade, localmente gerada.” (SANTOS, 1999, p. 227), da resistência.

O declínio dos espaços de produção (tipografias) e comercialização (feiras) dos folhetos na segunda metade do século XX não aconteceu mediante relações de causa e efeito instantâneas, nem em uma curva descendente linear, sem nuances. $\mathrm{O}$ afamado editor de folhetos Manoel Camilo dos Santos, por exemplo, não abandonou a escrita de sua história com a poesia com o encerramento das atividades de sua tipografia instalada na Feira Central de Campina Grande. Fixou prateleiras no novo casebre para expor seus os romances e tentou refazer as premissas escritas no seu mapa astral com

147 "Eu num sei dizer porque eu não ia. Sei que tinha festa pra lá e era um dos cabaré mais ricos de Campina. [...] Mas pelo que eu sugiro, assim, era como se fosse um clube, uma boate, entendeu?" me explicou Dona Teresa. 0 Cassino Eldorado foi uma casa de espetáculos, jogos, dança e prostituição, destinada a elite algodoeira, construída em 1937 na Rua Manoel Pereira de Araújo, localizada nas adjacências da Feira Central. (SOUZA, 2005)

148 Para saber mais sobre o assunto ler: MELO, Rosilene Alves de. Do rapa ao registro: a literatura de cordel como patrimônio cultural do Brasil. Revista de Estudos Brasileiros, São Paulo, v. 72, p. 245-272, 2019a. 
a publicação de horóscopos e almanaques ${ }^{149}$, no início de 1960. Na década seguinte, o poeta-editor consegue lançar seu primeiro livro (Autobiografia do poeta Manoel Camilo dos Santos, 1979) com o selo da editora da Universidade Federal da Paraíba, na esteira da institucionalização do cordel como campo de pesquisa.

O fechamento das portas de algumas tipografias especializadas não representa um ponto final na historiografia deste comércio narrativo. Neste enredo, atravessado por intempéries de ordem macrossocial, serão inseridas outras páginas que colocam em cena a história de um poeta que não foi detentor dos meios de produção no campo da editoração popular, Toinho da Mulatinha, mas continuou publicando brochuras até as primeiras décadas do século XXI.

\section{O CINTILAR DA ESTRELA DO ORIENTE}

Em 1970, quando a Estrella da Poesia já estava com seu brilho esvanecido, o poeta Antônio da Mulatinha lança a folhetaria Estrela do Oriente - associada ao endereço da própria residência ${ }^{150}$. O nome de batismo, uma referência explícita ao empreendimento do poeta Manoel Camilo dos Santos, pode ser lido como uma homenagem, ou mesmo como uma artimanha do cantador, decorrente do desejo de ser associado ao editor que dominou o mercado de folhetos no estado da Paraíba.

Nesse período, marcado pelo enfraquecimento da maior parceira de embolada de Toinho, a Feira Central campinense, o poeta começa a frequentar novos espaços de comercialização de folhetos: os Festivais.

Quando tinha os festivais de violeiro aqui no Teatro Municipal, Toinho ia levar o cordel dele pra vender mais a veinha dele. Vendia também uma caninha, aquela cachacinha misturada, chamada pau dentro. E tinha um poeta aí que gostava de beber e depois não se lembrava de pagar. Aí teve um ano que o poetinha bebeu umas 5 canequinhas, uma cuinha de cachaça. Daí quando foi no outro ano, chegou no outro congresso aí disse: Toinho tem daquela aí? E ele

149 Para acessar uma análise historiográfica sobre a presença dos almanaques de cordel no Brasil ver: MELO, Rosilene Alves de. Almanaques de cordel: do fascínio da leitura para a feitura da escritura, outro campo de pesquisas. Revista Do Instituto De Estudos Brasileiros, v. 52, p. 107-136, 2011.

150 A inscrição "Folhetaria Estrela do Oriente" passa a ser impressa nos folhetos de Toinho da Mulatinha a partir de 1970. Menção à localização da folhetaria aparece pela primeira vez no folheto História de Campina Centenária (1964), em forma rimada ("Endereço do poéta/ Antonio da Mulatinha/ É no bairro Santo Antonio, cazado com uma velinha/ é trezentos e vinte sete/ é o número da cazinha"), e depois em 1968 no folheto A morte do radialista e compositor nordestino Rosil Assis Cavalcante, na página oito, até ser regularmente anunciado junto ao nome da folhetaria. 
disse: "Tem, tem daquela bem boazinha...E aí você junta com aquelas do ano passado e vai pagar quando?”[risos] (LIMA, 2018) $)^{151}$

Os festivais de cantoria de viola tornaram-se corriqueiros em Campina Grande a partir de 1974 (com a realização anual do Congresso Nacional de Violeiros pela Associação de Repentistas e Poetas Nordestinos), e configuraram-se como espaços financeiramente oportunos para vendedores de folhetos, emboladores de coco, declamadores e aboiadores, que participavam com apresentações pontuais, sem entrar na competição (SAUTCHUK, 2009). Contudo, é preciso frisar que estes eventos eram protagonizados por repentistas, considerados como detentores de uma arte maior (em décimas!), embranquecida pela memória de empresários e políticos ${ }^{152}$ que reatualizavam as vivências dos salões das fazendas. Nesses espaços formava-se e reproduzia-se uma elite da cantoria, associada a promotores de poder, que deixavam à margem aqueles que não acompanhavam o Galope à Beira Mar.

Os festivais de Campina Grande tornaram-se vitrine da cantoria de viola e abriram espaços para a inserção mais veemente das músicas de tradição oral nas rádios, entre 1970 e 1980. Na deixa dessa onda sonora, Toinho da Mulatinha embolou programas como "Retalhos do Sertão”, na Rádio Borborema e o "Crepúsculo ao som da viola”, da Rádio Caturité (Campina Grande), que costumava convidar emboladores para encerrar o núcleo musical de cantoria de repente ${ }^{153}$. Nesse interim a produção sonora do poeta-feirante foi registrada nos discos de Vinil "Geraldo Mousinho e Toinho da Mulatinha - Coco pra

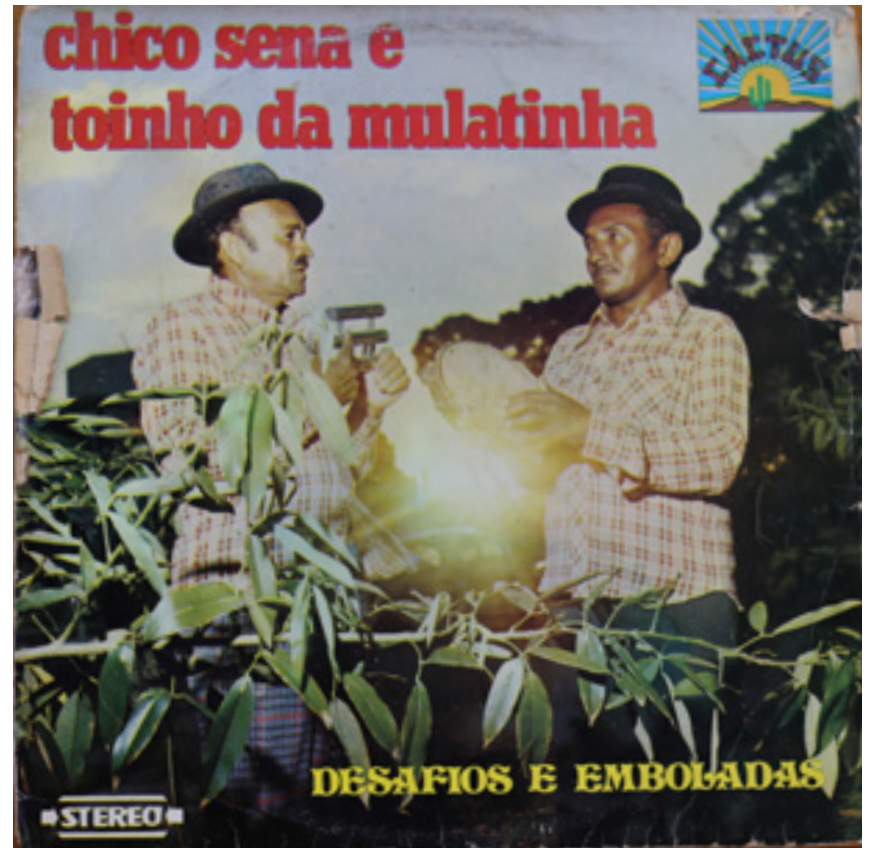

Figura 33 - Capa do disco de vinil Chico Sena e Toinho da Mulatinha - desafios e emboladas (1976)

Fonte: Acervo da pesquisadora

151 LIMA, Tião. Depoimento [mar. 2018]. Entrevista concedida à pesquisadora. Campina Grande, 2018 152 Estes eventos contavam com apoio das prefeituras e dos governos estaduais, sendo frequentemente integrados aos calendários festivos e de eventos artísticos dessas instâncias governamentais. (SAUTCHUK, 2009).

153 TRAVASSOS, Elizabeth. "O avião brasileiro": análise de uma embolada. In: MATOS, Cláudia Neiva de; TRAVASSOS, Elizabeth; MEDEIROS, Fernanda Teixeira de (orgs.). Ao encontro da palavra cantada: poesia, música e voz. Rio de Janeiro: ? Letras/ CNPq, 2001, p. 99-103. 
todo Lado" e "Chico Sena e Toinho da Mulatinha - desafios e emboladas" (1976) [Figura 33], entretanto, é através da literatura impressa que o poeta-embolador vai reelaborar sua existência no lado B da modernidade.

O volume de produção de Toinho da Mulatinha entre as décadas de 1960 e 1980, dá indícios de que a decadência dos grandes editores do gênero incitou o cantador a realocar-se neste meio produtivo. Com a inauguração da "Folhetaria Estrela do Oriente", passou a oferecer “Grande sortimento de Romances, Folhetos e Canções Populares”, recorrendo às gráficas de jornais/ de serviços diversos para materializar as publicações do seu catálogo e estabelecendo contatos para montar um estoque de folhetos para venda consignada.

A abertura da folhetaria demonstra o ímpeto do cantador em posicionar-se de maneira sistemática no mercado de poesia impressa. No final da década de 1960, Toinho da Mulatinha deixa de se anunciar como um "poéta caipira”, passa a se intitular como "autor proprietário” e começa a gerenciar a produção de colegas de profissão, imprimindo o nome da sua folhetaria em publicações de terceiros. Na "Figura 34" vemos a contracapa do folheto de Dedé da Mulatinha impressa com o "nome fantasia" da casa editorial do irmão e a capa estampada com uma matriz de gravura pertencente ao arcabouço de ilustrações da Folhetaria Estrela do Oriente:
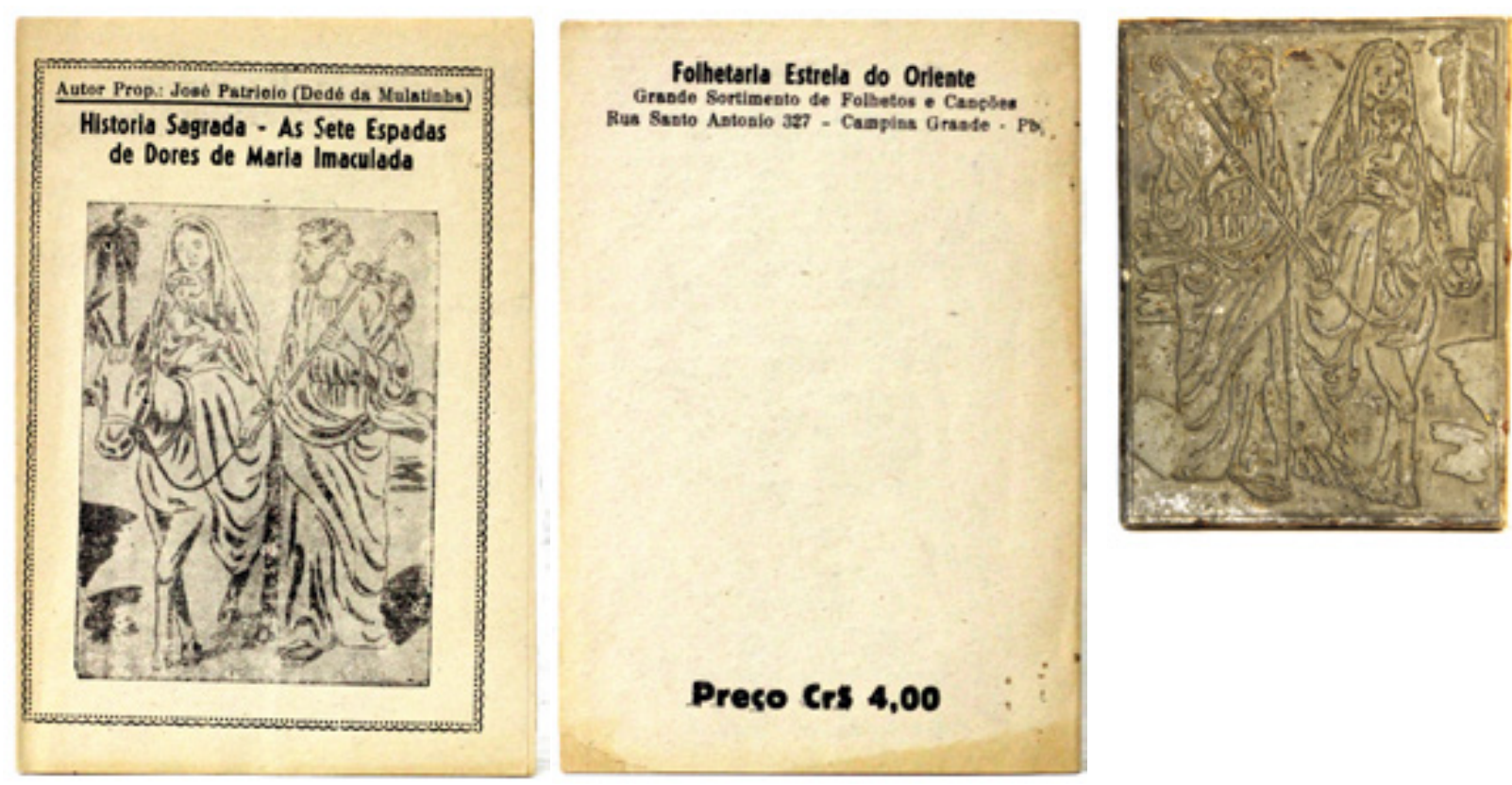

Figura 34 - Folheto de Dedé da Mulatinha editado pela Folhetaria Estrela do Oriente e a matriz de zincogravura correspondente à estampa da capa - armazenada no acervo da casa editorial de Toinho da Mulatinha

Fonte: Biblioteca de Obras Raras Átila Almeida (BORAA/ UEPB); Acervo do poeta Toinho da Mulatinha 
As matrizes de gravura e os manuscritos em "formato linguado", armazenados na casa de Toinho da Mulatinha, são sinais de que o poeta passa a acumular funções editoriais. O "linguado" 154 funciona como um "boneco" do miolo da publicação. Ele acolhe o texto completo e revisado, registrado com letra legível ${ }^{155}$, pronto para ser encaminhado à gráfica. Seu principal objetivo é orientar o arte-finalista e o impressor a confeccionarem o leiaute e realizarem a paginação da publicação corretamente. $\mathrm{Na}$ “Figura 35” é possível observar o protótipo da brochura Quando minha mãe morreu, do poeta Cícero Vieira (1982), organizado pelo editor incipiente:

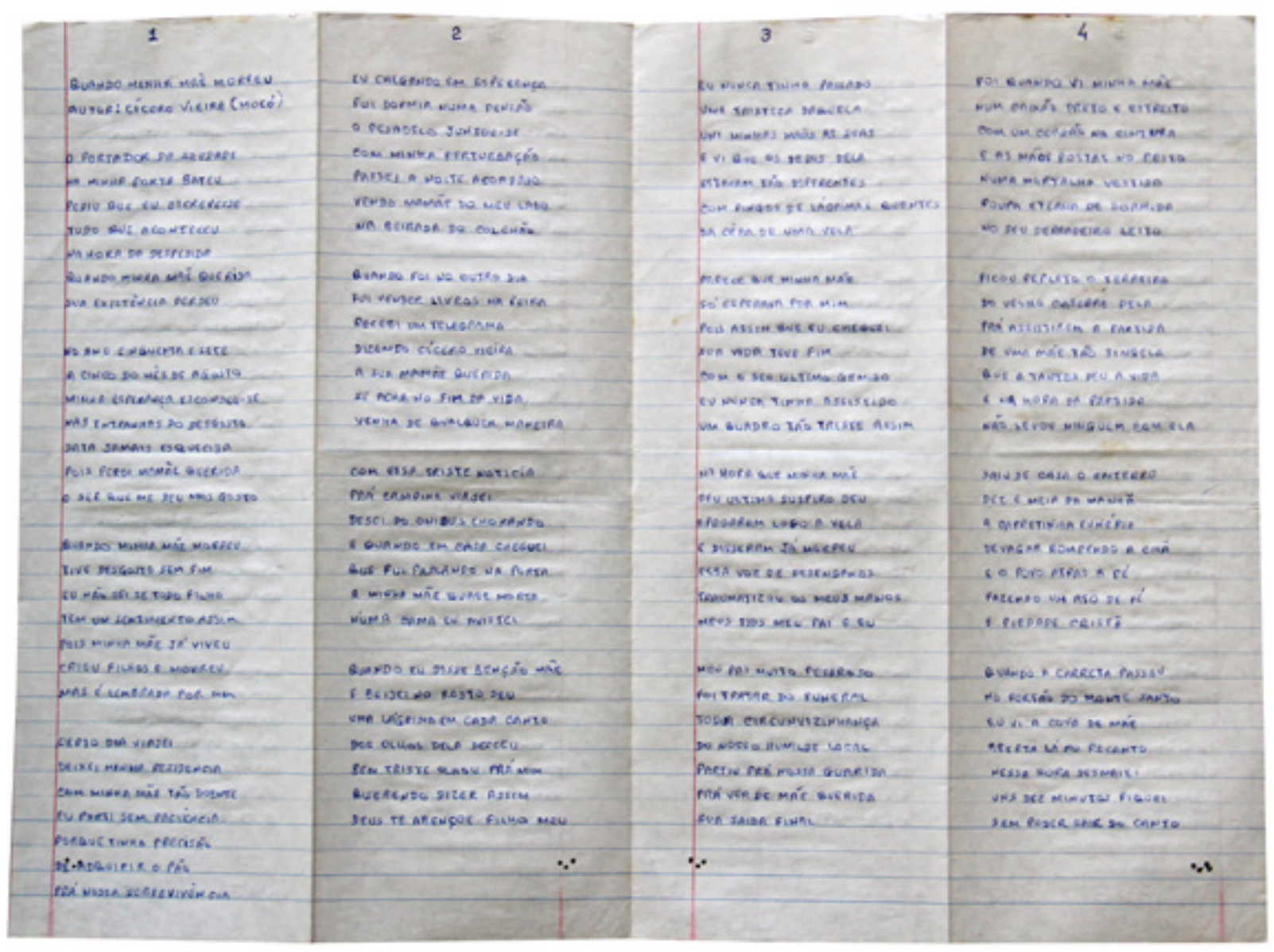

Figura 35 - Protótipo da brochura Quando minha mãe morreu [VIEIRA[Mocó], 1982]

Fonte: Acervo do poeta Toinho da Mulatinha

154 Linguado é o nome dado ao manuscrito original entregue às tipografias de jornal ou de revista, registrado em papel almaço pautado dobrado ao meio, formando uma tira longilínea. (GUILHERME, 1996)

$155 \mathrm{Na}$ comparação desses manuscritos, revisados e com letra "legível", com o material escrito à mão pelo próprio Toinho da Mulatinha, fica patente que ele pedia a outra pessoa para "passar a limpo" seus escritos, a fim de enviá-los para a gráfica de forma compreensível. Em pesquisa de campo iniciada em 2015, no contexto do Trabalho de Conclusão de Curso da graduação em Artes Visuais (UNESP), tive acesso ao acervo pessoal do poeta concedido por sua esposa, a senhora Digna Maria dos Santos. 
No livreto Cachimbinho e Geraldo Mousinho cantando suas emboladas (1976), o poeta apresenta-se como editor, conforme a subscrição: "Este folheto foi editado por Antonio da Mulatinha com autorização dos Autores". Presumivelmente, o título foi adquirido através da modalidade denominada, por José Alves Sobrinho, "Permissão" "significa ter autorização do autor ou editorproprietário para publicar uma obra sem nenhum vínculo comercial: compra, troca ou côngrua”. (SOBRINHO, 2008 apud DIAS, 2009, p. 180) ${ }^{156}$. Ao estampar, na capa do folheto, que a publicação foi feita mediante concessão [Figura 36], Toinho, mostra-se consciente das responsabilidades legais imbricadas na prática editorial - exacerbadamente publicizadas por Manoel Camilo dos Santos.

Uma anotação, a lápis, presente na quarta capa do folheto Mata Sete - O monstro do sertão o assassino de uma familia em Princesa Isabel (1979), dá indícios de que o poeta dominava as técnicas de impressão por tipos móveis e que chegou a manusear prelos: "Impresso por toinho (tipografia Zane-Gráfica) em Campina Grande (Monte Castelo)". A nota é um rastro de uma história miúda, das relações estabelecidas no ramo gráfico entre operários de pequenos/grandes prelos e proletários da poesia.

A carência de material bibliográfico acerca dos vínculos estabelecidos entre poetas autônomos e trabalhadores da indústria gráfica que acolhiam este tipo de produção, deve-se ao fato destas oficinas, na maioria das vezes, não estamparem suas logomarcas nos folhetos. Dentre as gráficas registradas no conjunto de quarenta e quatro publicações de Toinho da Mulatinha pertencentes ao acervo da Biblioteca de
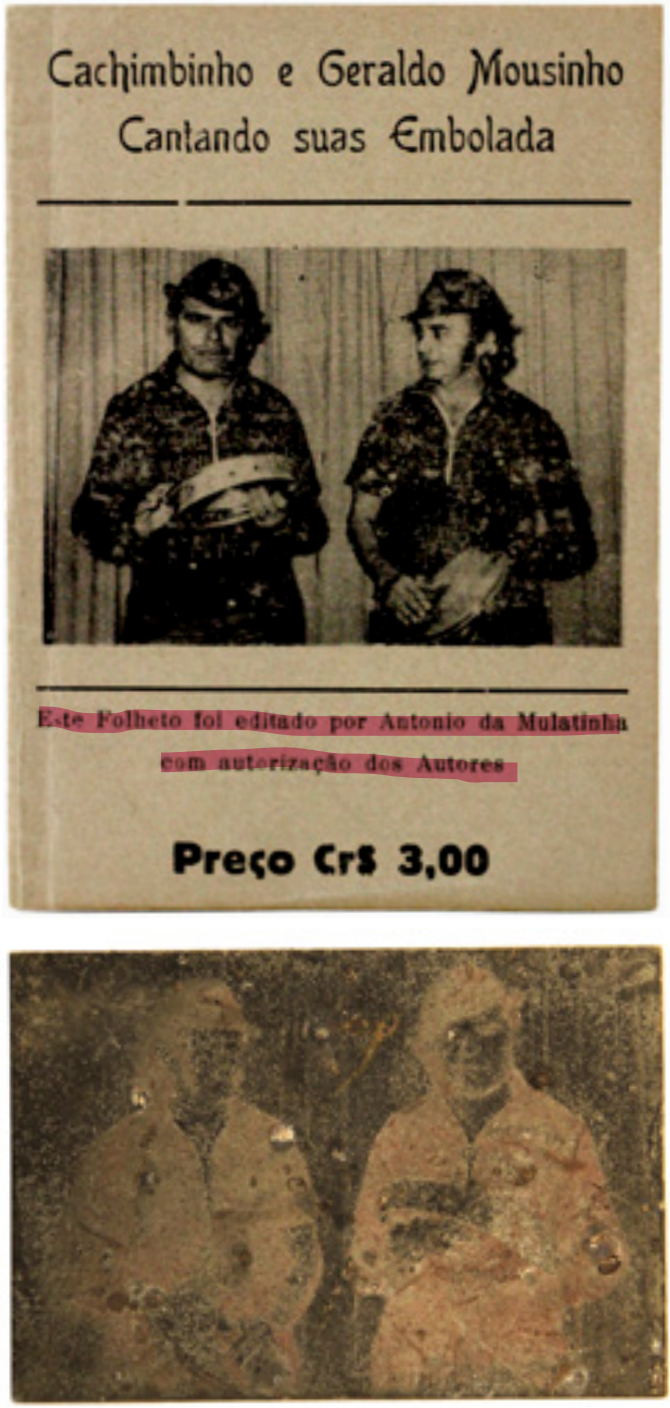

Figura 36 - Capa de folheto editado por Toinho da Mulatinha. Abaixo matriz de fotogravura correspondente à imagem da capa, propriedade da Folhetaria Estrela do Oriente. Grifo realizado digitalmente pela pesquisadora

Fontes: Biblioteca de Obras Raras Átila Almeida (BORAA/ UEPB); Acervo do poeta Toinho da Mulatinha 
Obras Raras Átila Almeida, que datam de 1955 até 1982, apenas sete têm inscritas as tipografias nas quais ganharam corpo:

- Gráfica São Jorge (Campina Grande - PB): As missões de Frei Damião em Bom Jardime a tempestade em Limoeiro (1955); Os sofrimentos dos nortistas pelo o Sul ganhando o pão (1959).

- Gráfica São Paulo (Esperança - PB): A reportagem do fogo no Paraná e a mortandade do povo (1960) $)^{157}$; A história de Campina centenária (1964) ${ }^{158}$.

- Tipografia São José (Campina Grande - PB): O cruzeiro novo (1964) ${ }^{159}$; A paixão de Cristo (sem data).

- Gráfica Vitória (Campina Grande - PB): O exemplo da moça que virou cachorra no carnaval de oitenta porque zombou de Frei Damião (1982).

O irmão de Toinho, Dedé da Mulatinha, também utilizou o serviço da Gráfica São Jorge (Campina Grande) para imprimir publicações [Figura 37]. A logomarca da tipografia aparece estampada no folheto A história da Santa Milagrosa - A virgem do Socorro (Padroeira em Bodocongó), (19--):
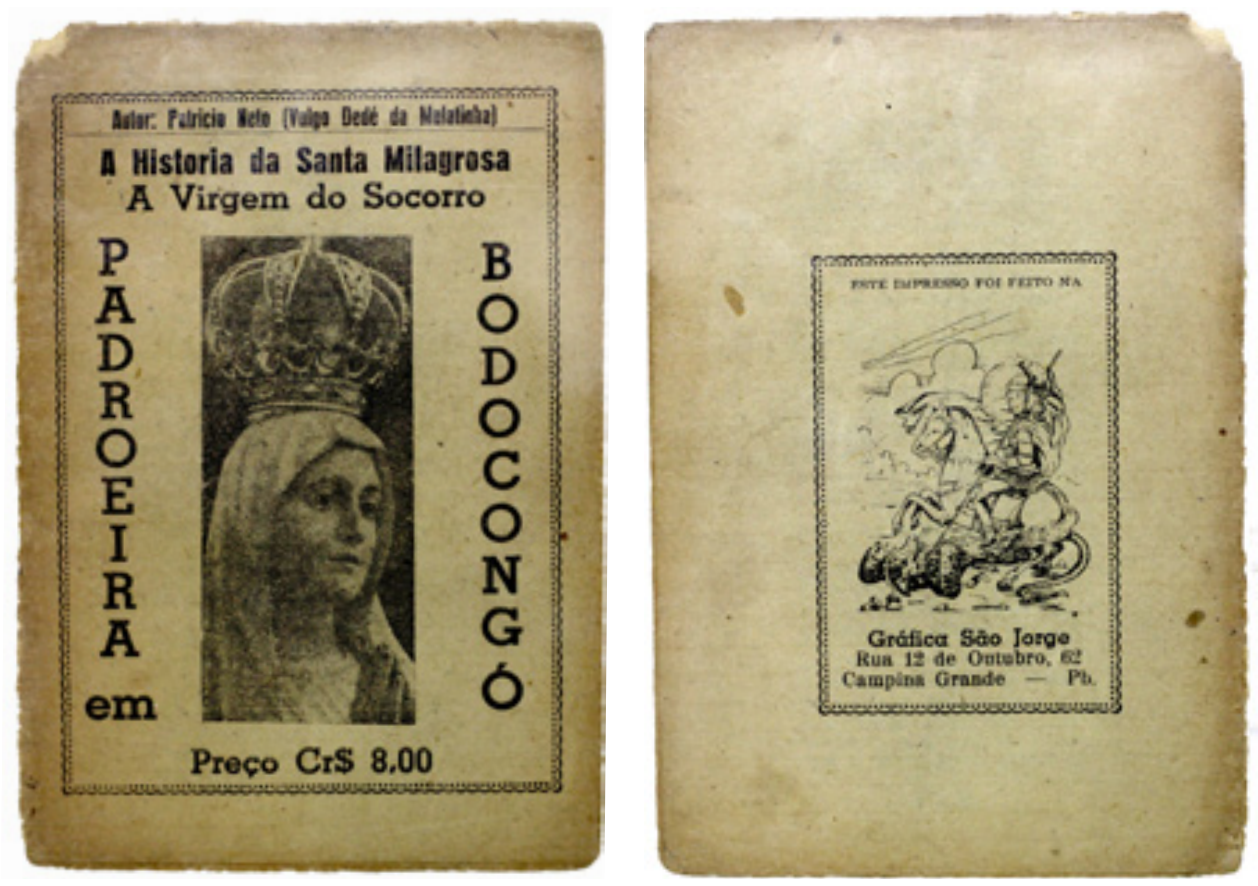

Figura 37 - Folheto de Dedé da Mulatinha com insígnia da Gráfica São Jorge

Fonte: Biblioteca de Obras Raras Átila Almeida (BORAA/ UEPB)

157 Data estimada de acordo com o evento veiculado.

158 Data estimada de acordo com o evento veiculado.

159 Data estimada de acordo com o evento veiculado. 
O folheto Meu Avião Brasileiro Voando em Direção ao Espaço Sideral (Dedé da Mulatinha, 19--), amplia o mapa das casas tipográficas não-especializadas parceiras dos poetas atuantes na região da Serra da Borborema, ao indicar a Indústria Gráfica Jacira (Campina Grande - PB) como impressora. Mundinho, neto de Dedé da Mulatinha, colabora com a composição de um mapa das gráficas impressoras de folheto em Campina Grande ao informar outro prelo que recebia encomendas de poesias populares: "Tinha a gráfica da prefeitura lá...era no Açude Velho, a Gráfica Municipal, aí tinha outros canto aqui em Campina Grande que fazia....mas no momento eu não tô lembrado não...". 160

A Gráfica Júlio Costa ${ }^{161}$, referenciada por José Alves Sobrinho como uma das "mais alinhadas"162 impressoras de folhetos na década de 1940, continuou, em meados dos anos 1960, imprimindo narrativas de poetas campinenses. O bicho do mazagão (sem autor; "original de Rosil Cavalcanti”, 1964 - acervo da Biblioteca de Obras Raras Átila Almeida) guarda esse registro.

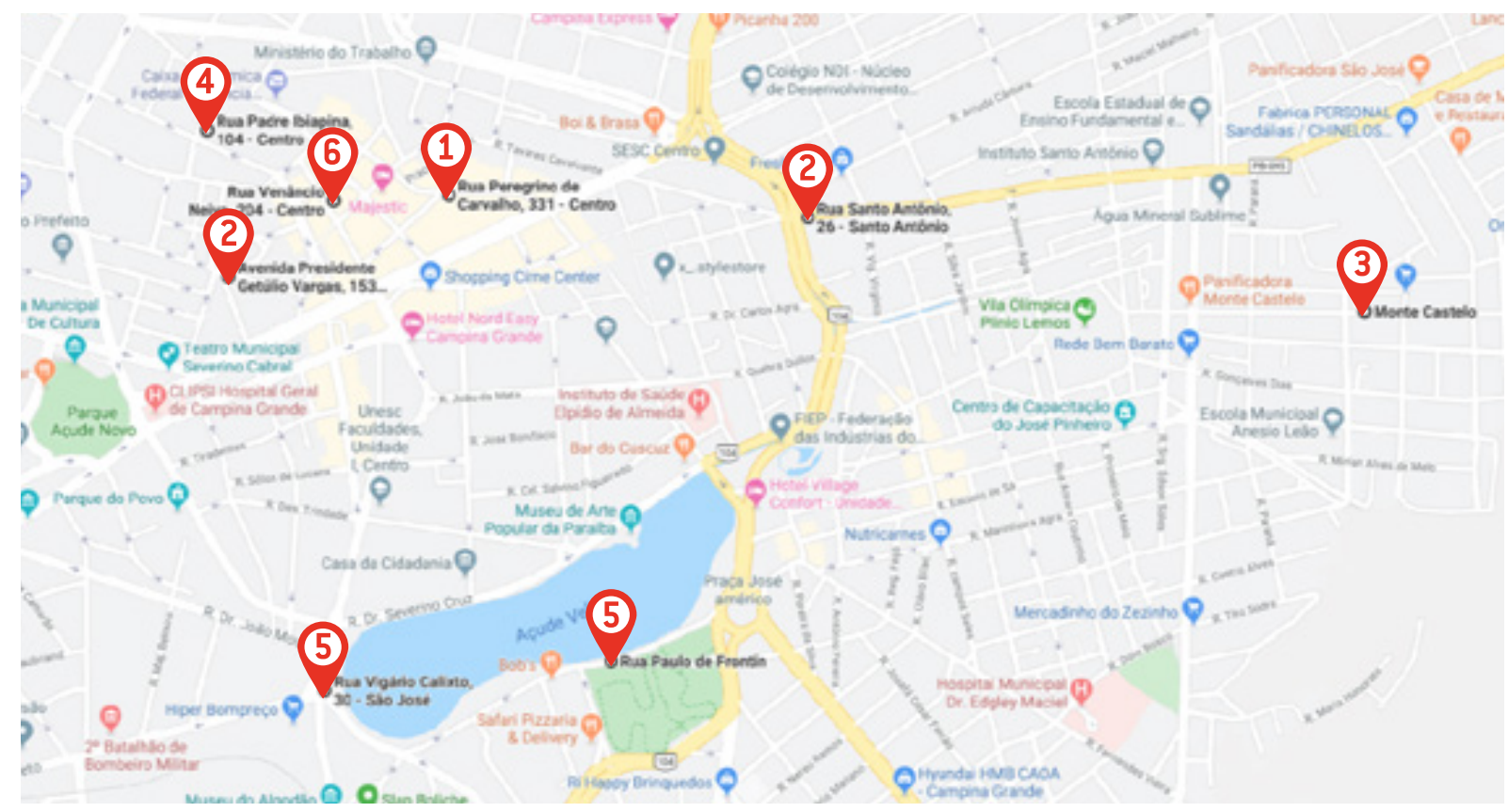

Figura 38 - Gráficas ativas em Campina Grande entre 1955 e 1982, "não especializadas", porém, impressoras de folhetos: 1] Gráfica Vitória: Rua Peregrino de Carvalho, 331; 2] Tipografia São José: Getúlio Vargas, 153 / Santo Antônio, 26; 3) Zane-Gráfica: Bairro Monte Castelo; 4) Industria Gráfica Jacira: Rua Padre Ibiapina, 104; 5] Gráfica Municipal de Campina Grande: Rua Vigário Calixto, 30 / Rua Paulo Frontim, s.n.; 6) Gráfica Júlio Costa: Rua Venâncio Neiva, 204;

7) Gráfica São Jorge: Rua Doze de Outubro, 62 (endereço não localizado)

Fonte: Localizações adicionadas pela pesquisadora em base cartográfica do Google Maps (2019)

160 LIMA, Eduardo ["Mundinho"]. Depoimento [mar. 2018]. Entrevista concedida à pesquisadora. Campina Grande (PB), 2018.

161 A tipografia "Júlio Costa" permanece aberta no mesmo endereço sob o mesmo nome e é mantida pela família do falecido tipógrafo.

162 Informação extraída de entrevista com José Alves Sobrinho, realizada pelo pesquisador Maurílio Antônio Dias. Ver mais em: DIAS, 2009. 
As publicações de Toinho da Mulatinha, sinalizam que o cantador itinerante não se filiou a nenhuma tipografia específica no momento de instauração da sua folhetaria/editora. Ademais, indicam que a rede de contatos com profissionais do ramo gráfico não se restringiu à Campina Grande, posto que imprimiu folhetos em cidades vizinhas: sua terra natal, Esperança (A história de Campina centenária, 1964; O desastre do caminhão que ia de Esperança a usina Santa Maria, 1977) e na capital do estado, João Pessoa (Eu e minha namorada e o mundo pegando fogo/Côco no periquito é assim,1980). O poeta, provavelmente, armava parceria com gráficas das redondezas, de acordo com as conveniências financeira e logística - determinada pelo seu itinerário geo-poético.

A existência de um acervo de matrizes de gravura (fotogravura, zincogravura e xilogravura) na antiga folhetaria Estrela do Oriente, corrobora o pressuposto do envolvimento do poeta com o meio editorial a partir da década de 1960/70 - universo com o qual não parece ter intimidade durante a década áurea de atuação dos editores especializados na diagramação/ impressão de folhetos na Paraíba.

$\mathrm{O}$ variado acervo de matrizes determina a multiplicidade visual das capas de suas publicações e a ausência de uma identidade gráfica extremamente delineada (tal como a configurada por Manoel Camilo no auge da Estrella da Poesia). O material arquivado por Antônio da Mulatinha é composto por: 9 clichês fotográficos; 1 desenho em zincogravura; 27 matrizes de xilogravura, sendo 13 sem autoria e 14 gravadas por Antônio Lucena.

A presença de fotogravuras no cabedal tutelado pela família, é uma evidência da associação do cantador com profissionais das gráficas não-especializadas. O processo de aquisição destas imagens junto aos prelos de jornais é relatado pelo poeta Palito, que trabalhara na Gráfica de João José, proprietário da tipografia Luzeiro do Norte (1950 1973, Recife - PE):

Aquilo era baratinho; aqueles clichês a gente comprava no "Jornal do Commercio". Depois de usado durante a semana, como reclame de filme. E, foi não foi, a gente aparecia lá e perguntava: "Qual a imundície que tem aí pra a gente?” E o pessoal lá já sabia e ia buscar clichê velho de cinema. (PALITO apud MARANHÃO, 1981, p. 65)

"Poeta repórter", Toinho adquiriu junto às gráficas de jornais clichês protagonizados por personagens locais [Figura 39]: 

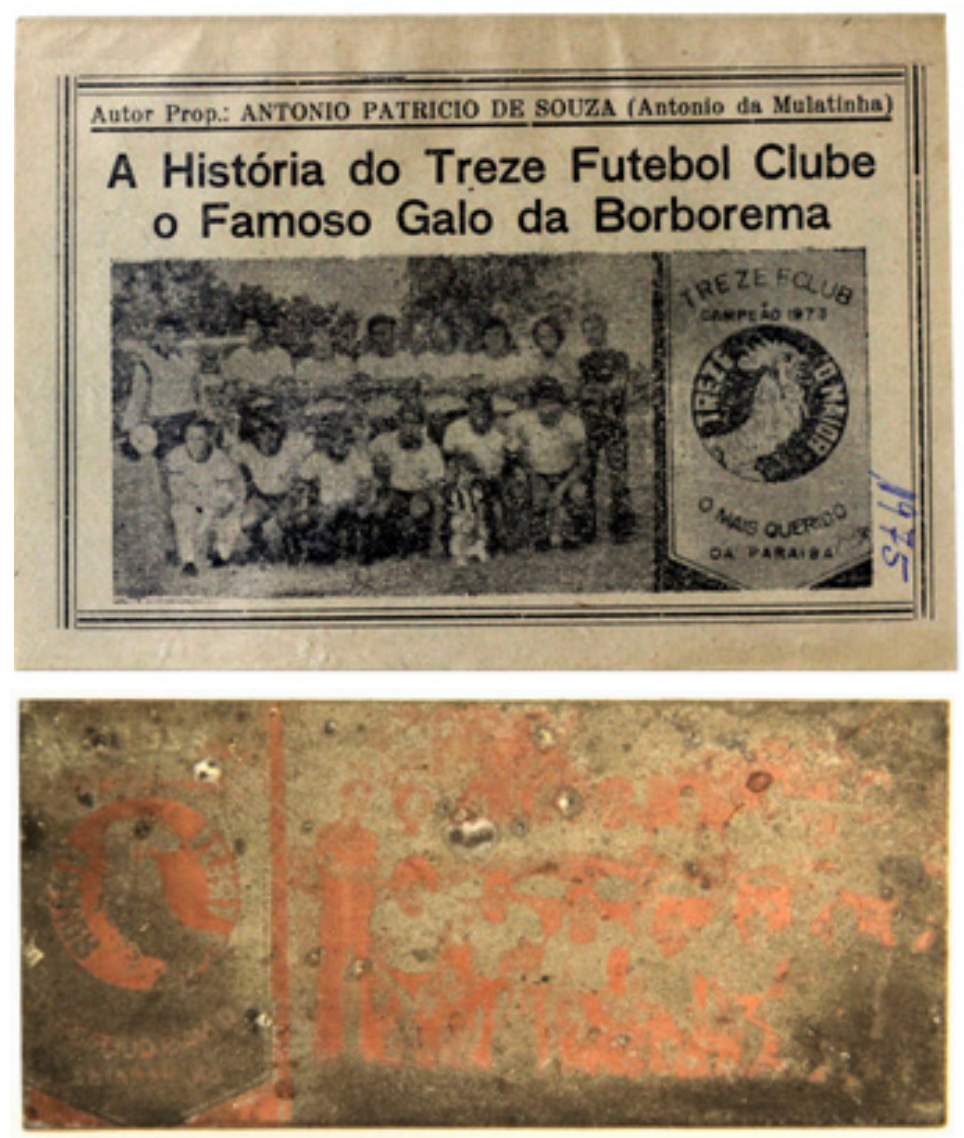

Figura 39 - Fotogravura dos jogadores do "Galo da Borborema". Imagem impressa na capa do folheto que tematiza a história do time e a matriz metálica correspondente

Fontes: Biblioteca de Obras Raras Átila Almeida (BORAA/ UEPB); Acervo do poeta Toinho da Mulatinha

As capas dos folhetos de Toinho da Mulatinha inscritas no período ora abordado, 1960 - 1980, nada têm de improviso. As páginas que fornecem a primeira impressão das "narrativas de época” do autor-editor são diagramadas de acordo com determinações do projeto gráfico jornalístico ${ }^{163}$ (estabelecido pelas tipografias nãoespecializadas). Estruturalmente, o princípio básico que rege o design de jornais é a organização e, portanto, a hierarquização de informações no suporte verticalizado, bastante evidente no folheto O cruzeiro novo (1967), que assume forma de “primeira página”. 


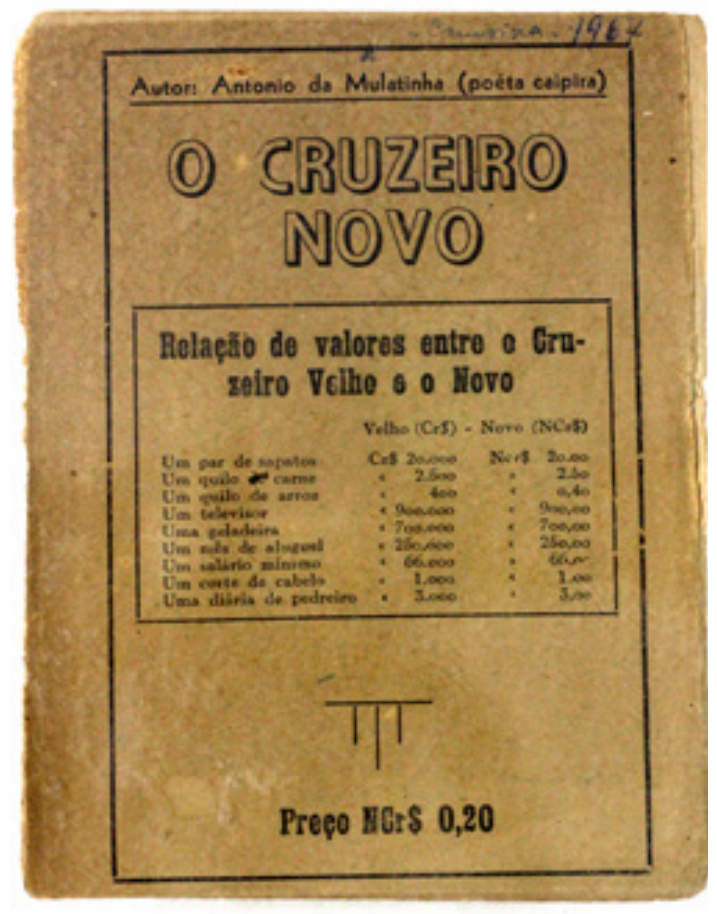

Figura 40 - Capa de publicação de Mulatinha com visualidade jornalística

Fonte: Biblioteca de Obras Raras Átila Almeida (BORAA/ UEPB)

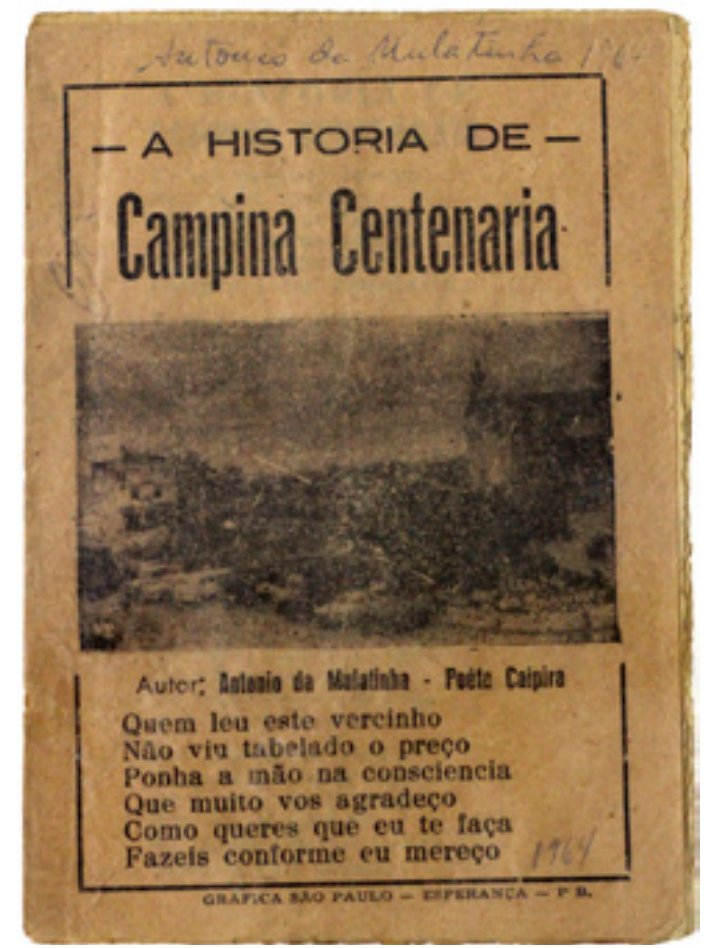

Figura 41 - Capa do Folheto A História de Campina Centenária [1964]

Fonte: Biblioteca de Obras Raras Átila Almeida [BORAA/ UEPB]
A diagramação dessa capa funciona como um convite à leitura ao oferecer uma decodificação rápida da temática abordada, através de contrastes oriundos da harmonização de massas de texto e espaços em branco, e da combinação adequada das tipografias (com tamanhos, pesos e formas equilibrados) com outros elementos gráficos, como arabescos. O caráter utilitário do folheto, evidenciado pela escolha de uma tabela informativa, invés de uma ilustração, seduz o/a freguês a adquirir a edição.

Na capa destacada [Figura 40], podese salientar componentes estruturantes da superfície do jornal, considerando a nomenclatura estipulada na área: o "fio" (linha utilizada para separar conteúdos da página) e o "box" (moldura contendo texto auxiliar à notícia principal, inserida para gerar um interesse ótico e condensar informações complementares, como dados técnicos). A "colunagem" da tabela inserida no quadro, também remete à visualidade compositiva do gênero.

A face da publicação $O$ cruzeiro novo (1967) é orientada por um esqueleto similar àquele estruturado no gride de $A$ História da Campina Centenária (1964) [Figura 41]. Neste há uma "arte" (imagem) no lugar do "box", ocupando área proporcional, e um gracejo acerca do custo do folheto, substituindo o preço: "Quem leu este vercinho/ Não viu tabelado o preço/ Ponha a mão na consciência/ Que muito vos agradeço/ Como queres que eu te faça/ Fazeis conforme eu mereço". 
A História do Desastre na Lagoa do Parque Solon Lucena em João Pessoa (1975) [Figura 42], flerta de maneira explícita com o diário de notícias ao carregar na capa uma pequena matéria jornalística, interpretada poeticamente no interior do folheto.
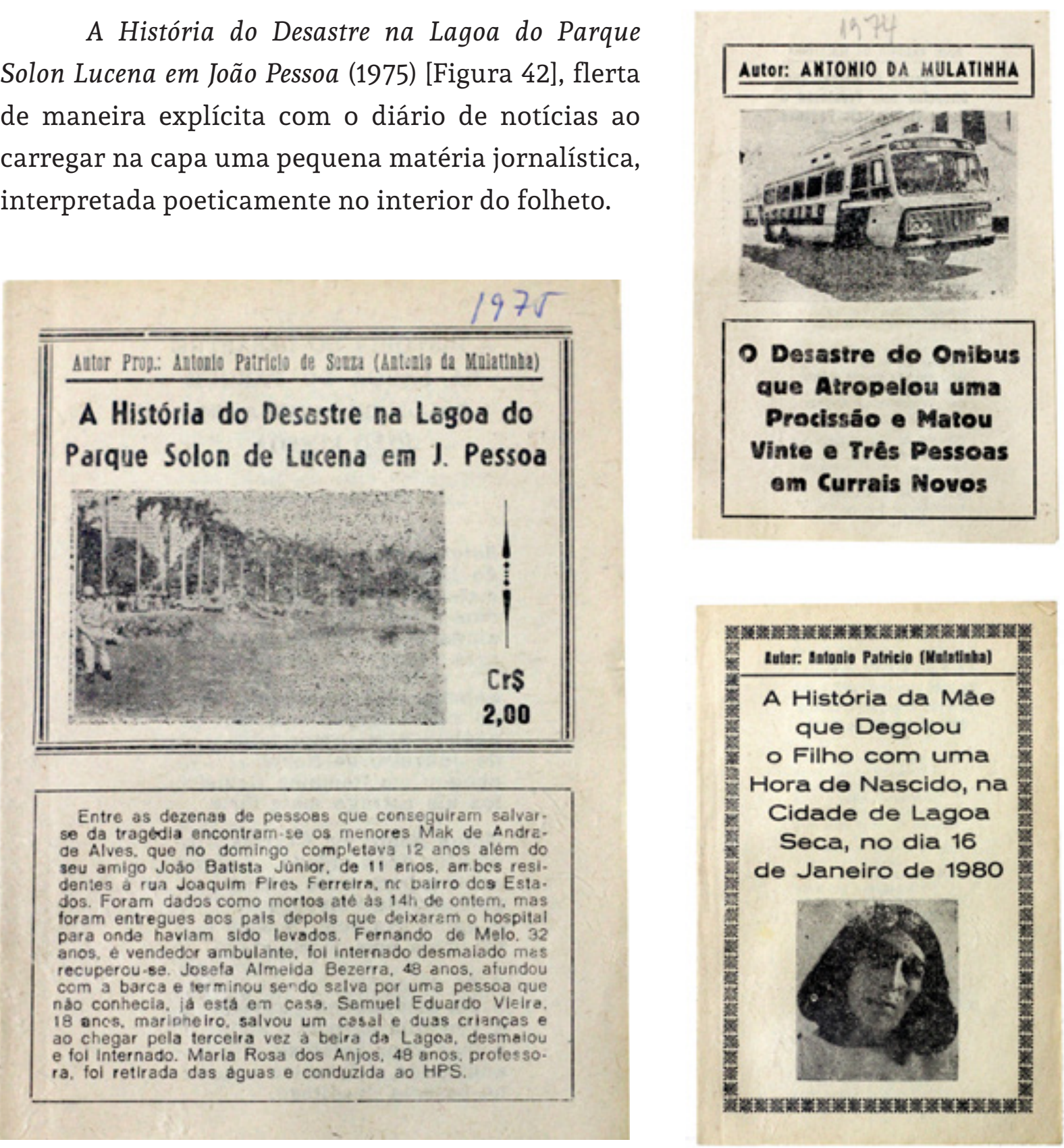

Figura 42 - Capa do folheto A História do desastre na Lagoa do Parque Solon Lucena em João Pessoa (Toinho da Mulatinha, 1975)

Fonte: Biblioteca de Obras Raras Átila Almeida (BORAA/ UEPB)

Figura 43 - Capas de folhetos de Mulatinha cujo os títulos funcionam como "lead"

Fonte: Biblioteca de Obras Raras Átila Almeida (BORAA/ UEPB)

Os títulos de algumas edições de "acontecido" soam como manchetes, mas, principalmente como "lead": o primeiro parágrafo de uma matéria jornalística, posto em evidência, que fornece à/ao leitor(a) informações objetivas que situam o conteúdo no tempo e no espaço, localizando os sujeitos da ação - Quem? Fez o que? Quando? Como? Onde? Por quê? É o que vemos nas capas a seguir [Figura 43]. 
Os folhetos de Toinho da Mulatinha são suportes oriundos de encontros, entre fatos reais e narrativas ficcionais, entre matérias jornalísticas e poesia em verso, entre agentes da indústria gráfica hegemônica e agentes da editoração popular. Encontros mantenedores do brilho da Estrela que orientou o poeta em Campina Grande.

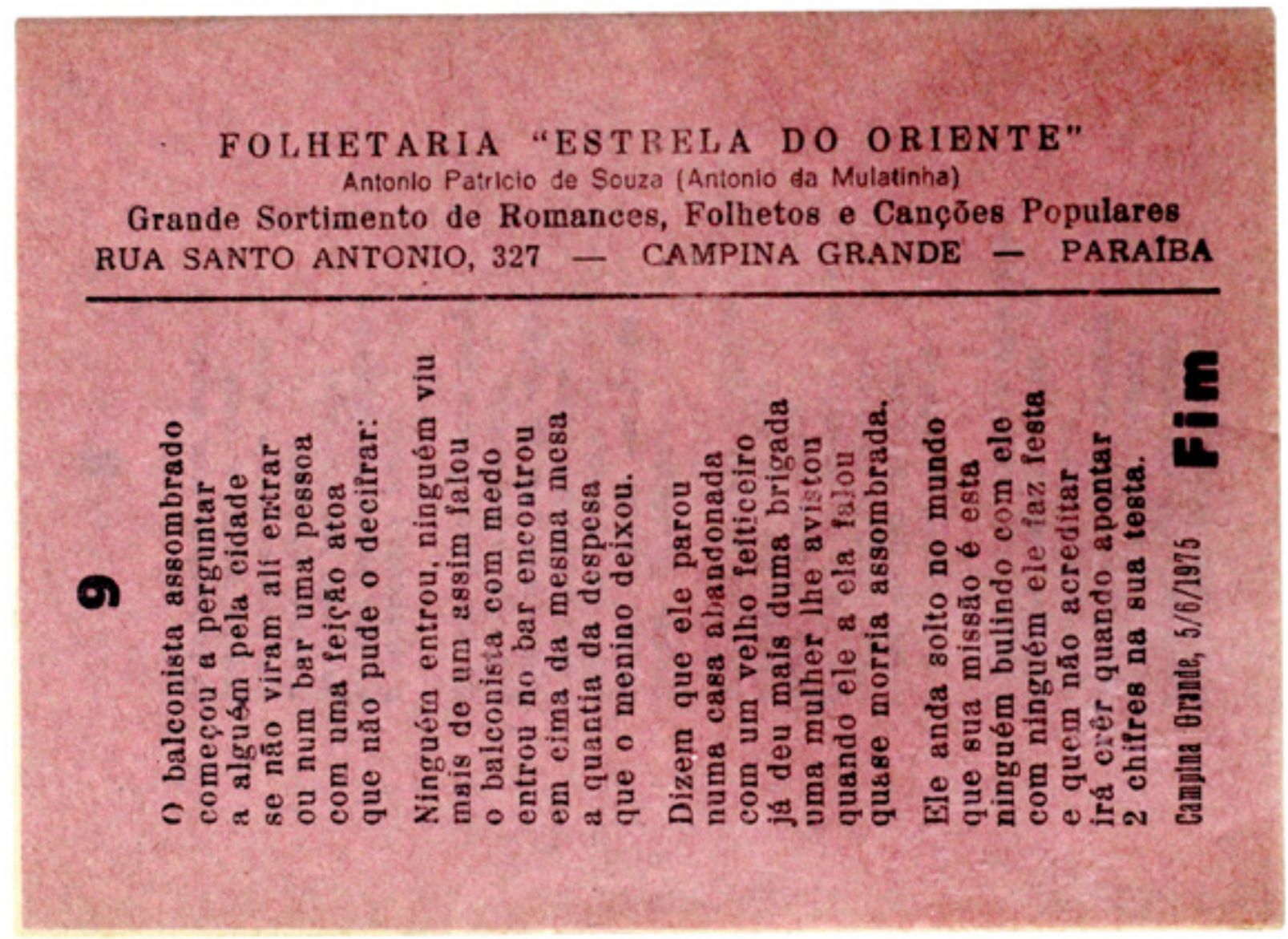

Figura 44 - Quarta capa de folheto autoral do proprietário da Folhetaria Estrela do Oriente, contendo a propaganda da casa editorial/comercial

Fonte: Biblioteca de Obras Raras Átila Almeida (BORAA/ UEPB) 
Ao cotejar os folhetos tutelados pela Biblioteca de Obras Raras Átila Almeida e as gravuras salvaguardas por Toinho da Mulatinha e família, é possível realizar uma espécie de "jogo da memória", descobrindo matrizes e impressos que se combinam e vão formando os pares entre folhetos de autoria de Toinho ${ }^{164}$ e de outros autores. Desta forma, ao olhar esse tabuleiro armado foi possível reconstituir outros jogos e muitos cruzamentos entre poetas de profissão.

O acervo híbrido de Toinho aponta para estratégias de enxadrista. Mexemos as peças desse jogo num xadrez enviesado. Assim, movemos o peão do "poetinha feirante", que a narrativa oficial campinense imobilizou. Mesmo o jogador principiante sabe que peões andam é para frente. Toinho, homem do entre-lugares, moveu-se e foi muito. Aqui, nesse trabalho de intensa pesquisa sobre sua produção, ele avança em zig-zag e anda por muitas casas. Deixamos de lado o diminutivo condescendente. Toinho se move sozinho e ocupa o seu lugar de merecimento: o de poeta-editor.

Figura 45 - Folheto com matriz xilográfica correspondente à ilustração da capa

Fontes: Biblioteca de Obras Raras Átila Almeida (BORAA/ UEPB); Acervo do Poeta Toinho da Mulatinha
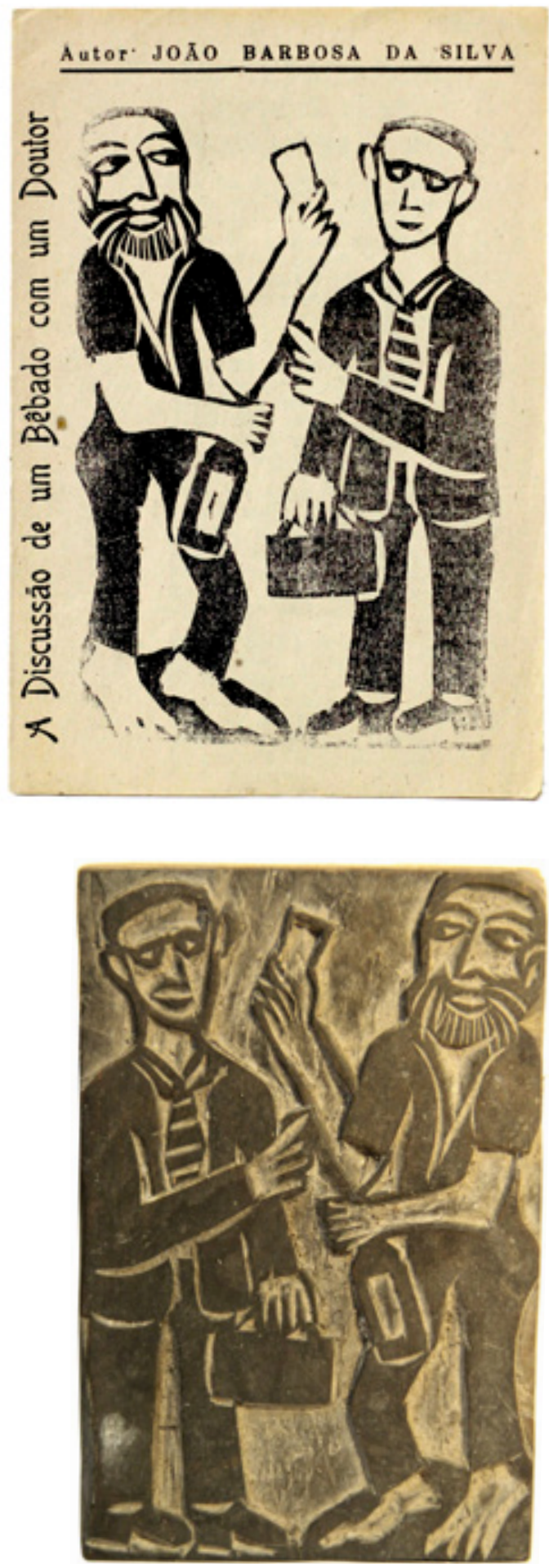

164 Folhetos de autoria de Toinho da Mulatinha (BORAA/UEPB) que têm gravações correspondentes no acervo de matrizes do poeta, ordenadas cronologicamente: A tromba d'água do estado da Guanabara (1966); A Morte do coronel Ludogero e seu companheiro Otrope (1970); A Morte do coronel Ludogero e seu companheiro Otrope (19--); O desastre do ônibus que atropelou uma procissão e matou vinte e tre $\hat{s}$ pessoas em Currais Novos (1974); A história da mulher que matou o filho e jogou num caixão de lixo (1974); A história do Treze Futebol Clube o famoso galo da Borborema (1975); Campina Grande, a viola e as belezas do Nordeste (1976); 0 desastre do caminhão que ia de Esperança a usina Santa Maria (1977); 0 poema do filho que matou o pai no sítio Araçá entre Arara e Serraria (1977) - clichê reutilizado de A tromba d'água do estado da Guanabara (1966); 0 homem que deixou a mulher para viver com uma jumenta (1982); 0 casamento de Bernarde com Maria de Saguim ou o rapaz que casou-se e correu com medo da mulher no dia do casamento (19--). 


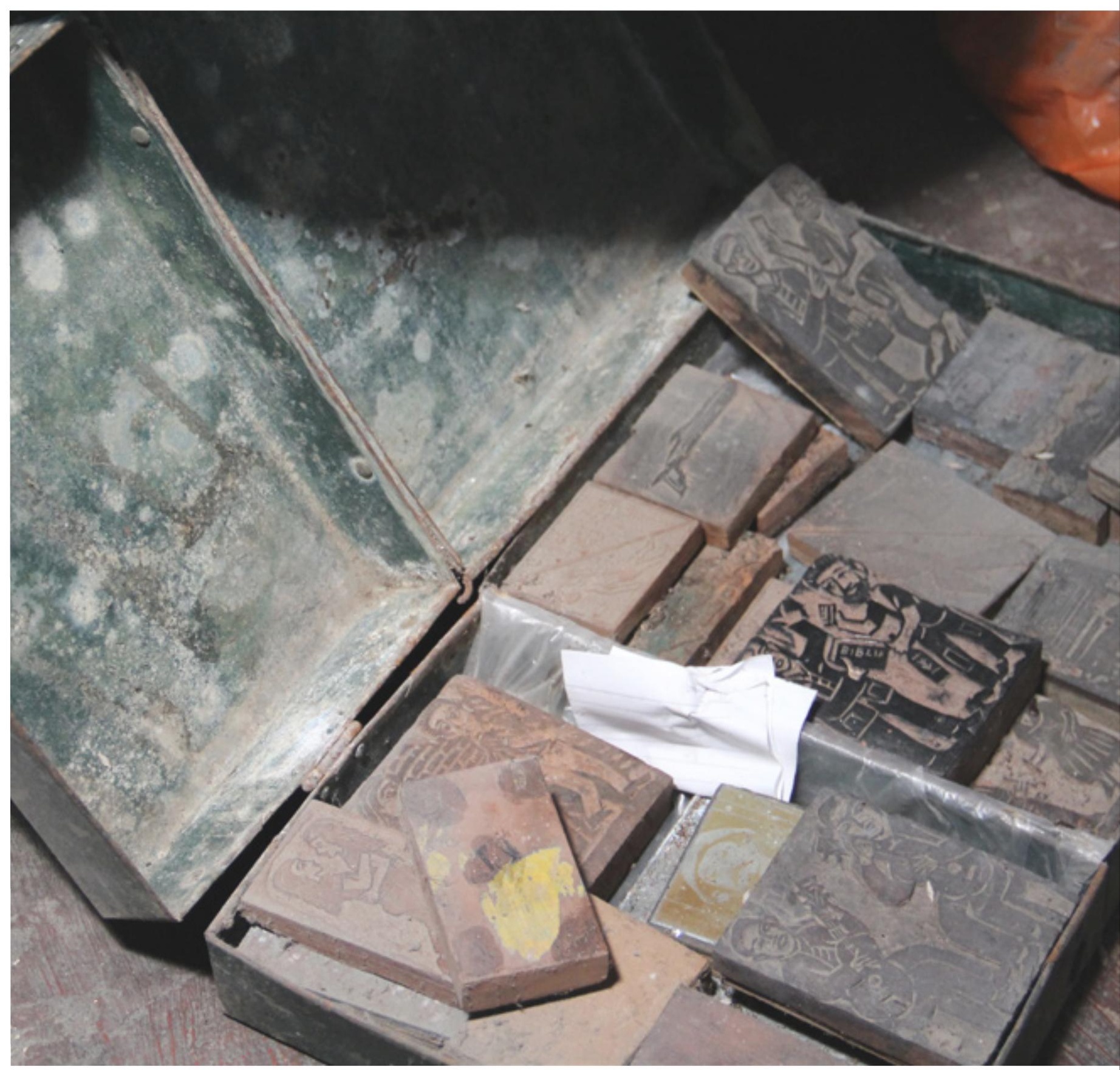

Figura 46 - Maleta na qual Toinho armazenava as matrizes pertencentes ao acervo da Folhetaria Estrela do Oriente

Fonte: Acervo do Poeta - Fotografia: Milla Pizzignacco (2015) 

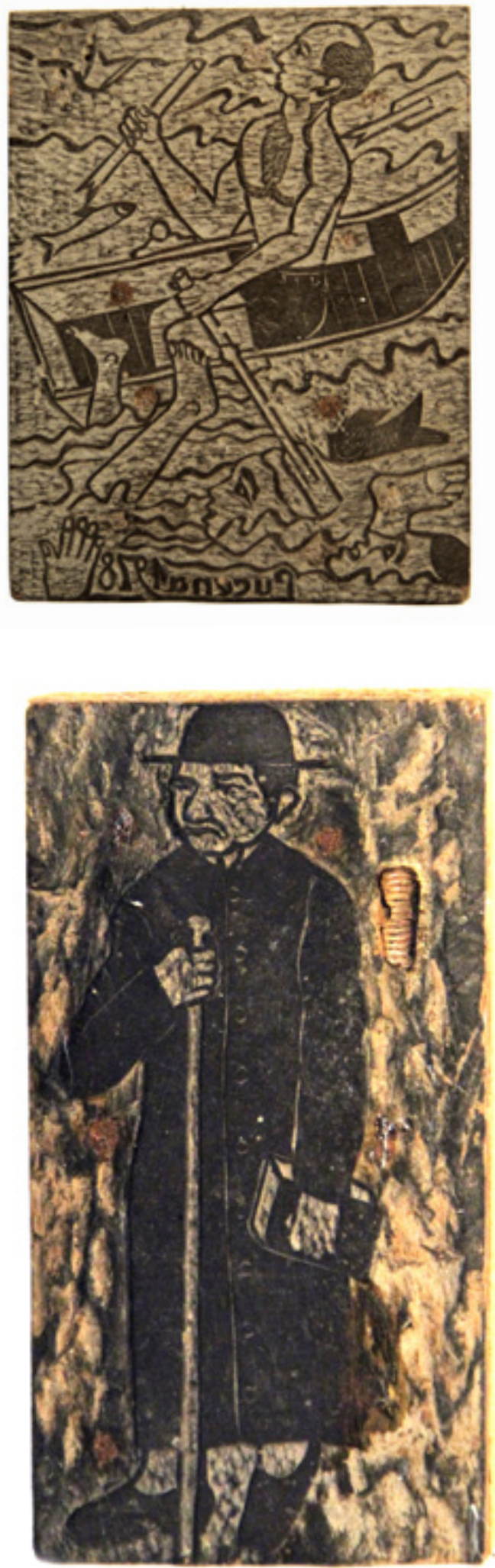

Figura 47 - Seleta de xilogravuras armazenadas no acervo de clichês da Folhetaria Estrela do Oriente

Fonte: Acervo de Toinho da Mulatinha (Tutelado pela família do poeta)
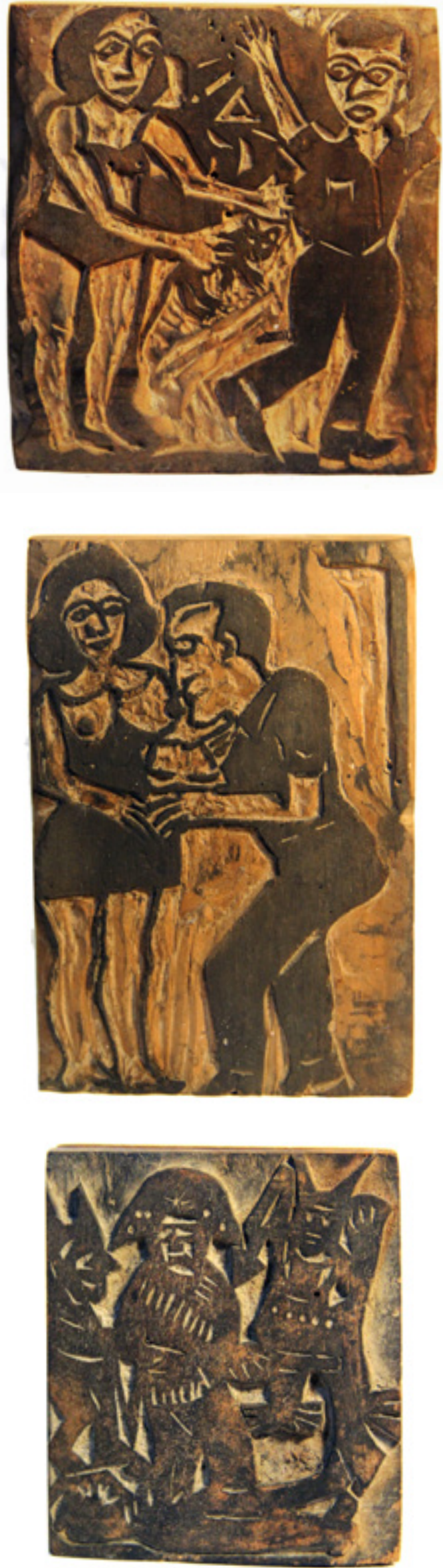

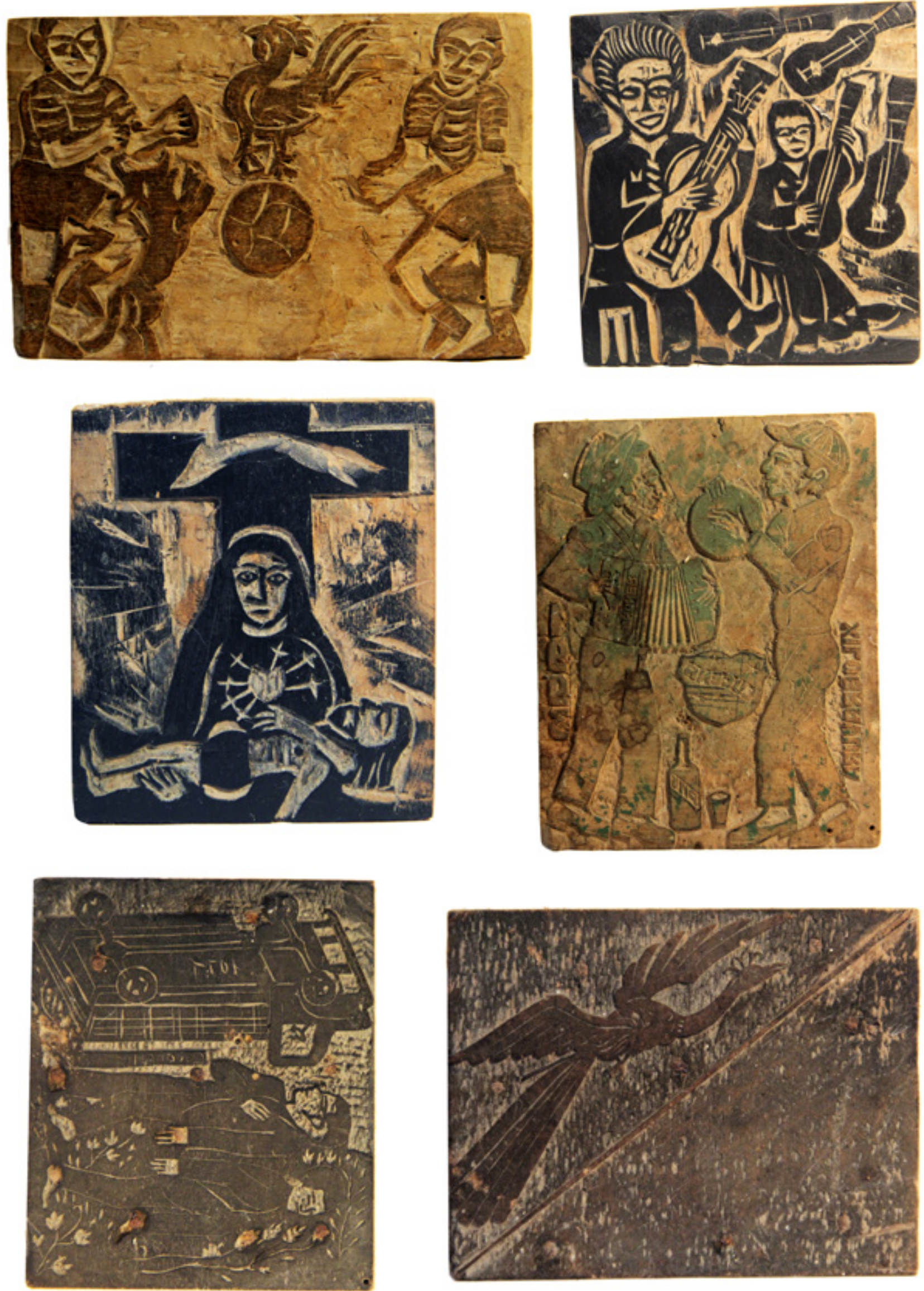
Em meados da década de 1970, o editor Toinho da Mulatinha elege a xilogravura como linguagem predileta para estampar as capas dos folhetos editados pela Estrela do Oriente. A coleção de matrizes de madeira do acervo pessoal do poeta [Figuras 46 e 47] testemunha o vínculo estabelecido com agentes de seu campo produtivo - gravadores especializados em sintetizar poemas metrificados em narrativas visuais.
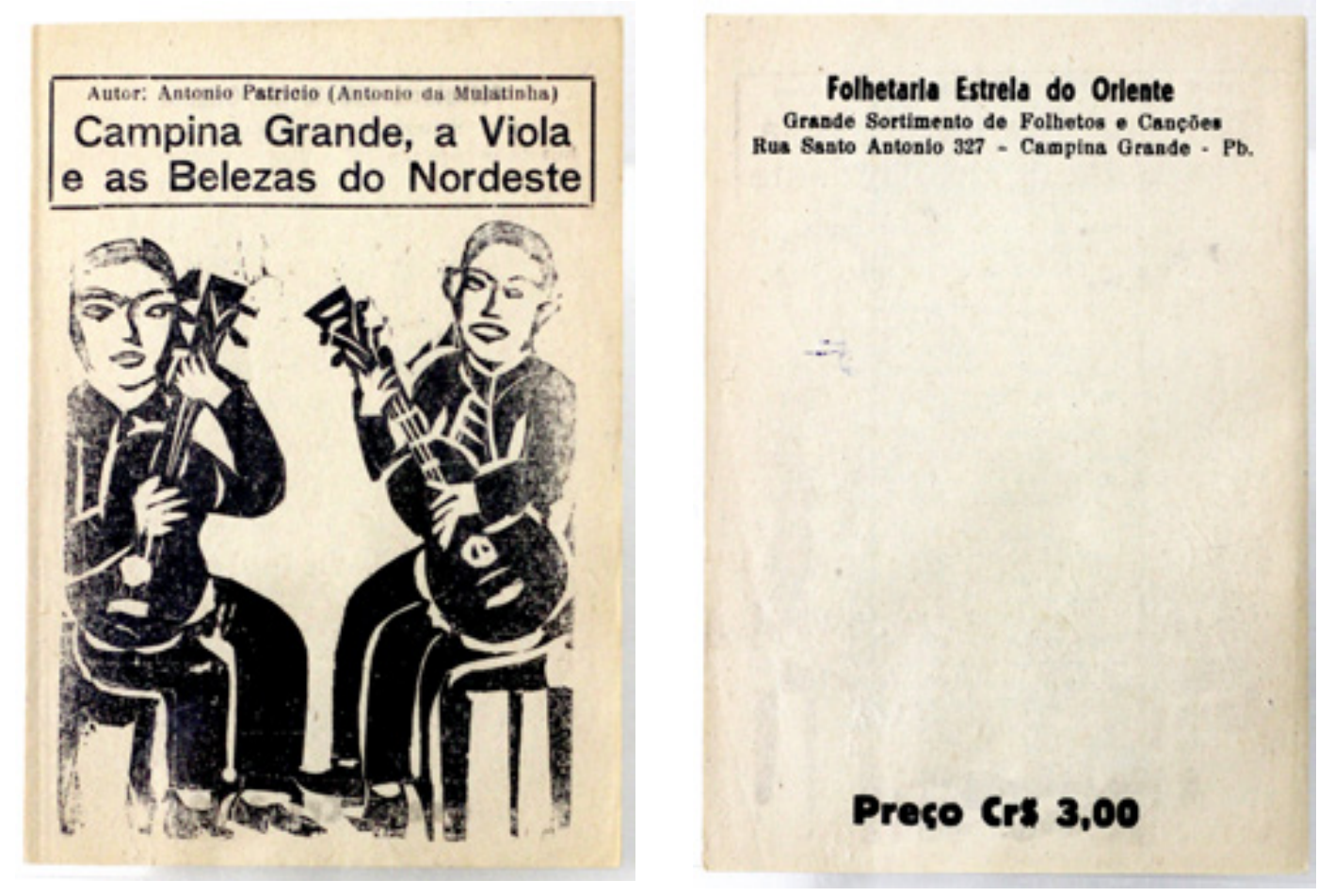

Figura 48 - Folheto de Toinho da Mulatinha ilustrado com xilogravura e matriz correspondente à imagem da capa. Artista desconhecido

Fontes: Biblioteca de Obras Raras Átila Almeida (BORAA/ UEPB); Acervo do poeta Toinho da Mulatinha

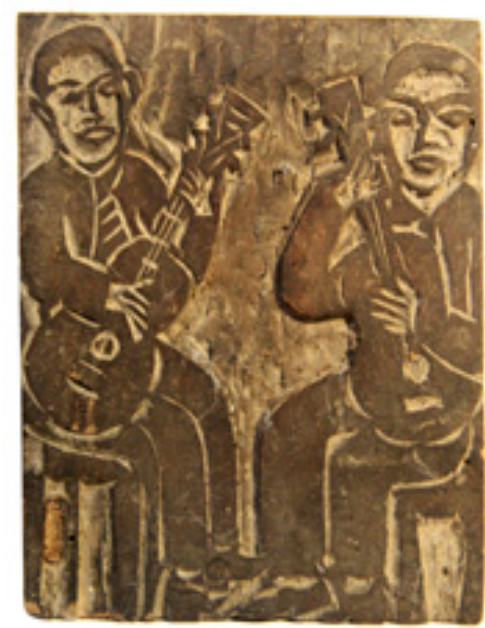

A ausência de assinatura em uma parcela dos tacos do acervo não permite a determinação dos artistas filiados ao poeta-embolar. Porém, aventa-se que entre as treze matrizes sem autoria identificada haja mais de uma matriz gravada pelo artista pernambucano José Costa Leite, detentor de um traço peculiar - memorável diante da ampla disseminação de suas imagens pela mídia. Essa hipótese ganha sustento pelo fato de haver duas impressões originais de Costa Leite no mesmo acervo [Figura 49]. 

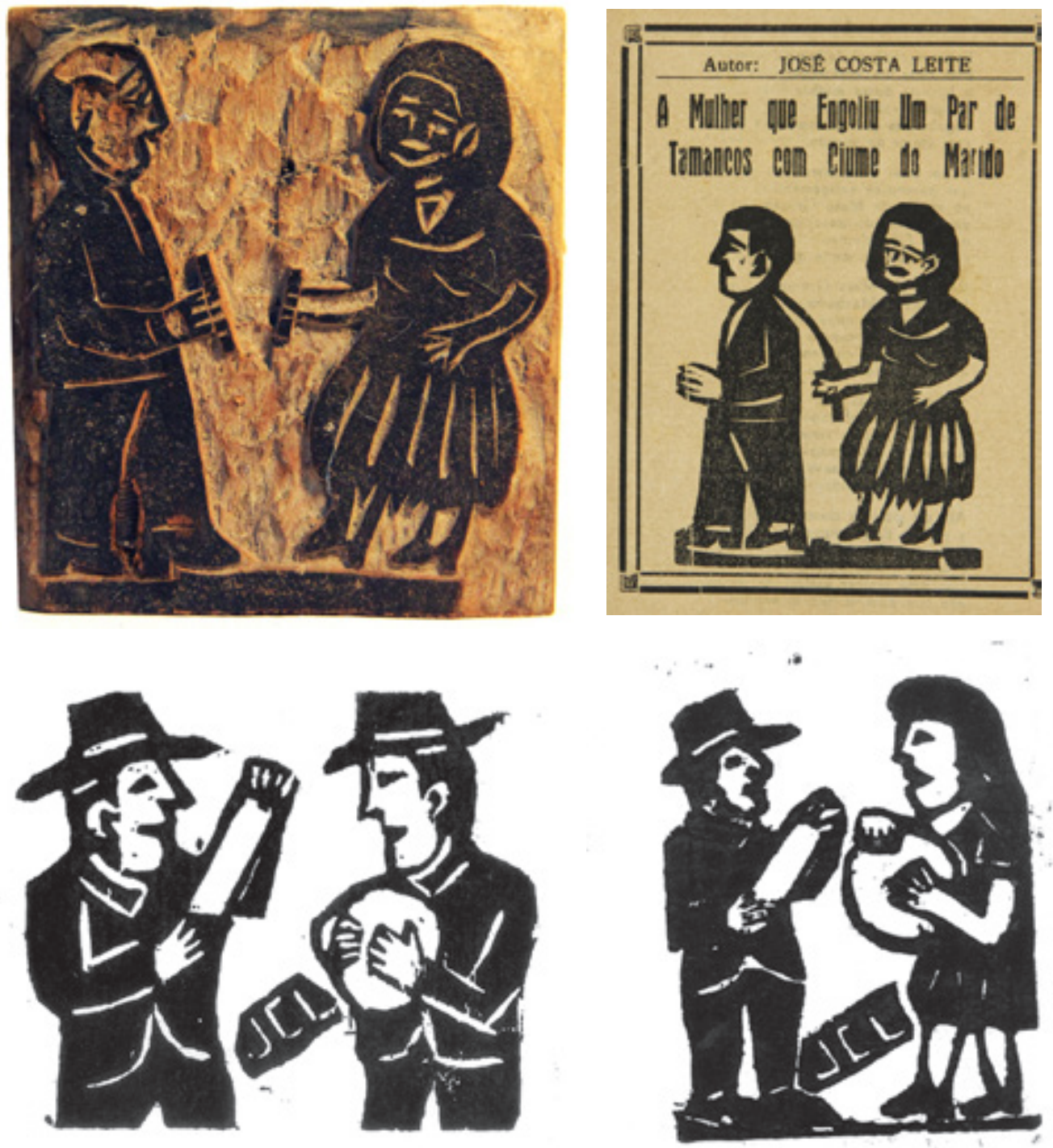

Figura 49 - Taco talhado por José Costa Leite e impressões realizadas a partir de matrizes do xilógrafo

Fonte: Acervo do poeta Toinho da Mulatinha 
Averígua-se no acervo de ilustrações a associação de Toinho da Mulatinha com o poeta-xilogravador Antônio de Araújo Lucena (1931 - 2005), "capista” de renome no seu meio social, que deu rosto a incontáveis folhetos de autores paraibanos e estampou narrativas de poetas consagrados, como Manoel Thomas de Assis e Manoel Monteiro (seu maior parceiro a partir da década de 1990). A estreita parceria da "Folhetaria Estrela do Oriente" com o xilogravurista, é expressa pela quantidade de tacos assinados por Lucena nesse espólio ( $40 \%$ das imagens presentes na coleção de xilos, clichês fotográficos e zincogravuras) e pela existência de "rascunhos" em madeira nesse conjunto, matrizes nunca impressas [Figura 50].
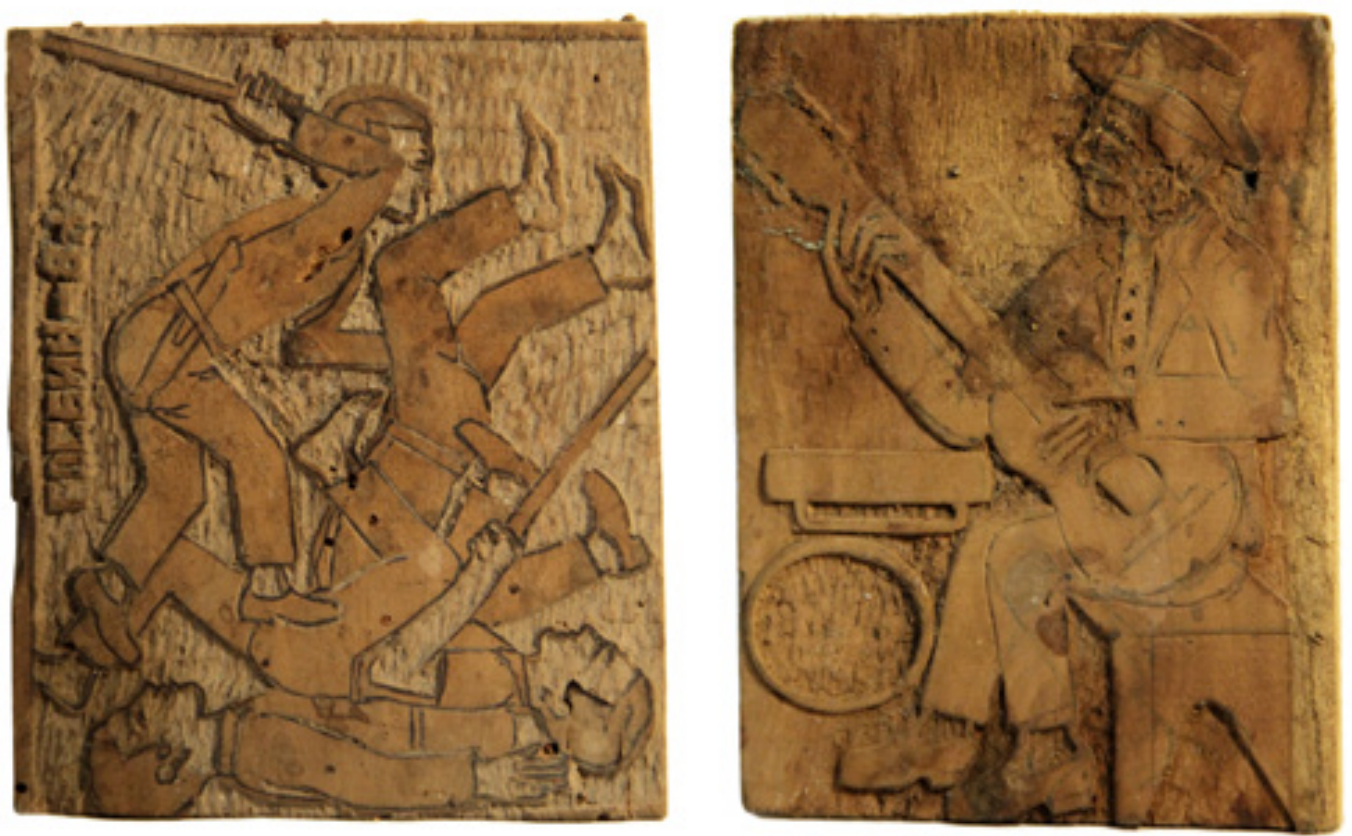

Figura 50 - Matrizes talhadas por Antônio Lucena. Observa-se que nunca foram impressas diante da ausência de resíduos de tinta e da presença de marcações a lápis

Fonte: Acervo do poeta Toinho da Mulatinha

Antônio Lucena tornou-se aclamado entre poetas, por encher os olhos do público com figuras de proporções "vitruvianas”, gravadas por finos traços. A destreza técnica permitiu que o artista criasse corpos e faces expressivos e individualizados, assim como cenas mais complexas, compostas através da sobreposição de elementos em camadas, planos de ação que potencializam a narrativa visual. 


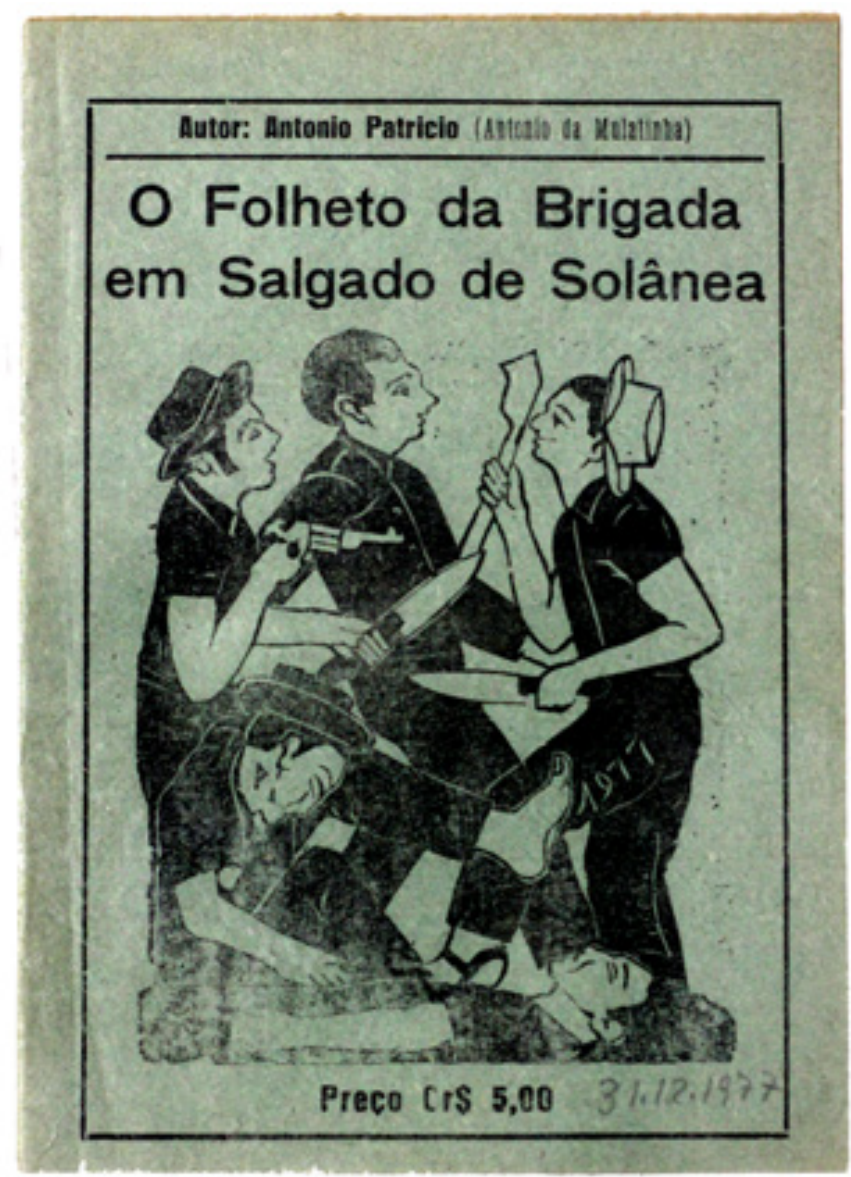

Figura 51 - Capa de folheto escrito por Toinho da Mulatinha e ilustrado por seu parceiro "capista", Antônio Lucena

Fonte: Biblioteca de Obras Raras Átila Almeida (BORAA/ UEPB)
A ilustração da capa do Folheto da Brigada em Salgado de Solânea (MULATINHA, 1977) põe em relevo o senso estético de Lucena, o poetaxilogravurista: o desenho é esquadrado pela posição das personagens na cena e assentado por uma figura estirada na horizontal, que oferece uma base para o desenvolvimento da ação. O conflito dinamiza-se por meio de diversas triangulações, que podem ser estabelecidas na ligação das cabeças das personagens. $\mathrm{O}$ posicionamento das armas, em diagonais, movimenta o olhar no quadro e, condensa a cena, ao convergir em um centro ótico. O estilo empreendido pelo artista refuta narrativas folclóricas sobre a gravura popular, como sendo aquela definida por gestos grosseiros, rudimentares, de forma expressiva inocente, naif.

Ao executar ilustrações com contornos delgados e não apenas massas gráficas positivas e negativas

em contraste, o xilogravador se aproxima do universo das zincogravuras - matrizes que durante a primeira metade do século XX permaneceram como as preferidas dos poetas, sejam desenhadas ou fotogravadas com imagens de cinema/ cartão-postal (difundidas a partir de1920). Através de levantamento bibliográfico acerca da associação da xilogravura à literatura de folhetos e da legitimação desta produção como objeto artístico (HATA, 1999; FRANKLIN, 2007; RAMOS; 2010), podemos perceber essa noção de "estética popular" como produto de um processo de seleção imposto pelo meio letrado. 
No artigo Do mercado ao museu: a legitimação artística da gravura popular (2010), Everardo Ramos destaca algumas instituições universitárias e museológicas que colaboraram na sedimentação desse imaginário e atenta para a exclusão de determinados nomes na história da xilogravura "popular" brasileira (João Pereira da Silva, por exemplo), posto que não atendiam critérios estéticos suficientes, determinados por estudiosos, para integrar a categoria: achatamento dos planos, traços rígidos, ausência de proporções acadêmicas e simplicidade, expressa pela quantidade reduzida de elementos gráficos, como texturas.

A apologia às formas rústicas aparece no discurso do poeta-xilogravurista José Francisco Borges ${ }^{165}$, através da comparação da "gravura popular" com a "erudita", especificamente com as produzidas por Gilvan Samico - um dos representantes do Movimento Armorial:

Você vê que as gravuras do Samico é tudo bem medida... Se ele faz dez risco aqui, os risco são tudo de um tamanho só, na mesma medida, com muito cuidado. Se ele faz as duas mãos, as duas mão é igual uma outra. O popular não, faz uma orelh maior e uma menor, faz um dedo grosso e outro mais fino, daí o trabalho avança muito [em termos de criatividade]. O erudito obedece às regras do desenho para fazer aquilo muito bem sofisticado, muito bem medido, bem desenhado. (BORGES, 2015) ${ }^{166}$

Interessante que o primeiro registro xilográfico identificado por pesquisas da área, impresso em uma página interna do folheto Antônio Silvino - O rei dos cangaceiros (Francisco das Chagas Batista, Imprensa Industrial - Recife, 1907) não atende esses critérios [Figura 52]. Assim, as gravuras produzidas por Antônio Lucena não entraram para catálogos ou coleções de "gravura popular brasileira", mesmo produzindo ativamente durante o período da invenção dessa categoria artística, na década de 1960 - época marcada por peregrinações em busca de cópias de ilustrações e matrizes de xilogravura para constituição da primeira coleção do gênero, criada pelo do Museu de Arte da Universidade do Ceará (MAUC).

165 José Francisco Borges (1935, Bezerros - PE) é poeta e xilogravurista. Filho de agricultores, frequentou a escola aos 12 anos, por poucos meses. Em 1964 escreveu seu primeiro folheto, 0 Encontro de Dois Vaqueiros no Sertão de Petrolina, ilustrado por Dila de Caruaru. Entusiasmado com o sucesso de vendas, produziu 0 Verdadeiro Aviso de Frei Damião Sobre os Castigos que Vem (196-), que o conduziu pela primeira vez à xilogravura. Desde então, começou a fazer matrizes para ilustrar suas publicações e encomendas. Hoje suas gravuras são produzidas em grandes dimensões e quantidade, sendo comercializadas no Brasil e no exterior como objeto de arte. Borges mantém em funcionamento uma oficina de xilogravura e folhetaria em sua terra natal.

166 BORGES, José Francisco. Depoimento [jan. 2015]. Entrevista concedida à pesquisadora. Bezerros (PE), 2015 


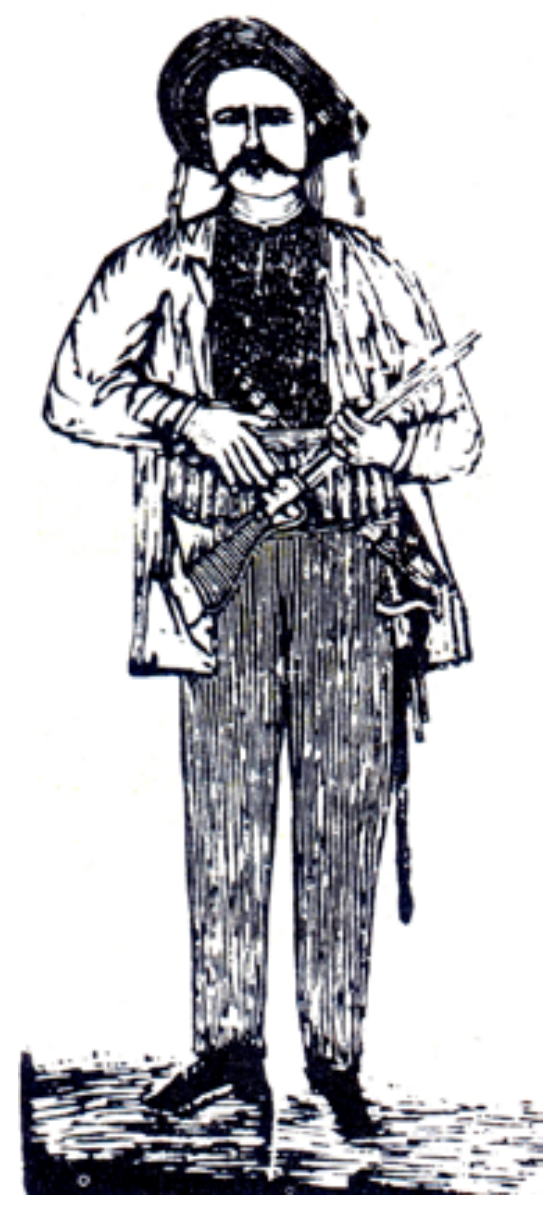

Figura 52 - Primeira xilogravura encontrada em folheto (Antônio Silvino - O rei dos cangaceiros. Francisco das Chagas Batista, 1907)

Fonte: FRANKLIN (2007)
As instituições artísticas e acadêmicas foram fundamentais na construção do discurso que imprimiu forte julgamento estético às técnicas e imagens utilizadas nas capas dos folhetos, criando uma amálgama entre xilogravura "primitiva" e literatura de cordel - lembrando que este termo foi implementado por intelectuais. Essa narrativa, responsável pelo "achatamento de planos", foi, inclusive, capaz de inverter o lugar histórico da xilogravura na ilustração das capas dos folhetos. Esse anacronismo constitui o discurso do crítico de arte Lourival Machado, diretor do Museu de Arte Moderna de São Paulo, instituição que abrigou a primeira exposição exclusiva do gênero:

[asxilogravuras] jádesapareciam,nosmostruários dos cantores-vendedores, sob o maior número de folhetos capeados por péssimas reproduções de fotos tiradas de revista de cinema [...]. Os xilógrafos populares já cediam inteiramente seu território físico - as capas dos folhetos - à fotografia imbecil dos cartões postais, à pobre caricatura das revistas litorâneas, à romântica reprodução das cenas de filme. (MACHADO, 1960 apud RAMOS, 2010, p. 46-47)

Na perspectiva do crítico paulista, a técnica de xilogravura parecia mais adequada ao domínio "popular", por se tratar da mais antiga técnica de reprodução de imagem, realizada por um processo integralmentemanual.Em contraposição, a zincogravura é condenada por ser um processo fotomecânico, fruto da Revolução Industrial do século XIX, e também pela sua representação realista, além do seu vínculo com o cinema, uma invenção moderna. Privilegiar a primeira técnica em detrimento da segunda, revela a romantização diante do artesanal.

Na obra pioneira sobre as capas e os ilustradores de folhetos populares, Liêdo Maranhão (1981) evidencia 
a predileção dos poetas e do público tradicional de folhetos pelos clichês de metal à moda belle époque, responsáveis inclusive por conferir autenticidade às histórias, posto que algumas imagens já eram consagradas na representação de determinados títulos, além de possibilitarem a associação rápida com o gênero do folheto.

A noção de autenticidade levou a Tipografia São Francisco (Juazeiro do Norte - CE) a reproduzir fotografias cinematográficas em xilogravura na década de 50, com o objetivo de substituir clichês desgastados pelo uso e pela ação do tempo ${ }^{167}$. Manoel Caboclo, poeta-impressor-editor, rejeitou a remenda. Em sua perspectiva:

A zincogravura é uma coisa que ajuda o povo de menor cultura porque o clichê de zinco representa figura nítida e perfeita de um artista. E o clichê de madeira representa a inteligência. Eu não desprezo nem um nem outro. Um é para o matuto, o outro para o intelectual, porque o intelectual acha que seja mais perfeita uma coisa manual do que mecânica. [...] Para os turistas, a gravura de madeira é melhor. Para o pessoal da praça do mercado, eles preferem a gravura de zinco. As novas, eles não gostam muito, porque pensam que é falsificada. Um romance tem que ter um clichê bom, se não o matuto olha e não tem vontade de comprar. [...] Eu já avisei a dona Maria José $^{168}$ que as gravuras que estão botando naqueles romances vai findar ninguém comprando mais. A não ser turista, porque turista compra. Sendo de zinco ele não quer. De madeira eles querem, porque interessa mais a gravura do que a história. Agora mesmo, rejeitei o romance Rosa Munda e a Morte do Gigante, era uma capa de zinco, mudaram para madeira. Se eu apresentar este romance a qualquer pessoa aqui da praça, eles vão dizer que é falsificado. Que isto não é Rosa Munda. Isto é qualquer coisa por ai! Quem lê folheto é gente quase analfabeta. É um sujeito que está acostumado com aquelas gravuras de Athayde. [...] E o prejuízo vem pra mim, porque eu vendo ao pequeno folheteiro. E a decadência do folheto vem por causa disso. Uma gravura esquisita não fica idêntica ao que era antigamente e torna-se ruim para vender. (MARANHÃO, 1981, p.23-25.) (169 $^{16}$

Ao destinar cada tipo de gravura a um determinado público, polarizado pelos termos "matuto" e "intelectual”, Manoel Caboclo veicula um discurso diametralmente oposto àquele empregado pelo crítico de arte paulista e reitera o fato de a xilogravura ser uma técnica escolhida por intelectuais, mais interessados com a exterioridade dos folhetos do que com o conteúdo. A opção das capas xilogravadas por Toinho da Mulatinha, justamente na década de 1970, momento de criação do Movimento Armorial por Ariano Suassuna, pode ser associada a esta

167 Para acessar as imagens das reproduções xilográficas de clichês de metal, ver: HATA, 1999, p. 70.

168 Filha do editor-proprietário José Bernardo da Silva.

169 Grifos da pesquisadora. 
tendência, ou mesmo ao desejo de fazer capas com "clichê bom”, já que o artista era hábil em gravar "figuras nítidas" em madeira.

As xilogravuras são fixadas nas capas dos folhetos de Toinho da Mulatinha [Figura 53], no mesmo momento em que institui a palavra "cordel" para designar o suporte de sua literatura. A implementação do termo, resultado da confluência entre os campos acadêmico e popular, revela a percepção de Toinho sobre o novo contexto de inserção dos folhetos de feira, no qual "estava ganhando terreno em literatura", mas "perdendo em leitura", como diagnosticou Manoel Camilo dos Santos (CAMILO DOS SANTOS apud LESSA, 1984, p. 76).

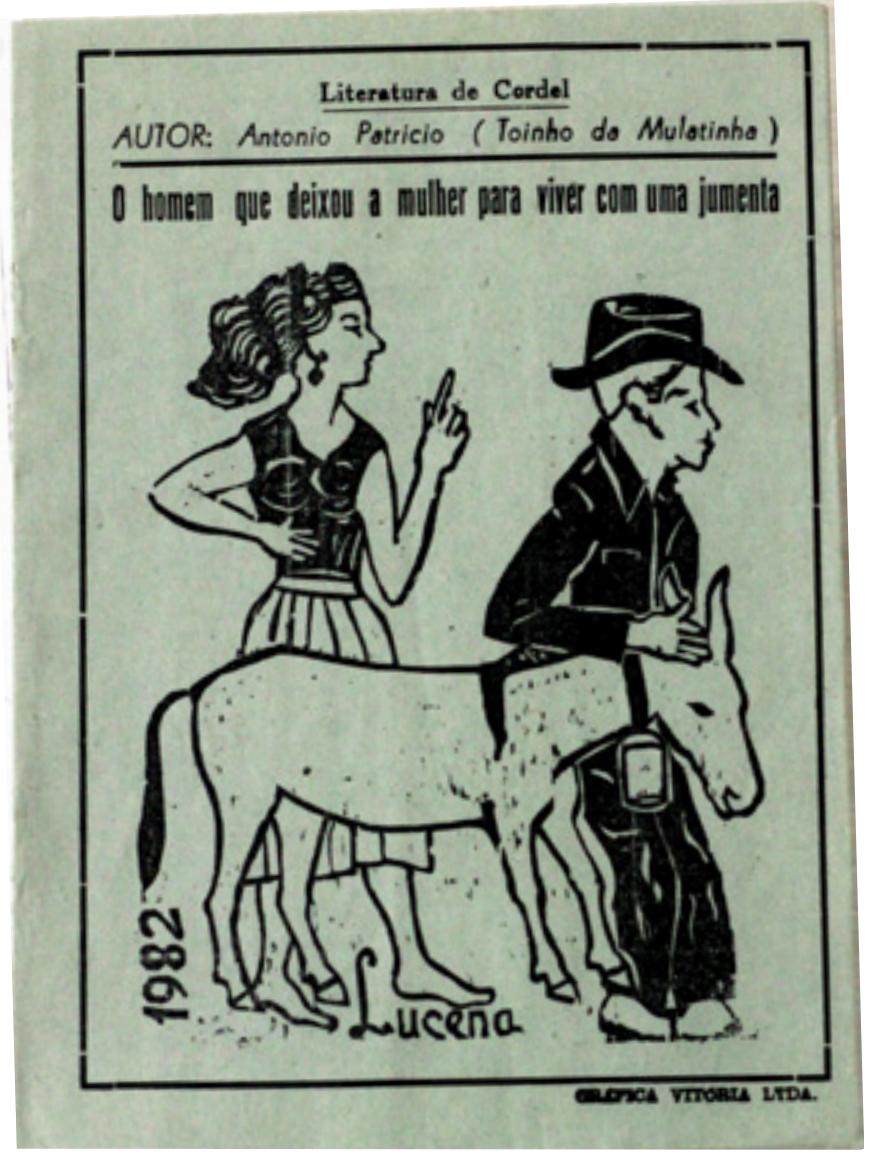

Figura 53 - Capa de folheto escrito por Toinho da Mulatinha e ilustrado por Antônio Lucena

Fonte: Biblioteca de Obras Raras Átila Almeida (BORAA/ UEPB);

Essa breve explanação sobre a "estética popular", motivada pelas gravuras de Antônio Lucena, mostra que as artes e a ciência foram estruturantes na construção de determinados discursos sobre "cordel", "Nordeste" e "cultura popular", assim como passam a ser fundamentais na construção de outros discursos, como nos mostra Liêdo Maranhão (1981), produtor de uma pesquisa quem surge na esteira de discussões mais engajadas sobre a "cultura popular", elencadas no próximo tópico. $\mathrm{O}$ aumento do interesse institucional pelo tema também irá fomentar a formação de acervos que fornecem vestígios de personagens integrantes de uma narrativa decolonial. 


\section{ESTRELANDO NA “CULTURA”}

Poesia popular, hoje, é coisa importante. É assunto de gente danada pra saber das coisas em João Pessoa, Salvador, Rio, São Paulo, Nova Iorque... - Antigamente uma pessoa vinha do Rio (se lembra?) pra falar com a gente, era novidade. Hoje é o que não falta! Vem o professor não sei quem, lá da Europa. Vem aquela professora bacana da universidade, não me lembro o nome, um negócio chamado Arizona na Califórnia (É Estados Unidos não é?) ${ }^{170}$ toma nota, escreve adoidada, enxuga o olho, tira fotografia, me abraça. Teve um que gastou oito rolos de fita pra gravar um livro meu que ainda não saiu. Dá até vontade de falar inglês pra conversar melhor com os homens, saber o que eles vão fazer com a vida da gente. (CAMILO, 1979 apud LESSA, 1984, p. 76)

$\mathrm{O}$ acesso às publicações de Toinho da Mulatinha exibidas até esta etapa do trabalho, deve-se ao fato das brochuras populares estarem, nos capítulos finais do século XX, "ganhando terreno em literatura" - como constatou Manoel Camilo dos Santos. As transformações ocorridas entre as décadas de 1970 e 1980 relativas às perspectivas teóricas dos estudos sobre folhetos e o interesse crescente das universidades na formação de coleções especializadas no gênero determinaram a existência dessa e de outras pesquisas que estavam lidando, e ainda iriam lidar, com o folheto-suporte.

A formação do acervo do poeta-embolador, pertencente ao arquivo da biblioteca da Universidade Estadual da Paraíba (BORAA/UEPB), deriva-se de iniciativas de arquivamento que ganharam força a partir da década de 1960 com a institucionalização dos estudos sobre cordel no Brasil e a conceituação desta prática cultural enquanto poesia popular impressa e autoral. ${ }^{171}$ A coleção de folhetos de Antônio Patrício de Souza (Toinho da Mulatinha) foi composta através da aquisição do espólio de cordéis do professor Átila Almeida (2004) ${ }^{172}$ e doação de exemplares pelo Núcleo de Pesquisa e Ensino de Letras - NUPEL da UFPB $(2014)^{173}$.

As ações para construção de bancos de dados desenvolvidas a partir da segunda metade do século XX, têm como lastro histórico as Missões de Pesquisas Folclóricas de Mário de Andrade (1938), a fundação da Sociedade Brasileira de Folclore por Câmara Cascudo (1941) e a criação da Comissão Nacional de Folclore (1947) - demandada pela Organização das Nações Unidas para a Educação, a Ciência e a Cultura (UNESCO) em

170 Refere-se à Candace Slater, autora do livro: $A$ vida no barbante: a literatura de cordel no Brasil (1984).

171 A "divisão entre a literatura folclórica (anônima e transmitida pela oralidade) e a literatura popular (impressa e marcada pela autoria)" foi implementada na década de 1980 pela Fundação Casa de Rui Barbosa - Rio de Janeiro (MELO, 2019b, p. 79).

1720 referido acervo foi adquirido em 2003 pelo Governo Estadual da Paraíba, em negociação com a viúva de Átila Almeida, Ruth Almeida, e transferido para a Universidade Estadual da Paraíba (UEPB) em 2004.

173 Informação fornecida pela equipe da Biblioteca de Obras Raras Átila Almeida via e-mail (12/09/2019). 
vistas da implantação de mecanismos para documentar e preservar tradições nacionais “em vias de desaparecimento”, de acordo com avaliação do órgão (MELO, 2019b).

A ação encabeçada pela UNESCO resultou na instalação da Campanha de Defesa do Folclore Brasileiro (1958) ${ }^{\mathbf{1 7 4}}$ e na convocatória de poetas paraibanos contemporâneos de Toinho da Mulatinha para integrar uma operação designada à composição de um arquivo para o estudo das tradições nacionais. Dentre os nomeados estava o poeta José Alves Sobrinho (1921 - 2011), um dos responsáveis pela formação do cabedal que sustenta esse trabalho, uma vez que atuou na constituição do acervo pessoal de Átila Almeida (vendido à Universidade Estadual da Paraíba, em 2003). Nessa empreitada específica, o repentista colaborou com a coleta de materiais para compor as coleções da Fundação Casa de Rui Barbosa e da Biblioteca Amadeu Amaral, no Rio de Janeiro, e da Universidade Federal de Campina Grande, em Campina Grande.

Antes mesmo dos caminhos de Zé Alves serem atravessados por agentes de instituições de pesquisa empenhadas no arquivamento de registros tangíveis das poéticas populares, o cantador-semeador já coletava narrativas dos poetas que cruzavam seu itinerário geo-poético. Na década de 1960 um trauma nas cordas vocais (responsável por tornar o repentista afônico no auge de sua carreira) ${ }^{175}$, ampliou seu desejo de fixar narrativas no papel, para que não se dissipassem no ar ou fossem levadas com as vozes dos narradores.

A rouquidão demandou do Uirapuru ${ }^{176}$ o desenvolvimento de novas maneiras de ordenar palavras, reapresentadas em estruturas rígidas, exigentes de uma interação solitária. Nesse silêncio reconstruiu seu espaço de voz, como escritor de folhetos e pesquisador, e viveu uma viagem “entre mundos” (o empírico e o científico), tão intensa quanto aquelas que fizera entre as décadas de 1930 e 1960.

Essa "viagem" tem como ponto de partida o encontro com Átila Almeida (1923 - 1991), um professor de física que se aproximou das fórmulas da poesia popular e de matemáticos rítmicos por intermédio de seu pai, o historiador Horácio de Almeida, um dos fundadores da Academia Paraibana de Letras. Da parceria firmada entre o poeta-pesquisador com o folclorista, nos anos 1970, despontou a primeira publicação em livro de Zé Alves: Sabedoria de Cabôco (1975).

José Alves Sobrinho protagoniza esse momento da pesquisa pois desbravou outros

\footnotetext{
174 A "Campanha do Folclore Brasileiro"(1958), primeiro órgão permanente dedicado a esse campo, foi inicialmente vinculada ao Ministério da Educação e Cultura e incorporada em 1976 à Funarte como "Instituto Nacional do Folclore". Em 2003, a instituição é denominada "Centro Nacional de Folclore e Cultura Popular" e passa a integrar a estrutura do Iphan (Instituto do Patrimônio Histórico e Artístico Nacional). Informações disponíveis em: < http://www.cnfcp.gov.br/interna.php?ID_Secao=1 >. Acesso em: 20 nov. 2019.

1750 poeta recuperou a voz através de fisioterapia, mas não pôde voltar a praticar cantoria.

176 Alcunha pela qual foi conhecido o cantador-repentista José Alves Sobrinho.
} 
itinerários para o cordel, calcando em Campina Grande uma ação ímpar realizada entre o campo acadêmico e o de ciências que a academia não domina.

Em 1977 José Alves Sobrinho passou a integrar a Universidade Federal da Paraíba como pesquisador, a convite do professor Átila Almeida. No ano seguinte publicou em co-autoria com o folclorista o Dicionário bio-bibliográfico de repentistas e poetas de bancada (1978). Escrito em apenas setenta dias, o Dicionário de dois volumes é fruto da compilação de anotações realizadas durante décadas por José Alves, acrescidas de informações sobre poetas de bancada e repentistas da nova geração - recolhidas por meio de trabalho de campo financiado por Átila Almeida e depois pela Universidade Federal da Paraíba (DINIZ, 2010). Essa foi a primeira publicação a grafar uma pequena biografia do poeta-embolador Antônio Patrício de Souza, assim como catalogar uma biografia parcial de sua obra (ÁTILA; SOBRINHO, 1978, p. 229).

Ainda que Átila Almeida estivesse vinculado a correntes ideológicas folcloristas, expressas no seu desejo de colecionamento e classificação das poéticas da oralidade (patente no Dicionário bio-bibliográfico de repentistas e poetas de bancada), sua prática alinhase com princípios ideológicos gestados no ambiente acadêmico ao longo das décadas de 1960 e 1970, pautados na desobjetificação dos sujeitos das pesquisas, que passam a ter um papel ativo na construção das narrativas históricas; na compreensão do folheto-suporte como material literário e fonte documental, de potencial interdisciplinar; na construção de ações concretas de fomento e salvaguarda destas produções. A participação do professor em congressos onde foram empreendidos "debates entre a visão folclorizada da literatura de cordel e a defesa de uma arte marcada pelos processos de ressignificação da cultura popular", tal como o "II Ciclo de Literatura de Cordel” (Universidade Federal do Ceará, 1981), sustentam essa asserção (NOGUEIRA, 2019, p. 269).

$\mathrm{O}$ ano de ingresso de José Alves Sobrinho na Universidade Federal da Paraíba é marcado por iniciativas de salvaguarda da literatura de folhetos: a criação de um acervo de folhetos de cordel no campus de João Pessoa, motivado pelo "Programa de pesquisa em Literatura Popular” vinculado ao departamento de Letras Clássicas e Vernáculas e a publicação de uma série de títulos de poetas locais pela UFPB, dentre os acessados: A verdadeira história de Jesuino Brilhante cangaceiro e herói - Volume II (José Alves Sobrinho, 1977 - publicação n ${ }^{\circ}$ 3); Vida, obra, glória e morte do Dr. Osvaldo Cruz (José Alves Sobrinho, 1977 - publicação n ${ }^{\circ}$ 4) [Figura 54]; Descrição da flora medicinal. Quais as plantas que curam (Dedé da Mulatinha, 1997 - publicação n 6); Peleja de João Severo de Lima com Manoel Camilo dos Santos (João Severo de Lima, 1977 - publicação ${ }^{\circ}$ 9); A gente pode livrar-se do mal que faz o barbeiro (Severino Sertanejo, 1977 - publicação n $\left.{ }^{0} 10\right)^{177}$.

177 A coleção das publicações realizadas pela Universidade Federal da Paraíba em 1977 não foi encontrada na íntegra nos acervos investigados, Biblioteca de Obras Raras Átila Almeida (UEPB) e Acervo José Alves Sobrinho (Universidade Federal de Campina Grande - UFCG). 

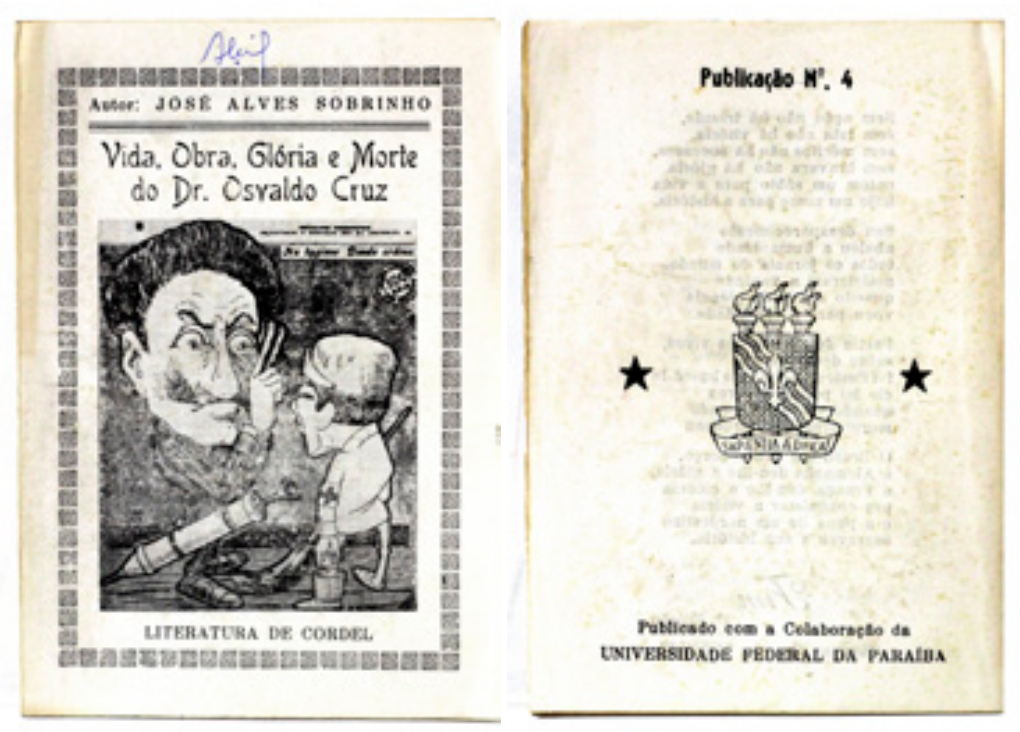

Figura 54 - Folheto de José Alves Sobrinho publicado com a colaboração da Universidade Federal da Paraíba [1977)

Fonte: Biblioteca de Obras Raras Átila Almeida (BORAA/ UEPB);

Em Campina Grande, a Universidade Regional do Nordeste (atual Universidade Estadual da Paraíba), editou textos de poetas da região, como As plantas medicinais (Caetano Cosme da Silva,1981), e folhetos de tributo, como Homenagem aos poetas populares e repentistas paraibanos (Universidade Regional do Nordeste,1976).

A Publicação do cordel II Congresso Nacional de Violeiros Campina Grande Paraíba; 22 - 24 de Agôsto de 1975 [Figura 55], realizada pela Universidade Regional em parceria com a Associação de Poetas e Repentistas Nordestinos (fundada em 1974), mostra além do papel da universidade no circuito de impressão de brochuras populares, o impacto dos festivais de viola na produção de poesia escrita em Campina Grande.
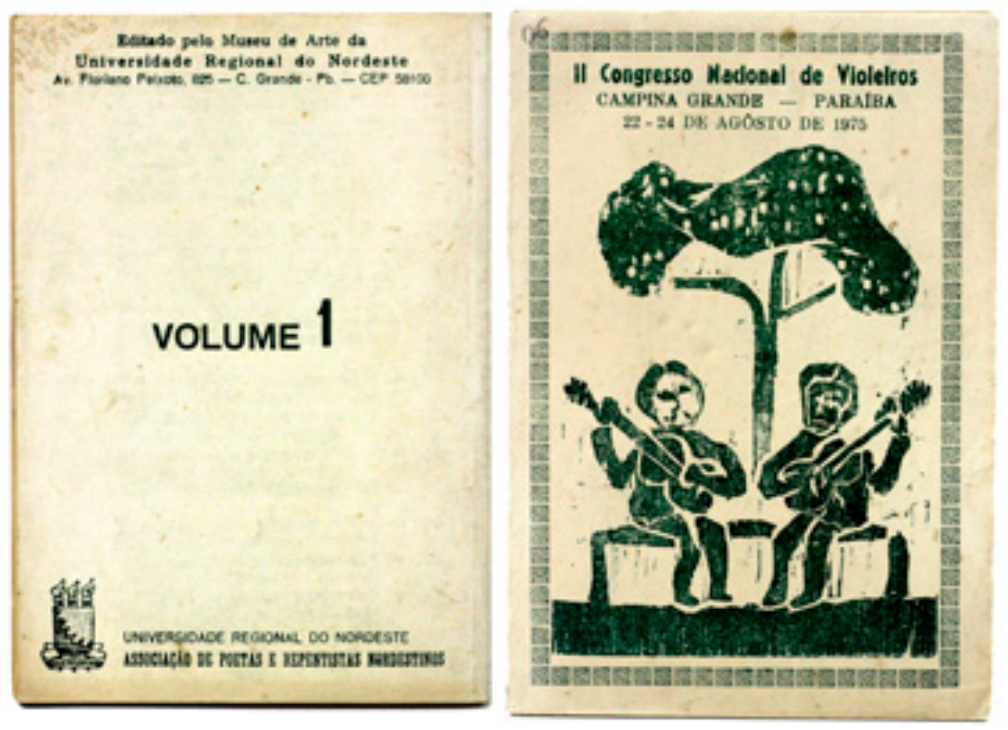

Figura 55 - Folheto acerca do ll Congresso Nacional de Violeiros, realizado em Campina Grande - editado pelo Museu de Arte da Universidade Regional do Nordeste (1975)

Fonte: Biblioteca de Obras Raras Átila Almeida (BORAA/ UEPB); 
$\mathrm{Na}$ quarta capa do folheto O Caboclo do Bode (1974), Manoel Camilo dos Santos saúda iniciativas de fomento, tecendo agradecimentos aos intelectuais "filantrópicos" que publicavam gratuitamente poesias populares, nomeadamente a Ariano Suassuna (na época, diretor do Departamento de Educação e Cultura da Universidade Federal de Pernambuco) [Figura 56]. No texto, ao enfatizar a poesia popular como alicerce de obras "eruditas", legitima essa produção e reivindica, silenciosamente e cordialmente, a colaboração dos bacharéis para o soerguimento da classe poética. Afinal, tudo que tocavam reluzia. Residiria nos intelectuais a réstia de luz da Estrella da Poesia?

Os folhetos impressos com acolaboração da universidade apontam para uma mudança significativa nos processos editoriais da literatura de folhetos em Campina Grande, posto que a partir desse momento as publicações deixam de ser domínio exclusivo dos poetas. Destarte, é indispensável refletirmos sobre o processo de institucionalização dos bens culturais, através do colecionamento e do controle da produção do cordel, bem como sobre a relação estabelecida entre agentes de diferentes campos nessa conjuntura.

As iniciativas de arquivamento acabam deslocando os objetos culturais das esferas sociais nas quais eles ganham sentido, esvaziando sua totalidade enquanto fato cultural. Nesse novo contexto os bens materiais são reclassificados a partir de outras categorias, que promovem "a instauração de outros usos, a configuração de outras séries discursivas e a elaboração de outros conceitos” (MELO, 2019b, p. 81). O colecionamento constitui-se também como um modo de entesouramento dos bens culturais por uma elite intelectual e financeira, que os tornam inacessíveis às próprias comunidades produtoras, se considerarmos que as universidades se mantêm encasteladas (ALBUQUERQUE JÚNIOR, 2013). 
O folheto de cordel, ao ser legitimado pelas instâncias oficiais como objeto privilegiado da "arte popular" e alçar o estatuto de "colecionável”, tornou-se simbólica e financeiramente rentável no interior das instituições - sobretudo na negociação de acervos considerados raros, dotados da "beleza do morto" (CERTEAU, 1995). Esses repositórios mobilizaram mais recursos no campo acadêmico, ao incentivar pesquisas financiadas por agências de fomento, do que nos circuitos tradicionais do cordel, contemplados com ações mais pontuais, como o financiamento das tiragens de folhetos.

O etnomusicólogo Alberto Ikeda (2013) aponta para algumas problemáticas relativas a exploração comercial dos grupos tradicionais pelos intelectuais, no pleiteio de subsídios para salvaguarda das produções populares - sobretudo em relação aos editais, mais difundidos no século XXI:

[...] ocorre também algum tipo de apropriação quando os corriqueiros mediadores (produtores culturais, pesquisadores, professores e outros) acabam se tornando intermediadores dos grupos tradicionais com os órgãos públicos e privados, para o encaminhamento de projetos diversos para a obtenção de apoio financeiro, transformando-se em uma espécie de empresário desses, pressupondo, evidentemente, ganhos como profissional especializado ou como produtor cultural, que, quando exorbitam, transformam-se mesmo em "atravessadores" da cultura popular, no pior sentido. São muitos os "intelectuais" que acabam assumindo funções desse tipo, sobretudo diante dos detalhes burocráticos perante os órgãos governamentais e empresas privadas, na busca dos recursos financeiros para a sobrevivência das atividades. (IKEDA, 2013, p. 183)

Acerca das edições de folhetos pelas universidades, é importante atentarmos para as relações que tentam ou tendem à simetria. Estas aparecem, por exemplo, na escrita de Manoel Camilo dos Santos, que chama os intelectuais de "filantrópicos", como ilustrado anteriormente. Devemos também pensar nos processos de seleção de títulos e autores pelo meio intelectual, bem como sobre as determinações estéticas das edições, realizadas a partir de critérios concernentes a este campo.

Voltemos ao folheto $O$ caboclo do bode (1974), aquele no qual Camilo agradece a Suassuna. Sua capa traz estampada uma xilogravura, técnica calcada na bandeira do movimento Armorial e pouco utilizada ao longo da trajetória do poeta-editor, insinuando que Camilo entendeu bastante bem como dialogar com a academia. Uma academia que, por meio de alguns de seus representantes, vinha reconhecendo um saber particular, que não precisava ser adjetivado como "popular", essa categoria erudita (CHARTIER, 1995). A dicotomia "intelectuais-poetas populares", talvez precise ser lida a partir dos seus pontos de contato, pelas linhas borrosas e vivas das fronteiras e não pelas polaridades rígidas. 
O estreitamento dos vínculos entre intelectuais e poetas populares no período é visível no folheto-suporte A pedra do Meio dia ou Artur e Isadora ${ }^{178}$ [Figura 57], romance de autoria do pesquisador de literatura fantástica Bráulio Tavares, editado em 1979 em um pequeno prelo artesanal ${ }^{179}$, e lançado em seguida pela Folhetaria de Toinho da Mulatinha (a Estrela do Oriente, Campina Grande - PB), junto a um segundo poema. Neste caso, a insígnia do poeta popular é rubricada na publicação do intelectual.

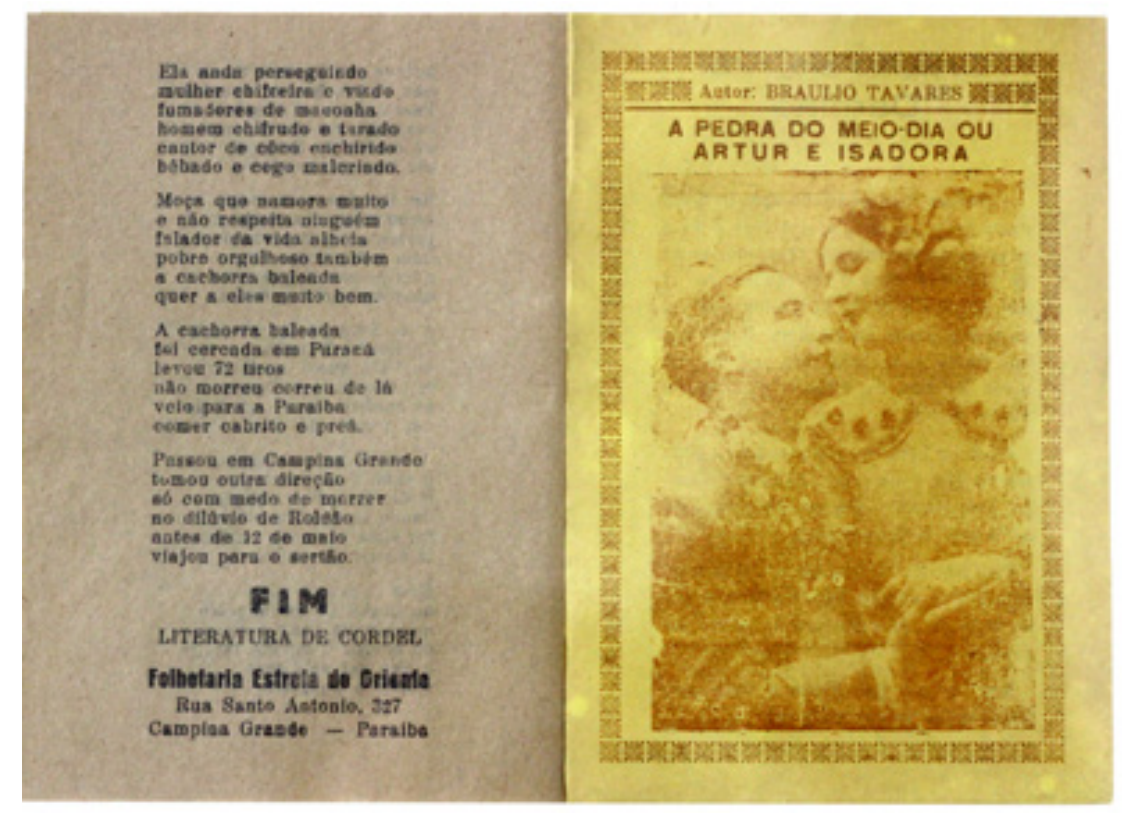

Figura 57 - Folheto de autoria de Bráulio Tavares editado pela Folhetaria Estrela do Oriente (198-)

Fonte: Biblioteca de Obras Raras Átila Almeida (BORAA/ UEPB]

A década de 1970 aguça em Campina Grande a confluência entre campos de saber-fazer ${ }^{\mathbf{1 8 0}}$, visível nas publicações mostradas nesse capítulo, nos catálogos das bibliotecas que passam a abrigar coleções de folhetos e, expressa de forma emblemática

1780 Romance A pedra do Meio dia ou Artur e Isadora (Bráulio Tavares, 1979) foi publicado em 1998 em forma de livro pela editora 34 (São Paulo) e mantido até os dias de hoje no catálogo da editora, a publicação é a mais vendida do autor.

179 Quem cuidou da primeira impressão do folheto A pedra do Meio dia ou Artur e Isadora (Bráulio Tavares, 1979) foi o pai do escritor, junto a um poeta-editor da cidade (Bráulio não se recorda do nome), que escolheu o clichê para estampar o milheiro. Esta informação foi fornecida pelo autor via e-mail no dia 16/09/2019.

180 Não por acaso, os vínculos entre pesquisadore/as e poetas/poetizas se estreitam no período de enrijecimento da ditadura brasileira. Esse contato se intensificou devido a busca de reestabelecimento da participação popular no campo ético e estético pelos/as intelectuais que não se sentiam representados/as por esse regime político violador e almejavam recuperar as memórias e os sentidos de uma nação expropriada por violências sistêmicas. Vale salientar que, neste trabalho, a ditadura militar brasileira não ganha relevo diante da ausência de registros de vínculos do poeta que protagoniza a pesquisa (Toinho da Mulatinha), com o tema - seja adesão ao regime totalitário ou engajamento político nos movimentos de resistência, de forma poética ou pela participação social direta. Dentre os poetas campinenses abordados ao longo do texto, Manoel Monteiro é o único que aderiu à luta, integrando o Partido Comunista e o sindicato dos gráficos. 
na vinculação do poeta-pesquisador José Alves Sobrinho com a Universidade Federal da Paraíba, assim como na expansão da apropriação técnica, estética e temática do cordel por dramaturgos, compositores e escritores locais, como Bráulio Tavares.

Entretanto, há de se reconhecer que os acessos fronteiriços de um campo ao outro são desiguais. A porteira do "popular" é, muitas vezes, atravessada de maneira invasiva pelos agentes externos ao campo, que muitas vezes carregam bens materiais e imateriais para espaços de acesso blindado. O relato de Manoel Camilo dos Santos que epigrafa esse subcapítulo denota entraves dessa relação: “Teve um [pesquisador] que gastou oito rolos de fita pra gravar um livro meu que ainda não saiu. Dá até vontade de falar inglês pra conversar melhor com os homens, saber o que eles vão fazer com a vida da gente." ${ }^{81}$ (CAMILO, 197- apud LESSA, 1984, p. 76).

José Alves Sobrinho verseja sobre o interstício com “essa gente lá de fora”. Embora mantivesse diálogo com interlocutores empenhados em construir novas maneiras de pensar e se relacionar com as poéticas populares desde a década de 1960, continua no século XXI vislumbrando o estabelecimento de um outro universo de trocas:

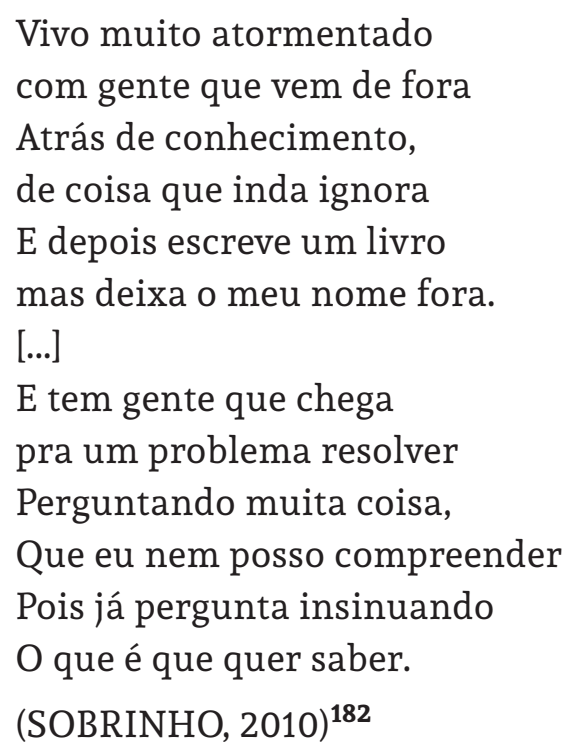

Se as sextilhas de Zé Alves apontam para a "reprodução" das formas de "dominação" por grupos que concentram capitais econômicos e culturais convencionados como superiores, são elas próprias resistência a esse processo social. No documentário A voz do Poeta, o repentista reafirma a potência dos capitais culturais adquiridos no seu campo nativo na relação de forças com um campo “distintamente separado” do seu.

181 Grifo da pesquisadora.

182 SOBRINHO, José Alves. "Essa gente lá de fora". Estudos de Literatura Brasileira Contemporânea, Brasília, n. 35. p. 251-253, 2010. Poema compartilhado com a pesquisadora de sua obra, Joseilda de Sousa Diniz. 
Eu nasci pra isso [cantar]. Eu não nasci pra ensinar nada, universidade. [...] Agora, eu me meti com isso pra não me divorciar daquilo que eu gostava de fazer. Só por isso. Só por isso. E aí é com isso que eu me agarro. [...] Mas a poesia é distintamente separada de cultura e de erudição. Poesia é uma coisa, é uma propriedade, que pode ser até anexa com a propriedade da erudição, mas é outra. E é essa que eu amo. Eu num dou um cantador como Generino [poeta-repentista de Campina Grande], pelo maior doutor do mundo, um Raimundo Asfora, que era um poeta. Num dou. Fico com Generino. Porque ali eu estou me vendo. Ali é o reflexo da minha pessoa. É a continuação da minha pessoa ali. ${ }^{183}$

Zé Alves luta para marcar esse campo de saber, o popular, como tão ou mais potente que aquele construído como hegemônico. Diante de um longo e intricado processo histórico de "hegemonia cultural" - o "intelectual orgânico" insiste na existência de campos polarizados. Resiste alçando a erudição de Generino acima daquela dos "doutores" com quem ele passou a conviver. Não se trata de simples inversão de hierarquias de saber, mas de reconhecer, descolonizando-se, que na voz do poeta-repentista, ele, Zé, e outros tantos zés, encontram com suas histórias.

Desta última perspectiva que incorpora reflexões sobre uma percebida dominação cultural, participaram, principalmente a partir da década de 1970, intelectuais marxistas que receberam a reconhecida influência de Antonio Gramsci. As culturas subalternas, em sua perspectiva, seriam o resultado da distribuição desigual dos bens econômicos e culturais, ao mesmo tempo que poderiam oferecer uma forma de oposição à cultura hegemônica, dos setores dominantes. Criavam-se as bases de reflexão sobre o caráter resistente dos setores populares, oprimidos em suas condições de vida e cultura.

É nesse momento que começam a ser gestadas ideias que propõem, além da “integração cultural”, a “integração entre estratos sociais”, rompendo com pensamentos folclóricos que, no ato de manter, preservavam as estruturas de classe e, portanto, lugares de poder. Se o folclore valorizava o tradicional e o que permanecia como traço da identidade cultural nacional, a sociologia da década de 1960, liderada por Florestan Fernandes, passou discutir as culturas populares no contexto da modernização, da transformação social e das desigualdades do país.

Em Literatura de cordel, conceitos, intelectuais, arquivos, Rosilene Alves de Melo (2019b) expõe as mudanças epistemológicas relativas às práticas culturais tradicionais ao longo do século XX, que vão culminar na cisão do campo acadêmico com as vertentes de matriz folclórica. No texto, aborda a disseminação do termo "cultura popular" no

183 REIS, Diana. A voz do Poeta. Campina Grande - PB: Quarto crescente, 2007. 1 DVD (26 min). Disponível em: <https://www.youtube.com/watch?v=i5CnYOnqvpU>. Grifo da pesquisadora. Acesso em: 20 nov. 2019. 
Brasil como uma dobra operada na perspectiva analítica sobre fenômenos culturais até então esvaziados de suas dimensões política e social - sob óticas modernistas, folcloristas, regionalistas e outros tantos "istas" preocupados em delinear uma identidade para um país amorfo, esgarçado pela colonização.

A pesquisadora, destaca o papel do "Centro de Cultura Popular" e da "União Nacional dos Estudantes”, nos anos 1960, no processo de debate sobre os problemas da cultura nacional dentro do quadro da formação social brasileira. As problemáticas levantadas pelos agentes do movimento estudantil com a implementação do termo “cultura popular”, são impressas no livro Cultura posta em questão, pelo militante “cepecista” Ferreira Gullar (1965):

A expressão 'cultura popular' surge como uma denúncia dos conceitos culturais em voga que buscam esconder o seu caráter de classe. Quando se fala em cultura popular acentua-se a necessidade de pôr a cultura a serviço do povo, isto é, dos interesses coletivos do país. Em suma, deixa-se clara a separação entre uma cultura desligada do povo, não-popular, e outra que se volta para ele e, com isso, coloca-se o problema da responsabilidade social do intelectual, o que obriga a uma opção. Não se trata de teorizar sobre a cultura em geral, mas de agir sobre a cultura presente procurando transformá-la, estendê-la, aprofundá-la. (GULLAR, 1965, p.1)

No trecho de Cultura posta em questão, Gullar pontua a necessidade de lidar com as práticas artísticas em relação à condição social de seus produtores, assim como o compromisso dos intelectuais com a transformação da realidade social, que jamais será feita através de "sambas brancos na poesia e pretos demais no coração". Rompe, portanto, com a visão folclorista sobre a eficiência da "cultura popular" para a construção da nação, situando-a como operativa para a revolução. O cordel foi colocado a serviço desse projeto de base marxista pelo poeta-intelectual, como ferramenta de “conscientização" do povo. ${ }^{184}$

Nesse quadro, a concepção de “cultura popular” assume uma função pedagógica e até mesmo messiânica, alegada como ensejo para a libertação (ROCHA, 2009), ou seja, os/as intelectuais se mantêm no lugar de mediadores, porta-vozes do "povo", ignorando a premente análise das relações de poder que atravessam o movimento de apropriação teórica ou material dos bens culturais. Observa-se alguns ranços modernistas ainda nessa corrente ideológica, posto que a cultura popular ainda é vista como matéria bruta para criação de uma arte nacional-revolucionária, pelos intelectuais. Assim como

184 Para aprofundar a discussão sobre os cordéis de Ferreira Gullar, ver: RIGGI, Fábio. Cordéis cepecistas de Ferreira Gullar. Revista de poesia e crítica literária, v.1, n.19, n.p., 2009. Disponível em: < https://sibila.com. br/critica/cordeis-cepecistas-de-ferreira-gullar/3155>. Acesso em: 20 nov. 2019. 
resquícios folcloristas, manifestos na percepção da cultura popular como expressão subalterna e, portanto, "pura". Nesse caso, menos corrompida pela lógica do capital.

$\mathrm{Na}$ década de 1970 a universidade aguçou o debate político sobre culturas populares com a ampliação das pesquisas antropológicas e sociológicas no contexto de consolidação da pós-graduação no território nacional. Aliando a consciência da dominação imperialista a de dominação de classe, parte da universidade brasileira enterrava a noção aristocrática de cultura e caminhava no sentido de um pensamento que dialoga com os saberes subalternos.

Falar de saberes subalternos não é, portanto, apenas dar voz àquelas e àqueles que foram privados de voz. Mais do que isso, é participar do esforço para prover outra gramática, outra epistemologia, outras referências que não aquelas que aprendemos a ver como as “verdadeiras" e, até mesmo, as únicas dignas de serem aprendidas e respeitadas. (PELÚCIO, 2012, p. 399).

Em relação ao cordel, Ruth Terra é pesquisadora pioneira na abordagem do tema a partir de enfoque histórico engajado, a partir da orientação marxista do historiador Edward Thompson, que privilegia a "ótica dos dominados". Em Memórias de Lutas (1979) a autora interpreta o fenômeno cultural a partir dos seus significados políticos, analisando os folhetos como suportes de memórias de conflitos sociais, meios de exercício da atividade crítica. Abrindo espaço para os estudos culturais na bibliografia dessa área de pesquisa, Terra investiga os folhetos a partir de seu contexto de produção e recepção, dando atenção aos conflitos e negociações entre formas culturais. (IUMATTI, 2012).

O questionamento das hierarquias entre formas e práticas culturais, a expansão da noção de cultura e o entendimento de que cultura é sempre política - pois se disputa forma de qualificar o mundo -, implementados pelos estudos culturais, reverberou não só nas páginas acadêmicas, mas também em folhetos do período. Esta perspectiva é condensada na frase "Folheto Também é Cultura" - impressa no cordel A menina que queria enricar ou Maria Boa Semente (Gerald Califórnia, 1980 - Campina Grande) [Figura 58]: 

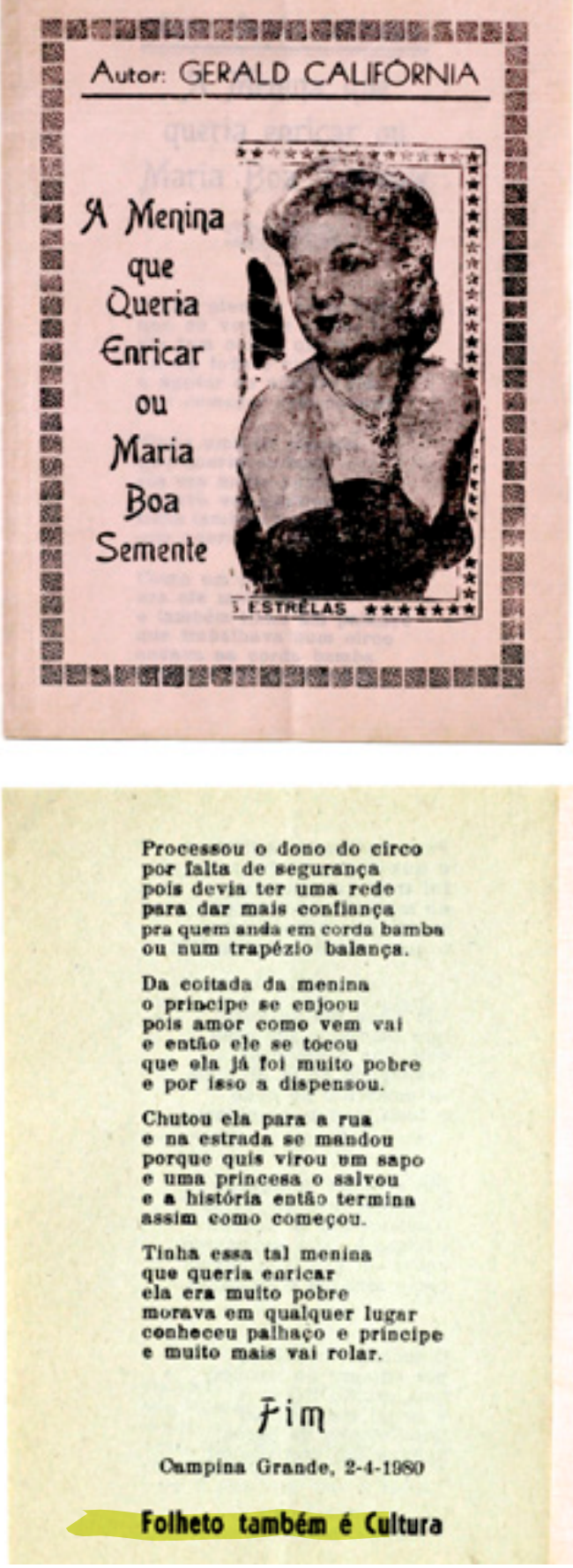

Figura 58 - Última página de $A$ menina que queria enricar ou Maria Boa Semente. Observa. se a subscrição: "Folheto também é Cultura", indicativa da expansão da noção de cultura no período. Grifo realizado digitalmente pela pesquisadora

Fonte: Biblioteca de Obras Raras Átila Almeida (BORAA/ UEPB)
As mudanças conceituais desenvolvidas no interior das universidades, com a institucionalização das ciências sociais, afastaram um segmento dos estudos folclóricos dos currículos de graduação e pós-graduação e, portanto, das publicações acadêmicas. Considerados pré-científicos, em função de seu pretenso caráter mais descritivo que interpretativo, e identificados com forças mais conservadoras, determinados estudos folclóricos mantiveram-se alinhados a campanhas de salvaguarda promovidas pelo governo federal e junto aos projetos das secretarias de turismo e cultura.

A assimilação das práticas culturais populares enquanto produtos culturais por diversas esferas do poder público passa a mobilizar recursos financeiros significativos, oriundos de aparelhos do Estado e, até mesmo, de instâncias privadas. O “Maior São João do Mundo em Campina Grande” é um exemplo desse processo de comercialização das culturas populares, assim como das disputas políticas travadas a partir da noção de tradição.

Se nas décadas de 1970 e 1980, as pesquisas assumem caráter institucional e governamental, "com vistas a sua monumentalização” (MELO, 2019b, p. 76), em 1990 as políticas de fomento vão ganhar contornos neoliberais que conduzem à espetacularização. Em Campina Grande, as luzes do espetáculo não vão servir à poesia. Na terra de poetas-políticos é a poesia que vai servir à política. 

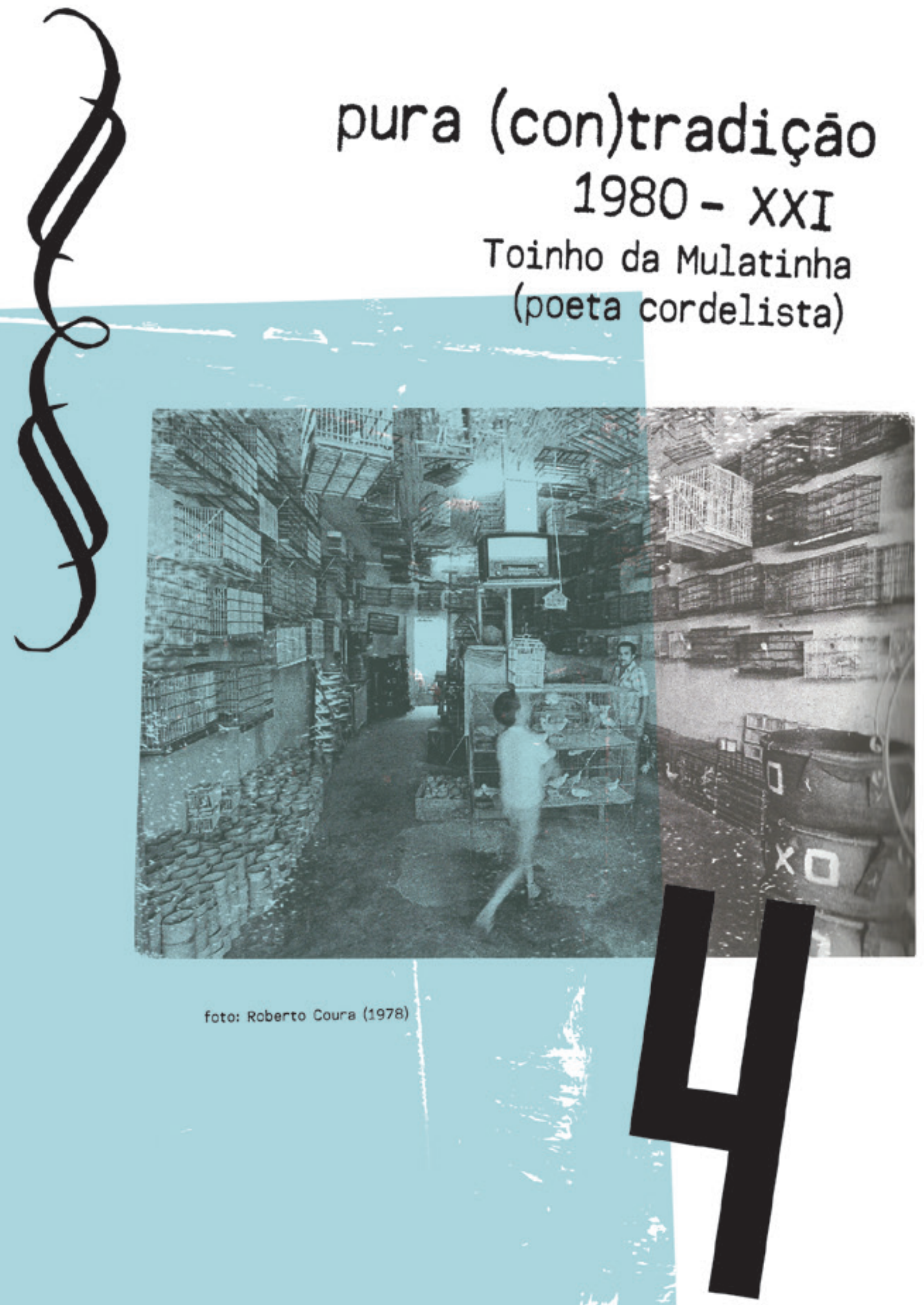


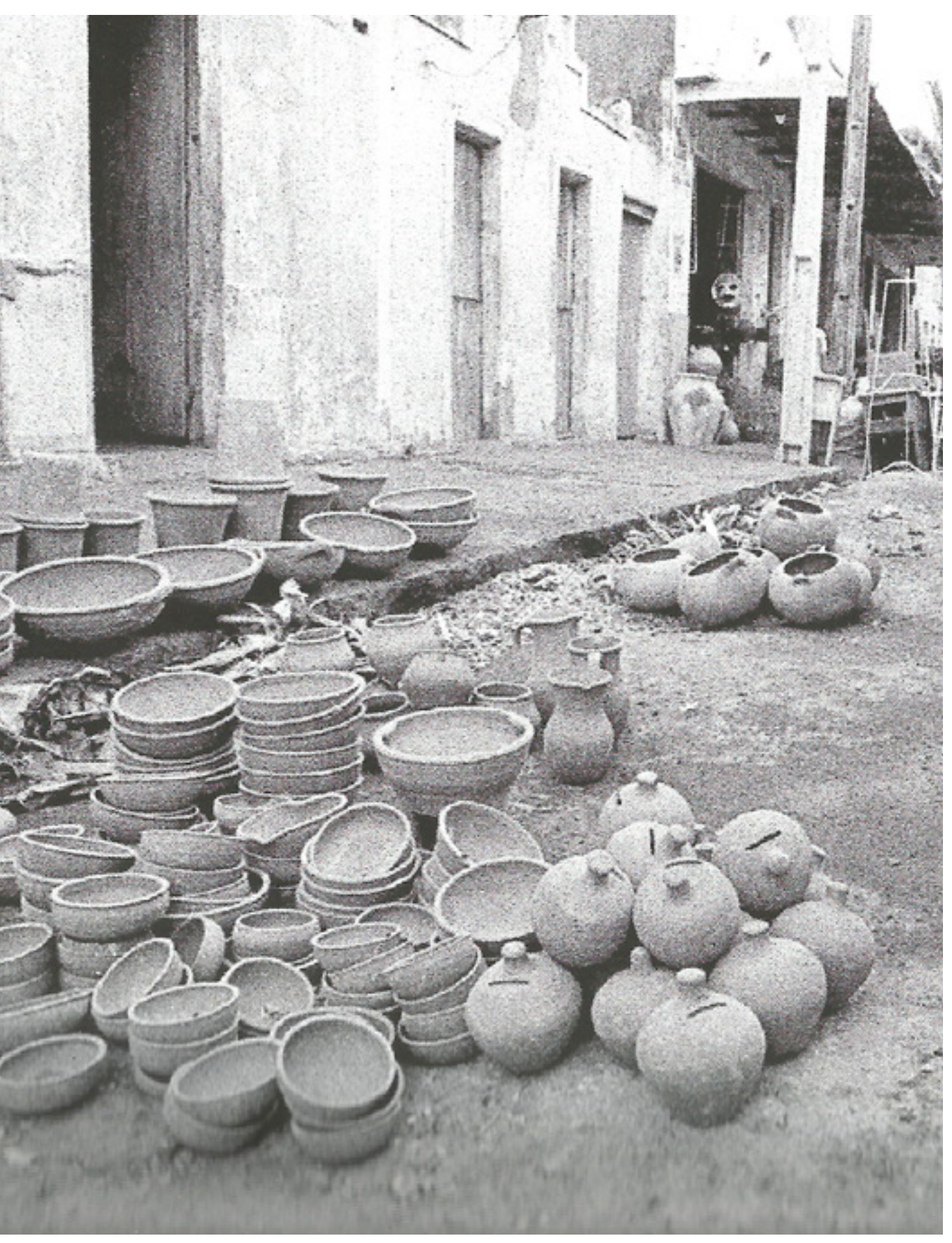

Figura 59 - Panelas de barro na Feira Central de Campina Grande

Fonte: Roberto Coura, 2014 


\section{A VEIA POÉTICA DA POLÍTICA CAMPINENSE}

Nas duas últimas décadas do século XX, momento no qual a literatura de cordel dava vida a publicações acadêmicas, a folhetaria Estrela do Oriente ecoava um silêncio sepulcral, derivado da ausência de folhetos de Toinho da Mulatinha publicados entre os anos 1980 e $2000^{185}$. O apagamento da réstia de luz da tipografia Estrella da Poesia, com o falecimento do poeta-editor Manoel Camilo dos Santos em 1987, aterra a imagem de Campina Grande como "trono dos poetas da nação”, tornando os versos que a entoavam como "lugar onde o brasileiro/ ganha mais fácil seu pão/ com melodia e canção" (MUlATINHA, 1976), mero epitáfio. O fim de um ciclo poético em Campina Grande era também o prenúncio do "novo cordel" na cidade - como veremos mais adiante.

Ao longo deste período, abafaram-se as cantorias que versejavam a rotina da Feira Central de Campina Grande. Poetas e poetizas que antes batalhavam pelo espaço sonoro, procuravam novas formas de sustento, como conta Toinho da Mulatinha: "Quando era ruim pra vender folheto, eu ia carregar peso na feira, balaieiro, pra comprar farinha” (ARAÚJO, 2006, p.129).

Aquelas vozes pareciam ter perdido o feitiço de agrupar volumosa freguesia entorno de um livreto. A viúva do poeta-feirante nos conta sobre a diminuição o ritmo das vendas no período: "Passava o dia lá né...pelejando pra vender alguma coisa. Daí vendia um, vendia dois, vendia três... Às vezes não vendia nenhum. Vendia era cachaça... naquele tempo o povo andava mais atrás de cana do que de um cordel pra ler."186

Entretanto, a escassez de fregueses e folhetos de Toinho da Mulatinha no desfecho do século não sepulta as atividades do poeta no ramo (como veremos mais adiante), tampouco deixa lacunas nesta pesquisa. Isto porque uma das composições identificadas como produzidas no período, O Maior São João do Mundo e a Micarande em Campina Grande (1993 - $1^{\text {a }}$ edição; 2001 - $2^{\text {a }}$ edição), lança um mote para a uma prosa fundamental nesse trabalho investigativo sobre as permanências e rupturas da edição de folhetos em Campina Grande: como a literatura de cordel foi inserida no projeto político que deu a ver Campina Grande como uma "Capital Cultural”?

Antes de identificarmos o lugar do cordel nessa conjuntura, vamos explorar, com aporte do livro Enredando Campina Grande nas Teias da Cultura: (des)inventando festas e (re)inventando a cidade (1965 - 2002), de Wagner Geminiano dos Santos (2016), como em um curto período de tempo, do final da década 1960 ao início dos anos 2000,

185 As publicações de Toinho da Mulatinha datadas entre 1980 e 2000 configuram, aproximadamente, 7,5\% dos 80 folhetos que integram o corpus dessa pesquisa (1955 - 2008).

186 SANTOS, Digna Maria dos. Depoimento [jul. 2015]. Entrevista concedida à pesquisadora. Campina Grande (PB), 2015. 
Campina deixa de ser nomeada como a "Capital do Trabalho" para ser dita e vista como “Capital Cultural”. Essa obra será estruturante para compreendermos os processos de invenção de determinadas práticas culturais em Campina Grande, a partir dos anos 1980 e, por extensão, exclusão de outras preexistentes.

Na segunda metade do século XX Campina Grande começa a perder a função de organizadora do espaço regional, primeiro com a decadência do seu mercado algodoeiro, e, depois, com o desmoronamento de seu distrito industrial, decorrente da cessação dos incentivos fiscais da Superintendência de Desenvolvimento do Nordeste (SUDENE) aliada às crises cíclicas da economia nacional (ressaca do "milagre econômico") e às crises do capitalismo mundial na década de 1970. Conjugados, estes eventos políticoeconômicos vão colaborar no desmonte concreto e discursivo da imagem de Campina COMO Grande e abrir um espaço de disputa para o salvacionismo da falida Rainha da Serra da Borborema.

No início da década de 1980, Campina encontrara uma figura salvacionista: Ronaldo Cunha Lima (1936 - 2012) [Figura 60].

Volto à minha Campina, No templo e no Evangelho! E ao entrar nesta cidade, Afoguei minhas saudades, Nas águas do Açude Velho. (CUNHA LIMA, 1982) $^{187}$

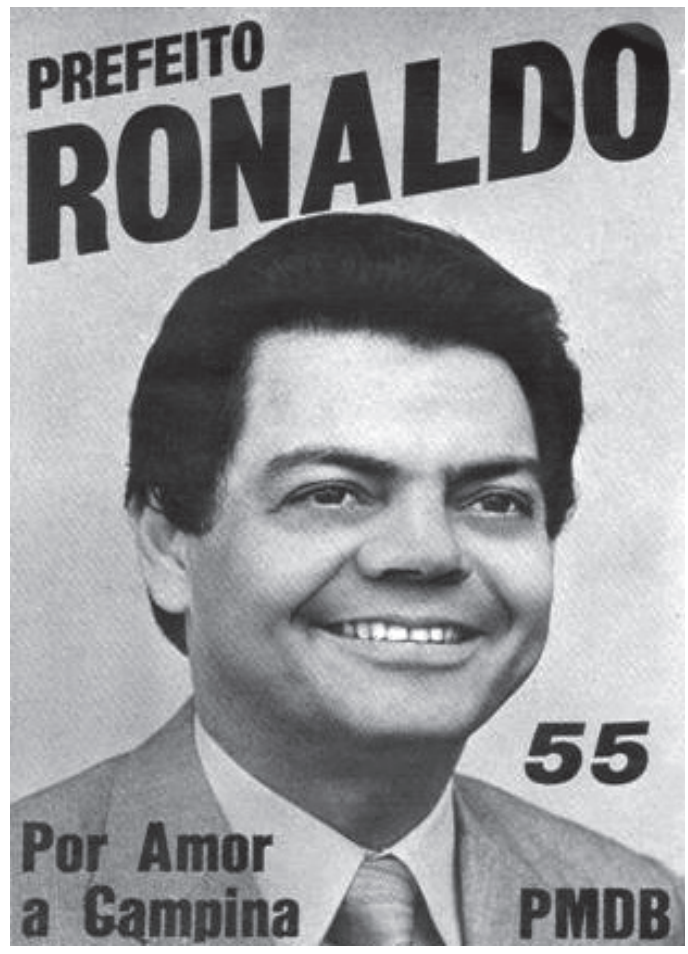

Figura 60 - Foto oficial da Campanha de Ronaldo Cunha Lima [1982]

Fonte: Blog "Retalhos históricos de Campina Grande"

187 CUNHA LIMA, Ronaldo, 1982 apud ARAÚJO, Adriano; SOUSA, Emmanuel. Memória política: "Voltei para o meu lugar!" (Ronaldo Cunha Lima retorna à Campina Grande). Retalhos Históricos de Campina Grande (Blog), 2012. Disponível em: <http://cgretalhos.blogspot.com/search?q=cunha+lima\#.XZyKVedKj0Q.> Acesso em: 20 nov. 2019. 
Eleito em 1982 por meio de discursos inflamados sobre o "amor àquele torrão" e ao "seu povo" o poeta-político do $\mathrm{PMDB}^{188}$ anunciara, no seu primeiro ano de mandato como prefeito $^{189}$, 1983, sua grande ideia para o soerguimento econômico da Rainha e restauração da imagem de cidade desenvolvida e progressista: a construção de uma indústria sem chaminés, a indústria do turismo.

De acordo com o historiador Wagner Geminiano dos Santos (2016) a estratégia política do prefeito era deslocar as práticas discursivas sobre a cidade do plano econômico-social para o plano sociocultural, mostrando Campina como uma "cidade vocacionada para o turismo de eventos” (SANTOS, 2016, p. 198). Por meio da articulação dos conceitos aparentemente contraditórios de tradição e modernidade, dá vida a sua obra superlativa: o “Maior São João do Mundo” (1983) [Figura 61].

Figura 61 - Festejos do "Maior São João do Mundo" no século XXI

Fonte: TripAdivisor (https://www.tripadvisor.com.br/ LocationPhotoDirectLink-g793400-d2414980-i335649330-People Park-Campina_Grande_State_of_Paraiba.html]

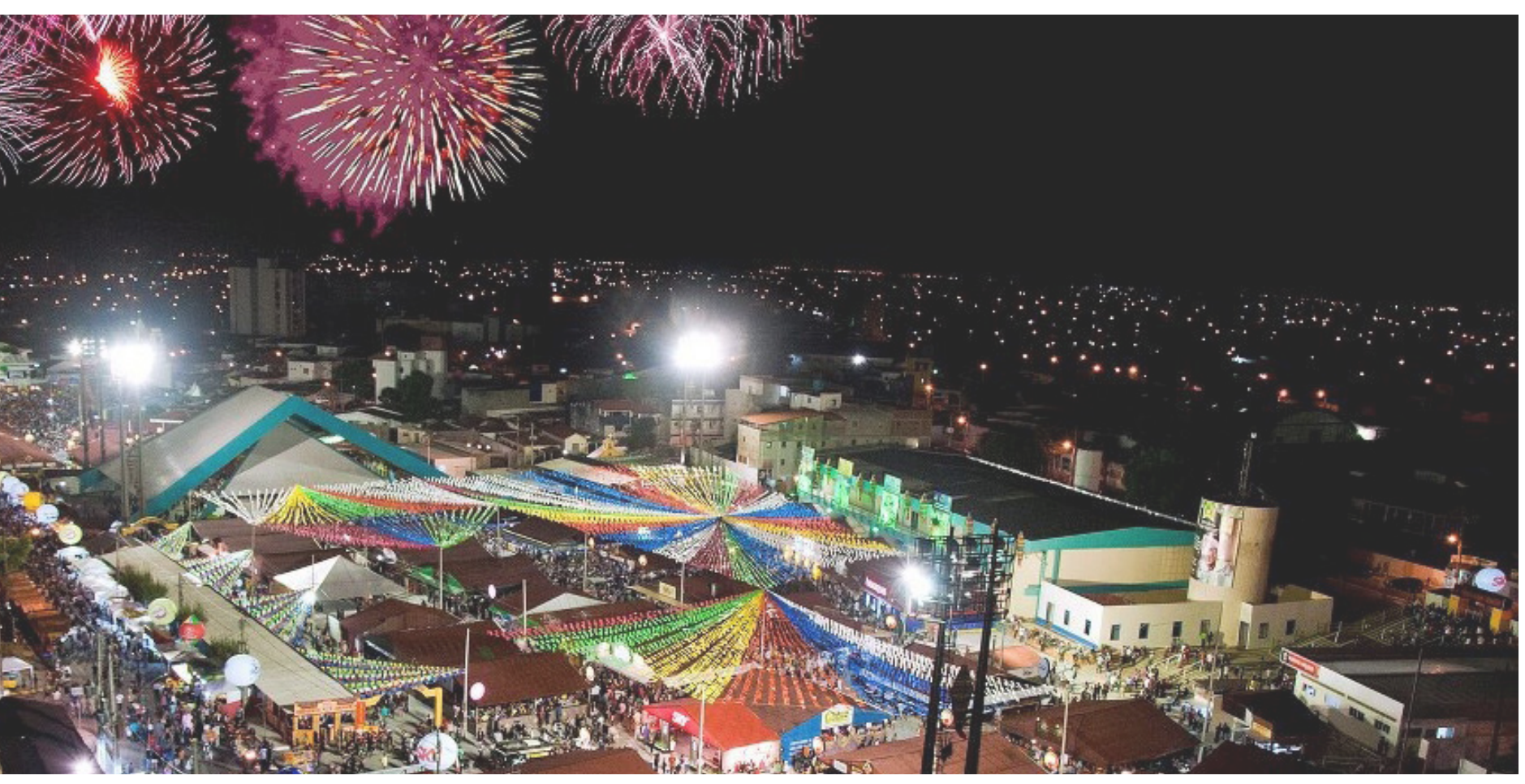

188 Ronaldo Cunha Lima foi filiado, ao longo da sua trajetória política, aos seguintes partidos: Partido da Social Democracia Brasileira (PSDB), 2001-2012; Partido do Movimento Democrático Brasileiro (PMDB), 1980-2001; Movimento Democrático Brasileiro (MDB), 1969-1980; Partido Trabalhista Brasileiro (PTB), 1959-1969.

189 "Ronaldo José da Cunha Lima até então havia sido eleito vereador em 1959 pelo PTB e eleito Deputado Estadual por duas vezes consecutivas, em 1962 e 1966, cargo do qual renunciou para disputar as eleições municipais em 1968 pelo MDB quando se elegeu prefeito [de Campina Grande] derrotando as chapas da ARENA, encabeçadas pelo ex-prefeito Severino Cabral aliado direto de João Agripino e seu vice-governador. Ronaldo ficou no cargo por apenas 41 dias, de 31 de janeiro a 14 de março de 1969 quando foi cassado pelo governo do 'Regime Militar'” (SANTOS, 2016, p.73). 


\begin{abstract}
São João é certamente
Um festival bem falado

Intitulado e criado

Por um cidadão decente

Famoso e inteligente

Que merece nossa estima

Vate que conhece rima,

Origem, estilo e meta

Que é o grande poeta

Ronaldo da Cunha Lima.

(MULATINHA, 1992) ${ }^{190}$
\end{abstract}

Com este evento Ronaldo Cunha Lima almejava inventar um passado para e cidade, assim como uma "essência", produzida com e para os seus habitantes e turistas. Conclamando os/as cidadã(o)s à missão de retirar a cidade da letargia e da crise e construindo uma identidade "ousada e criativa" para o povo campinense - que sucumbia as agruras financeiras de uma ampla fração social - o poeta ganha sustentação para redimensionar as formas de ver e dizer a cidade e instalar, de uma vez por todas, o regime de verdade de Campina (como) Grande - a "maior", a "melhor", em todos os aspectos.

Os versos de Toinho da Mulatinha evidenciam a estima de Ronaldo Cunha Lima em Campina Grande. Fixado entre retratos de família e símbolos religiosos na casa do poeta-embolador, Ronaldo Cunha Lima também era prezado por Mulatinha por carregar o sobrenome daquele que proporcionou a primeira cantoria de sua vida, o coronel José Antonio Maria da Cunha Lima Filho, Major do Engenho "Mundo Novo" $(\text { Areia - PB })^{191}$. A popularidade do poeta-político, deve-se, para além de seus atributos factíveis (carisma) e de suas ações concretas - salienta-se como significativa no contexto desta pesquisa a criação da Casa do Poeta Popular (Campina Grande) -, à produção de um marketing político muito bem articulado, capaz de mobilizar afetos, memórias de um "paraíso perdido” na Borborema.

Através das mídias locais, o “político-celebridade” construiu uma imagem adequada para veneração. As quadrinhas realizadas para inauguração do "Parque do Povo”, local onde os festejos juninos ocorrem desde sua primeira edição ${ }^{192}$, demonstram o manejo de uma arma publicitária potente pelo patrono da família Cunha Lima, a poesia popular:

190 MULATINHA, Toinho da. O Maior São João do Mundo e a Micarande em Campina Grande, 1992 ( $1^{\text {a }}$ edição], p. 6, 2001.

191 Relato extraído de entrevista concedida por Toinho da Mulatinha à revistinha Cordeletras - n 6 (2007, p.6).

192 A primeira edição do "Maior São João do Mundo" (1983) foi realizada em uma área denominada de "Coqueiros de Zé Rodrigues". O local, passou por uma reforma e recebeu um monumento em forma de pirâmide projetado para receber grandes shows, sendo rebatizado de "Parque do Povo" (1986). 
Que este meu gesto marque

O nascer um tempo novo

O povo pediu um parque

Eu fiz um parque pro povo

(CUNHA LIMA, 1989, n.p.) ${ }^{193}$

A habilidade retórica do político irá tornar sua figura tão folclórica quanto as obras e festas espetaculares por ele instituídas, indissociáveis de sua persona. "O nascer de um tempo novo" é também o renascer do lugar privilegiado da família na sociedade local. O anúncio de "transferência da coroa" se deu no encerramento do seu mandato como prefeito, em 1988, no "Maior São João do Mundo”, seu grande palanque eleitoral.

No "Parque do Povo", o "pai” da “cidade-rainha” apresenta o seu sucessor imediato, incumbido de cuidar da sua "menina dos olhos" [Figura 62]: "Essa Festa eu criei como se cria um filho pequeno, crescendo e jogando-o ao mundo. E só um filho poderia prosseguila no Maior São João do Mundo. Por isso, entrego Cássio ao próprio destino de Campina” (CUNHA LIMA, 2002, p. 164). Diante da população, o jovem político (à época com 25 anos de idade) compromete-se em dar continuidade ao projeto do patriarca, "para que Campina permaneça com encontro marcado para o futuro” (Ibidem).

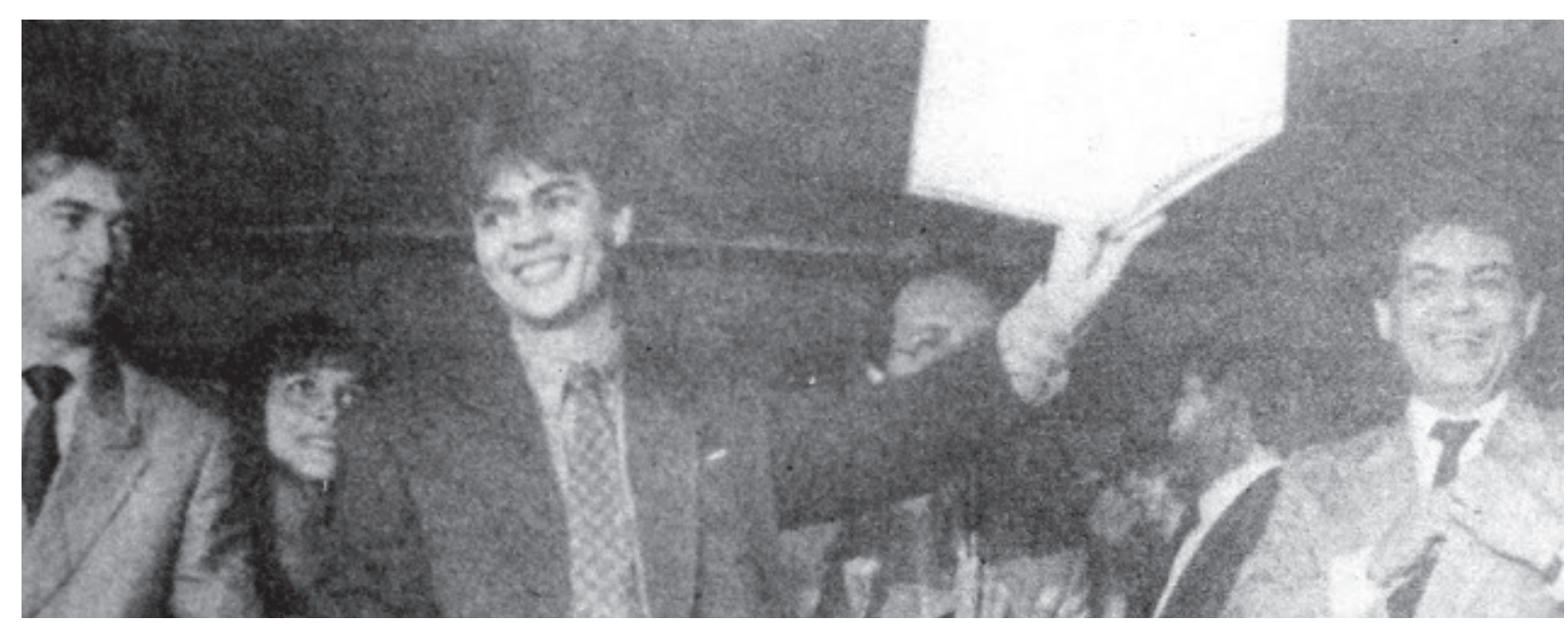

Figura 62 - Cássio Cunha Lima exibe o livro onde consta ter assumido o cargo ocupado pelo pai, Ronaldo Cunha Lima sorridente ao lado direito da fotografia

Fonte: Blog "Retalhos Históricos de Campina Grande"

193 Versos extraídos do Programa Memória Viva: TV Universitária da UFRN [Universidade Federal do Rio Grande do Norte]. Rio Grande do Norte, 24/02/1989, divulgado no Canal de Cássio Cunha Lima no YouTube. Ver mais em: LIMA, Cássio Cunha. Campina Grande se traduz nos versos de Ronaldo Cunha Lima. 3'19", 1989. Disponível em: <https://www.youtube.com/watch?v=1bwEMrS51 m0 >. Acesso em: 20 nov. 2019. 
Esse discurso sela a instauração da hegemonia nepotista da família no aparelho de poder municipal e aporta o lançamento da mesma para o governo do estado da Paraíba, assumido por Ronaldo em 1991. Com uma das votações mais expressivas da história de Campina Grande, Cássio Rodrigues da Cunha Lima alveja à prefeitura em 1989 e, no ano seguinte, dá prosseguimento ao projeto megalomaníaco do seu antecessor na "cidade vocacionada ao turismo de eventos”, alinhando-o cada vez mais à direita e dotando-o de contornos neoliberais. Nessa toada, ressuscita o carnaval do município (enterrado por ele próprio) e faz com que reencarne como "Micarande" (Micareta + Grande) - “O maior carnaval fora de época do País”, agendado para depois da quaresma.

Mascarado de moderno e destemido, o jovem prefeito se lança na batalha política regional amparado por armas midiáticas que vão fornecer uma nova roupagem para velhas formas de fazer política. Isto porque o político populista e popular irá tomar decisões à moda oligárquica, à revelia do seu povo. Inclusive em relação ao tradicional carnaval de rua de Campina Grande, riscado do calendário oficial sob o pretexto de que esta festa não rendia lucro para a cidade, pelo contrário, gerava prejuízo, uma vez que era frequentada por usuários de drogas e bandidos e não pelos “cidadãos campinenses” - ativados em seus discursos como laboriosos, herdeiros da capital do trabalho. Sujeitos inventivos e destemidos, empenhados com o projeto da cidade grandiosa.

O carnaval popular estandartizava os conflitos políticos da cidade, colocava como porta-bandeira uma campina carente, violenta porque violentada por um cotidiano segregador. Comprometia a identidade que os Cunha Lima vinham desenhando para a Rainha e para seu povo, sobretudo, porque mostrava os bastidores da cidade-espetáculo, as rachaduras por de trás do seu cenário art-decó/modernista, abria alas para o desfile de uma campina sem sobrenome.

Além disso, os blocos de “zé-ninguém”, papangus, de la-ursas ${ }^{194}$ não representavam o projeto cosmopolita do prefeito, que almejava, com trios elétricos potentes, reverberações internacionais para seu evento. Projetado para congregar os "melhores" e "maiores" carnavais nacionais, o do Rio de Janeiro, Recife e Salvador, a Micarande iria oferecer uma experiência brasileiríssima. (Para quem cara pálida?)

A Micarande vendida como plural era, na verdade, "um evento planejado, planificado, segmentado pela lógica do marketing, pela lógica capitalista e moldada e estratificada por práticas que a instituem como uma festa de e para as elites e classes

194 Papangu e La Ursa são folias tradicionais do carnaval de Pernambuco, brincadas também em municípios da Paraíba. Na primeira, os foliões - fantasiados com longas vestes de pano e máscaras caricatas - passam de casa em casa para deleitar-se com comida (originalmente, angu) sem serem reconhecidos. Na segunda, há uma teatralidade: saem às ruas personagens vestidos de urso, caçador e domador, acompanhados por uma orquestra que coordena a brincadeira com ritmos regionais ou por crianças batucando baldes e panelas, entoando o refrão "A la ursa quer dinheiro, quem não dá é pirangueiro...". 
médias locais” (SANTOS, 2016, p. 240). Os cordões, abadás e pulseiras que delimitavam quem poderia integrá-la instauraram uma atmosfera de insegurança pública durante os dias de evento, muito maior do que aquela que justificou a coibição do "carnaval tradicional" campinense.

Estes e outros fatores, como a própria datação da Micarande (festejada na quaresma), vão exigir que o prefeito crie alternativas para reparar as deficiências e preencher as lacunas discursivas em torno da festa ${ }^{195}$, assim como defender constantemente sua criação, e por extensão o plano de governo do seu criador. Os veículos de comunicação de massa serão seu carro alegórico nesse processo, incluindo o cordel.

O Maior São João do Mundo e a Micarande em Campina Grande, folheto realizado por Toinho da Mulatinha sob encomenda, a partir de um briefing bem delimitado pelo prefeito, reúne todos os argumentos que sustentam a festa, sendo os centrais: (1) A inscrição do evento em um projeto político de sucesso desenvolvido por seu mestre e pai, o então governador do estado; (2) a criação do evento como estratégia econômica fundamental para a capitalização de recursos para o município.

Os versos a seguir demonstram o desejo de garantir o apoio dos pequenos comerciantes da região (agentes das camadas populares que leriam o cordel, na perspectiva do político) para as festividades campinenses, garantindo que são boas para "muita gente":
Donos de cervejarias
Ganharam muitos cruzeiros,
Hoteleiros, barraqueiros
E donos de padarias
Botequins, mercearias,
Botaram os donos pra frente
Quem vendeu cachorro-quente
Ganhou pra comprar usina
O bom São João em Campina
É bom para muita gente.
Muitos cruzeiros ganharam
Cobradores e motoristas
E os nossos taxistas

1950 "Encontro para a Nova Consciência", evento religioso lançado por Cássio Cunha Lima em 1992 para ser o "maior encontro ecumênico do mundo", foi produzido com objetivo de preencher o vazio deixado pelo carnaval tradicional de Campina Grande, eliminado do calendário oficial na gestão do então prefeito. 0 evento "buscava também atender aos ensejos e interesses de meia dúzia de intelectuais da cidade ligados a família Cunha Lima que reivindicavam posições e espaços de movimentação estratégicos e privilegiados na e para a sociedade local. E que dentro do projeto da família Cunha Lima vão ser alocados nesse novo espaço de poder, que é o Encontro para a Nova Consciência". (SANTOS, 2016, p. 280) 
Muitos deles enricaram

Suas continhas pagaram

Hoje é tudo contente

Um diz em seu ambiente

Foi bom pra sair da ruína

Nosso São João em Campina

É bom para muita gente.

Gritava um, estou de cima

Olhando para os cruzeiros

Entoavam os barraqueiros

Viva Cássio Cunha Lima

E seu pai, homem de estima,

Governador consciente

Um poeta inteligente

Que nos tira da ruína

Esse São João em Campina

É bom para muita gente.

(MULATINHA, 2001, p. 09)

As décimas também integram a exposição de políticas para sanar a insegurança pública nos grandes eventos da cidade:

Mais de mil policiais

Fortes homens militares

Na grande festa e nos bares

Lutaram eles demais

Com ordens especiais

Levando bêbados valentes

Desordeiros insolentes

Tudo para a disciplina

Nosso São João em Campina

Foi bom para muita gente

[...]

Com medo das ordens

Dos fortes policiais

Em Campina os marginais

Que conduzem facas nuas

Não saíram nem nas ruas

Com medo da boca quente

O que bebeu água ardente

Foi se esconder nas Malvinas

A Micarande em Campina

Foi bom para muita gente. 
[...]

Findou-se a festa em paz

Graças a Deus pais amado

E o Governo do Estado

Com os seus policiais

E Cássio, um homem aliás,

Prefeito bom e descente,

Brincou, comeu com a gente

Carne de bode e de rês

E no ano noventa e três

Brincaremos novamente.

(MULATINHA, 2001, p. 10-11)

Os versos da última estrofe citada forjam a aproximação do político com o povo, ao veicular que festejam juntos comendo "carne de bode e de rês". Também apregoam a continuidade dos festejos no ano seguinte, com o mesmo prefeito, "E no ano noventa e três/ Brincaremos novamente”. Afinal, repetir o evento vale a pena:

Campina crescendo está

E o povo lhe dando louvo

Pega do parque do povo

Ao vale do jatobá

A Nossa Campina Grande

O seu nome se expande

Desde o primeiro ao segundo

O MAIOR SÃO JOÃO DO MUNDO

E A NOSSA MICARANDE.

(MULATINHA, 2001, p. 10-12)

O cordel, composto por Toinho da Mulatinha sob encomenda daqueles que protagonizam a narrativa poética e histórica de Campina GRANDE, os Cunha Lima, foram publicados estrategicamente em duas datas específicas: Em 1992 ${ }^{196}$, fim do mandato de Cássio Cunha Lima na prefeitura da cidade e em 2001, encerramento de sua segunda empreitada na prefeitura (1997 - 2002) e véspera do lançamento da sua candidatura do para governador do estado da Paraíba.

196 Data definida de acordo com a $21^{\text {a }}$ estrofe do folheto 0 maior São João do Mundo e a Micarande em Campina Grande (MULATINHA, 2001), na qual o poeta anuncia que em 1993 haverá festa novamente: "Findouse a festa em paz/Graças a Deus pais amado/ E o Governo do Estado/ Com os seus policiais/ E Cássio, um homem aliás,/ Prefeito bom e descente,/ Brincou, comeu com a gente/ Carne de bode e de rês/ $\mathcal{E}$ no ano noventa e três/ Brincaremos novamente". (MULATINHA, 2001, p. 10-11. Grifo da pesquisadora). 
A reedição do folheto em 2001 e, depois, em 2011(por iniciativa do próprio poeta, mesmo após o fim da Micarande) ${ }^{\mathbf{1 9 7}}$, atesta a perenidade da narrativa que substancializou Campina como Grande, a partir da tríade "festa, cidade e povo" (SANTOS, 2016). Reitera a versão da história que monumentaliza Campina Grande a partir das figuras estatuárias da família Cunha Lima, que funde criatura e criadores.

As prosas suscitadas no folheto, vitrine popular da administração da família Cunha Lima, mascaram os interesses alicerçados na fundação das festas "tradicionais", do “Parque do Povo”. Para Wagner Geminiano dos Santos (2016), as tradições inventadas para Campina Grande, que urdem a construção de novos lugares sociais e existenciais para a cidade, reerguiam territórios antigos, práticas políticas reacionárias. Ou seja, por debaixo da grandeza de Campina escondiam-se pequenos currais eleitorais. Para o autor, Cássio Cunha Lima, é o maior exemplo, na Paraíba, daqueles que queriam "encobrir os ranços das práticas políticas de seus antepassados com a máscara da modernidade” (SANTOS, 2016, p. 218).

Os historiadores Eric Hobsbwam e Terence Ranger (1997, p. 09), compreendem as "tradições inventadas" como "um conjunto de práticas, normalmente reguladas por regras tácitas ou abertamente aceitas. Tais práticas, de natureza ritual ou simbólica, visam inculcar certos valores e normas de comportamento através da repetição”. Deste modo, as "tradições inventadas", estabelecem com o passado uma relação de continuidade bastante dissimulada, que tem como objetivo a invariabilidade e, portanto, o controle. As "novas tradições campinenses", projetadas em direção ao passado legitimavam aquele presente.

A construção de uma unidade imagético-discursiva imutável "tenta evitar que os homens se apropriem de sua história, que a façam, mas sim que vivam uma história pronta, já feita pelos outros” (ALBUQUERQUE, 2001, p. 85). Portanto, a manutenção da tradição, especificamente do Nordeste tradicional, está circunscrita por um jogo de poder. Lendo Durval Muniz de Albuquerque, Giovanna Aquino Araújo (2006), sintetiza:

Em nome do costume, da tradição e do ato de manter, percebe-se na
verdade a manutenção hegemônica de classes, e dos discursos que
forjam tal teoria com o intuito de reproduzir estabelecer e manter o
poder sob as classes, instituições, iludidas por tradições, costumes e
estereótipos inventados e legítimos pela 'cultura' mal empregada e
regulamentada todo instante, sobretudo pelos meios de comunicação de
massa. (ARAÚJO, 2006, p. 47)

197 A Micarande teve fim em 2008 na gestão do prefeito Veneziano Vital do Rego, diante de fatores econômicos e da rejeição do evento por uma parcela considerável dos habitantes de Campina Grande, insatisfeitos com violência urbana instaurada durante os festejos. 
A cidade cenográfica instalada no Parque do Povo para os festejos juninos representa as práticas políticas que se instituíram na cidade a partir da gestão Cunha Lima, visto que remonta uma Campina provinciana: com capelinha, prédios históricos de estilo colonial e estabelecimentos que eram frequentados pelos barões do algodão, como o saudoso Cassino Eldorado este estande temático, geralmente, é alugado por restaurantes de grande porte, a exemplo do Bar do Cuscuz, que alimenta com comida regional (a preços elevados) os maiores "coxinhas"198 de Campina GRANDE. Ou seja, na festa, os populares não acessam a sala de jantar.

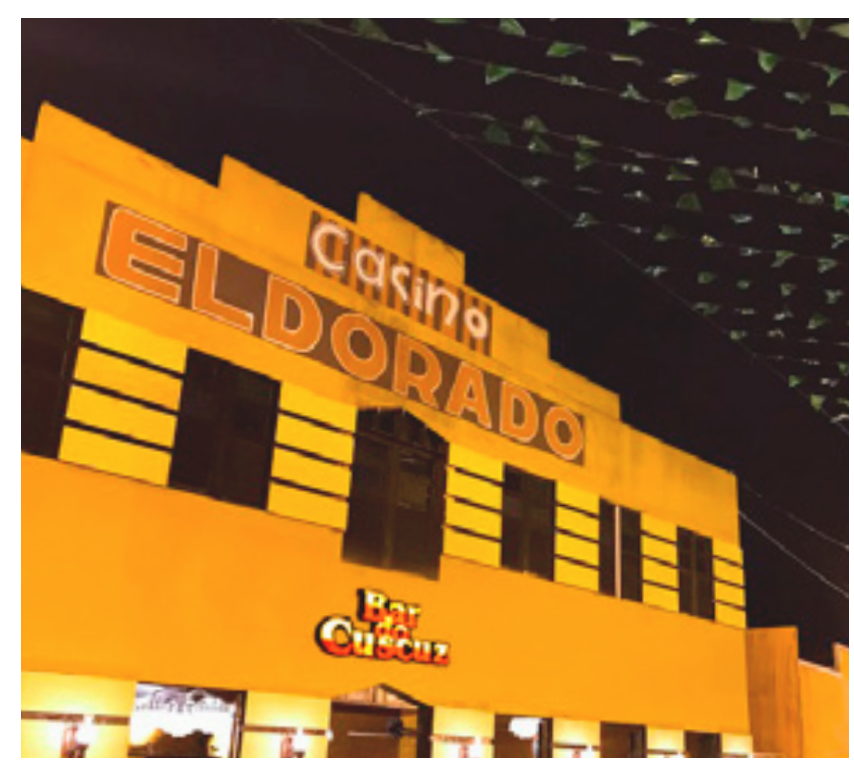

Figura 63 - Simulação do Cassino Eldorado na cidade cenográfica instalada no Parque do Povo para os festejos juninos (Campina Grande - PB, 2014)

Fonte: G1 Paraíba (http://g1.globo.com/pb/ paraiba/noticia/2014/07/antigo-casino-eldoradodesaba-na-feira-central-de-campina-grande.

$\underline{\mathrm{html} \text { ) }}$

As tradições que iriam compor o grande projeto de soerguimento econômico e simbólico da antiga Rainha da Borborema foram criadas in vitro, artificialmente inseminadas. O novo passado inventado para a cidade recobria um outro passado, formado por espaços tradicionais e práticas culturais recusados como constituidores da identidade da cidade, por macularem as pretensões de modernidade que Campina dos Cunha Lima aspirava na busca por realocar-se na economia regional.

Os festejos espetaculares criados nas administrações Cunha Lima irão invizibilizar outros lugares de memória, como uma das maiores feiras livres do país, tornada um limbo no meio da cidade: a Feira Central de Campina Grande. Talvez porque ela seja mesmo, a contragosto, o umbigo de Campina Grande. Ou uma representação dos conflitos políticos que a constituem. Tal como o "carnaval tradicional", a feira, vai ser colocada como excrecência, um lugar poluidor, associado às classes subalternizadas - até que seja registrada Patrimônio Cultural (2017) e torne-se objeto de novas disputas governamentais.

Por meio de discursos, mas sobretudo silêncios, o projeto político da "Capital Cultural” acabou por produzir cidadã(o)s que ignoram o valor de práticas culturais locais que fizeram Campina grande nas glosas mostradas no primeiro capítulo desse

198 "Coxinha" é uma gíria brasileira usada para identificar, de maneira pejorativa, pessoas que ostentam um padrão de vida de custo elevado e posturas políticas conservadoras. 
trabalho. O resultado desse desprestígio é notabilizado na fala de Condor, atualmente embolador da Feira campinense:

\begin{abstract}
E muita gente, muita gente não entende a cultura direito. O pessoal costumava dizer assim: "pô, fulano de tal, Robério, tava no ônibus, ele tá passando pandeiro, como se fosse algo vergonhoso. Por achar que estava pedindo. Não entende, não sabe diferenciar. Muitas vezes a gente tá cantando e eu escuto alguma pessoa dizer: "É melhor tá fazendo isso do que tá roubando". Quer dizer... a pessoa compara a arte ao absurdo. (SILVA, 2018) ${ }^{199}$
\end{abstract}

No “Maior São João do Mundo”, Condor também estende seu pandeiro, uma vez que não lhe estendem um palco. A vivência profissional de Condor atesta que as políticas públicas gestadas nos anos 1980, que hastearam a "bandeira do "tradicionalpopular”, não incluíram, de fato, os produtores daquilo que é enaltecido como "local”. Na programação dessa festa que se pretende "tradicional-popular", ícones da cultura de massa, como Wesley Safadão e Padre Fábio de Melo, têm mais espaço de atuação do que os grupos musicais da cidade [Figura 64]. Os famosos são acolhidos nos grandes palcos, enquanto os conjuntos anônimos, geralmente do gênero forró, são destinados a se apresentar nas "ilhas de forró” dispersas pelo Parque do Povo.

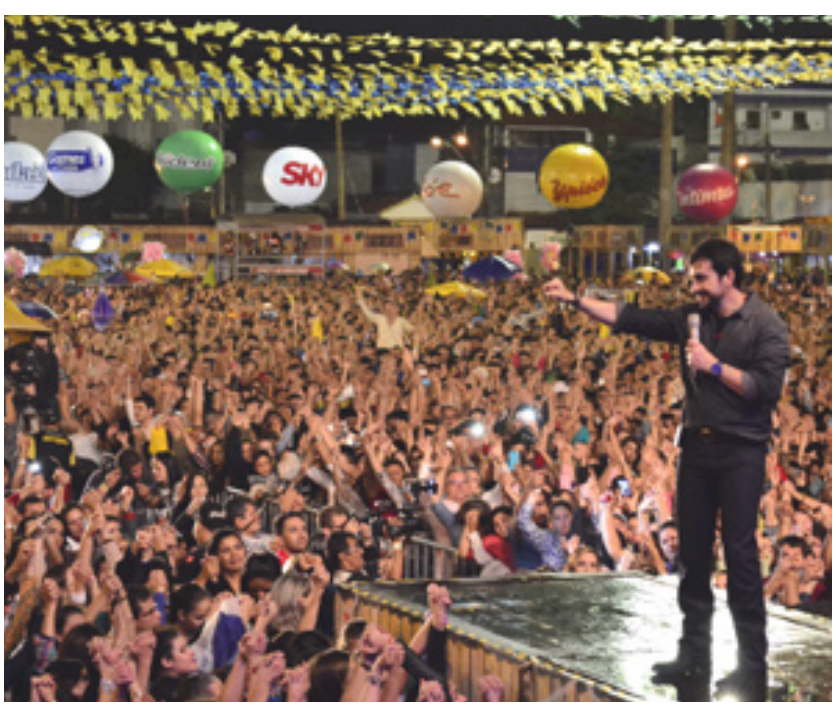

Figura 64 -Padre Fábio de Melo cantando no palco principal do "Maior São João do Mundo" (Campina Grande - PB, 2016]

Fonte: http://www.jampajovens.com.br/2016/06/show-dopadre-fabio-de-melo-reune-100.html
Repentistas, emboladores e bandas de pífano são remetidos, durante os festejos juninos da cidade, ao "Sítio São João" - um polo do "Maior São João do Mundo” criado em 1997 pelo vereador, “teatrólogo" e poeta João Dantas, durante o segundo mandato de seu amigo Cássio Cunha Lima na prefeitura municipal. Isto porque estas práticas musicais são percebidas como condizentes àquele ambiente, que representa um vilarejo rural. Montado por meio da colagem de "momentos" de Campina, como proferiu seu

199 SILVA, José Robério Barbosa da [Condor]. Depoimento [mar. 2018]. Entrevista concedida à pesquisadora. Campina Grande (PB), 2018. 
fundador ${ }^{\mathbf{2 0 0}}$, o parque temático comprime no tempo e no espaço paisagens nordestinas desde o século XIX (representadas pelo saudoso engenho de açúcar de Gilberto Freyre) até o século XX, quando a Vila Nova da Rainha respirava ares de modernidade, com o cinema, o rádio e a imprensa gráfica.

Em 2019 a "Vila Sítio São João", coordenada por Tupac Dantas [filho do idealizador João Dantas], foi alojada em uma unidade fixa ${ }^{\mathbf{2 0 1}}$ de quase 3 hectares, em um terreno de concessão pública, e ganhou casas de shows capazes de acolher entre 1.500 e 4.500 visitantes. Por 25 reais pode-se acessar a "Matutolândia” (100\% privada) ${ }^{\mathbf{2 0 2}}$ e ver “cinderelas" descascando mandioca nas casas de farinha, assimcomooutros personagens encenando trabalhos em expositores que reconstituem as casas desfibradoras de sisal, as feiras de mangaio, as bodegas, e até mesmo as tipografias de cordel [Figuras 65 e 66].
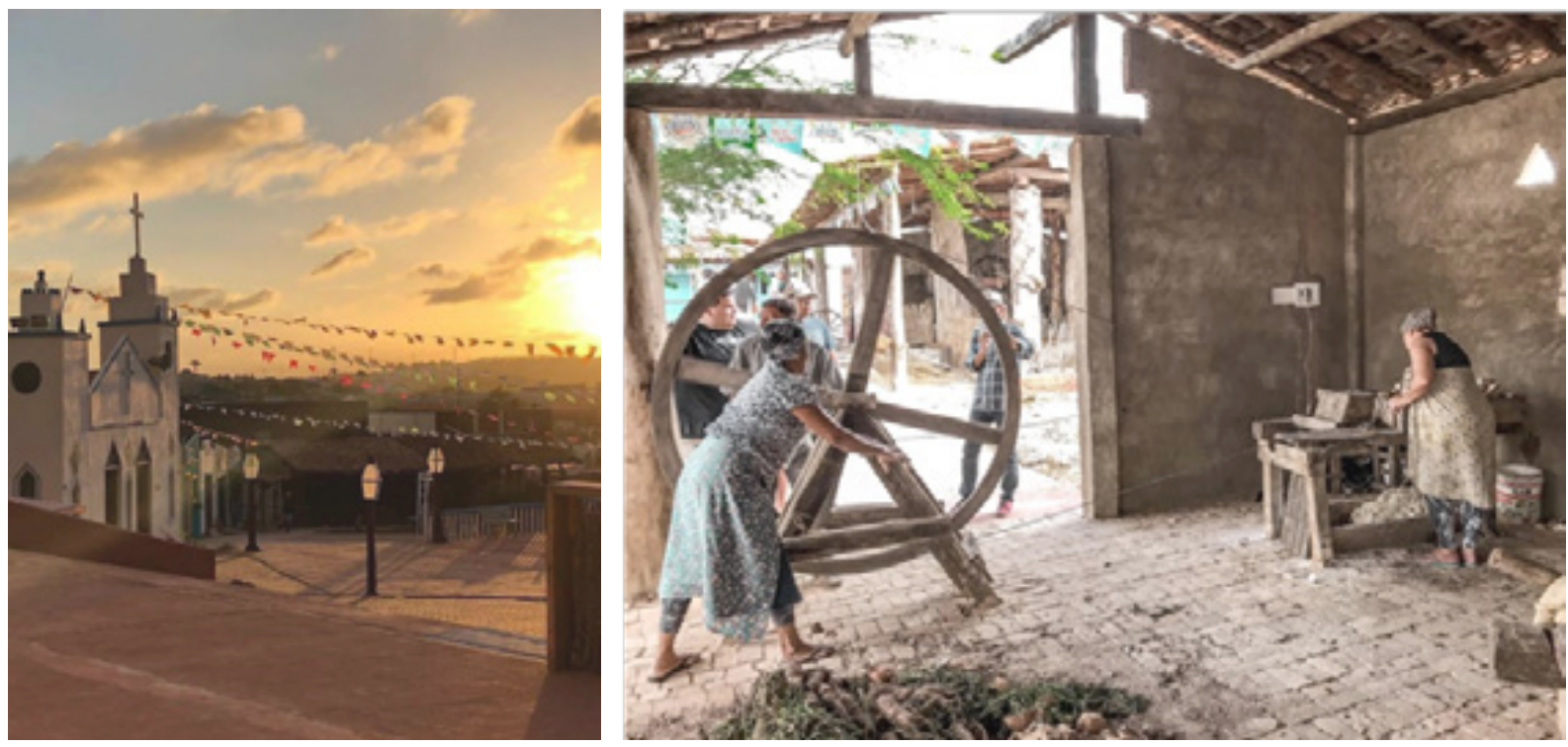

Figura 65 - Vila Sítio São João (2018]

Fonte: Perfil oficial, no Facebook, do vereador João Dantas

200 Entrevista com o fundador do Sítio São João, João Dantas, no qual o vereador explicita os ideais que movem o projeto (Canal Agito, YouTube). DANTAS, João. São João de Campina Grande - João Dantas do "Sítio São João" (6:08 mins), 2012. Disponível em: <https://www.youtube.com/watch?v=-bL5SW7fEjM>. Acesso em: 20 nov. 2019.

201 Antes de receber uma sede fixa na Avenida Floriano Peixoto, a cidade cenográfica "Sítio São João", foi montada em outros logradouros de Campina Grande, nos bairros: São José (Parque do Povo), Centro, Alto Branco, Nações e Catolé. A vila rural já foi instalada no Parque do Anhembi em São Paulo. Informações coletadas no "Programa Diversidade: TV Itararé. Campina Grande". Ver mais em: Programa Diversidade. Sítio São João 2016 [4'24"), 2016. Disponível em: < https://www.youtube.com/watch?v=lo2E8fGX7Qg>. Acesso em: 20 nov. 2019. 202 Informação fornecida por Tupac Dantas no "Programa Ponto a Ponto: TV Itararé.". Programa Ponto a Ponto. Tv itararé - Tupac Dantas. 25'29", 2019. Disponível em: <http://www.tvitarare.com.br/video. php?cod=1-eBNBklhqA. >. Acesso em: 20 nov. 2019. 


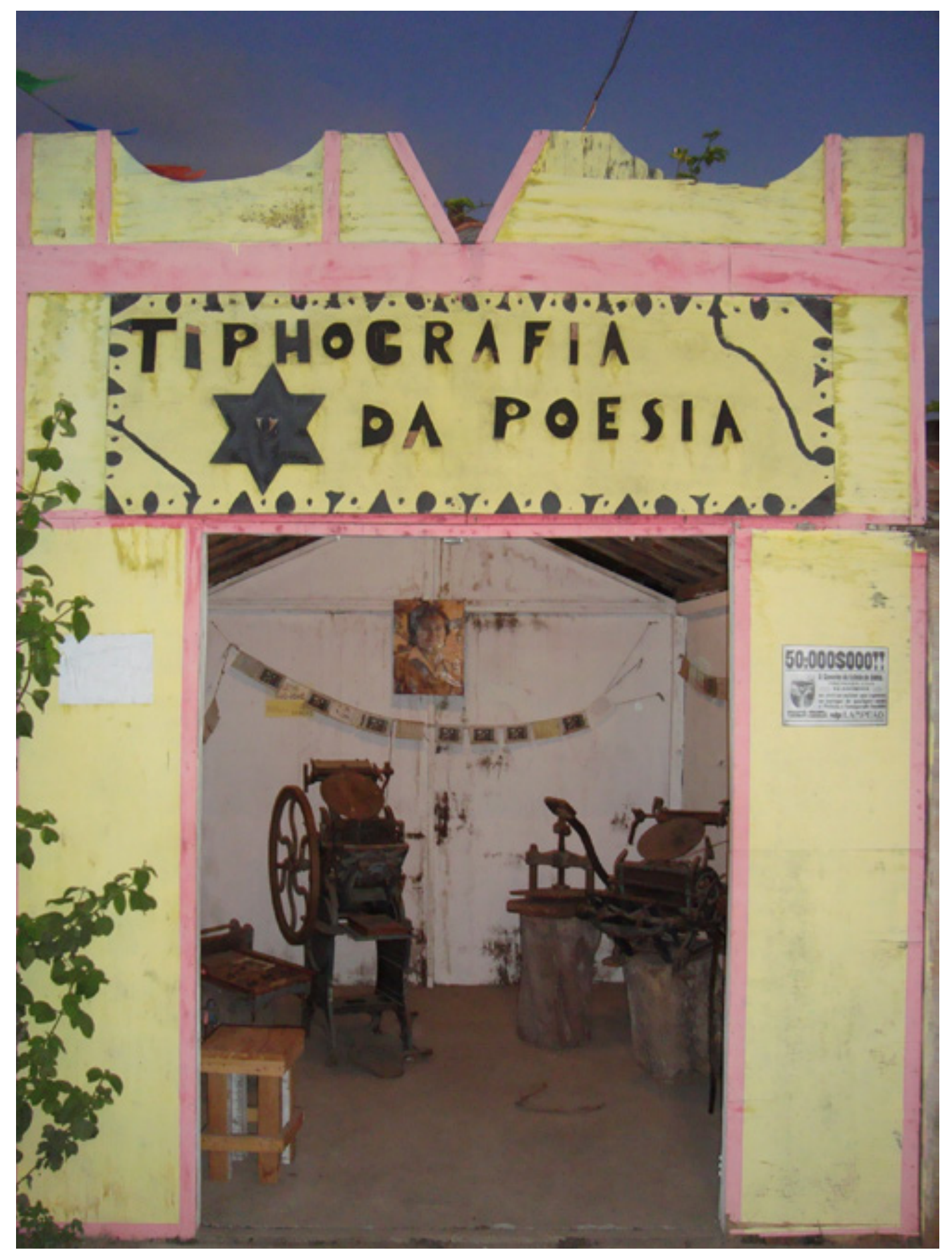



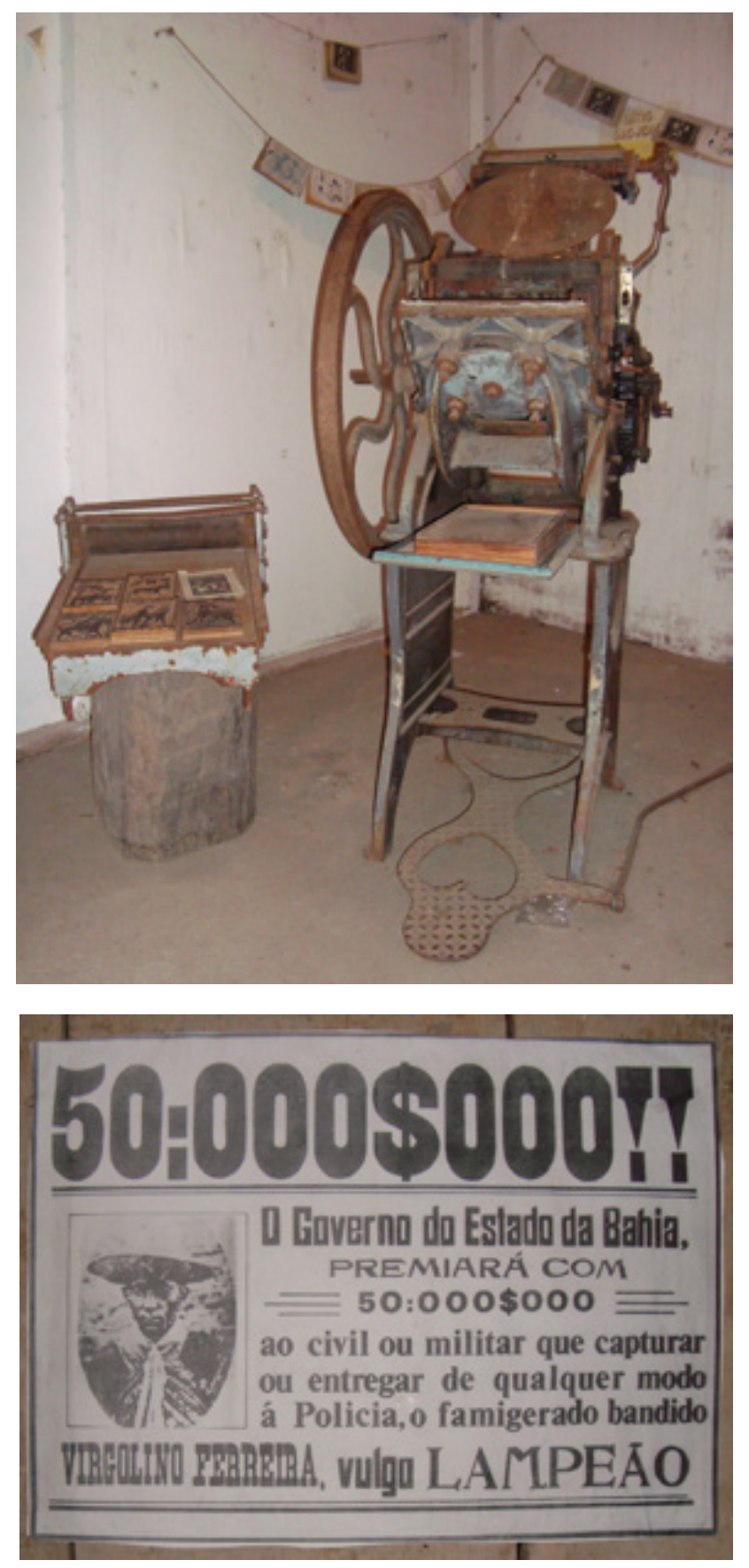

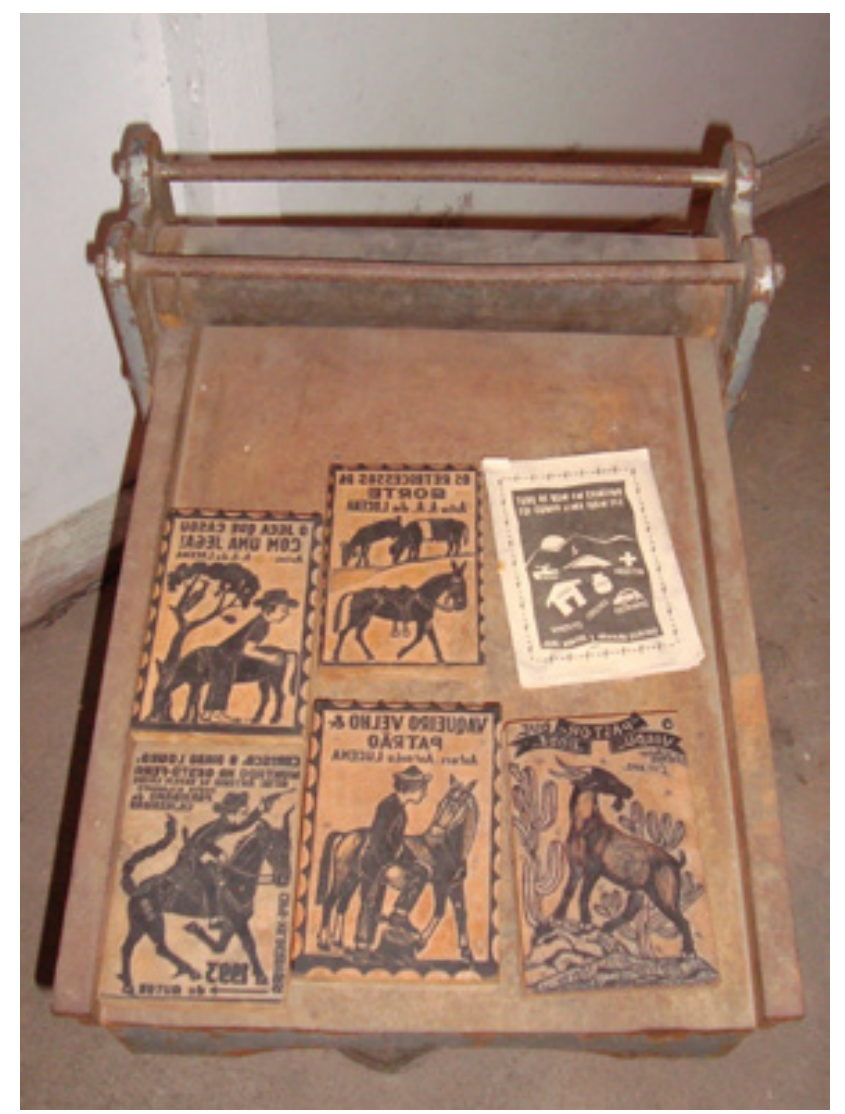

Figura 66 - Tipografia Estrella da Poesia representada no Parque temático do Sítio São João [2012]. A estrutura foi transferida integralmente para a sede atual

Fonte: https://www.flickr.com/photos/50496888@ N00/with/7410737452/ 
O simulacro da Estrella da Poesia nas imagens acima ${ }^{203}$, de certo seria considerado pelo proprietário da casa comercial, Manoel Camilo dos Santos, como insidioso, pois, além da ambientação “mambembe” não ser fiel à estrutura exigida para a produção do impresso abrigando a maquinaria em cima de tocos de árvore, sucumbia a técnica por ele privilegiada para ilustrar suas capas, o clichê - substituído na exibição pela xilogravura, considerada mais representativa do "popular". Além disso, há um elemento inusitado no lado externo da casa tipográfica: um cartaz de "procura-se" que anuncia recompensa financeira para quem encontrar o refugiado Lampião.

Kátia Monteiro, filha do falecido poeta Manoel Monteiro, conta que o pai tinha uma postura crítica diante das imagens estigmatizantes fabricadas no Sítio São João. Inclusive por ter sido submetido pelos produtores culturais do parque temático a um constrangimento durante uma negociação de trabalho, diante da alegação de que deveria usar um figurino específico para comercializar folhetos no evento, Kátia relembra a reação do poeta na situação:

Primeiro que eu não uso chapéu de couro porque eu não sou cangaceiro. Nunca usei chapéu de couro na minha vida e não é agora que eu vou usar. E chita era antigamente que se usava, hoje em dia todo mundo usa material sintético. Eu tô aqui para mostrar um trabalho de qualidade, eu não tô aqui para ser palhaço para ninguém não. (MONTEIRO, 2015) ${ }^{\mathbf{2 0 4}}$.

A banquinha rústica de Toinho da Mulatinha armada no sítio São João (2006), com cordéis no cordão, dá a ver a teatralidade questionada por Monteiro [Figura 67]:

203 Imagens oriundas da plataforma virtual Flickr, concebidas por Murilo Endriss (2012), quando o Sitio São João permaneceu instalado no bairro Catolé (Campina Grande). Disponível em:

< https://www.flickr.com/photos/50496888@N00/7410742920/in/photostream/>. Acesso em: 20 nov. 2019.

204 MONTEIRO, Kátia. Depoimento [jul. 2015]. Entrevista concedida à pesquisadora. Campina Grande (PB), 2015. 


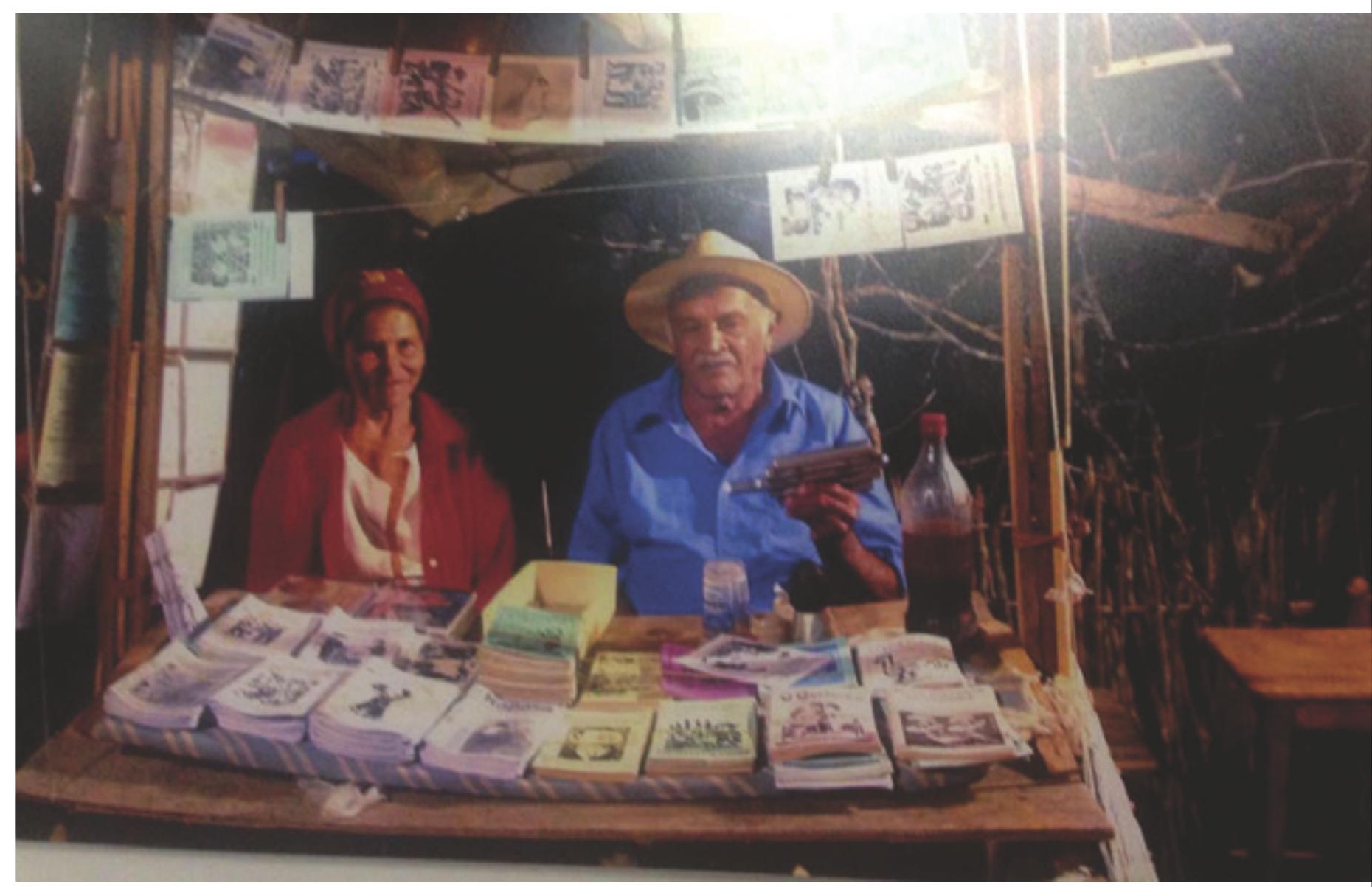

Figura 67 - Toinho da Mulatinha e Digna Maria dos Santos comercializando folhetos no Sítio São João (2006)

Fonte: Memorial São João (Campina Grande - PB) 
De acordo com o etnomusicólogo Alberto Ikeda, no final da década de 1980 as culturas populares passaram a interessar diversos setores da esfera cultural, das artes, da educação e dos governos, do turismo e da produção de espetáculos. Na visão do autor, integraram essa "onda etnicista" propostas de fomento e salvaguarda "pautadas por vícios conceituais, resultantes de visões reducionistas, fragmentadas, e por demais generalizadas das culturas populares” (IKEDA, 2013, p. 184). Ao privilegiarem as exterioridades imaginadas para as culturas de tradição oral, como o chapéu de couro, a camisa de chita, o cordel no cordão, acabam desconsiderando os sentidos mais profundos das manifestações, no caso, da poesia. Assim como a compreensão dos produtores/as sobre eles/as próprios/as e os interesses dos/as mesmos/as nessa aproximação.

No artigo Culturas populares no presente: fomento, Salvaguarda e Devoração (IKEDA, 2013), o pesquisador tece reflexões que nos ajudam a problematizar questões inerentes ao "Maior São João do Mundo" e a inclusão do cordel e seus representantes no evento, como Manoel Monteiro e Toinho da Mulatinha:

Se admitirmos que esses fatos culturais estão ligados a grupos subalternos e periféricos da sociedade, todas as iniciativas, mesmo as governamentais, e até as artísticas e de inclusão social acabam resultando em processos que de algum modo chegam às apropriações e expropriações culturais, ou na transformação de conteúdos e sentidos sociais e políticos, sobretudo quando servem para preencher programações como espetáculos artísticos em instituições culturais, ou mesmo em apresentações oficiais organizadas por órgãos públicos, como referencias da cultura nacional. Afinal, o simples ato da transposição desses fatos culturais de seus locais convencionais de realização (comumente inseridos em festas e rituais tradicionais) para outros transforma a atividade em uma simples representação, uma apresentação apenas. (IKEDA, 2013, p.183)

Conforme as reflexões desse autor, historicamente o modo como muitos produtores culturais e pesquisadores compreendem e admitem essas expressões é predominantemente pela via estética, exibindo-as como entretenimento. Nestor Garcia Canclini (2004) corrobora:

Esse reducionismo anacronizante fomentou uma idealização do popular que subsiste hoje, mais do que nas pesquisas, nas políticas de exibição. Os museus de cultura popular e os grupos artísticos que recriam para os públicos urbanos a música e as danças tradicionais operam nesta mesma descontextualização: mostram os produtos e escondem o processo social que os origina, selecionam os objetos, os movimentos que melhor se adaptam aos critérios estéticos das elites, e eliminam os signos de pobreza 
e a história contraditória de lutas com a natureza e entre os homens que estão na origem dos artesanatos e das danças. (CANCLINI, 2004, p. 154) $)^{205}$

Os espetáculos exaltados no folheto O maior São João do Mundo e a Micarande em Campina Grande (MULATINHA, 2001) - impressos como responsáveis pela abundância financeira dos habitantes da cidade - escondem as condições sociais do poeta mantenedor de tradições da cidade (os folhetos de feira e a embolada), que na terceira idade carregou pesados balaios na Feira Central da cidade para manter seu sustento. A poesia também oculta os interesses políticos que financiam a publicação, metrificada perfeitamente para fixar a produção discursiva da família que se colocou como missionária do projeto de refazer Campina como Grande.

A reedição do folheto, encomendado ao Toinho sob o pretexto de promoção da poesia pela prefeitura municipal - comprometida em "contribuir para o fortalecimento das manifestações artísticas desse povo criativo e pertinaz" (CUNHA LIMA, 2001 apud MULATINHA, 2001, p. 01)” - promove o $2^{\circ}$ mandato do prefeito Cássio Cunha Lima (PMDB, 1997 - 2002) e, consequentemente, prepara a sua candidatura para Governador do estado (PSDB, 2003 - 2009) ${ }^{\mathbf{2 0 6}}$. O cordel também serve de cartaz para o Diretor Executivo da Fundação de Cultura e Esportes de Campina Grande, o pai do sítio São João, João Dantas [atualmente vereador pelo PSD em Campina Grande], autor do prefácio do folheto.

O silêncio da produção editorial de Toinho da Mulatinha entre as décadas de 1980 e o século XXI revela que o poeta foi sucumbido pelos projetos da "Capital Cultural”, arquitetados por políticos-poetas “amantes da tradição”. Desprovido de ações de fomento para a manutenção de sua produção editorial, Toinho engendrou estratégias para manter ativa a Folhetaria Estrela do Oriente. Entretanto, passou a produzir folhetos esteticamente inoperantes para o conceito de "popular" estipulado pelos Cunha Lima e Cia. limitada, realizando tiragens que o arrastaram cada vez mais para as margens da terra do “Maior São João do Mundo”.

\footnotetext{
205 Tradução da pequisadora. Original: "Ese reduccionismo anacronizante fomentó una idealización de lo popular que subsiste hoy, más que en las investigaciones, en las políticas de exhibición. Los museos de cultura popular y los grupos artísticos que recrean para públicos urbanos la música y las danzas tradicionales operan en esa misma descontextualización: muestran los productos y esconden el proceso social que los engendró, seleccionan los objetos, los movimientos que mejor se adaptan a los criterios estéticos de las élites, y eliminan los signos de pobreza y la historia contradictoria de luchas con la naturaleza y entre los hombres que está en el origen de las artesanías y las danzas." (CANCLINI, 2004, p. 154)

206 Trajetória política de Cássio Cunha Lima (1963 - ): $1^{\circ}$ Vice-presidente do Senado Federal do Brasil (2017 - 2019); Senador pela Paraíba (2011- 2019); 48 Governador da Paraíba (2003 - 2009); 34 Prefeito de Campina Grande (1997 - 2002); 31º Prefeito de Campina Grande (1989-1993); Deputado federal pela Paraíba ( $1^{\circ}$ mandato: $1987-1989 / 2^{\circ}$ mandato: $1995-1997$ ).
} 


\section{XEROCAR O PASSADO, IMPRIMIR O FUTURO}

No século XXI Toinho da Mulatinha fez da máquina fotocopiadora, mais conhecida pela metonímia xérox, suporte para construção gráfica e reprodução de suas brochuras. Os esboços, em folhas-soltas, Coco em sonho, cantei no céu pra cristo rei dos poetas (1999) e Conselho de José Cláudio na Patrulha da cidade (1999) [Figura 68] revelam que no preâmbulo da virada do século o poeta gestava novas possibilidades de imprimir sua produção na cena do cordel campinense.

No poema Conselho de José Cláudio na Patrulha da cidade podemos observar que Mulatinha mobiliza não só artimanhas técnicas para se reinscrever como poeta, mas também comerciais, ao inserir um "santinho" de propaganda política e um slogan publicitário ("Tome Forte Vite”), seguido de um jingle em forma de quadras que funciona como uma sinopse do poema, dedicado a divulgar o produto (suplemento alimentar): "Vou comprar vou comprar / sou fraco sem apetite/ vou tomar o forte vite/ para me fortificar”.
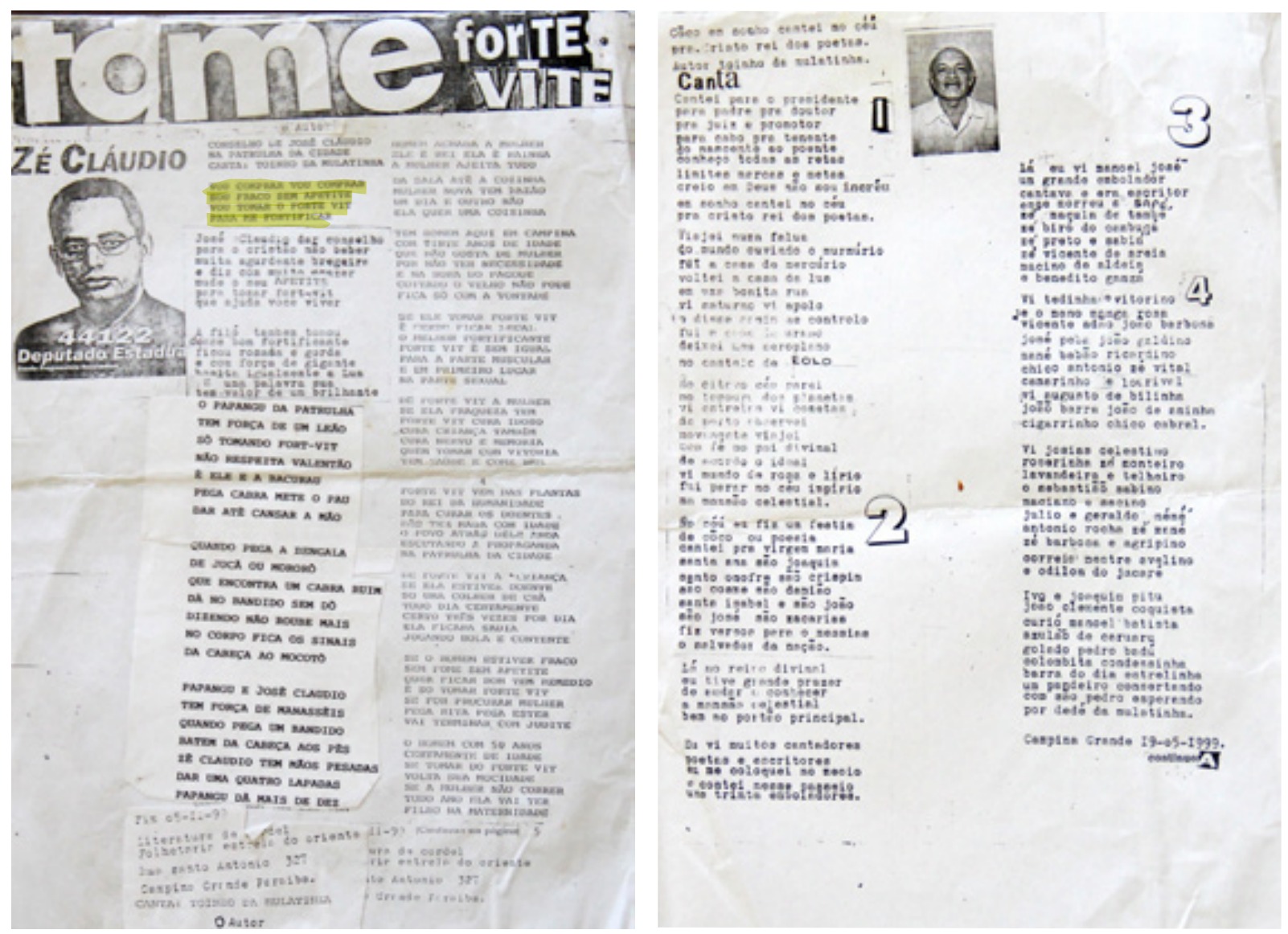

Figura 68 - Folhas-soltas compostas em máquina fotocopiadora por Toinho da Mulatinha (1999). Grifo realizado digitalmente pela pesquisadora

Fonte: Acervo do poeta Toinho da Mulatinha 
Sem apoio do poder público da "Capital Cultural" para manter a economia do ramo folheteiro ativa, se apropria da sua "total liberdade de comércio" apregoada pelo jovem e eufórico neoliberalismo no Brasil, ativando um recurso mercadológico intrínseco ao jornalismo impresso nacional: os anúncios publicitários, que desde a década de 1960 proviam 80\% da receita dos grandes jornais (ALVES DE ABREU, 2002). Convém sublinhar que os "poemas-propaganda" tornam-se costumeiros na editoração popular da década de 1970. A quarta capa do folheto Com a Viola no Peito (1976), de Antônio Lucena, carrega versos exemplares dessa prática, ao divulgar indústrias alimentícias regionais, Vitamilho e São Braz:

O QUE É BOM

Indústria e Com. José Carlo S/A

Rua Simeão Leal, 56 - Campina Grande - PB.

C. G. C. $08.811 .226 / 0001-84$

Cavalo, quando é bacheiro;

Abacaxi de Sapé

Festa com arrasta-pé

E mulher... do mundo inteiro!

Saúde, paz e dinheiro

E o tempo de rapaz

Carinho de nossos pais

E a compreensão do filho

- Canjica de VITAMILHO

E café, quando é SÃO BRAZ.

[...] (LUCENA, 1976).

A folha-solta Conselho de José Cláudio na Patrulha da cidade, diagramada na eminência dos anos 2000 (05/11/1999), demarca a renovação estética das edições de Toinho da Mulatinha e a instauração de novos processos de produção pela Folhetaria Estrela do Oriente. Observando esta publicação, podemos constatar que o poeta encontra em jornais e revistas sucateados a possibilidade de centralizar, cada vez mais, as etapas de produção de suas narrativas em folhetos, uma vez que estes impressos lhe ofereciam recursos gráficos como ilustrações e "caracteres móveis" variados. Ao transformar impressos em matrizes, alterando a ordem dos fatores, o editor-embolador inventou uma "tipografia de improviso".

A máquina fotocopiadora configurou-se como um aparato fundamental do "prelo" reconstituído por Mulatinha. No corpus de 35 folhetos publicados pela Estrela 
do Oriente, datados de 1999 - 2008 $\mathbf{2 0 7}$, podemos identificar usos distintos da fotocópia e variados processos de fixação das poesias no "miolo-matriz" - aquele que originaria a tiragem. Os procedimentos de composição/impressão dos folhetos foram categorizados da seguinte forma:

1 - Design caseiro: as lâminas da publicação eram diagramadas no formato A4 em um processador usual de texto ${ }^{208}$ e impressas em máquinas domésticas de toner ou cartucho, provavelmente por terceiros (colegas detentores do equipamento ou profissionais das casas fotocopiadoras). Neste caso, o xérox era utilizado apenas como dispositivo para multiplicação do "folheto-matriz” [Figura 69].

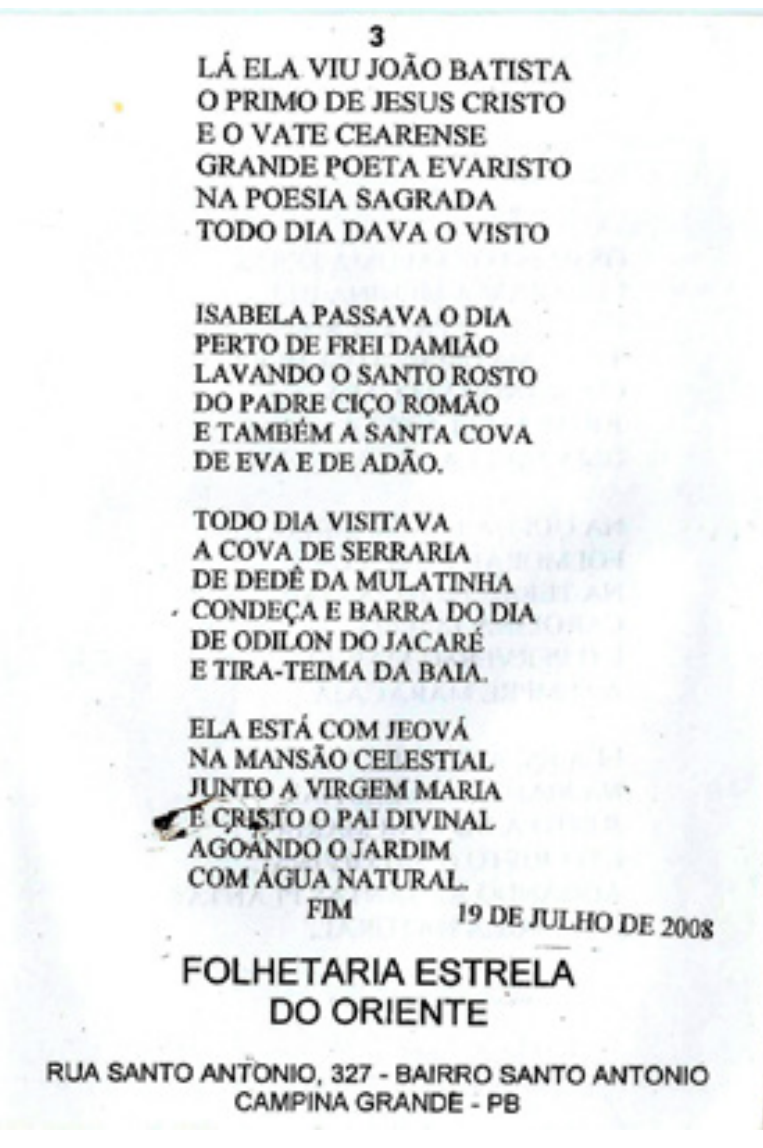

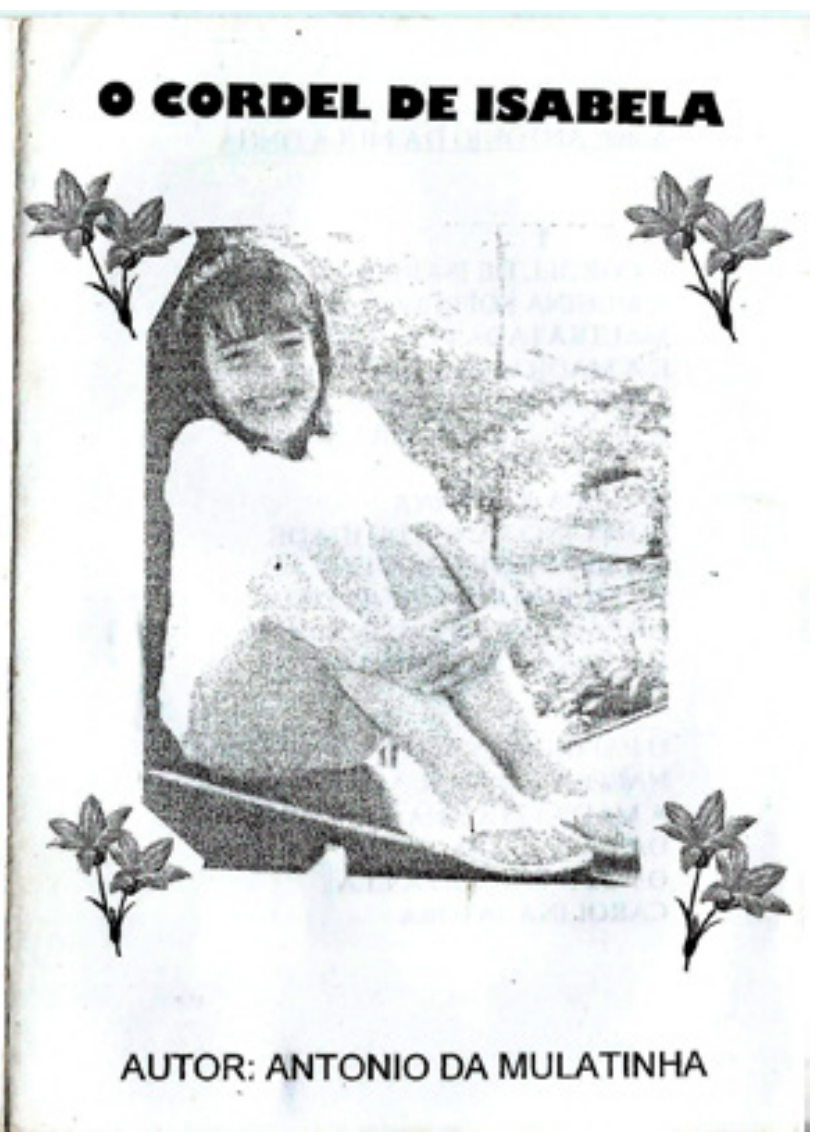

Figura 69 - Capa e quarta capa do folheto 0 Cordel de Isabela (MULATINHA, 2008)

Fonte: Acervo da Pesquisadora

207 Acervo pessoal. Folhetos comprados na Folhetaria Estrela do Oriente em janeiro de 2015.

208 Aparentemente os folhetos eram diagramados no Microsoft Word (parte do conjunto de aplicativos do Microsoft Office). 
2 - Adequação de "texto primário": a narrativa originalmente datilografada em modelo linguado, procedente da época em que o poeta materializava publicações em prelos de tipos-móveis, era fotocopiada e reduzida para acomodar-se à dimensão da brochura, formato A6. Nesse contexto a máquina fotocopiadora adquiria a função de formatadora de imagem, além de produtora de reedição da tiragem [Figura 70].

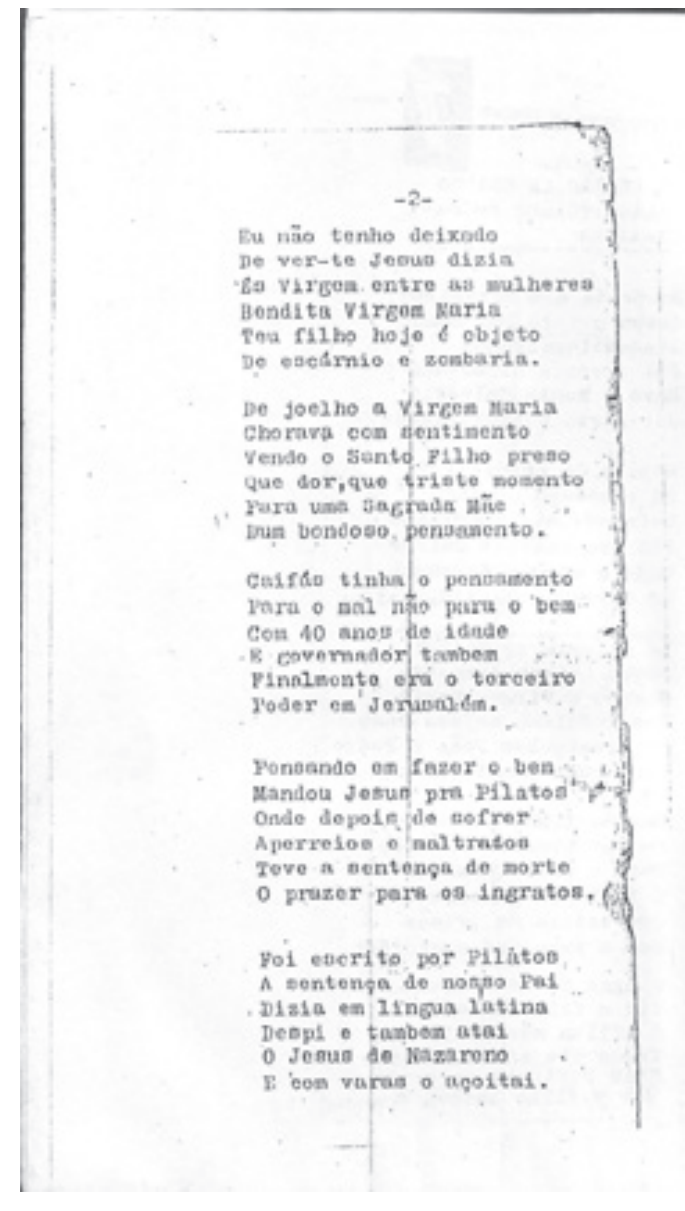

Figura 70 - Miolo do folheto A Paixão de Cristo (MULATINHA, 2001). Marcações realizadas digitalmente pela pesquisadora

Fonte: Acervo da Pesquisadora

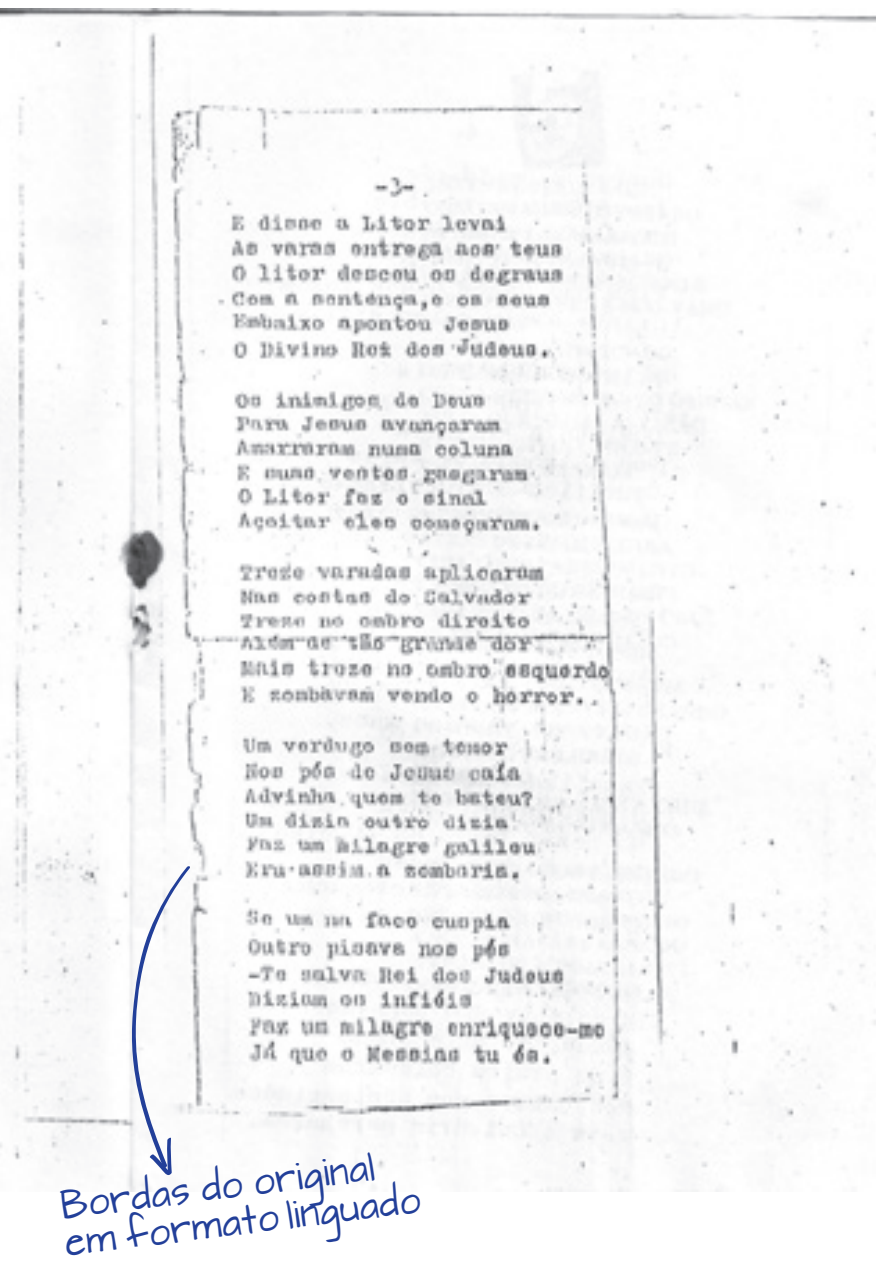


3 - Composição por "elementos-móveis": o miolo era composto através da colagem de estrofes (recortadas de um poema previamente datilografado ou digitado em computador) sobre um protótipo em branco na dimensão da publicação (10,5 x $14,8 \mathrm{~cm}$ ) e a numeração das páginas por meio da colagem de algarismos extraídos de jornais e revistas. O trabalho de programação visual era feito por “elementos-móveis", encaixados artesanalmente no layout [Figura 71].

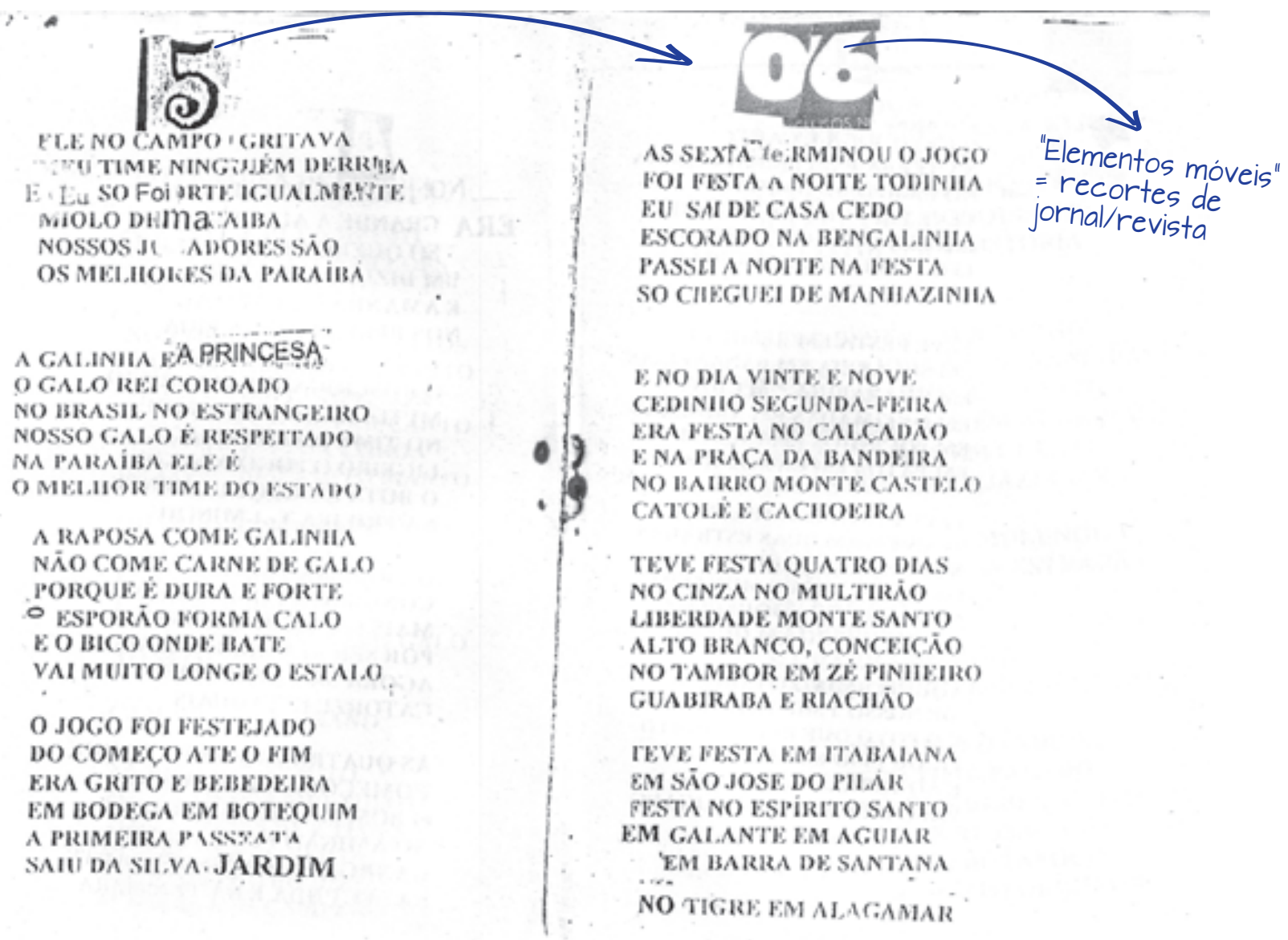

Figura 71 - Miolo do folheto 0 Treze é Bicampeão - Campeão 2006 (MULATINHA, 2006). Marcações realizadas digitalmente pela pesquisadora

Fonte: Acervo da Pesquisadora 
As formas de concepção das peças gráficas classificadas aparecem combinadas em algumas publicações de Mulatinha. No folheto $O$ mote de um viciado ou um homem biriteiro - Eu era um desmantelado Jesus mudou meu viver/ o folheto do chupa cabra (1999) observa-se a fusão entre "composição por elementos-móveis” (capa), “design caseiro” (p.1) e “adequação de ‘texto primário” (p.8) [Figura 72] :

O mote de um viciado

Ou um homem biriteiro

Eu cra un desunatelado

Jesus mudou meu viver

Canta : Toinho da Mulatinha - o Autor

Eu era um desmantelado Bebendo vinho St̃o João Conhaque de alcatrão Com cachaça misturado - Quando estava cmbriagado Era brabo sem poder

7 Pedi a Deus para ser Um crente de Jesus Cristo Senhor de tudo está visto Jesus mudou meu viver

bioginara do rotza

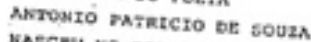

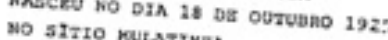

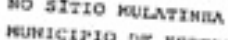

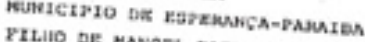

FIL

zecurtona mata on cencirço

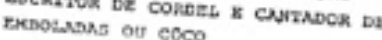

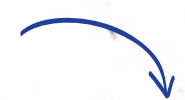

Design caseiro

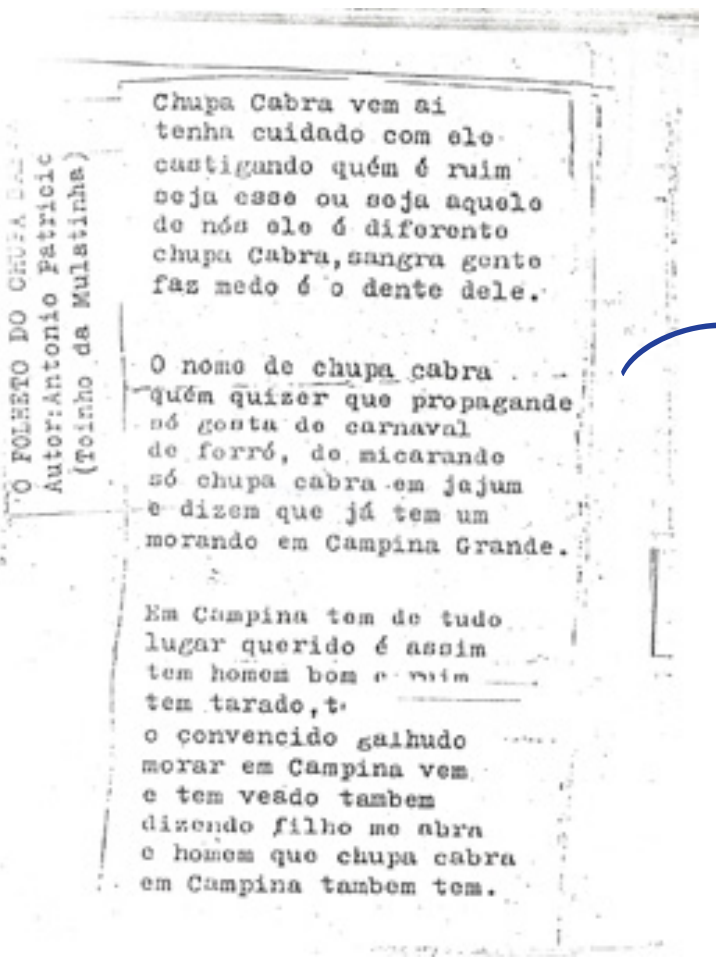

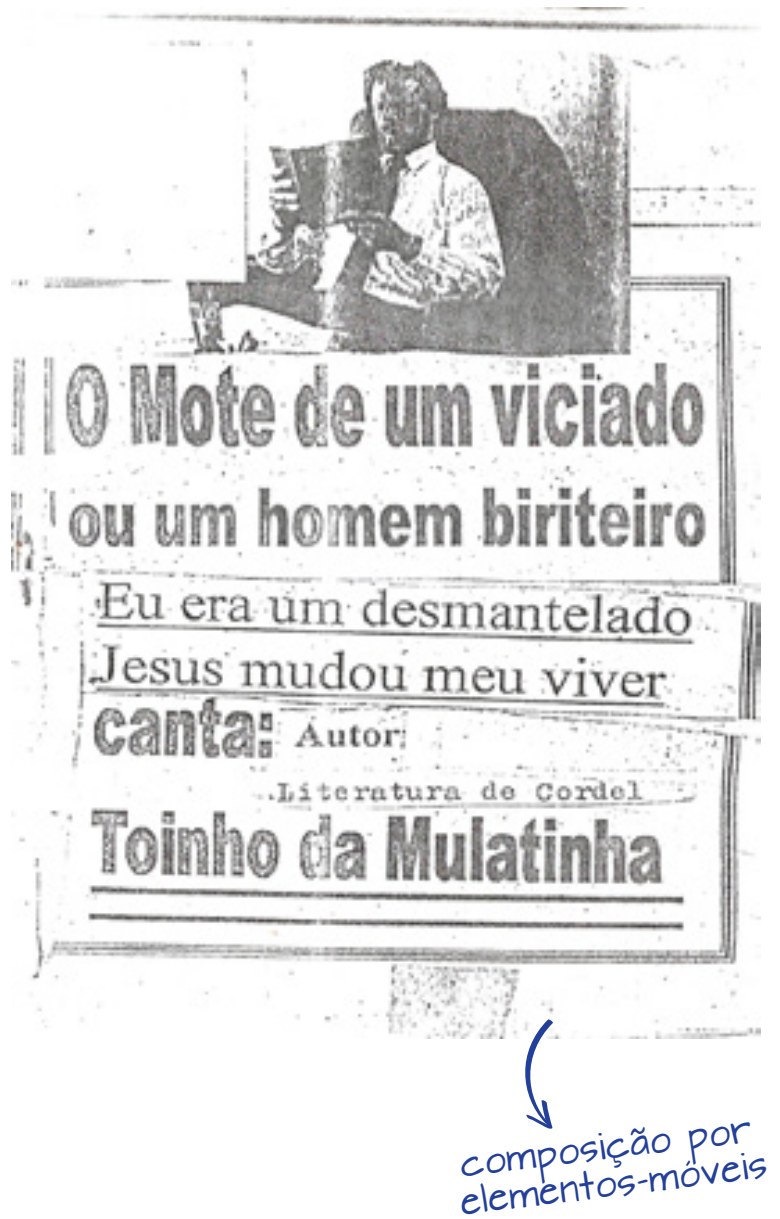

Figura 72 - Capa e páginas internas do folheto 0 mote de um viciado ou um homem biriteiro - Eu era um desmantelado Jesus mudou meu viver/ 0 folheto do chupa cabra. (MULATINHA, 1999). Marcações realizadas digitalmente pela pesquisadora

Fonte: Acervo da Pesquisadora 
Examinando a produção de Toinho da Mulatinha, constata-se que o poeta utilizou a máquina fotocopiadora como software de diagramação e edição de texto e imagem. Nos folhetos a seguir [Figura 73] podemos observar o resultado do trabalho de correção da redação e edição do conteúdo, pelo acréscimo ou sobreposição de palavras, versos e estrofes nas massas de texto, viabilizado por esta técnica de reprodução:

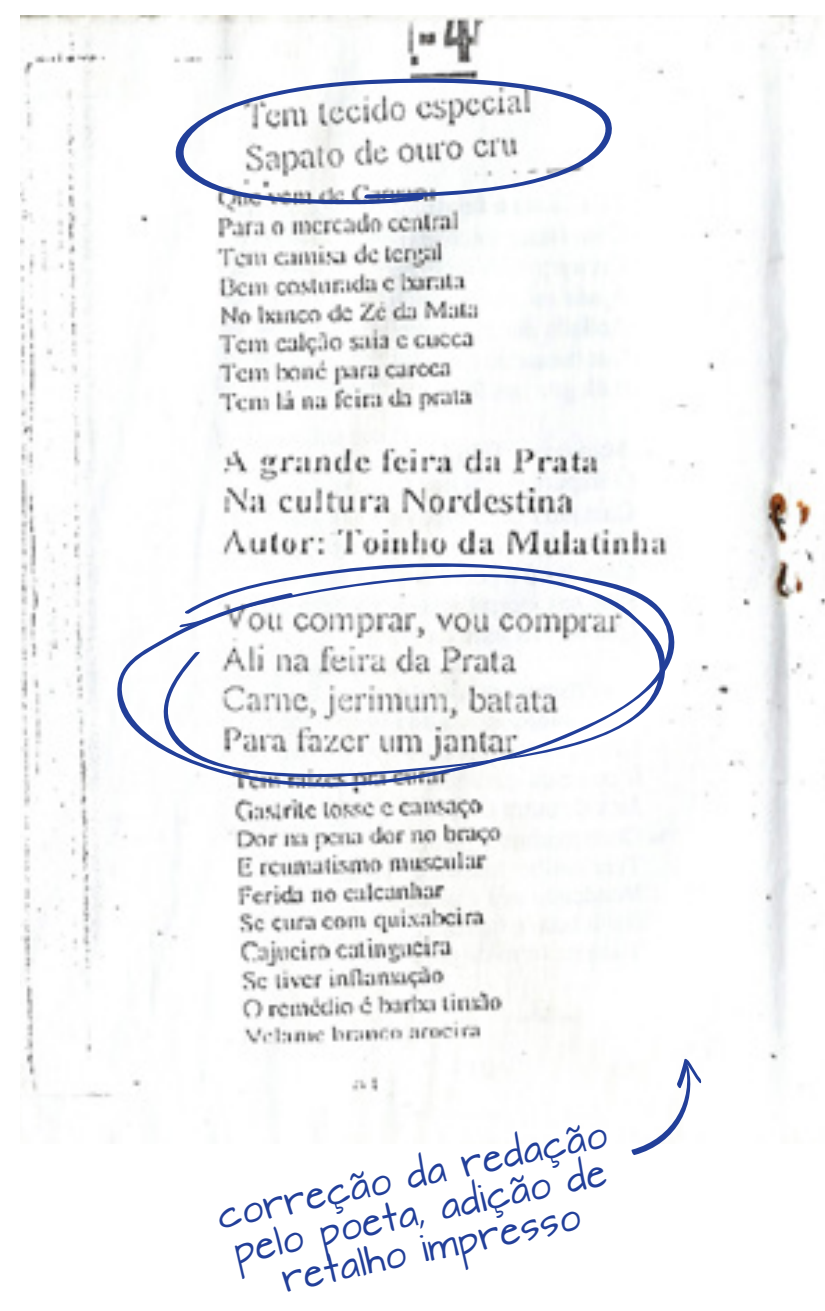

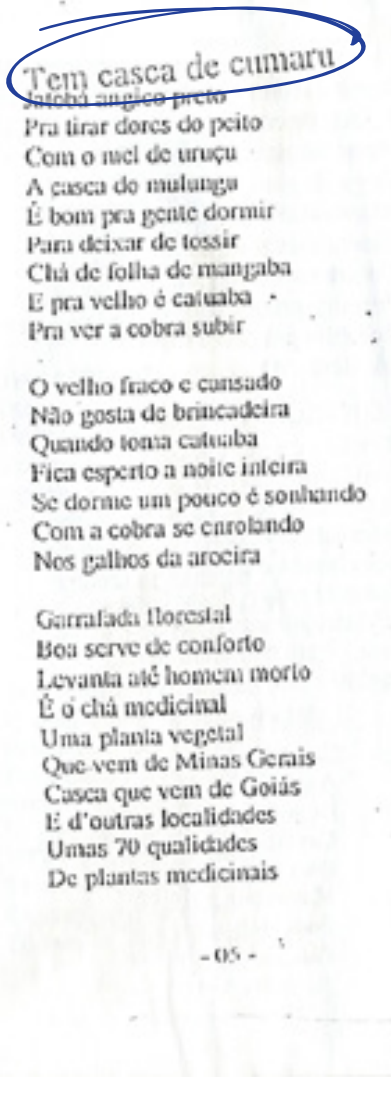

Figura 73 - Miolo do folheto A Grande Feira da Prata na Cultura Nordestina (MULATINHA, 2002) Marcações realizadas digitalmente pela pesquisadora

Fonte: Acervo da Pesquisadora

O procedimento de adição de excertos e imagens sobre os impressos tornouse para o poeta, ademais de ferramenta para reparação textual, recurso para o desenvolvimento de uma linguagem criativa. O fascínio de Toinho da Mulatinha pela atividade editorial faz-se patente na renovação visual de folhetos publicados com patrocínio da Prefeitura Municipal, como O maior São João do Mundo e a Micarande em Campina Grande (2001), no qual o poeta pretere o design originalmente elaborado e insere novas informações (textuais e imagéticas) que considera importantes. Nas reedições (datadas do mesmo ano, 2001) reitera o gênero literário "cordel” e o modo de enunciação do texto; “canta: Toinho da Mulatinha”; demarca a autoria, por meio 
da implantação de uma autobiografia e de uma fotografia $3 \times 4$; acrescenta novas ilustrações na capa e/ou contracapa. Também extrai aquilo que julga excedente, como a introdução realizada pelo então prefeito Cássio Cunha Lima e o pelo Diretor Executivo da Fundação de Cultura e Esportes, João Dantas - intervenção que demanda reestruturação da paginação. Ou seja, invés de ampliar a tiragem do folheto por meio da fotocópia, gera novas edições [Figura 74]:
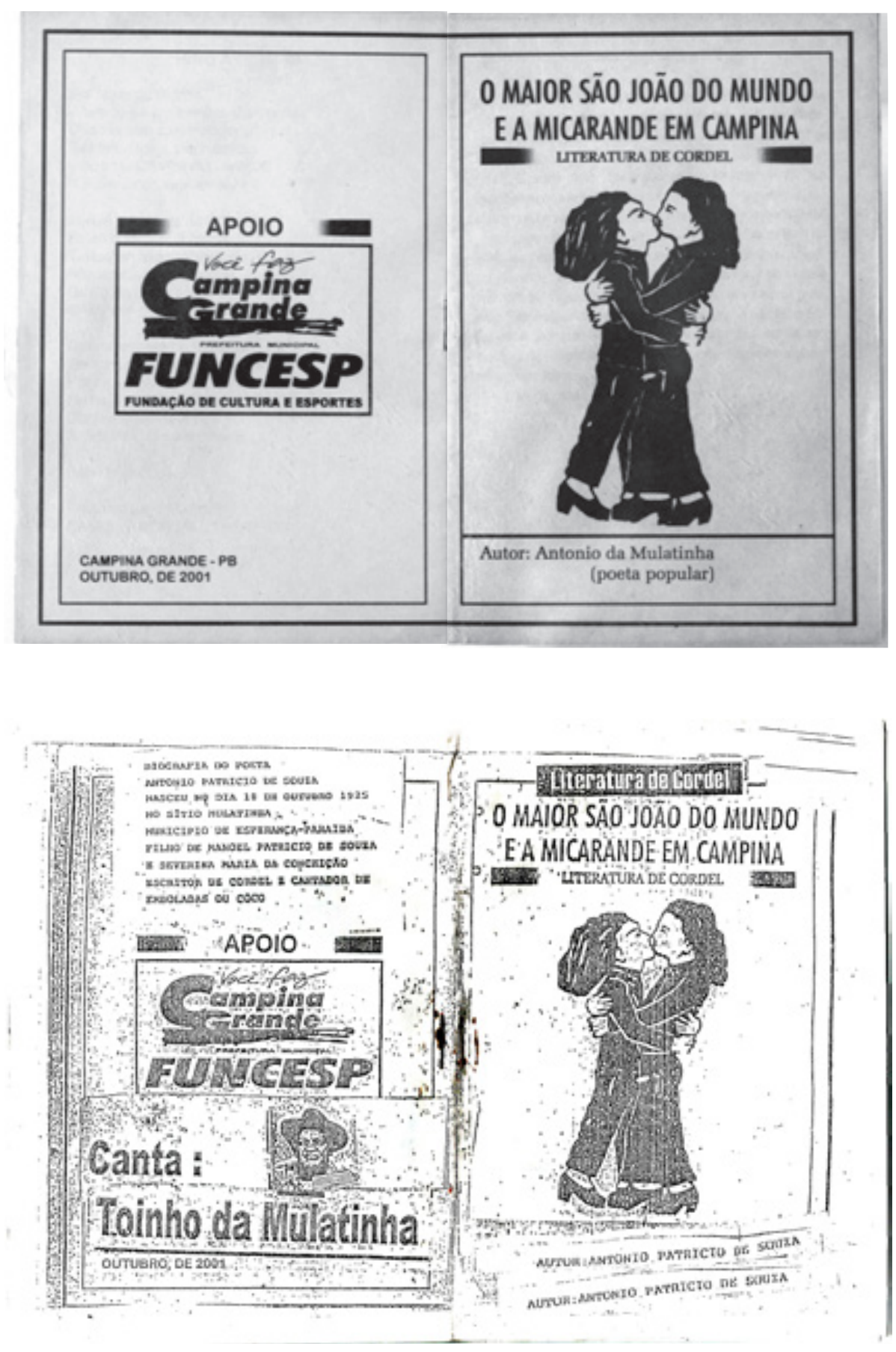

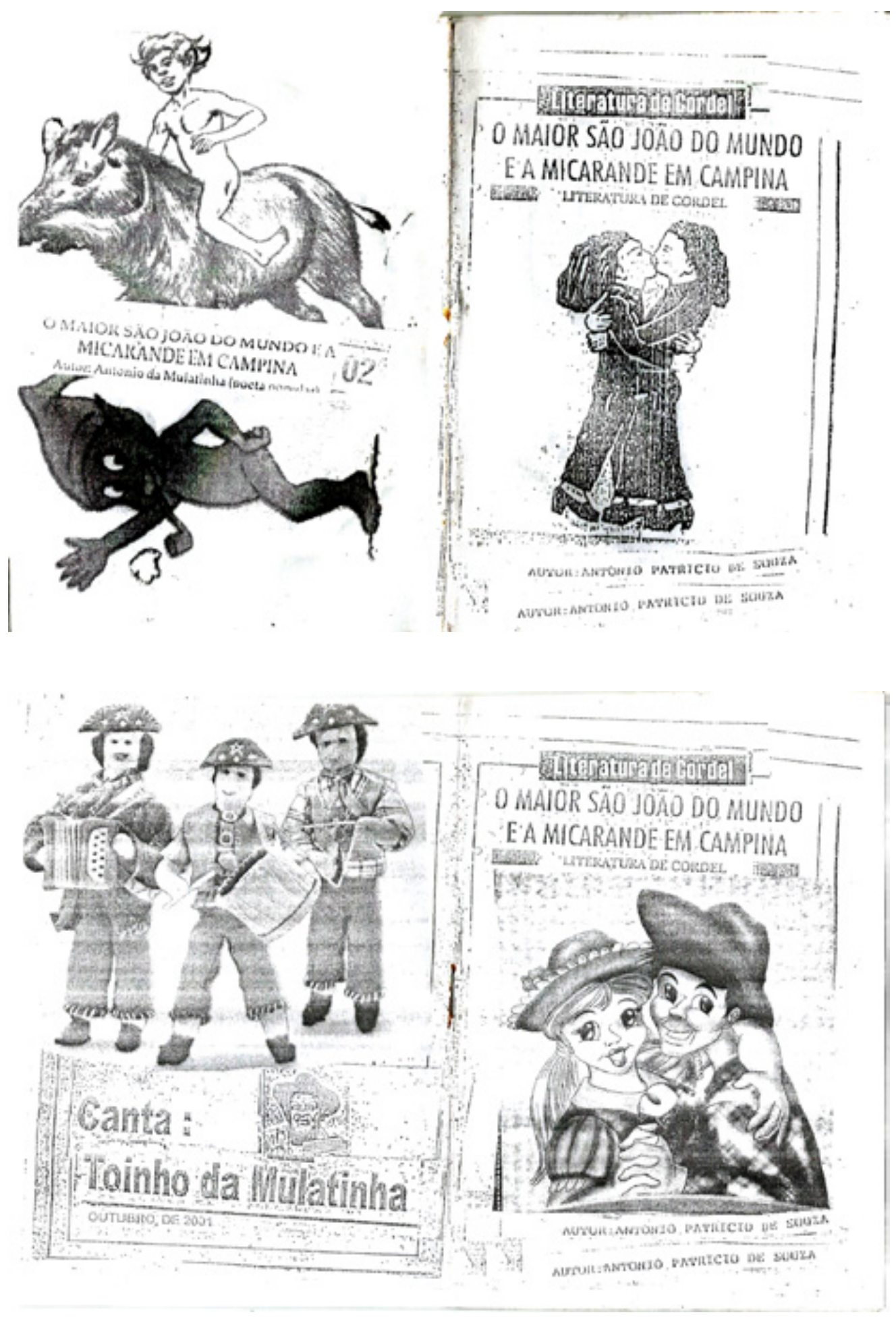

Figura 74 - Capas e quarta capas de editorações do mesmo título: o Maior São João do Mundo e a Micarande em Campina Grande (MULATINHA, 2001). A primeira publicação foi diagramada por gráfica parceira da prefeitura de Campina Grande (financiadora do folheto) e as demais por Toinho da Mulatinha 
De maneira correspondente aos editores que armazenavam tipos-móveis e clichês, Toinho arquivou em sua folhetaria recortes de palavras, frases, pequenos textos e imagens para estampar suas publicações - muitas delas aparecem com recorrência em suas edições do século XXI. Na caixinha onde guardara sua nova ferramenta de trabalho, uma tesoura, e os materiais por ela processados, recortes de revistas e jornais, mantinha 7 pregadores de "fixar cordel" [Figura 75] para dar-lhe sorte no seu porvir impreterível pelas linhas do barbante.

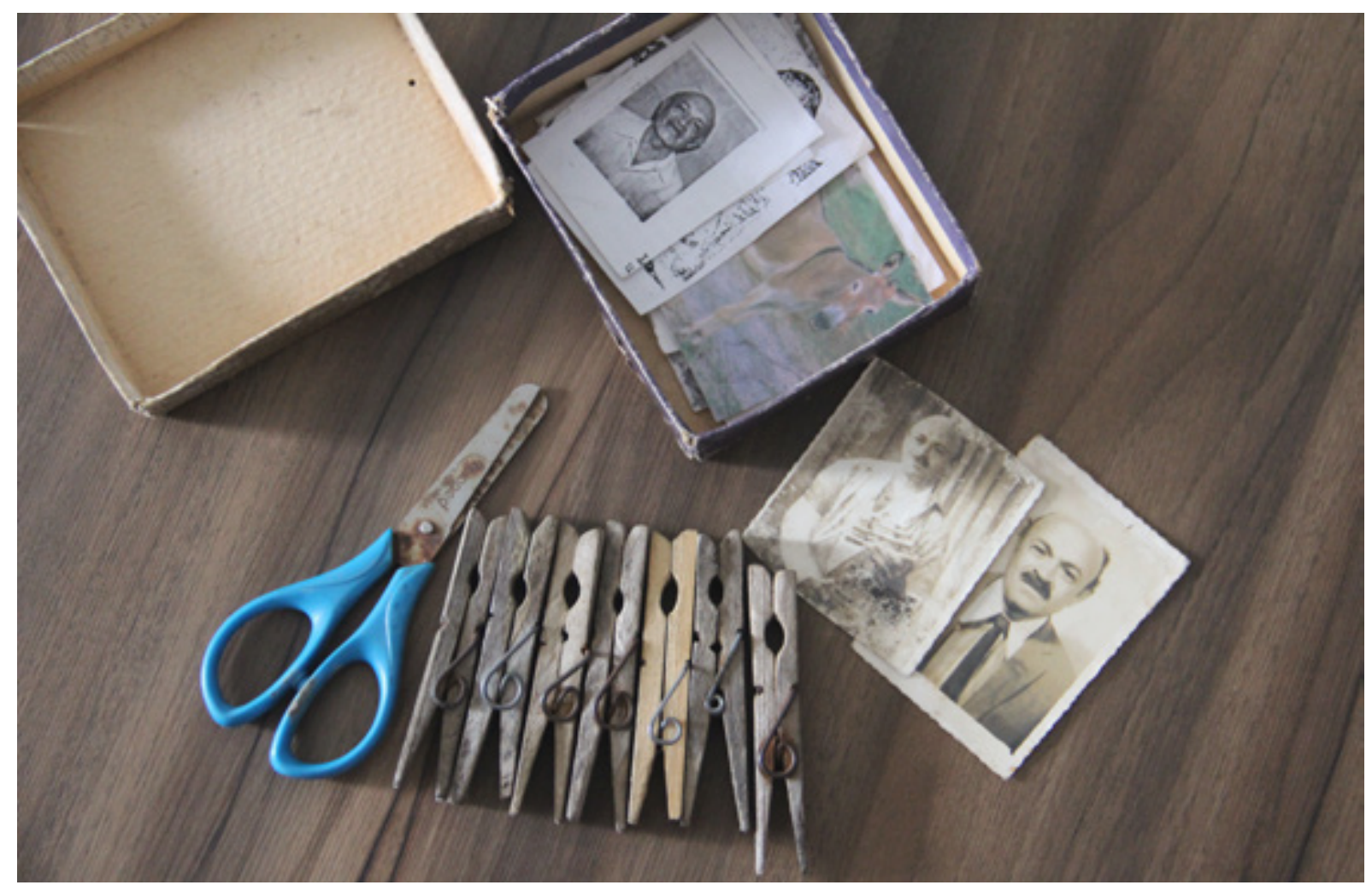

Figura 75 - Material de produção gráfica de Toinho da Mulatinha

Fonte: Acervo do poeta - Fotografia realizada pela pesquisadora (2016)

As capas de Toinho da Mulatinha, criadas através da composição de imagens advindas de diferentes fontes, sobretudo as veiculadas em suportes da cultura de massa, são uma ressignificação das ilustrações realizadas a partir da apropriação de fotogravuras adquiridas em prelos gutemberguianos. Assim como folheteiros da primeira metade do século XX, Toinho reaproveitou no início do XXI, imagens sucateadas, produzidas em princípio para outra finalidade, recontextualizando-as e combinando-as com os títulos de suas publicações. 
A similaridade estrutural de capas produzidas a partir da adaptação de figuras recolhidas em jornais, em diferentes períodos, pode ser observada na comparação de A História de Campina Grande Centenária (1964) e Em 2004 o inverno sangrou até boqueirão (2004) [Figura 76]:
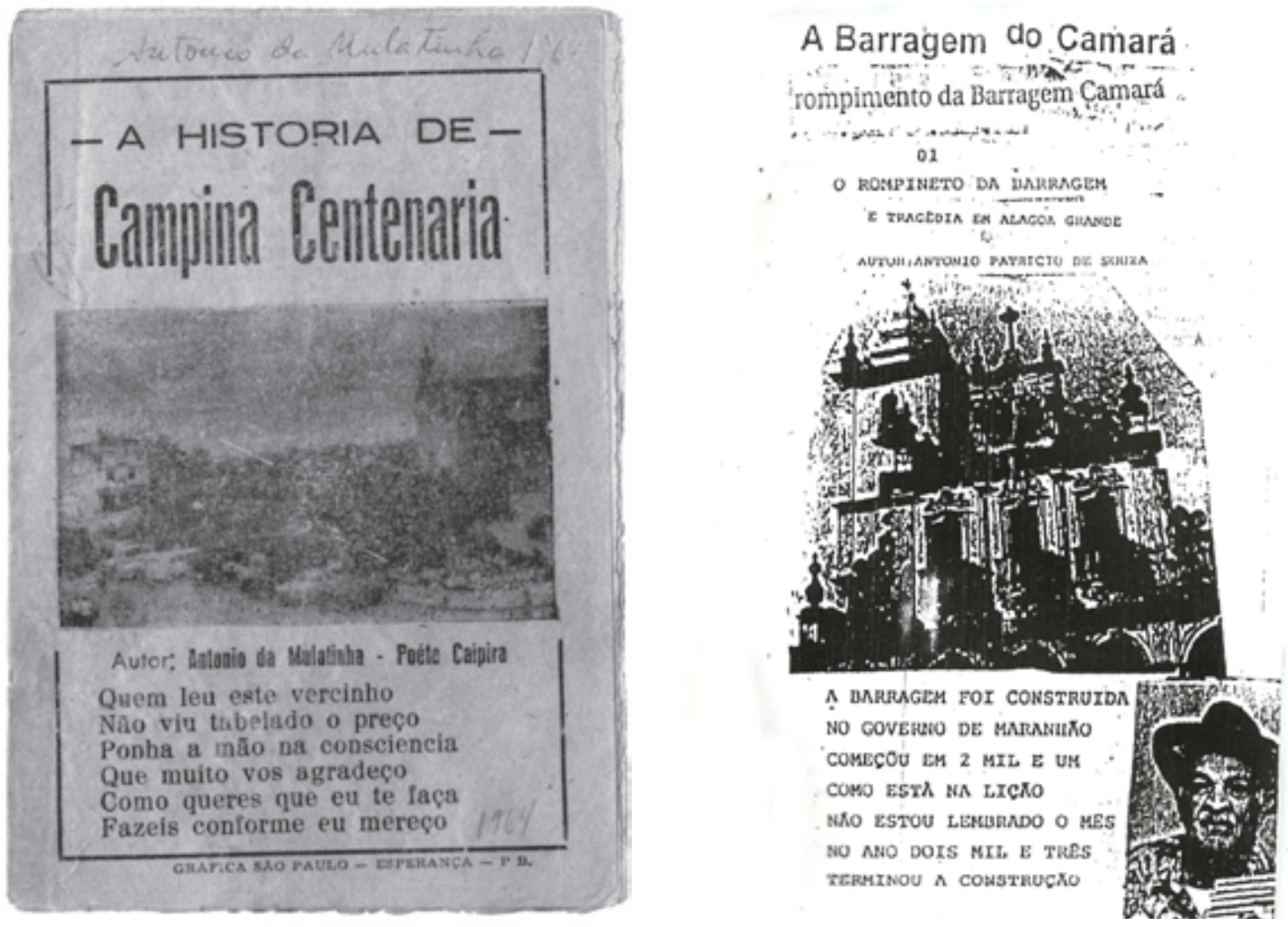

Figura 76 - Capas de folhetos de autoria de Toinho da Mulatinha compostas a partir de estrutura gráfica similar

Fontes: Biblioteca de Obras Raras Átila Almeida; Acervo da Pesquisadora

Os processos de “hibridação cultural” (CANCLINI, 2006) expressos nas capas dos folhetos ilustrados por zincogravuras, que associavam estrelas do cinema hollyodiano a personagens locais, como "Pedro Quengo" ou a "Bela Sertaneja” de Manoel Camilo dos Santos [Figura19], são notórios nas capas de Toinhoda Mulatinha, no séculoXXI. No cordel Ofolheto da filha que matou a mãe pela cabeça de um peixe (19--/20--) a “mãe" é representada por uma modelo de biquíni, dentro de padrões de beleza impostos na contemporaneidade - divergentes daqueles em voga no período de A Bêla Sertanêja (1957). 
O Folheto da filha que matou a mãe pela cabeça de um peixe, integra métodos de ilustração utilizados por Toinho em diferentes tempos de sua carreira profissional: enquanto a capa é composta pela colagem de imagens retiradas de mídias massivas, a quarta capa apresenta a fotocópia de uma xilogravura de Antônio Lucena, realizada sob encomenda para ilustrar o título mencionado [Figura 77].
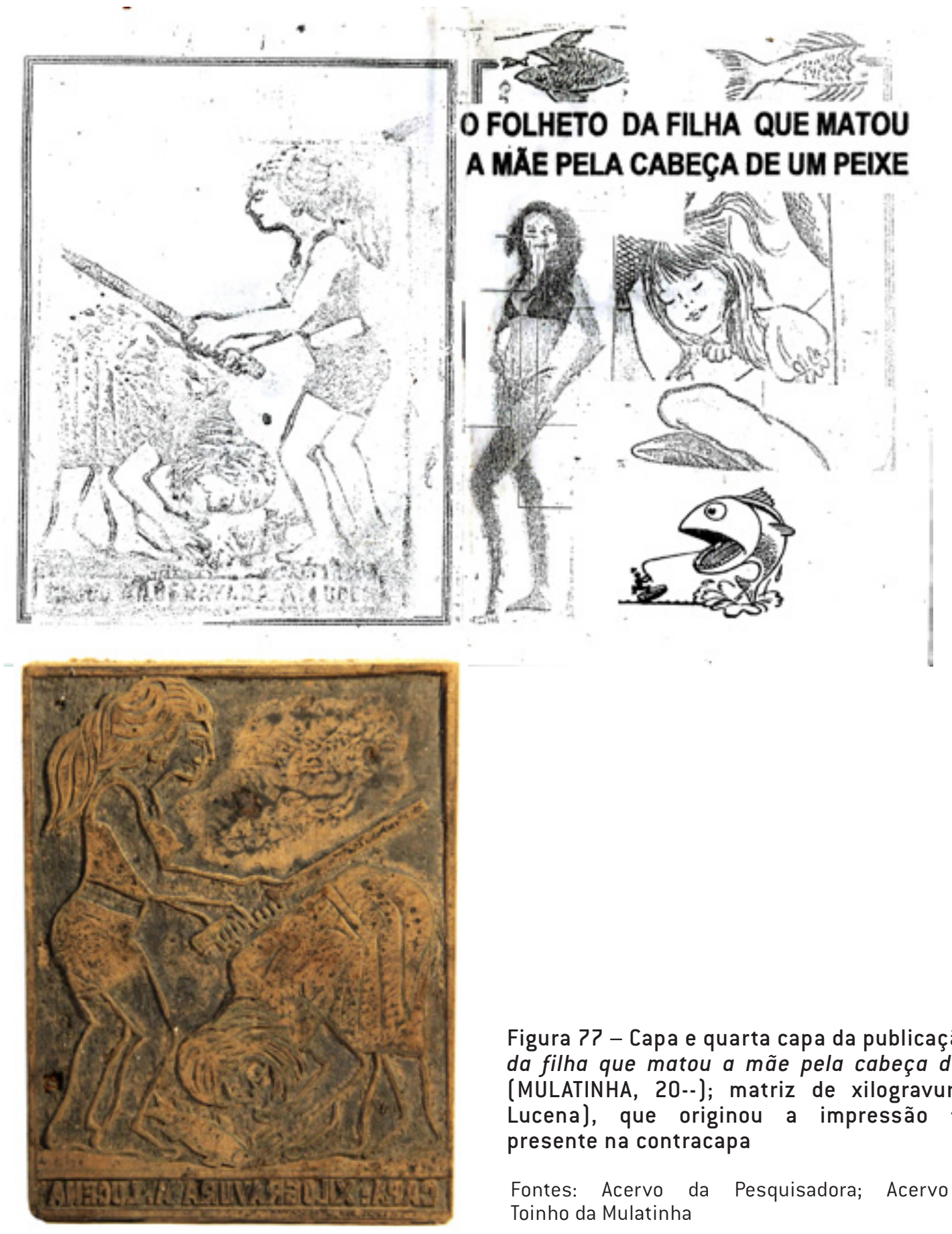

Figura 77 - Capa e quarta capa da publicação 0 folheto da filha que matou a mãe pela cabeça de um peixe (MULATINHA, 20--); matriz de xilogravura (Antônio Lucena), que originou a impressão fotocopiada presente na contracapa

Fontes: Acervo da Pesquisadora; Acervo do poeta Toinho da Mulatinha 
A dissonância estética entre as imagens estampadas na capa e na quarta capa do último folheto exibido, aponta para a tradição das brochuras brasileiras em suas descontinuidades, suas recriações. A estética multifacetada de Toinho sinaliza a impossibilidade de redução dos objetos tradicionais a modelos fechados, unitários e homogêneos de pertencimento cultural; revela a identidade dos sujeitos pós-modernos como uma "celebração móvel: formada e transformada continuamente em relação às formas pelas quais somos representados ou interpelados nos sistemas culturais que nos rodeiam" (HALL, 2006, p. 12-13).

Sob a ótica dos estudos culturais, Nestor Garcia Canclini (2001) corrobora com teorias do sociólogo Stuart Hall e nos ajuda a relativizar o fundamentalismo que contorna as identidades culturais, através da elaboração de um pensamento mais abrangente, capaz de abarcar as interações e integrações entre as categorias culturais simuladas pela modernidade: erudito, popular e massivo. De acordo com o autor, nada é puro, as culturas são híbridas, permeáveis, fruto de processos de intercâmbios e mesclas de culturas, ou entre formas culturais:

Os fenômenos culturais folk ou tradicionais são hoje o produto multideterminado de agentes populares e hegemônicos, rurais e urbanos, locais, nacionais e transnacionais. Por extensão, é possível pensar que o popular é constituído por processos híbridos e complexos, usando como signos de identificação elementos procedentes de diversas classes e nações. (CANCLINI, 2001, p. 220-221)

Toinho da Mulatinha não permanece intocado na imaginada "esfera do popular", mas trafega e agrega referências de diferentes campos socioculturais, tanto no plano narrativo, através da interpretação simultaneamente fantasiosa e religiosa (católica), em sextilhas, de tragédias veiculadas na televisão - como no Cordel de Isabela, por exemplo; quanto no âmbito estético, posto que dialoga com técnicas gráficas desenvolvidas no contexto das Artes Plásticas. Ainda que de forma irrefletida, o poeta-diagramador tangencia a visualidade (mas não a dimensão conceitual) inerente as colagens da Pop Art, que ganharam força nos anos 1950, assim como se aproxima de expressões da Poesia Marginal dos anos 1970, corporificada através de meios de impressão alternativos, como o mimeógrafo e a fotocópia.

A ausência de um componedor - peça que, nas tipografias, serve para a composição manual das matrizes - concedeu ao poeta a liberdade de escapar às molduras e grades de alinhamento dos caracteres e do clichê, como podemos observar no cotejo das capas dos folhetos a seguir, que tematizam o "Treze Futebol Clube" O galo da Borborema (1975/ 2006) [Figura 78]. 

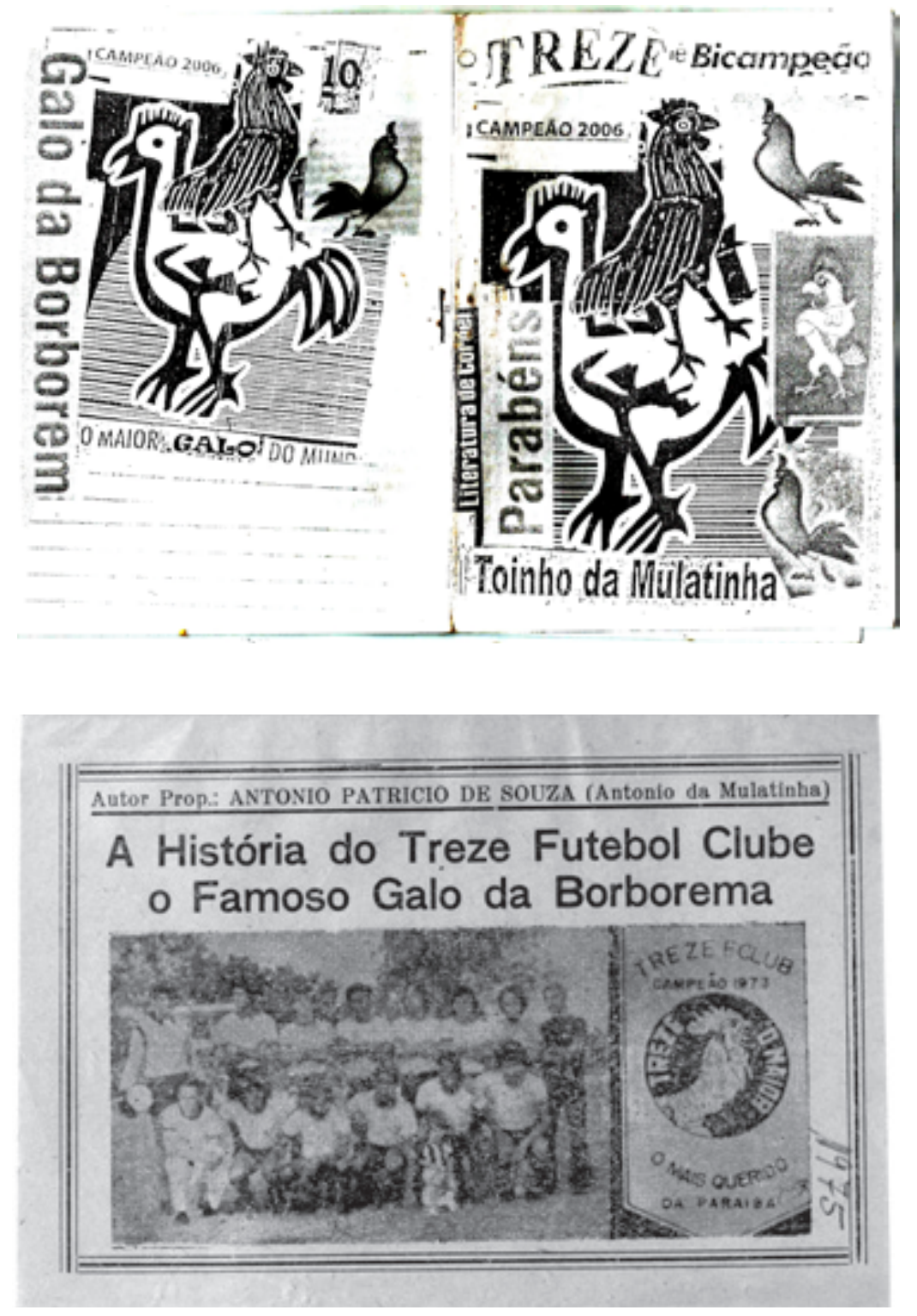

Figura 78 - Capas de publicações de Mulatinha que tematizam o Treze Futebol Clube, impressas em 2006 e 1975, respectivamente

Fontes: Acervo da Pesquisadora; Acervo da Biblioteca de Obras Raras Átila Almeida (BORAA/UEPB)

Em análise comparativa é possível constatar que a capa realizada através da colagem guarda ogesto criativo do compositor, aintencionalidadedoautor.Adiagramação do séculoXXIé menos institucional do que aquela realizada no séculoXX, mais intuitiva. O despojamento da reedição deve-se à escolha do mascote do Treze Futebol Clube para ilustrar a narrativa, assim como pela viabilidade operacional de sobreposição das imagens, que oportuniza investidas em recursos estilísticos como o pleonasmo e a hipérbole, auferidos por meio da repetição. A presença do editor também aparece na congratulação ao time, expressa na palavra "Parabéns". 
As capas dos folhetos produzidos por Toinho da Mulatinha se aproximam, esteticamente, dos Zines: auto publicações independentes produzidas por e para entusiastas de fenômenos culturais específicos (como um gênero literário ou musical), a partir da reunião de textos verbais e não-verbais, autorais e apropriados. Estas brochuras, com tiragens fotocopiadas, são projetadas de maneia intuitiva e confiante, despojadas das convenções do design gráfico profissional [Figuras 79 e 80] ${ }^{209}$.

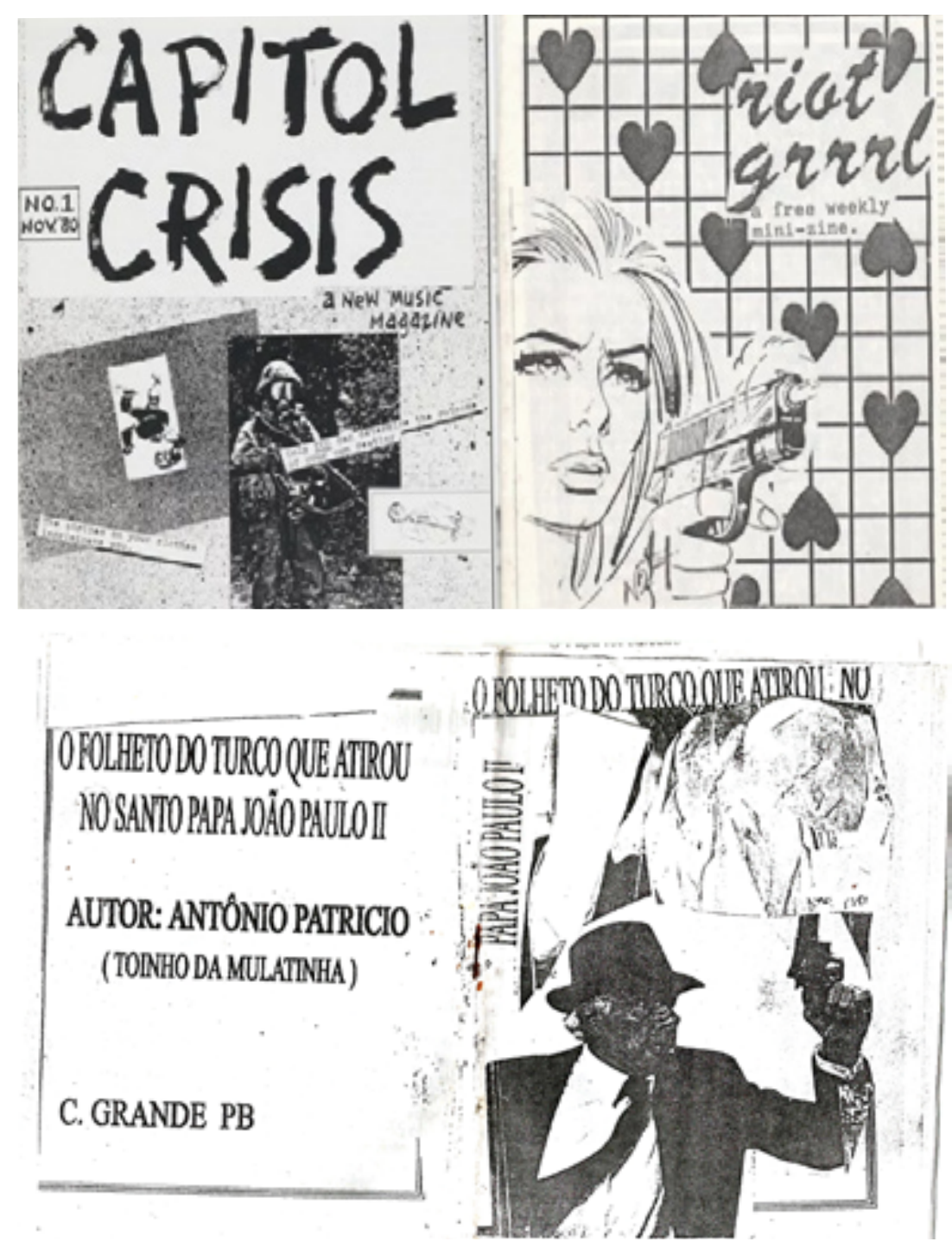

Figura 79 - Zine do coletivo Riot Grrrl, inscrito na cena punk de Washington (EUA) nos anos 1990; Folheto publicado por Toinho da Mulatinha no início dos anos 2000

Fontes: https://www.washingtonian.com/2016/08/04/zinesdeserve-a-bigger-place-in-dc-punk-history-heres-why/; Acervo da pesquisadora

209 Os primeiros zines (abreviação de fanzines), surgiram nos EUA nos anos 1930, sendo que o termo foi criado em 1940 pelo jogador de xadrez estadunidense Russ Chauvenet, que combinou as palavras Fanatic e Magazine (CAMARGO, 2011). 


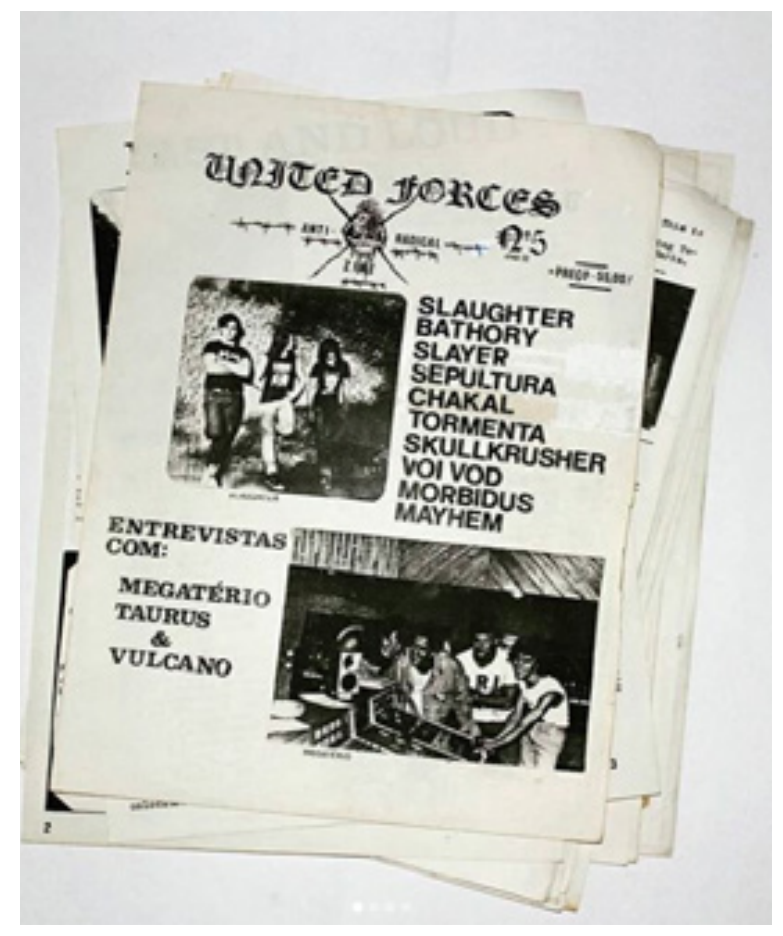

Figura 80 - Fanzine Metal-Punk underground, "United Forces", que circulou no Brasil entre 1986 e 1991. Editado por Marcelo Batista em São Paulo.

Fonte: Instagram oficial do "United Forces" - https://www. instagram.com/p/By6KW6yg5R8/

Figura 81 - Zines da coleção do MoMa (The Museum of Modern Art). Produzidos por artistas mulheres vanguardistas das publicações independentes nos Estados Unidos no final do século XX. Da esquerda para a direita: a] Kathleen Hanna, Billy Karren, Tobi Vail, Kathi Wilcox. Bikini Kill: Girl Power, no. 2. 1991. Fotocópia; capa por Hanna; b) Kathleen Hanna, Billy Karren, Tobi Vail, Kathi Wilcox. Bikini Kill: A Color and Activity Book, no. 1. 1991. Fotocópia; capa por Hanna; c) Molly Neuman, Allison Wolfe. Girl Germs, no. 5. c. 1993-94. Fotocópia; capa por Miss Pussycat.

Fonte:https://www.moma.org/explore/inside_out/2010/08/12/ riot-on-the-page-thirty-years-of-zines-by-women/

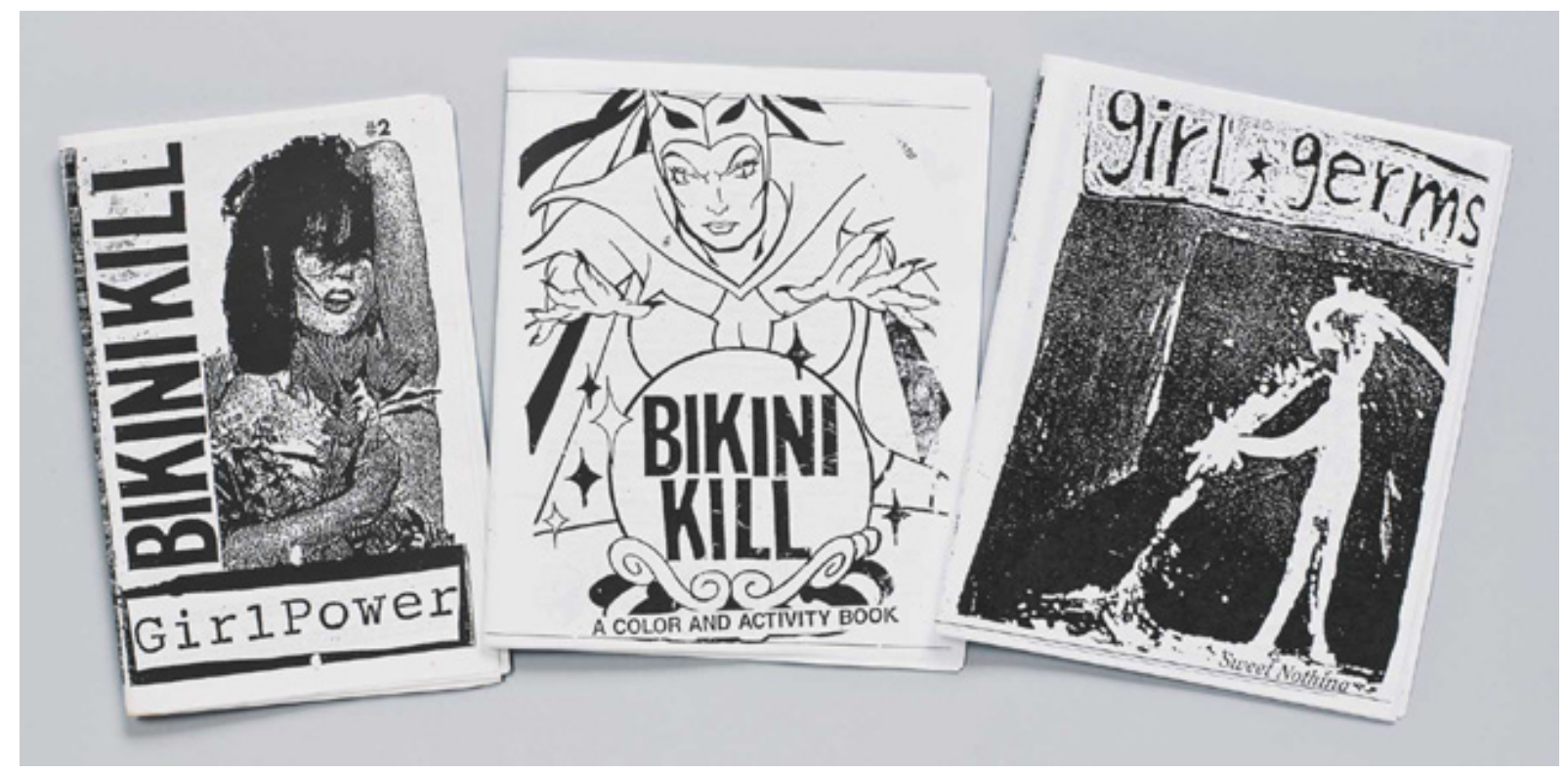



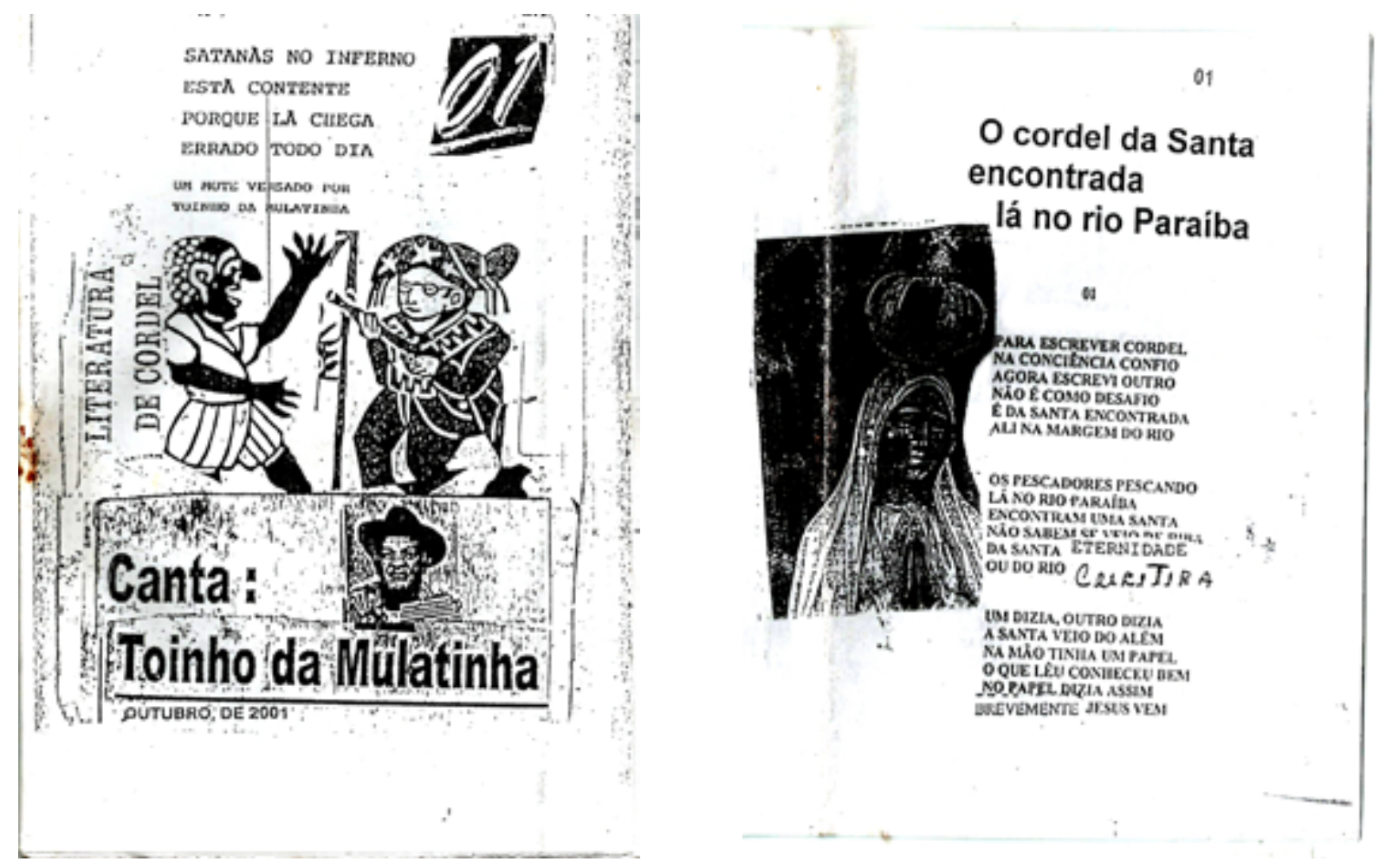

Figura 82 - Folhetos com aspecto de zine compostos por Toinho da Mulatinha no início do século $X X$

Fonte: Acervo da pesquisadora

A mudança nas técnicas de materialização dos folhetos de Toinho da Mulatinha, a partir dos anos 2000, revelam que as culturas populares permanecem desenvolvendo mecanismos de adaptação. Os folhetos expostos nesse capítulo, "Pura (con)tradição", desafiam a estética eleita como adequada para representar "o popular", por movimentos de matriz folclórica. Mesmo a presença da xilogravura em sua produção mais recente não atende idealizações, pois as matrizes e impressões são fotocopiadas [Figura 83]. $\mathrm{O}$ artesanal é submetido à máquina digital. 


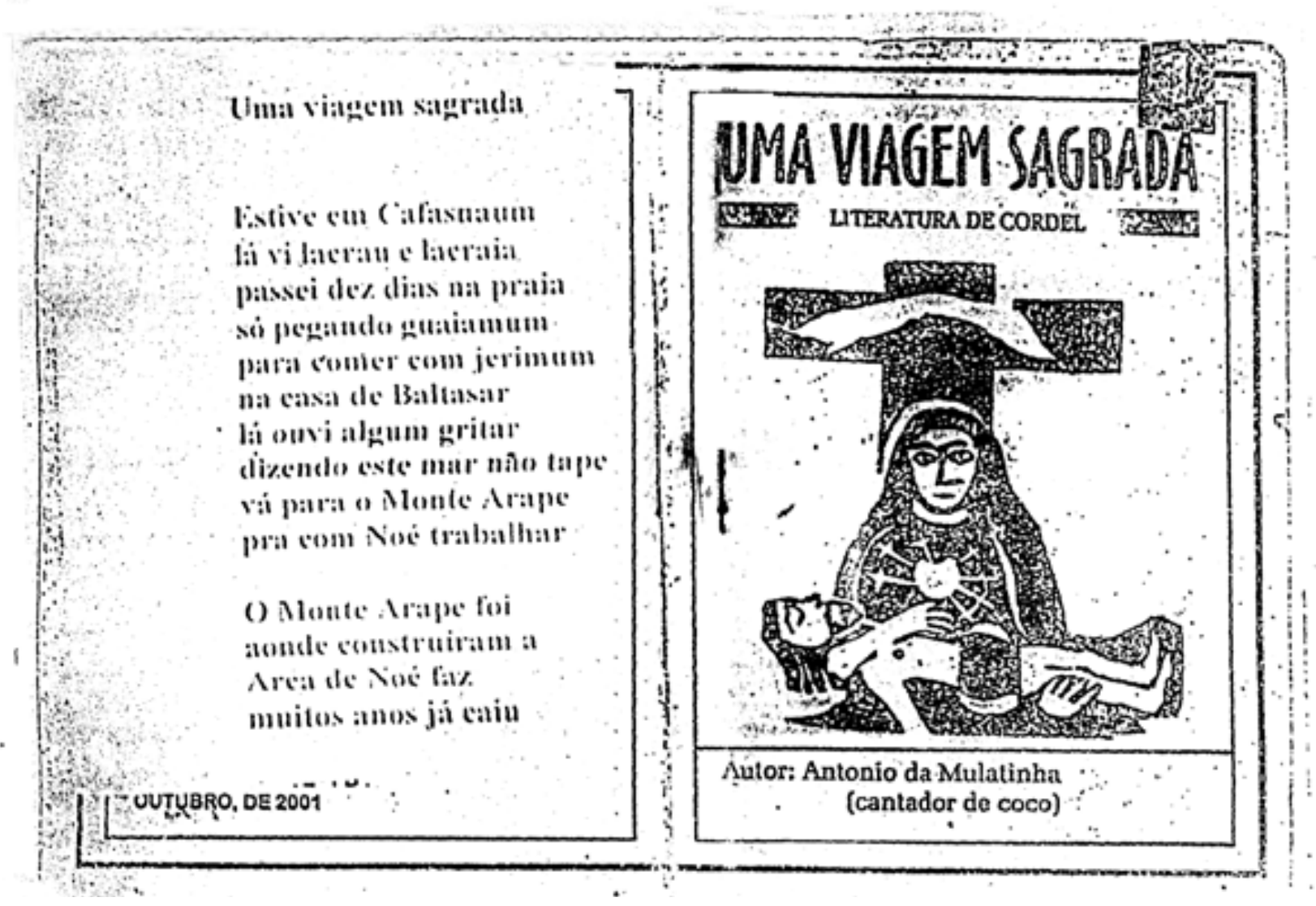

Figura 83 - Capa do folheto Uma Viagem Sagrada (MULATINHA, 2001), ilustrada por xilogravura fotocopiada

Fonte: Acervo da pesquisadora

Os cordéis mimeografados e fotocopiados, representativos de uma geração de poetas e poetizas que utilizaram esses aparatos para a manutenção do próprio ofício permanecem inexplorados por agentes dos campos acadêmico e, sobretudo, museológico - geralmente ligado ao turismo. Esse vazio abre espaço para a constatação de que alguns paradigmas acerca das produções denominadas populares, discutidos há pelo menos meio século pela intelectualidade brasileira, foram mais superados no discurso do que na prática investigativa/expositiva. Analisando a sobrepujança da valorização dos objetos culturais mais pela repetição do que pela transformação, Garcia Canclini (2006) sistematiza refutações às perspectivas anacronizantes de raiz folclórica:

a) o desenvolvimento [pós]moderno não suprime as culturas populares [...]; b) as culturas camponesas e tradicionais já não representam a parte majoritária da cultura popular [...]; c) o popular não se concentra nos objetos [...]; d) o popular não é monopólio dos setores populares [...]; e) o popular não é vivido pelos sujeitos populares como complacência melancólica para com as contradições [...]; f) a preservação pura das tradições não é sempre o melhor recurso popular para se reproduzir e reelaborar sua situação [...]. (CANCLINI, 2006, p. 215). 
Destaco essa última observação de Canclini, que me faz lembrar imediatamente as representações presentes no Sítio São João (Campina Grande), onde repetidos discursos criam uma tradição de desconhecimento do passado e do presente. No contato estreito com diferentes dimensões de Campina Grande - onde desde 2015 andei pelos becos da Feira e ouvi gente antiga que ali se criou, visitei museus da cidade e acervos guardados por "poetas-caipiras”, presenciei o Maior São João do Mundo e apresentações poéticas no calçadão da Cardoso Vieira, transitei entre as universidades e sítios - , percebo que as instituições promotoras das artes e espetáculos “culturais” foram aquelas, que diferente de artistas como Toinho, não conseguiram acompanhar os sobressaltos dos novos tempos. Ainda dialogando com Canclini, proponho que o cordel talvez seja exemplar de que a modernização latino-americana, mais do que uma força alheia e dominadora que busca substituir o tradicional, é sua razão de ser.

\section{NOVOS SUPORTES PARA UMA PRÁTICA ANCIÃ}

No novo século o poeta ancião Toinho da Mulatinha recolheu-se na cidade onde escreveu a própria história de vida, estendendo a rotina de folheteiro, diariamente, na sua banca situada na Feira Central de Campina Grande, junto com a esposa Digna.

Até hoje eu ainda canto, embora as pernas estejam doendo. Andei por elas e conheço quase todas as feiras da Paraíba e de Pernambuco. Picuí, Cuité, Esperança, Remigio, Solanea, Juazeiro, Soledade, Taperoá, Patos... Eu ia de feira em feira vendendo folheto e depois 'emburacava' no Côco, e assim passava o dia todo. A literatura era, e ainda é, um modo de vida, me ajudou muito (MULATINHA, 2007). ${ }^{\mathbf{2 1 0}}$

Da Estrela do Oriente, Toinho recolheu notícias de lugares onde as pernas não alcançavam mais através da televisão, das revistas, dos jornais, para compor poemas de época. No silêncio do seu reduto criativo recortou palavras, colou imagens, como quem tentava reconstituir o tempo próspero de sua Viagem à Lua (1945). A idade e as dificuldades financeiras limitaram o acesso de Toinho ao mundo virtual que irrompia o céu da cidade consolidada como uma das maiores exportadoras de software do país ${ }^{\mathbf{2 1 1}}$.

Se a atualidade das tecnologias e a viabilidade econômica das mesmas foi um predicado para existência do cordel, desde os tipos móveis, a internet configurava-se

210 Relato extraído de entrevista concedida por Toinho da Mulatinha à revistinha Cordeletras - n 6 (2007, p. 6). 211 Para mais informações sobre a importância do polo tecnológico de Campina Grande ver: SANTOS FILHO, Ernani Martins. 0 Tecnopolo Campina Grande e sua Inserção nas Redes de Informação Global. 2016. 128f. Tese (Doutorado em Geografia) - Universidade Federal de Pernambuco, Pernambuco, 2016. 
como seu o destino inexorável. As telas tornam-se suportes da poesia e passam a mediar pelejas no final dos anos 1990, consolidando-se, com a popularização do acesso à web em 2013 (PNAD, 2013) ${ }^{\mathbf{2 1 2}}$, como suporte privilegiado de versos codificados.

$\mathrm{O}$ advento das redes sociais no Brasil, assentou espaços de encontro para poetas de bancada e violeiros. Com a conectividade nas palmas das mãos, após a difusão do smartphone, os encontros nessas plataformas virtuais tornam-se mais corriqueiros e os repentes, via WhatsApp, instantâneos. Hoje, no Facebook, poetas e poetizas montam “perfis profissionais”, postam estrofes ávidas por “curtidas”, realizam transmissões de cantorias ao vivo e criam "eventos” para promover reuniões presencias. No YouTube, também abrem “canais” para compartilhar músicas de tradição oral.

A pesquisadora Maria Alice Amorim (2009), autora do livro Pelejas em rede: vamos ver quem pode mais, constatou em seu percurso acadêmico que a internet, além de terreno para divulgação, "é monte parnaso e ribeira, onde os poetas se encontram para emulação e exercício de jogos poéticos, para debate de ideias e troca de opiniões acerca da vida e do ofício do verso" (AMORIM, 2009b, p. 68) ${ }^{\mathbf{2 1 3}}$. Ou seja, nos nós dessa rede tramam micropolíticas de resistência, tecem espaços de apoio, de salvaguarda.

Em 1997, quando a internet ainda não era aparato domiciliar, tão pouco vislumbrava ser extensão da nossas ações cotidianas, os poetas José Honório e Américo Gomes, desbravaram caminhos no sistema global de redes e encontraram no correio eletrônico espaço para armar uma peleja cibernética pioneira, glosada como poesia de bancada, ao longo de 15 dias sob o mote "me vencer na peleja virtual/ só quebrando primeiro o meu teclado" (SILVA, 2007, p. 6). Em 1995, o poeta pernambucano Honório já flertava com o tema das tecnologias da informação/comunicação no folheto O meu marco cibernético construído em Timbaúba (1995), que teve a primeira edição materializada pelo autor em impressora de uso doméstico ${ }^{\mathbf{2 1 4}}$.

\footnotetext{
Não preciso da Internet

para acessar minha musa

quem assim crer, certamente

tem uma mente obtusa

pois nenhum computador

me dirá como produza.
}

212 Pesquisa Nacional por Amostra de Domicílios - Síntese dos Indicadores (2013) - IBGE (Instituto Brasileiro de Geografia e Estatística). Disponível em: < https://biblioteca.ibge.gov.br/visualizacao/livros/ liv94414.pdf >. Acesso em: 20 nov. 2019.

213 Grifo da pesquisadora.

214 Folheto disponível em: <http://www.cibertecadecordel.com.br/detalhe.php?id=?603>. Acesso em: 20 nov. 2019. 
Se pena, lápis, caneta

cumpriram sua missão

e a máquina de escrever

deu sua contribuição

que mal há em nos valermos

da nova computação.

Não importa por qual via

o verso chegue ao leitor

se impresso em tipos móveis

fax ou computador

importa sim, que traduza

um espírito criador.

Sou vate moderno

pois uso a tecnologia

mas procuro ficar fiel

à minha filosofia

de manter toda a estética

secular da poesia

[...]

Musa minha, por favor

não se sinta desprezada

somente por minha lira

ficar informatizada

pois rendi-me à high-tech

pra vê-la ressuscitada.

(HONÓRIO, 1995 apud AMORIM, 2009b, p.62)

A conectividade entre cibercultura e tradição inaugurou um "novo cordel”, não no sentido estrutural do verso como nos mostra Honório em seu marco, ao "manter toda a estética secular da poesia" (rima/ métrica/ ritmo/ divisão de estrofe), mas pela emergência de um novo pensamento, sincronizado com demandas contemporâneas, sociais, políticas, ambientais.

Para além dos modelos poéticos adotados, a química da poesia é que reverbera o novo, dá consistência ao novo, e não simplesmente o contrário. Misturar linguagens da tradição a novas ferramentas, oferecer novos modos de pensar a partir de confluências do espírito do tempo poderão garantir a permanência da voz poética que se ofereça de modo 
singular, criativo, original. Aliado à técnica do versejar em formas fixas, $o$ talento do poeta de cordel é que define fronteiras, estabelece limites entre o consagrador e o descartável. (AMORIM, 2009, p. 68) ${ }^{215}$.

Aquilo que passa a ser considerado descartável, por poetas e poetizas, deriva-se de mudanças nos campos discursivos incitadas pela implantação de políticas afirmativas "neodesenvolvimentistas", no início do século XXI, que ampliaram o acesso de sujeitos (antes sujeitados a cidadanias precárias) à escola e à universidade; promoveram a autonomia das mulheres, a partir de programas sociais como o Bolsa Famíla ${ }^{\mathbf{2 1 6}}$, fomentando a consciência de gênero; inscreveram no plano jurídico (e, portanto, no âmbito das relações objetivas) os direitos civis, sociais e sexuais de grupos historicamente subalternizados, na esteira do reconhecimento das diferenças desde a Constituição de 1988.

As ações de movimentos sociais nas redes sociais digitais (feminista, negro, LGBTQ+, dentre outros) também colaboraram na ampliação de um vocabulário inclusivo, capaz de abrir lugares de fala para personagens como A negra da trouxa grande de Toinho da Mulatinha (1957 - $1^{\text {a }}$ edição), recusada na narrativa como integrante da “civilização nos trópicos”. Ao expor essa conjuntura não pretendo insinuar que o cordel tenha se tornado uma ferramenta revolucionária, ou mesmo a literatura panfletária sonhada pelos "cepecistas" do Movimento Estudantil de 1960, mas uma arena mais plural, pela qual circulam saberes insurgentes, como o "cordel akilombado" do poeta campinense Silas Silva, e na qual se inserem figuras que permaneceram apagadas da historiografia do gênero no século XX, inclusive por terem assinado suas produções com pseudônimos masculinos ${ }^{217}$ : as mulheres.

Se o cordel foi fundamental na reiteração de um sistema de representação de um Nordeste cabra macho, o "novo cordel” passa a ser fundamental na reposição desse imaginário.

O blog “Cordel de saia”, organizado pelas poetizas Dalinha Catunda e Rosário Pinto em 2010, corrobora a construção de um renovado retrato dessa literatura, lida por correntes historiográficas dos anos 1970 como portadora de valores ultraconservadores (IUMATTI, 2012), pois, além de comportar motes que levantam questões de gênero, como violência conta a mulher - "Pra sua faca afiada/ tem couro minha bainha"218 -, marca a ruptura de uma tradição masculina, ao firmar a vez das escritoras na cultura popular.

215 Grifos da pesquisadora.

216 Sobre o programa ver: REGO, Walquiria Leão; PINZANI, Alessandro. Vozes do Bolsa Família: autonomia, dinheiro e cidadania. São Paulo: Unesp. 2013.

217 Alusão a Altino Alagoano, pseudônimo atrás do qual se escondia uma mulher, Maria das Neves Batista Pimentel, filha do poeta e editor Francisco das Chagas Batista.

218 Glosa disponível em: < http://cordeldesaia.blogspot.com/>. Acesso em: 20 nov. 2019. 
Nesse sentido, mudar o modus operandi a partir dos usos das Tecnologias de Informação e Comunicação, apareceu também como alternativa de transformar as práticas discursivas em vigor. Mas, o "novo cordel” não circula apenas nos meios digitais, ele tem sua face impressa, afinal, "o que está sendo chamado de novo cordel nada mais é que uma revalorização, com mais qualidade na versificação e mais atualidade temática, do bom e velho folheto de feira nordestina”, alega o poeta-ensaísta Glauco Mattoso (2009, apud AMORIM, 2009a, p. 61).

Manoel Monteiro, em Campina Grande, foi uma liderança do “novo cordel” no início da década de 2000. O movimento que sustenta a produção do poeta radicado em Campina Grande, demarcado em correspondência com a acepção conceitual de Mattoso ${ }^{\mathbf{2 1 9}}$, alinhase a correntes específicas que usaram a terminologia para definir folhetos de dimensão educativa, especificamente "paradidática", vislumbrando um público leitor formado por alunos e professores vinculados a instituições de educação formal.

Há de se considerar que o termo "novo cordel” é controverso, por abarcar produções de gêneros distintos (repente, embolada de coco e poesia de bancada), inseridos em diferentes suportes (redes sociais digitais, livros infanto-juvenis e paradidáticos), remetendo a públicos determinados. Também é necessário salientar que alguns dos elementos elencados na atribuição da condição de novo são intrínsecos a essa prática. A exemplo do comprometimento com o uso correto da língua portuguesa pelos poetas de bancada, cujo a preocupação é registrada em versos por gerações antecessoras: "E desses pequenos versos/ peço dissimulação/ por ser pobre poéta/ que não tive educação/ criado na Mulatinha/ Plantando milho e feijão” (MULATINHA, 1964, p. 08). Lembremos que muitos poetas pagavam pela revisão de seus textos no tempo das tipografias especializadas.

A ampliação do perfil social dos/as escritores/as de cordel no final do século XX, configura-se como uma das mudanças significativas em relação às transformações desta prática tradicional. Hoje, poetas e poetizas de profissão são estudantes universitários/ as, pesquisadora/es, profissionais liberais, microempreendedores/as ou exclusivamente literatos/as dedicados/as ao verso e/ou a prosa (embora seja necessário relativizar que desde o final do XIX o cordel não era território exclusivo de trabalhadores rurais). Os modos de inserção da poesia oral ou de bancada na vida dessas pessoas também foram modificados, diante do fato do cordel ter sido integrado a diversas esferas da sociedade.

O poeta-embolador Condor, figura que teve suas vivências com a poesia oral/ impressa ao longo da infância nos passeios pela Feira Central de Campina Grande, embalados pelo ganzá de Toinho da Mulatinha, reconhece como disparador da sua

219 Para Manoel Monteiro, o "novo cordel" "não destoa na poesia, nem nas regras, nem na forma; prima, contudo, pela correção da língua, pela riqueza e pela atualidade das informações" (MONTEIRO, 2008 apud MONTENEGRO, 2014, p. 24). 
carreira profissional o seu contato com a prática da embolada no ensino fundamental, na primeira década de 2000.

A gente [Condor e Cleiton] começou fazendo [poesia] na escola que a gente estudava...começou através de um professor meu, que realmente abordou esse assunto de arte popular, cordel, cantoria... e a gente fez repente. Daí ele gostou muito! Começou com gincana, com esses eventos que tem em escola. Na época junina a gente começou a fazer essas apresentações. Então, os professores que davam aulas em outras escolas queriam levar a gente pra apresentar porque acharam legal. (SILVA, 2018).

A narrativa de Condor incita a hipótese de que os novos espaços de fruição da poesia de bancada, atrelados aos novos suportes, é que determinam, de fato, um "novo cordel". Para compreendermos mais detidamente as reinscrições da literatura de folhetos no século XXI, as permanências e rupturas na editoração do gênero em Campina Grande, é imprescindível nos aproximarmos, ainda que rapidamente, da obra de Manoel Monteiro.

O "novo cordel" de Monteiro, é formulado a partir de suas experiências como poeta em dois tempos, visto que sua atuação no ofício não foi contínua (1950 - 1960; 1990 - 2014), e daquelas oriundas das atividades profissionais exercidas nesse ínterim de trinta anos. Após atuar durante dez anos como poeta de bancada e declamador na Feira Central campinense, Manoel Monteiro deixa o circuito editorial especializado no gênero para associar-se a tipografias de relevo na cidade, atuando como gráfico na Livraria Pedrosa e como revisor no Diário da Borborema. No período, ingressou no sindicado dos gráficos e vinculou-se ao Partido Comunista, pelo qual candidatouse a vereador, em 1963. Preso com o Golpe Militar, afastou-se em 1964 do universo da palavra impressa. A fim de esquivar-se da repressão passou a trabalhar, desde então, como representante comercial no setor calçadista, caminhando rumo ao comércio de impressos poéticos-paradidáticos, no qual fecha seu ciclo profissional.

$\mathrm{Na}$ década de 1990, quando Manoel Monteiro volta a produzir poesia em folhetos, se depara com outro cenário, contemplado por um olhar maturado pelas experiências descritas acima. Segundo a filha, Valentina Monteiro, o poeta começa a projetar o "novo cordel” no epílogo do século XX, por perceber que essa prática cultural "estava em evidência". Refutando as teses sobre a morte da literatura de folhetos, uma vez que "literatura não morre", o poeta argumentava que o cordel "estava hibernando [,na segunda metade do século XX,] na universidade, na França, onde as pessoas entendem de literatura." (MONTEIRO, 2018) 220.

220 MONTEIRO, Valentina. Depoimento [mar. 2018]. Entrevista concedida à pesquisadora. Campina Grande (PB), 2018. 
Ciente de que os folhetos haviam se consolidado como objetos de pesquisa, colecionáveis, Manoel Monteiro busca sistematizar seus impressos, incluindo informações como ano, edição e local de produção. A percepção aguçada do autor sobre a "anatomia do livro", desenvolvida no contato com o mercado editorial livresco na tipografia da Livraria Pedrosa, corroborou a regularização das edições.

O estabelecimento da Cordelaria Poeta Manoel Monteiro, em 2003, inaugura uma fase de grande produtividade literária do poeta (autor de quase duas centenas de títulos), determinada pelo foco no viés pedagógico do texto. Em Campina Grande, Manoel Monteiro é figura representativa de uma geração que passa a produzir sextilhas paradidáticas, motivada pela inserção do gênero nos Parâmetros Curriculares Nacionais (PCN) para o ensino de Língua Portuguesa, em 1997. Segundo Maria do Socorro Montenegro (2014), os folhetos do autor guardam evidentes relações com os PCN, uma vez que "tratam de temáticas diversificadas, como meio ambiente, saúde, fauna, flora dentre outros que se enquadram no domínio dos estudos transversais de que tratam o referido documento" (MONTENEGRO, 2014, p. 36-37).

Alguns trabalhos acadêmicos corroboraram o processo de inclusão da literatura de cordel no ensino básico, como o precursor Cordel na sala de aula (2001). O livro, elaborado por docentes de universidades paraibanas especializados em Literatura Brasileira - José Hélder Pinheiro (Universidade Federal de Campina Grande) e Ana Cristina Marinho (Universidade Federal da Paraíba) -, "oferece ao professor-leitor algumas alternativas de abordagem do poema de cordel em sala de aula. Não se trata de um manual, embora encontremos inúmeras sugestões de leitura e de atividades para sala de aula. Mas as sugestões apresentadas pressupõem uma atitude particular diante da cultura popular"221. Cordelistas também realizaram publicações voltadas para o ensino formal, como Arievaldo Viana, autor da publicação Acorda cordel na sala de aula: a literatura popular como ferramenta na educação (2006), produto da elaboração teórica sobre uma experiência pedagógica realizada em escolas do Canindé, no Ceará (BRASIL, 2018).

Não apenas o cordel, mas as/os próprias/os cordelistas passam a frequentar as instituições escolares no século XXI, fazendo-se poetas-palestrantes, poetas-oficineiros, poetas-professores. Manoel Monteiro, apelidado de professor ainda na infância, por declamar folhetos para os trabalhadores rurais e ensiná-los a ler com a poesia em brochuras, atualiza sua experiência didática na terceira idade em uma nova conjuntura sociocultural - apresentada no início desse subcapítulo. Kátia Monteiro, filha do poeta, relata em entrevista as atividades exercidas pelo pai:

221 Resenha do livro Cordel na Sala de Aula. Ver mais em: LÚCIO; PINHEIRO, 2001. 
Ele gostava de passar esse conhecimento, tanto na sala de aula, desde o nível mais fundamental até a universidade, quanto para professores, porque ele preparava oficinas para os professores também. Tanto professor do fundamental e médio, como o próprio professor universitário. Ele fazia minicursos, fazia palestras pra eles também. Então, ele tinha essa bagagem e essa disposição! Também para orientar os novos escritores, os novos cordelistas. Incentivava eles a se descobrirem cordelistas e depois orientava o trabalho deles. De vários. (MONTEIRO, 2018)

Os cordéis metalinguísticos, que ensinam sobre as regras de escrita do cordel, são resultado do processo de escolarização da literatura de folhetos, do desejo de formação de uma nova geração de poetizas e poetas de bancada:

A MÉTRICA mede o tamanho

Do verso desenvolvido

- UM VERSO É SÓ UMA LINHA

(desde já fique entendido)

Composto em sílabas poéticas,

Fugindo dessas estéticas

Arranha e "fere" o ouvido.

(MONTEIRO, 2002, p. 06) 222

No século XXI a sala de aula torna-se o lócus preponderante de difusão da poesia de folhetos e de exercício profissional de poetas e poetizas. O contato com a estrutura curricular, concedeu à literatura de folhetos uma função utilitária, de modo que os versos passam a ser constituídos a partir de informações objetivas, abordando temáticas vinculadas às disciplinas escolares e aos livros didáticos que as orientam. A linguagem poética e, até mesmo a ficção, são operacionalizadas para a veiculação de informações vinculadas a conteúdos específicos, a exemplo do cordel O holocausto dos homens nus (Manoel Monteiro, 2003), que aborda a colonização portuguesa no Brasil, potencial aliado do livro didático de História.

O historiador francês Roger Chartier, traz contribuições teóricas relevantes para pensarmos os significados inerentes à inscrição do livro nos ambientes institucionais de ensino/aprendizagem, eficazes para refletirmos sobre a inscrição do cordel nos mesmos ambientes. Para o autor,

[...] quando se estabelece no mundo das escolas, das universidades, a leitura se torna uma prática intelectual [...] e a partir deste ponto a função atribuída ao texto escrito não é somente uma função de conservação ou

222 MONTEIRO, Manoel. Quer escrever um cordel? Aprenda a fazer fazendo. Campina Grande: Gráfica Martins, 2002. 
de repositório, é o próprio objeto do trabalho intelectual [...]. A leitura do mundo escolástico, do mundo das escolas, é, por sua vez, uma leitura que busca o deciframento, uma leitura da inteligibilidade, da compreensão (CHARTIER, 2001, p. 40).

Monteiro produziu também textos relativos a demandas contemporâneas do ambiente escolar, como a questão do bullyng ${ }^{223}$ - prática de atos violentos, intencionais e repetidos, contra um indivíduo, que podem causar danos físicos e psicológicos às vítimas -, e acerca da incorporação de tecnologias recreativas pelos professores em atividades pedagógicas ${ }^{224}$. As produções mencionadas demonstram o direcionamento da produção da Cordelaria Poeta Manoel Monteiro para um público e um nicho de mercado específico.

Para a linguista Maria do Socorro Moura Montenegro (2014), pesquisadora da obra de Monteiro, as publicações desenvolvidas pelo poeta a partir do viés educacional assumem caráter paradidático-publicitário, evidente nas "chamadas” fixadas nas quartas-capas das poesias em brochuras, a exemplo: "Senhores professores: Utilizem o Cordel em sala de aula e surpreendam-se com o aproveitamento" (MONTEIRO, 2011 apud MONTENEGRO, 2014, p. 56). A autora ressalta as estratégias de marketing impressas nas "páginas-extras" dos folhetos do poeta, reservadas para legitimar tanto a finalidade pedagógica do cordel, quanto o conteúdo das poesias. Este último aspecto se faz evidente na publicação O poder das plantas na cura das doenças (2004), prefaciado por Ivan Coelho Dantas, farmacêutico bioquímico professor da Universidade Estadual da Paraíba, que chancela o comprometimento intelectual do poeta e o conhecimento científico veiculado no cordel ${ }^{225}$.

A implementação de prefácios desta ordem, indicativos do flerte do poeta com o universo livresco, fomentou a inserção de Manoel Monteiro no mercado de publicações paradidáticas. No final da primeira década do século XXI o poeta vincula-se às editoras Scipione, DCL (São Paulo - SP) e Ensinamento (Brasília - DF).

A Espanhola Inglesa (2008), interpretação versificada do conto homônimo de Miguel de Cervantes por Monteiro, realizada sob encomenda da editora Scipione é uma publicação exemplar de um movimento implementado pelas editoras no

223 MONTEIRO, Manoel. Brincar de bullyin? É... besteira!. Campina Grande: Cordelaria Poeta Manoel Monteiro, 2013.

224 MONTEIRO, Manoel. Os games na escola: Jogos eletrônicos. Um bem ou um mal? Campina Grande: Cordelaria Poeta Manoel Monteiro, 2008.

225 Para acessar análise detalhada sobre o teor paradidático-publicitário da obra de Manoel Monteiro ver: MONTENEGRO, Maria do Socorro Moura. Manoel Monteiro e as várias faces do texto de cordel. 2014. 170f. Tese (Doutourado em Linguística) -Centro de Ciências Humanas, Letras e Artes, Universidade Federal da Paraíba, João Pessoa, 2014. p. 57-114. Para conhecer as temáticas variadas que se cruzam na obra do poeta, assim como características estéticas da sua escrita, ler: NOGUEIRA, Carlos. A literatura de cordel de Manoel Monteiro. Symposium: A Quarterly Journal in Modern Literatures, v. 68, n. 1, p. 37-50. 
período: publicação de adaptações de obras “clássicas” da literatura nacional e estrangeira para o gênero cordel com finalidade didática. $O$ fato de o cordel, quando comprado por um/a professor/a, vir acompanhado de um guia didático com propostas para sua utilização em sala de aula, reitera a dimensão utilitária atribuída ao impresso, que configura mudanças expressivas nas práticas de fruição do texto, principalmente no que diz respeito aos gestos da leitura e às razões de ler.

A transfiguração das brochuras em livros ${ }^{226}$ é um ponto imprescindível para a discussão sobre as transformações editoriais na historiografia da literatura de folhetos, afinal, do impresso não lemos apenas aquilo que está escrito, mas também o objeto de leitura, o suporte, de modo que “o 'mesmo' texto, fixo em sua letra, não é o 'mesmo' se mudam os dispositivos de sua inscrição ou de sua comunicação” (CHARTIER, 2002, p. 256). Kátia Monteiro faz uma breve avaliação sobre a mudança simbólica operada pela forma da publicação:

E, daí, dá outra visão né, um cordel em formato de livro paradidático, né? Aí todo mundo quer comprar, quer ler, quer levar pra sala de aula. Diferente de um cordel no formato tradicional. Só que o conteúdo quando élevado, quando vence essa barreira do preconceito, faz até os estudantes pedirem para os professores darem continuidade aos projetos com poesia, como aconteceu com a minha irmã, que é professora em Puxinanã. [...] A poesia é atrativa demais! Uma pessoa pra não se atrair pela poesia precisa estar muito desorganizada das ideias. (MONTEIRO, 2018)

A fala de Kátia atesta as significações produzidas pela nova fórmula editorial da literatura de cordel e as construções de sentido incitadas por ela nas/os leitoras/es. A exuberância gráfica do "cordel-livro" ou "cordel-ilustrado", como são denominadas as publicações do gênero no mercado editorial livresco, tem motivado o reconhecimento do cordel como literatura por um público mais abrangente.

\footnotetext{
Figura 84 - Capa do livro $A$ Espanhola Inglesa (MONTEIRO, 2008), ilustração realizada pelo desenhista Jô Oliveira

Fonte: FLORES, Célia. Navarro. Uma "Espanhola inglesa" abrasileirada. Caracol, v. 1, p. 204-232, 2013.
}

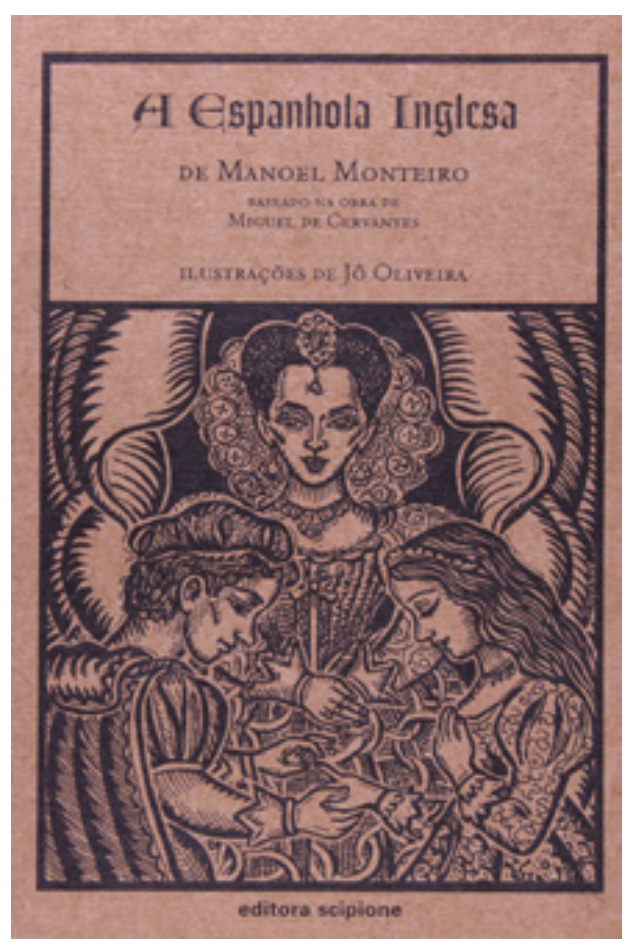

226 Dentre as editoras que incluíram em seus catálogos publicações da literatura de cordel em formato de livro estão: A Editora Cortez, a Editora Nova Alexandria (São Paulo - SP), a Editora Tupynanquim, a Editora IMEPH (Fortaleza - CE) e a Editora Queima Bucha (Mossoró - RN). 


\section{À MARGEM DO NOVO AÇUDE VELHO}

Seguindo os passos dos poetas que fizeram de Campina seu parnaso - Toinho da Mulatinha, Manoel Camilo dos Santos, José Alves Sobrinho e Manoel Monteiro -, é possível constatar que a manutenção de suas obras se efetuou através da transformação. Trilhando a linha do tempo traçada por essas figuras, observa-se a expansão da rede que sustenta o circuito literário do gênero, sobretudo a partir da década de 1970, quando o cordel se institucionaliza, consolidando-se como campo de pesquisa nas universidades e, depois, como conteúdo curricular nos ciclos básicos de ensino. Reconhecido como objeto cultural, cai nas teias da cultura de Campina Grande, servindo de suporte discursivo para arquiteturas políticas "tradicionais".

Ao estilo da embolada, concluo esta pesquisa de forma acelerada, passando por eventos que irão tecer nós com os capítulos finais da vida de Toinho da Mulatinha. São eles: o registro do Cordel (2018) e da Feira Central de Campina Grande (2017) como patrimônios culturais pelo Instituto do Patrimônio Histórico e Artístico Nacional (Iphan); os projetos de Requalificação da Feira campinense (2009/2013).

Comecemos com o reconhecimento do Cordel, processo que se inicia quando Toinho já não tem saúde para ir à Feira. O ano era 2010, a Academia Brasileira de Literatura de Cordel (ABLC), solicitou, por meio do Centro de Folclore e Cultura Popular (CNFCP) ao Instituto do Patrimônio Histórico e Artístico Nacional (Iphan), o registro dessa prática cultural como patrimônio imaterial brasileiro. A ação da Academia, assim como a própria formação da Academia de Literatura de Cordel (1988) - fundada depois das tentativas frustradas do poeta Raimundo Santa Helena (1926 - 2018) se inserir na Academia Brasileira de Letras (ABL) - reiteram a tese que venho insinuando ao longo deste trabalho acerca da capacidade de agência dos poetas. Santa Helena lançou o desafio à $\mathrm{ABL}$, recusado, improvisou.

Filiados cada vez mais a esfera da "ordem", sem perder a resistência que a vida pelas brechas ensinou, poetas e poetizas passaram a criar suas próprias instituições e recorrer àquelas já consolidadas, para manter ativa essa prática cultural e para se fazer reconhecerem.

Os membros da Academia

Da cultura guardiã

Solicitam ao IPHAN

Que veja com simpatia

Nossa eterna poesia

Como histórico documento

E neste Requerimento

De conteúdo fiel 
Queremos para o cordel

Seu registro e tombamento.

(SILVA, 2010 apud NOGUEIRA, 2018, p.182)

O registro do cordel foi efetivado em setembro de 2018, após um processo intenso e extenso de trabalho, transcorrido ao longo de oito anos, envolvendo levantamento de fontes documentais em instituições de pesquisa, universidades, bibliotecas, museus, editoras, pontos de comercialização de folhetos e acervos especializados no gênero; coleta de relatos orais dos detentores do bem cultural; mapeamento das expressões do cordel em diversos estados do país - testemunho da difusão da poesia de bancada no território brasileiro, capaz de desestabilizar imaginários que a sedimentaram no sertão nordestino. Atuaram nessa "missão", empreendida em prol da produção do "Dossiê de Registro"227, poetas e intelectuais vinculados a suas organizações/instituições representativas (MELO, 2019a).

Deacordocomaprofessora RosileneAlves deMelo(UniversidadeFederaldeCampina Grande), consultora do Iphan (2012-2018) e coordenadora da pesquisa desenvolvida para a elaboração do referido Dossiê, os diálogos entre detentores e pesquisadores, aportados pelas reflexões oriundas do trabalho de campo, viabilizaram a significação coletiva dessa prática cultural e oportunizaram o delineamento de iniciativas para a persistência e disseminação do cordel, em vistas da ampliação do acesso à fruição desse saber/fazer pela população nacional. A pesquisadora, que reconhece a instrumentalidade do registro da literatura de cordel como patrimônio cultural para a concretização de ações de fomento/ salvaguarda, ressalta os sentidos implicados na titulação:

Do ponto de vista simbólico representa o reconhecimento pelo Estado de uma prática cultural que já tinha sido reconhecida no Brasil havia mais de um século por diversos grupos: poetas, comunidades de leitores e movimentos intelectuais. Por outro lado, possui um significado político, uma vez que de agora em diante essa forma de expressão e seus agentes adquirem maior possibilidade de ocupar outras posições na gestão das políticas culturais que permitam a salvaguarda do cordel e a democratização do acesso a esse bem pelos cidadãos. Uma terceira dimensão se refere aos desdobramentos da tutela do Estado e os usos dessa arte na formulação de construções identitárias decorrentes de sua patrimonialização. (MELO, 2019a, p. 246) ${ }^{228}$

227 Sobre o processo de produção do Dossiê de Registro ver: MELO, 2019a. 0 Dossiê apresentado ao Conselho Consultivo do Instituto do Patrimônio Histórico e Artístico Nacional para a avaliação da pertinência do registro da Literatura de Cordel como Patrimônio Cultural Brasileiro pode ser acessado no portal do Iphan. Disponível em: <http://portal.iphan.gov.br/uploads/ckfinder/arquivos/Dossie_Descritivo(1).pdf >.

228 Grifo da pesquisadora. 
As dimensões do processo de patrimonialização, ressaltadas por MELO (2019a), abrem espaço para a explanação de disputas travadas em torno de um patrimônio cultural inextricavelmente ligado ao cordel: a Feira Central de Campina Grande. As tensões que cerceiam esse bem de natureza imaterial, se expressam através de dois projetos distintos de "requalificação" do espaço (2009 e 2013, respectivamente), que compreendem o registro da Feira campinense como patrimônio brasileiro pelo Instituto do Patrimônio Histórico e Artístico Nacional, sob diferentes óticas: (1) Como etiqueta potente para integrar a Feira ao cardápio turístico da Grande Campina; (2) Como via de salvaguarda das particularidades imateriais do espaço, associadas a características materiais ameaçadas pelo primeiro projeto, elaborado pela prefeitura municipal ${ }^{229}$. Temos, portanto, de um lado reverberações da política inaugurada pelos Cunha Lima, e de outro o empenho de intelectuais que, em parceria com feirantes e fregueses/as, procuram barrar a "shopinização" da Feira (PIZZIGNACCO, 2019). É o que veremos nos próximos parágrafos.

A reinvindicação do registro da Feira Central de Campina Grande no "Livro de Registro dos lugares” do Iphan, em 2007, foi articulada pela pesquisadora Giovanna de Aquino Fonseca Araújo, autora do livro Múltiplos Discursos Sobre a Feira Central de Campina Grande (2006), à época gerente de projetos da Secretaria Municipal de Educação, Esporte e Cultura (SEDUC), em Campina Grande. Araújo (2006) reconhece, em seus estudos acadêmicos a necessidade de preservação da Feira campinense diante do significado histórico e cultural peculiar daquele espaço, que, associado à formação da cidade de Campina Grande, representa o passado de muitas gerações que fizeram dela um modo de sobrevivência no sentido não apenas econômico, mas também político e principalmente social.

O processo de registro da Feira Central de Campina Grande no "Livro de Registro dos lugares" do Iphan, que alimentou o projeto de gentrificação da Feira pelos gestores da cidade “vocacionada para o turismo", se tornou, na verdade, estratégico na inviabilização de sua desfiguração. Em laudo, o órgão patrimonial alegou que o desenho arquitetônico projetado para a requalificação, em $2009^{230}$, desrespeitava “as referências culturais dos feirantes, sua organização espacial tradicional, dissolvendo as formas de apropriação, uso e ocupação do espaço urbano", atestando a "dificuldade de entendimento, pelos interventores, dos valores sociais da feira enquanto patrimônio cultural”231.

\footnotetext{
229 Gestão do prefeito Veneziano Vital do Rêgo (Movimento Democrático Brasileiro - MDB).

230 A partir da reforma proposta em 2009, o Mercado Central seria o núcleo da Feira e abrigaria bancas de frutas, laticínios, verduras e raízes, aglutinando em um espaço fechado, atividades que até então ocupam o espaço da rua. Arquitetonicamente o projeto de Requalificação previa fechar as laterais do Mercado, produzindo uma entrada principal, e refazer a cobertura do galpão com uma estrutura metálica contendo claraboias de vidro. A instalação de uma fonte luminosa no centro do pátio, também integrava este projeto de Requalificação.
}

231 Laudo emitido pelo Iphan, no ano de 2011 (ARAÚJ0, 2013, p. 8-9). 
Através do uso estratégico do patrimônio, tal projeto se alinha ao Marketing Urbano, "cujas práticas compreendem um conjunto de intervenções urbanas voltadas à transformação de sítios históricos degradados em áreas de entretenimento urbano e consumo cultural." (LEITE, 2008, p. 36). Esse tipo de "enobrecimento" acaba por suprimir a natureza pública do espaço urbano, pois, ao segmentar e disciplinar determinadas áreas das cidades, instaura possibilidades desiguais de uso do espaço. Geralmente voltados para o turismo e para o mercado de construção civil, os projetos "revitalizadores" impactam o lugar da comunidade local.

Assim como as/os feirantes, Giovanna Araújo (2013) reconhece a urgência de reformas estruturais na Feira Central, mas salienta que deve haver sensibilidade na realização destas intervenções.

[...] é preciso que haja um equilíbrio entre as intervenções físicas e os aspectos sociais e culturais, sob pena de, com esse projeto de requalificação, a feira se torne vitrina folclórica para turistas ver, descaracterizando sua essência. É preciso manter o estímulo aos seus sentidos sensoriais: os sons, os cheiros, as cores e os sabores. Os melhoramentos são bem vindos, até para desconstruir o estereótipo de que a feira é sinônimo de "bagunça" e de "sujeira”. No entanto, o equilíbrio - características físicas, sociais e culturais - deve ser perseguido. (ARAÚJO, 2013, p. 11)

Nesse trabalho acadêmico, é importante sublinhar o lugar de intelectuais universitários que somam suas ações aos intelectuais da Feira desde a solicitação do registro desse bem cultural. Reconhecendo, a necessidade de inclusão das(os) feirantes nas decisões relativas à Feira Central e, percebendo a pertinência de colocar tal questão em cena no momento de mudança de gestão da prefeitura, professores/as e alunos/as da Universidade Federal de Campina Grande (UFCG) se uniram para demandar "um projeto democrático" para a requalificação da Feira Central de Campina Grande, que salvaguardasse suas particularidades culturais, materiais e imateriais: a forma-conteúdo (SANTOS, 1978).

Em 2013, o poder público acordou uma parceria com segmentos dessa instituição acadêmica, incumbidos de elaborar diretrizes e partidos projetuais para a requalificação da Feira Central, nos campos do projeto urbano, da engenharia, da arquitetura e do design.

Objetivando integrar a comunidade campinense às decisões relativas à reforma do comércio foi realizada a Oficina de Projeto Participativo "Qual é sua ideia para a Feira deCampina Grande?"232 - fruto de um projeto de Extensão do Curso de Arquitetura e Urbanismo da Universidade Federal de Campina Grande (CAUUFCG), coordenado

2320 Relatório do Projeto de Extensão está disponível em: <https://www.dropbox.com/s/v32k1lqhjアros3d/ Feira\%20CG_Oficina\%20de\%20Projeto\%2OParticipativo_Relat\%[3\%B3rio\%20Final.pdf?dl=0 >. Acesso em: 20 nov. 2019. 
pelo professor Marcus Vinicius Dantas de Queiroz em parceria com Secretaria de Planejamento da Prefeitura Municipal de Campina Grande (SEPLAN/PMCG) ${ }^{\mathbf{2 3 3}}$.

Nas oficinas, foram apresentadas propostas de gestão e estruturação física do espaço, previamente elaboradas por equipes multidisciplinares que realizaram estudos precedentes com intuito de identificar, a partir do levantamento bibliográfico e imersão a campo, problemáticas locais e demandas das e dos feirantes (heterogêneas!) ${ }^{234}$. As proposições desenvolvidas, apresentadas com a utilização de maquetes e projeções audiovisuais, foram debatidas em plenárias. As atas das plenárias foram base para a constituição das diretrizes projetuais para a nova requalificação da Feira Central campinense, a ser desenvolvida pela Secretaria de Planejamento da Prefeitura Municipal da cidade, com acompanhamento dos membros do Coletivo Feira ${ }^{235}$. O novo projeto para a Feira Central de Campina Grande, aprovado pelo Instituto do Patrimônio Histórico e Artístico do Estado da Paraíba (Iphaep) em $2014^{236}$, poderá evitar transformações insidiosas do lugar, registrado como Patrimônio Imaterial em 2017.

Com esse rodopio ligeiro pelas disputas políticas e sociais que circunscrevem a Feira campinense, não almejo "cantar ciência” (enumerando acontecimentos), mas registrar um trecho de uma peleja complexa, demorada, que se estende na cronologia da "Capital Cultural”. Busco nas deixas discursivas dos projetos para revitalização do entreposto comercial embrionário da cidade, mostrar que os dispositivos normativos,

233 A Oficina de Projeto Participativo contou com o apoio e a participação da Secretaria de Desenvolvimento Econômico (SEDE), Secretaria de Educação (SEDUC), Secretaria de Cultura (SECULT), Gerência de Vigilância Sanitária (GVISA) e Superintendência de Trânsito e Transporte Público (STTP) da Prefeitura Municipal de Campina Grande; Unidade Acadêmica de Ciências Sociais (UACS), Unidade Acadêmica de Design (UADesign), Unidade Acadêmica de História (UAHis), Unidade Acadêmica de Geografia (UAG) e grupo de extensão Campina Grande (PB), arquitetura e patrimônio cultural (PROBEX) da Universidade Federal de Campina Grande; Curso de Arquitetura e Urbanismo da Universidade Federal da Paraíba (CAUUFPB), Curso de Arquitetura e Urbanismo da Universidade Federal de Pernambuco (CAUUFPE), Instituto do Patrimônio Histórico e Artístico Nacional (IPHAN), Instituto do Patrimônio Histórico e Artístico do Estado da Paraíba (IPHAEP).

234 "É importante destacar que as disputas e negociações relativas à Feira não se dão apenas entre diferentes setores, mas dentro dos próprios segmentos sociais, que não são homogêneos. Entre os(as) comerciantes há uma série de disputas internas, seja por poder político, reivindicado pela Associação dos Feirantes e Comerciantes do Mercado Central de Campina Grande (Afemec), seja por questões econômicas, como é o caso de proprietários de bancas que monopolizam determinados tipos de serviços ou produtos no local, a exemplo do comércio de calçados localizado no Mercado Central, dominado por um único cidadão que recusa mudanças no regimento interno da Feira, pois impactarão em seus privilégios". (PIZZIGNACCO, 2019, p. 107).

235 Grupo formado por representantes de diversos setores da sociedade e por pessoas que, de algum modo, se dispuseram a contribuir com o debate acerca dos rumos da Feira e do Mercado Central de Campina Grande. Seu objetivo é discutir, acompanhar e participar das ações de requalificação da área, empreendidas pelo poder público municipal. Os nomes dos membros e instituições integrantes do grupo estão registrados no Anexo 01 do Relatório do Projeto de Extensão: <https://www.dropbox.com/s/v32k1lqhj7ros3d/Feira\%20 CG_Oficina\%20de\%20Projeto\%20Participativo_Relat\%C3\%B3rio\%20Final.pdf? dl=0>. Acesso em: 20 nov. 2019.

236 Mesmo após o registro da Feira de Campina Grande como Patrimônio Cultural Imaterial (2018), o segundo projeto de requalificação da Feira permanece engavetado. A primeira ação derivada da patrimonialização, realizada em 2019 pela prefeitura municipal em parceria com empresas privadas, foi denominada "Bom é na Feira" e consiste em ciclos de atividades para capacitação das/os trabalhadores do local e na promoção de atividades culturais no Mercado Central. 
geradores de movimentos de desagregação, são também produtores de enfrentamentos e novas possibilidades, afinal, os debates entorno desse Patrimônio Cultural dinamizaram os processos de produção daquele espaço, que vinha sendo insistentemente apagado. Contribuíram para a "produção de localidades" (APPADURAI, 2005).

Assim como o cordel, a feira (r)existe imersa em um campo de atritos entre diferentes segmentos sociais e a partir da relação agônica entre mudanças e continuidades, engendrando novas estratégias de sobrevivência e ancorandose na potência regida pela ancestralidade de saberes e fazeres locais. Como toinho, poeta-feirante, os/as comerciantes também vêm fazendo suas "colagens" na contemporaneidade: anunciando produtos como "orgânicos", resultado de agricultura familiar, autossustentada, que mobiliza valores contemporâneos daqueles que, em outro momento, deixaram de frequentá-las; incorporando produtos industriais de baixo custo, que desafiam algumas definições de "cultura popular" como sendo aquela que cristaliza o passado, perpetuando usos e sentidos das coisas e das relações sociais que se efetivam em torno delas.

Há de se considerar que o campo de ressignificação simbólica da feira e do cordel advém também da recente patrimonialização desses bens culturais e das pesquisas acadêmicas que estes temas têm inspirado. Com esse trabalho intento religar a história desses patrimônios campinenses, reinserindo na feira as histórias da Tipografia Estrella da Poesia, hoje abatida por uma granja de galinhas, bem como as memórias de cantadores, que iam até ela "como quem vai a uma festa" (palavras de Zé Alves Sobrinho) ${ }^{237}$.

Convido a leitora e o leitor, a um passeio rápido pelo perímetro turístico de Campina Grande, para entre arquiteturas modernas e tradições arquitetadas, encontrarmos com as vozes que corporificam a memória social da cidade. Contemplaremos então a região do Açude Velho, o grande espelho d'água dos Narcisos da política campinense, no qual refletem edificações e monumentos que se harmonizam com a primeira requalificação desenhada para a Feira.

No entorno mais imediato do Açude estão localizados os recém construídos Museu de Arte Popular da Paraíba (último projeto de Oscar Niemeyer, inaugurado em 2012) e o Monumento aos 150 anos de Campina Grande (projetado por Argemiro Brito Monteiro da Franca, inaugurado em 2015) [Figura 85], edificação que tematiza a história dos tropeiros, construída ao modelo modernista para o sesquicentenário de Campina. O edifício, que hoje abriga o Museu Digital, permaneceu vazio, sem destinação, durante dois anos após sua inauguração, cumprindo seu papel de aparato cenográfico.

237 REIS, Diana. A voz do Poeta. Campina Grande - PB: Quarto crescente, 2007. 1 DVD (26 min). Disponível em: <https://www.youtube.com/watch?v=i5CnYOnqvpU>. Acesso em: 20 nov. 2019. 
Também integram a "região cartão-postal" de Campina, o Museu do Algodão (situado na antiga estação Ferroviária destinada ao transporte desta matéria-prima) e duas esculturas que celebram a cultura local [Figura 86]: Os Pioneiros da Borborema (Abelardo da Hora, 1964), obra de formas arredondadas e sintéticas que alude ao mito de formação da cidade a partir da representação do índio, da catadora de algodão e do tropeiro; Farra de Bodega (Joás Pereira Passos, 2003), escultura em bronze que lisonjeia dois protagonistas da tradição musical regional que se popularizaram nacionalmente, “Jackson do Pandeiro e Luiz Gonzaga”, representados tocando seus instrumentos. O tamborete cravado entre as estatuetas, produzido para as pessoas sentarem e serem fotografadas, é um vestígio da pretensão turística do objeto. Opera como potencial divulgador da cidade, sobretudo em tempos de smartphones e redes sociais digitais.
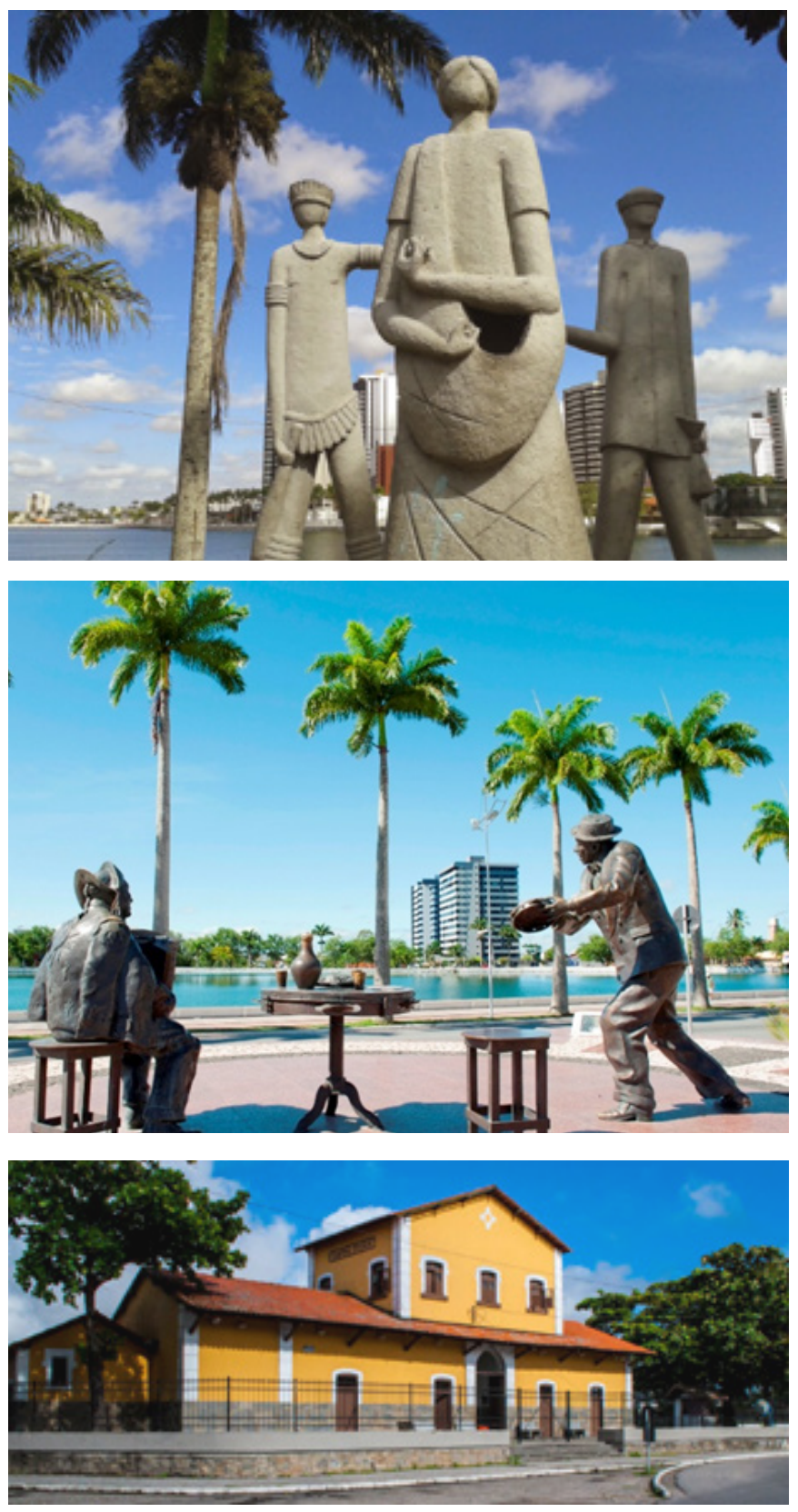

Figura 86 - Monumentos e sítio histórico que contornam o Açude Velho de Campina Grande; Escultura Os Pioneiros da Borborema; Escultura Farra de Bodega; Museu do Algodão (antiga estação ferroviária)

Fontes:https://www.paraibacriativa.com.br/ artista/os-pioneiros-da-borborema/; https:// www.euamocampinagrande.com.br/ empresaseservicos/farra-de-bodega.html; https://www.facebook.com/PBCultural/ posts/886943021325815/ 

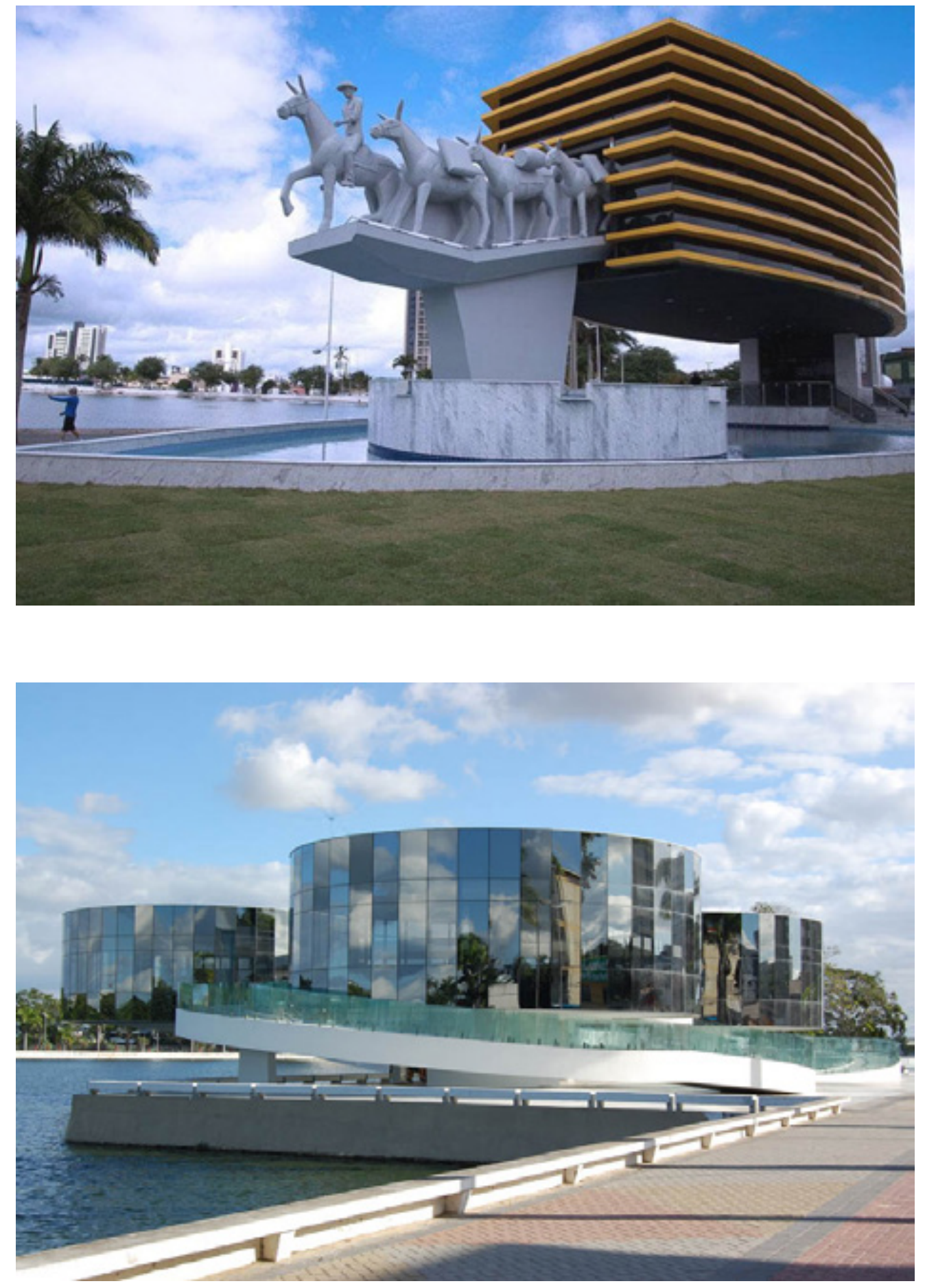

Figura 85 - Museu Digital de Campina Grande e Museu de Arte Popular da Paraíba, respectivamente

Fontes:https://www.euamocampinagrande.com. br/empresaseservicos/museu-de-arte-popular-daparaiba.html\#photos; https://vidasemparedes.com. br/dicas-o-que-fazer-em-campina-grande-paraiba/ 
O planejamento urbano da região emblemática do projeto monumental de Campina Grande, atende a uma perspectiva civilizatória que não é apenas local, mas responde a anseios nacionais de longa data, os quais remontam nossas heranças coloniais de seguir modelos globalizados de cidade a fim de nos constituirmos como nação viável. A obliteração de gestos, de expressões de natureza verbal e corporal, a maquiagem da diversidade étnica local nas margens do Açude Velho, cria flagrante contraste com a cena diária composta por aqueles que ainda usam a barragem para pescar, não por lazer, mas para se alimentar ou gerar renda pela venda dos peixes.

Perto do cartão-postal de Campina, no bairro Santo Antônio, na rua de mesmo nome, Antônio Patrício de Souza, viveu seus últimos anos confinado no espaço de sua casa humilde, pintada com azul cor de céu. Vivo, o poeta já era dado como morto pelos seus antigos companheiros de feira, abandonado que estava à sua própria sorte. Campina se fazia grande enquanto Toinho minguava numa cama sob os olhos de Jesus e de Ronaldo Cunha Lima, enquadrados na parede da sala. Em 2014, o poeta-itinerante vai ser conduzido numa cadeira de rodas até o Museu de Arte Popular da Paraíba, onde é homenageado ${ }^{\mathbf{2 3 8}}$. Apesar do reconhecimento, materialmente, nada mudou na vida esquecida de Toinho e Digna após aquela cerimônia. Antônio da Mulatinha, que foi uma espécie de metonímia do Cordel e da própria Feira, morreu em 2016, antes que aqueles fossem reconhecidos como patrimônio.

Campina Grande, que foi ninho para poetas de meados do século XX arma agora arapucas para cultura popular. Na "Matutolândia" ou nas linhas orgânicas de espaços modernos culturas vivas (a)parecem capturadas. Porém, “onde há poder, há resistência” (FOUCAULT, 1999, p. 91).

Figuras locais mantêm manifestações artísticas em diferentes espaços da cidade, aproveitando mesmo da arquitetura monumental do "Museu dos três pandeiros", dotado de um "vão livre" preenchido por emboladas de coco, rodas de capoeira, desafios de street dance. O calçadão da Cardoso Vieira, a Praça da Bandeira, o bar do Genival e a Feira Central, continuam sendo espaços privilegiados das expressões culturais que rimaram tradição e modernidade na Campina da década de 1950.

O embolador Condor, começou em 2007 a sonorizar os labirintos da feira, aos sábados, formando dupla com o ancião Lua Nova (1959 - 2017) e, em seguida, com Will, com quem prossegue em atividade regular [Figura 89]. Canário do Império (Felipe Batista), é um jovem violeiro que faz da feira um dos seus palcos de atuação e de eventual comércio de folhetos [Figura 88]. O “Bar da Tereza - encontro dos poetas", localizado no Mercado Central há meio século, reúne uma quantidade significativa de repentistas que fazem, aos sábados, longas sessões de desafio [Figura 87].

238 Homenagem realizada no dia 6 de dezembro de 2014 pelo Museu de Arte Popularda Paraíba em parceriacom a Associação de Repentistas Nordestinos e com a Casa do Cantador. 


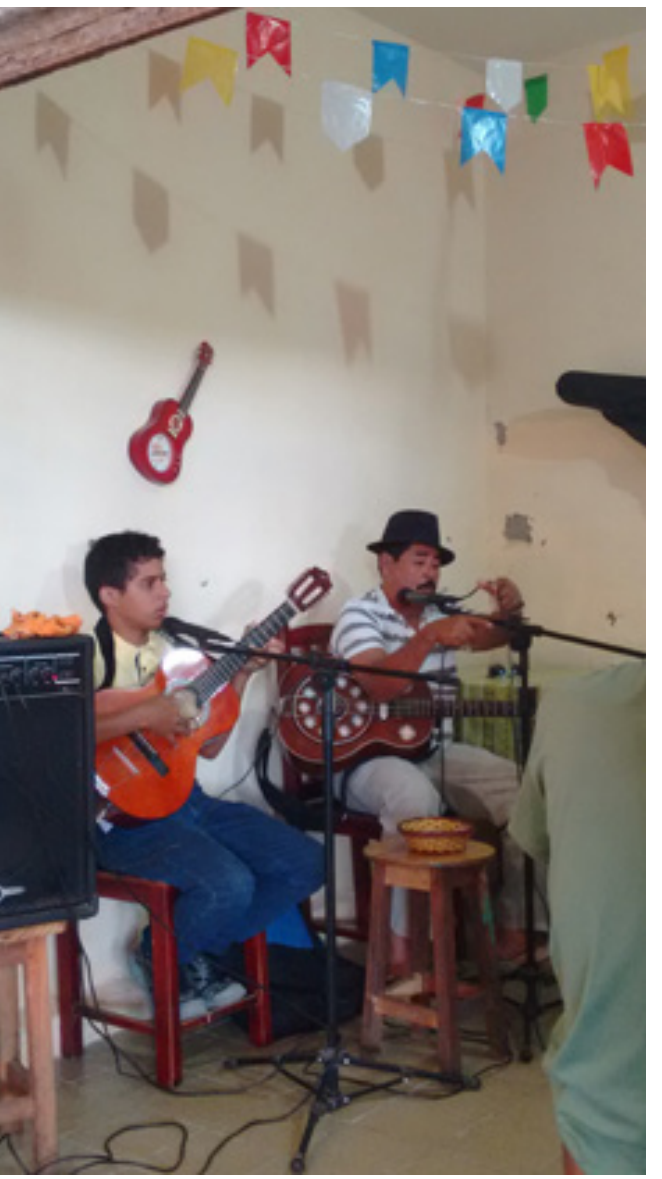

Figura 87 - Sábado de repente no Bar da Tereza - Mercado Central de Campina Grande [2016]

Fonte: Milla Pizzignacco, 2016

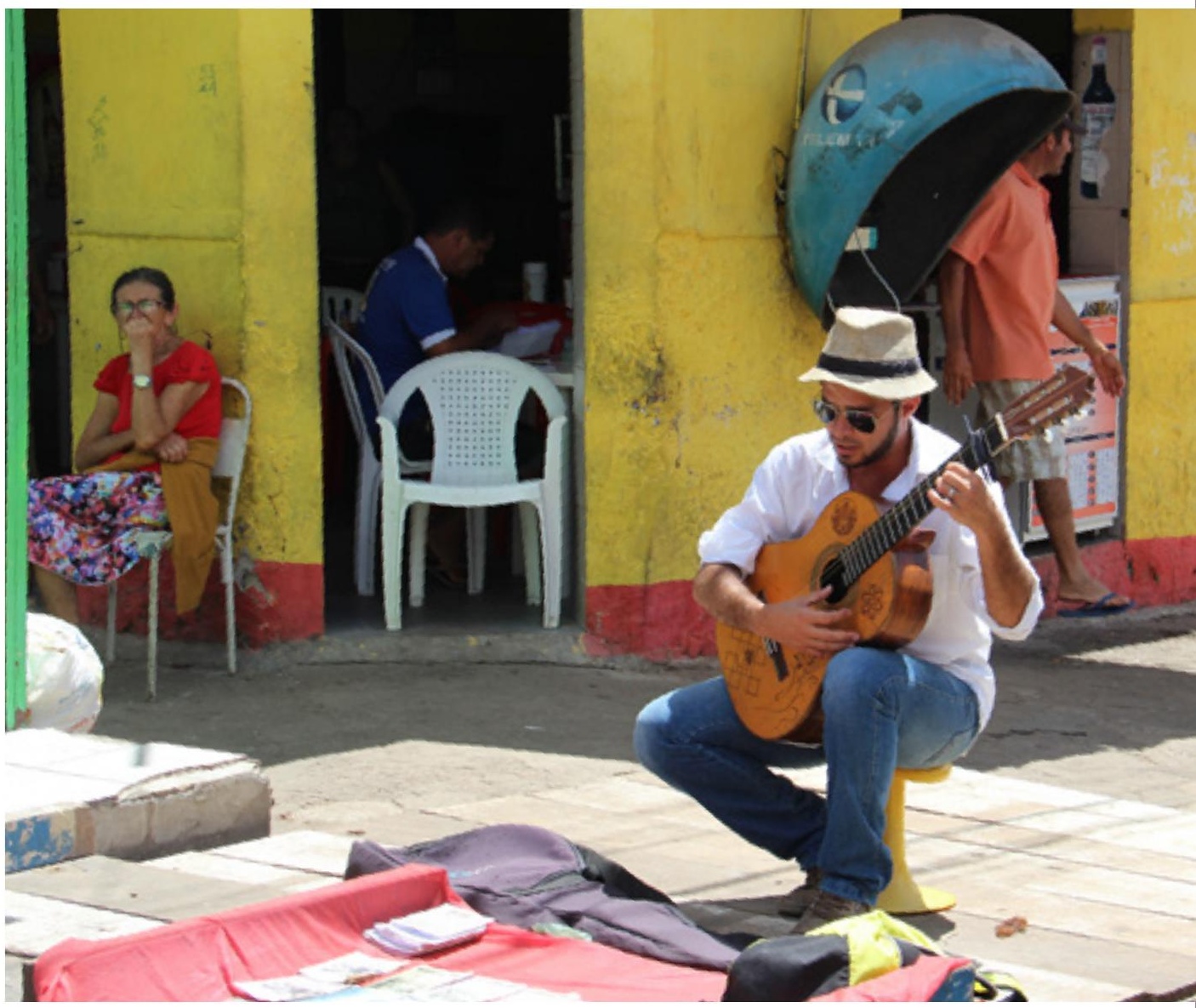

Figura 88 - Felipe Batista tocando violão e vendendo folhetos na Feira Central campinense (2016)

Fonte: Milla Pizzignacco, 2016 
A potência da poesia oral na feira se manifesta na expressão dos feirantes durante as apresentações de cantoria no local, como as de embolada de coco, que arrancam risos no meio da labuta. Estas figuras tornam mais espessa a camada de sociabilidade do local: costurando com versos relações entre as barracas, remendando memórias, (re)criando a faculdade de lazer da feira.

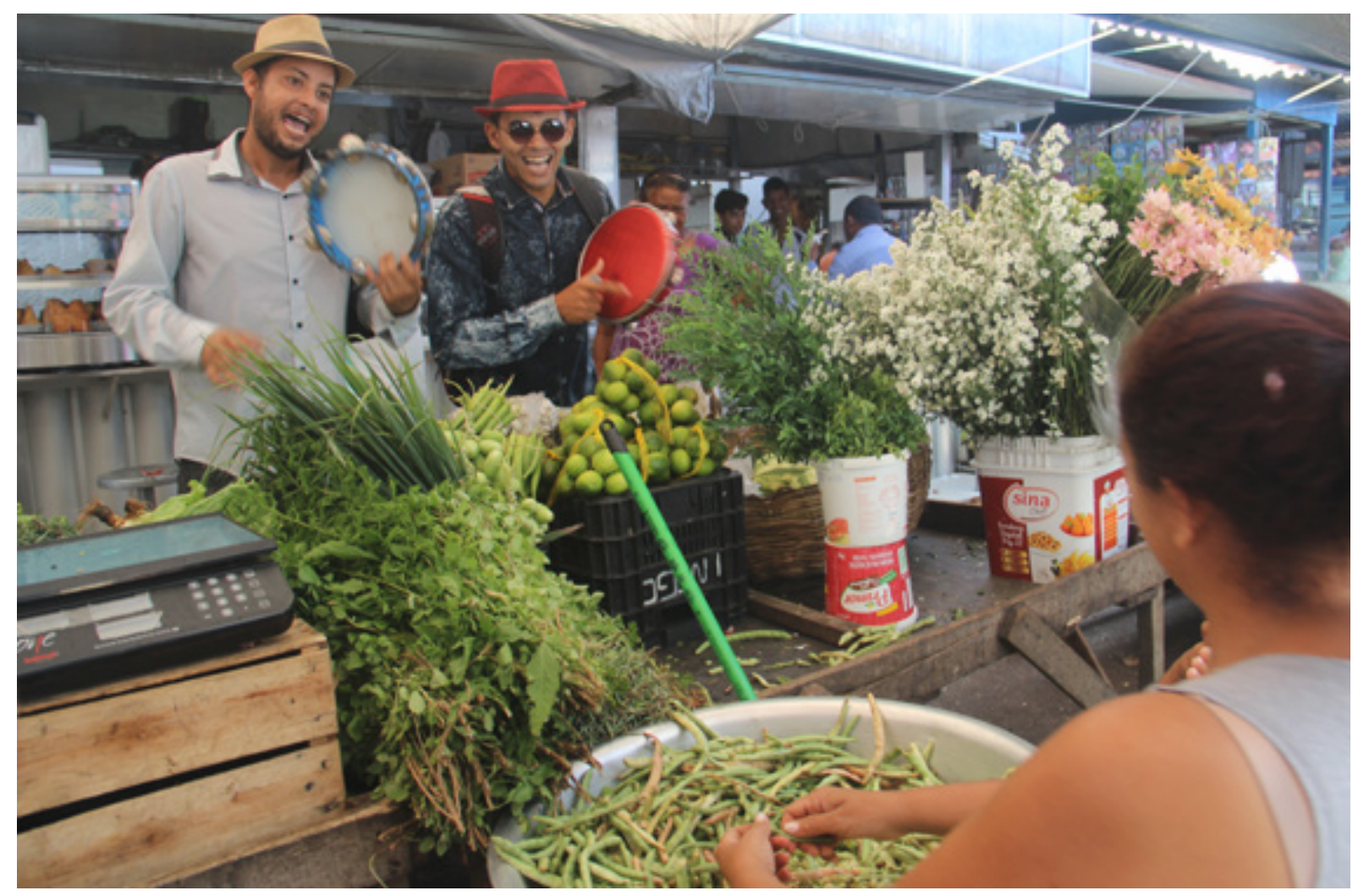

Figura 89 - Condor e Will embolando a Feira Central campinense [2018]

Fonte: Milla Pizzignacco, 2018

A poesia de bancada resiste silenciosa na cordelaria de Manoel Monteiro, no bairro Santo Antônio, aquele que guarda histórias de Manoel Camilo dos Santos e de Toinho da Mulatinha, um poeta de Esperança. 


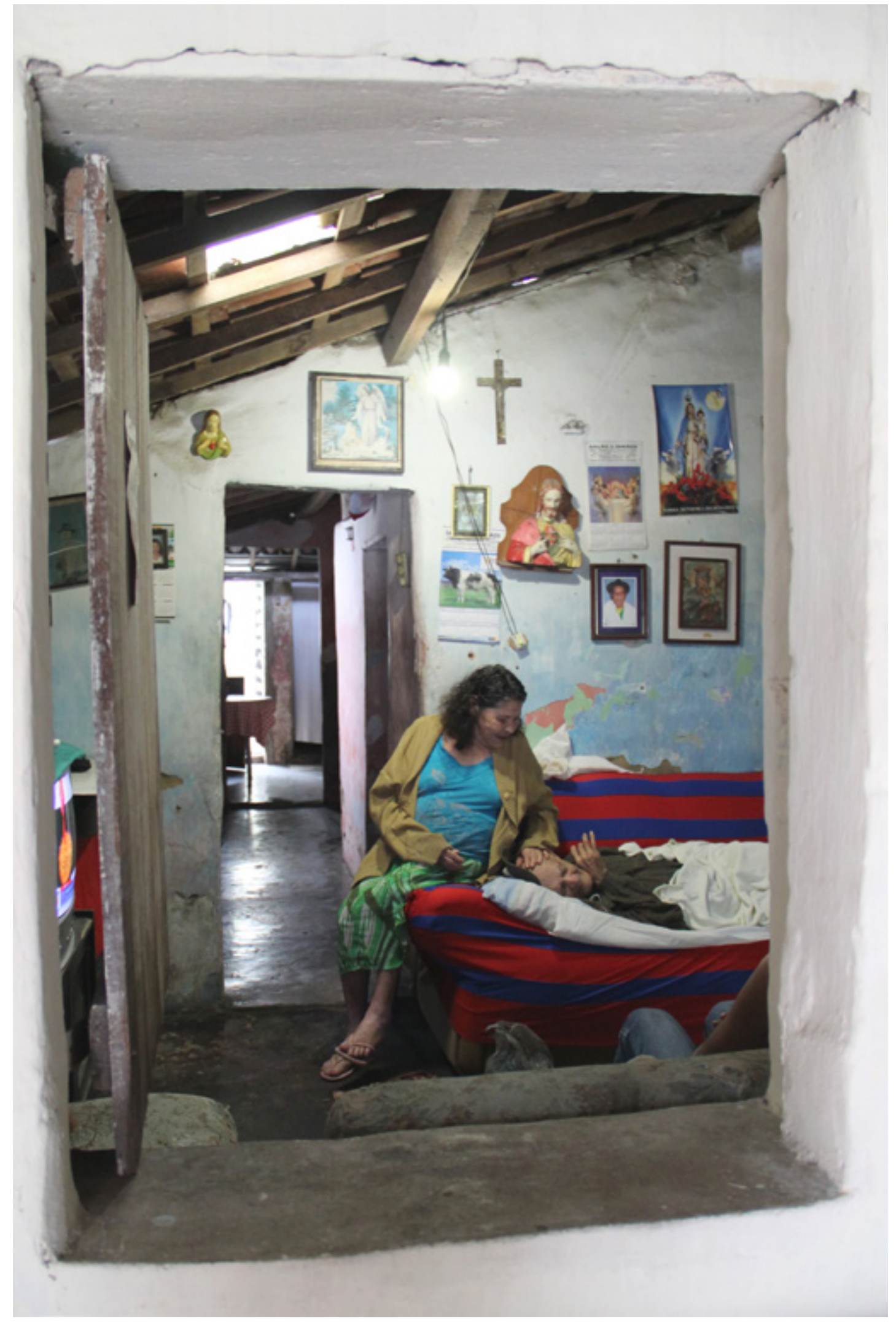

Figura 90 - Dona Digna e Toinho da Mulatinha na casa que acolheu a Estrela do Oriente (2016)

Fonte: Milla Pizzignacco, 2016 


\section{desembolando narrativas}




\section{CONSIDERAÇÕES FINAIS}

Pontuo essa pesquisa com reticências, imersa nos labirintos da Feira, no embolado das falas, em meio a um volume de cordéis que ramificam percursos investigativos. Dada a extensão da trajetória trilhada nesse trabalho, composta pelos rastros de um poeta que viveu 92 anos, mais de seis décadas deles cantando folhetos na Feira Central de Campina Grande e em tantas outras feiras paraibanas (Toinho da Mulatinha), considero que vale a pena destacar as proposições levantadas e defendidas no caminho traçado para o cumprimento do objetivo central da pesquisa, que consistiu em dimensionar os processos sociais, culturais e históricos que impactaram a edição e circulação dos folhetos de feira em Campina Grande (Paraíba). Nesse fechamento, considero importante o reconhecimento daquilo que escapou às análises, assim como a exposição dos desdobramentos reflexivos e práticos do trabalho.

Uma das teses apresentadas diz respeito à concomitância do ápice produtivo do circuito editorial especializado na literatura de folhetos, com o auge da Feira Central de Campina Grande como entreposto comercial durante a década de 1950. Aponta também para a consonância entre a queda da Feira e da poesia metrificada em brochuras, ao longo da segunda metade do século XX, derivada de transformações estruturadas pelo processo político “modernizatório" do lado de baixo do Equador. A hipótese acerca do imbricado enredo desses espaços de saber/fazer, o folheto-suporte e seu lócus de disseminação, se sustenta no século XXI através das ressignificações dessas práticas culturais, sobretudo a partir de relações tramadas com instituições acadêmicas, e do registro sincrônico da Feira campinense e do cordel como patrimônios culturais imateriais pelo Instituto do Patrimônio Histórico e Artístico Nacional.

Almejo ter contribuído para colocar Toinho da Mulatinha em cena como um poeta-patrimônio que personifica o cordel e a Feira de Campina Grande, assim como um homem de "agência", com capacidade reflexiva de ação, que nos trilhos de trens e nos trilhos componedores de caracteres fez sua história de vida e suas histórias em folhetos.

No decorrer da pesquisa, o poeta peregrino me conduziu por caminhos que promoveram encontros com figuras que me apresentaram diferentes formas de existir no circuito especializado no gênero. Esses personagens, autores de biografias que se entrelaçam na Serra da Borborema, colaboraram na composição de uma narrativa em "três tempos" sobre o ciclo produtivo da literatura de folhetos em Campina Grande.

Manoel Camilo dos Santos, figura representativa da passagem mais próspera das práticas editoriais do cordel na historiografia do gênero, protagonizou trechos da pesquisa por fazer da Feira Central não só um lócus de distribuição, mas de produção de narrativas impressas. Seu protagonismo se deu também pelo fato de ter desbravado 
caminhos na Serra da Borborema, motivando poetas a se radicarem em Campina Grande. O poeta-editor fez girar o ciclo produtivo da poesia em folhetos por meio da trama urdida com poetas-escritores, poetas-impressores, poetas-ilustradores, poetas-agenciadores e poetas-vendedores - como os mascates Toinho da Mulatinha e José Alves Sobrinho.

Autor do paraíso utópico de "São Saruê", Camilo imprimiu nas entrelinhas das quartas-capas de suas publicações o desejo de integrar-se ao campo literário hegemônico, assim como à esfera da “ordem” (CANDIDO, 1970), fornecendo textos fundamentais para compreendermos a complexidade do ramo editorial de folhetos e tirar o cordel do lugar arcaico, aliando-o à modernidade e ao processo de urbanização tecido pelo ciclo do algodão em Campina Grande. Como fenômeno associado às tecnologias de seu tempo, o cordel chega à internet no fechamento do trabalho, desafiando a importância concedida ao impresso no auge da Estrella da Poesia.

José Alves Sobrinho, aquele que cruza os trajetos de Toinho formando o itinerário geo-poético paraibano, marca, nesta dissertação, a reinscrição do cordel no contexto de desmoronamento do circuito especializado no gênero - impelido pelas reverberações objetivas e subjetivas do desenvolvimentismo à brasileira, "50 anos em 5!" - a partir das estratégias armadas dentro de sua esfera artística/intelectual e das relações construídas junto às instituições acadêmicas da cidade. Nessa pesquisa o poeta-pesquisador corrobora a asserção acerca da sobrevivência da poesia de bancada na década de 1970 e abre espaço para reflexões sobre as relações fronteiriças entre diferentes campos de saber.

Quando comeceia escrever esse trabalho,incorrino risco depolarizar "acadêmicos" e "poetas", contradizendo minha própria prática. No encontro com Zé Alves começo a suavizar as linhas dessas fronteiras entre diferentes universos de fazer/saber (sem perder a perspectiva crítica), enxergar os pontos de contato entre os agentes atuantes nesses espaços, as trocas frutíferas entre o lugar que falo hoje e aquele que alimenta o meu trabalho de pesquisa. No decorrer desse processo, pude compreender a importância da universidade na construção de um espaço de memória da literatura popular, assim como no desenvolvimento de perspectivas teóricas politicamente engajadas.

A partir da trajetória do Uirapuru, atinei para o fato de que projetar os poetas no lugar de "subjugados", na relação intercampo, significa fragilizá-los, repetir chavões inoperantes para a argumentação construída ao longo da pesquisa, sobre as "agências" dos poetas.

Manoel Monteiro aparece na dissertação em “dois tempos”, contribuindo para o delineamento das permanências e rupturas na produção da poesia de bancada em Campina Grande: primeiro, como mais um sujeito que, na década de 1950, viu em Campina a possibilidade de viver de literatura, diante da existência da Feira Central 
da cidade e da Tipografia Estrella da Poesia; e, depois, com maior proeminência, como agente promotor do "novo cordel”. A relevância da segunda empreitada profissional do poeta, nesse trabalho investigativo, deve-se ao fato de demarcar transformações significativas relativas aos espaços e os modos de fruição do cordel no século XXI, determinadas pela consolidação das instituições escolares como espaços primordiais de sua difusão, pelo teor paradidático atribuído à literatura popular e pela mudança de suporte dos versos, das "brochuras módicas" para o livro ilustrado. Ao manter uma cordelaria ativa, vinculada a editoras nacionais de médio e grande porte, e engajarse na disseminação do cordel no ensino básico de seu município, Monteiro realocou Campina Grande como um polo produtor de cordel na contemporaneidade.

Visei, com essas dissonantes histórias de vida, apresentar múltiplos modos de ser poeta. Delineio Toinho da Mulatinha como poeta-embolador-editor, a partir das correspondências e as dissidências com agentes do seu meio profissional, exibidas através das formas como responderam as mesmas transformações socioculturais, desestabilizando narrativas estanques. O clímax da biografia de Toinho, por exemplo, acontece justamente no momento convencionado como aquele de "queda" do cordel, a década de 1970, período no qual o poeta "pega a deixa” da Estrella do Poesia para abrir a Estrela do Oriente. Dentre os poetas mencionados, Mulatinha foi único de todos que não arredou o pé da Feira Central de Campina Grande nos momentos de crise do circuito editorial do cordel.

Do silêncio produtivo de Toinho entre as décadas de 1980 e 1990, emergiu a premissa de que o poeta encarnou as políticas inauguradas pela família Cunha Lima, responsáveis por calar determinadas tradições de Campina Grande com tradições espetacularmente inventadas. De acordo com a argumentação erigida, a Grande Campina se reergue economicamente através da encenação de uma "cultura popular" achatada e adaptada aos critérios estéticos de um público consumidor de experiências temáticas, prole do neoliberalismo na periferia do capitalismo. Proponho que, nesse contexto, a poesia de folhetos tenha se configurado como produto cultural adequado para a teatralização do "popular-tradicional" - evidenciada pela representação da Tipografia Estrella da Poesia no Sítio São João (Campina Grande) - e, sobretudo, recurso para uma glosa populista.

Ao enredar as atividades culturais da feira campinense nas teias da "Capital Cultural”, almejo ter evidenciado que os dispositivos de poder que ergueram Campina como Grande no final do século XX não dicotomizam “dominantes” e “dominados”, mas os aproximam, colocando-os em constante tensão. Nesse sentido, busquei conduzir o olhar de quem me lê para os campos de forças que atravessam a narrativa histórica da Rainha da Borborema, impressa na geografia da cidade. Nos meus percursos geo- 
poéticos tencionei apresentar as narrativas literárias e visuais fixadas nos folhetossuporte de Toinho da Mulatinha e de personagens coadjuvantes, como fenômenos multiculturais, móveis, em vistas de romper com a ideia da linearidade da história dos "populares” e com os equívocos de compreender esses modos de experiência cultural como inteiramente autênticos ou totalmente corrompidos.

Nessa imersão intensa, confesso que não estive lá muito preocupada em travar peleja com definições já bastante discutidas sobre "arte” versus "arte popular", se a poesia de bancada, a xilogravura ou a cantoria podem assim ser chamadas. Espero ter conseguido mostrar que é como arte (e não como subcategoria de uma Arte) que as trato e que considero as produções dos "poetas-caipiras” obras literárias. Preterindo concepções folclóricas - paternalistas, cristalizadoras daquilo que é em movimento, a cultura - apresento o personagem "folclórico" da feira, Toinho, como um híbrido, um bricoleur.

Xerocando, colando, imprimindo, o poeta-embolador emendou sua sobrevivência a partir de conhecimentos que se apropriou: a produção poética e editorial de cordel. Ao analisar os impressos da "tipografia do improviso" de Toinho da Mulatinha, produzidos no século XXI, anseio incentivar pesquisas que tragam para a cena folhetos ainda pouco explorados por essa área de pesquisa, pertencentes à "geração mimeógrafo" da arte dita popular. Aspiro que quem me lê tenha extraído a dimensão criativa do que chamo de "tipografia de improviso", mostrada não como um fazer sem intenção, mas como uma resposta ligeira (ao modo do coco), às transformações socioculturais que embolavam o país. Os folhetos fotocopiados de Toinho fundamentam o discurso construído desde o início do trabalho sobre o diálogo que o cordel manteve e mantêm com as tecnologias possíveis, assim como a correlação com produções editoriais de outros campos sociais, das "brochuras módicas de além-mar" até os "zines".

Toinho da Mulatinha desafiou essa pesquisa por ser um sujeito difícil de apreender, em seus trânsitos e hibridações. Detentor de saberes nascidos nas brechas de um país de contornos amorfos, foi um poeta de profissão que usou nos desafios de sua existência armas de "branco" e de "negro", a caneta e o ganzá - instrumento percussivo. Figura que expressou a "dialética da ordem e da desordem" na rima da "munganga" e da "moral”, do catolicismo e do catimbó (guardado em suas garrafadas), da poesia de improviso (embolada) e da poesia de bancada (cordel) - arranjada milimetricamente com "elementos móveis" (metálicos ou fotocopiados) sobre a superfície dos folhetos. Cantador que incorporou os tipos arcaicos benjaminianos: o "camponês sedentário", fixado na Feira Central de Campina Grande, e o "marinheiro comerciante" de uma literatura impressa com a voz em municípios da Paraíba e de estados vizinhos.

No exercício de observar o mapa conceitual que percorri ao longo da composição do texto acadêmico, atinei ao fato do trabalho ser integralmente atravessado pela 
dialética candiana da "ordem e da desordem". De maneira que o referido esquema interpretativo poderia ser retomado de maneira mais explícita ao longo do texto, por exemplo, quando Toinho da Mulatinha produz, para sair do ostracismo, o "poemapanfleto" sobre O Maior São João do Mundo e a Micarande em Campina Grande (1992). Este cordel me fez perceber a necessidade de salientar os vínculos estabelecidos por essa figura das brechas com a esfera da "ordem".

O alinhamento com os discursos da hegemonia aparece na produção literária do poeta-embolador e até mesmo nas paredes da Folhetaria Estrela do Oriente, representados pela imagem do "pai da Capital Cultural”, Ronaldo Cunha Lima, e do "pai nosso", Jesus Cristo, enquadrados na sala. Vale lembrar, que o Jesus presente na casa e nos versos de Toinho, não é aquele reformista igualitário que peregrinou pela Galiléia (diga-se de passagem, muito mais próximos da sua história de vida), mas o filho de um Deus que vigia e pune, o dono do seu destino, aquele que fez da sua vida uma embolada.

A cidade que encantou Mulatinha e que o poeta escolheu para cantar, Campina, é também a cidade da brecha, da encruzilhada, da "ordem" e da "desordem" - dialética visível nas disputas entorno da requalificação da Feira Central campinense. Com esse trabalho intento inserir Campina Grande na bibliografia desse campo de pesquisa, dada a relevância que a cidade ocupou no circuito especializado no gênero em meados do século XX, sendo descrita por Toinho como "líder cidade poética/ falada no mundo inteiro/ a mais importante praça/ do Nordeste brasileiro" (MULATINHA, 1964, p.03). Sobretudo, evidenciar a necessidade de que sejam pensadas as problemáticas relativas à gestão da "Capital Cultural”, às arquiteturas políticas edificadas desde o final do século XX que sufocam tradições ao privilegiar a memória e o projeto de uma elite local - de passado algodoeiro, de sina turística, refletidos no Açude Velho.

O Museu de Arte Popular da Paraíba, fruto da corrente de redimensionamento da cidade, pautada na tentativa de união do "tradicional" e o "moderno" (evidente em seu slogan: "MAAP - Passado e futuro, presentes"), de certo mereceria mais espaço na discussão sobre as estratégias políticas de reterritorialização histórica e temporal da Grande Campina, inclusive por ser um espaço que diz respeito à minha área de formação, artes visuais. O MAPP nasce com a intenção de homenagear a "arte popular" local, mas não remunera as/os artistas produtoras/es pelos seus trabalhos, doados sob a alegação subjacente de que estar em um museu, orçado em mais de 10 milhões de reais ${ }^{239}$, é pagamento simbólico suficiente para artistas dessa categoria. As/os profissionais da arte que preenchem a programação do museu não são beneficiados com a divulgação de seus artefatos, isto porque muitas das peças expostas (sobretudo aquelas inseridas

239 Informação extraída do site: http://g1.globo.com/pb/paraiba/noticia/2012/12/museu-de-arte-popular-obra-de-niemeyer-e-inaugurado-na-paraiba.html. Acesso em: 20 nov. 2019. 
na sala de artesanato), são esvaziadas de autoria, local de origem ou outras informações necessárias para tirar essa produção do anonimato, próprio de concepções folcloristas.

O Museu de Arte Popular operacionaliza um descolamento do real, condenando as/os visitantes a conviverem com o patrimônio cultural como se fosse algo alheio às experiências vitais dos/das mesmos/as. Nesse sentido, acaba tolhendo a potencialidade educativa das artes locais, que reside na capacidade de engendrar ou recolher histórias pessoais, familiares ou sociais, abrir espaços de simbolização para a compreensão dos artefatos no contexto de quem os produziu. Penso "em quem produziu" de maneira bem alargada, englobando a conjuntura histórica e as políticas culturais que os originaram, ocultadas pela curadoria através da devoção (ou devoração) dos objetos.

Como arte-educadora, penso que o "museu dos três pandeiros" (como foi alcunhado pela população) é um lugar propício para a formação de indivíduos/as aptos em interpretar, questionar e participar conscientemente da cultura e sociedade locais, assim como para disseminar uma concepção mais fluida de arte, indicando que, em frente àquela fortaleza modernista, as ruas se abrem em uma exposição do cotidiano, na qual podemos viver experiências estéticas em sua totalidade, como aquelas armadas diariamente na feira, localizada há poucos metros dali, ou emboladas no vão livre embaixo do próprio museu.

Mais que recontar uma História engrandecida de Campina, busquei nessa pesquisa trazer outras vozes, outros olhares sobre um passado e um presente inextrincavelmente ligados à Feira e a poesia de folhetos. Talvez isso seja o que alguns autores e autoras vêm chamando de perspectiva decolonial (matriz epistemológica na qual pretendo me aprofundar em pesquisas futuras). Nas palavras de Celina Nunes (2018):

\begin{abstract}
Abordagens decoloniais tornaram-se temática incontornável para a pesquisa nas artes (PALERMO, 2009), na educação, nas letras e em todas as áreas no campo das ciências humanas (MIGNOLO, 2015). Ao partir de um novo olhar epistemológico, o decolonial não apenas reivindica posições pós-coloniais para os problemas que afligem o mundo contemporâneo, mas também, ao fazer isso, evidencia inseparavelmente sua implicação direta com a edificação violenta de um padrão de poder instaurado com o colonialismo moderno. Em vista disso, observa-se a crescente expansão de estudos que procuram dar visibilidade e protagonismo a vozes excluídas, marginalizadas e, sobretudo, colocadas (não de forma ingênua) histórica e politicamente em bordas hierarquicamente arranjadas para que determinados grupos possam falar em detrimento de outros. (ALCÂNTARA, 2018, n.p)
\end{abstract}

Me empenhei em escrever esse texto costurando narrativas de gente que viveu e vive as manifestações culturais que motivaram essa pesquisa, que começa lá em 2015, no 
meu primeiro contato com a Feira Central de Campina Grande. Pronto, "bebi a água do Boqueirão" (como brincam as/os campinenses referindo-se às pessoas que ingerem a água do Açude que abastece a cidade e se amarram a ela), e lá me instalei em 2016, nas imediações da Feira, na rua Quebra Quilos - aquela que carrega o peso da resistência popular, da história decolonial. Na Feira ensina-se sobre "pesos e medidas" da balança social, sobre cura e ervas, ensina-se a ler com folheto, a tirar "leite de pedra" e estabelecer alianças e parcerias em jogos políticos que não se findaram no momento em que eu busco um ponto final para a pesquisa.

A feira me fez pesquisadora. Me apresentou as fissuras da Grande Campina. Me engoliu em um copo de caldo nas tardes de repente no bar da Teresa. Me pendurou no trem de cabedelo, com os emboladores de coco Condor, Will e Lindalva (discípulos do mestre Mulatinha). Me conduziu à “escrita de bancada”. E cá estou, encostando minha rotina naquela de gente que tanto soube combinar palavras.

Gravei no corpo, na memória, em aparelhos gravador e fotográfico, vozes daqueles que tiveram e têm a feira como espaço vital, como dona Cheirinho, debulhadora de feijão verde há mais de 70 anos: "Eu cheguei aqui com 7 anos e tô com 90, só saio quando morrer! Que se lasque!” (apud PIZZIGNACCO, 2019). Na bibliografia especializada em cordel, também procurei vestígios orais dos detentores dessa prática cultural. A voz de Toinho da Mulatinha, encontrei na escuta solitária dos LPs que rodaram seus sonhos de embolador. Ampliei minhas referências assistindo documentários, como A voz do poeta, do qual extraí falas de José Alves Sobrinho que integram essa pesquisa. E, claro: ouvi os ecos do arranco do grito de poetas e poetizas no silêncio da palavra impressa em folhetos.

Essas vozes inseriram Toinho da Mulatinha no seu universo geo-poético, que não pôde prescindir do político, e fizeram com que o embolador-escritor-editor ganhasse toda sua expressão. Desse modo, com essa pesquisa intenciono ter contribuído para fixar a memória dessa figura no papel, suporte aliado dos poetas e poetizas de cordel. Desejo que essa dissertação sirva de contribuição teórica, mas que se inscreva no mundo da palavra escrita como "dispositivo de afeto". Que faça rir, faça chorar, que sensibilize esteticamente leitores/as brasileiro/as que aprenderam a recusar a potência de determinadas expressões de cultura.

Aqui compreendo os "dispositivos de afeto" como contradispositivos do poder (PIZZIGNACCO, 2018). As artes de rua e de feira, operam nesse sentido, por catalisarem experiências sensíveis no espaço público, tornado via de passagem entre ambientes privados. Perturbando os fluxos regulares da rotinização, os músicos e cantadores urbanos de Campina Grande enfrentam contradiscursivamente os "dispositivos do poder" da moderna racionalidade estruturante do projeto urbano da cidade. Interpelam por meio da ação cotidiana os processos de ordenamento social, 
contornando/confrontando/intervindo nos dispositivos de captura de outros modos de viver Campina. As artes de feira como “dispositivos de afeto”, se inserem na esfera das micropolíticas de resistência: lutas imediatas, que não questionam diretamente a instância de um macropoder, são voltadas para o sujeito anti o assujeitamento, para as identidades, para as técnicas de si.

Reconhecendo Toinho da Mulatinha como sujeito que se define de maneira ativa pelas técnicas de si encontradas em práticas culturais locais, procurei por meio desse texto apresentá-lo e, deixá-lo se apresentar, como poeta que projetou a voz em alto e bom tom em uma sociedade hierarquizada, como editor representante de uma geração de poetas/poetisas responsáveis pela socialização da literatura nas margens da cidade e do centro econômico do país. Foi Toinho quem inscreveu essa pesquisa no viés das abordagens decoloniais, percebo agora nas conclusões. Afinal, seria muito pretensioso da minha parte querer falar por um poeta que a propagou sua voz por tantos municípios de estados nordestinos (registrados nos manuscritos pertencentes ao acervo da Folhetaria Estrela do Oriente).

Ao longo do trabalho de campo foi desafiador pensar sobre meu lugar de "paulista estudante do Nordeste”, em meio a tantas discussões espinhosas, mas imprescindíveis, sobre "lugar de fala". Nesse processo descobri que meu lugar de fala é a academia. Dela e nela coloco minha energia criativa, em um momento em que a universidade pública se torna alvo de ataques e os cursos de humanas são desvalorizados por líderes políticos que anunciam as pesquisas dessa área como inúteis e "ideológicas" (como se todo processo educativo não fosse ideológico), ameaçando o pensamento crítico com cortes orçamentários no ensino superior.

Empilho palavras, criando um texto ao modo de Manoel de Barros, inspirado em “ignorãnças” que mais um poeta me ensinou. Na superfície do papel busco "desplanificar" olhares sobre a terra, sobre o Brasil, criar "balbúrdias”, imprimir ideias que colaborem na observação das mudanças históricas da vida em sociedade em nosso país, aplicar na ciência a magia que a literatura e a embolada me ensinaram. Agradeço por concluir essa pesquisa de mestrado com financiamento público da Fundação de Amparo à Pesquisa do Estado de São Paulo e pelejarei para que outras gerações possam ter o trabalho de pesquisa remunerado, reconhecido como um ofício.

Provocada pelo meu campo investigativo, tenho empreendido esforços, ao lado da Profa. Dra. Joseilda Diniz ${ }^{\mathbf{2 4 0}}$, para que o acervo armazenado por Toinho da

240 Joseilda de Sousa Diniz é Consultora de Cultura na Pró-Reitoria de Cultura da Universidade Estadual da Paraíba e curadora responsável pelas pesquisas e museologia do espaço dedicado à cantoria, cordel, xilogravura, dentre outras poéticas orais, no Museu de Arte Popular da Paraíba. Pesquisadora na Biblioteca de Obras Raras Átila Almeida, tem experiência em aquisições de acervos, como o do Dr. Severino Bezerra de Carvalho, do poeta Marcelo Soares, do Prof. Dr. Gilmar de Carvalho, da Profa. Dra. Francisca Pereira dos Santos e do poeta Apolônio Alves dos Santos. 
Mulatinha seja adquirido pela Universidade Estadual da Paraíba ${ }^{\mathbf{2 4 1}}$. Propomos que o referido espólio seja salvaguardado por esta instituição específica: (1) diante do compromisso ético de manter o material na cidade que criou condições para de Toinho fazer-se poeta de profissão, Campina Grande; (2) devido ao fato do conjunto complementar o catálogo de folhetos do autor pertencente à Biblioteca de Obras Raras Átila Almeida (BORAA/ UEPB), proporcionando, portanto, uma visão panorâmica da produção do poeta-embolador; (3) pela razão desta universidade ser detentora de um espaço cultural especializado, o Museu de Arte Popular da Paraíba (MAPP/ UEBP), dotado de uma ala dedicada ao cordel.

A Universidade Estadual da Paraíba, priorizada para aquisição da obra em virtude de seu aparato institucional e de sua responsabilidade com a cultura local, deverá se comprometer em conservar, catalogar e restaurar, em caso de necessidade, o patrimônio material adquirido, assim como assegurar o devido arquivamento, disponibilizando-o para a pesquisa e promovendo exposições que contribuam com a preservação da memória do artista, Toinho da Mulatinha, e dos folhetos de cordel em Campina Grande, na Paraíba e no Brasil.

A atribuição financeira, quesito fundamental para que seja efetuada a transferência de tutela do acervo, da família do poeta para a Universidade Estadual da Paraíba, visa promover a dignidade de subsistência da herdeira direta do poeta, Digna Maria dos Santos, que participou ativamente da comercialização de folhetos na Feira Central de Campina Grande. O pagamento, a ser integralmente destinado à companheira do poeta, é um recurso de reconhecimento concreto dos fazeres e saberes da cultura local e uma ação comprometida em iniciar um círculo virtuoso capaz de

2410 espólio de Antônio Patrício de Souza (Toinho da Mulatinha) é composto por uma centena de folhetos de autores diversos e de sua produção mais recente (desenvolvida a partir da década de 2000); 30 manuscritos; 27 matrizes de xilogravura (sendo 14 gravadas pelo aclamado gravurista Antônio Lucena); 9 matrizes de fotogravura e 1 de zincogravura. 0 substancioso conjunto, patrimônio da família de Antônio Patrício de Souza, representada pela viúva Digna Maria dos Santos, tem como fiéis depositárias a Profa. Dra. Joseilda Sousa Diniz (PRAC/UEPB) e a pesquisadora Milla Pizzignacco (IEB/USP), responsáveis pela mediação do processo de comercialização da obra. As tramitações legais que envolvem a aquisição do patrimônio de Antônio Patrício de Souza pela Universidade Estadual da Paraíba (UEPB), iniciadas em 2016 - após reunião realizada com o Magnifico Reitor Dr. Antonio Guedes Rangel Junior, com o Pró-Reitor de Cultura Francisco Pereira da Silva Junior e com o Procurador da UEPB, Ebenezer Pernambucano Limoeiro Silva -, foram paralisadas diante da falta de recursos financeiros da universidade (referidos no projeto como indispensáveis para a transferência de tutela do espólio). Em 2019, o Projeto de Salvaguarda do acervo de Toinho da Mulatinha foi reelaborado pelas pesquisadoras, que ressaltaram a pertinência da aquisição do cabedal neste momento, diante do recente registro da literatura de cordel e da Feira campinense como Patrimônios Culturais Imateriais do Brasil (2018 e 2017, respectivamente). 0 Dossiê, contendo catalogação das obras e justificativa acerca da importância de Toinho da Mulatinha para a cultura local, será reapresentado em 2020 aos gestores da universidade, junto a uma solicitação para a formação de uma comissão $A d$ Hoc, pela UEPB, encarregada de determinar um valor monetário a ser remetido à herdeira do poeta. 
reverter a lógica de apropriações e expropriações da produção artística daqueles denominados, por subtração, de "populares".

Com essa iniciativa objetivamos quebrar a profecia impressa no desfecho do primeiro folheto composto por Toinho da Mulatinha, Uma viagem à Lua (1945), no qual constrói um paraíso de fartura que não consegue permanecer, uma vez que para um matuto-mulato ele é possível apenas na dimensão poética. Ao longo da minha trajetória de pesquisa, a única frase que ouvi de Toinho da Mulatinha, à época com 90 anos, expressa, justamente, um desejo pueril e desafia minha posição de pesquisadora. Na sala de sua residência, enquanto dona Digna compartilhava suas memórias com a poesia, me virei para o poeta e perguntei:

- O Sr. gostaria de acrescentar alguma coisa na sua história?

Toinho respondeu em tom baixo:

- Eu quero um pão com manteiga e um café com leite. 
referências 


\section{REFERÊNCIAS BIBLIOGRÁFICAS}

ABREU, Márcia (Org). Histórias de cordéis e folhetos. Campinas: Mercado das Letras/ Associação de Leitura do Brasil, 1999.

ABREU, Márcia. Cordel portugues/folhetos nordestinos: confrontos um estudo historicocomparativo. 1993. 360f. Tese (Doutorado em Literatura) - Instituto de Estudos da Linguagem, Universidade de Campinas, Campinas, 1993.

ABREU, Márcia. Duzentos anos: Os primeiros livros brasileiros. In: BRAGANÇA, Aníbal; ABREU, Márcia (orgs.). Impresso no Brasil: dois séculos de livros brasileiros. 1. ed. São Paulo: Editora Unesp, 2010. p.101-137.

ALBUQUERQUE JÚNIOR, Durval Muniz de. A feira dos mitos: a fabricação do folclore e da cultura popular (nordeste 1920 - 1950). São Paulo: Intermeios, 2013.

ALBUQUERQUE JÚNIOR, Durval Muniz de. A invenção do Nordeste e outras artes. São Paulo/Recife: Cortez, 2001.

ALCÂNTARA, Celina Nunes. O Decolonial na pesquisa em artes no Brasil [online]. SciELO em Perspectiva: Humanas, 2018. Disponível em:< https://humanas.blog.scielo.org/ blog/2018/10/23/o-decolonial-na-pesquisa-em-artes-no-brasil/>. Acesso em: 20 nov. 2019.

ALENCAR, José de. Iracema. 24ed. São Paulo: Ática, 1991. [1ª ed. 1865].

ALMEIDA, Elpídio de. História de Campina Grande. 2. ed. João Pessoa: Editora Universitária/UFPB, 1978 [1ª ed. 1962].

ALVES DE ABREU, Alzira Alves de. A Modernização da Imprensa (1970 - 2000). 1. ed. Rio de Janeiro: Jorge Zahar Editora, 2002.

ALVES SOBRINHO, José. Cantadores, repentistas e poetas populares. Campina Grande: Bagagem, 2003.

ALVES SOBRINHO, José. Essa gente lá de fora. Estudos de Literatura Brasileira Contemporânea, Brasília, n. 35, p. 251-253, 2010.

AMORIM, Maria Alice. Existe um novo cordel? Imaginário, tradição e cibercultura. Cibertextualidades, Porto, v. 03, p. 59-71, 2009a.

AMORIM, Maria Alice. No visgo do improviso ou a peleja virtual entre cibercultura $e$ tradição. 1. ed. São Paulo: Educ, 2009b.

AMORIM, Maria Alice. Pelejas em rede: vamos ver quem pode mais. 1. ed. Recife: Zanzar Edições, 2019.

ANDRADE. Mário de. Os cocos. Introdução e notas de Oneyda Alvarenga. 2. ed. Belo Horizonte: Itatiaia, 2002.

ANSELMO, Artur. Estudos de história do livro. Lisboa: Guimarães Editores, 1997. 
APPADURAI, Arjun. Aprèsle colonialisme: les consequences culturelles dela globalisation. Paris: Petit Bibliotèque Payot, 2005.

ARAÚJO, Fátima. Paraíba: imprensa e Vida - Jornalismo Impresso 1826 a 1984 . João Pessoa: Grafset, 1986.

ARAÚJO, Giovanna de Aquino Fonseca. As feiras livres nortistas portuguesas e nordestinas brasileiras como lócus de trabalho informal, e de bens simbólicos na contemporaneidade. In: IV Congresso Internacional de História, Maringá, 2009.

ARAÚJO, Giovanna de Aquino Fonseca. Continuidade e descontinuidade no contexto da globalização: um estudo de feiras em Portugal e no Brasil (1986-2007). 2011. 700f. Tese (Doutorado em História) - Instituto de Ciências Sociais (UMINHO) e Faculdade de Filosofia e Ciências Humanas (UFBA). Universidade do Minho. Guimarães - Portugal, 2011.

ARAÚJO, Giovanna de Aquino Fonseca. Múltiplos Discursos sobre a Feira de Campina Grande. Campina Grande: Agenda, 2006.

ARAÚJO, Giovanna de Aquino Fonseca. Requalificação espacial e Elaboração de Inventário imaterial: duas experiências em andamento na centenária Feira Central de Campina Grande- PB. In: VI Congresso Internacional de História, Maringá, 2013.

ARAÚJO, Jair Barbosa de. O algodão de Campina Grande: uma discussão acerca dos livros didáticos de História. Agenda: Campina Grande, 2006.

ASSANO, Christiane Reis Dias Villela. Entre fala, canto e grito: os pregões do centro de Niterói. 2007. 222f. Tese (Doutorado em Música) - Centro de Letras e Artes, Universidade Federal do Estado do Rio de Janeiro, Rio de Janeiro, 2007.

AYALA, Maria Ignez Novaes. No arranco do grito: aspectos da cantoria nordestina. São Paulo: Ática, 1988.

AYALA, Maria Ignez Novais; AYALA, Marcos (orgs.). Cocos: alegria e devoção. Natal: EDUFRN, 2000.

AYALA, Maria Ignez Novais. Os cocos: uma manifestação cultural em três momentos do século XX. Estudos Avançados, São Paulo, v. 13, n.35, p. 231-253, 1999.

AZEVÊDO, Jimmy Vasconcelos de. A poesia dos cocos. In: AYALA, Maria Ignez Novais; AYALA, Marcos (orgs.). Cocos: alegria e devoção. Natal: EDUFRN, 2000a. p. 73-82.

AZEVÊDO, Jimmy Vasconcelos de. O pandeiro e o folheto: a embolada enquanto manifestação oral e escrita. In: AYALA, Maria Ignez Novais; AYALA, Marcos (orgs.). Cocos: alegria e devoção. Natal: EDUFRN, 2000b. p. 83-104.

BAKHTIN, Mikhail. A cultura popular na Idade Média e no Renascimento. 3. ed. São Paulo: Hucitec, 1993.

BARBOSA, Socorro de Fátima Pacífico. Os intermediários da leitura na Paraíba do Oitocentos: livreiros e tipógrafos. In: BRAGANÇA, Aníbal.; ABREU, Márcia. (orgs.). Impresso no Brasil: dois séculos de livros brasileiros. São Paulo: Unesp, 2010. p. 205-220. 
BAUMAN, Richard. Verbal Art as Performance. Illinois: Waveland Press, 1977.

BENJAMIN, Walter. O narrador: considerações sobre a obra de Nikolai Leskov. In: Magia e técnica, arte e política. São Paulo: Brasiliense, 1985. p. 197 - 221.

BIGNOTTO, Cilza. Monteiro Lobato: editor revolucionário?. In: BRAGANÇA, Aníbal; ABREU, Márcia (orgs.). Impresso no Brasil: Dois séculos de livros brasileiros. 1ed.São Paulo: Editora da Unesp, 2010. p. 121-138.

BOSI, Ecléa. Memória e sociedade: lembrança de velhos. São Paulo: Companhia das Letras, 1998. BOURDIEU, Pierre. As regras da arte. São Paulo: Companhia das Letras 1996.

BOURDIEU, Pierre. O poder simbólico. Rio de Janeiro: Bertrand Brasil, 2003.

BRAGANÇA, Aníbal. António Isidoro da Fonseca e Frei José Mariano da Conceição Veloso: Precursores. In: BRAGANÇA, Aníbal; ABREU, Márcia (orgs.). Impresso no Brasil: Dois séculos de livros brasileiros. 1ed.São Paulo: Editora da Unesp, 2010, p. 25-39.

BRAGANÇA, Aníbal.; ABREU, Márcia (orgs.). Impresso no Brasil: dois séculos de livros brasileiros. São Paulo: Editora Unesp, 2010.

BRANDÃO, Carlos Rodrigues (Org). O que é método Paulo Freire. São Paulo: Brasiliense, 1981. BRASIL. Instituto do Patrimônio Histórico e Artístico Nacional - Iphan. Centro Nacional de Folclore e Cultura Popular - CNFCP. Dossiê de Registro. Brasília: Iphan, 2018. Disponível em: 〈http://portal.iphan.gov.br/uploads/ckfinder/arquivos/Dossie_Descritivo(1).pdf.〉. Acesso em: 20 nov. 2019.

CABRAL, Alfredo do Vale. Anais da Imprensa Nacional do Rio de Janeiro, 1808 - 1822. Rio de Janeiro: Typographia Nacional, 1881.

CABRAL, Muniz Sodré de Araújo. Samba: o dono do corpo. 2. ed. Rio de Janeiro: Mauad, 1998. CAMARGO, Ana Maria de Almeida; MORAES, Rubens Borba de. Bibliografia da Impressão Régia no Rio de Janeiro. São Paulo: Edusp, Kosmos, 1993.

CAMILO DOS SANTOS, Manoel. Autobiografia do poeta. João Pessoa: Editora Universitária /UFPb, 1979.

CAMPOS, Augusto; CAMPOS, Haroldo; PIGNATARI. Décio. Teoria da poesia concreta: Textos críticos e manifestos 1950-1960. Cotia: Ateliê Editorial, 2006. [1.ed. 1956]

CANCLINI, Nestor Garcia. Cultura popular: de la épica al simulacro. Quaderns Portàtils MACBA (Museu d'Art Contemporani de Barcelona), 2007. Disponível em: < http://www. macba.es/uploads/20070307/QP_06_Canclini.pdf>. Acesso em: 20 nov. 2019.

CANCLINI, Nestor Garcia. Culturas Híbridas: Estratégias para entrar e sair da modernidade. São Paulo: Edusp, 2006. 
CANCLINI, Nestor. ¿De qué estamos hablando cuando hablamos de lo popular?, em Antología sobre cultura popular e indígena. In: Seminario Diálogos en la Acción. Primera Etapa,México, Conaculta, 2004.

CANDIDO, Antonio. Dialética da Malandragem. Revista do Instituto de Estudos Brasileiros. São Paulo: USP, n. 8, p. 67-89, 1970.

CANDIDO, Antonio. Direitos Humanos e literatura. In: FESTER, Antônio Carlos Ribeiro (org.) Direitos humanos e literatura. São Paulo: Ed. Brasiliense, 1989. p. 107-126.

CANDIDO, Antonio. Os parceiros do Rio Bonito. Estudo sobre o caipira paulista e a transformação dos seus meios de vida. Rio de Janeiro: José Olympio, 1964.

CANDIDO, Antonio. Vários Escritos. $4^{\mathrm{a}}$ Ed. São Paulo: Duas Cidades, 2004.

CARVALHO, Gilmar de. Madeira Matriz: cultura e memória. São Paulo: Annablume, 1999.

CASCUDO, Luis da Câmara. Dicionário do folclore brasileiro. São Paulo: EDUSP, 1988.

CAVIGNAC, Julie. A literatura de cordel no Nordeste do Brasil: da história escrita ao relato oral. Natal: EDUFRN, 2006.

CERTEAU, Michel de. A cultura no plural. Campinas: Papirus, 1995.

CHARTIER, Roger. A Ordem dos Livros: Leitores, autores e bibliotecas na Europa entre os séculos XIV e XVIII. Tradução Mary Del Priore. Brasília: EdUNB, 1994.

CHARTIER, Roger. A aventura do livro: do leitor ao navegador. Tradução: Reginaldo Carmello Corrêa de Moraes. São Paulo: Editora UNESP, 1998.

CHARTIER, Roger. Cultura escrita, Literatura e História. Tradução: Ernani Rosa. Porto Alegre: Artmed Editora, 2001.

CHARTIER, Roger. Cultura popular: revisitando um conceito historiográfico. Estudos Históricos, Rio de Janeiro, v. 08, n. 16, p. 179 -192, 1995.

CHARTIER, Roger. História Cultural: entre práticas e representações. Tradução: Maria Manuela Galhardo. Rio de Janeiro: Bertrand do Brasil, 1990.

CHARTIER, Roger. Os desafios da escrita. Tradução: Fulvia M. L. Moretto. São Paulo: Editora UNESP, 2002.

CHUVA, Márcia. Os arquitetos da memória: sociogênese das práticas de preservação do patrimônio cultural no Brasil (1930-1940). Rio de Janeiro: EdUFRJ, 2009.

CIPRIANO, Maria do Socorro. Tipografia de cordel na Paraíba: entre o comércio e a poesia. In: XXVII Simpósio Nacional de História. Natal, 2013.

COSTA, Antônio Albuquerque da. Sucessões e coexistência do Espaço Campinense na sua inserção do meio Técnico-Científico-Informal: a feira de Campina Grande na interface desse processo. 2003. 245f. Dissertação (Mestrado em Geografia) - Centro de Filosofia e Ciências Humanas, Universidade Federal de Pernambuco, Recife, 2003. 
CURRAN, Mark Joseph. História do Brasil em Cordel. $2^{a}$ ed. São Paulo: EdUSP, 2003.

DAMASCENO, Patrícia Lopes. Design de Jornais: projeto gráfico, diagramação e seus elementos. BOCC - Biblioteca Online de Ciências da Comunicação, v. 1, p. 1-40, 2013.

DIÉGUES JUNIOR., Manuel. Literatura Popular em Verso. Belo Horizonte: Itatiaia, Universidade de São Paulo e Fundação Casa Rui Barbosa, 1989. (Coleção Reconquista do Brasil - 2a. Série, vol. 94).

DINIZ, Joseilda de Sousa. A construção da identidade do poeta José Alves Sobrinho. In: Jose Hélder Pinheiro Alves (org.). Territorio da Linguagem. 1. ed. Campina Grande: Bagagem, 2004.

DINIZ, Joseilda de Sousa. José Alves Sobrinho: um poète entre deux mondes. 2009. 380f. Tese (Doutorado em Lingüística, Letras e Artes; Literatura Brasileira.) - Instituto de Ciências Humanas e Sociedade. Université de Poitiers, Poitiers, 2009.

DINIZ, Joseilda de Sousa. Recriar o espaço de voz do poeta: a memória entre dois mundos. Estudos de Literatura Brasileira Contemporânea, Brasília, n. 35, p. 103-128, 2010.

EINSTEIN, Elisabeth L. A revolução da cultura impressa. São Paulo: Ática, 1998.

EL FAR, Alessandra. Ao gosto do povo: As edições baratíssimas de finais do século XIX. In: BRAGANÇA, Aníbal.; ABREU, Márcia (orgs.). Impresso no Brasil: dois séculos de livros brasileiros. São Paulo: Unesp, 2010. p.89-100.

EMERSON, Robert.; FRETZ, Rachel.; SHAW, Linda. Notas de Campo na Pesquisa Etnográfica. Revista Tendências: Caderno de Ciências Sociais, Crato, v. 7, n. 1, p. 355-388, 2013.

FEITOSA, Sonia Couto Sousa. Paulo Freire, a reinvenção de um legado. 1.ed. Brasília: Liber Livro Editora Ltda, 2008.

FERREIRA, Antônio Celso. Literatura - A fonte fecunda. In: LUCA, Tania Regina de; PINSKY, Carla Bassanezi (orgs.). O Historiador e suas fontes. São Paulo: Contexto, 2013. p. 61-92.

FERREIRA, Jerusa Pires. Armadilhas da memória. 2. ed. Cotia: Ateliê Editorial, 2004.

FERREIRA, Jerusa Pires. Cavalaria em Cordel. São Paulo: Hucitec, 1993.

FERREIRA, Jerusa Pires. Matrizes impressas da oralidade. In: BERND, Zilá; MIGOZZI, Jacques (orgs.). Fronteiras do Literário: literatura oral e popular Brasil/ França. Porto Alegre: EdUFRGS, 1995. p. 45-54.

FERREIRA, Jerusa Pires. Oralidade em tempo e espaço. São Paulo: Educ/Fapesp, 1999.

FERREIRA, Jerusa Pires. Quero que vá tudo pro inferno: cultura popular e indústria cultural. Comunicação e Sociedade, UMESP, São Bernardo do Campo, n. 13, p.179-185, 1985. FERREIRA, Orlando da Costa. Imagem e letra. 2. ed. São Paulo: Edusp, 1994.

FOUCAULT, Michel. História da sexualidade I: a vontade de saber. Rio de Janeiro: Graal, 1999. 
FOUCAULT, Michel. Vigiar e punir: nascimento da prisão. Tradução: Raquel. Ramalhete. Petrópolis, Vozes, 1987.

FRANCO JÚNIOR, Hilário. Cocanha: várias faces de uma utopia. Cotia: Ateliê Editorial, 1998. FRANCO, Maria Sylvia de Carvalho. Homens Livres na Ordem Escravocrata. São Paulo: Kairos, 1979.

FRANKLIN, Jeová. Xilogravura popular na literatura de cordel. Brasília: LGE, 2007.

GALVÃO, Ana Maria de Oliveira. Cordel: leitores e ouvintes. Belo Horizonte: Autêntica, 2001.

GARCIA, Mario. Contemporary newspaper design. 2. ed. Englewood Fields: Prentice-Hall. 1987.

GARCIA, Walter. Melancolias, mercadorias: Dorival Caymmi, Chico Buarque, o Pregão de Rua e a Canção Popular-Comercial no Brasil. Cotia: Ateliê Editorial, 2013.

GONÇALVES, Marco Antonio. Imagem-palavra: a produção do cordel contemporâneo. Revista de Sociologia e Antropologia. Rio de Janeiro, v. 1, n. 2., p.221-234. 2011. Disponível em:<http://www.scielo.br/scielo.php?pid=S2238-38752011000200219\&script=sci_ arttext $>$. Acesso em: 20 nov. 2019.

GUATTARI, Félix. Espaço e Poder: A Criação de Territórios na Cidade. Espaço e Debates. São Paulo, v.5, n.16, p. 45-59, 1985.

GUERREIRO, Manuel Viegas. Guia de Recolha de Literatura Popular. Lisboa: Ministério da Educação e Investigação Cientifica, 1976.

GULLAR, Ferreira. Cultura posta em questão. Rio: Civilização Brasileira, 1965.

HALBWACHS, Maurice. A Memória Coletiva. São Paulo: Vértice, 1990.

HALL, Stuart. A identidade cultural na pós-modernidade. Tradução: Tomaz Tadeu da Silva e Guacira Lopes Louro. Rio de Janeiro: DP\&A Editora, 2006.

HALL, Stuart. Stuart Hall por Stuart Hall. In: SOVIK, Liv (Orgs). Da Diáspora: identidades e mediações culturais. Tradução: Adelaine La Guardia Resende; Ana Carolina Escosteguy; Claudia Alvares; Francisco Rudiger; Sayonara Amaral. Belo Horizonte: EdUFMG, 2003. 405 - 432.

HALL, Stuart. Identidade Cultural e Diáspora. Revista do Patrimônio Histórico e Artístico Nacional, n.24, p.68-75, 1996.

HALL, Stuart. Represenation: Cultural Representations and Signifying Practices. London: Sage, 1997.

HARVEY, David. A condição pós-moderna. São Paulo: Loyola. 1992.

HATA, Luli. O Cordel das Feiras às Galerias. 199. 224f. Dissertação (Mestrado em Teoria Literária). Instituto de Estudos da Linguagem, Universidade Estadual de Campinas, Campinas, 1999. Disponível em: <http://www.bibliotecadigital.unicamp.br/ document/?code=vtls000199277\&fd=y $>$. Acesso em: 20 nov. 2019. 
HOBSBAWN, Eric; RANGER, Terence (orgs.) A invenção das tradições. Tradução: Celina Cerdim Cavalcante. 2. ed. São Paulo: Paz e Terra, 1997.

HOLANDA, Sergio Buarque de. Raízes do Brasil, Rio de Janeiro: José Olympio, 1936.

IGLESIAS, Maria Lúcia Diaz. Xilogravura popular brasileira: iconografia e edição. 1992. Dissertação (Mestrado em Comunicação e Artes). Escola de Comunicação e Artes, Universidade de São Paulo, São Paulo, 1992.

IKEDA, Alberto Tsuyoshi. Culturas populares no presente: fomento, salvaguarda e devoração. Estudos Avançados, São Paulo, v. 27, n. 79, p. 173-190, 2013.

IUMATTI, Paulo Teixeira . Arte e trabalho: aspectos da produção do livro em São Paulo (1914-1945). 2.ed. São Paulo: Hucitec, 2016.

IUMATTI, PAULO TEIXEIRA . Cordel e patrimônio. Revista do Instituto de Estudos Brasileiros, São Paulo, v. 72, p. 221-224, 2019.

IUMATTI, Paulo Teixeira. Herança escravista e forma poética no Brasil. Luso-brazilian review, São Paulo, v. 54, p. 28-54, 2017.

IUMATTI, Paulo Teixeira. História e folhetos de cordel: caminhos para a continuidade de um dialogo interdisciplinar. Escritural. Écritures d'Amérique Latine, São Paulo, v. 6, p. 3-32, 2012.

IUMATTI, Paulo Teixeira. Monumentalização da memória, afirmação hiperbólica do eu poético e herança escravista na construção dos espaços da cantoria. Escritural: Écritures d’Amérique Latine, São Paulo, v. 10, p. 08, 2017.

IUMATTI, Paulo Teixeira. Vozes negras na cantoria (1870-1925): o caso de Severino Perigo. Literatura e Sociedade (USP), São Paulo, v. 19, p. 100-116, 2014.

JACKSON, Kenneth David. Augusto de Campos e o trompe-l'oeil da poesia concreta. In: SÜSSEKIND, Flora; GUIMARÃES, Júlio Castañon (orgs.). Sobre Augusto de Campos. Rio de Janeiro: 7Letras- Fundação Casa de Rui Barbosa, 2004, p. 11-35.

KHOURY, Y. A. Narrativas orais na investigação da história social. Projeto História. Revista do Programa de Estudos Pós-Graduados de História. São Paulo, v. 22, n. 0, 2001. Disponível em: < http://revistas.pucsp.br/index.php/revph/article/view/10731> . Acesso em: 20 nov.2019.

LANG, Alice Beatriz da Silva Gordo. História oral: muitas dúvidas, poucas certezas e uma proposta. In: MEIHY, José Carlos Sebe Bom (org.). (Re)introduzindo história oral no Brasil. São Paulo: Xamã, 1996.

LARROSA, Jorge. O ensaio e a escrita acadêmica. Revista Educação er Realidade, Porto Alegre, vol.28, n.2, 2003. p.101-115.

LEITE, Rogério Proença de. Localizando o espaço público: gentrification e cultura urbana. Revista Crítica de Ciências Sociais, n. 83, p.35-54, 2008. 
LEMAIRE, Ria. Folheto ou literatura de cordel: uma questão de vida ou morte. In: XII Congresso de Folclore. Natal, 2008.

LESSA, Orígenes. A Voz dos Poetas. Rio de Janeiro: Fundação Casa de Rui Barbosa, 1984.

LEWIN, Linda. Um conto de dois textos: Oralidade, história oral e insulto poético. In: MARQUES, Ana Claudia (org.). O Desafio de Romano e Inácio em Patos (1874). Fortaleza/ Campinas, SP: UFCE/FUNCAP/CNPQ-Pronex/ Pontes Editores, 2007. p. 81-107.

LIMA, Elisabeth Cristina de Andrade. A Fábrica dos Sonhos: a invenção da festa junina no espaço urbano João Pessoa: Ideia, 2002.

MARANHÃO, Liêdo. O folheto popular: sua capa, seus ilustradores. Recife: Fundação Joaquim Nabuco e Editora Massangana, 1981.

MARQUES, Francisco Cláudio Alves. O País de São Saruê: um correlato da Cocanha medieval no sertão nordestino. In: II Simpósio Nacional de Letras e Linguística: Linguagem, História e Memória - UFG, v. I., p. 322-339, 2011.

MARTINELLI, Maria Lúcia (Org). Pesquisa qualitativa: um instigante desafio. São Paulo: Veras,1999.

MASCARENHAS, Gilmar. Feira Livre: Territorialidade Popular e Cultura na Metrópole Contemporânea. Ateliê Geográfico - Revista Eletrônica (UFG - IESA). Goiânia-GO, v.2, n.4, p.72-87, 2008.

MAXADO. Franklin. Cordel, Xilogravura e Ilustrações. Rio de Janeiro: Editora Codecri,1982.

MEIHY, José Carlos Sebe Bom; HOLANDA, Fabíola. História oral: como fazer, como pensar. São Paulo: Contexto, 2007.

MEIHY, José Carlos Sebe Bom. Manual de história oral. 4. ed. São Paulo: Loyola, 2002.

MELLO, Josemir Camilo de. Modernização e mudanças: O trem inglês nos canaviais do Nordeste (1852-1902). 2000. 377f. Tese (Doutorado em História) - Centro de Filosofia e Ciências Humanas, Universidade Federal de Pernambuco, Recife, 2000.

MELO, Rosilene Alves de. Almanaques de cordel: Do fascínio da leitura para a feitura da escritura, outro campo de pesquisas. Revista do Instituto de Estudos Brasileiros , São Paulo, v. 52, p. 109-122, 2011.

MELO, Rosilene Alves de. Do rapa ao registro: a literatura de cordel como patrimônio cultural do Brasil. Revista de Estudos Brasileiros, São Paulo, v. 72, p. 245-272, 2019a.

MELO, Rosilene Alves de. Literatura de cordel: Historiografia, práticas, arquivos. Projeto História - Revista Do Programa De Estudos Pós Graduados De História , São Paulo, v. 65, p. 66-99, 2019b.

MELO, Rosilene Alves de. Memória visual do cordel no Brasil: uma análise transdisciplinar. Escritural: Ėcritures D’Amérique Latine, Poitiers, v. 10, p. 210-230, 2017.

MELO, Rosilene Alves. Arcanos do verso: trajetórias da literatura de cordel. Rio de Janeiro: Letras, 2010. 
MONTENEGRO, Maria do Socorro Moura. Manoel Monteiro e as várias faces do texto de cordel. 2014. 170f. Tese (Doutourado em Linguistica) - Centro de Ciências Humanas, Letras e Artes, Universidade Federal da Paraíba, João Pessoa, 2014.

MORAES, Rubens Borba de. A impressão régia do Rio de Janeiro: Origens e produção. In: CAMARGO, Ana Maria de Almeida; MORAES, Rubens Borba de. Bibliografia da Impressão Régia do Rio de Janeiro. São Paulo: EDUSP, Livraria Kosmos Editora, 1993, p.XXIX.

MORAES, Rubens Borba de. O bibliófilo aprendiz. São Paulo: Companhia Editora Nacional, 1975.

MOTTA, Ana Raquel. Editora Luzeiro: um estudo de caso. Horizontes, Bragança Paulista, v. 15, p. 251-269, 1997.

MULATINHA, Toinho da. [Antônio Patrício de Souza]. Entrevista. Revista Cordeletras, Campina Grande - PB, n.6, outubro de 2007.

NEMER, Sylvia. Feira de São Cristóvão: contando histórias, tecendo memórias. 2012. 255f. Tese (Doutorado em História) - Departamento de História, Pontífica Universidade Católica do Rio de Janeiro, Rio de Janeiro, 2012.

NETO, João Cabral de Mello. Morte e Vida Severina. 1. ed. Rio de Janeiro: Alfaguara, 2007. [1 $1^{\mathrm{a}}$ ed. 1955].

NEUMANN, Erich. História do nascimento da consciência. São Paulo: Cultrix, 1995.

NIZZA DA SILVA, Maria Beatriz. Cultura e Sociedade no Rio de Janeiro (1808 - 1821). São Paulo: Ed. Nacional, 1978.

NIZZA DA SILVA, Maria Beatriz. História da leitura luso-brasileira: balanços e perspectivas. In: ABREU, Márcia (org.). Leitura, história e história da leitura. Campinas: Mercado de Letras, Associação de Leitura do Brasil/ São Paulo: Fapesp, 1999. p.147-164.

NOGUEIRA, Antonio Gilberto Ramos. Literatura de Cordel: folclore, coleção e patrimônio imaterial. Revista do Instituto de Estudos Brasileiros, São Paulo, n. 72, p. 262 - 275, 2019.

NOGUEIRA, Antonio Gilberto Ramos. O campo do patrimônio cultural e a história: itinerários conceituais e práticas de preservação. Antíteses, Londrina, v. 7, n. 14, p.45-67, 2014.

NOGUEIRA, Antonio Gilberto Ramos. O registro do Cordel como patrimônio imaterial e as políticas de preservação da cultura popular no Brasil Anos 90. Revista do Programa de Pós-Graduação em História da Universidade Federal do Rio Grande do Sul, Porto Alegre, v. 25, n. 48, p. 181-212, 2018.

NOGUEIRA, Carlos. A literatura de cordel de Manoel Monteiro. Symposium: A Quarterly Journal in Modern Literatures, Reino Unido, v. 68, n. 1, p. 37 - 50, 2014.

NOGUEIRA, Carlos. A Literatura de cordel portuguesa. Lisboa: eHumanista, 2012.

NORA, Pierre. Les lieux de mémoire. Paris: Gallimard, 1984. 
NUNES, Geice Peres. A poética de Manoel Camilo dos Santos: um diálogo entre a poesia popular do Nordeste e a literatura culta. 2014. 238f. Tese (Doutorado em Letras) - Centro de Artes e Letras, Universidade Federal de Santa Maria, Santa Maria, 2014.

ORTIZ, Renato. Românticos e folcloristas: cultura popular. São Paulo: Olho d’Água, 1992. PAZERA Jr., Eduardo. A feira de Itabaiana - PB: Permanência e mudança. 2003. 377f. Tese (Doutoramento em Geografia Humana) - Faculdade de Filosofia, Letras e Ciências Humanas, Universidade de São Paulo, São Paulo, 2003.

PELÚCIO, Larissa. Subalterno quem, cara pálida? Apontamentos às margens sobre pós colonialismos, feminismos e estudos queer. Contemporânea - Revista de Sociologia da UFSCar, São Carlos, v. 2, p. 395-418, 2012.

PEREIRA DE QUEIROZ, Maria Isaura. Bairros rurais paulistas. São Paulo: Duas Cidades, 1973.

PIMENTEL, Cristino. Mais um mergulho na história campinense. Campina Grande: Edições Caravela, 2001.

PINSKY, Carla Bassanezi; LUCA, Tania Regina de (orgs.). Fontes históricas. São Paulo: Contexto, 2005.

PINSKY, Carla Bassanezi; LUCA, Tania Regina de (orgs.). O historiador e suas fontes. São Paulo: Contexto, 2009.

PINTAUDI, Silvana Maria. O lugar do Supermercado na cidade Capitalista. Boletim de Geografia Teorética, Rio Claro, v. 9, n. 17, p.37-54, 1984.

PIZZIGNACCO, Milla Maués Pelúcio. Estetização das Disputas Narrativas sobre a Feira Central de Campina Grande (PB). In: Anais do 27o Encontro Nacional da Anpap - Práticas e Confrontações, São Paulo, 2018. p. 1084 - 1098.

PIZZIGNACCO, Milla Maués Pelúcio. Histórias que vós me Nordestes: discursos sobre "o popular” em Campina Grande. 2016. 205f. Monografia (Graduação em Artes Visuais). Instituto de Artes, Universidade Estadual Paulista Júlio de Mesquita Filho, São Paulo, 2016.

PIZZIGNACCO, Milla Maués Pelúcio. Representações do Nordeste no Nordeste: realocando a Feira Central em Campina Grande (PB). Cadernos do IEB São Paulo, v.11, p. 91-111, 2019.

PROENÇA, Ivan Cavalcanti. A ideologia do cordel. 2. ed. Rio de Janeiro: Brasília/Rio, 1977. QUEIROZ, Marcus Vinicius Dantas de. Qual é sua ideia para a feira de Campina Grande? Oficina de projeto participativo. Disponível em:<http://www.vitruvius.com.br/revistas/ $\mathrm{read} / \mathrm{minh}$ acidade/14.165/5125>. Acesso em: 20 nov. 2019.

QUIJANO, Aníbal. Colonialidad del poder y clasificacion social. Journal of Worldsystems Research. v.2 , p. 342- 386. 2000.

QUIJANO, Aníbal. Colonialidade do poder, Eurocentrismo e América Latina.In:LANDER, Edgardo. A colonialidade do saber: eurocentrismo e ciências sociais - perspectivas latinoamericanas. Buenos Aires: CLACSO, Consejo Latinoamericano de Ciencias Sociales, p.107-130, 2005. 
RAMOS, Everardo. Ariano Suassuna e a gravura popular brasileira ou a (de)formação de um pensamento crítico. In: ZACCARA, Madalena; PEDROSA, Sebastião (orgs.). Artes visuais: conversando sobre. Recife: Ed. Universitária da UFPE, 2008. p.23-43.

RAMOS, Everardo. Do mercado ao museu: a legitimação artística da gravura popular. Visualidades - Revista do Programa de Mestrado em Cultura Visual da UFG, v. 8, n. 1, 2010, p.145-164.

RAMOS, Everardo. Escritores-ilustradores de folhetos de cordel: processos de criação popular. Encontro Regional de ABRALIC - Literatura, Artes, Saberes, 2007.

RIBEIRO, Leda Tâmega. Mito e poesia popular. Rio de Janeiro: FUNARTE, 1985.

ROCHA, Gilmar. Cultura popular: do folclore ao patrimônio. Mediações: Revista de Ciências Sociais, Londrina, v. 14, n. 1, p. 218-236, 2009.

ROIPHE, Alberto. Forrobodó na Linguagem do sertão. Rio de Janeiro: Lamparina, 2012.

RONCOLATO, Murilo et al Guilherme Falcão, Ariel Tonglet e Ricardo Monteiro. Os versos e traços da literatura de cordel. Nexo. São Paulo, 2017. Disponível em: < https:// www.nexojornal.com.br/especial/2017/05/03/Os-versos-e-tra\%C3\%A7os-da-literaturade-cordel >. Acesso em: 20 nov. 2019.

SAMPAIO, Albino Forjaz de. Teatro de cordel (catálogo da colecção do autor): subsídios para a História do teatro português. Lisboa: Academia das Ciências, 1922.

SANTHIAGO, Ricardo. Da fonte oral à história oral: debates sobre legitimidade. Saeculum - Revista de História, João Pessoa, n. 18, p.33-46, 2008.

SANTOS, Boaventura de Sousa. Descolonizar el saber, reinventar el poder, Montevideo: Trilce Extensión Universitaria, 2010.

SANTOS, Milton. A natureza do Espaço: Técnica, Razão e Emoção. São Paulo: Hucitec, 1999. SANTOS, Milton. Espaço e Método. São Paulo: Nobel, 1985.

SANTOS, Milton. Metrópole Corporativa Fragmentada. São Paulo: Edusp, 2009.

SANTOS, Milton. O Espaço Dividido: os dois circuitos da Economia Urbana dos países desenvolvidos. São Paulo: Edusp, 1979.

SANTOS, Milton. O trabalho do geógrafo no Terceiro Mundo. São Paulo: Hucitec, 1978.

SANTOS, Milton. Os Dois Circuitos da Economia Urbana e suas Implicações Espaciais. In: Da totalidade ao lugar. São Paulo: Edusp, 2008. p. 93-116.

SANTOS, Milton. Técnica, Espaço e Tempo: Globalização e meio técnico-científico informacional. São Paulo: Edusp, 1994.

SANTOS, Wagner Geminiano. Enredando Campina Grande nas Teias da Cultura: (des) inventando festas e (re)inventando a cidade (1965-2002). 1.ed. São Paulo: Paco Editora, 2016. 
SARAIVA, Arnaldo. Literatura Marginal/izada - novos ensaios. Porto: Edições Árvore, 1980.

SAUTCHUK, João Miguel Manzolillo. A poética do improviso: prática e habilidade no repente nordestino. 2009. 214f. Tese (Doutorado em Antropologia) - Instituto de Ciências Sociais, Universidade de Brasília, Brasília, 2009.

SCHWARZ, Roberto. Pressupostos, salvo engano, da Dialética da Malandragem. In: SCHWARZ, Roberto. Que Horas São? Ensaios. São Paulo, Companhia das Letras, 1987. p.129-155.

SILVA, José. Honório; MACHADO, Mauro. O duelo cibernético de José Honório com Mauro Machado. Recife: União dos Cordelistas de Pernambuco. 2007.

SILVA, José. Honório. O marco cibernético construído em Timbaúba: das redes de Mocós à Internet. Timbaúba: Cordelnet. 1995.

SILVA, José. Honório. Peleja virtual entre Américo Gomes (PB) e José Honório(PE): a primeira cantoria via Internet. Timbaúba: Edições Cordelnet. 1997.

SILVEIRA, Regina Paula Silva da. O Papel de Elpídio de Almeida para Construção da História de Campina Grande. In: IX Seminário Nacional de Estudos e Pesquisas "História, Sociedade e Educação no Brasil”. Universidade Federal Da Paraíba, João Pessoa, 2012.

SLATER, Candace. A vida no barbante: a literatura de cordel no Brasil. Tradução: Octavio Alves Velho. Rio de Janeiro: Civilização Brasileira, 1984.

SOBRINHO, José Alves. Essa gente lá de fora. Estudos de Literatura Brasileira Contemporânea, Brasília, n. 35, p. 251-253, 2010.

SOUSA, Maurílio Antonio Dias. A Estrella da Poesia: impressões de uma trajetória. 2009. 498f. Dissertação (Mestrado em Letras) - Instituto de Letras, Universidade Federal da Bahia, Salvador, 2009.

SOUZA, Antônio Clarindo Barbosa de. Cidade e vida boêmia: Um passeio pelos "maus costumes” de Campina Grande. In: ANPUH - XXIII Simpósio Nacional de História, Londrina, 2005, p.1-10.

SOUZA, Liêdo Maranhão de. Classificação Popular da Literatura de Cordel. Petrópolis: Editora Vozes, 1976.

SOUZA, Liêdo Maranhão de. O folheto popular, sua capa e seus ilustradores. Recife: Editora Massangana, 1981.

SOUZA, Simone Cristina Mendonça de. Primeiras impressões: romances publicados pela Impressão Régia do Rio de Janeiro (1808-1822). 2007. 211f. Tese (Doutorado em Teoria e História Literária) - Instituto de Estudos da Linguagem, Universidade de Campinas, Campinas, 2007.

TARGINO, Itapoan Bôtto. Preservação do patrimônio ferroviário: as estações de trem da Paraíba. João pessoa: Ideia, 2001. 
TAVARES JÚNIOR, Luiz. O Mito na Literatura de Cordel. Rio de Janeiro: Tempo Brasileiro, 1980.

TERRA, Ruth Brito Lemos. Memória de lutas: literatura de folhetos do Nordeste (1893 1930). São Paulo: Global, 1983.

TRAVASSOS Elizabeth. Palavras que consomem: Contribuição à análise dos cocos-deembolada. Revista IEB, São Paulo, n. 51, p. 13-40, 2010. Disponível em:< www.revistas. usp.br/rieb/article/download/34658/37396>. Acesso em: 20 nov. 2019.

TRAVASSOS, Elizabeth. "O avião brasileiro": Análise de uma embolada. In: MATOS, Cláudia Neiva de; TRAVASSOS, Elizabeth; MEDEIROS, Fernanda Teixeira de (orgs.). Ao encontro da palavra cantada: poesia, música e voz. Rio de Janeiro: 7 Letras, 2001. p. 89-103.

VILHENA, Luís Rodolfo. Projeto e missão: o movimento folclórico brasileiro (1947 -1964). Rio de Janeiro: Funarte - FGV, 1997.

WEBER, Max. A Ética Protestante e o Espírito do Capitalismo. São Paulo: Cia das Letras, 2004.

WOODWARD, Kathryn. Identidade e Diferença: Uma introdução teórica e conceitual. In: SILVA, Tomaz Tadeu (org.); HALL, Stuart; WOODWARD, Kathryn. Identidade e Diferença: a perspectiva dos estudos culturais. 11a ed. Petrópolis: Vozes, 2012. p. 7 -72.

ZAPPATERRA, Yolanda. Art direction + editorial design. USA: Abrahams Studio. 2007.

ZUMTHOR, Paul. A letra e a voz: a "literatura" medieval. São Paulo: Companhia das Letras, 1993.

ZUMTHOR, Paul. Introdução à poesia oral. São Paulo: Hucitec/Educ Ltda, 1997.

ZUMTHOR, Paul. Performance, recepção e leitura. São Paulo: Educ, 2000.

\section{REFERÊNCIAS LITERÁRIAS - CORDÉIS}

BARBOSA, João. A discussão de um bêbado com um doutor. Campina Grande - PB, 1976. BATISTA, Francisco das Chagas. A história de Antônio Silvino. Recife - PE: Imp. Industrial, 1907. CALIFÓRNIA, Gerard. A Menina que Queria Enricar ou Maria Boa Semente. Campina Grande - PB, 1980.

CAMELO, José. As aventuras de um sertanejo generoso. Campina Grande - PB: Sebastião José do Nascimento (Editor), 1953.

CAMILO DOS SANTOS, Manoel. Autobiografia do Poeta. Campina Grande - PB: Tipografia e Folhetaria Santos, 1953. 
CAMILO DOS SANTOS, Manoel. Autobiografia do poeta. João Pessoa - PB: Editora Universitária (UFPB), 1979.

CAMILO DOS SANTOS, Manoel. A Béla Sertanêja. Campina Grande - PB: Estrella da Poesia, 1960.

CAMILO DOS SANTOS, Manoel. A candidatura de Severino Cabral. Campina Grande - PB: Estrella da Poesia, 1959.

CAMILO DOS SANTOS, Manoel. A vida de Maria Madalena. Campina Grande - PB: Folhetaria Santos, 1954.

CAMILO DOS SANTOS, Manoel. A vida do Padre Cícero. Campina Grande - PB: Tipografia e Folhetaria Santos, 1956.

CAMILO DOS SANTOS, Manoel. A pobre orfã engeitada nas malhas da traição. Campina Grande - PB: Tipografia e Folhetaria Santos, 1957.

CAMILO DOS SANTOS, Manoel. A Rainha das Fadas. Campina Grande - PB: Estrella da Poesia, 1960.

CAMILO DOS SANTOS, Manoel. As Aventuras de Pedro Quengo. Campina Grande - PB: Tipografia e Folhetaria Santos, 1957.

CAMILO DOS SANTOS, Manoel. As Aventuras de Pedro Quengo. Campina Grande - PB: A Estrella da Poesia, 1959.

CAMILO DOS SANTOS, Manoel. As Aventuras de Pedro Quengo. Campina Grande - PB: Estrella da Poesia, 1961.

CAMILO DOS SANTOS, Manoel. As palhaçadas de Biu. Campina Grande - PB: Estrella da Poesia, 1958.

CAMILO DOS SANTOS, Manoel. Lourival e Teresinha. Guarabira - PB: Tipografia e Folhetaria Santos, 1943.

CAMILO DOS SANTOS, Manoel. Lourival e Teresinha. Campina Grande - PB: Estrella da Poesia, 1959.

CAMILO DOS SANTOS, Manoel. Nascimento, Vida, Milagres e Morte de Jesus. Guarabira PB: Tipografia e Folhetaria Santos, 1952.

CAMILO DOS SANTOS, Manoel. O Caboclo do Bode. Campina Grande - PB: Estrella da Poesia, 1974.

CAMILO DOS SANTOS, Manoel. O Choro dos Nortistas no Rio e a Palestra de Luiz Gonzaga. Campina Grande - PB: Tipografia e Folhetaria Santos, 19--.

CAMILO DOS SANTOS, Manoel. O grande romance: O ébrio e suas canções. Campina Grande - PB, 1956. 
CAMILO DOS SANTOS, Manoel. O monstro do Pageú. Campina Grande - PB: Estrella da Poesia, 1974.

CAMILO DOS SANTOS, Manoel. O monstro do Pageú. Guarabira - PB: Tipografia e Folhetaria Santos, 1950.

CAMILO DOS SANTOS, Manoel. O sabido sem estudo. Campina Grande - PB: Tipografia e Folhetaria Santos, 1957.

CAMILO DOS SANTOS, Manoel. O Valente Sebastião. Campina Grande - PB: Estrella da Poesia, 1957.

CAMILO DOS SANTOS, Manoel. Os horrores do Nordeste e a solidariedade campinense. Campina Grande - PB, 1953.

CAMILO DOS SANTOS, Manoel. Os Que Souberam Se Amar. Campina Grande - PB: Estrella da Poesia, 1960.

CAMILO DOS SANTOS, Manoel. Viagem a São Saruê. Campina Grande - PB: Estrella da Poesia, 1965. (1 ${ }^{\text {a }}$ edição 1948)

CAVALCANTE, Rosil. O Bicho do Mazagão. Campina Grande - PB: Gráfica Júlio Costa, 1975.

COSME DA SILVA, Caetano. As plantas medicinais. Campina Grande - PB: Universidade Regional do Nordeste, 1981.

FILHO, Manoel D’Almeida. A voz de José Américo - O Salvador Nordestino. Campina Grande - PB: Casa Pereira. Manoel D’Almeida Filho (Editor), 1950.

GALDINO, Argemiro. Historia completa de Euclides e Florimar. Campina Grande - PB: Tipografia Borborema. Manoel Pereira Sobrinho (Editor), 19--.

HONÓRIO, José. O marco cibernético construído em Timbaúba. Timbaúba - PE, 1995.

JUNIOR, RANGEL. Louvação a Toinho da Mulatinha. Campina Grande - PB: Museu de Arte Popular da Paraíba - Gráfica Universitária (UEPB), 2016.

LUCENA, Gérson. A deusa da Borborema e Meu amor por Campina. Campina Grande - PB, 19--. LUCENA, Antônio. Com a Viola no Peito. Campina Grande - PB, 1976.

MARIA, Enock José de. A voz do Padre Cícero. Campina Grande - PB: Tipografia e Folhetaria Santos, 1957.

MELCHIADES, João. Descripção do Estado da Parahyba do Norte. Parahyba [João Pessoa]: F. C. Baptista Irmão Popular Editora, 19--.

MELQUÍADES, João. Romance do Pavão Misterioso. Campina Grande - PB: Estrella da Poesia, 1959.

MELQUÍADES, João. Rosa Branca da Castidade. Campina Grande - PB: Estrella da Poesia, 1960. 
MONTEIRO, Manoel. A Espanhola Inglesa: baseado na obra de Miguel de Cervantes. São Paulo: Scipione, 2008.

MONTEIRO, Manoel. Brincar de bullyin? É... besteira!. Campina Grande - PB: Cordelaria Poeta Manoel Monteiro, 2013.

MONTEIRO, Manoel. Campina dos meus amores: ode a Rainha da Borborema. Campina Grande - PB: Cordelaria Poeta Manoel Monteiro, 2000.

MONTEIRO, Manoel. Grande marco de Campina Grande. Campina Grande - PB: Cordelaria Poeta Manoel Monteiro, 2009.

MONTEIRO, Manoel. Grande marco de Campina Grande. 2. ed. Campina Grande - PB: Cordelaria Poeta Manoel Monteiro, 2009.

MONTEIRO, Manoel. O milagre do algodão colorido. Campina Grande - PB: Cordelaria Poeta Manoel Monteiro, 2003.

MONTEIRO, Manoel. O poder das plantas na cura das doenças. Campina Grande - PB: Cordelaria Poeta Manoel Monteiro, 2004.

MONTEIRO, Manoel. Os games na escola: jogos eletrônicos. Um bem ou um mal? Campina Grande - PB: Cordelaria Poeta Manoel Monteiro, 2008.

MONTEIRO, Manoel. Quer escrever um cordel? Aprenda a fazer fazendo. Campina Grande - PB: Gráfica Martins, 2002.

MONTEIRO, Manoel. Salvem a fauna! Salvem a flora! Salvem as águas do Brasil!. Campina Grande - PB: Cordelaria Poeta Manoel Monteiro, 2010.

MONTEIRO, Manoel. Salvem a fauna! Salvem a flora! Salvem as águas do Brasil!. Coleção Cesta Básica da Cultura e do Conhecimento. Brasília: Ensinamento Editora, 2010.

MONTEIRO, Manoel. Uma longa viagem: de Campina a Santa Tereza. Campina Grande - PB: Cordelaria Poeta Manoel Monteiro, 2002.

MONTEIRO, Manoel; MULATINHA, Toinho da. Nascimento, vida e morte de Dedé da Mulatinha. Campina Grande - PB, 1999.

MOTA JUNIOR. Moysés. A descrição da cidade de Campina Grande estado da Parahyba. Campina Grande - PB, 1936.

MULATINHA, Dedé da. [José Patrício de Souza]. A História da Santa Milagrosa; A Virgem do Socorro- Padroeira em Bodocongó. Campina Grande - PB: Gráfica São Jorge, 19--.

MULATINHA, Dedé da. [José Patrício de Souza]. Descrição da Flora Medicinal: quais as Plantas que Curam. Campina Grande - PB: Universidade Federal da Paraíba, 1977.

MUlATINHA, Dedé da. [José Patrício de Souza]. História Sagrada: as Sete Espadas de Dores de Maria Imaculada. Campina Grande - PB: Folhetaria Estrela do Oriente, 1976. 
MULATINHA, Dedé da. [José Patrício de Souza]. Meu avião Brasileiro Voando em Direção ao Espaço Sideral. Campina Grande - PB: Indústria Gráfica Jacira, 19--.

MULATINHA, Toinho da. [Antônio Patrício de Souza]. A Grande Feira da Prata na Cultura Nordestina. Campina Grande - PB: Folhetaria Estrela do Oriente, 2002.

MULATINHA, Toinho da. [Antônio Patrício de Souza]. A Barragem Camará: Rompimento da Barragem Camará - Rompimento da barragem e a tragédia em Alagoa Grande. Campina Grande - PB, 2004.

MULATINHA, Toinho da. [Antônio Patrício de Souza]. A história da Mãe que Degolou o Filho com uma Hora de Nascido, na Cidade de Lagoa Seca, no dia 16 de Janeiro de 1980. Campina Grande - PB: Folhetaria Estrela do Oriente, 1980.

MULATINHA, Toinho da. [Antônio Patrício de Souza]. A Historia de Campina Centenária. Esperança - PB: Gráfica São Paulo, 19--. (data estimada: 1964)

MULATINHA, Toinho da. [Antônio Patrício de Souza]. A História do Desastre na Lagoa do Parque Solon de Lucena em J. Pessoa. 19--. (data estimada: 1975)

MULATINHA, Toinho da. [Antônio Patrício de Souza]. A História do Monstro que Roubou e Incendiou a Igreja do Rosário. Campina Grande - PB, 1956.

MULATINHA, Toinho da. [Antônio Patrício de Souza]. A História do Treze Futebol Clube o Famoso Galo da Borborema. Campina Grande - PB: Folhetaria Estrela do Oriente, 19--. (data estimada: 1975)

MULATINHA, Toinho da. [Antônio Patrício de Souza]. A Morte do Radialista e Compositor Nordestino Rosil Assis Cavalcante. Campina Grande - PB, 1968.

MUlatinHA, Toinho da. [Antônio Patrício de Souza]. A Paixão de Cristo. Campina Grande - PB: Folhetaria Estrela do Oriente, 2005.

MUlatinhA, Toinho da. [Antônio Patrício de Souza]. A Paixão de Cristo. Campina Grande - PB: Tipografia São José, 19--.

MULATINHA, Toinho da. [Antônio Patrício de Souza]. A Queda do SKYLAB e o Medo do Pessoal. Campina Grande - PB: Folhetaria Estrela do Oriente, 19--. (data estimada: 1979).

MULATINHA, Toinho da. [Antônio Patrício de Souza]. A Reportagem do Fogo no Paraná e a Mortandade do Povo. Esperança - PB: Gráfica São Paulo, 19--. (data estimada: 1960)

MULATINHA, Toinho da. [Antônio Patrício de Souza]. As missões de Frei Damião em Bom Jardim e a tempestade em Limoeiro. Campina Grande - PB: Gráfica São Jorge, 1955.

MULATINHA, Toinho da. [Antônio Patrício de Souza]. As missões de Frei Damião em nossa Campina Grande. Campina Grande - PB, 2001.

MULATINHA, Toinho da. [Antônio Patrício de Souza]. As Missões de Frei Damião em Solanéa, Bananeiras e Serraria ele se despedindo do povo e esplicando a missa aos catolicos. 1955. 
MULATINHA, Toinho da. [Antônio Patrício de Souza]. As missões de frei Damião em Solidade e o castigo de um amancebado. 19--.

MULATINHA, Toinho da. [Antônio Patrício de Souza] (org). Cachimbinho e Geraldo Mousinho Cantando suas emboladas. Campina Grande - PB, 1976.

MULATINHA, Toinho da. [Antônio Patrício de Souza]. Campina Grande, a Viola e as Belezas do Nordeste. Campina Grande - PB: Folhetaria Estrela do Oriente, 1976.

MULATINHA, Toinho da. [Antônio Patrício de Souza]. Campina Grande e as violas. 20--.

MULATINHA, Toinho da. [Antônio Patrício de Souza]. Carregando quem não presta: a negra da trouxa grande. Campina Grande - PB: Folhetaria Estrela do Oriente, 20--.

MULATINHA, Toinho da. [Antônio Patrício de Souza]. Coco de embolada sobre Leandro rei do cordel. Manuscrito - Formato "Linguado". 1955.

MUlatinHA, Toinho da. [Antônio Patrício de Souza]. Coco em sonho cantei no céu pra cristo rei dos poetas. Folha-solta - xérox. 1999.

MUlatinHA, Toinho da. [Antônio Patrício de Souza]. Conselho de José Cláudio na Patrulha da cidade Folha-solta - xérox. 1999.

MULATINHA, Toinho da. [Antônio Patrício de Souza]. Emboladas sobre o corpo humano. Manuscrito - Formato "Brochura”. 19--.

MUlatinhA, Toinho da. [Antônio Patrício de Souza]. "Mata Sete” o Monstro do Sertão o Assassino de uma Família em Princesa Isabel. Campina Grande - PB: Folhetaria Estrela do Oriente, 1979.

MULATINHA, Toinho da. [Antônio Patrício de Souza]. O Bebê Diabo: A História do Menino que Nasceu com 2 Chifres e Peludo em São Bernardo do Campo - São Paulo.Campina Grande - PB: Folhetaria Estrela do Oriente, 1975.

MULATINHA, Toinho da. [Antônio Patrício de Souza]. O cordel da Santa encontrada lá no rio Paraíba. Campina Grande - PB: Folhetaria Estrela do Oriente, 20--. (1ª edição 1975).

MULATINHA, Toinho da. [Antônio Patrício de Souza]. O cordel de Isabela. Campina Grande - PB: Folhetaria Estrela do Oriente, 2008.

MULATINHA, Toinho da. [Antônio Patrício de Souza]. O cruzeiro novo. Campina Grande - PB: Tipografia São José, 19--. (data estimada: 1967)

MULATINHA, Toinho da. [Antônio Patrício de Souza]. O Desastre do Ônibus que Atropelou uma Procissão e Matou Vinte e Três Pessoas em Currais Novos. Campina Grande - PB: Folhetaria Estrela do Nordeste, 19--. (data estimada: 1974)

MUlatinHA, Toinho da. [Antônio Patrício de Souza]. O Desastre do Caminhão que ia de Esperança a Usina Santa Maria. Campina Grande - PB: Folhetaria Estrela do Oriente, 1977.

MULATINHA, Toinho da. [Antônio Patrício de Souza]. O Dilúvio de Roldão não veio: As Borboletas Azuis erram a Profecia. 19--. (data estimada: 1980) 
MULATINHA, Toinho da. [Antônio Patrício de Souza]. O Exemplo da Moça que virou Cachorra no Carnaval de 80 porque zombou de Frei Damião. 19--. (data estimada: 1980).

MULATINHA, Toinho da. [Antônio Patrício de Souza]. O Folheto da Brigada em Salgado de Solânea. Campina Grande - PB: Folhetaria Estrela do Oriente, 1977.

MULATINHA, Toinho da. [Antônio Patrício de Souza]. O folheto da filha que matou a mãe pela cabeça de um peixe. Campina Grande - PB: Folhetaria Estrela do Oriente, 20--.

MULATINHA, Toinho da. [Antônio Patrício de Souza]. O folheto do turco que atirou no Papa João Paulo II. Campina Grande - PB: Folhetaria Estrela do Oriente, 20--. (1 ${ }^{\text {a }}$ edição 1981).

MULATINHA, Toinho da. [Antônio Patrício de Souza]. O homem que deixou a mulher para viver com uma jumenta. Campina Grande - PB: Gráfica Vitória, 1982.

MUlATINHA, Toinho da. [Antônio Patrício de Souza]. O maior São João do Mundo e a Micarande em Campina Grande. Campina Grande - PB, 2001. (1 ${ }^{\text {a }}$ edição. Campina Grande: FUNCESP, 1992).

MULATINHA, Toinho da. [Antônio Patrício de Souza]. O mote de um viciado ou um homem biriteiro: eu era um desmantelado Jesus mudou meu viver; O folheto do chupa cabra. 1999.

MUlATINHA, Toinho da. [Antônio Patrício de Souza]. O Navio Brasileiro. 19--. (data estimada: 1967)

MUlATINHA, Toinho da. [Antônio Patrício de Souza]. O Povo Chora com Pena do Frade Frei Damião. Campina Grande - PB: Folhetaria Estrela do Oriente, 1977.

MUlatinHA, Toinho da. [Antônio Patrício de Souza]. O Treze é Bicampeão - Campeão 2006. Campina Grande, 2006.

MULATINHA, Toinho da. [Antônio Patrício de Souza]. Os Milagres de Frei Damião.1978.

MULATINHA, Toinho da. [Antônio Patrício de Souza]. Os sofrimentos dos nortistas pelo o Sul ganhando o pão. Campina Grande - PB: Gráfica São Jorge, 1959.

MULATINHA, Toinho da. [Antônio Patrício de Souza]. Peleja de Antônio da Mulatinha com Francisco de Sena. 19--.

MUlATINHA, Toinho da. [Antônio Patrício de Souza]. Peleja de Antonio da Mulatinha com Manoel Batista. 19--.

MUlatinhA, Toinho da. [Antônio Patrício de Souza]. Peleja de Antonio da Mulatinha com Vem-vem do Piancó. Campina Grande - PB: Folhetaria Estrela do Oriente, 20--. (1 ${ }^{\text {a }}$ edição 1964).

MULATINHA, Toinho da. [Antônio Patrício de Souza]. Satanás no inferno está contente porque lá chega errado todo dia. Campina Grande - PB: Folhetaria Estrela do Oriente, 2001a. (1 ${ }^{a}$ edição: 1964)

MULATINHA, Toinho da. [Antônio Patrício de Souza]. Satanás no inferno está contente 
porque lá chega errado todo dia. Mossoró - RN: Fundação vingt-un rosado - Coleção Mossoroense, 2001.

MULATINHA, Toinho da. [Antônio Patrício de Souza]. Toinho da Mulatinha Cantando coco nas feiras. Manuscrito - Formato "Linguado”. 1955.

MUlatinHA, Toinho da. [Antônio Patrício de Souza]. Toinho da Mulatinha e sua biografia .20--.

MULATINHA, Toinho da. [Antônio Patrício de Souza]. Toinho da Mulatinha na Paraíba cidades principais vilas povoados e lugares onde ele passou e cantou. Manuscrito - Formato “Linguado”. 19--.

MULATINHA, Toinho da. [Antônio Patrício de Souza]. Uma viagem sagrada. 2001 (1 edição: 1953).

MULATINHA, Toinho da. [Antônio Patrício de Souza]. Uma viagem à Lua. Campina Grande - PB: Folhetaria Estrela do Oriente, 20--. (1ª edição: 1945).

MULATINHA, Toinho da. [Antônio Patrício de Souza]; MOUSINHO, Geraldo. Eu e minha namorada (Antonio da Mulatinha); O mundo pegando fogo (Geraldo Mouzinho); Côco no periquito é assim (Geraldo Mouzinho). João Pessoa - PB, 1980

PAULO, Mário. Uma Vingança bem Feita Ou os Sofrimentos de um órfão. Campina Grande - PB: Estrella da Poesia, 1960.

REI, João de Cristo. A Mais nova Profecia de Frei Vidal da Penha A Contar de 1951 a 1960. Campina Grande - PB: Tipografia Borborema, 19--.

SENA, Joaquim Batista de. Chiquinho e Juliana - O amor que vence. Juazeiro do Norte CE: Manoel Caboclo e Silva (Editor), 19--.

SERTANEJO, Severino. A gente pode livrar-se do mal que faz o barbeiro. Campina Grande - PB: Universidade Federal da Paraíba, 1977.

SEVERO DE LIMA, João. Peleja de João Severo de Lima com Manoel Camilo dos Santos. Campina Grande - PB: Universidade Federal da Paraíba, 1977. SOBRINHO, José Alves. A verdadeira história de Jesuino Brilhante cangaceiro e herói Volume II. Campina Grande - PB: Universidade Federal da Paraíba, 1977.

SOBRINHO, José Alves. A História de Campina Grande em Versos. Campina Grande - PB, 2004.

SOBRINHO, José Alves. Vida, Obra, Glória e Morte do Dr. Osvaldo Cruz - Volume II. Campina Grande - PB: Universidade Federal da Paraíba, 1977.

TAVARES, Bráulio. A Pedra do Meio-dia ou Artur e Isadora. Campina Grande - PB: Folhetaria Estrela do Oriente, 198-.

UNIVERSIDADE REGIONAL DO NORDESTE. Homenagem aos poetas populares $e$ repentistas paraibanos. Campina Grande - PB: Universidade Regional do Nordeste, 1976. 
UNIVERSIDADE REGIONAL DO NORDESTE. II Congresso Nacional de Violeiros Campina Grande - Paraíba; 22 - 24 de Agôsto de 1975. Campina Grande - PB: Universidade Regional do Nordeste/ Associação de Poetas e Repentistas Nordestinos, 1975.

VASCONCELLOS, Alceu Cabral. Descripção parahybana / Elevação de Campina Grande. Campina Grande - PB, 19--.

VIEIRA, Cícero. [mocó]. Quando minha mãe morreu. Manuscrito - Formato "Linguado”. Rio de Janeiro, 1982.

\section{REFERÊNCIAS DAS ENTREVISTAS}

AGRA, João. Depoimento [jan. 2016]. Entrevista concedida à pesquisadora. Campina Grande (PB), 2016.

BATATA, Severino [Biu da Batata]. Depoimento [jul. 2015]. Entrevista concedida à pesquisadora. Campina Grande (PB), 2015.

BATISTA, Agnaldo. Depoimento [jul. 2015]. Entrevista concedida à pesquisadora. Campina Grande (PB), 2015.

BEZERRA, Inácia Firmino. Depoimento [jul. 2015]. Entrevista concedida à pesquisadora. Campina Grande (PB), 2015.

BELEZA, Luiz. Depoimento [jul. 2015]. Entrevista concedida à pesquisadora. Campina Grande (PB), 2015.

BORGES, José Francisco. Depoimento [jan. 2015]. Entrevista concedida à pesquisadora. Bezerros (PE), 2015

FELIPE, Lindalva. Depoimento [jul. 2015]. Entrevista concedida à pesquisadora. Campina Grande, 2015.

MUNDINHO, Eduardo Lima. Depoimento [mar. 2018]. Entrevista concedida à pesquisadora. Campina Grande (PB), 2018.

LIMA, Tião. Depoimento [mar. 2018]. Entrevista concedida à pesquisadora. Campina Grande (PB), 2018.

MACIEL, Teresa. Depoimento [jul. 2015]. Entrevista concedida à pesquisadora. Campina Grande (PB), 2015.

MONTEIRO, Kátia. Depoimento [mar. 2018]. Entrevista concedida à pesquisadora. Campina Grande (PB), 2018. 
MONTEIRO, Valentina. Depoimento [mar. 2018]. Entrevista concedida à pesquisadora. Campina Grande (PB), 2018.

PEREIRA, Lindete Martins. Depoimento [mar. 2018]. Entrevista concedida à pesquisadora. Campina Grande (PB), 2018.

SANTOS, Digna Maria dos. Depoimento [jul. 2015]. Entrevista concedida à pesquisadora. Campina Grande (PB), 2015.

SILVA, José Robério da [Condor]. Depoimento [mar 2018]. Entrevista concedida à pesquisadora. Campina Grande (PB), 2018.

SILVEIRA, Samuel Lopes da. Depoimento [jul.2015]. Entrevista concedida à pesquisadora. Campina Grande (PB), 2015. 


\section{LISTA DE FIGURAS}

Figura 1 - Sábado de embolada na Feira Central de Campina Grande - Lua Nova no arranco do grito. Fonte: Milla Pizzignacco, 2016.

Figura 2 - Feira Central de Campina Grande (1978). Fonte: Roberto Coura, 2014.

Figura 3 - Cenas da Feira Central de Campina Grande. Fonte: Milla Pizzignacco, 2016.

Figura 4 - Toinho da Mulatinha no Sítio São João (Campina Grande, 2006). Fonte: Acervo do poeta.

Figura 5 - Dona Inácia comercializando raízes na Rua Manoel Pereira de Araújo (2015). Fonte: Milla Pizzignacco, 2016.

Figura 6 - Capa do folheto Descrição da Flora Medicinal - Quais Plantas que Curam (Dedé da Mulatinha, 1977). Fonte: Biblioteca de Obras Raras Átila Almeida (BORAA/UEPB).

Figura 7-Mapa indicativo dos pontos onde foram fixadas as bancas de folhetos e raízes dos irmãos Dedé e Toinho da Mulatinha na Feira Central de Campina Grande, em meados do século XX. Fonte: Milla Pizzignacco, 2018. Mapa desenhado pela pesquisadora com base cartográfica do Google Maps.

Figura 8 - Quarta capa do folheto Chiquinho e Juliana - O amor que vence (19--). Grifo realizado digitalmente pela pesquisadora. Fonte: Acervo da pesquisadora.

Figura 9- Lindalva desafiando Condor na Feira de Cabedelo, João Pessoa (2018). Fonte: Milla Pizzignacco, 2018.

Figura 10 - Capa do folheto Peleja de Antônio da Mulatinha com Vem-vem do Piancó (Toinho da Mulatinha, 2000). Fonte: Acervo da pesquisadora.

Figura 11 - Capas e quarta capa de folhetos nos quais Toinho da Mulatinha reitera seu vínculo com a oralidade. Grifos realizados digitalmente pela pesquisadora. Fonte: Acervo da pesquisadora.

Figura 12 - Capa do folheto A paixão de Cristo (Toinho da Mulatinha, 19--), em destaque menção à oralidade. Grifo realizado digitalmente pela pesquisadora. Fonte: Acervo da pesquisadora.

Figura 13 - Capa de folheto diagramada a partir da composição de tipos móveis. Fonte: Biblioteca de Obras Raras Átila Almeida (BORAA/ UEPB).

Figura 14 - Declamação de folheto na Feira Central de Campina Grande (1978). Fonte: Roberto Coura, 2014.

Figura 15- Folhetos com a chancela da Tipografia Borborema. Fonte: Biblioteca de Obras Raras Átila Almeida (BORAA/ UEPB). Grifos realizados digitalmente pela pesquisadora. 
Figura 16 - Folhetos com o timbre da Gráfica São Jorge. Fonte: Biblioteca de Obras Raras Átila Almeida (BORAA/ UEPB). Grifos realizados digitalmente pela pesquisadora.

Figura 17 - Folhetos de autoria de Manoel Pereira Sobrinho editado e comercializado pela Casa Pereira, propriedade do autor. Fonte: Biblioteca de Obras Raras Átila Almeida (BORAA/ UEPB). Grifo realizado digitalmente pela pesquisadora.

Figura 18 - Folheto de autoria de José Camelo editado por Sebastião José do Nascimento. Fonte: Biblioteca de Obras Raras Átila Almeida (BORAA/ UEPB). Grifo realizado digitalmente pela pesquisadora.

Figura 19 - Folhetos de autoria de Manoel Camilo dos Santos editados pela Estrella da Poesia no período em que se manteve instalada na Feira Central de Campina Grande. Observa-se a homologia visual das impressões do período. Fonte: Biblioteca de Obras Raras Átila Almeida (BORAA/ UEPB).

Figura 20 - Folhetos de autores diversos editados por Manoel Camilo dos Santos. É possível perceber nas publicações a manutenção de uma identidade gráfica, estabelecida a partir do renovado maquinário da Tipografia Estrella da Poesia, durante seu auge comercial. Fonte: Biblioteca de Obras Raras Átila Almeida (BORAA/ UEPB).

Figura 21 - Fotografia de Manoel Camilo dos Santos fixada na quarta capa do folheto A Béla Sertanêja (1960), de sua autoria. Fonte: Biblioteca de Obras Raras Átila Almeida (BORAA/ UEPB).

Figura 22 - Multidão esperando o trem na estação ferroviária de Campina Grande (1907). Fonte: Blog “Retalhos Históricos de Campina Grande”.

Figura 23 - Mapa das linhas férreas inauguradas no estado da Paraíba entre 1883 e 1960. Os municípios indicados são aqueles que receberam estações de trem no período. A imagem foi redesenhada pela pesquisadora com base no mapa de TARGINO (2001). Fonte: TARGINO (2001, p. 104).

Figura 24 - Capa: As missões de Frei Damião em Solânea, Bananeiras e Serraria ele se despedindo do povo e explicando a missa aos católicos (1955). Fonte: Biblioteca de Obras Raras Âtila Almeida (BORAA/ UEPB).

Figura 25 - Mapa da Paraíba grafado com o conjunto de rotas do itinerário da cantoria no estado, realizado por Maurílio Antônio Dias (2009) a partir dos relatos de José Alves Sobrinho e Toinho da Mulatinha. A imagem foi redesenhada pela pesquisadora. Fonte: DIAS (2009, p. 84).

Figura 26 - Quarta capa do folheto A vida de Padre Cícero (CAMILO DOS SANTOS, 1956). Grifo realizado digitalmente pela pesquisadora. Fonte: Biblioteca de Obras Raras Átila Almeida (BORAA/UEPB).

Figura 27-Quarta capa do folheto A Candidatura do deputado Severino Cabral (CAMILO DOS SANTOS, 1959). Fonte: Biblioteca de Obras Raras Átila Almeida (BORAA/UEPB).

Figura 28 - Quarta capas de folhetos editados por Manoel Camilo dos Santos contendo 
declarações acerca da aquisição de títulos. Fonte: Biblioteca de Obras Raras Átila Almeida (BORAA/UEPB).

Figura 29- Quarta capa do folheto Os horrores do Nordeste e a solidariedade campinense (CAMILO DOS SANTOS, 1953). Grifo realizado digitalmente pela pesquisadora. Fonte: Biblioteca de Obras Raras Átila Almeida (BORAA/UEPB).

Figura 30 - Folheto de autoria de Toinho contendo a autodenominação "vulgo Antônio da Mulatinha”. Grifo realizado digitalmente pela pesquisadora. Fonte: Biblioteca de Obras Raras Átila Almeida (BORAA/UEPB).

Figura 31 - Folhetos de autoria de Toinho da Mulatinha contendo a autodenominação "poeta caipira”. Grifos realizado digitalmente pela pesquisadora. Fonte: Biblioteca de Obras Raras Átila Almeida (BORAA/UEPB).

Figura 32 - Bochicho na Feira Central de Campina Grande (1978). Fonte: Roberto Coura, 2014.

Figura 33-Capa do disco de vinil Chico Sena e Toinho da Mulatinha - desafios e emboladas (1976). Fonte: Acervo da pesquisadora.

Figura 34 - Folheto de Dedé da Mulatinha editado pela Folhetaria Estrela do Oriente e a matriz de zincogravura correspondente à estampa da capa - armazenada no acervo da casa editorial de Toinho da Mulatinha. Fonte: Biblioteca de Obras Raras Átila Almeida (BORAA/ UEPB); Acervo do poeta Toinho da Mulatinha.

Figura 35 - Protótipo da brochura Quando minha mãe morreu (VIEIRA[Mocó], 1982). Fonte: Acervo do poeta Toinho da Mulatinha.

Figura 36 - Capa de folheto editado por Toinho da Mulatinha. Abaixo matriz de fotogravura correspondente à imagem da capa, propriedade da Folhetaria Estrela do Oriente. Grifo realizado digitalmente pela pesquisadora. Fontes: Biblioteca de Obras Raras Átila Almeida (BORAA/ UEPB); Acervo do poeta Toinho da Mulatinha.

Figura 37 - Folheto de Dedé da Mulatinha com insígnia da Gráfica São Jorge. Fonte: Biblioteca de Obras Raras Átila Almeida (BORAA/ UEPB).

Figura38-GráficasativasemCampinaGrandeentre1955e1982,“nãoespecializadas”,porém, impressoras de folhetos: 1) Gráfica Vitória: Rua Peregrino de Carvalho, 331; 2) Tipografia São José: Getúlio Vargas, 153 / Santo Antônio, 26; 3) Zane-Gráfica: Bairro Monte Castelo; 4) Industria Gráfica Jacira: Rua Padre Ibiapina, 104; 5) Gráfica Municipal de Campina Grande: Rua Vigário Calixto, 30 / Rua Paulo Frontim, s.n.; 6) Gráfica Júlio Costa: Rua Venâncio Neiva, 204; 7) Gráfica São Jorge: Rua Doze de Outubro, 62 (endereço não localizado). Fonte: Localizações adicionadas pela pesquisadora em base cartográfica do Google Maps (2019).

Figura 39 - Fotogravura dos jogadores do "Galo da Borborema”. Imagem impressa na capa do folheto que tematiza a história do time e a matriz metálica correspondente. Fontes: Biblioteca de Obras Raras Átila Almeida (BORAA/ UEPB); Acervo do poeta Toinho da Mulatinha. 
Figura 40 - Capa de publicação de Mulatinha com visualidade jornalística. Fonte: Biblioteca de Obras Raras Átila Almeida (BORAA/ UEPB).

Figura 41 - Capa do Folheto A História de Campina Centenária (1964). Fonte: Biblioteca de Obras Raras Átila Almeida (BORAA/ UEPB).

Figura 42 - Capa do folheto A História do desastre na Lagoa do Parque Solon Lucena em João Pessoa (Toinho da Mulatinha, 1975). Fonte: Biblioteca de Obras Raras Átila Almeida (BORAA/ UEPB).

Figura 43 - Capas de folhetos de Mulatinha cujo os títulos funcionam como "lead". Fonte: Biblioteca de Obras Raras Átila Almeida (BORAA/ UEPB).

Figura 44 - Quarta capa de folheto autoral do proprietário da Folhetaria Estrela do Oriente, contendo a propaganda da casa editorial/comercial. Fonte: Biblioteca de Obras Raras Átila Almeida (BORAA/ UEPB).

Figura 45 - Folheto com matriz xilográfica correspondente à ilustração da capa. Fontes: Biblioteca de Obras Raras Átila Almeida (BORAA/UEPB); Acervo do Poeta Toinho da Mulatinha.

Figura 46 - Maleta na qual Toinho armazenava as matrizes pertencentes ao acervo da Folhetaria Estrela do Oriente. Fonte: Acervo do poeta - Fotografia: Milla Pizzignacco (2015).

Figura 47-Seleta de xilogravuras armazenadas no acervo de clichês da Folhetaria Estrela do Oriente. Fonte: Acervo de Toinho da Mulatinha (Tutelado pela família do poeta).

Figura 48 - Folheto de Toinho da Mulatinha ilustrado com xilogravura e matriz correspondente à imagem da capa. Artista desconhecido. Fontes: Biblioteca de Obras Raras Átila Almeida (BORAA/ UEPB); Acervo do poeta Toinho da Mulatinha.

Figura 49- Taco talhado por José Costa Leite e impressões realizadas a partir de matrizes do xilógrafo. Fonte: Acervo do poeta Toinho da Mulatinha.

Figura 50 - Matrizes talhadas por Antônio Lucena. Observa-se que nunca foram impressas diante da ausência de resíduos de tinta e da presença de marcações a lápis. Fonte: Acervo do poeta Toinho da Mulatinha.

Figura 51 - Capa de folheto escrito por Toinho da Mulatinha e ilustrado por seu parceiro “capista”, Antônio Lucena. Fonte: Biblioteca de Obras Raras Átila Almeida (BORAA/ UEPB).

Figura 52 - Primeira xilogravura encontrada em folheto (Antônio Silvino - O rei dos cangaceiros. Francisco das Chagas Batista, 1907). Fonte: FRANKLIN (2007).

Figura 53 - Capa de folheto escrito por Toinho da Mulatinha e ilustrado por Antônio Lucena. Fonte: Biblioteca de Obras Raras Átila Almeida (BORAA/ UEPB).

Figura 54 - Folheto de José Alves Sobrinho publicado com a colaboração da Universidade Federal da Paraíba (1977). Fonte: Biblioteca de Obras Raras Átila Almeida (BORAA/ UEPB).

Figura 55 - Folheto acerca do II Congresso Nacional de Violeiros, realizado em Campina Grande - editado pelo Museu de Arte da Universidade Regional do Nordeste (1975). Fonte: Biblioteca de Obras Raras Átila Almeida (BORAA/ UEPB). 
Figura 56 - Quarta capa do folheto O Caboclo do Bode, de Camilo dos Santos (1974). Nela, Manoel exalta as ações de intelectuais que passaram a financiar suas obras poéticas e de colegas de profissão. No texto, destaca a participação de Ariano Suassuna no fomento à poesia de bancada. Fonte: Biblioteca de Obras Raras Átila Almeida (BORAA/ UEPB).

Figura 57 - Folheto de autoria de Bráulio Tavares editado pela Folhetaria Estrela do Oriente (198-). Fonte: Biblioteca de Obras Raras Átila Almeida (BORAA/ UEPB).

Figura 58 - Última página de A menina que queria enricar ou Maria Boa Semente. Observase a subscrição: "Folheto também é Cultura", indicativa da expansão da noção de cultura no período. Grifo realizado digitalmente pela pesquisadora. Fonte: Biblioteca de Obras Raras Átila Almeida (BORAA/ UEPB).

Figura 59 - Panelas de barro na Feira Central de Campina Grande. Fonte: Roberto Coura, 2014.

Figura 60 - Foto oficial da Campanha de Ronaldo Cunha Lima (1982). Fonte: Blog "Retalhos históricos de Campina Grande".

Figura 61-Festejos do “Maior São João do Mundo" no século XXI. Fonte:TripAdivisor(https:// www.tripadvisor.com.br/LocationPhoto-DirectLink-g793400-d2414980-i335649330People_Park-Campina_Grande_State_of_Paraiba.html). Acesso em: 20 nov. 2019.

Figura 62 - Cássio Cunha Lima exibe o livro onde consta ter assumido o cargo ocupado pelo pai, Ronaldo Cunha Lima - sorridente ao lado direito da fotografia. Fonte: Blog "Retalhos Históricos de Campina Grande".

Figura 63 - Simulação do Cassino Eldorado na cidade cenográfica instalada no Parque do Povo para os festejos juninos (Campina Grande - PB, 2014). Fonte: G1 Paraíba (http:// g1.globo.com/pb/paraiba/noticia/2014/07/antigo-casino-eldorado-de-saba-na-feiracentral-de-campina-grande.html). Acesso em: 20 nov. 2019.

Figura 64 - Padre Fábio de Melo cantando no palco principal do "Maior São João do Mundo" (Campina Grande - PB, 2016). Fonte: http://www.jampajovens.com.br/2016/06/ show-do -padre-fabio-de-melo-reune-100.html. Acesso em: 20 nov. 2019.

Figura 65 - Vila Sítio São João (2018). Fonte: Perfil oficial, no Facebook, do vereador João Dantas.

Figura 66 - Tipografia Estrella da Poesia representada no Parque temático do Sítio São João (2012). A estrutura foi transferida integralmente para a sede atual. Fonte: https:// www.flickr.com/photos/50496888@N00/ with/7410737452/. Acesso em: 20 nov. 2019.

Figura 68 - Folhas-soltas compostas em máquina fotocopiadora por Toinho da Mulatinha (1999). Grifo realizado digitalmente pela pesquisadora. Fonte: Acervo do poeta Toinho da Mulatinha.

Figura 69 - Capa e quarta capa do folheto O Cordel de Isabela (MULATINHA, 2008). Fonte: Acervo da Pesquisadora.

Figura 70 - Miolo do folheto A Paixão de Cristo (MULATINHA, 2001). Marcações realizadas digitalmente pela pesquisadora. Fonte: Acervo da Pesquisadora. 
Figura 71 - Miolo do folheto O Treze é Bicampeão - Campeão 2006 (MULATINHA, 2006). Marcações realizadas digitalmente pela pesquisadora. Fonte: Acervo da Pesquisadora.

Figura 72 - Capa e páginas internas do folheto $O$ mote de um viciado ou um homem biriteiro - Eu era um desmantelado Jesus mudou meu viver/ O folheto do chupa cabra. (MULATINHA, 1999). Marcações realizadas digitalmente pela pesquisadora. Fonte: Acervo da Pesquisadora.

Figura 73-Miolo do folheto A Grande Feira da Prata na Cultura Nordestina (MULATINHA, 2002) Marcações realizadas digitalmente pela pesquisadora. Fonte: Acervo da Pesquisadora.

Figura 74 - Capas e quarta capas de editorações do mesmo título: O Maior São João do Mundo e a Micarande em Campina Grande (MULATINHA, 2001). A primeira publicação foi diagramada por gráfica parceira da prefeitura de Campina Grande (financiadora do folheto) e as demais por Toinho da Mulatinha. Fonte: Acervo da Pesquisadora.

Figura 75 - Material de produção gráfica de Toinho da Mulatinha. Fonte: Acervo do poeta - Fotografia realizada pela pesquisadora (2016).

Figura 76 - Capas de folhetos de autoria de Toinho da Mulatinha compostas a partir de estrutura gráfica similar. Fontes: Biblioteca de Obras Raras Átila Almeida; Acervo da Pesquisadora.

Figura 77-Capa e quarta capa da publicação Ofolheto da filha que matou a mãe pela cabeça de um peixe (MULATINHA, 20--); matriz de xilogravura (Antônio Lucena), que originou a impressão fotocopiada presente na contracapa. Fontes: Acervo da Pesquisadora; Acervo do poeta Toinho da Mulatinha.

Figura 78 - Capas de publicações de Mulatinha que tematizam o Treze Futebol Clube, impressas em 2006 e 1975, respectivamente. Fontes: Acervo da Pesquisadora; Acervo da Biblioteca de Obras Raras Átila Almeida (BORAA/UEPB).

Figura 79 - Zine do coletivo Riot Grrrl, inscrito na cena punk de Washington (EUA) nos anos 1990; Folheto publicado por Toinho da Mulatinha no início dos anos 2000. Fontes: https://www.washingtonian.com/2016/08/04/zines-deserve-a-bigger-place-indc-punk-history-heres-why/. Acesso em: 20 nov. 2019; Acervo da pesquisadora.

Figura 80 - Fanzine Metal-Punk underground, “United Forces”, que circulou no Brasil entre 1986 e 1991. Editado por Marcelo Batista em São Paulo. Fonte: Instagram oficial do "United Forces” - https://www. instagram.com/p/By6KW6yg5R8/. Acesso em: 20 nov. 2019.

Figura 81 - Zines da coleção do MoMa (The Museum of Modern Art). Produzidos por artistas mulheres vanguardistas das publicações independentes nos Estados Unidos no final do século XX. Da esquerda para a direita: a) Kathleen Hanna, Billy Karren, Tobi Vail, Kathi Wilcox. Bikini Kill: Girl Power, no. 2. 1991. Fotocópia; capa por Hanna; b) Kathleen Hanna, Billy Karren, Tobi Vail, Kathi Wilcox. Bikini Kill: A Color and Activity Book, no. 1. 1991. Fotocópia; capa por Hanna; c) Molly Neuman, Allison Wolfe. Girl 
Germs, no. 5. c. 1993-94. Fotocópia; capa por Miss Pussycat. Fonte: https://www.moma. org/explore/inside_out/2010/08/12/ riot-on-the-page-thirty-years-of-zines-by-women/. Acesso em: 20 nov. 2019.

Figura 82 - Folhetos com aspecto de zine compostos por Toinho da Mulatinha no início do século XX. Fonte: Acervo da pesquisadora.

Figura 83 - Capa do folheto Uma Viagem Sagrada (MULATINHA, 2001), ilustrada por xilogravura fotocopiada. Fonte: Acervo da pesquisadora.

Figura 84 - Capa do livro A Espanhola Inglesa (MONTEIRO, 2008), ilustração realizada pelo desenhista Jô Oliveira. Fonte: FLORES, Célia. Navarro. Uma 'Espanhola inglesa' abrasileirada. Caracol , v. 1, p. 204-232, 2013.

Figura 85 - Museu Digital de Campina Grande e Museu de Arte Popular da Paraíba, respectivamente. Fontes: https://www.euamocampinagrande.com. br/ empresaseservicos/museu-de-arte-popular-da-paraiba.html\#photos; https:// vidasemparedes.com.br/ dicas-o-que-fazer-em-campina-grande-paraiba/. Acesso em: 20 nov. 2019.

Figura 86 - Monumentos e sítio histórico que contornam o Açude Velho de Campina Grande; Escultura Os Pioneiros da Borborema; Escultura Farra de Bodega; Museu do Algodão (antiga estação ferroviária). Fontes: https://www.paraibacriativa.com. br/artista/os-pioneiros-da-borborema/; https://www.euamocampinagrande.com.br/ empresaseservicos/farra-de-bodega.html; https:/www.facebook. com/PBCultural/ posts/886943021325815/. Acesso em: 20 nov. 2019.

Figura 87 - Sábado de repente no Bar da Tereza - Mercado Central de Campina Grande (2016). Fonte: Milla Pizzignacco, 2016.

Figura 88 - Felipe Batista tocando violão e vendendo folhetos na Feira Central campinense (2016). Fonte: Milla Pizzignacco, 2016.

Figura 89 - Condor e Will embolando a Feira Central campinense (2018). Fonte: Milla Pizzignacco, 2018.

Figura 90 - Dona Digna e Toinho da Mulatinha na casa que acolheu a Estrela do Oriente (2016). Fonte: Milla Pizzignacco, 2016. 


\section{corpus central}

da pesquisa

(Toinho da Mulatinha) 


\section{FOLHETOS DE TOINHO DA MULATINHA}

ACERVO DA BIBLIOTECA DE OBRAS RARAS ÁTILA ALMEIDA

(UNIVERSIDADE ESTADUAL DA PARAÍBA - CAMPINA GRANDE)

MUlatinHA, Toinho da. [Antônio Patrício de Souza]. A história da Mãe que Degolou o Filho com uma Hora de Nascido, na Cidade de Lagoa Seca, no dia 16 de Janeiro de 1980. Campina Grande - PB: Folhetaria Estrela do Oriente, 1980.

MUlATINHA, Toinho da. [Antônio Patrício de Souza]. A História da Mulher que Matou o Filho e Jogou num Caixão de Lixo. 19--. (data estimada: 1974)

MUlATINHA, Toinho da. [Antônio Patrício de Souza]. A Historia de Campina Centenária. Esperança - PB: Gráfica São Paulo, 19--. (data estimada: 1964)

MUlATINHA, Toinho da. [Antônio Patrício de Souza]. A História do Desastre na Lagoa do Parque Solon de Lucena em J. Pessoa. 19--. (data estimada: 1975)

MUlatinHA, Toinho da. [Antônio Patrício de Souza]. A História do Monstro que Roubou e Incendiou a Igreja do Rosário. Campina Grande - PB, 1956.

MUlatinHA, Toinho da. [Antônio Patrício de Souza]. A História do Treze Futebol Clube o Famoso Galo da Borborema. Campina Grande - PB: Folhetaria Estrela do Oriente, 19--. (data estimada: 1975)

MUlatinHA, Toinho da. [Antônio Patrício de Souza]. A Morte do Coronel Ludogero e do seu Companheiro Otrope. Campina Grande - PB, 19--. (data estimada: 1970)

MULATINHA, Toinho da. [Antônio Patrício de Souza]. A Morte do Radialista e Compositor Nordestino Rosil Assis Cavalcante. Campina Grande - PB, 1968.

MUlatinHA, Toinho da. [Antônio Patrício de Souza]. A morte do Trovador Patricio de Oliveira. 19--. (data estimada: 1956)

MUlatinha, Toinho da. [Antônio Patrício de Souza]. A Paixão de Cristo. Campina Grande - PB: Tipografia São José, 19--.

MULATINHA, Toinho da. [Antônio Patrício de Souza]. A Queda do SKYLAB e o Medo do Pessoal. Campina Grande - PB: Folhetaria Estrela do Oriente, 19--. (data estimada: 1979)

MUlatinHA, Toinho da. [Antônio Patrício de Souza]. A Reportagem do Fogo no Paraná e a Mortandade do Povo. Esperança - PB: Gráfica São Paulo, 19--. (data estimada: 1960)

MUlATINHA, Toinho da. [Antônio Patrício de Souza]. As missões de Frei Damião em Bom Jardim e a tempestade em Limoeiro. Campina Grande - PB: Gráfica São Jorge, 1955a.

MUlATINHA, Toinho da. [Antônio Patrício de Souza]. As missões de Frei Damião em Bom Jardim e a tempestade em Limoeiro. Campina Grande - PB, $1955 \mathrm{~b}$.

MULATINHA, Toinho da. [Antônio Patrício de Souza]. As Missões de Frei Damião em Solanéa, 
Bananeiras e Serraria ele se despedindo do povo e esplicando a missa aos catolicos. 1955.

MUlATINHA, Toinho da. [Antônio Patrício de Souza]. As missões de frei Damião em Solidade e o castigo de um amancebado. 19--.

MULATINHA, Toinho da. [Antônio Patrício de Souza]. A tromba d'água do Estado da Guanabara. 19--. (data estimada: 1966)

MULATINHA, Toinho da. [Antônio Patrício de Souza]. A Verdadeira História da Morte do Coronel Ludugero e seu Companheiro Otrope. Campina Grande - PB, 19--.

MUlatinHA, Toinho da. [Antônio Patrício de Souza]. A vitória do Brasil / a seleção brasileira o Brasil tri-campeão. Campina Grande - PB: Folhetaria Estrêla do Oriente, 19--. (data estimada: 1970)

MUlatinHA, Toinho da. [Antônio Patrício de Souza]. Campina Grande, a Viola e as Belezas do Nordeste. Campina Grande - PB: Folhetaria Estrela do Oriente, 1976.

MULATINHA, Toinho da (org). Cachimbinho e Geraldo Mousinho Cantando suas emboladas. Campina Grande - PB, 1976.

MUlATINHA, Toinho da. [Antônio Patrício de Souza]. "Mata Sete” o Monstro do Sertão o Assassino de uma Família em Princesa Isabel. Campina Grande - PB: Folhetaria Estrela do Oriente, 1979.

MULATINHA, Toinho da. [Antônio Patrício de Souza]. O banho da praia. 19--.

MULATINHA, Toinho da. [Antônio Patrício de Souza]. O Bebê Diabo: A História do Menino que Nasceu com 2 Chifres e Peludo em São Bernardo do Campo - São Paulo. Campina Grande - PB: Folhetaria Estrela do Oriente, 1975.

MULATINHA, Toinho da. [Antônio Patrício de Souza]. O Casamento de Bernarde com Maria de Saguim ou o Rapaz que casou-se e correu com medo da mulher no dia do casamento. 19--.

MULATINHA, Toinho da. [Antônio Patrício de Souza]. O cruzeiro novo. Campina Grande - PB: Tipografia São José, 19--. (data estimada: 1967)

MULATINHA, Toinho da. [Antônio Patrício de Souza]. O Desastre do Ônibus que Atropelou uma Procissão e Matou Vinte e Três Pessoas em Currais Novos. Campina Grande - PB: Folhetaria Estrela do Nordeste, 19--. (data estimada: 1974)

MUlatinHA, Toinho da. [Antônio Patrício de Souza]. O Desastre do Caminhão que ia de Esperança a Usina Santa Maria. Campina Grande - PB: Folhetaria Estrela do Oriente, 1977.

MULATINHA, Toinho da. [Antônio Patrício de Souza]. O Dilúvio de Roldão não veio: As Borboletas Azuis erram a Profecia. 19--. (data estimada: 1980)

MUlatinHA, Toinho da. [Antônio Patrício de Souza]. O Exemplo da Moça que virou Cachorra no Carnaval de 80 porque zombou de Frei Damião. 19--. (data estimada: 1980).

MULATINHA, Toinho da. [Antônio Patrício de Souza]. O Folheto da Brigada em Salgado 
de Solânea. Campina Grande - PB: Folhetaria Estrela do Oriente, 1977.

MULATINHA, Toinho da. [Antônio Patrício de Souza]. O homem que deixou a mulher para viver com uma jumenta. Campina Grande - PB: Gráfica Vitória, 1982.

MULATINHA, Toinho da. [Antônio Patrício de Souza]. O homem que matou sete pessoas numa casa em Princesa Isabel. 1979.

MULATINHA, Toinho da. [Antônio Patrício de Souza]. O Navio Brasileiro. 19--. (data estimada: 1967)

MULATINHA, Toinho da. [Antônio Patrício de Souza]. O Poema do Filho que Matou o Pai no Sítio Araçá entre Arara e Serraria. Campina Grande - PB, 1977.

MUlatinHA, Toinho da. [Antônio Patrício de Souza]. O Povo Chora com Pena do Frade Frei Damião. Campina Grande - PB: Folhetaria Estrela do Oriente, 1977.

MULATINHA, Toinho da. [Antônio Patrício de Souza]. Os Milagres de Frei Damião.1978.

MUlatinHA, Toinho da. [Antônio Patrício de Souza]. Os Milagres de Frei Damião. Campina Grande - PB, 19--.

MULATINHA, Toinho da. [Antônio Patrício de Souza]. Os Sofrimentos do Povo Cearense, com Mêdo do Jaguaribe ou os Dessastres do Inverno e as Cobras da Baía. 19--.

MULATINHA, Toinho da. [Antônio Patrício de Souza]. Os sofrimentos dos nortistas pelo o Sul ganhando o pão. Campina Grande - PB: Gráfica São Jorge, 1959.

MUlAtinhA, Toinho da. [Antônio Patrício de Souza]. Peleja de Antônio da Mulatinha com Francisco de Sena. 19--.

MULATINHA, Toinho da. [Antônio Patrício de Souza]. Peleja de Antonio da Mulatinha com Manoel Batista. 19--.

MULATINHA, Toinho da; LUCENA, Gérson. Desafio dos poetas Gérson Lucena e Antonio da Mulatinha ao som da viola. Campina Grande - PB, 19--.

MULATINHA, Toinho da. [Antônio Patrício de Souza]; MOUSINHO, Geraldo. Eu e minha namorada (Antonio da Mulatinha); O mundo pegando fogo (Geraldo Mouzinho); Côco no periquito é assim (Geraldo Mouzinho). João Pessoa - PB, 1980. 


\section{FOLHETOS DE TOINHO DA MULATINHA}

ACERVO DA PESQUISADORA (MILLA PIZZIGNACCO)

MUlATINHA, Toinho da. [Antônio Patrício de Souza]. A Barragem Camará: Rompimento da Barragem Camará - Rompimento da barragem e a tragédia em Alagoa Grande. Campina Grande - PB, 2004.

MUlatinHA, Toinho da. [Antônio Patrício de Souza]. A cidade de Esperança e seu derivado. 20--. (1 ${ }^{\text {a }}$ edição 1975)

MULATINHA, Toinho da. [Antônio Patrício de Souza]. A Grande Feira da Prata na Cultura Nordestina. Campina Grande - PB: Folhetaria Estrela do Oriente, 20--.

MULATINHA, Toinho da. [Antônio Patrício de Souza]. A Grande Feira da Prata na Cultura Nordestina. Campina Grande - PB: Folhetaria Estrela do Oriente, 2002.

MULATINHA, Toinho da. [Antônio Patrício de Souza]. A morte de Marinês. 2007.

MUlatinha, Toinho da. [Antônio Patrício de Souza]. A Paixão de Cristo. Campina Grande - PB: Folhetaria Estrela do Oriente, 2005.

MUlATINHA, Toinho da. [Antônio Patrício de Souza]. Campina Grande e as violas. 20--.

MUlATINHA, Toinho da. [Antônio Patrício de Souza]. Carregando quem não presta: a negra da trouxa grande. Campina Grande - PB: Folhetaria Estrela do Oriente, 20--.

MUlatinHA, Toinho da. [Antônio Patrício de Souza]. Cordel de Nossa Senhora Padroeira do Brasil. Campina Grande - PB: Folhetaria Estrela do Oriente, 20--. (1 $1^{\mathrm{a}}$ edição 1965).

MUlatinha, Toinho da. [Antônio Patrício de Souza]. Cordel Jackson do Pandeiro. Campina Grande - PB: Folhetaria Estrela do Oriente, 20--.

MUlatinHA, Toinho da. [Antônio Patrício de Souza]. Em 2004 Boqueirão. Campina Grande - PB: Folhetaria Estrela do Oriente, 20--. (data estimada: 2004)

MUlATINHA, Toinho da. [Antônio Patrício de Souza]. Nascimento, vida e morte do frade Frei Damião. 20--.

MULATINHA, Toinho da. [Antônio Patrício de Souza]. O Bebê Diabo: A História do Menino que Nasceu com 2 Chifres e Peludo em São Bernardo do Campo - São Paulo. Campina Grande - PB: Folhetaria Estrela do Oriente, 20--. (1 ${ }^{\mathrm{a}}$ edição: 1975)

MUlatinHA, Toinho da. [Antônio Patrício de Souza]. O coco do mouco e a mouca: o mouco serrando o toco e a moura [mouca] aparando o pó. Campina Grande - PB: . Folhetaria Estrela do Oriente, 20--. (1 $1^{\mathrm{a}}$ edição: 1980).

MUlatinHA, Toinho da. [Antônio Patrício de Souza]. O cordel da Santa encontrada lá no rio Paraíba. Campina Grande - PB: Folhetaria Estrela do Oriente, 20--. (1 $1^{\mathrm{a}}$ edição 1975). 
MULATINHA, Toinho da. [Antônio Patrício de Souza]. O cordel de Isabela. Campina Grande - PB: Folhetaria Estrela do Oriente, 2008.

MULATINHA, Toinho da. [Antônio Patrício de Souza]. O folheto da filha que matou a mãe pela cabeça de um peixe. Campina Grande - PB: Folhetaria Estrela do Oriente, 20--.

MULATINHA, Toinho da. [Antônio Patrício de Souza]. O folheto do turco que atirou no Papa João Paulo II. Folhetaria Estrela do Oriente: Campina Grande, 20--. (1 ${ }^{\text {a }}$ ediç̧ão 1981).

MUlATiNHA, Toinho da. [Antônio Patrício de Souza]. O maior São João do Mundo e a Micarande em Campina Grande. Campina Grande - PB: FUNCESP - Fundação de Cultura e Esportes (Prefeitura Municipal de Campina Grande), 2001. A

MULATINHA, Toinho da. [Antônio Patrício de Souza]. O maior São João do Mundo e a Micarande em Campina Grande. Campina Grande - PB, 2001. (1 ${ }^{a}$ edição: FUNCESP: Campina Grande, 1992).B

MULATINHA, Toinho da. [Antônio Patrício de Souza]. O maior São João do Mundo e a Micarande em Campina Grande. Campina Grande - PB, 2001. (1 ${ }^{a}$ edição: FUNCESP: Campina Grande, 1992).C

MULATINHA, Toinho da. [Antônio Patrício de Souza]. O maior São João do Mundo e a Micarande em Campina Grande. Campina Grande - PB, 2001. (1 ${ }^{a}$ edição: FUNCESP: Campina Grande, 1992).D

MULATINHA, Toinho da. [Antônio Patrício de Souza]. O mote de um viciado ou um homem biriteiro - Eu era um desmantelado Jesus mudou meu viver; O folheto do chupa cabra. 1999.

MUlatinhA, Toinho da. [Antônio Patrício de Souza]. O Treze é Bicampeão - Campeão 2006. Campina Grande - PB, 20--. (data estimada: 2006)

MULATINHA, Toinho da. [Antônio Patrício de Souza]. O Treze é Bicampeão - Campeão 2006. Campina Grande - PB, 2006.

MUlatinHA, Toinho da. [Antônio Patrício de Souza]. Peleja de Antonio da Mulatinha com Vem-vem do Piancó. Campina Grande - PB: Folhetaria Estrela do Oriente, 20--. (1 ${ }^{\text {a }}$ edição 1964).

MULATINHA, Toinho da. [Antônio Patrício de Souza]. Satanás no inferno está contente porque lá chega errado todo dia. Campina Grande - PB: Folhetaria Estrela do Oriente, 2001. (1 $1^{\text {a }}$ edição: 1964$)$

MULATINHA, Toinho da. [Antônio Patrício de Souza]. Satanás no inferno está contente porque lá chega errado todo dia. Mossoró - RN: Fundação vingt-un rosado - Coleção Mossoroense, 2001.

MULATINHA, Toinho da. [Antônio Patrício de Souza]. Toinho da Mulatinha e sua biografia .20--. 
MULATINHA, Toinho da. [Antônio Patrício de Souza]. Tragédia em Campina Grande. 20--. MULATINHA, Toinho da. [Antônio Patrício de Souza]. Uma homenagem ao Doutor Damião e a Doutora Lígia mão amiga. Campina Grande - PB: Folhetaria Estrela do Oriente, 20--.

MULATINHA, Toinho da. [Antônio Patrício de Souza]. Uma homenagem ao prefeito Veneziano. Campina Grande - PB: Folhetaria Estrela do Oriente, 2006.

MULATINHA, Toinho da. [Antônio Patrício de Souza]. Uma viagem à Lua. Campina Grande - PB: Folhetaria Estrela do Oriente, 20--. (1ª edição: 1945).

MULATINHA, Toinho da. [Antônio Patrício de Souza]. Uma viagem à Lua. Campina Grande - PB: Projeto Cordel Campinense - Prefeitura Municipal de Campina Grande, 2004. (1 ${ }^{\mathrm{a}}$ edição: 1945$)$.

MULATINHA, Toinho da. [Antônio Patrício de Souza]. Uma viagem sagrada. 2001 (1 edição: 1953).

\section{MANUSCRITOS DE TOINHO DA MULATINHA}

ACERVO DO POETA/FOLHETARIA ESTRELA DO ORIENTE

MULATINHA, Toinho da. [Antônio Patrício de Souza]. A cidade de Esperança e seu derivado. Manuscrito - Formato "Linguado". 19--.

MUlATINHA, Toinho da. [Antônio Patrício de Souza]. A História do aja-pau ou do filho contra a mãe. Manuscrito - Formato "Linguado”. 19--.

MULATINHA, Toinho da. [Antônio Patrício de Souza]. A véia debaixo da cama o ás de copa o minhocão. Manuscrito - Formato “Linguado”. Campina Grande - PB, 1980.

MULATINHA, Toinho da. [Antônio Patrício de Souza]. Coco de embolada sobre Leandro rei do cordel. Manuscrito - Formato "Linguado". 1955.

MULATINHA, Toinho da. [Antônio Patrício de Souza]. Cordel de Nossa Senhora Padroeira do Brasil. Manuscrito - Formato “Linguado”. 1965 (1ª edição).

MULATINHA, Toinho da. [Antônio Patrício de Souza]. Emboladas sobre o corpo humano. Manuscrito - Formato "Brochura". 19--.

MULATINHA, Toinho da. [Antônio Patrício de Souza]. 2003. Lula e uma parte de sua história. Manuscrito - Formato “Linguado”. 2003.

MULATINHA, Toinho da. [Antônio Patrício de Souza]. Milagres de Frei Damião. Manuscrito - Formato "Linguado”. Campina Grande - PB, 1978.

MULATINHA, Toinho da. [Antônio Patrício de Souza]. O adeus da despedia ao piloto 
Airton Senna. Manuscrito - Formato “Linguado”. 1994.

MULATINHA, Toinho da. [Antônio Patrício de Souza]. O coco do mouco e da mouca: o mouco serrando o toco e a mouca aparando o pó. Manuscrito - Formato “Linguado”. 1965.

MULATINHA, Toinho da. [Antônio Patrício de Souza]. O encontro de Toinho da Mulatinha com o cantador de coco tira-teima. Manuscrito - Formato “Linguado”. 1945.

MULATINHA, Toinho da. [Antônio Patrício de Souza]. O folheto do valentão da usina Santa Maria. Manuscrito - Formato "Linguado”. Campina Grande - PB, 19--.

MULATINHA, Toinho da. [Antônio Patrício de Souza]. O folheto sobre os meninos jogadores de peão. Manuscrito - Formato "Linguado". 19--.

MULATINHA, Toinho da. [Antônio Patrício de Souza]. O rompimento da barragem $e$ tragédia em Alagoa Grande. Manuscrito - Formato "Linguado”.19--.

MULATINHA, Toinho da. [Antônio Patrício de Souza]. Peleja de Antonio da Mulatinha com Vem-vem do Piancó. Manuscrito - Formato "Linguado”. Campina Grande - PB, 19--.

MULATINHA, Toinho da. [Antônio Patrício de Souza]. Peleja de Toinho da Mulatinha com João Barbosa embolador. Impressão - Formato “Linguado”. Campina Grande. 19--.

MULATINHA, Toinho da. [Antônio Patrício de Souza]. Peleja de Toinho da Mulatinha com Lavandeira do Norte. Manuscrito - Formato “Linguado”. Campina Grande - PB, 19--.

MULATINHA, Toinho da. [Antônio Patrício de Souza]. Peleja de Toinho da Mulatinha com Zabelê da Paraíba. Manuscrito - Formato “Linguado”. 19--.

MULATINHA, Toinho da. [Antônio Patrício de Souza]. Toinho da Mulatinha Cantando coco nas feiras. Manuscrito - Formato "Linguado”. 1955.

MULATINHA, Toinho da. [Antônio Patrício de Souza]. Toinho da Mulatinha cantando sobre a Arca de Noé. Manuscrito - Formato “Linguado”. Campina Grande - PB, 1975.

MULATINHA, Toinho da. [Antônio Patrício de Souza]. Toinho da Mulatinha na Paraíba cidades principais vilas povoados e lugares onde ele passou e cantou. Manuscrito - Formato “Linguado”. 19--.

MULATINHA, Toinho da. [Antônio Patrício de Souza]. Uma homenagem aos namorados no dia de Santo Antonio. Vida de Santo Antonio. Manuscrito - Formato "Linguado". 19--.

MULATINHA, Toinho da. [Antônio Patrício de Souza]. Uma Viagem à Juazeiro. Manuscrito - Formato "Linguado". 19--.

MULATINHA, Toinho da. [Antônio Patrício de Souza]. Uma viagem à Lua. Manuscrito Formato “Linguado”. Campina Grande - PB, 1945 (1ª edição). 


\section{FOLHAS-SOLTAS DE TOINHO DA MULATINHA}

ACERVO DO POETA TOINHO DA MULATINHA/ FOLHETARIA ESTRELA DO ORIENTE

MUlATINHA, Toinho da. [Antônio Patrício de Souza]. Coco em sonho cantei no céu pra cristo rei dos poetas. Folha-solta - xérox. 1999.

MUlatinha, Toinho da. [Antônio Patrício de Souza]. Conselho de José Cláudio na Patrulha da cidade Folha-solta - xérox. 1999.

MULATINHA, Toinho da. [Antônio Patrício de Souza]. Uma embolada sobre os movimentos do mar. Folha-solta - xérox. 19--.

\section{MATRIZES DE XILOGRAVURA}

ACERVO DO POETA TOINHO DA MULATINHA/ FOLHETARIA ESTRELA DO ORIENTE

Antônio Lucena [não assinada pelo autor - identificada pelo traço]. Matriz de xilogravura: "acidente de caminhão" [ilustração do folheto: O Desastre do Caminhão que ia de Esperança a Usina Santa Maria - Toinho da Mulatinha, 19--]. 7,9 x 9,4 cm. 19--.

Antônio Lucena [não assinada pelo autor-identificada pelo traço]. Matriz de xilogravura: "avião" [Ilustração estampada na quarta capa do folheto: A Morte do Coronel Ludogero $e$ do seu Companheiro Otrope - Toinho da Mulatinha, 19--]. 8,4 x 7,2 cm. 19--.

Antônio Lucena. Matriz de xilogravura: "casal dançando" [ilustração similar a do folheto: O maior São João do Mundo e a Micarande em Campina Grande - Toinho da Mulatinha, 2001]. 5,8 x 10,2 cm. 1984.

Antônio Lucena [não assinada pelo autor - identificada pelo traço]. Matriz de xilogravura: "casal se beijando". 5,8 x 10,5 cm. 19--.

Antônio Lucena [não assinada pelo autor - identificada pelo traço]. Matriz de xilogravura: "garoto de bermuda" [aparentemente nunca impressa]. 6,2 x 7,6 cm. 19--.

Antônio Lucena. Matriz de xilogravura: "homem, jumento e mulher apontando com o dedo indicador" [ilustração do folheto: O homem que deixou a mulher para viver com uma jumenta - Toinho da Mulatinha, 1982]. 8,8 x 10,2 cm. 1982.

Antônio Lucena. Matriz de xilogravura: "homem remando e outros na água". 7,9 x 10,1 cm. 1978.

Antônio Lucena. Matriz de xilogravura: "luta" [aparentemente nunca impressa]. 8,5 x 10,4 cm. 1984.

Antônio Lucena. Matriz de xilogravura: "mulher batendo em outra que tenta pegar um peixe no chão" [ilustração original do folheto: $O$ folheto da filha que matou a mãe pela cabeça de um peixe - Toinho da Mulatinha, 20--]. 8,5 x 10,4 cm. 19--. 
Antônio Lucena [não assinada pelo autor - identificada pelo traço]. Matriz de xilogravura: "Padre Cícero" [ilustração do folheto: Poema Dedicado aos Romeiros de Meu Padrinho Cícero do Juazeiro do Norte - Dedé da Mulatinha, 19--]. 5,5 x 10,1 cm. 19--.

Antônio Lucena [não assinada pelo autor - identificada pelo traço]. Matriz de xilogravura: “pavão A” [aparentemente nunca impressa]. 6,2 x 7,4 cm. 19--.

Antônio Lucena [não assinada pelo autor - identificada pelo traço]. Matriz de xilogravura: "pavão B”. 9,8 x 7,7 cm. 19--.

Antônio Lucena. Matriz de xilogravura: "sanfoneiro e pandeirista” [aparentemente nunca impressa]. 8,6 x 10,9 cm. 1993.

Antônio Lucena [não assinada pelo autor - identificada pelo traço]. Matriz de xilogravura: "violeiro" [aparentemente nunca impressa]. 7,2 x 9,8 cm. 19--.

Autoria não identificada. Matriz de xilogravura: "cangaceiro e dois demônios”. 8,0 x 9,2 cm. 19--.

Autoria não identificada. Matriz de xilogravura: "crianças jogando bola com galinha e cachorro brincando". 13,5 x 8,8 cm.19--.

Autoria não identificada. Matriz de xilogravura: "cruz, caixão, homem” [ilustração dos folhetos: A tromba d'água do Estado da Guanabara, 1966; O Poema do Filho que Matou o Pai no Sítio Araçá entre Arara e Serraria - Toinho da Mulatinha, 1977]. 10,5 x 7,6 cm. 19--.

Autoria não identificada. Matriz de xilogravura: "emboladores de coco" com parede de tijolos ao fundo" [ilustração do folheto: Peleja de Antonio da Mulatinha com Vem-vem do Piancó - Toinho da Mulatinha, 20--]. 10,5 x 9,5 cm. 19--.

Autoria não identificada. Matriz de xilogravura: “figuras de mãos dadas”. 10,2 x 10,2 cm. 19--.

Autoria não identificada. Matriz de xilogravura: "mulher assustando um rapaz com um animal" - desenho na frente e no verso da matriz [ilustrações similares a do folheto: $O$ Casamento de Bernarde com Maria de Saguim ou o Rapaz que casou-se e correu com medo da mulher no dia do casamento - Toinho da Mulatinha, 19-- ]. 10,0 x 11,0 cm. 19--.

Autoria não identificada. Matriz de xilogravura: "Nossa Senhora com Jesus nos braços" [ilustração do folheto: Uma Viagem Sagrada - Toinho da Mulatinha, 2001]. 8,5 x 9,7cm. 19--.

Autoria não identificada. Matriz de xilogravura: "rapaz beijando o seio de uma mulher". $9,0 \times 13,1 \mathrm{~cm} .19--$.

Autoria não identificada. Matriz de xilogravura: "rapaz com bíblia pregando para um cachaceiro". 9,0 x 10,4 cm. 19--.

Autoria não identificada. Matriz de xilogravura: "rapaz de terno com maleta em mãos e outro com garrafa” [ilustração do folheto: A Discussão de um Bêbado com um Doutor João Barbosa da Silva, 1976]. 8,5 x 12,6 cm. 19--.

Autoria não identificada [supostamente: José Costa Leite]. Matriz de xilogravura: "rapaz e moça com bastão na mão”. 8,0 x 8,7 cm.19--. 
Autoria não identificada. Matriz de xilogravura: "violeiros" [ilustração do folheto: Campina Grande, a Viola e as Belezas do Nordeste - Toinho da Mulatinha, 1976 ]. 9,2 x 11,4 cm. 19--.

Autoria não identificada. Matriz de xilogravura: "violeiros com violas ao fundo preenchendo a composição”. 10,8 x 11,1 cm. 19--.

\section{MATRIZ DE ZINCOGRAVURA}

ACERVO DO POETA TOINHO DA MULATINHA/FOLHETARIA ESTRELA DO ORIENTE

Autoria não identificada. Matriz de zincogravura [alto relevo]: "Maria fugindo com São José e o Menino Jesus do Rei Herodes” [ilustação do folheto: História Sagrada - As Sete Espadas de Dores de Maria Imaculada - Dedé da Mulatinha, 1976]. 12,5 x 16,0 cm. 19--.

\section{CLICHÊS FOTOGRÁFICOS}

ACERVO DO POETA TOINHO DA MULATINHA/FOLHETARIA ESTRELA DO ORIENTE

Clichê fotográfico: "emboladores de coco: Toinho da Mulatinha e Geraldo Mousinho" [ilustração do folheto: Eu e Minha Namorada/O Mundo Pegando Fogo/Côco no Periquito é Assim - Toinho da Mulatinha e Geraldo Mousinho, 1980]. 9,3 x 6,4 cm. 19--.

Clichê fotográfico: "logotipo do Treze Futebol Clube à esquerda e jogadores de futebol à direita" [ilustração do folheto: A História do Treze Futebol Clube - O Famoso Galo da Borborema - Toinho da Mulatinha, 1975]. 12,3 x 5,6 cm. 19--.

Clichê fotográfico: "mulher" [ilustração do folheto: A História da Mulher que Matou o Filho e Jogou num Caixão De Lixo - Toinho da Mulatinha, 19--]. 9,8 x 6,1 cm. 19--.

Clichê fotográfico: "ônibus" [ilustração do folheto: O Desastre do Onibus que Atropelou uma Procissão e Matou vinte e Três Pessoas em Currais Novos - Toinho da Mulatinha, 19--. $8,0 \times 5,4 \mathrm{~cm} .19--$

Clichê fotográfico: “Papa João Paulo II”. 9,0 x 10,5 cm. 19--.

Clichê fotográfico: "pessoa carregando criança/ retratos 3x4 de três pessoas ao fundo". 10,0 x 6,0 cm. 19--.

Clichê fotográfico: "retrato: homem de bigode”. 5,1 x 6,3 cm. 19--.

Clichê fotográfico: "retrato de homem de bigode armado" [ilustração do folheto: A Morte do Coronel Ludogero e seu Companheiro Otrope - Toinho da Mulatinha, 1970]. 8,0 x 12,7 cm. 19--.

Clichê fotográfico: “violeiros” [ilustração do folheto: Campina Grande, a Viola e as Belezas do Nordeste - Toinho da Mulatinha, 1976]. 9,8 x 6,6 cm. 19--. 


\section{EMBOLADAS TIPOGRÁFICAS EM CAMPINA GRANDE (PB):}

Permanências e rupturas na edição dos folhetos do poeta Toinho da Mulatinha (1925 - 2016)

Versão eBook. Publicação diagramada por Galinha Preta - Arte Gráfica com edição impressa em papel Pólen Bold 90g/m² (miolo) e Kraft 300 g/m² (capa) pela Gráfica Oxdealer em São Paulo, 2020. 


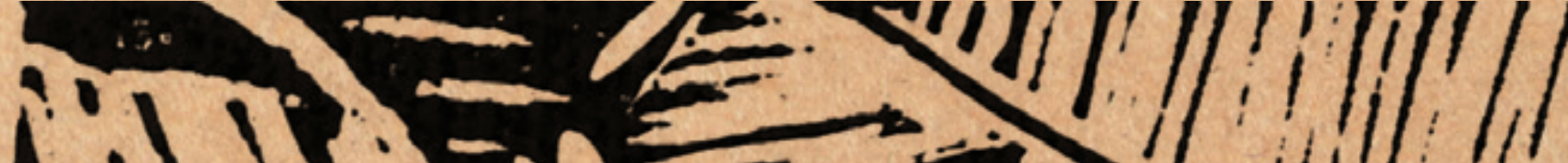
$1: 11 .-1=11 i 1$ (fill. 111 111.1 $\times->->$

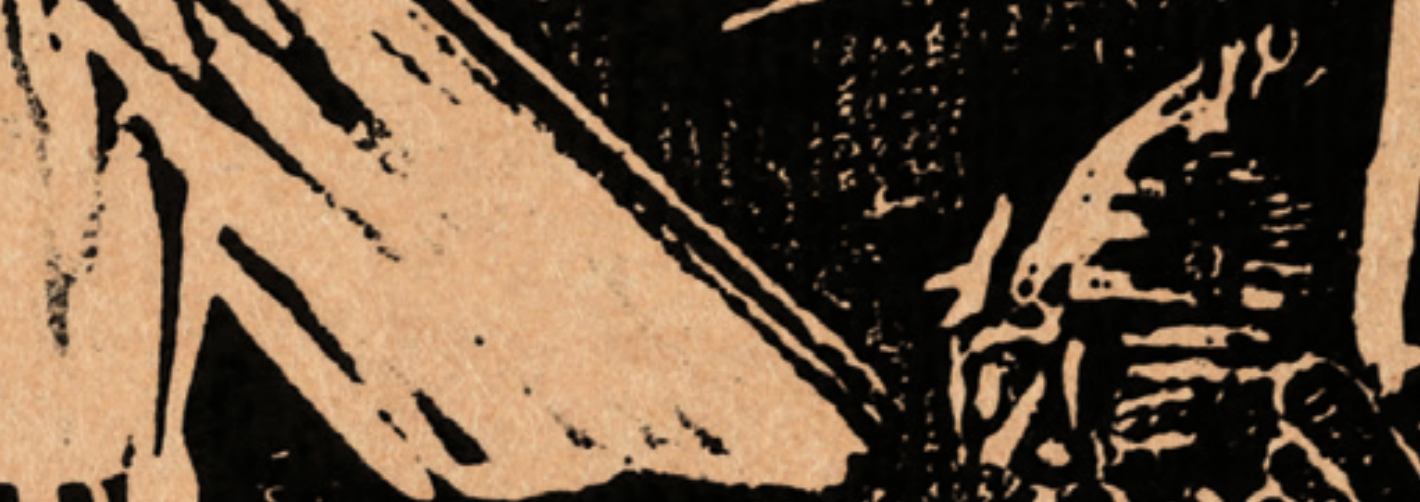

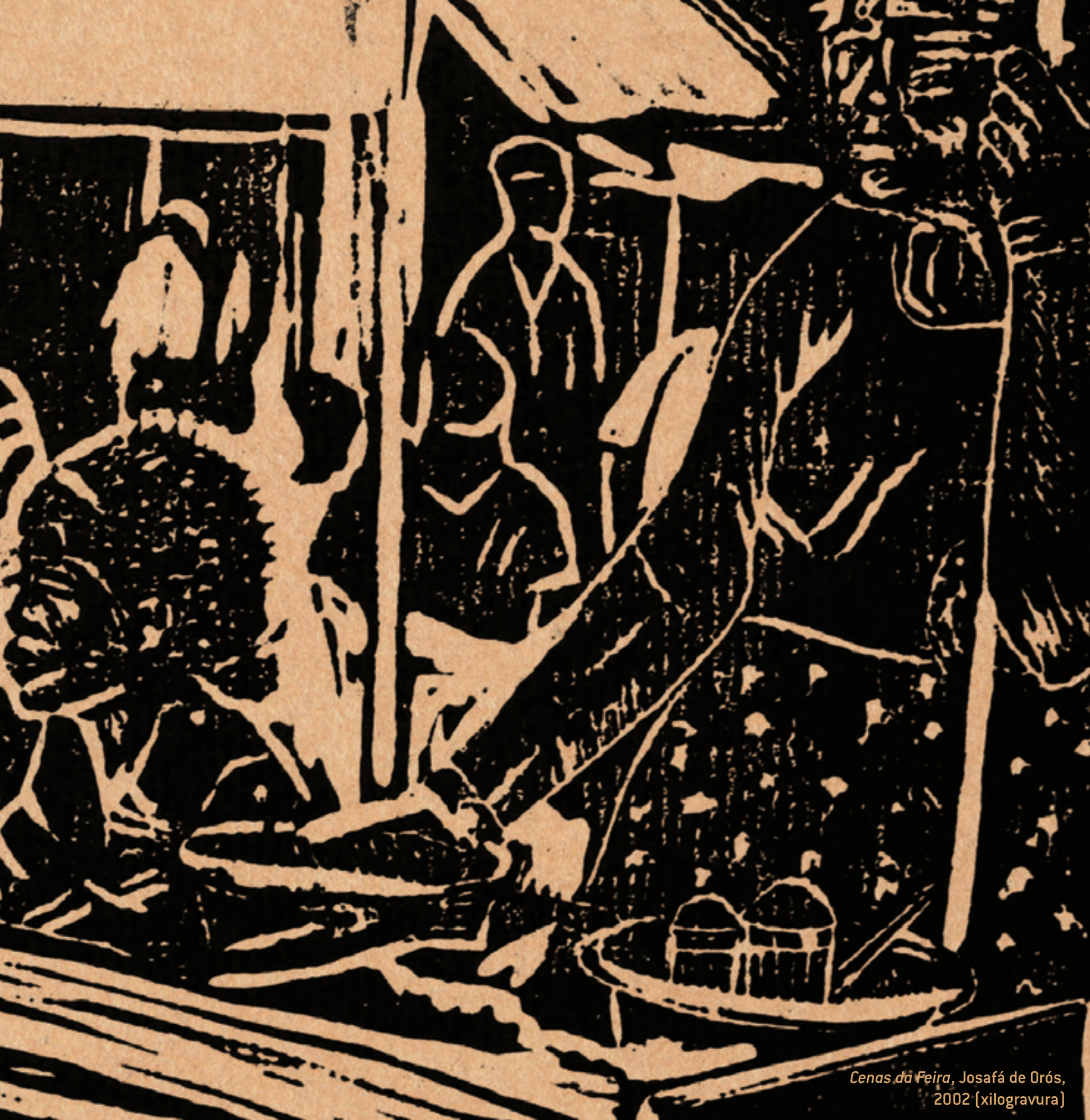

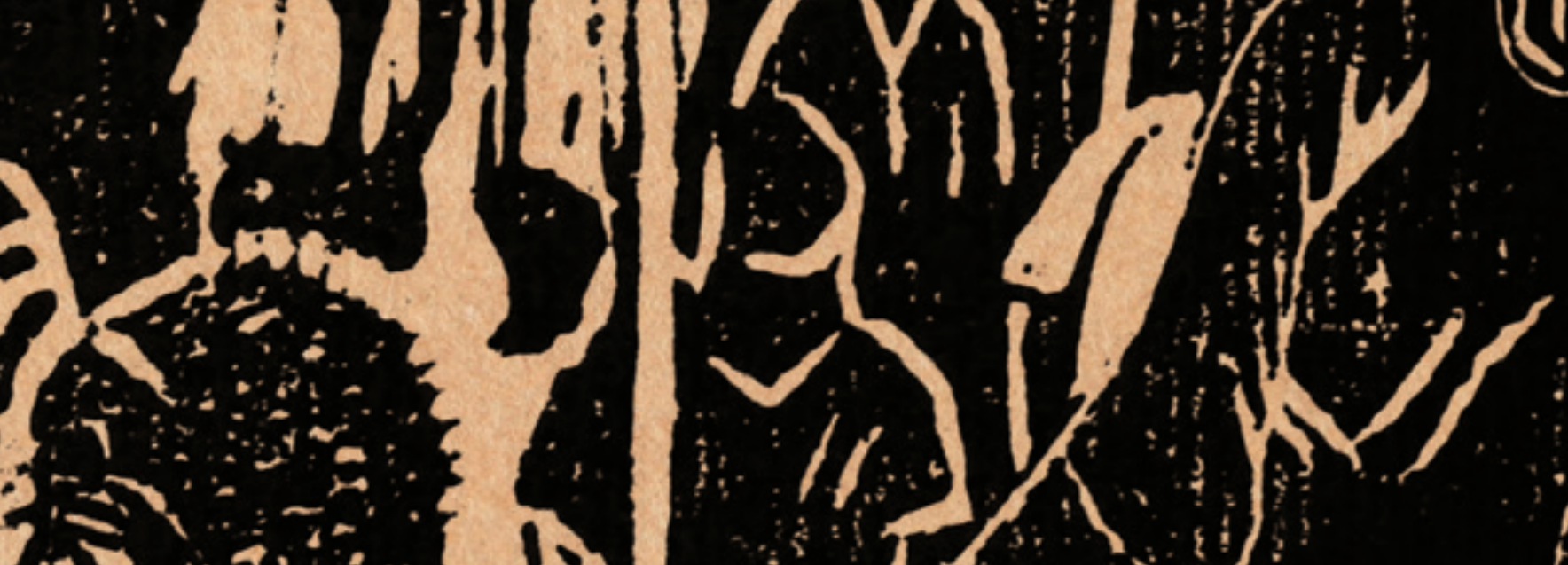
(4) 10,1 $2=-4 i$

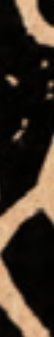


